\title{
Synthesis of monosaccharide and nucleoside conjugates of estrone derivatives
}

Ph. D. thesis

\section{Brigitta Bodnár}

Supervisor:

Dr. Zoltán Kupihár

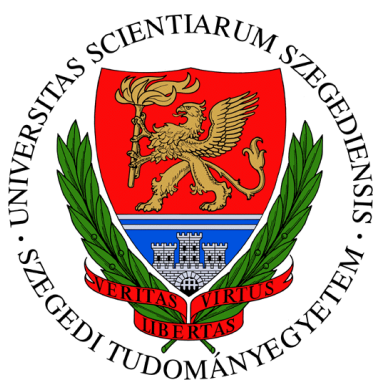

Doctoral School of Theoretical Medicine

Department of Medicinal Chemistry

Faculty of Medicine

University of Szeged

Szeged, Hungary

2018 
"Mindennek megszabott ideje van, megvan az ideje minden dolognak az ég alatt."

Préd, 3,1

"There is a time for everything, and a season for every activity under the heavens."

Ecclesiastes 3,1 


\section{Acknowledgement}

First of all, I would like to thank to my supervisor, Zoltán Kupihár, who introduced me to the mystery of research work. Thanks for his helpful support, patience and that he gave me professional help for solving all the theoretical and practical problems arising during my work. I also would like to thank him for not letting me down and not letting me give it up. Furthermore I want to thank him for carefully inspecting this manuscript.

I owe thanks to Lajos Kovács for the many helpful, theoretical and practical advices. His professional remarks, guidance and suggestions were crucial for this work. I want to thank him for carefully inspecting this manuscript.

I wish to say thanks to Erzsébet Mernyák for all the theoretical and practical guidance, patience, advises and good intentions. Thank you for your attention guiding all my work.

I wish to thank to our cooperating partners Johanna Zóka and Erzsébet Mernyák for steroids, Izabella Sinka and István Zupkó for antiproliferative assays, Bianka Edina Herman and Mihály Szécsi for enzyme inhibition assays.

I owe a lot of thanks to all the former and current colleagues in the Department of Medicinal Chemistry and Nucleic Acids Laboratory, especially Eszter Tétényi, Zsanett Szécsényi, Gábor Endre, Dávid Rakk, Csaba Balázs and Zoltán Váradi.

Last but not at least I want to thank to my friends Anita, Ditta, Niki and Léna, my parents and my brother who always supported and encouraged me during my education and doctoral work. I owe the biggest gratitude to my Love, Norbert, who was always standing by my side, put up with me and helped me to reach my goals by being patient and providing a stable and calm background for me. I wish to dedicate this thesis to them.

Brigitta Bodnár, February 2018 


\section{List of Publications}

I. Bodnár B., Mernyák E., Wölfling J., Schneider G., Herman B. E., Szécsi M., Sinka I., Zupkó I., Kupihár Z. and Kovács L. Synthesis and biological evaluation of triazolyl 13 $\alpha$-estrone-nucleoside bioconjugates. Molecules, 2016, 21, 1212-1228. IF: 2.861 (2016)

II. Bodnár B., Mernyák E., Szabó J., Wölfling J., Schneider G., Zupkó I., Kupihár Z. and Kovács L. Synthesis and in vitro investigation of potential antiproliferative monosaccharide-D-secoestrone bioconjugates, Bioorganic and Medicinal Chemistry Letters, 2017, 27, 1938-1942. IF: 2.454 (2016)

III. Kupihár Z., Bodnár B., Kovács L. 5'-Linker modified nucleosides, Hungarian patent P1700542, 2017.12.19. (5'-Linkerrel módosított nukleozidok, magyar szabadalmi bejelentés)

IV. Bodnár B., Kovács L., Kupihár Z. An efficient way to synthesize azide-containing nucleosides for click conjugations (in preparation)

V. Bodnár B., Kovács L., Kupihár Z. Synthesis of versatile 5'-linker containing purine nucleosides as clickable building blocks for efficient synthesis of bisubstrate inhibitors (in preparation) 


\section{Table of content}

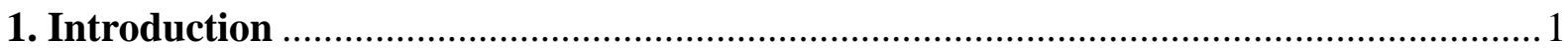

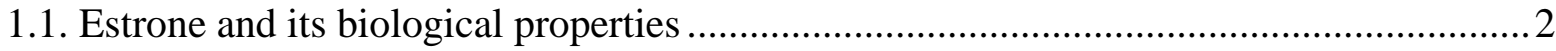

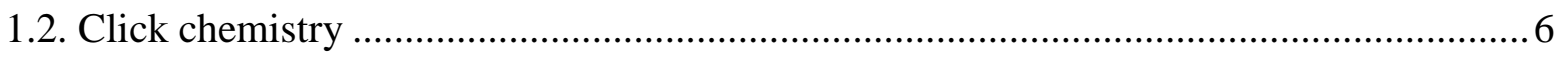

1.3. Monosaccharides, glycosyl azides and glycoconjugates ............................................. 9

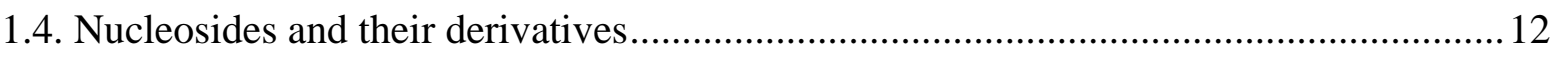

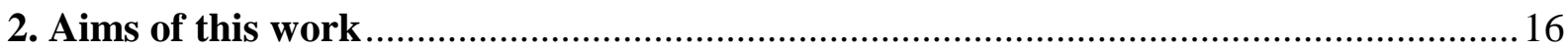

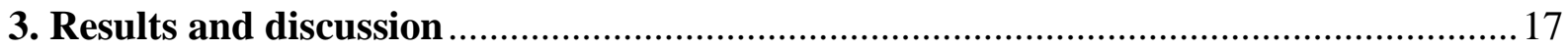

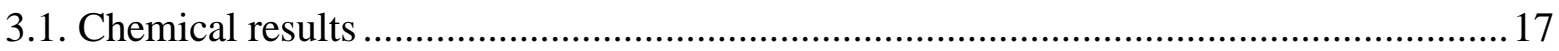

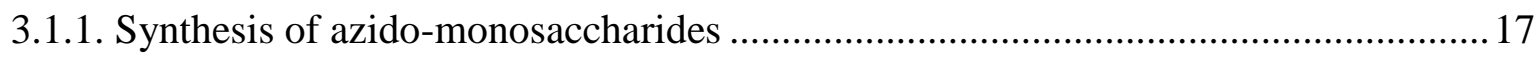

3.1.2. The click reaction between azido-monosaccharides and D-secoestrones ................. 19

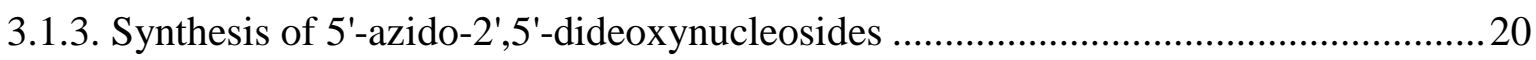

3.1.4. The click reaction between azido-nucleosides and a $13 \alpha$-estrone derivative .............23

3.1.5. Synthesis of 5'-linker-containing azido-nucleosides................................................... 24

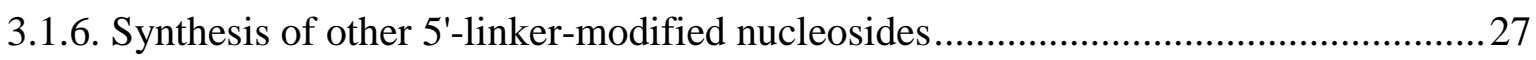

3.1.7. CuAAC between the 5'-linker modified nucleosides with 15-O-propargyl-13ß-

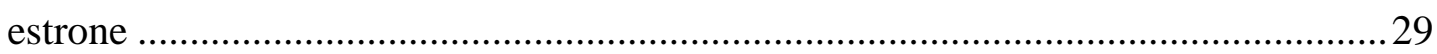

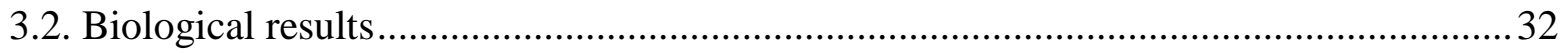

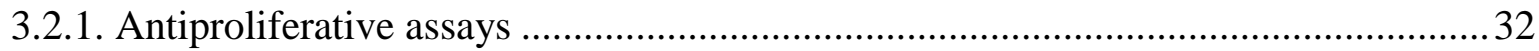

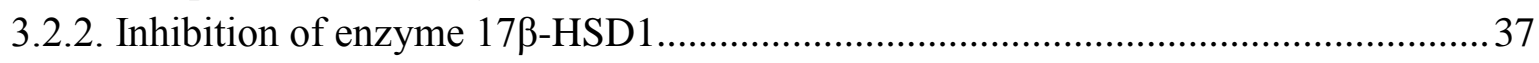

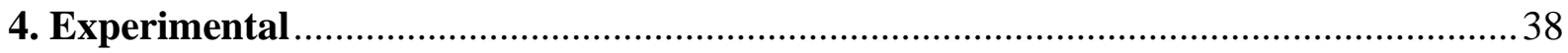

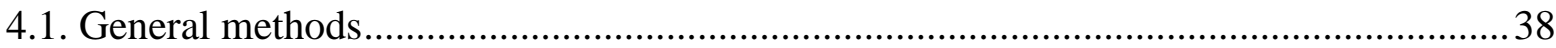

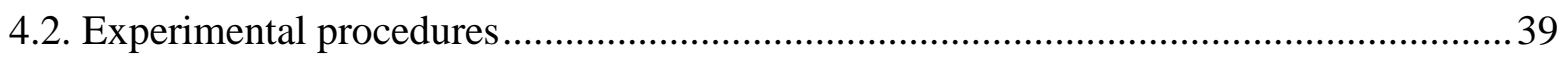

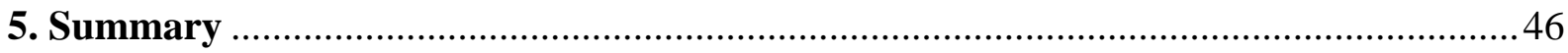

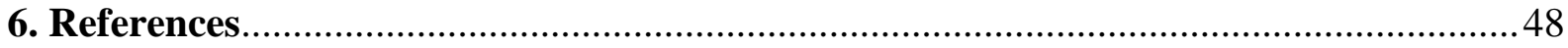

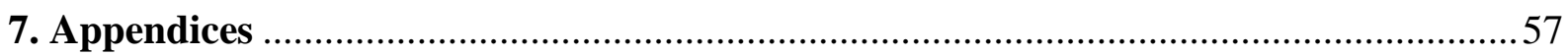




\section{List of abbreviations}

Ac

$\mathrm{Ac}_{2} \mathrm{O}$

$\mathrm{Bn}$

Boc

$\mathrm{Bz}$

$\mathrm{CDCl}_{3}$

$\mathrm{CD}_{3} \mathrm{CN}$

CDI

$\mathrm{CD}_{3} \mathrm{OD}$

$\mathrm{CH}_{2} \mathrm{Cl}_{2}$

$\mathrm{CuAAC}$

DIPEA

DMAP

DMF

DMSO

DMTr

EtOAc

HSD

IPA

$\mathrm{MeCN}$

$\mathrm{Me}_{3} \mathrm{SiN}_{3}$

$\mathrm{MeOH}$

MTT

$\mathrm{NH}_{3} / \mathrm{MeOH}$

$\mathrm{P}(\mathrm{Ph})_{3}$

TBAF

THF

TLC

$\operatorname{Tr}$

Ts acetyl

acetic anhydride

benzyl

tert-butyloxycarbonyl

benzoyl

deuterochloroform

acetonitrile- $\mathrm{d}_{3}$

1,1'-carbonyldiimidazole

methanol-d $\mathrm{d}_{4}$

dichloromethane

copper(I)-catalyzed alkyne-azide cycloaddition

$N, N$-diisopropylethylamine

4- $N, N$-Dimethylaminopyridine

$\mathrm{N}, \mathrm{N}$-dimethylformamide

dimethyl sulfoxide- $\mathrm{d}_{6}$

4,4'-dimethoxytrityl

ethyl acetate

hydroxysteroid dehydrogenase

isopropyl alcohol

acetonitrile

trimethylsilyl azide

methanol

3-(4,5-dimethylthiazol-2-yl)-2,5-diphenyltetrazolium bromide ammonia solution in methanol

triphenylphosphane

tetrabutylammonium fluoride

tetrahydrofuran

thin layer chromatography

trityl (triphenylmethyl)

p-toluenesulfonyl 


\section{Introduction}

Nobody questions the crucial significance of natural compounds in therapeutics. Herbal and other naturally occurring compounds play an important role in pharmaceutical research today. The currently applied anticancer therapy has a number of drawbacks, including the lack of selectivity and a large set of side-effects. Structural modifications of naturally occurring biologically active substances may lead to new, more selective therapeutic agents. Steroids are a major group of natural carbon compounds, which are widely used by living organisms for transmitting information in a chemical way. These compounds with diverse structures having hormonal action play tremendeous role in regulating essential biochemical processes of cells, therefore any substance involved in the production, dissimilation, modification and the transport of these compounds, can be used as potential agents in medications as well as any molecules that bind to them in any particular way. ${ }^{1,2}$ Therefore, steroids containing various modifications are widely used recently as therapeutic agents. One of the key conditions for widening their application area is to provide sufficient selectivity, in addition to increasing the effectiveness for a given purpose, in other words to minimize side effects. This is achieved, on the one hand, by the preparation of a compound with such structure that is preferably bound to only one target; or it can be achieved by the use of an agent that is capable of being enriched in the target organ, tissue or cell type. ${ }^{3}$ Nowadays, conjugation of an effective steroid with a bioactive substance common in nature, e.g. amino acid, peptide, ${ }^{4}$ fatty acid, ${ }^{5}$ carbohydrate $^{6}$ or nucleoside ${ }^{7}$ units, becomes more and more popular and provides methods for both types of selectivity enhancements. This approach is not quite new, since even Nature employs this strategy, where the biological potency of the new conjugates may exceed that of the parent compounds separately. ${ }^{3}$ Usually steroids can penetrate the cell membrane and specifically bond to the proper receptors, therefore they offer a number of pharmacological possibilities. In the last decade the Steroid Chemistry Research Group of the University of Szeged that we have been cooperating with, has produced various antitumor steroid derivatives.

In my doctoral work, I planned to synthesize carbohydrate- and nucleoside-containing bioconjugates of these steroids with already established antiproliferative properties and investigate how the conjugation affects the strength of the anticancer activity and selectivity. 


\subsection{Estrone and its biological properties}

Estrogen is a female sex hormone, therefore it is responsible for the development of secondary female character, plays a role in the thickening of the endometrium and in the regulation of the menstrual cycle. There are three estrogenic compounds in the human body:

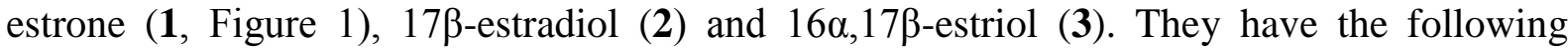
common structural elements: an aromatic A-ring and trans-annellation between the B and C cyclohexane rings, the B-ring has a half-chair or sofa conformation while the C-ring possesses a chair conformation. The oxygen atoms in the molecules are at a well-defined distance which is responsible, in part, for the estrogen and estradiol hormone activity. ${ }^{8}$
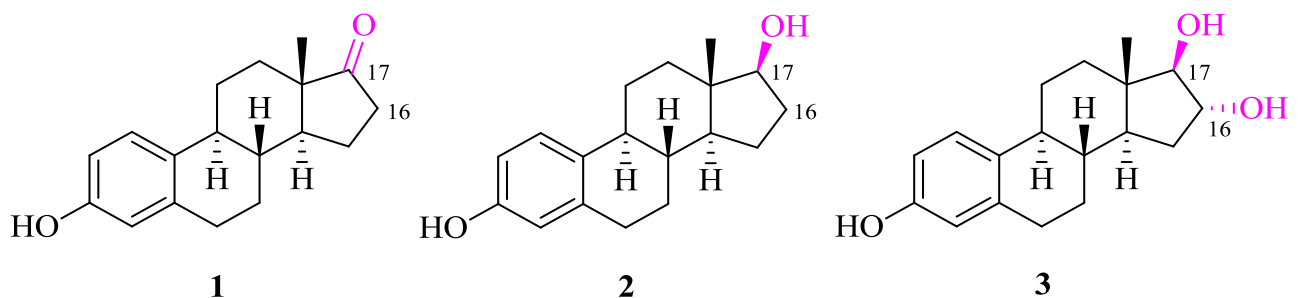

Figure 1. Structures of estrogenes (1-3)

Estrone and estradiol are biosynthesised by aromatisation of androstenedione and testosterone. They can also be interconverted by the action of $17 \beta-H S D$ enzymes. Estriol is synthesised from estrone via a $16 \alpha$-hydroxyestrone intermediate. Estrogen sulfotransferase is a cytosolic enzyme that catalyzes the sulfonation of estrogens. Steroid sulfatase catalyzes the conversion of estrone sulfate to estrone. Aromatase catalyzes the aromatisation of the A-ring of androstendione to produce estrone and the aromatisation of the A-ring of testosterone to produce estradiol. 17 $\beta$-HSD1 catalyses the conversion of estrone to estradiol, and that of $16 \alpha-$ hydroxyestrone to estriol. The reverse reactions are catalysed by $17 \beta-\mathrm{HSD} 2$ which also facilitates the conversion of testosterone to androstenedione, the reverse reaction of which is catalysed by $17 \beta-$ HSD3 (Scheme 1$)^{9}$

Anti-estrogens compete with estrogen to inhibit its binding to its own receptor, ${ }^{10}$ there are steroid sulfatase enzyme inhibitors, ${ }^{11-16}$ aromatase enzyme inhibitors ${ }^{17}$ and 17ß-HSD1 enzyme inhibitors. ${ }^{7,18-23} 17 \beta$-HSD1 is an oxidoreductase enzyme ${ }^{24}$ which plays crucial role in the biosynthesis of estrogene, it catalyzes the reduction of estrone to the more potent $17 \beta$ - 
estradiol which enhances the proliferation of certain cancer cells. By inhibiting this enzyme, the synthesis of female sex hormones can be influenced and their inhibition can be an alternative to the protection against many estrogen-dependent tumor diseases. Since estrogens play an essential role in the cell proliferation, their overproduction may lead to enhanced proliferation of hormone sensitive cells, resulting in hormone dependent cancers: ovarian, uterine, breast, prostate and endometrial. ${ }^{25}$ Estrone-based anticancer drugs have been developed as antiproliferative/antihormonal or cytotoxic agents acting on non-hormonal targets. ${ }^{10}$
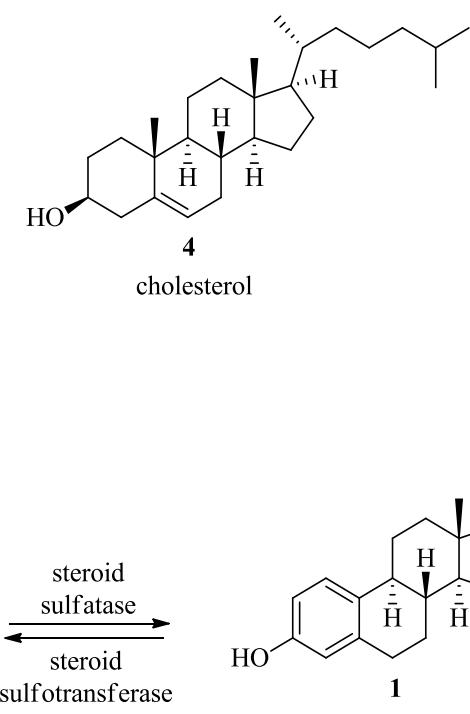<smiles>CC(C)C1CCC2C1CCC1C2CCC2(C)C(=O)CCC12</smiles>
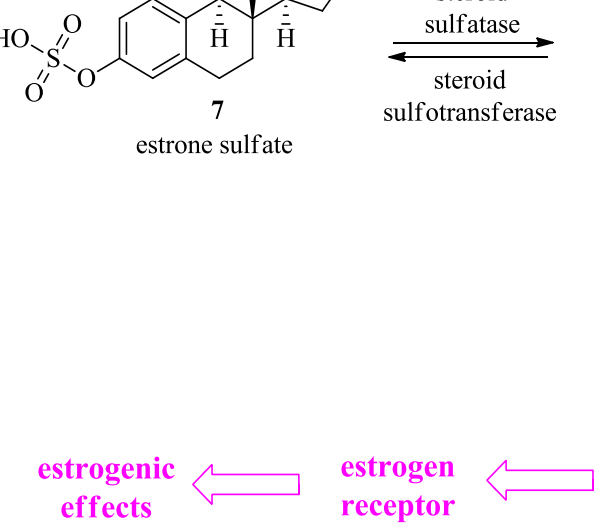
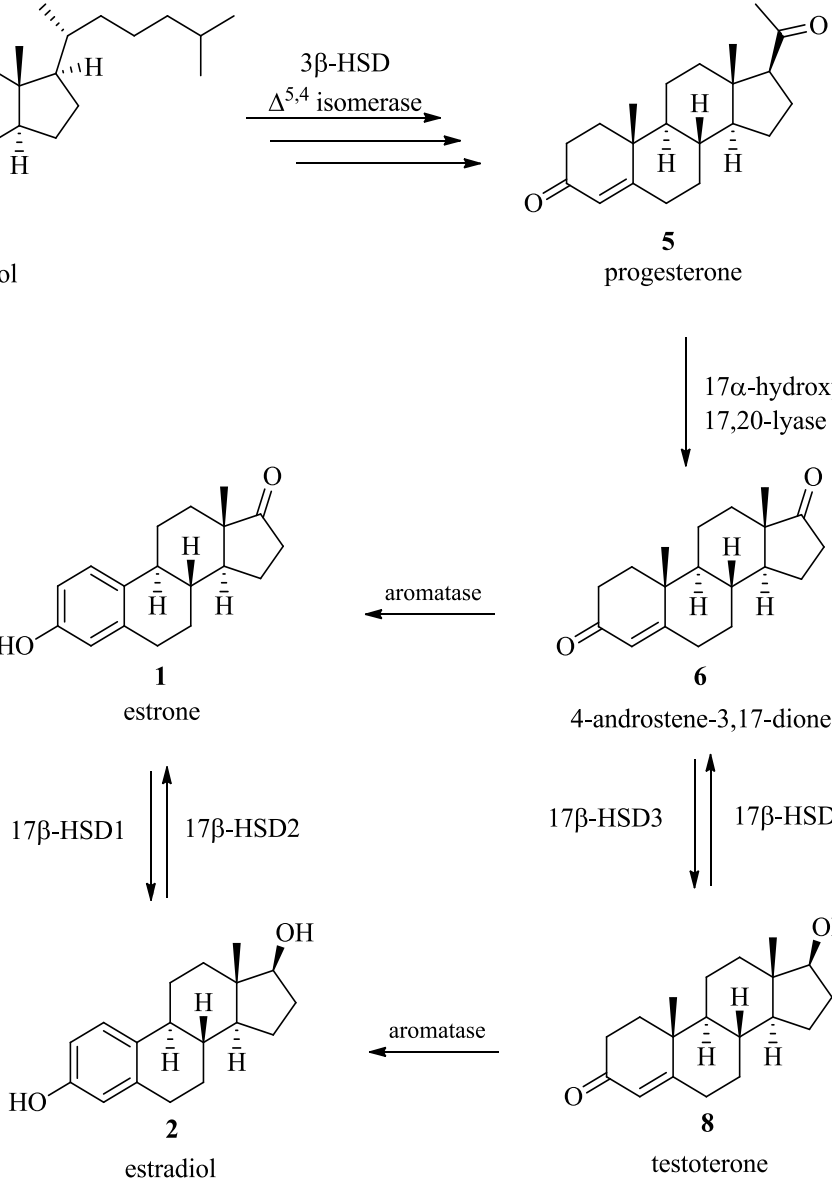

$17 \alpha$-hydroxylase 17,20-lyase
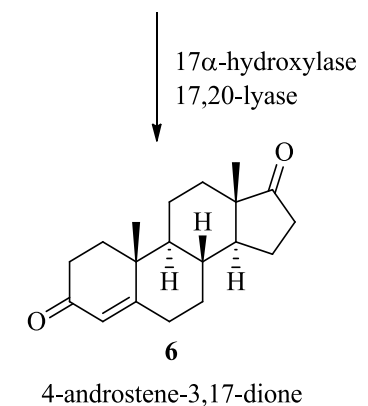

$17 \beta$-HSD3 $\downarrow \mid 17 \beta$-HSD2

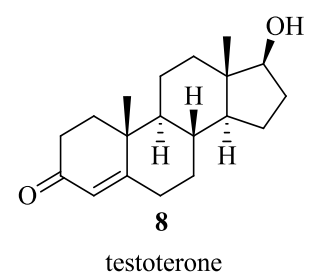

Scheme 1. Biosynthesis of estrone (1) and estradiol (2)

Chemical modifications of estrone may lead to compounds lacking hormonal behavior ${ }^{10,26,27}$ and may lead to estrone-based anticancer agents. ${ }^{28-32}$ Substitution at C-2, opening of ring D or inversion at $\mathrm{C}-13$ of the estrane skeleton usually leads to the loss of estrogenic activity. ${ }^{8,33-36}$ 
Poirier et al. carried out the effect test of the 4 isomeric estradiols (2, 9-11, Figure 2), tested in vitro their affinity to estrogen receptors, and in vivo uterotropic and in vitro cell-based methods. ${ }^{35}$

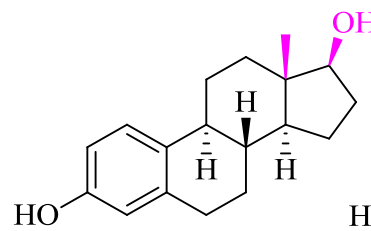

2

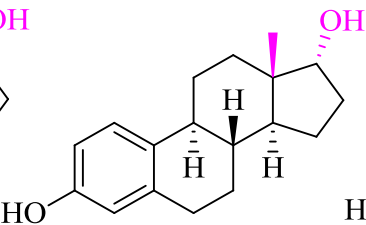

9

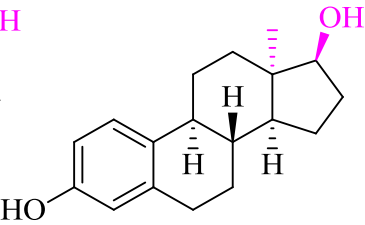

10

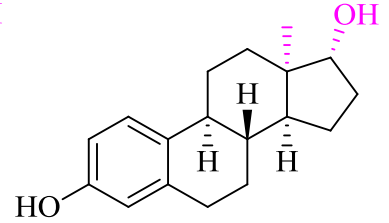

11

Figure 2. Structure of four estradiol isomers $(\mathbf{2}, \mathbf{9 - 1 1})$

The results showed that compound $\mathbf{1 0}$ exhibits the lowest affinity for estrogen receptors, the estrogen effect is the lowest on estrogen-dependent cell lines, and there is no hormone effect in vivo. From the results it can be concluded that the inversion of the angular methyl group significantly reduces the estrogenic effect. At higher concentrations $(>5 \mu \mathrm{M})$, the estradiol and its analogues $(\mathbf{2}, \mathbf{9 - 1 1})$ had considerable/significant cytotoxic effect on different breast cell lines (MCF-7 and T-47D) and this effect was the highest in case of compound 11. 13 $\alpha$ Estrone may be an excellent scaffold for the design of hormonally inactive agents having antiproliferative activity and fortunately it is readily available from native $13 \beta$-estrone by the method of Yaremenko and Khvat, using 1,2-phenylenediamine and acetic acid. ${ }^{37}$

By opening the D-ring, D-secosteroids can be obtained. D-secoaldehydes $(\mathbf{1 2}, \mathbf{1 3})$ were already produced earlier by the Steroid Chemistry Research Group at the University of Szeged, ${ }^{27,38,39}$ then later their oximes were also formed $(\mathbf{1 4}, \mathbf{1 5}),{ }^{40}$ and the propenyl side chains of oximes were saturated. In case of the 3-O-benzyl ether derivatives the hydrogenation of the side chain also resulted in the cleavage of the benzyl group releasing the free phenolic hydroxy group (17, Scheme 2$){ }^{41}$ 


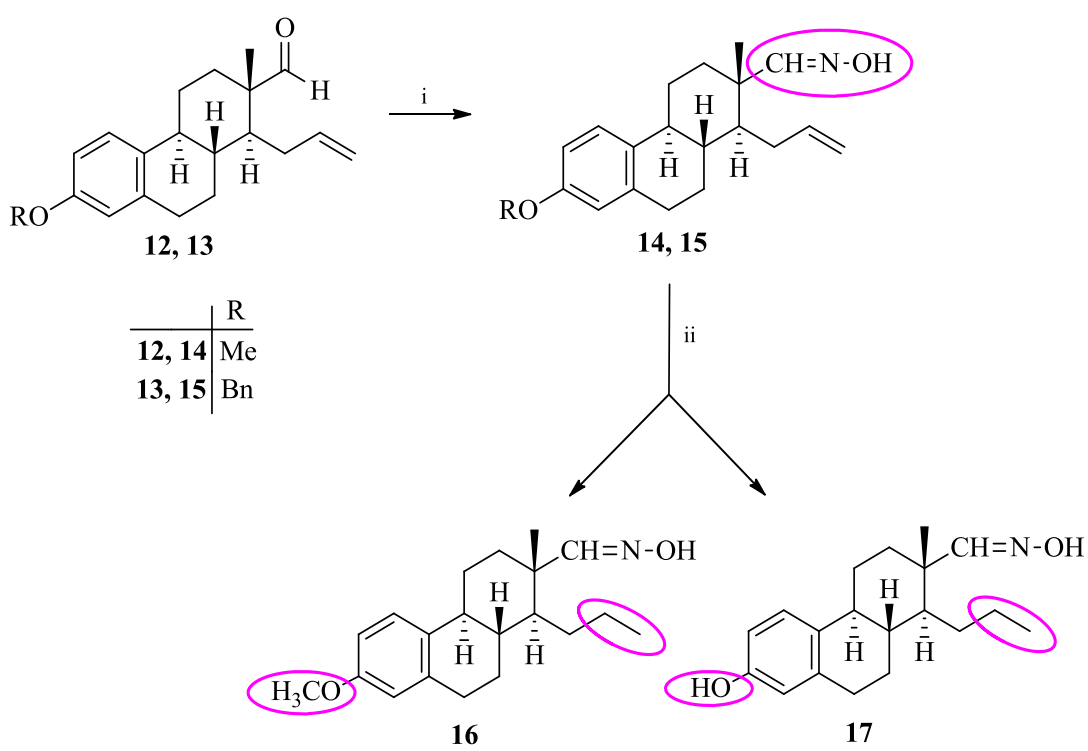

Scheme 2. Synthesis of secooxime derivatives $(\mathbf{1 6}, \mathbf{1 7})$. Reagents: (i) $\mathrm{NH}_{2} \mathrm{OH} \cdot \mathrm{HCl}, \mathrm{NaOAc}$, $\mathrm{MeCN}$; (ii) $\mathrm{H}_{2}, \mathrm{Pd} / \mathrm{C}, 20$ bar.

For further derivatization purposes, starting with the benzyl-protected D-secoaldehyde (13), D-secoalcohol (18) was produced in a good yield. ${ }^{42}$ Similarly to oximes, the removal of the 3$O$-benzyl protecting group and the saturation of the propenyl side chain are accomplished simultaneously by hydrogenolysis $(\mathbf{1 9}$, Scheme 3$){ }^{43}$

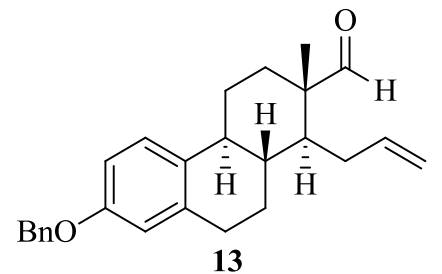

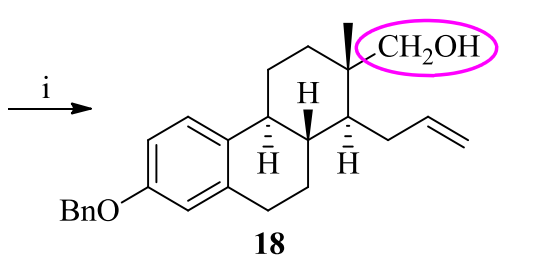

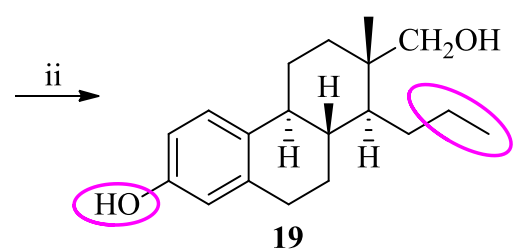

Scheme 3. Synthesis of secoalcohol (19). Reagents: (i): $\mathrm{KBH}_{4}, \mathrm{MeOH}$; (ii): $\mathrm{H}_{2}, \mathrm{Pd} / \mathrm{C}, 20$ bar.

The antiproliferative effect of these compounds (14-19) was tested by in vitro MTT method on several human adherent cell lines: HeLa (cervical cancer), MCF-7 (estrogen receptor positive breast cancer), A2780 (ovarian carcinoma), A431 (epidermoid carcinoma) and MRC5 (human fibroblast). The results show that the 3-O-methyl derivatives $(\mathbf{1 4}, \mathbf{1 6})$, synthesized from secoestrones, showed lower $\mathrm{IC}_{50}$ values than the reference compounds (cisplatin) on multiple cell lines (HeLa, A2780, MCF-7) but were not selective among the individual cell lines at their effective concentration. However, the compounds obtained by saturation of the 
side chain and the simultaneous removal of the benzyl protecting group $(\mathbf{1 7}, \mathbf{1 9})$ did not influence the cell proliferation even at high concentrations, therefore it can be concluded that the presence of free phenolic hydroxy groups for secoestrones weakens the antitumor activity. These results suggest that among the secooxime and secoalcohol derivatives, the $13 \alpha$ isomers are ideal for incorporation of further modifications and formation of bioconjugates.

\subsection{Click chemistry}

One of the most selective conjugation techniques is the copper-catalyzed azide-alkyne click reaction that requires the presence of a terminal alkyne group on one of the conjugated molecules and an azide group on the other. ${ }^{44-46}$

At the beginning of the 2000s, Kolb, Finn and Sharpless introduced the concept of "click" chemistry with the aim of linking small molecules with two structural units under mild conditions with a selective, high yield reaction without the formation of byproducts. ${ }^{47}$ In 2002, the research groups of Sharpless ${ }^{44}$ and Meldal $^{48}$ have already reported independently on the azide-alkyne cycloaddition $(\mathrm{CuAAC})$ with efficient $\mathrm{Cu}(\mathrm{I})$ catalysis. Historically, since the mid-20th century, Huisgen ${ }^{49}$ studied this type of reaction in more details. The Huisgen reaction results in a 1,4- (22) and 1,5-disubstituted (23) isomeric mixture, however the $\mathrm{Cu}(\mathrm{I})$ catalyzed click reaction under mild reaction conditions results selectively in 1,4-disubstituted triazoles (22) in high yield.

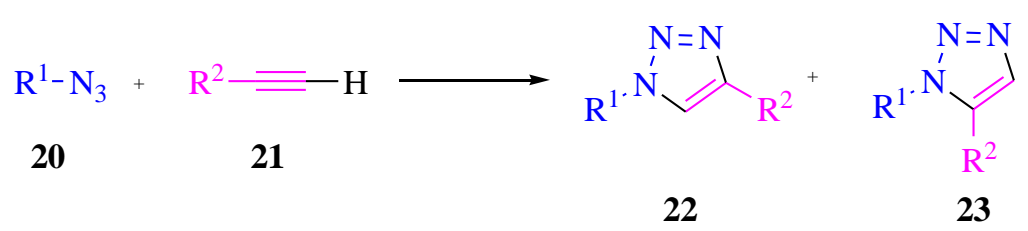

Scheme 6. Huisgen click chemistry

The advantage of click chemistry is that it can be achieved at a wide temperature $\left(0-160{ }^{\circ} \mathrm{C}\right)$ and $\mathrm{pH}$ ranges $(\mathrm{pH}=4-12)$, and the copper $(\mathrm{I})$-catalyzed conversion rate is ca. $10^{7}$ times greater than that of the classic version. It can be performed even at room temperature in a few hours, and it can be carried out in many organic solvents or even in water as well. 
Many copper-containing catalysts can be used for the $\mathrm{CuAAC}$ reaction. $\mathrm{Cu}(\mathrm{I})$ ions can be added directly to the reaction mixture in the form of a salt, ${ }^{50-52}$ but in this case an amine base or higher temperature is required to assist to the formation of the $\mathrm{Cu}(\mathrm{I})$-acetylide complex. $\mathrm{Cu}(\mathrm{I})$ ions can also be made in situ from $\mathrm{Cu}(\mathrm{II})$ ions, most commonly $\mathrm{CuSO}_{4} \cdot 5 \mathrm{H}_{2} \mathrm{O}$ is used together with sodium ascorbate as a reduction agent. ${ }^{53}$ When using elemental copper (metal fiber, powder, nanoparticles) $)^{54,55}$ the desired $\mathrm{Cu}(\mathrm{I})$ ions are formed on the surface by oxidation.

The most important role of the solvent or solvent mixture in the CuAAC reaction is to make the substrates and the catalyst soluble in order to react quickly. Polar solvents favor the formation of bonding with the heteroatom, they also help dissolve the substrate and the substrates, but if the substrate is highly nonpolar then toluene, dichloromethane or even the more polar tetrahydrofuran can be used. ${ }^{46}$

The mechanism of CuAAC reaction is still unclear, but it is supposed to be a sequence of multi-step reactions shown in the Scheme $7 .{ }^{56}$ In the first step, a $\pi$-complex forms between copper(I) ion (i) and the terminal alkyne (ii) significantly reducing the $\mathrm{pK}_{\mathrm{a}}$ of alkyne (about 9 to 10 units), therefore the hydrogen of alkyne becomes sufficiently acidic to deprotonate and copper(I)-acetylide (iii) forms in aqueous medium as well. In the next step, the nitrogen atom of the organic azide (iv) (in the prescribed mesomeric resonance structure the one containing negative charge) is coordinated to the copper center and displaces a ligand (v). Subsequently, the more distant nitrogen of the azide interacts with the C-2 carbon atoms of acetylene and a six-membered copper metallacycle (vi) is formed by intramolecular cyclization.

The formation of this intermediate with the unusual structure is an endothermic process, but the need for activation energy is considerably lower than that of a catalyst-free transformation, which explains the seven-magnitude velocity increase (confirming the name "click reaction" for this transformation). In the last steps of the reaction, a copper triazolyl derivative (vii) is formed by a ring closure, and by protonating it, the desired product (viii) is formed besides the regeneration of the active form of the catalyst. 


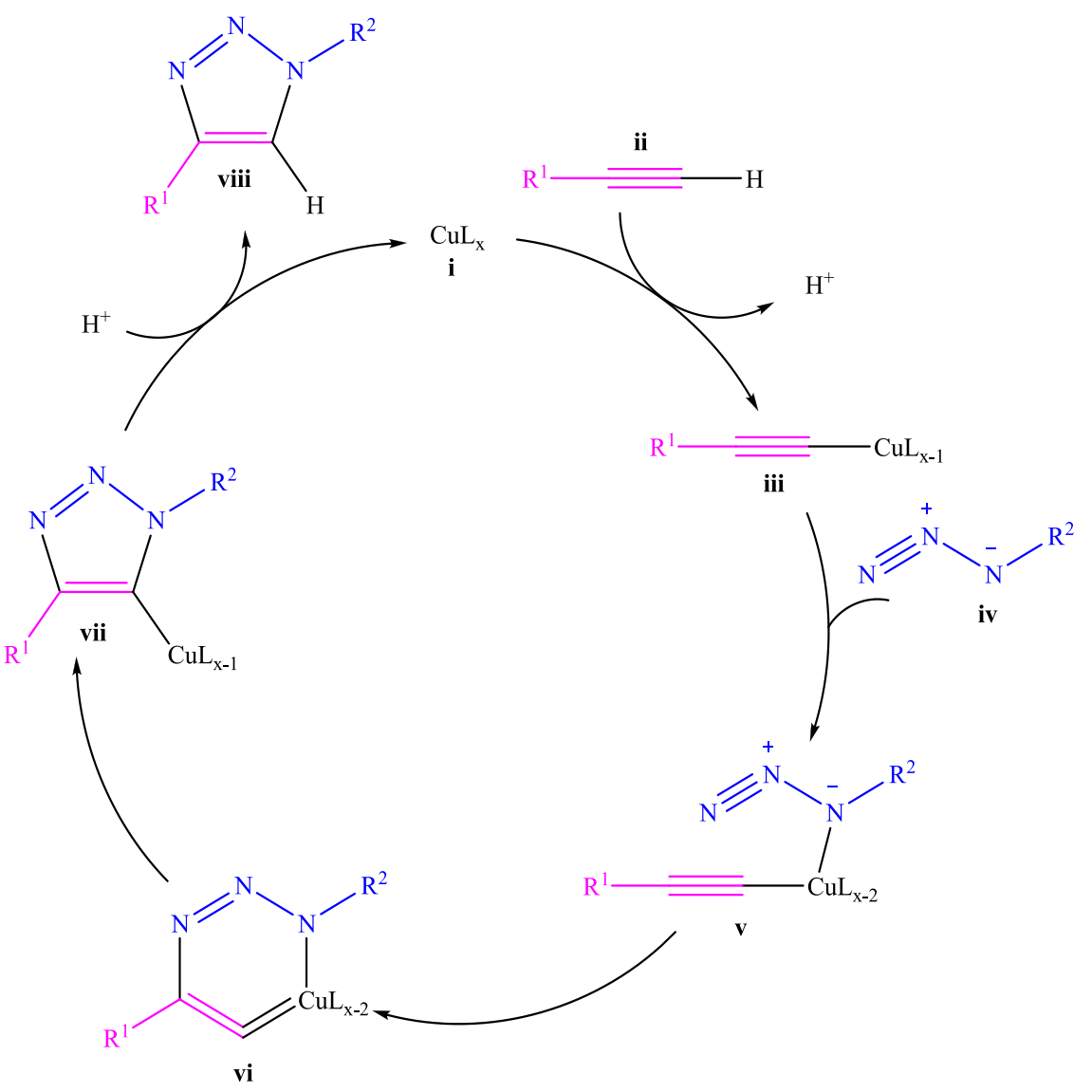

Scheme 7. The proposed mechanism of the alkyne-azide click reaction

Thanks to the beneficial properties of the click reaction, it became a preferred method in several areas of chemistry. The triazole moiety has a high similarity to peptide bonding, e.g. it is capable of forming $\mathrm{H}$-bonds, however it is chemically and metabolically stable, unlike the peptides. $^{53}$

There are already number of literature examples of the synthesis of antiproliferative steroidal triazoles ${ }^{41,57-64}$ and the triazole moiety is also used as a linker arm in bioconjugates owing to its high proteolytic and metabolic stability. There are lots of examples in literature for triazole-containing sugar derivatives, that have anticancer, ${ }^{65-67}$ antiviral, ${ }^{68-70}$ antimicrobical ${ }^{71-74}$ effects and are glycosidase and glycosyltransferase inhibitors. ${ }^{75-77}$ Among the nucleoside-triazoles there are ones with antiviral, ${ }^{78,79}$ anticancer, ${ }^{80,81}$ antimicrobial, ${ }^{81}$ antifungal, ${ }^{82}$ antibacterial, ${ }^{83}$ antitubercular ${ }^{84,85}$ effects. Therefore, click chemistry became a novel approach to the synthesis of drug molecules that can accelerate the drug developement process by making conjugates under relatively mild conditions even from sensitive molecules. 


\subsection{Monosaccharides, glycosyl azides and glycoconjugates}

Carbohydrates are the most abundant bioorganic compounds in the world. Their role includes energy storage, structural materials of cell walls, intermediates in metabolic processes, RNA and DNA building blocks etc. The most simple carbohydrates are the monosaccharides which are polyhydroxyaldehydes or -ketones and consist of three or more carbon atoms (the most frequent ones contain five or six carbons).

There are several possibilities for the derivatization of monosaccharides to obtain compounds that are suitable for conjugation purposes. Among them, glycosyl azides are important and versatile derivatives in carbohydrate chemistry. Due to their dipolar characteristics the azide groups work both as electrophiles and as nucleophiles so they easily participate in dipolar cycloaddition reactions. Since the azido group is relatively stable, therefore it can be used as starting material for the production of several nitrogen-containing compounds like amines, ureas, carbodiimides etc. ${ }^{86}$

The first glycosyl azide was synthesized by Bertho in $1930 .{ }^{87}$ Since that time, several methods have been developed for the production of monosaccharide-containing azido group in different positions. For the conversion of a carbohydrate into an azide, the nucleophilic substitution of a good leaving group by azide ion is a common approach which can happen at the anomeric, primary or a secondary carbon atom as well. Converting acetylated glycosyl halides (24) to glycosyl azides (25) with sodium azide is a widely used method for making glycosyl azides. ${ }^{88}$

The homogenous and one-phase reaction in DMF requires high temperature ${ }^{89}$ but phase transfer catalysis allows for milder reaction conditions. ${ }^{90}$ The disadvantage of this method is the instability of glycosyl halides, besides their actual production method. Therefore a process has been developed wherein the peracetylated glycosyl acetate (26) is directly converted to a glycosyl azide (27) with trimethylsilyl azide in the presence of a Lewis acid catalyst. ${ }^{91}$ 


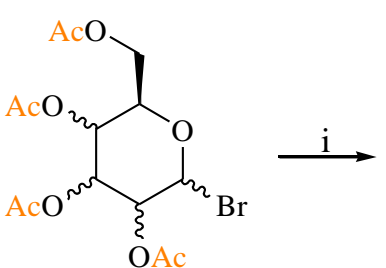

24

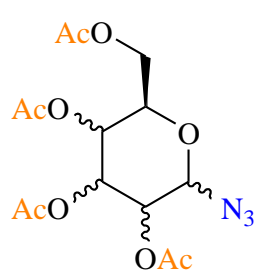

25
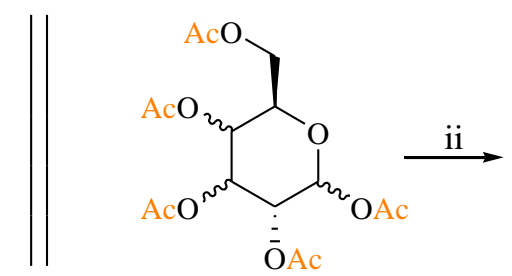

26

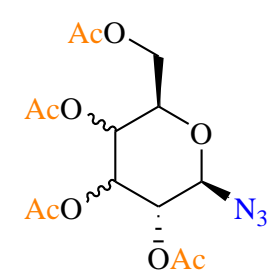

27

Scheme 4. Synthesis of azido-monosaccharides $(\mathbf{2 5}, \mathbf{2 7})$. Reagents: (i) $\mathrm{NaN}_{3}$, DMF, $100{ }^{\circ} \mathrm{C}, 2$ h; (ii) $\mathrm{Me}_{3} \mathrm{SiN}_{3}, \mathrm{SnCl}_{4}, \mathrm{CH}_{2} \mathrm{Cl}_{2}, 24 \mathrm{~h}$.

In the $\mathrm{S}_{\mathrm{N}} 1$-mechanism reaction, we can expect an anomeric mixture, however, in the case of carbohydrates containing acyl protecting group in position 2, 1,2-trans-configured azide is formed due to the acyl neighbouring group participation. Another easy possibility for the synthesis of carbohydrate azides is the modification of the primary hydroxy groups in sugars. To make the modification on this end, first the protection of the anomeric hydroxy group is needed (e.g. by acetal formation), then the tosyl-azide exchange on the primary hydroxy group is easily achievable without the protection of the secondary hydroxy groups. From a reactivity point of view, Nature also favours the anomeric position, so in a potential biocompatible conjugation this position seems to be beneficial (it has also synthetic chemical advantage), but it is important that if a glycosyl azide is clicked with a conjugation intent then how stable it will be. It is also an important question whether after the conjugate preparation any protecting groups can be removed without compromising the two parts of the linking element.

Houston et al. ${ }^{92}$ studied the stability of glycosyl triazoles (Scheme 5) toward reaction conditions commonly used in carbohydrate chemistry. Silyl, trityl, acetyl, benzoyl, and benzyl protecting groups were all incorporated smoothly onto the alcohol moiety of $\mathbf{2 8}$ to generate compounds 29-33, respectively, with the triazole linkage remaining intact. Reaction conditions to remove these protecting groups were also compatible with the triazole linkage, either regenerating 28 or the globally deprotected analogue 34. Protection and deprotection yields were excellent. The azide displacement of the crude mesylated intermediate from compound $\mathbf{2 8}$ to form triazole azide (31) provides a system for carrying out iterative click reactions. 


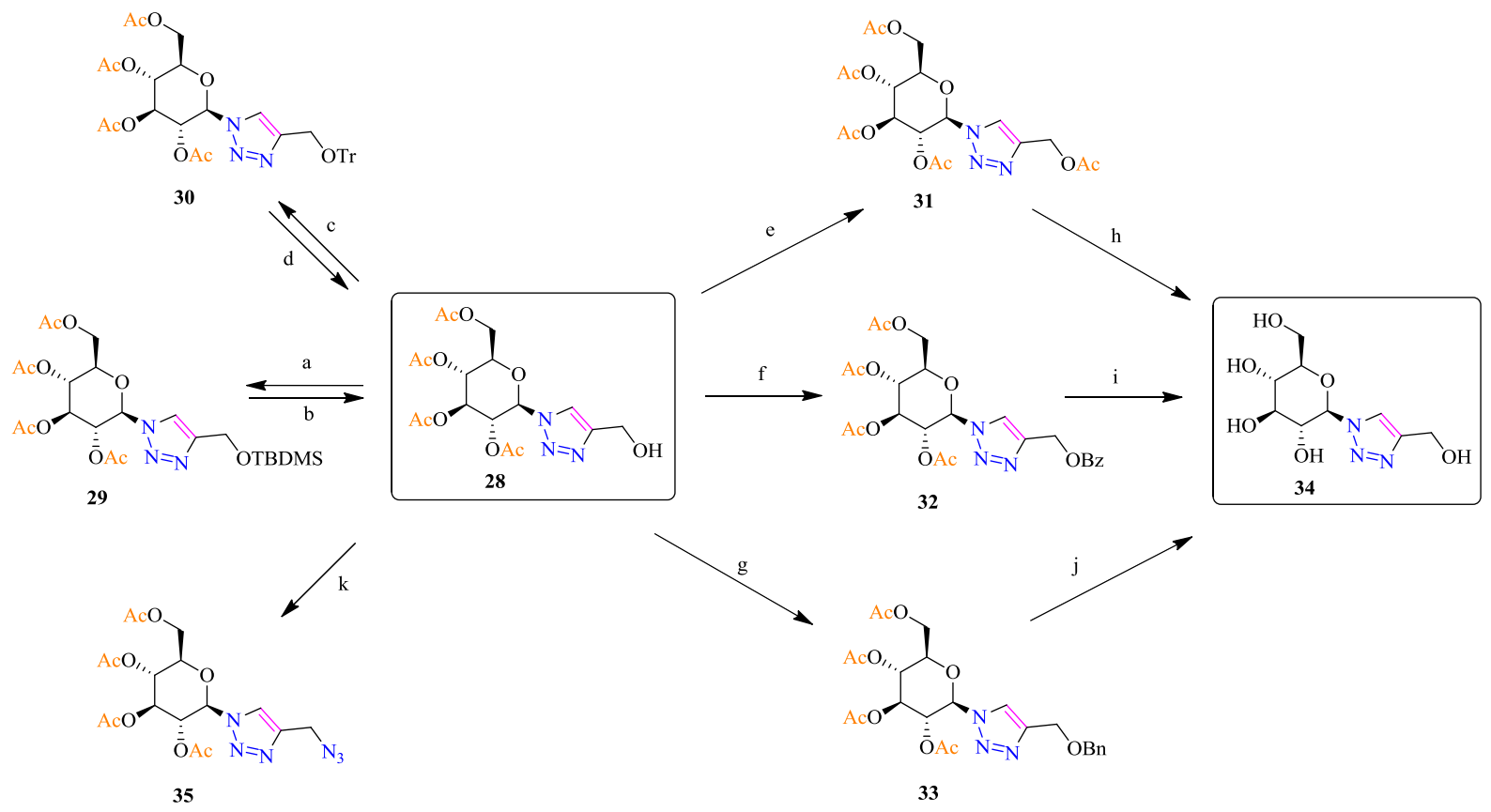

Scheme 5. Stability of glygosyl triazoles. Reagents: (a) tert-butyldimethylsilyl chloride, imidazole, $\mathrm{CH}_{2} \mathrm{Cl}_{2}$; (b) TBAF, THF; (c) TrCl, pyridine; (d) camphorsulfonic acid, $\mathrm{CH}_{2} \mathrm{Cl}_{2}$; (e) $\mathrm{Ac}_{2} \mathrm{O}$ /pyridine; (f) $\mathrm{BzCl}, \mathrm{Et}_{3} \mathrm{~N}, \mathrm{CH}_{2} \mathrm{Cl}_{2}$; (g) (i) $\mathrm{NaOCH}_{3}, \mathrm{MeOH}$; then (ii) $\mathrm{NaH}, \mathrm{BnBr}, \mathrm{DMF}$; (h) $\mathrm{NaOCH}_{3}, \mathrm{MeOH}$; (i) $\mathrm{NaOCH}_{3}, \mathrm{MeOH}$; (j) $\mathrm{H}_{2}, 30 \% \mathrm{Pd}(\mathrm{OH})_{2} / \mathrm{C}, \mathrm{MeOH} / \mathrm{CH}_{2} \mathrm{Cl}_{2}$; (k) (i) $\mathrm{MsCl}, \mathrm{Et}_{3} \mathrm{~N}, \mathrm{CH}_{2} \mathrm{Cl}_{2}$; then (ii) $\mathrm{NaN}_{3}$, DMF.

The new substance that is formed between a sugar and another bioactive compound is called glycoconjugate. Glycoconjugates play important roles in many biological processes, ${ }^{93,94}$ including cellular recognition in the case of inflammation, ${ }^{95,96}$ tumor metastasis, ${ }^{97}$ immune respons, ${ }^{98,99}$ and bacterial or viral infections. ${ }^{93}$

Steroid-sugar conjugates can enhance the transport of polar molecules across cellular membranes ${ }^{100}$ and there are biologically active ones among them with cytotoxic, ${ }^{101-103}$ antifungal, ${ }^{104}$ anti-inflammatory ${ }^{105}$ and antiviral activities. ${ }^{106,107}$ Sugars per se have no therapeutic action in glycosylated steroid conjugates but they have a dramatic effect on the physical, chemical and biological properties of bioconjugates and the sugar moieties act as molecular elements that control the pharmacokinetics of a drug, such as absorption, distribution, metabolism and excretion. ${ }^{108}$ As it was reported, the number, location and type of sugar units in steroidal glycoalkaloids, even with identical aglycons, play an important role in the antiproliferative activity. ${ }^{109}$ Similarly, subtle sugar modifications can dramatically, and 
independently modulate both the cytotoxic properties and the $\mathrm{Na}^{+} / \mathrm{K}^{+}$-ATPase inhibitory properties of cardiac glycosides. ${ }^{110}$

\subsection{Nucleosides and their derivatives}

The nucleic acids are constructed by nucleotides in the way that the 5'- and 3'-hydroxy groups of the pentoses in the polynucleotide chain are linked by phosphoric acid diester bonding to form a linear polymer chain. On carbon atom 2' of 2'-deoxy-D-ribose the hydroxy group is missing in DNA and there is a free hydroxy group in position 2 ' in RNA (36-43, Figure 3). The pyrimidine bases form an $\mathrm{N}$-glycosidic bond with their nitrogen atom in position 1 while the purine bases do it with their nitrogen in position 9 and in both cases $\beta$-glycosidic bonds are formed.

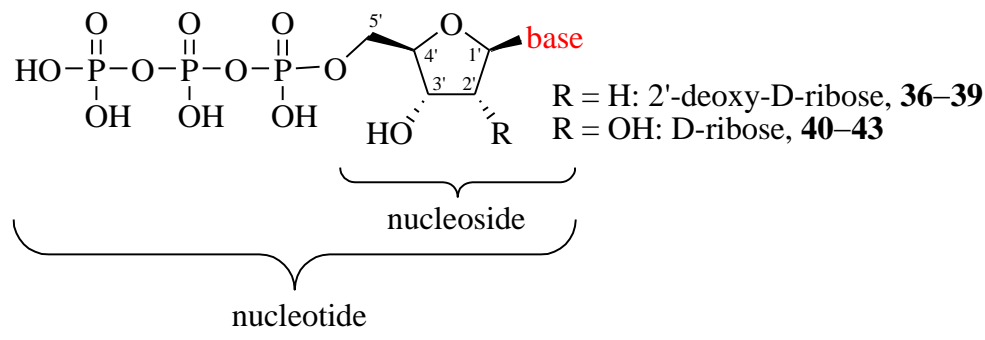

DNA bases<smiles>CCn1cnc2c(N)ncnc21</smiles><smiles>CCn1cnc2c(N)ncnc21</smiles>

40<smiles>CCn1cnc2c(=O)[nH]c(N)nc21</smiles>

37<smiles>CCn1cnc2c(=O)[nH]c(N)nc21</smiles>

41<smiles>CCCCn1ccc(N)nc1=O</smiles>

38<smiles>Cn1ccc(N)nc1=O</smiles>

42<smiles>Cc1cn(C)c(=O)[nH]c1=O</smiles>

39<smiles>Cn1ccc(=O)[nH]c1=O</smiles>

43

Figure 3. Structure of DNA (36-39) and RNA (40-43) nucleoside monomers

The backbone of the polymer molecule is the pentose phosphate chain, and the order of the hanging nucleobases determine the primary structure of both DNA and RNA. These 
compounds are responsible for storing the genetic code (DNA), as well as for transferring and translating (RNA) it into proteins. The information is carried by the sequence of nucleobases and the two polynucleotide chains of DNA form a double helix, twisting side by side, the bases pair together with hydrogen bonds. Adenine can only form a base pair with thymine, while guanine can only do it with cytosine. To create this regular structure, it is necessary for the structure of the two folding chains to match each other exactly. The base sequences of the two strands are complementary, so the base sequence of one strand strictly determines the sequence of the other strand. Double-stranded DNA allows a cell to divide into two new cells with the same genetic information as both strands can serve as a template to re-create the original double helix. RNA, on the other hand, initially is single-stranded because it is used for the transfer of information (mRNA) and as a creator of molecular machinery for translation (rRNA, tRNA). In comparison with DNA, RNA exhibits more variable polymorphism than DNA.

The other important class of nucleotides containing natural molecules in cells are the nucleotide coenzymes, which are small molecules made of one or two nucleotide units, assistants for enzymes that catalyze certain metabolic processes. These are needed as reagents or reactants for the enzymes that catalyze biological processes. The most important of them are adenosine 5'-triphosphate (ATP) and adenosine 5'-diphosphate (ADP) which act as phosphorylation agents and transient energy storage molecules, the cyclic adenosine monophosphate (cAMP), which is an important element of signaling processes, the acetylcoenzyme A (CoA), which is the coenzyme of acetylation/deacetylation processes and the NAD/NADH coenzymes and their phosphorylated analogues (NADP/NADPH), which are oxidizing/reducing agents in redox reactions. It is important to note that all of the above coenzymes contain an adenosine unit which has the potential to bind the coenzyme to the enzyme. $17 \beta-H S D 1$ is a NADPH-dependent oxidoreductase enzyme which plays a key role in the biosynthesis of estrogens by catalyzing the conversion of estrone to estradiol. Inhibition of the enzyme may be an alternative to the control of many estrogen-dependent tumor diseases.

The above processes are key to the lives of cells, viruses, bacteria and tumor cells that attack the healthy ones. Therefore, influencing these physiological processes and interacting with enzymes, receptors or other proteins involved in these processes can be of therapeutic significance if it is possible to exploit the difference between the healthy and tumorous cells 
or the differences in the biochemical processes/enzymes of alien organisms (bacteria, viruses) and of the own cells of the body. For example, bacteria/viruses often change their genes to survive, meaning that their polymerase enzymes readily accept non-natural nucleotides, as opposed to human polymerase enzymes, which are far more conservative. Therefore, modified nucleotides (and their precursors, nucleosides, nucleobases) that affect the original properties of the nucleic acids (e.g. H-bonding pattern modifiers or 3'-deoxy chainterminators) will selectively damage the viral DNA, RNA. Such antiviral agents are, for example, the 5-substituted pyrimidine derivatives and the 3'-deoxy-modified nucleosides (5fluorouracil, 3'-azidothymidine). ${ }^{111-113}$

Beside the above mentioned simple nucleobase or nucleoside therapeutics, a number of nucleoside conjugates are also found in literature, which are either enzyme inhibitors, ${ }^{114}$ or are

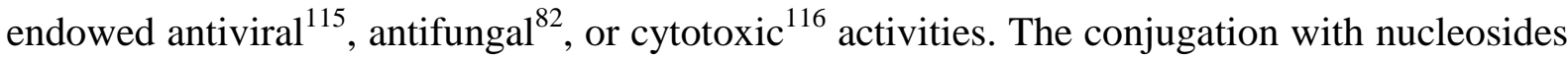
may significantly increase the efficiency and selectivity of the potential active anticancer ingredients. On one hand, cancer cells require higher amount of nucleoside building blocks for their proliferation, therefore they have significantly higher uptake of nucleosides by the different nucleoside transporters. ${ }^{113,117,118}$ This fact can be used to prepare nucleosides, as targeting moieties covalently bound to anticancer drug molecules which will be selectively enriched in cancer cells. On the other hand, the advantage of using a nucleoside-conjugate could be the higher activity on targeted enzymes overrepresented in cancer cells. There is an option to increase the selectivity of a therapeutic drug if a bisubstreate inhibitor is prepared wherein a portion of the conjugate is a nucleoside coenzyme mimic. Poirier et al. synthesized adenosine-estrone bioconjugates ${ }^{7,119-121}$ and Iyer et al. have also obtained some adenine- and adenosine-containing bioconjugates, ${ }^{122}$ in which cases a linker molecule was inserted between the nucleoside and the steroid moieties using an ester connection and they used these compounds as enzyme inhibitors against $17 \beta-H S D 1$.

However, in order to form nucleoside-drug conjugates nucleoside building blocks are needed that can be selectively coupled to the drug molecules containing a high number of diverse functional groups. The 5' position of the nucleosides is best suited for the formation of an appropriate functional group. Considering a very selective alkyne-azide click reaction for making bioconjugates, the elaboration of azide group in nucleosides is simplest by the replacement of the 5'-hydroxy group. This transformation generally involves many side 
reactions and results in low yields. The preparation of 5'-azido-5'-deoxy nucleosides in the commonly used two-step method 5'-O-activation by introduction of tosylate, ${ }^{123-127}$ mesylate, $^{123}$ halogen ${ }^{124,127-134}$ or other good leaving groups ${ }^{135,136}$ followed by azide substitution is hampered by several side-reactions and variable yields. The most relevant sidereactions are 3',5'-bis- $O$-tosylation followed by 3',5'-diazide formation, ${ }^{124} 4$ ',5'-elimination and $2,3^{\prime} / 5^{\prime}$-anhydronucleoside formation (in the case of pyrimidine nucleosides). ${ }^{131,136}$ As a rule, the yields of these transformations are highly dependent on the identity of the nucleobase (cytidine and especially guanine are troublesome), ${ }^{126,129-131,134,136}$ configuration of sugar moiety, ${ }^{124,137}$ protecting group pattern ${ }^{125}$ of the nucleobase and the sugar, steric congestion $^{128,132}$ and the actual method used. ${ }^{127,133,135}$ Hence, the overall yields of these reactions are usually not very high, generally around $40-60 \%$ or even lower. Alternatively, Mitsunobu reaction ${ }^{138-140}$ with hydrogen azide, trimethylsilyl azide or zinc azide-pyridine complex $^{141}$ is also a possible alternative to synthesize azides from nucleosides, provided that the sensitive sugar moieties survive these conditions. 


\section{Aims of this work}

The purpose of my work was to synthesize estrone-monosaccharide and estrone-nucleoside conjugates, in which the two components are linked by click reaction as a sequel of the previous results of the Steroid Chemistry Research Group.

First, azide derivatives needed to be made from the most simple monosaccharides (Dglucose, D-mannose, D-galactose, D-ribose) and nucleosides (DNA monomers), followed by coupling in a click reaction. In the case of monosaccharides, development of the azide functional group was designed to replace glycosidic or primary hydroxy groups, while for nucleosides the 5'-hydroxy groups.

The azide derivatives produced this way were expected to react with the estrone derivatives (D-secoestrone, $13 \alpha$ - and $\beta$-estrone) containing the propargyl functional group in positions 3 and 15, previously produced by the Steroid Chemistry Research Group, in the presence of a copper(I) catalyst.

The structure of the new compounds were planned to be investigated by structure elucidation methods $\left({ }^{1} \mathrm{H}\right.$ and ${ }^{13} \mathrm{C}$ NMR spectroscopy and mass spectrometry) and evaluated in vitro by means of MTT assays for antiproliferative activity against a panel of human adherent cancer cell lines (HeLa, MCF-7 and A2780); and the potential inhibitory activity of the new conjugates on human 17 $\beta$-HSD1 was anticipated to be investigated via in vitro radiosubstrate incubation. 


\section{Results and discussion}

\subsection{Chemical results}

\subsubsection{Synthesis of azido-monosaccharides}

In the first part of my work, I have obtained azidated monosaccharide derivatives of Dglucose, D-mannose, D-galactose and D-ribose, the most abundant monosaccharides in Nature, to prepare the relevant building blocks. We aimed at synthesizing the azide derivatives in which the azide group is built into their glycosidic position or in place of their primary hydroxy groups (position 6 in hexopyranoses and position 5 in ribofuranoses). The most common ways for the preparation of glycosyl azides are either an $\mathrm{S}_{\mathrm{N}} 2$ substitution of a protected glycosyl halide by sodium azide at high temperature in $\mathrm{DMF}^{88}$ or an $\mathrm{S}_{\mathrm{N}} 1$ substitution of a peracetylated monosaccharide under mild conditions using a Lewis acid catalyst and trimethylsilyl azide. ${ }^{86,142,143}$ We have chosen the latter method as all of our sugars contained a neighbouring participation group at position 2 ( $O$-acetyl or $O$-benzoyl) that can ensure the desired stereoselectivity. The primary hydroxy groups of the monosaccharides can be replaced to azides in a two-step procedure ${ }^{144}$ involving the introduction of a good leaving group (e.g. a tosyl) to the primary hydroxy and a subsequent azide substitution of the tosylate by sodium azide in DMF.

First, the hexoses studied were peracetylated according to a literature method ${ }^{144}$ to yield compounds 44-46 (Scheme 8). Next, the glycosidic $O$-acetyl groups were replaced with the azide group using tin tetrachloride as a Lewis acid catalyst and trimethylsilyl azide as the source of the nucleophilic azide ion to afford compounds 47-49.

The $S_{N} 1$ type substitution resulted in only 1,2-trans products due to the neighbouring group participation of the $O$-acyl group at position 2. For D-glucose and D-galactose the $\beta$ anomer, for D-mannose the $\alpha$-anomer formed in this way in $72-79 \%$ yields, respectively. The purity of the azide products and their quantities were sufficient for the subsequent conjugation reactions. 

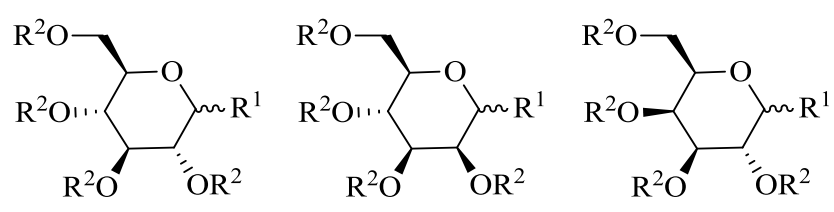

D-glucose

44

$47 \beta$
D-mannose

45

$48 \alpha$

$$
\begin{gathered}
\text { D-galactose } \\
46 \\
49 \beta
\end{gathered}
$$

Scheme 8. Synthesis of protected glycosyl azides (47-49). Reagents: (i) $\mathrm{Ac}_{2} \mathrm{O}, \mathrm{NaOAc}$; (ii) $\mathrm{SnCl}_{4}, \mathrm{Me}_{3} \mathrm{SiN}_{3}, \mathrm{CH}_{2} \mathrm{Cl}_{2}, 72-79 \%$.

In order to introduce the azide group to positions 6 (hexopyranoses) and 5 (pentofuranose), first the methyl glycosides of D-glucose, D-mannose and D-ribose (50-52, Scheme 9) were selectively tosylated in pyridine on their primary hydroxy groups without the protection of the secondary hydroxy groups. This distinction was allowed by the higher reactivity of the primary hydroxy groups over the secondary ones.


Scheme 9. Synthesis of 6-azido-6-deoxy-D-hexopyranose $(\mathbf{5 9 ,}, \mathbf{6 0})$ and 5-azido-5-deoxy-Dribofuranose (61) derivatives. Reagents: (i) $\mathrm{TsCl}$, pyridine; (ii) $\mathrm{BzCl}$, pyridine; (iii) $\mathrm{NaN}_{3}$, $\mathrm{LiBr}, \mathrm{DMF}, 65-71 \%$.

Unfortunately, the direct replacement of the tosyl group with azide in compounds 53-55 was not successful probably due to solubility reasons, therefore the secondary hydroxy groups were benzoylated first and then the tosyl-azide exchange has successfully occurred in all the fully protected monosaccharides (56-58) and resulted in the fully protected 6-azido-6-deoxyand 5-azido-5-deoxymonosaccharides (59-61). 


\subsubsection{The click reaction between azido-monosaccharides and D-secoestrones}

We know from initial results that the 3-O-benzyl ethers of D-secoestrone alcohol or oxime (63a,b Scheme 10) display substantial in vitro antiproliferative action against certain cancer cell lines in the low micromolar range. ${ }^{41,145}$

The starting compounds bearing phenolic hydroxy groups $(\mathbf{6 2 a}, \mathbf{b})$ did not influence the proliferation of the investigated cell lines. The cytostatic potential of benzyl ethers $(\mathbf{6 3 a}, \mathbf{b})$ was successfully improved by the introduction of a 1,2,3-triazole moiety between the benzyl and the hydroxy groups. The heterocyclic ring was introduced to C-3 via a short oxymethylene group applying CuAAC reaction. The resulting 3-O-[(1-benzyl-1H-1,2,3triazol-4-yl)methyl] derivatives $(\mathbf{6 5 a}, \mathbf{b})$ displayed submicromolar $\mathrm{IC}_{50}$ values against certain human reproductive adherent cancer cell lines. ${ }^{43}$ Therefore these two derivatives were chosen for later conjugation.

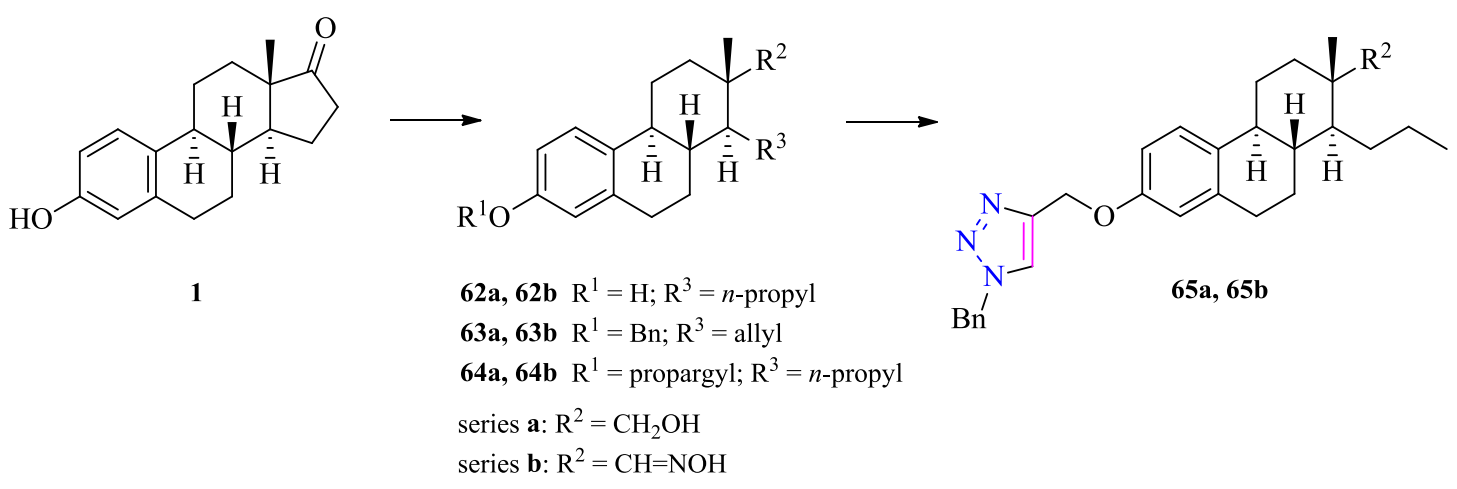

Scheme 10. The synthesis of estrone derivatives $(\mathbf{6 2 - 6 5})$ obtained earlier.

The azide group-containing monosaccharides (47-49 and 59-61) were coupled to the alkynecontaining D-secoalcohol (64a) and D-secooxime (64b) using similar CuAAC conditions by applying copper(I) iodide, triphenylphosphane and DIPEA as a base with a slight access of propargyl-D-secosteroid in toluene at boiling temperature until TLC showed quantitative conversions. 

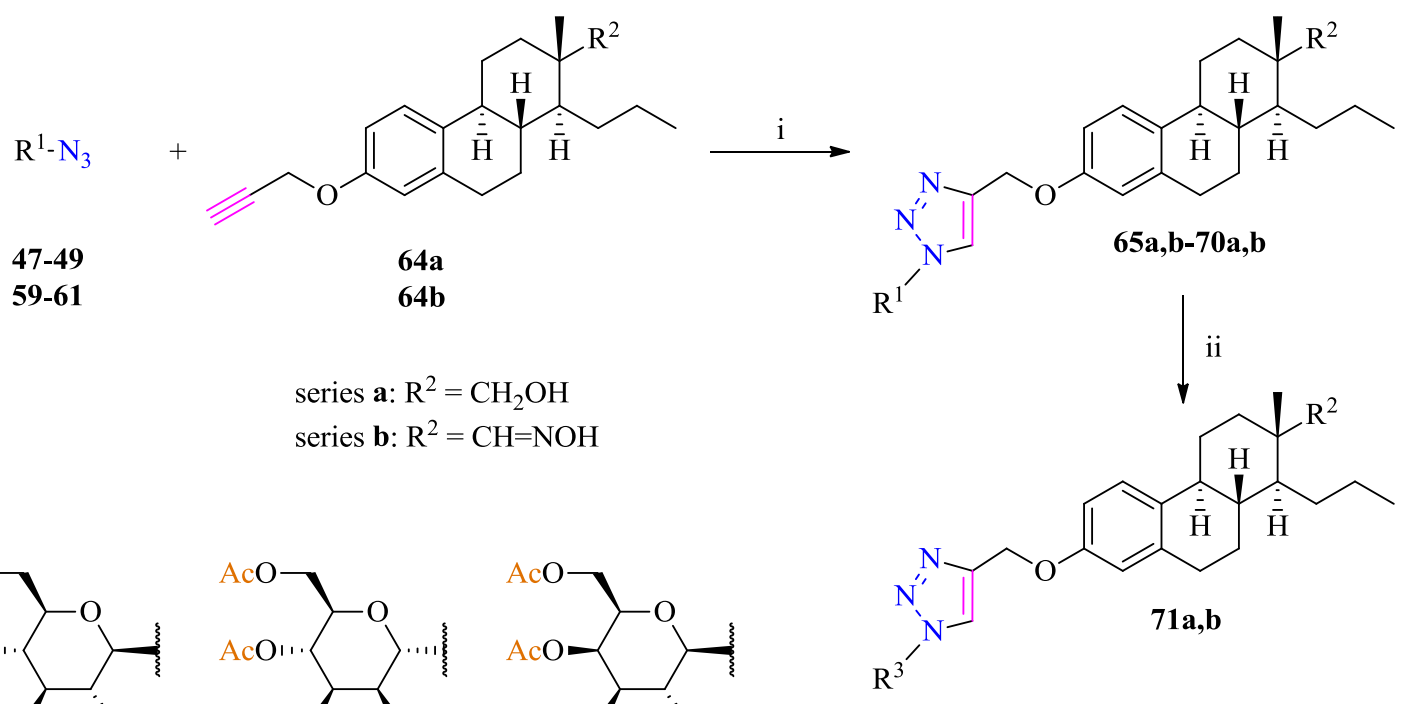

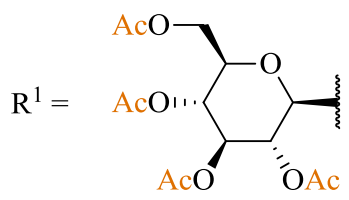

$47 \beta, 65 a, 65 b$

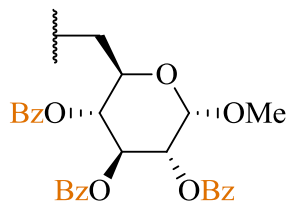

$59,68 a, 68 b$

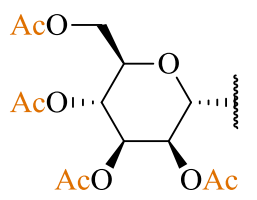

$48 \alpha, 66 a, 66 b$<smiles>[R6]O[C@H]1[C@H](O[18O])[C@@H](OC)O[C@H](CCC)[C@H]1OC</smiles>

$60,69 a, 69 b$

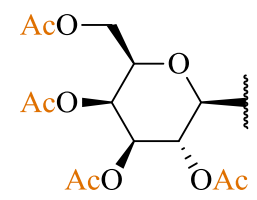

$49 \beta, 67 a, 67 b$<smiles>[R16]O[C@H]1[C@H](OC)[C@@H](OC)O[C@@H]1CC(C)C</smiles>

61, 70a, 70b

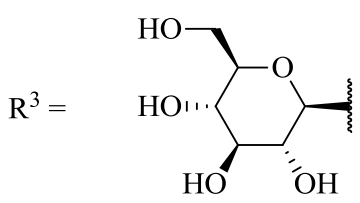

71a, 71b

Scheme 11. The synthesis of monosaccharide-D-secoestrone bioconjugates (65-71). Reagents: (i) $\mathrm{Cu}(\mathrm{I}),(\mathrm{Ph})_{3} \mathrm{P}$, DIPEA, toluene, reflux, 72-83\%; (ii) $\mathrm{NaOMe}, \mathrm{MeOH}, 76-82 \%$.

In case of two glucose-containing bioconjugates $(\mathbf{6 5 a}, \mathbf{b})$, which showed the best biological activities, the acetyl protecting groups were removed by the Zemplén's method ${ }^{146}$ using sodium methylate in methanol to obtain their unprotected derivatives (71a,b).

\subsubsection{Synthesis of 5'-azido-2',5'-dideoxynucleosides}

For the preparation of 5'-azido-2',5'-dideoxynucleosides, first we have followed the tosylazide replacement method based on the literature but the isolated yields were significantly lower in our hands owing to the formation of by-products (Scheme 12, path a) compared to those described in the literature, ${ }^{123-127}$ therefore we decided to protect the 3'-hydroxy groups (Scheme 12, path b). 
path a
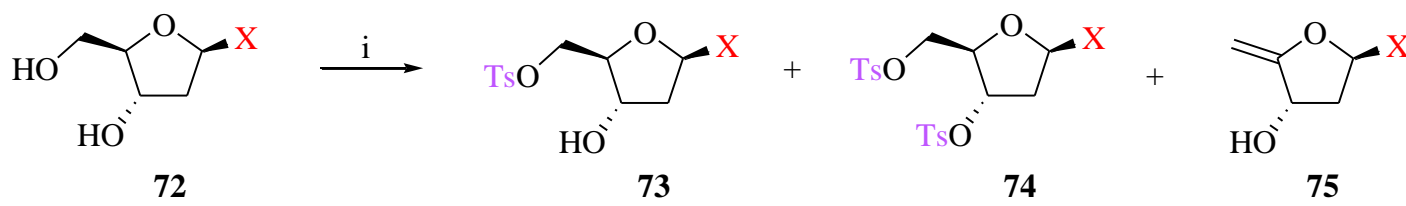

path $b$
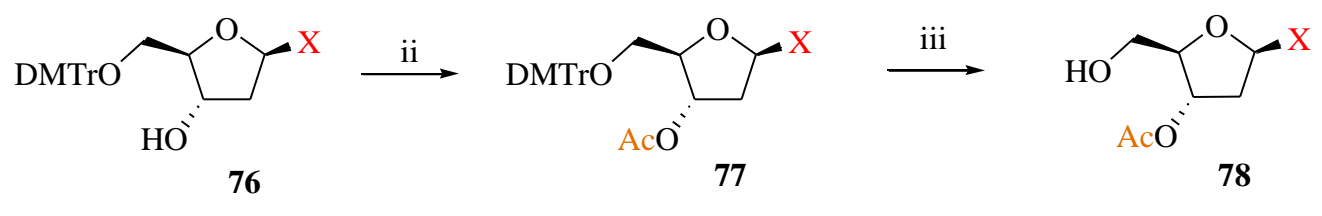

path c
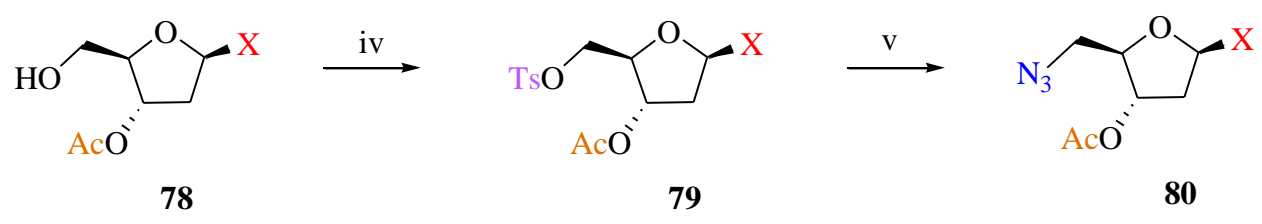

pathd<smiles>[X]C1C[C@H](O)[C@@H](CO)O1</smiles><smiles>[X]=Cn1cnc2c(N)ncnc21</smiles>

a

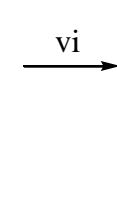<smiles>Cc1cn([N+](=O)[O-])c(=O)[nH]c1=O</smiles>

b<smiles>[X]C1C[C@H](O[W])[C@@H](CN)O1</smiles>

80

Scheme 12. Synthesis of 5'-azido-2',5'-dideoxynucleosides (80a-d). Reagents: (i) TsCl, pyridine; (ii) $\mathrm{Ac}_{2} \mathrm{O}$, pyridine; (iii) $\mathrm{BF}_{3} \cdot \mathrm{Et}_{2} \mathrm{O}, \mathrm{CF}_{3} \mathrm{CH}(\mathrm{OH}) \mathrm{CF}_{3}, \mathrm{CH}_{3} \mathrm{NO}_{2}$; (iv) TsCl, pyridine;

(v) $\mathrm{NaN}_{3}, \mathrm{LiBr}, \mathrm{DMF}, 76-85 \%$; (vi) $\mathrm{Ph}_{3} \mathrm{P}, \mathrm{EtO}_{2} \mathrm{CN}=\mathrm{NCO}_{2} \mathrm{Et}, \mathrm{Zn}\left(\mathrm{N}_{3}\right)_{2} \cdot 2$ py or $\mathrm{TMSN}_{3}$.

Although the 3'-protection requires two more steps (3'-O-acylation and 5'-O-deprotection when the starting material is a $5^{\prime}-O$-(4,4'-dimethoxytrityl)- $N$-acyl-protected nucleoside), it helps to avoid bis-3',5'-O-tosylation and increases the solubility of the nucleosides which might also be a reason of the low yields. We have chosen acetyl protection of the 3'-hydroxy group because it was considered to be compatible with the final deprotection of the steroidnucleoside conjugates. The crude acetylated material was used for the 5 '- $O$-DMTr deprotection without chromatographic purification. As a commonly used 3\% trichloroacetic 
acid/dichloromethane deprotection resulted in a considerable amount of depurination sideproducts (mainly in the case of 2'-deoxyadenosine) therefore we have changed the reagent to a deprotection mixture containing the Lewis acid boron trifluoride in a 1,1,1,3,3,3hexafluoroisopropanol-nitromethane solution $^{147}$ (Scheme 12, path b). Using the 5'-OH containing, 3'-O-acetyl-protected nucleosides $(\mathbf{7 8 a}-\mathbf{d})$ we have carried out the 5 '-O-tosylation in pyridine at room temperature and after purification the tosyl-azide exchange reaction in DMF at $50{ }^{\circ} \mathrm{C}$ (Scheme 12, path c). We have obtained better yields compared to the ones without 3'-O-protection but the yields were still not too high, around 50\%. Moreover, in case of 2'-deoxyguanosine, the tosylation reaction gave a very low yield $(<10 \%)$, probably due to the very poor solubility. Therefore we stopped our attempts to obtain the tosylate (79d) and its further derivatization was also abandoned. As we were not satisfied with the isolated yields of azidonucleosides we attempted to improve them by applying Mitsunobu reaction to obtain the 5'-azides directly in a one-step reaction from the 3'-O-acetyl-protected nucleosides (Scheme 12, path d). The Mitsunobu reaction requires an acid component which should be $\mathrm{HN}_{3}$ in our case but we did not want to use a Brønsted acid to avoid the potential glycoside bond cleavage therefore, instead of the protic acid, we have tried two Lewis acids, $\mathrm{Zn}\left(\mathrm{N}_{3}\right)_{2} \cdot 2$ py or trimethylsilyl azide which were also used for Mitsunobu reactions. ${ }^{138-141}$ Although we have tried to optimize the reaction conditions by varying the starting materials (2'-deoxyadenosine, thymidine, 2'-deoxycitidine, 2'-deoxyguanosine), the azodicarboxylate reagents (diethyl or diisopropyl esters), the azide-containing acids and also applying different temperatures $\left(0{ }^{\circ} \mathrm{C}\right.$ and room temperature), we were unable to detect the formation of a considerable amount of 5'-azido-2',5'-dideoxynucleosides. Only in case of 2'-deoxyadenosine we have got a $20 \%$ of the desired product, by using trimethylsilyl azide reagent at $0{ }^{\circ} \mathrm{C}$ in a $1 \mathrm{~h}$ reaction time. In all other cases only the 5'-O-trimethylsilylated nucleoside side-products were identified by mass spectrometric analyses of the newly appearing TLC spots. These side-products have decomposed during the work up procedure giving back the starting nucleosides. As the Mitsunobu reaction failed to produce the desired 5'-azido-2',5'-dideoxynucleosides, we eventually have used the 3 '- $O$-protected tosyl-azide exchange route to prepare the required amounts of 5'-azido-2',5'-dideoxynucleosides $(\mathbf{8 0 a}-\mathbf{c})$ for the conjugation reactions from crude tosylates (79a-c) (Scheme 12, path c). 


\subsubsection{The click reaction between azido-nucleosides and a 13a-estrone derivative}

We learned during our preliminary research that one of the most potent antiproliferative compounds was 3-O-[(1-benzyl-1H-1,2,3-triazol-4-yl)methyl]-13 $\alpha$-estrone bearing intact ring $\mathrm{D}\left(\mathbf{8 1}\right.$, Figure 4). Based on its remarkable cytostatic potential $\left(\mathrm{IC}_{50}=0.3-0.9 \mu \mathrm{M}\right),{ }^{63}$ this $13 \alpha-$ estrone triazole conjugate $\mathbf{( 8 1 )}$ was used as a model compound for further derivatization with dual aim: to improve its cell growth-inhibitory potential to nanomolar scale, and to enhance its tumor selectivity.

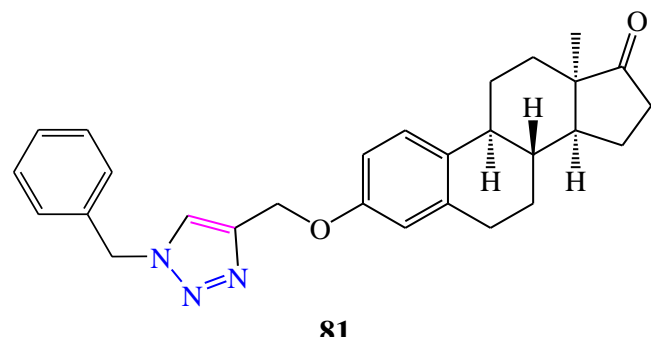

Figure 4. Structure of 3-O-[(1-benzyl-1H-1,2,3-triazol-4-yl)methyl]-13 $\alpha$-estrone (81)

We decided to conjugate the obtained nucleosides to such estrone derivative that contains propargyl functional group at position 3. Therefore, 5'-azido-2',5'-dideoxynucleosides $(\mathbf{8 0 a}-\mathbf{c})$ were connected to 3-O-propargyl-13 $\alpha$-estrone ${ }^{63}(\mathbf{8 2})$ in a CuAAC reaction (Scheme 13). The solvent of the click-reaction was toluene (thymidine and 2'-deoxyadenosine) or anhydrous tetrahydrofuran (2'-deoxycytidine) due to solubility problems. Initially, we have followed the commonly used literature methods, ${ }^{58,123,125}$ using $0.01-0.2$ equivalent of copper(I) iodide catalyst along with 0.2 equivalent of triphenylphosphane and DIPEA but the reaction did not proceed well even if higher temperature, different solvents and prolonged reaction times (3 days) were applied. The highest reaction temperature was limited to as high as $50{ }^{\circ} \mathrm{C}$, to avoid the potential side-reactions in the nucleoside moieties.

We supposed that the reason of the very low yields ( $<30 \%$ according to TLC monitoring) could be the high complex-forming affinity of the $N$-acyl-protected nucleosides which trapped the $\mathrm{Cu}(\mathrm{I})$ ion catalyst. ${ }^{148}$ Therefore we increased the amount of the $\mathrm{Cu}(\mathrm{I})$ catalyst and DIPEA to 1.5 equivalent and eliminated triphenylphosphane from the reaction mixture. With this modified method all conjugation reactions were complete in one day at $50{ }^{\circ} \mathrm{C}$ according to TLC and the final isolated yields of protected conjugates $(\mathbf{8 3 a}-\mathbf{c})$ were acceptable. 


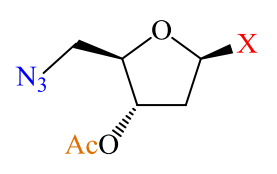

80a-c<smiles>[Z1]Nc1ncnc2c1ncn2C#[X]</smiles>

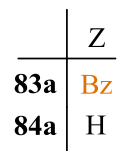

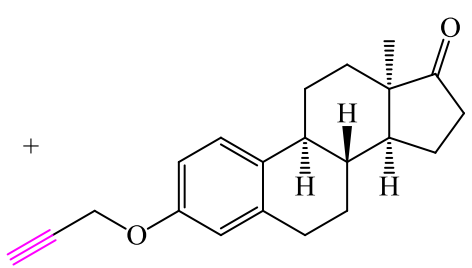

82<smiles>Cc1cn(C)c(=O)[nH]c1=O</smiles>

83b 84b<smiles>CCNc1ccn(CC)c(=O)n1</smiles>

\begin{tabular}{l|l}
$\mathrm{Z}$ \\
\hline $\mathbf{8 3 c}$ & $\mathrm{Bz}$
\end{tabular}

$84 \mathrm{c}$
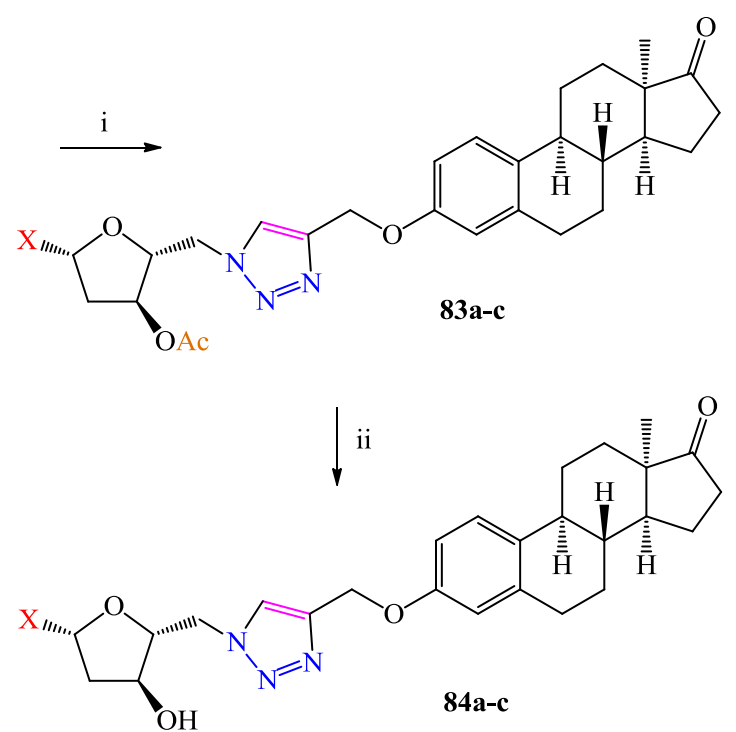

Scheme 13. CuAAC conjugation reaction of 3'- $O$-acetyl-5'-azido-2',5'-dideoxynucleosides $(\mathbf{8 0 a}-\mathbf{c})$ and 3-O-propargyl-13 $\alpha$-estrone (82). Reagents: (i) CuI, DIPEA, toulene or THF, 61$76 \%$; (ii) $\mathrm{NH}_{3} / \mathrm{MeOH}, 81-89 \%$.

The synthesized bioconjugates contained the 3'-O-acetyl and $\mathrm{N}$-benzoyl protecting groups in their nucleoside moiety which helped to increase the solubility in the synthetic reactions but for the biological experiments we needed the unprotected nucleoside conjugates. Aqueous ammonia is commonly used for the deprotection of these protecting groups in the nucleic acid chemistry but the protected conjugates were not soluble in the aqueous media therefore this deprotection method failed. We have tested the Zemplén deacetylation protocol using $0.1 \mathrm{M}$ of sodium methylate in methanol but only the acetyl group was removed from the 3'-hydroxy group. Finally, $4 \mathrm{M}$ ammonia solution in methanol was used at $50{ }^{\circ} \mathrm{C}$ which removed all the acyl protecting groups of the conjugates in 16 hours to yield conjugates $(\mathbf{8 4 a}-\mathbf{c})$.

\subsubsection{Synthesis of 5'-linker-containing azido-nucleosides}

The transformation of 2'-deoxyguanosine to the corresponding 5'-deoxy-5'-azido-2'deoxyguanosine could not be performed with any of the methods described in the literature. Thus we have aimed at a method that has been developed whereby the azide groups were incorporated into the 5 '-position resulting in significantly better yields compared to all other previous methods, and we were able to produce all eight derivatives of native nucleosides in 
the D-ribo and 2-deoxy-D-ribo series. Our aim was to produce general nucleoside building blocks that can be coupled to any substrate containing a terminal alkyne functional group. Since the 5 ' position of the nucleosides is best suited for the formation of a proper functional group, a non-natural (enzyme-resistant), non-ionic (easier cell membrane penetrating) linker moiety was foreseen with the corresponding functional group (azide group) at the terminus. The azido linker molecule was engineered to be bound to the nucleoside with carbamate bond. Although, the literature contains examples about the preparation of nucleoside conjugates applying ester bond or most preferably phosphate ester bonds to attach the nucleoside to a linker or the other part of the conjugate, ${ }^{10,149}$ the enzymatic stability under in vivo circumstances of these natural bonds are weak while the penetration into cells of phosphodiesters are more difficult due to their negative charge. On the other hand, the disadvantage of the carboxylic acid ester linkage is that it is incompatible with the removal of protecting groups commonly used for the synthesis of bioconjugates. The carbamate bond is stable enough to withstand the deprotection conditions applied in nucleosides and have higher enzymatic resistance in vivo.

To introduce the carbamate linker with azide terminus, a linker containing azide on one side and an amine on the other was requested. There are several possibilities to obtain these linkers with azido and amino functional groups. First, 1,6-dibromohexane was chosen as the starting material to replace both bromines with azide and selectively reduce one azide group. ${ }^{150}$ Although the reaction proceeded cleanly, we have found that the starting 1,6-dibromohexane contained an impurity that could not be removed completely during the purification, thus this route was abandoned. Then methyl bromoacetate (85, Scheme 14) was azidated $^{151}$ and the methyl ester (86) was aminolysed with excess 1,3-diaminopropane (87). Both reaction steps were quick and the final product was easily purified with extraction or a simple evaporation to give the linker $(\mathbf{8 8})$ in a high yield.

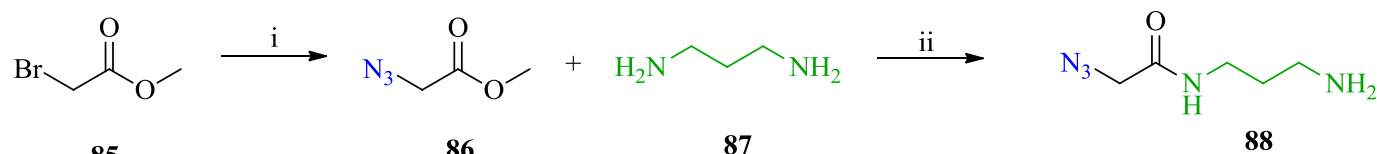

Scheme 14. Synthesis of $N$-(3-aminopropyl)-2-azidoacetamide linker (88). Reagents: (i) $\mathrm{NaN}_{3}$, DMF; (ii) 1,3-diaminopropane (87), $\mathrm{MeOH}, 90 \%$. 
Next, the coupling reaction of the linker to the nucleoside was effected through a urethane intermediate (91a-d and 92a-c,e, Scheme 14). First, nucleosides containing the free 5'hydroxy group (78a-d and 89a-c,e) were reacted with 1,1'-carbonyldiimidazole (90) and then excess azidoamine linker (88) was added to the reaction mixture. After stirring overnight, the reaction was quenched with an amount of sodium hydrogen sulfate equivalent to the amine, evaporated and extracted, finally purified by column chromatography. With this method all eight natural azide derivates of nucleosides (93a-d and 94a-c,e) could be obtained in very good yields (76-86\%) and quite easily.

We were interested in whether the carbamate functional group can survive the circumstances of deprotection. $4 \mathrm{M}$ ammonia solution in methanol was used at room temperature which removed all the acyl protecting groups of the protected nucleosides in 16 hours to yield unprotected nucleosides $(95 \mathbf{a}-\mathbf{d}, \mathbf{9 6 a}-\mathbf{c}, \mathbf{e})$ but the carbamate function remained intact. 

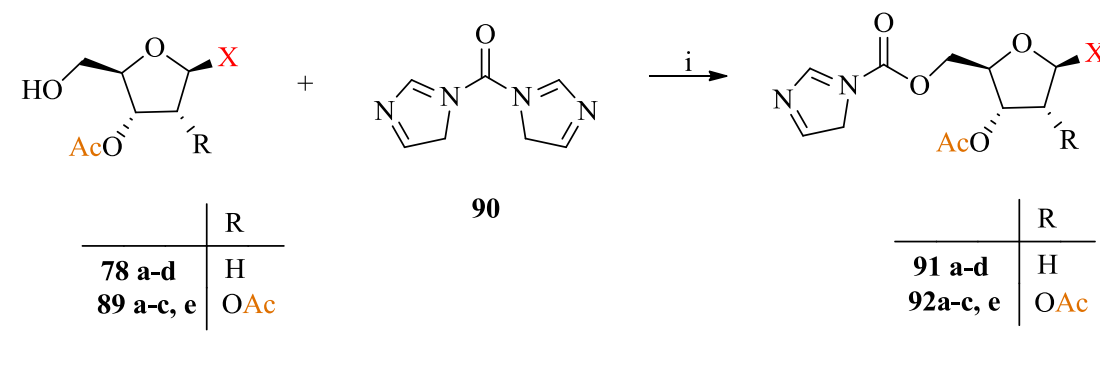

90

$$
\begin{array}{c|l} 
& \mathrm{R} \\
\hline \text { 91 a-d } & \mathrm{H} \\
\text { 92a-c, e } & \mathrm{OAc}
\end{array}
$$<smiles>[N]CC(=O)NCCCN</smiles>

88

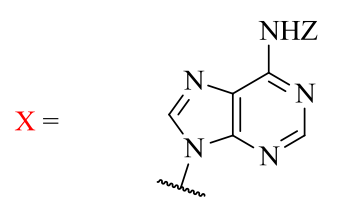

$\mathbf{a}$ \begin{tabular}{r|c} 
& $\mathrm{Z}$ \\
\hline $\mathbf{7 8 , 8 9 , 9 1 , 9 2 , 9 3 , 9 4}$ & $\mathrm{Bz}$ \\
$\mathbf{9 5 , 9 6}$ & $\mathrm{H}$
\end{tabular}<smiles>[R]Nc1ccn(C)c(=O)n1</smiles>

c

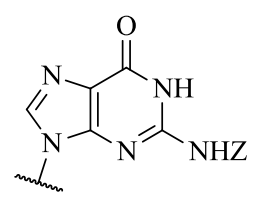

b

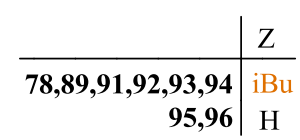

d<smiles>Cn1ccc(=O)[nH]c1=O</smiles>

e<smiles>[X]C1OC(COC(=O)NCCCNC(N)=O)C([R])C1[O-]</smiles>

$$
\begin{array}{l|l} 
& \mathrm{R} \\
\hline \mathbf{9 3} \text { a-d } & \mathrm{H} \\
\mathbf{9 4} \text { a-c, e } & \text { OAc }
\end{array}
$$$$
\downarrow \text { iii }
$$<smiles>[X]C1OC(COC(=O)NCCCNC(N)=O)C([R])C1O</smiles>

$$
\begin{array}{c|l} 
& \mathrm{R} \\
\hline \mathbf{9 5} \text { a-d } & \mathrm{H} \\
\mathbf{9 6} \text { a-c, e } & \mathrm{OH}
\end{array}
$$

Scheme 15. Synthesis of 5'-linker-containing azidonucleosides (93a-d, 94a-c,e and 95a-d, 96a-c,e). Reagents: (i) CDI, DMAP, DMF; (ii) azidoamine linker (88), 76-86\%; (iii) $\mathrm{NH}_{3} / \mathrm{MeOH}, 78-89 \%$.

\subsubsection{Synthesis of other 5 '-linker-modified nucleosides}

When we realized the relative simplicity and effectivity of building in the azide containing linker to the 5'-position of the nucleosides using the carbamate connection, we considered a wider applicability of this novel approach. Our further aim was to check the possibility of making clickable nucleoside building blocks with versatile linker properties. First, we decided to use the two purine nucleosides as model compounds, because the guanosine is synthetically the most problematic nucleoside and adenosine is the most important common unit in nucleotide coenzymes. Second, we chose several, commercially available linkers which had different physicochemical properties and we considered to make both the azide and alkyne 
groups to the linker termini. Beside these possibilities, we have tested the applicability of thiocarbamate type connection as well between the linker and the nucleoside. Although, we were aware of the potential base lability of the thiocarbamate group, during the applied relatively mild basic ammonia treatments the thiocarbamate groups usually remaind intact. Based on the available commercial sources, we purchased alkylene and polyethylenglycol type linkers with either azide or alkyne termini on one end and amino on the other. Beside these commercially available linkers, we prepared a similar alkylamido linker (100) we made previously with azide functional group, but here we prepared its terminal alkyne analogue from propiolic acid (97) by a two-step synthesis (Scheme 16 A). The following scheme summarizes the linkers (100-104) which were used to make these new linker containing purine nucleoside building blocks.

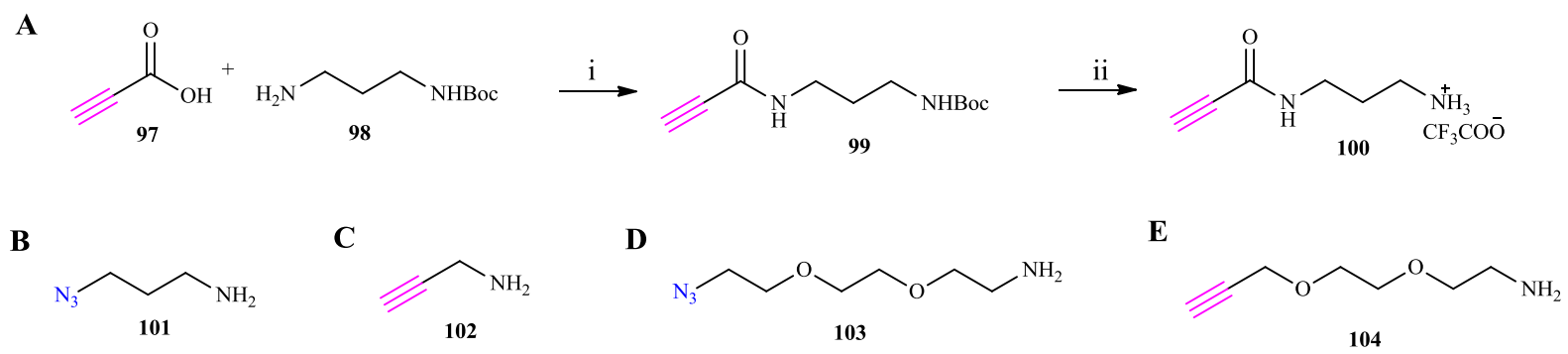

Scheme 16. Synthesis of $N$-(3-aminopropyl)-2-propynamide (100), reagents: (i) DCC, $\mathrm{CH}_{2} \mathrm{Cl}_{2}$; (ii) $\mathrm{CF}_{3} \mathrm{COOH}, \mathrm{CH}_{2} \mathrm{Cl}_{2}, 74 \%$; and structure of compounds 101-104.

The three different linker types can give different biochemical and pharmacokinetic properties to the proposed bioconjugate, which can enhance the ultimate biological effect in different cases. The alkyne or azide end makes the conjugation possibilities flexible, depending on which functional group is available on the other molecule. Scheme 17 shows the two-step synthesis of these linker-containing nucleosides (105a-113a, 114b-118b), which is completely analogous to that described above, except here in certain cases 1,1'-thiocarbonyldiimidazole was also used beside 1,1'-carbonyldiimidazole (Scheme 15). $4 \mathrm{M}$ ammonia solution in methanol was used at room temperature which removed all the acyl protecting groups of the protected nucleosides in 16 hours to yield unprotected derivatives (119a-127a, 128b-132b). 


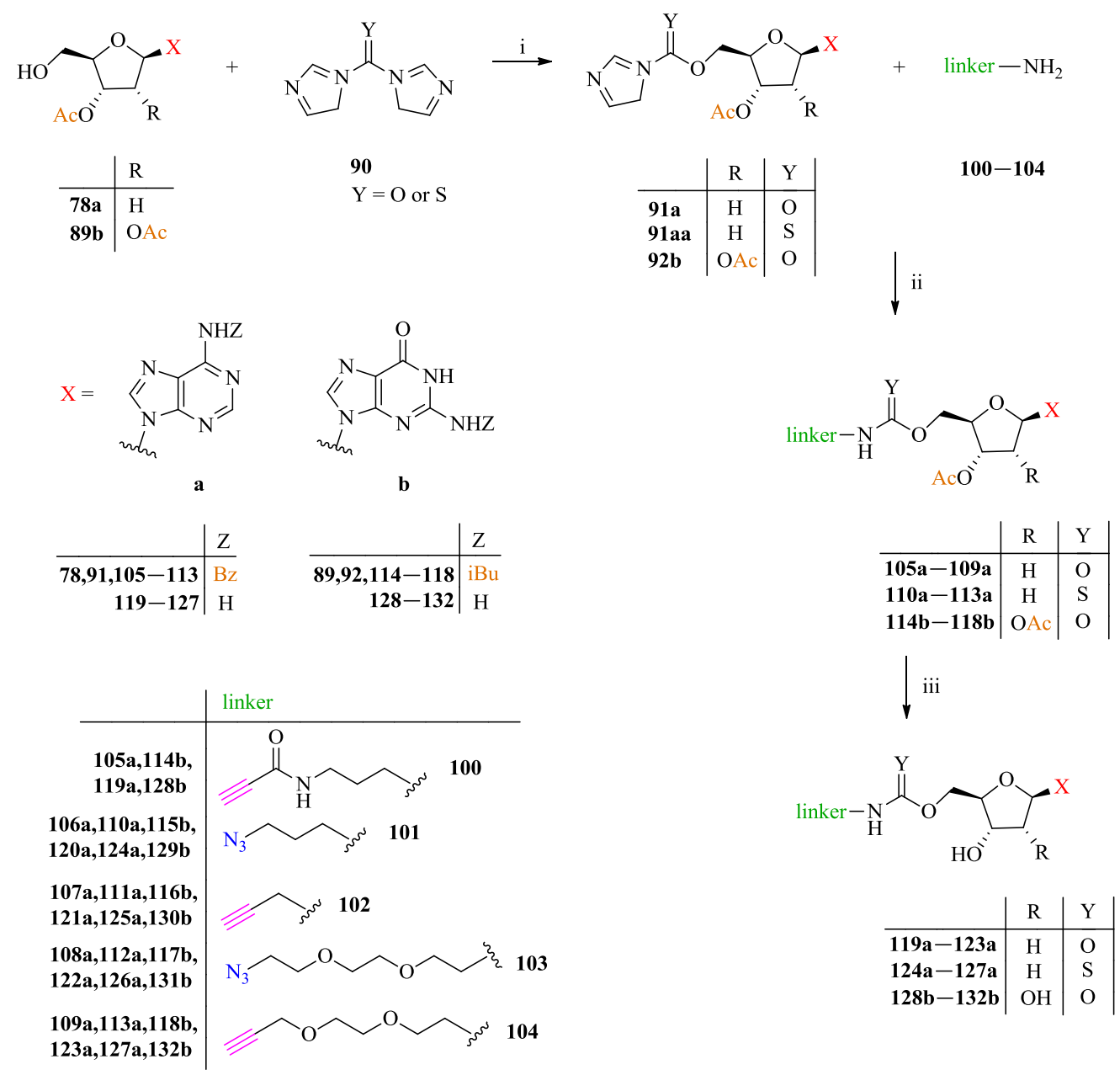

Scheme 17. Synthesis of 5'-linker-containing adenosine and guanosine derivatives (105a113a, 114b-118b and 119a-127a, 128b-132b). Reagents: (i) CDI or thiocarbonyldiimidazole (90), DMAP, DMF; (ii) linker (100-104), 71-84\%; (iii) $\mathrm{NH}_{3} / \mathrm{MeOH}, 45-88 \%$.

\subsubsection{CuAAC between the 5'-linker modified nucleosides with $15-O$-propargyl-13 $\beta$ - estrone}

Conventional enzymatic inhibitors target only the substrate binding site (the active center) of the enzyme, while the so-called bisubstrate enzyme inhibitors, when binding to the target enzyme, bind to the coenzyme binding site besides the substrate binding site on the enzyme surface with coenzyme-mimicking molecule unit attached through a linker. Thus, substantially stronger binding is achieved, i.e., more effective enzyme inhibition by such double-bonded bisubstrate inhibitors based on literature references. ${ }^{152-161}$ Since nucleotide coenzymes/coenzyme mimics generally contain purine-based nucleosides, most preferably an 
adenosine as a molecule set to be recognized by the enzyme's coenzyme binding site, therefore these naturally occurring purine nucleosides are the most important ones in the design and synthesis of bisubstrate inhibitors.

The nucleoside-estrone conjugates produced by us (where the nucleoside moiety is attached through the triazole ring to the steroid C-3 carbon atom) unfortunately did show only weak enzyme inhibitory effects. According to the literature, it is known that adenosine or a smaller molecule linked via linker to the 16-carbon atom of the steroid D-ring has been shown to be a potent enzyme inhibitor. ${ }^{7,121,162}$ Nucleosides have not yet been linked to the 15 -carbon atom of the estrone skeleton via linker. Consequently, we have designed conjugates in which adenosine is linked via linker to carbon atom 15 of estrone. The previously synthesized azidoamine linker (88) and a longer chain $N$-(6-aminohexyl)-2-azidoacetamide linker (134) were coupled via a carbamate bond to the 5'-OH group of the nucleoside. Scheme 18 shows the two steps synthesis of the longer linker (134) which was prepared as shown in Scheme 14. The prepared linker was coupled to the nucleoside as shown in Scheme 17.

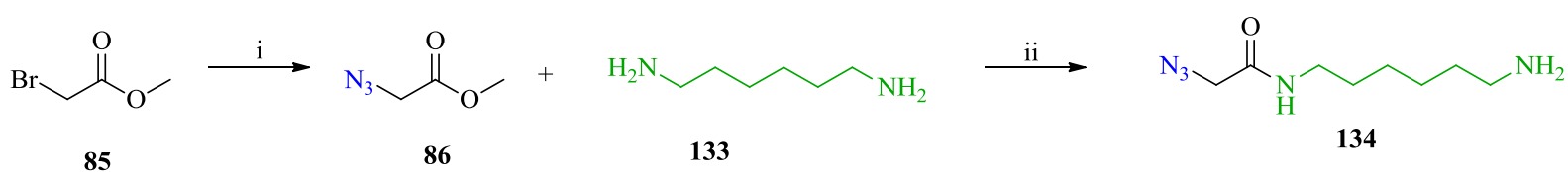

Scheme 18. Synthesis of $N$-(6-aminohexyl)-2-azidoacetamide linker (134). Reagents: (i) $\mathrm{NaN}_{3}$, DMF; (ii) 1,6-diaminohexane (133), MeOH, 84\%.

The estrone containing a propargyl functional group in the D ring (135) was coupled to the linker-containing adenosine $(\mathbf{9 4 a}, \mathbf{1 3 6})$ by a click reaction. The reaction was completed in abs. THF, at $50{ }^{\circ} \mathrm{C}$ overnight with 1 equiv. copper(I) catalyst $\left(\mathrm{P}(\mathrm{Ph})_{3}\right.$ was not used here either). The crude product was evaporated and purified by column chromatography. Then $4 \mathrm{M}$ ammonia solution in methanol was used at room temperature which removed all the acyl protecting groups of the conjugates in 16 hours to yield conjugates $(\mathbf{1 3 9 , 1 4 0 )}$. 

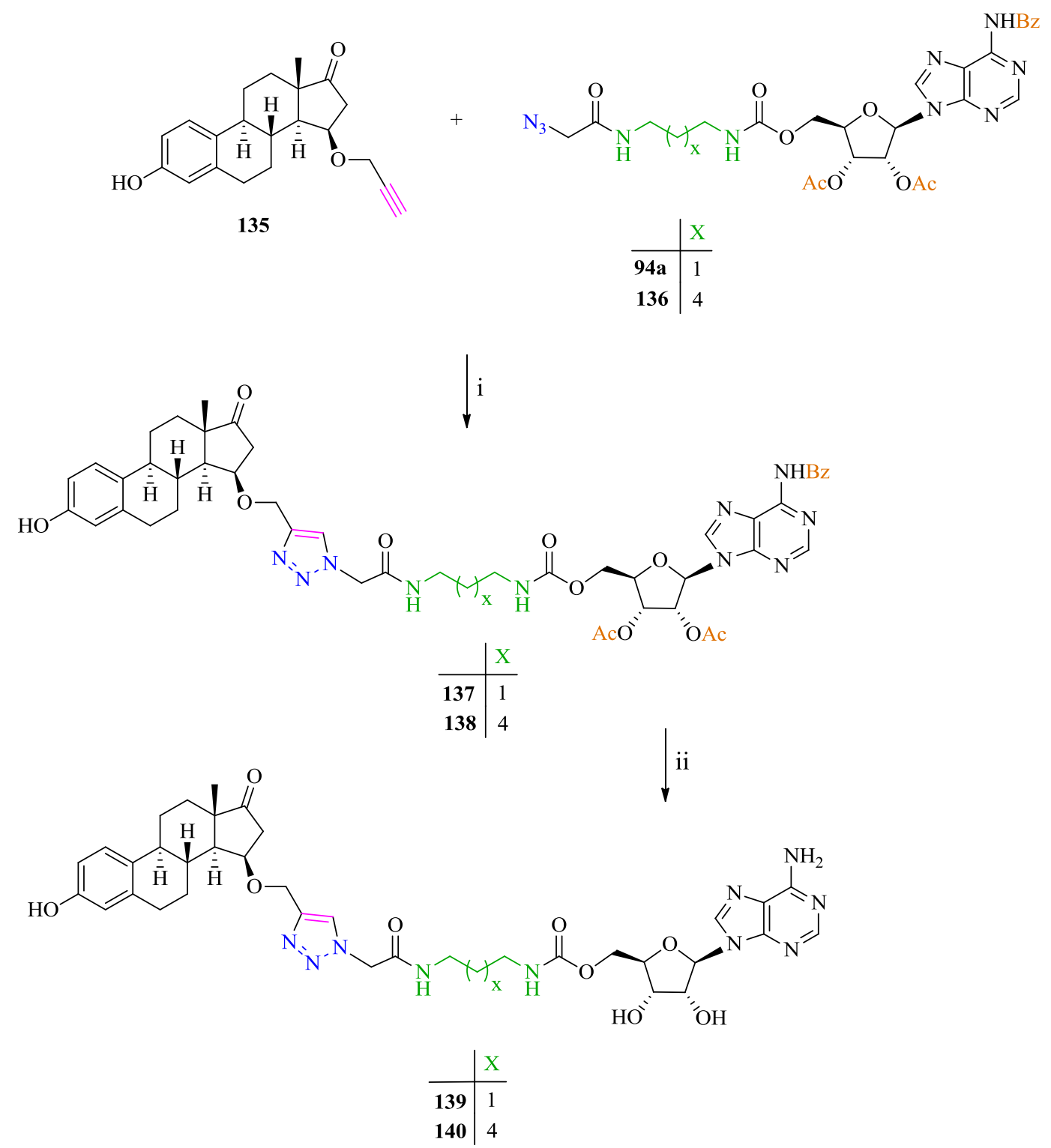

Scheme 19. CuAAC between azidlinker containing nucleosides $(\mathbf{9 4 a}, \mathbf{1 3 6})$ and $15-\mathrm{O}$ propargyl-13ß-estrone (135). Reagents: (i) CuI, DIPEA, THF, 78-82\%; (ii) $\mathrm{NH}_{3} / \mathrm{MeOH}, 83-$ $84 \%$. 


\subsection{Biological results}

\subsubsection{Antiproliferative assays}

The antiproliferative properties of the new conjugates $(65 \mathbf{a}, \mathbf{b}-71 \mathbf{a}, \mathbf{b}$ and $\mathbf{8 3 a}-\mathbf{c}$ and $\mathbf{8 4 a}-\mathbf{c})$ were characterized in vitro on a panel of human adherent cancer cell lines (HeLa, A2780 and MCF-7) by means of MTT assays at the Department of Pharmacodynamics and Biopharmacy, University of Szeged. The antiproliferative properties of some of the presented compounds proved to comparable to that of reference agent cisplatin that is utilized clinically in the treatment of certain gynaecological malignancies. ${ }^{163,164}$ For pharmacological investigations, $10 \mathrm{mM}$ stock solutions of the tested compounds were prepared with DMSO.

The MTT method is suitable for inspecting cell viability and proliferation. The method is based on the fact that metabolically active cells reduce the dye 3-(4,5-dimethylthiazol-2-yl)2,5-diphenyltetrazolium bromide (MTT, 141) to form insoluble violet-coloured $(E, Z)-5-(4,5-$ dimethylthiazol-2-yl)-1,3-diphenylformazan (142) crystals (Scheme 20). The resulting crystals are dissolved in DMSO, photometrated and the resulting color intensity ratio is proportional to the amount of living cells. In cases where the test substance had at least $50 \%$ inhibition of cell division at $10 \mu \mathrm{M}$ concentration, its $\mathrm{IC}_{50}$ value was also determined. The $\mathrm{IC}_{50}$ value is the concentration at which the test substance exerts a $50 \%$ inhibition.

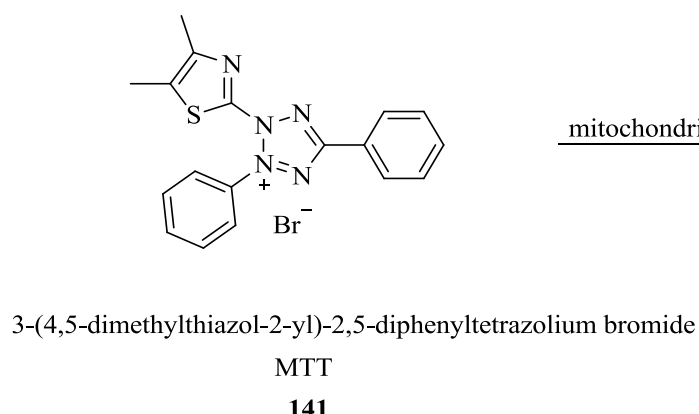

141

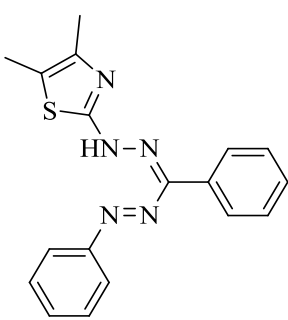

(E,Z)-5-(4,5-dimethylthiazol-2-yl)-1,3-diphenylformazan Formazan

142

Scheme 20. The chemical reaction the MTT assay is based on 
In the case of monosaccharide conjugates, the most potent compounds $(65 \mathbf{b}, 66 \mathbf{b}$ and $67 \mathbf{b})$ exhibited remarkable activities with $\mathrm{IC}_{50}$ values in the range $5.3-20.5 \mu \mathrm{M}$, exerting their best effects against A2780 cells. Among the potent compounds the glucoside conjugate (65b) displayed the highest, the mannoside derivative (66b) the lowest cell-line selectivity. Considering the results of Table 1, important structure-activity relationships appear.

The antiproliferative activities of the compounds greatly depend on the attachment site of the monosaccharide unit, and on the nature of the functional group at $\mathrm{C}-13$, but do not significantly depend on the type of monosaccharide attached. It can be stated that the glycoside derivatives $(\mathbf{6 5}-67)$ are more potent than their methyl glycoside analogues $(68-70)$ which were attached to the triazole ring at the 6'- or 5'-positions of the carbohydrate units. The removal of the protecting groups from the most potent $(\mathbf{6 5 b})$ compound results in a compound (71b) with decreased antiproliferative properties showing the importance of the nonpolar nature of the moiety attached to the triazole ring for the bioactivity. Comparison of the results for acetylated conjugates formed from the D-secooxime and the D-secoalcohol reveals that the presence of the oxime function generally improves the growth-inhibitory properties of the conjugates. Extending the discussion on our recent results, it seems that both the polarity and the size of the fragment at C-3 position greatly influence the antiproliferative properties. The presence of the less polar, but bulky benzyl functional group is advantageous over the phenolic hydroxy group, and further enhancement in the activity is achieved by incorporation of a triazole ring between the 3-hydroxy and the benzyl groups. An additional determining factor is the nature (type, attachment position and polarity) of the substituent on the triazole ring. The benzyl to monosaccharide exchange decreases the cell growth-inhibition. Even the most potent hexose conjugates $(65 \mathbf{b}, 66 \mathbf{b}$ and $67 \mathbf{b})$ displayed one order of magnitude higher $\mathrm{IC}_{50}$ values than certain recently described 3-O-[(1-benzyl-1H-1,2,3-triazol-4-yl)methyl] derivatives (65a and 65b). Cancer selectivity is a critical parameter determining the fate of a potential drug candidate. A viability assay on mouse fibroblasts cannot substitute the toxicological evaluation. However, it seems advantageous that our most potent compounds $(65 b, 66 b$ and 67b) exert substantially less growth inhibiting action on fibroblasts than on cancerous cell lines. 


\begin{tabular}{|c|c|c|c|c|c|c|}
\hline \multirow{2}{*}{$\begin{array}{l}\text { Compd } \\
\text { code }\end{array}$} & \multirow{2}{*}{$\begin{array}{l}\text { Monosaccharide } \\
\text { configuration }\end{array}$} & \multirow{2}{*}{$\begin{array}{l}\text { Conc. } \\
(\mu \mathrm{M})\end{array}$} & \multicolumn{4}{|c|}{$\begin{array}{c}\text { Inhibition }(\%) \pm \text { SEM } \\
{\left.\text { [calculated } \mathrm{IC}_{50}(\mu \mathrm{M})\right]^{\mathrm{b}}}\end{array}$} \\
\hline & & & HeLa & A2780 & MCF-7 & $\begin{array}{c}\text { NIH/3T3 } \\
\text { (mouse } \\
\text { fibroblast) }\end{array}$ \\
\hline $65 a$ & $\beta-\mathrm{D}-\mathrm{Glc} p$ & $\begin{array}{l}10 \\
30\end{array}$ & $\begin{array}{l}34.5 \pm 0.7 \\
23.9 \pm 0.9\end{array}$ & $\begin{array}{l}21.0 \pm 1.6 \\
19.5 \pm 1.4\end{array}$ & $\begin{array}{l}27.4 \pm 2.8 \\
45.5 \pm 1.5\end{array}$ & $\begin{array}{l}- \\
-\end{array}$ \\
\hline $65 b$ & $\beta-\mathrm{D}-\mathrm{Glc} p$ & $\begin{array}{c}10 \\
30 \\
{\left[\mathrm{IC}_{50}\right]}\end{array}$ & $\begin{array}{c}20.4 \pm 1.8 \\
40.0 \pm 2.2 \\
{[>30]^{\mathrm{d}}}\end{array}$ & $\begin{array}{c}69.5 \pm 0.9 \\
76.7 \pm 0.8 \\
{[5.3]}\end{array}$ & $\begin{array}{c}46.7 \pm 1.3 \\
67.7 \pm 1.6 \\
{[10.7]}\end{array}$ & $\begin{array}{c}-^{\mathrm{c}} \\
28.4 \pm 0.9 \\
-\end{array}$ \\
\hline $66 a$ & $\alpha-\mathrm{D}-\operatorname{Man} p$ & $\begin{array}{l}10 \\
30\end{array}$ & $\begin{array}{l}51.9 \pm 1.0 \\
41.5 \pm 1.7\end{array}$ & $\begin{array}{l}34.9 \pm 2.3 \\
36.5 \pm 1.4\end{array}$ & $\begin{array}{l}26.3 \pm 2.2 \\
54.3 \pm 0.6\end{array}$ & $\begin{array}{l}- \\
-\end{array}$ \\
\hline $66 b$ & $\alpha-\mathrm{D}-\operatorname{Man} p$ & $\begin{array}{c}10 \\
30 \\
{\left[\mathrm{IC}_{50}\right]}\end{array}$ & $\begin{array}{c}52.4 \pm 1.7 \\
89.6 \pm 0.5 \\
{[8.9]}\end{array}$ & $\begin{array}{c}69.5 \pm 0.6 \\
86.4 \pm 0.8 \\
{[6.6]}\end{array}$ & $\begin{array}{c}53.9 \pm 0.9 \\
65.9 \pm 1.2 \\
{[9.4]}\end{array}$ & $\begin{array}{c}27.3 \pm 0.5 \\
34.8 \pm 0.3 \\
- \\
\end{array}$ \\
\hline $67 a$ & $\beta$-D-Gal $p$ & $\begin{array}{l}10 \\
30\end{array}$ & $\begin{array}{l}23.9 \pm 1.1 \\
31.8 \pm 1.2\end{array}$ & $\begin{array}{c}- \\
32.7 \pm 1.0\end{array}$ & $\begin{array}{c}- \\
61.9 \pm 0.9\end{array}$ & - \\
\hline $67 b$ & $\beta$-D-Gal $p$ & $\begin{array}{c}10 \\
30 \\
{\left[\mathrm{IC}_{50}\right]}\end{array}$ & $\begin{array}{c}31.5 \pm 2.0 \\
61.9 \pm 2.0 \\
{[20.5]}\end{array}$ & $\begin{array}{c}59.3 \pm 0.9 \\
85.2 \pm 0.4 \\
{[8.8]}\end{array}$ & $\begin{array}{c}59.1 \pm 2.2 \\
71.5 \pm 1.5 \\
{[8.0]}\end{array}$ & $\begin{array}{c}- \\
25.5 . \pm 1.4 \\
-\end{array}$ \\
\hline $68 \mathbf{a}$ & $\alpha-\mathrm{D}-\mathrm{Glc} p$ & $\begin{array}{l}10 \\
30 \\
\end{array}$ & $\begin{array}{l}- \\
- \\
\end{array}$ & $\begin{array}{l}- \\
-\end{array}$ & $\begin{array}{l}- \\
-\end{array}$ & $\begin{array}{l}- \\
-\end{array}$ \\
\hline $68 b$ & $\alpha$-D-Glc $p$ & $\begin{array}{l}10 \\
30\end{array}$ & - & $\begin{array}{l}28.4 \pm 0.8 \\
45.7 \pm 2.1\end{array}$ & - & - \\
\hline $69 a$ & $\alpha$-D-Man $p$ & $\begin{array}{l}10 \\
30 \\
\end{array}$ & - & $\begin{array}{l}- \\
- \\
\end{array}$ & - & $\begin{array}{l}- \\
-\end{array}$ \\
\hline $69 b$ & $\alpha-\mathrm{D}-\operatorname{Man} p$ & $\begin{array}{l}10 \\
30 \\
\end{array}$ & - & - & - & - \\
\hline $70 a$ & $\beta-\mathrm{D}-\mathrm{Rib} f$ & $\begin{array}{l}10 \\
30\end{array}$ & $\begin{array}{l} \\
-\end{array}$ & - & $\begin{array}{l}- \\
-\end{array}$ & $\begin{array}{l}- \\
-\end{array}$ \\
\hline $70 b$ & $\beta$-D-Rib $f$ & $\begin{array}{l}10 \\
30\end{array}$ & $\begin{array}{c}24.3 \pm 2.6 \\
-\end{array}$ & $\begin{array}{l}- \\
-\end{array}$ & $\begin{array}{l}- \\
-\end{array}$ & $\begin{array}{l}- \\
-\end{array}$ \\
\hline $71 \mathrm{a}$ & $\beta-\mathrm{D}-\mathrm{Glc} p$ & $\begin{array}{l}10 \\
30\end{array}$ & - & - & - & - \\
\hline $71 b$ & $\beta$-D-Glcp & $\begin{array}{c}10 \\
30 \\
{\left[\mathrm{IC}_{50}\right]} \\
\end{array}$ & $\begin{array}{c}- \\
31.5 \pm 0.4 \\
{[>30]}\end{array}$ & $\begin{array}{c}- \\
57.9 \pm 0.6 \\
{[27.4]}\end{array}$ & $\begin{array}{c}- \\
- \\
{[>30]}\end{array}$ & $\begin{array}{l}- \\
- \\
- \\
\end{array}$ \\
\hline cisplatin & - & $\begin{array}{c}10 \\
30 \\
{\left[\mathrm{IC}_{50}\right]}\end{array}$ & $\begin{array}{c}42.6 \pm 2.3 \\
99.9 \pm 0.3 \\
{[12.4]}\end{array}$ & $\begin{array}{c}83.6 \pm 1.2 \\
95.0 \pm 0.3 \\
{[1.3]}\end{array}$ & $\begin{array}{c}66.9 \pm 1.8 \\
96.8 \pm 0.4 \\
{[5.8]}\end{array}$ & $\begin{array}{c}94.2 \pm 0.4 \\
96.4 \pm 0.2 \\
{[3.2]}\end{array}$ \\
\hline
\end{tabular}

Table 1. Anticancer activity of monosaccharide-D-secoestrone conjugates (65a,b-71a,b) against different cell lines. ${ }^{a}$ The compound series a contain hydroxymethyl, series $\mathbf{b}$ oxime moieties at $\mathrm{C}-13$ position of the steroid skeleton. ${ }^{\mathrm{b}}$ Mean value from two independent determinations with five parallel wells; standard deviation $<15 \%$. ${ }^{c}$ Inhibition values $<20 \%$ are not presented. ${ }^{\mathrm{d}} \mathrm{IC}_{50}$ values $>30 \mu \mathrm{M}$ are not calculated. 
In the case of the nucleoside conjugates, the influence of the nature of the protected or unprotected nucleoside moiety on the cytostatic properties was investigated and the results are shown in Table 2 . The protected cytidine conjugate $(\mathbf{8 3 c})$ proved to be the most potent with IC $_{50}$ values in the range 9.0-10.4 $\mu \mathrm{M}$, although this value is an order of magnitude higher than the value of the $13 \alpha$-estrone triazole $(\mathbf{8 1})$. The removal of the benzoyl and/or the acetyl protecting groups from the nucleoside-13 $\alpha$-estrone conjugates $(\mathbf{8 3 a}-\mathbf{c})$ resulted in unprotected conjugates $(\mathbf{8 4 a}-\mathbf{c})$ with generally reduced cytostatic properties. Although we do not know the mechanism of action of our conjugates, but compared to the reference steroid (81), the nonpolar benzyl group was replaced to the polar deoxynucleoside units, therefore the lower activity could be due to the more pronounced steric effect and polar property of the nucleoside units. Interestingly, the conjugates containing less polar but larger protected nucleosides gave higher antiproliferative activity than the unprotected, more polar but smaller nucleosidecontaining ones. This fact highlights the importance of both the limited size and non-polar characteristics of the group at C-3 triazolyl moiety of $13 \alpha$-estrone derivatives.

On the other hand, this finding can also suggest that the hypothesized, potentially selective increase in the uptake of nucleoside conjugates of the estrone derivative might not be operative. The reason of the lower overall uptake could be the decrease of the passive transport of the more polar, nucleoside-estrone derivative through the cell membrane. If the passive transport has much higher contribution to the overall uptake than the nucleoside transporter mediated routes, then the loss of antiproliferative activity of the more polar, unprotected nucleoside-13 $\alpha$-estrone conjugates can be explained by lower concentration of the conjugates inside the cell. Either explanation is true, unfortunately, the triazolyldeoxynucleoside modification of $13 \alpha$-estrone on C-3 position did not help improving the antiproliferative activity of the model compound (81). 


\begin{tabular}{|c|c|c|c|c|c|}
\hline \multirow{2}{*}{$\begin{array}{l}\text { Compd. } \\
\text { code }\end{array}$} & \multirow{2}{*}{$\begin{array}{l}\text { Nucleoside } \\
\text { unit }\end{array}$} & \multirow{2}{*}{$\begin{array}{l}\text { Conc. } \\
(\mu \mathrm{M})\end{array}$} & \multicolumn{3}{|c|}{ 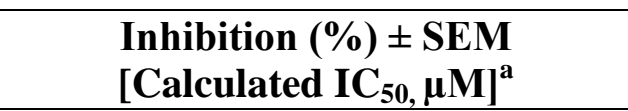 } \\
\hline & & & A2780 & HeLa & MCF-7 \\
\hline \multirow{3}{*}{$83 a$} & \multirow{3}{*}{ BzdAdoAc } & 10 & $39.4 \pm 2.4$ & ${ }^{b}$ & $-{ }^{b}$ \\
\hline & & 30 & $70.2 \pm 1.6$ & $55.5 \pm 0.6$ & $49.6 \pm 1.4$ \\
\hline & & {$\left[\mathrm{IC}_{50}\right]$} & [10.9] & [16.3] & {$[>30]^{c}$} \\
\hline \multirow{3}{*}{$83 b$} & \multirow{3}{*}{ ThdAc } & 10 & $29.8 \pm 0.2$ & - & $29.2 \pm 2.9$ \\
\hline & & 30 & $35.1 \pm 2.7$ & - & $26.7 \pm 2.0$ \\
\hline & & {$\left[\mathrm{IC}_{50}\right]$} & {$[>30]$} & {$[>30]$} & {$[>30]$} \\
\hline \multirow{3}{*}{$83 c$} & \multirow{3}{*}{ BzdCydAc } & 10 & $63.2 \pm 1.5$ & $53.5 \pm 1.0$ & $47.4 \pm 2.4$ \\
\hline & & 30 & $66.6 \pm 1.6$ & $61.9 \pm 1.2$ & $57.3 \pm 1.8$ \\
\hline & & {$\left[\mathrm{IC}_{50}\right]$} & [9.0] & [9.0] & [10.4] \\
\hline \multirow{3}{*}{$84 a$} & \multirow{3}{*}{ dAdo } & 10 & - & $26.6 \pm 1.8$ & - \\
\hline & & 30 & $41.9 \pm 1.7$ & $60.1 \pm 0.7$ & $36.6 \pm 1.0$ \\
\hline & & {$\left[\mathrm{IC}_{50}\right]$} & {$[>30]$} & [23.5] & {$[>30]$} \\
\hline \multirow{3}{*}{$84 b$} & \multirow{3}{*}{ Thd } & 10 & - & $25.9 \pm 0.8$ & - \\
\hline & & 30 & $32.4 \pm 2.0$ & $38.2 \pm 2.1$ & - \\
\hline & & {$\left[\mathrm{IC}_{50}\right]$} & [>30] & {$[>30]$} & {$[>30]$} \\
\hline \multirow{3}{*}{$84 c$} & \multirow{3}{*}{$\mathrm{dCyd}$} & 10 & $31.8 \pm 2.5$ & $41.4 \pm 1.5$ & - \\
\hline & & 30 & $31.6 \pm 3.6$ & $46.1 \pm 2.6$ & $26.4 \pm 2.2$ \\
\hline & & {$\left[\mathrm{IC}_{50}\right]$} & {$[>30]$} & {$[>30]$} & {$[>30]$} \\
\hline \multirow{3}{*}{81} & \multirow{3}{*}{ - } & 10 & $77.5 \pm 0.4$ & $90.9 \pm 0.3$ & $85.8 \pm 1.3$ \\
\hline & & 30 & $78.4 \pm 0.9$ & $93.3 \pm 0.2$ & $85.0 \pm 0.2$ \\
\hline & & {$\left[\mathrm{IC}_{50}\right]$} & {$[0.5]$} & [0.9] & {$[0.6]$} \\
\hline \multirow{3}{*}{ cisplatin } & \multirow{3}{*}{ - } & 10 & $83.6 \pm 1.2$ & $42.6 \pm 2.3$ & $66.9 \pm 1.8$ \\
\hline & & 30 & $95.0 \pm 0.3$ & $99.9 \pm 0.3$ & $96.8 \pm 0.4$ \\
\hline & & {$\left[\mathrm{IC}_{50}\right]$} & [1.3] & [12.4] & [5.8] \\
\hline
\end{tabular}

Table 2. Antiproliferative properties of the synthesized compounds $(\mathbf{8 3 a}-\mathbf{c}$ and $\mathbf{8 4 a}-$ c). ${ }^{a}$ Mean value from two independent determinations with five parallel wells; standard deviation $<15 \%$. ${ }^{\mathrm{b}}$ Inhibition values $<20 \%$ are not presented. ${ }^{\mathrm{c}} \mathrm{IC}_{50}$ values $>30$ $\mu \mathrm{M}$ are not calculated. 


\subsubsection{Inhibition of enzyme 17ß-HSD1}

The newly synthesized nucleoside conjugates $(\mathbf{8 3 a}-\mathbf{c}$ and $\mathbf{8 4 a}-\mathbf{c})$ of $13 \alpha$-estrone were tested against the human 17ß-HSD1 enzyme in vitro at the $1^{\text {st }}$ Department of Internal Medicine, University of Szeged.

Measurements were performed by in vitro radiosubstrate incubation using the general protocol $^{165}$ in HEPES buffer $\mathrm{pH}=7.3$ in the presence of an excess of NADPH cofactor. The essence of the procedure is that after quenching the enzyme reaction, the relative conversion can be determined by measuring the estradiol radioactivity with liquid scintillation apparatus. That is, the degree of inhibitory change compared to the inhibition control (100\%). The $\mathrm{IC}_{50}$ values of the test compounds reaching at least $50 \%$ inhibition at $10 \mu \mathrm{M}$ concentration were also determined. The $\mathrm{IC}_{50}$ value is the inhibitor concentration that reduces the enzyme activity to $50 \%$ under the given conditions.

The results in Table 3 show that only the unprotected thymidine conjugate $(\mathbf{8 4 b})$ exerted substantial inhibition, with an $\mathrm{IC}_{50}$ value of $19 \mu \mathrm{M}$. Other tested conjugates displayed weak inhibition. Compared to our previous results on $13 \alpha$-estrone and its $3-O$-methyl ether, these conjugates had lower inhibitory effect, similar to those of the 3-O-benzyl ether of $13 \alpha$ estrone. The decrease in the inhibitory potential of nucleoside conjugates is probably caused by the steric effect of the larger nucleoside-triazolyl unit on the C-3 position.

\begin{tabular}{c|c|c}
\hline Compd code & $\begin{array}{c}\text { Nucleoside } \\
\text { unit }\end{array}$ & $\begin{array}{c}\text { Relative conversion } \pm \text { SD } \\
\text { at } \mathbf{1 0} \boldsymbol{\mu M}(\%) \text { or } \text { IC }_{\mathbf{5 0}} \pm \\
\text { SD }(\boldsymbol{\mu M}) \mathbf{N A D P H}\end{array}$ \\
\hline $\mathbf{8 3 a}$ & BzdAdoAc & $90 \pm 13$ \\
\hline $\mathbf{8 3 b}$ & ThdAc & $89 \pm 7$ \\
\hline $\mathbf{8 3 c}$ & BzdCydAc & $98 \pm 14$ \\
\hline $\mathbf{8 4 a}$ & dAdo & $113 \pm 6$ \\
\hline $\mathbf{8 4 b}$ & Thd & $65 \pm 3 ; \mathrm{IC}_{50}=19 \pm 10$ \\
\hline $\mathbf{8 4 c}$ & dCyd & $91 \pm 4$ \\
\hline
\end{tabular}

Table 3. Inhibition results on $17 \beta$-HSD1. Relative conversions (control incubation with no inhibition is $100 \%$ ) measured in the presence of $10 \mu \mathrm{M}$ of the compound tested. $\mathrm{IC}_{50}$ : The inhibitor concentration that decreases the enzyme activity to 50\%. SD: standard deviation (for relative conversion $n=3$ ). 


\section{Experimental}

\subsection{General methods}

Melting points (mp) were determined on a Kofler block and an Electrothermal IA8103 apparatus and are uncorrected. The reactions were monitored by TLC on Kieselgel-G (Merck Si $254 \mathrm{~F})$ layers $\left(0.25 \mathrm{~mm}\right.$ thick). The $R_{\mathrm{f}}$ values were determined for the spots observed by illumination at $254 \mathrm{~nm}$. Flash chromatography: Merck silica gel 60, 40-63 $\mu \mathrm{m}$. All solvents were distilled prior to use. Reagents and materials were obtained from commercial suppliers and were used without purification.

The conjugates were detected by spraying with $5 \%$ phosphomolybdic acid in $50 \%$ aqueous phosphoric acid. For the identification of azides the TLC was placed in a $10 \%$ solution of triphenylphosphane in $\mathrm{CH}_{2} \mathrm{Cl}_{2}$ for 2 minutes, dried and then sprayed with ninhydrine solution (0.5\% ninhydrine and $5 \mathrm{mM} \mathrm{NaOH}$ in ethanol/water $3: 1 \mathrm{v} / \mathrm{v})$.

NMR spectra were obtained at room temperature with a Bruker DRX 500 instrument. Chemical shifts are reported in ppm ( $\delta$ scale), and coupling constants $(J)$ in Hz. For the determination of multiplicities, the $J$-MOD pulse sequence was used.

Mass spectra were recorded on a Finnigan MAT TSQ 7000 instrument equipped with an electrospray ion source, using the following parameters: positive ionization mode, nebulizing gas $\mathrm{N}_{2}$ (3.45 bar), capillary temperature: $200^{\circ} \mathrm{C}$, capillary voltage: $4500 \mathrm{~V}$ and an acetonitrile -water 1:1 (v/v) mixture containing $0.1 \%$ trifluoroacetic acid as eluent. The samples were dissolved in acetonitrile and injected directly. The base peaks were usually the $[\mathrm{M}+\mathrm{H}]^{+}$ signals along with far less abundant $[2 \mathrm{M}+\mathrm{H}]^{+}$signals. In case of measuring the monosaccharides the eluent was an isocratic acetonitrile-water mixture $1: 1(\mathrm{v} / \mathrm{v})$ and the samples were dissolved in acetonitrile and mixed with a $10 \mathrm{mM}$ aqueous $\mathrm{NH}_{4} \mathrm{HCO}_{3}$ solution in a 10:1 ratio to increase the sensitivity of the analyses (due to the high affinity of $\mathrm{NH}_{4}{ }^{+}$to carbohydrates). In these cases the base peaks corresponded always to the $\mathrm{NH}_{4}{ }^{+}$adduct ions and the $[\mathrm{M}+\mathrm{H}]^{+}$signals had relatively low intensities. 


\subsection{Experimental procedures}

The physical properties of all the newly prepared compounds are shown in the Appendices.

\subsubsection{Preparation of azido-monosaccharides (47-49 and 59-61)}

1,2,3,4,6-Penta- $O$-acetylated monosaccharides of D-glucose, D-mannose and D-galactose (compounds 6-8) were prepared according to the literature method. ${ }^{166}$

$1.00 \mathrm{~g}(2.56 \mathrm{mmol})$ of 1,2,3,4,6-penta- $O$-acetylated monosaccharide (44, 45 or $\mathbf{4 6})$ was dissolved in anhydrous $\mathrm{CH}_{2} \mathrm{Cl}_{2}(5 \mathrm{~mL})$, trimethylsilyl azide $(1 \mathrm{~mL}, 7.5 \mathrm{mmol})$ and $2.56 \mathrm{~mL}$ solution of $\mathrm{SnCl}_{4}\left(2.56 \mathrm{mmol}, 1 \mathrm{M}\right.$ in $\left.\mathrm{CH}_{2} \mathrm{Cl}_{2}\right)$ was added. The reaction mixture was stirred for $4 \mathrm{~h}$ at $50{ }^{\circ} \mathrm{C}$ then saturated aqueous solution of $\mathrm{NaHCO}_{3}$ was added until the $\mathrm{pH}$ reached 8 . The emulsion was filtered through a Celite pad three times. The filtrate was extracted with $\mathrm{CH}_{2} \mathrm{Cl}_{2}(2 \times 100 \mathrm{~mL})$, the combined organic layers were dried over $\mathrm{MgSO}_{4}$ and evaporated in vacuo. The resulting crude product was purified by column chromatography, with hexane/EtOAc (6:4) as eluent to give compounds 47-49.

Methyl glycosides 50, $\mathbf{5 1}$ and $\mathbf{5 3}$ were purchased as pure $\alpha$-, $\alpha$ - and $\beta$-anomers, respectively.

\subsubsection{Preparation of 6-azido-6-deoxymonosaccharides $(59,60)$}

Methyl glycoside $\mathbf{5 0}$ or $\mathbf{5 1}$ (5 mmol, $0.97 \mathrm{~g})$ was dissolved in pyridine (20 mL) and TsCl (0.95 g, 5 mmol, 1 equiv.) was added. The reaction mixture was stirred overnight, at room temperature, then evaporated in vacuo, redissolved in $\mathrm{CH}_{2} \mathrm{Cl}_{2}(100 \mathrm{~mL})$ and extracted with water $(2 \times 100 \mathrm{~mL})$. The combined organic layers were dried over $\mathrm{Na}_{2} \mathrm{SO}_{4}$ and evaporated in vacuo. The resulting crude product was purified by column chromatography, with $\mathrm{CH}_{2} \mathrm{Cl}_{2}$ /methanol (9:1) as eluent to give compound $\mathbf{5 3}$ or $\mathbf{5 4}$.

Methyl 6-O-(p-toluenesulfonyl) glycoside 53 or $54(1.00 \mathrm{~g}, 2.9 \mathrm{mmol})$ was dissolved in pyridine $(20 \mathrm{~mL})$ and $\mathrm{BzCl}(1.16 \mathrm{~mL}, 10 \mathrm{mmol})$ was added. The reaction was complete in $1 \mathrm{~h}$ at room temperature. The reaction mixture was evaporated in vacuo, redissolved in $\mathrm{CH}_{2} \mathrm{Cl}_{2}$ $(100 \mathrm{~mL})$ and extracted with $5 \%$ aqueous $\mathrm{KHSO}_{4}$ solution $(2 \times 100 \mathrm{~mL})$. The combined organic layers were dried over $\mathrm{Na}_{2} \mathrm{SO}_{4}$ and evaporated in vacuo. The resulting crude product was purified by column chromatography with hexane/EtOAc (5:5) as eluent to give compound 56 or 57. 
Methyl 6- $O$-( $p$-toluenesulfonyl)-2,3,4-tri- $O$-benzoyl glycoside 56 or 57 (1.00 g, $1.5 \mathrm{mmol})$ was dissolved in dry DMF $(5 \mathrm{~mL})$ then sodium azide $(0.49 \mathrm{~g}, 7.5 \mathrm{mmol})$ and lithium bromide $(0.65 \mathrm{~g}, 7.5 \mathrm{mmol})$ were added. The reaction mixture was stirred at $120{ }^{\circ} \mathrm{C}$ for $6 \mathrm{~h}$. The reaction mixture was evaporated in vacuo, redissolved in $\mathrm{CH}_{2} \mathrm{Cl}_{2}$ andextracted with $1 \%$ aqueous $\mathrm{KHSO}_{4}$ solution $(2 \times 100 \mathrm{~mL})$. The combined organic layers were dried over $\mathrm{Na}_{2} \mathrm{SO}_{4}$ and evaporated in vacuo. The resulting crude product was purified by column chromatography, with hexane/EtOAc (8:2) as eluent to give compound $\mathbf{5 9}$ or $\mathbf{6 0 .}$

\subsubsection{Preparation of 5-azido-5-deoxymonosaccharide (61)}

Methyl $\beta$-D-ribofuranoside (52) $(1.00 \mathrm{~g}, 6.1 \mathrm{mmol})$ was dissolved in pyridine $(20 \mathrm{~mL})$ and $\mathrm{TsCl}(1.20 \mathrm{~g}, 6.1 \mathrm{mmol})$ was added. The reaction mixture was stirred overnight at room temperature, then evaporated in vacuo, redissolved in $\mathrm{CH}_{2} \mathrm{Cl}_{2}(100 \mathrm{~mL})$, and extracted with water $(2 \times 100 \mathrm{~mL})$. The combined organic layers were dried over $\mathrm{Na}_{2} \mathrm{SO}_{4}$ and evaporated in vacuo. The resulting crude product was purified by column chromatography, with $\mathrm{CH}_{2} \mathrm{Cl}_{2} / \mathrm{MeOH}(9: 1)$ as eluent to give compound 55.

Methyl 5- $O$-toluenesulfonyl- $\beta$-D-ribofuranoside (55) $(1.00 \mathrm{~g}, 3.1 \mathrm{mmol})$ was dissolved in pyridine $(20 \mathrm{~mL})$ and $\mathrm{BzCl}(1.08 \mathrm{~mL}, 9.3 \mathrm{mmol})$ was added. The reaction was completed in 1 $\mathrm{h}$ at room temperature. The reaction mixture was evaporated in vacuo, redissolved in EtOAc $(100 \mathrm{~mL})$ and extracted with $5 \%$ aqueous $\mathrm{KHSO}_{4}$ solution $(2 \times 100 \mathrm{~mL})$. The combined organic layers were dried over $\mathrm{Na}_{2} \mathrm{SO}_{4}$ and evaporated in vacuo. The resulting crude product was purified by column chromatography with hexane/EtOAc (5:5) as eluent to give compound 58.

Methyl 5- $O$-toluenesulfonyl-2,3-di- $O$-benzoyl- $\beta$-D-ribofuranoside (58) (1.00 g, 1.9 mmol) was dissolved in dry DMF $(5 \mathrm{~mL})$ then sodium azide $(0.62 \mathrm{~g}, 9.5 \mathrm{mmol})$ and lithium bromide $(0.83 \mathrm{~g}, 9.5 \mathrm{mmol})$ were added. The reaction mixture was stirred at $120{ }^{\circ} \mathrm{C}$ for 6 hours, then the reaction mixture was evaporated in vacuo, redissolved in $\mathrm{CH}_{2} \mathrm{Cl}_{2}(100 \mathrm{~mL})$ and extracted with $1 \%$ aqueous $\mathrm{KHSO}_{4}$ solution $(2 \times 100 \mathrm{~mL})$. The combined organic layers were dried over $\mathrm{Na}_{2} \mathrm{SO}_{4}$ and evaporated in vacuo. The resulting crude product was purified by column chromatography with hexane/EtOAc (8:2) as eluent to give compound $\mathbf{6 1}$. 


\subsubsection{CuAAC between azido-monosaccharides and D-secosteroids (65a,b-70a,b)}

$50 \mathrm{mg}(0.094-0.134 \mathrm{mmol})$ of an azido monosaccharide (compounds 47-49 or 59-61) was dissolved in toluene $(10 \mathrm{~mL})$, then triphenylphosphane $(6.8 \mathrm{mg}, 0.026 \mathrm{mmol}), \mathrm{CuI}(2.5 \mathrm{mg}$, $0.013 \mathrm{mmol})$, DIPEA (70 $\mu \mathrm{L}, 0.4 \mathrm{mmol})$ and the terminal alkyne-containing steroid (64a and 64b, 1.1 equiv.) were added to the reaction mixture, and it was boiled for $6 \mathrm{~h}$. Then the mixture was evaporated in vacuo and the resulting crude product was purified by column chromatography, with EtOAc/ $\mathrm{CH}_{2} \mathrm{Cl}_{2}(5: 5)$ as eluent to furnish derivatives $\mathbf{6 5 a}, \mathbf{b}-\mathbf{7 0 a}, \mathbf{b}$, respectively.

\subsubsection{Removal of acetyl protecting groups of bioconjugates (65a and $65 \mathrm{~b})$}

$0.45 \mathrm{mmol}$ of conjugates (65a or $\mathbf{6 5} \mathbf{b})$ was dissolved in $10 \mathrm{ml}$ of $\mathrm{MeOH}$ and $2.4 \mathrm{mg}(0.045$ mmol, 0.1 equiv.) of sodium methylate was added. The reaction was monitored by TLC and showed a perfect conversion in 30 minutes. After evaporation, the crude product was purified by column chromatography using a $\mathrm{CH}_{2} \mathrm{Cl}_{2} / \mathrm{MeOH}$ (9:1) as eluent to give compound 71a or $71 b$.

\subsubsection{Synthesis of 3 '-O-acetyl-5'-azido- $N$-acyl-protected-2',5'-dideoxynucleosides $(80 \mathrm{a}-\mathrm{c})$}

$10 \mathrm{mmol}$ of 5'-O-DMTr- $N$-acyl-protected-2'-deoxynucleoside (76a, 76b, 76c or 76d) was dissolved in pyridine $(50 \mathrm{~mL})$ and $\mathrm{Ac}_{2} \mathrm{O}(10 \mathrm{mmol}, 945 \mu \mathrm{L})$ was added. The reaction mixture was stirred at $0{ }^{\circ} \mathrm{C}$ for $4 \mathrm{~h}$, evaporated in vacuo, redissolved in EtOAc $(100 \mathrm{~mL})$ and extracted with water $(2 \times 100 \mathrm{~mL})$. The combined organic layers were dried over $\mathrm{Na}_{2} \mathrm{SO}_{4}$ and evaporated in vacuo. The resulting crude product $(\mathbf{7 7 a}, \mathbf{7 7 b}, \mathbf{7 7} \mathbf{c}$ or $\mathbf{7 7 d}$ ) was directly used for the next step without further purifications.

$10 \mathrm{mmol}$ of 5'-O-(4,4'-dimethoxytrityl)-3'-O-acetyl- $\mathrm{N}$-acyl-protected-2'-deoxynucleoside (77a, 77b, 77c or 77d) was dissolved in nitromethane $(20 \mathrm{~mL})$ and a mixture of $1,1,1,3,3,3-$ hexafluoroisopropanol $(20 \mathrm{~mL}, 190 \mathrm{mmol})$, boron trifluoride diethyl etherate $(247 \mu \mathrm{L}, 2$ mmol) and triethylsilane $(6 \mathrm{~mL}, 38 \mathrm{mmol})$ was added. The reaction mixture was stirred at room temperature overnight, then $10 \%$ aqueous $\mathrm{NaHCO}_{3}$ solution was added and evaporated in vacuo. The resulting crude product was purified by column chromatography with EtOAc as eluent to give nucleoside $\mathbf{7 8 a}, \mathbf{7 8 b}, \mathbf{7 8 c}$ or $\mathbf{7 8 d}$, respectively.

3'- $O$-Acetyl- $N$-acyl-protected-2'-deoxynucleoside (78a, 78b, 78c or $\mathbf{7 8 d}$ ) (1 mmol) was dissolved in pyridine $(15 \mathrm{~mL})$ and $\mathrm{TsCl}(285 \mathrm{mg}, 1.5 \mathrm{mmol})$ was added. The reaction mixture 
was stirred at room temperature overnight, evaporated in vасио, redissolved in EtOAc (100 $\mathrm{mL})$ and extracted with $1 \%$ aqueous $\mathrm{KHSO}_{4}$ solution $(2 \times 100 \mathrm{~mL})$. The combined organic layers were dried over $\mathrm{Na}_{2} \mathrm{SO}_{4}$ and evaporated in vacuo. The resulting crude product was purified by column chromatography with EtOAc as eluent to afford tosylated nucleoside 79a, 79b, 79c or 79d, respectively.

3'-O-Acetyl- $N$-acyl-protected-2'-deoxy-5'-O-tosylnucleoside 79a, 79b or 79c $(1 \mathrm{mmol})$ was dissolved in dry DMF (20 mL) then sodium azide $(195 \mathrm{mg}, 3 \mathrm{mmol})$ and lithium bromide (261 mg, $3 \mathrm{mmol}$ ) were added. The reaction mixture was stirred at $50{ }^{\circ} \mathrm{C}$ for $6 \mathrm{~h}$. The reaction mixture was evaporated in vacuo, redissolved in EtOAc and extracted with water $(2 \times 100$ $\mathrm{mL}$ ). The combined organic layers were dried over $\mathrm{Na}_{2} \mathrm{SO}_{4}$ and evaporated in vacuo. The resulting crude product was recrystallized from EtOAc to yield azidonucleoside $\mathbf{8 0 a}, \mathbf{8 0 b}$ or 80c, respectively.

\subsubsection{CuAAC between azidonucleosides $(83 \mathrm{a}-\mathrm{c})$ and 3-O-propargyl-13 $\alpha$-estrone (82)}

Azidonucleoside $(\mathbf{8 0 a}, \mathbf{8 0 b}$ or $\mathbf{8 0 c})(0.15 \mathrm{mmol})$ was dissolved in toluene $(10 \mathrm{~mL})$ or THF (10mL), CuI (0.225 mmol, $42.75 \mathrm{mg}, 1.5$ eqv.), DIPEA (78 $\mu \mathrm{L}, 0.45 \mathrm{mmol}, 3$ eqv.) and 3-Opropargyl-13 $\alpha$-estrone $(\mathbf{8 2})(0.165 \mathrm{mmol}, 1.1 \mathrm{eqv}$.) were added to the reaction mixture and it was stirred for overnight at $50{ }^{\circ} \mathrm{C}$. Then the mixture was evaporated in vacuo, the resulting crude product was purified by column chromatography with EtOAc as eluent to yield protected conjugate (83a, $\mathbf{8 3 b}$ or $\mathbf{8 3 c}$, respectively).

\subsubsection{Deprotection of conjugates $(84 a-c)$}

Protected conjugate $(\mathbf{8 3 a}, \mathbf{8 3 b}$ or $\mathbf{8 3 c})(0.1 \mathrm{mmol})$ was deacylated by dissolving in $4 \mathrm{M} \mathrm{NH}_{3}$ in $\mathrm{MeOH}(5 \mathrm{~mL})$, stirring the mixture overnight at room temperature and then the mixture was evaporated in vacuo and the resulting crude product was purified by column chromatography with $\mathrm{EtOAc/MeCN}$ (9:1) as eluent to afford unprotected conjugate (84a, 84b or $84 c$, respectively).

\subsubsection{Preparation of acetylated nucleosides (78a-d and 89a-c, e) with free 5'-hydroxy groups}

Compounds $\mathbf{7 8 a}-\mathbf{d}$ and $\mathbf{8 9} \mathbf{a}-\mathbf{c}$, e were prepared according to literature methods. ${ }^{167}$ 


\subsubsection{Synthesis of $N$-(3-aminopropyl)-2-azidoacetamide (88)}

Methyl bromoacetate (13 g, $85 \mathrm{mmol})$ and sodium azide $(5.85 \mathrm{~g}, 90 \mathrm{mmol}, 1.06$ equiv.) in DMF (20 mL) was stirred at room temperature for $2.5 \mathrm{~h}$. An equivalent quantity of water was added and the resulting solution was extracted three times with EtOAc. The organic layer was washed six times with water and dried over $\mathrm{Na}_{2} \mathrm{SO}_{4}$ and evaporated in vacuo.

Methyl azidoacetate $(3.6 \mathrm{~g}, 31 \mathrm{mmol})$ and 1,3-diaminopropane (10 equiv., $26 \mathrm{~mL})$ in $\mathrm{MeOH}$ $(25 \mathrm{~mL})$ was stirred at room temperature for $16 \mathrm{~h}$ then evaporated in vacuo three times with $\mathrm{MeCN}$ and extracted six times with $10 \% \mathrm{NaHCO}_{3}$ and EtOAc.

\subsubsection{Coupling of linker (88) and nucleosides (synthesis of azides 93a-d, 94a-c, e)}

5'-Hydroxynucleoside (78a-d or 89a-c, e, $0.5 \mathrm{mmol}$ ) was dissolved in DMF (5 mL), then 1.4 equiv. $1,1^{\prime}$ carbonyldiimidazole and 0.1 equiv. DMAP were added to the reaction mixture that was stirred for $6 \mathrm{~h}$ at room temperature. Then 3 equiv. azide-containing linker was added and stirred for $16 \mathrm{~h}$. The reaction was quenched by adding $\mathrm{KHSO}_{4}$ solution equivalent with the amine, then extracted with water. The reaction mixture was evaporated in vacuo with MeCN three times and extracted with $5 \% \mathrm{KHSO}_{4}$ and EtOAc. The resulting crude product was purified by column chromatography, with EtOAc/MeCN (9:1) or EtOAc/MeOH (9:1) as eluent to furnish derivatives (93a-d, $94 \mathbf{a}-\mathbf{c}$ or $94 \mathbf{e}$, respectively).

\subsubsection{Removal of acetyl and benzoyl protecting groups of nucleosides (95a-d, 95a-c and 95e)}

Protected conjugate $(\mathbf{9 3 a}-\mathbf{d}, \mathbf{9 4 a}-\mathbf{c}$ or $94 \mathbf{e})(0.1 \mathrm{mmol})$ was deacylated by dissolving in $4 \mathrm{M}$ $\mathrm{NH}_{3}$ in $\mathrm{MeOH}(5 \mathrm{~mL})$, stirring the mixture overnight at room temperature and then the mixture was evaporated in vасио and the resulting crude product was purified by column chromatography with EtOAc/MeCN (8:2) as eluent to afford unprotected conjugate (95a-d, 95a-c or 95e, respectively).

\subsubsection{Synthesis of $N$-(3-aminopropyl)-2-propynamide (100)}

$2.06 \mathrm{~g}$ (0.01 mol, 1 equiv.) DCC (previously dissolved in $\mathrm{CH}_{2} \mathrm{Cl}_{2}$ and cooled to $-40{ }^{\circ} \mathrm{C}$ ) was added to $10 \mathrm{ml}$ anhydrous $\mathrm{CH}_{2} \mathrm{Cl}_{2}$ solution of $0.7 \mathrm{~g}(0.01 \mathrm{~mol})$ propiolic acid (97) cooled to $40{ }^{\circ} \mathrm{C}$ under argon atmosphere; then 5 minutes later anhydrous $\mathrm{CH}_{2} \mathrm{Cl}_{2}$ solution of $\mathrm{N}$ - $($ tertbutoxycarbonyl)-1,3-diaminopropane (98, $1.48 \mathrm{~g}, 0.0085 \mathrm{~mol}, 0.085$ equiv.) was added (10 $\mathrm{ml}$, that was cooled to $-40{ }^{\circ} \mathrm{C}$ under argon atmosphere) while constanly stirring the solution 
and stirring it for furher 3 hours while the reaction solution warmed to room temperature. 100 $\mathrm{ml}$ of diethyl ether was added to the resulting precipitate solution, the mixture was filtered and the filtrate was evaporated. The crude product was purified by column chromatography with $\mathrm{CH}_{2} \mathrm{Cl}_{2} / \mathrm{EtOAc}$ (8:2). The resulting tert-butoxycarbonyl protected linker (99) was dissolved in $50 \mathrm{ml}$ of $50 \%$ trifluoroacetic acid in dichloromethane and after 1.5 hours the reaction mixture was evaporated. This gives the trifluoroacetic acid salt of the desired $N$-(3-aminopropyl)-2propynamide (100) linker which is used for the synthesis of nucleosides by releasing 1.5 equivalents of DIPEA from its salt after adding the linker salt directly to the reaction mixture.

\subsubsection{Coupling of linkers (100-104) and nucleosides (78a and 89b)}

5'-Hydroxynucleoside (78a or $\mathbf{8 9 b}, 0.5 \mathrm{mmol}$ ) was dissolved in DMF (5 mL), then 1.4 equiv. $1,1^{\prime}$-carbonyldiimidazole (in the case of thiocarbamate bond 1,1'-tiocarbonyldiimidazole) and 0.1 equiv. DMAP were added to the reaction mixture that was stirred for $6 \mathrm{~h}$ at room temperature. Then 3 equiv. linker (100-104) was added and stirred for $16 \mathrm{~h}$. The reaction was quenched by adding $\mathrm{KHSO}_{4}$ solution equivalent with the amine, then extracted with water. The reaction mixture was evaporated in vacuo with $\mathrm{MeCN}$ three times and extracted with 5\% $\mathrm{KHSO}_{4}$ and EtOAc. The resulting crude product was purified by column chromatography, with EtOAc/MeCN $(8: 2)$ as eluent to furnish derivatives $(\mathbf{1 0 5 a}-\mathbf{1 1 3 a}$ or 114b-118b, respectively).

\subsubsection{Removal of acetyl and benzoyl protecting groups of nucleosides (119a-127a and 128b-132b)}

Protected conjugate $(\mathbf{1 0 5} \mathbf{a}-\mathbf{1 1 3 a}$ or $\mathbf{1 1 4 b}-\mathbf{1 1 8 b}, 0.1 \mathrm{mmol})$ was deacylated by dissolving in $4 \mathrm{M} \mathrm{NH}_{3}$ in $\mathrm{MeOH}(5 \mathrm{~mL})$, stirring the mixture overnight at room temperature and then the mixture was evaporated in vасио and the resulting crude product was purified by column chromatography with EtOAc/MeOH (8:2) as eluent to afford unprotected conjugate (119a$\mathbf{1 2 7} \mathbf{a}$ or $\mathbf{1 2 8 b}-\mathbf{1 3 2 b}$, respectively).

\subsubsection{Synthesis of $N$-(6-aminohexyl)-2-azidoacetamide (134)}

Methyl bromoacetate $(\mathbf{8 5}, 13 \mathrm{~g}, 85 \mathrm{mmol})$ and sodium azide $(5.85 \mathrm{~g}, 90 \mathrm{mmol}, 1.06$ equiv.) in DMF (20 mL) was stirred at room temperature for $2.5 \mathrm{~h}$. An equivalent quantity of water was added and the resulting solution was extracted three times with EtOAc. The organic layer was washed six times with water and dried over $\mathrm{Na}_{2} \mathrm{SO}_{4}$ and evaporated in vacuo. Crude methyl 
azidoacetate (86, $8.0 \mathrm{~g}, 70 \mathrm{mmol})$ and 1,6-diaminohexane (133, 10 equiv., $96.8 \mathrm{~mL})$ in $\mathrm{MeOH}$ $(30 \mathrm{~mL})$ was stirred at room temperature for $16 \mathrm{~h}$ then evaporated in vacuo three times with $\mathrm{MeCN}$ and extracted with $10 \% \mathrm{NaHCO}_{3}$ and EtOAc. The resulting crude product (134) was purified by column chromatography, with $\mathrm{MeCN} / \mathrm{MeOH} / \mathrm{H}_{2} \mathrm{O}(4: 1: 1+10 \%$ TEA).

\subsubsection{Coupling of linker (134) and nucleoside (89a)}

5'-Hydroxynucleoside (89a, $0.5 \mathrm{mmol})$ was dissolved in DMF (5 mL), then 1.4 equiv. 1,1 'carbonyldiimidazole and 0.1 equiv. DMAP were added to the reaction mixture that was stirred for $6 \mathrm{~h}$ at room temperature. Then 3 equiv. linker (134) was added and stirred for $16 \mathrm{~h}$. The reaction was quenched by adding $\mathrm{KHSO}_{4}$ solution equivalent with the amine, then extracted with water. The reaction mixture was evaporated in vacuo with $\mathrm{MeCN}$ three times and extracted with $5 \% \mathrm{KHSO}_{4}$ and EtOAc. The resulting crude product was purified by column chromatography, with EtOAc/MeOH (95:5) or EtOAc/MeOH (9:1) as eluent to furnish derivative (136).

\subsubsection{CuAAC between linker containing azidonucleosides (94a and 136) and 15- $O$ - propargyl-13ß-estrone (135)}

Azidonucleoside (94a or 136) (0.15 mmol) was dissolved in THF (10mL), CuI (0.15 mmol,

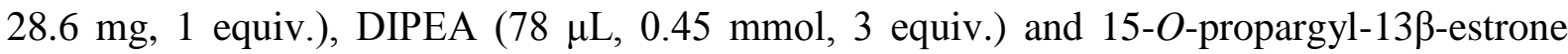
(135) $(0.165 \mathrm{mmol}, 1.1$ eqv.) were added to the reaction mixture and it was stirred for overnight at $50{ }^{\circ} \mathrm{C}$. Then the mixture was evaporated in vacuo, the resulting crude product was purified by column chromatography with EtOAc/MeOH $(9: 1)$ or EtOAc/MeOH $(8: 2)$ as eluent to yield protected conjugate (137 or $\mathbf{1 3 8}$, respectively).

\subsubsection{Deprotection of conjugates (139 and 140)}

Protected conjugate (137 or 138) $(0.1 \mathrm{mmol})$ was deacylated by dissolving in $4 \mathrm{M} \mathrm{NH}_{3}$ in $\mathrm{MeOH}(5 \mathrm{~mL})$, stirring the mixture overnight at room temperature and then the mixture was evaporated in vacuo and the resulting crude product was purified by column chromatography with $\mathrm{EtOAc} / \mathrm{MeOH}(8: 2)$ as eluent to afford unprotected conjugate (139 or 140, respectively). 


\section{Summary}

The aim of this work was the synthesis of estrone conjugates containing natural units (monosaccharides and nucleosides) as potential antitumor and enzyme inhibition agents.

As the estrone molecules already contained a terminal alkyne function for the $\mathrm{CuAAC}$ reaction, first we have introduced an azide functional group at the glycosidic or the primary hydroxy groups into the simplest monosaccharides (D-glucose, D-mannose, D-galactose, Dribose). The 1-azido monosaccharides (47-49) were produced with trimethylsilyl azide and the 6- and 5-azido monosaccharides (59-61) were obtained with the tosyl-azide exchange method. Then the azide group-containing monosaccharides (47-49 and 59-61) were coupled to the alkyne-containing D-secoalcohol (64a) and D-secooxime (64b) using CuAAC conditions. The conjugation reactions were successful in all cases $(\mathbf{6 5 a}, \mathbf{b}-\mathbf{7 0 a}, \mathbf{b})$ and the biological activity of the compounds were investigated. In case of the two glucose-containing bioconjugates (65a,b), which showed the best biological activities, the acetyl protecting groups were removed to obtain their unprotected derivatives 71a,b to test their biological activity as well.

In the next part of our work, we have synthesized 5'-azido-5'-deoxynucleosides $(\mathbf{8 0 a}-\mathbf{c})$ where the azide group was directly linked to the 5'-carbon of the nucleoside sugar moiety. As our first attempt, to directly functionalize the free hydroxy-containing nucleosides at their $5^{\prime}$ position in the tosyl-azide route failed due to several side-reactions, the secondary hydroxy groups have been protected which helped us to make almost all the desired 5'-azidonucleosides (unfortunately the synthesis of the similar 2'-deoxyguanosine derivative failed). The synthesized 5'-azido-5'-deoxynucleosides $(\mathbf{8 0 a}-\mathbf{c})$ were coupled to the steroid alkyne (82) by $\mathrm{CuAAC}$ reaction. The reaction conditions needed some optimization, we increased the amount of the catalyst to form all the conjugates $(\mathbf{8 3 a}-\mathbf{c})$ with acceptable rates. Beside the acyl protected conjugates, the biological activity of conjugates without the acyl protective groups $(\mathbf{8 4 a}-\mathbf{c})$ were also tested.

The antiproliferative properties of the new conjugates $(\mathbf{6 5 a}, \mathbf{b}-71 \mathbf{a}, \mathbf{b}$ and $83 \mathbf{a}-\mathbf{c}$ and $84 \mathbf{a}-$ c) were characterized in vitro on a panel of human adherent cancer cell lines (HeLa, A2780 and MCF-7) by means of MTT assays at the Department of Pharmacodynamics and Biopharmacy, University of Szeged. In the case of monosaccharide conjugates, the most 
potent compounds $(\mathbf{6 5 b}, \mathbf{6 6 b}$ and $67 \mathrm{~b})$ exhibited remarkable activities with $\mathrm{IC}_{50}$ values in the range 5.3-20.5 $\mu \mathrm{M}$, exerting their best effects against A2780 cells. Among the potent compounds the glucoside conjugate (65b) displayed the highest cell-line selectivity. In the case of the nucleoside-conjugates, the protected cytidine conjugate $(\mathbf{8 3 c})$ proved to be the most potent with $\mathrm{IC}_{50}$ values in the range 9.0-10.4 $\mu \mathrm{M}$. The newly synthesized nucleoside conjugates (83a-c and 84a-c) of $13 \alpha$-estrone were also tested against the human 17 $\beta$-HSD1 enzyme in vitro at the $1^{\text {st }}$ Department of Internal Medicine, University of Szeged. The unprotected thymidine conjugate (84b) exerted substantial inhibition, with an $\mathrm{IC}_{50}$ value of 19 $\mu \mathrm{M}$.

As the transformation of 2'-deoxyguanosine to the corresponding 5'-deoxy-5'-azido-2'deoxyguanosine could not be performed with any of the methods described in the literature, a method was developed to incorporate the azide group to the 5'-position using a linker resulting in significantly better yields compared to all other previous methods. We have synthesised an azido-alkylamido-amine linker (88) which was coupled successfully to the nucleosides through a carbamate bond. With this method all the eight natural azido derivates of nucleosides (93a-d and 94a-c,e) could be obtained in very good yields (76-86\%) and quite easily without side-reactions.

For the next part of our work, more nucleoside building blocks have been prepared which may be suitable for the production of nucleoside bioconjugates. The protected form of the two most sensitive purine-based nucleosides (2'-deoxyadenosine 78a and guanosine 89b) was chosen as starting materials and versatile linkers (100-104) were attached to the nitrogen atom of the carbamate/thiocarbamate functional group on the 5'-hydroxy group: alkyl amidoalkyl, alkylene and oligoethylene glycol moieties. In all cases the syntheses were successfull showing the general applicability of the method.

Finally, to test the applicability of the prepared nucleoside building blocks in the synthesis of bioconjugates, alkylamido linker containing azido-adenosines $(\mathbf{9 4 a}, \mathbf{1 3 6})$ with two different lengths were obtained and coupled to a $13 \beta$-estrone derivative containing the propargyl functional group at position $15(\mathbf{1 3 5})$ in a click reaction $(\mathbf{1 3 7}, \mathbf{1 3 8})$ and then the acyl protections were removed $(\mathbf{1 3 9}, \mathbf{1 4 0})$. The analytical results showed the expected products proving the applicability of these linker containing clickable nucleoside building blocks in the synthesis of bioconjugates. 


\section{References}

1. Pasqualini, J. R. Biochim. Biophys. Acta 2004, 1654, 123-143.

2. Warner, M.; Gustafsson, J.-Å. Biochem. Biophys. Res. Commun. 2010, 396, 63-66.

3. Tietze, L. F.; Bell, H. P.; Chandrasekhar, S. Angew. Chemie Int. Ed. 2003, 42, 39964028.

4. Shagufta, S.; Panda, G. Org. Biomol. Chem. 2007, 5, 360-366.

5. Vihma, V.; Tikkanen, M. J. J. Steroid Biochem. Mol. Biol. 2011, 124, 65-76.

6. $\quad$ Rivera, D. G.; Pérez-Labrada, K.; Lambert, L.; Dörner, S.; Westermann, B.; Wessjohann, L. A. Carbohydr. Res. 2012, 359, 102-110.

7. Poirier, D.; Boivin, R. P.; Tremblay, M. R.; Bérubé, M.; Qiu, W.; Lin, S.-X. J. Med. Chem. 2005, 48, 8134-8147.

8. Schönecker, B.; Lange, C.; Kötteritzsch, M.; Günther, W.; Weston, J.; Anders, E.; Görls, H. J. Org. Chem. 2000, 65, 5487-5497.

9. Thomas, M. P.; Potter, B. V. L. J. Steroid Biochem. Mol. Biol. 2013, 137, 27-49.

10. Gupta, A.; Sathish Kumar, B.; Negi, A. S. J. Steroid Biochem. Mol. Biol. 2013, 137, 242-270.

11. Ishida, H.; Nakata, T.; Suzuki, M.; Shiotsu, Y.; Tanaka, H.; Sato, N.; Terasaki, Y.; Takebayashi, M.; Anazawa, H.; Murakata, C.; Li, P.-K.; Kuwabara, T.; Akinaga, S. Breast Cancer Res. Treat. 2007, 106, 215-227.

12. Ciobanu, L. C.; Boivin, R. P.; Luu-The, V.; Labrie, F.; Poirier, D. J. Med. Chem. 1999, $42,2280-2286$.

13. Peters, R. H.; Chao, W.-R.; Sato, B.; Shigeno, K.; Zaveri, N. T.; Tanabe, M. Steroids 2003, 68, 97-110.

14. MacCarthy-Morrogh, L.; Townsend, P. A.; Purohit, A.; Hejaz, H. A. M.; Potter, B. V. L.; Reed, M. J.; Packham, G. Cancer Res. 2000, 60, 5441-5450.

15. Woo, L. W. L.; Howarth, N. M.; Purohit, A.; Hejaz, H. A. M.; Reed, M. J.; Potter, B. V. L. J. Med. Chem. 1998, 41, 1068-1083.

16. Wang, M.; Xu, L.; Gao, M.; Miller, K. D.; Sledge, G. W.; Zheng, Q.-H. Steroids 2012, 77, 864-870.

17. Numazawa, M.; Ando, M.; Watari, Y.; Tominaga, T.; Hayata, Y.; Yoshimura, A. $J$. Steroid Biochem. Mol. Biol. 2005, 96, 51-58.

18. Bérubé, M.; Poirier, D. Org. Lett. 2004, 6, 3127-3130.

19. Lawrence, H. R.; Vicker, N.; Allan, G. M.; Smith, A.; Mahon, M. F.; Tutill, H. J.; Purohit, A.; Reed, M. J.; Potter, B. V. L. J. Med. Chem. 2005, 48, 2759-2762.

20. Bydal, P.; Auger, S.; Poirier, D. Steroids 2004, 69, 325-342.

21. Poirier, D.; Bydal, P.; Tremblay, M. R.; Sam, K.-M.; Luu-The, V. Mol. Cell. 
Endocrinol. 2001, 171, 119-128.

22. Cadot, C.; Laplante, Y.; Kamal, F.; Luu-The, V.; Poirier, D. Bioorg. Med. Chem. 2007, $15,714-726$.

23. Poirier, D.; Dionne, P.; Auger, S. J. Steroid Biochem. Mol. Biol. 1998, 64, 83-90.

24. Marchais-Oberwinkler, S.; Henn, C.; Möller, G.; Klein, T.; Negri, M.; Oster, A.; Spadaro, A.; Werth, R.; Wetzel, M.; Xu, K.; Frotscher, M.; Hartmann, R. W.; Adamski, J. J. Steroid Biochem. Mol. Biol. 2011, 125, 66-82.

25. Chen, G. G.; Zeng, Q.; Tse, G. M. Med. Res. Rev. 2008, 28, 954-974.

26. Minorics, R.; Bózsity, N.; Wölfling, J.; Mernyák, E.; Schneider, G.; Márki, Á.; Falkay, G.; Ocsovszki, I.; Zupkó, I. J. Steroid Biochem. Mol. Biol. 2012, 132, 168-175.

27. Wölfling, J.; Mernyák, E.; Frank, É.; Falkay, G.; Márki, Á.; Minorics, R.; Schneider, G. Steroids 2003, 68, 277-288.

28. Ray, S.; Dwivedy, I. In Drug Research; Elsevier Masson SAS, 1997; Vol. 29, pp. 171270.

29. Deluca, D.; Möller, G.; Rosinus, A.; Elger, W.; Hillisch, A.; Adamski, J. Mol. Cell. Endocrinol. 2006, 248, 218-224.

30. Billich, A.; Nussbaumer, P.; Lehr, P. J. Steroid Biochem. Mol. Biol. 2000, 73, 225-235.

31. Husen, B.; Huhtinen, K.; Saloniemi, T.; Messinger, J.; Thole, H. H.; Poutanen, M. Endocrinology 2006, 147, 5333-5339.

32. Jourdan, F.; Leese, M. P.; Dohle, W.; Ferrandis, E.; Newman, S. P.; Chander, S.; Purohit, A.; Potter, B. V. L. J. Med. Chem. 2011, 54, 4863-4879.

33. Cushman, M.; He, H.-M.; Katzenellenbogen, J. A.; Varma, R. K.; Hamel, E.; Lin, C. M.; Ram, S.; Sachdeva, Y. P. J. Med. Chem. 1997, 40, 2323-2334.

34. Jovanović-Šanta, S.; Petrović, J.; Andrić, S.; Kovačević, R.; Đurendić, E.; Sakač, M.; Lazar, D.; Stanković, S. Bioorg. Chem. 2003, 31, 475-484.

35. Ayan, D.; Roy, J.; Maltais, R.; Poirier, D. J. Steroid Biochem. Mol. Biol. 2011, 127, 324-330.

36. Möller, G.; Deluca, D.; Gege, C.; Rosinus, A.; Kowalik, D.; Peters, O.; Droescher, P.; Elger, W.; Adamski, J.; Hillisch, A. Bioorg. Med. Chem. Lett. 2009, 19, 6740-6744.

37. Yaremenko, F. G.; Khvat, A. V Mendeleev Commun. 1994, 4, 187-188.

38. Schneider, G.; Bottka, S.; Hackler, L.; Wölfling, J.; Sohár, P. Liebigs Ann. der Chemie 1989, 1989, 263-267.

39. Wölfling, J.; Mernyák, E.; Forgó, P.; Schneider, G. Steroids 2003, 68, 451-458.

40. Mernyák, E.; Huber, J.; Benedek, G.; Pfoh, R.; Rühl, S.; Schneider, G.; Wölfling, J. Arkivoc 2010, 2010, 101-113.

41. Mernyák, E.; Fiser, G.; Szabó, J.; Bodnár, B.; Schneider, G.; Kovács, I.; Ocsovszki, I.; Zupkó, I.; Wölfling, J. Steroids 2014, 89, 47-55.

42. Frank, É.; Mernyák, E.; Wölfling, J.; Schneider, G. Synlett 2002, 2002, 1803-1806. 
43. Szabó, J.; Jerkovics, N.; Schneider, G.; Wölfling, J.; Bózsity, N.; Minorics, R.; Zupkó, I.; Mernyák, E. Molecules 2016, 21, 611.

44. Rostovtsev, V. V.; Green, L. G.; Fokin, V. V.; Sharpless, K. B. Angew. Chemie Int. Ed. 2002, 41, 2596-2599.

45. Meldal, M.; Tornøe, C. W. Chem. Rev. 2008, 108, 2952-3015.

46. Liang, L.; Astruc, D. Coord. Chem. Rev. 2011, 255, 2933-2945.

47. Kolb, H. C.; Finn, M. G.; Sharpless, K. B. Angew. Chemie Int. Ed. 2001, 40, 20042021.

48. Tornøe, C. W.; Christensen, C.; Meldal, M. J. Org. Chem. 2002, 67, 3057-3064.

49. Huisgen, R. Angew. Chemie Int. Ed. English 1963, 2, 565-598.

50. Malkoch, M.; Thibault, R. J.; Drockenmuller, E.; Messerschmidt, M.; Voit, B.; Russell, T. P.; Hawker, C. J. J. Am. Chem. Soc. 2005, 127, 14942-14949.

51. $\quad$ Liang, C.-H.; Yao, S.; Chiu, Y.-H.; Leung, P. Y.; Robert, N.; Seddon, J.; Sears, P.; Hwang, C.-K.; Ichikawa, Y.; Romero, A. Bioorg. Med. Chem. Lett. 2005, 15, $1307-$ 1310 .

52. Dondoni, A.; Marra, A. J. Org. Chem. 2006, 71, 7546-7557.

53. Bock, V. D.; Hiemstra, H.; van Maarseveen, J. H. European J. Org. Chem. 2006, 2006, $51-68$.

54. Pachón, L. D.; van Maarseveen, J. H.; Rothenberg, G. Adv. Synth. Catal. 2005, 347, 811-815.

55. Molteni, G.; Bianchi, C. L.; Marinoni, G.; Santo, N.; Ponti, A. New J. Chem. 2006, 30, 1137-1139.

56. Himo, F.; Lovell, T.; Hilgraf, R.; Rostovtsev, V. V.; Noodleman, L.; Sharpless, K. B.; Fokin, V. V. J. Am. Chem. Soc. 2005, 127, 210-216.

57. Kádár, Z.; Baji, Á.; Zupkó, I.; Bartók, T.; Wölfling, J.; Frank, É. Org. Biomol. Chem. 2011, 9, 8051-8057.

58. Kádár, Z.; Molnár, J.; Schneider, G.; Zupkó, I.; Frank, É. Bioorg. Med. Chem. 2012, 20, 1396-1402.

59. Kádár, Z.; Kovács, D.; Frank, É.; Schneider, G.; Huber, J.; Zupkó, I.; Bartók, T.; Wölfling, J. Molecules 2011, 16, 4786-4806.

60. Kádár, Z.; Frank, É.; Schneider, G.; Molnár, J.; Zupkó, I. Arkivoc 2012, 2012, 279 296.

61. Frank, É.; Molnár, J.; Zupkó, I.; Kádár, Z.; Wölfling, J. Steroids 2011, 76, 1141-1148.

62. Szabó, J.; Bacsa, I.; Wölfling, J.; Schneider, G.; Zupkó, I.; Varga, M.; Herman, B. E.; Kalmár, L.; Szécsi, M.; Mernyák, E. J. Enzyme Inhib. Med. Chem. 2016, 31, 574-579.

63. Szabó, J.; Pataki, Z.; Wölfling, J.; Schneider, G.; Bózsity, N.; Minorics, R.; Zupkó, I.; Mernyák, E. Steroids 2016, 113, 14-21.

64. Mernyák, E.; Kovács, I.; Minorics, R.; Sere, P.; Czégány, D.; Sinka, I.; Wölfling, J.; 
Schneider, G.; Újfaludi, Z.; Boros, I.; Ocsovszki, I.; Varga, M.; Zupkó, I. J. Steroid Biochem. Mol. Biol. 2015, 150, 123-134.

65. Slámová, K.; Marhol, P.; Bezouška, K.; Lindkvist, L.; Hansen, S. G.; Křen, V.; Jensen, H. H. Bioorg. Med. Chem. Lett. 2010, 20, 4263-4265.

66. Wilkinson, B. L.; Bornaghi, L. F.; Houston, T. A.; Innocenti, A.; Vullo, D.; Supuran, C. T.; Poulsen, S.-A. Bioorg. Med. Chem. Lett. 2007, 17, 987-992.

67. Yang, J.-W.; He, X.-P.; Li, C.; Gao, L.-X.; Sheng, L.; Xie, J.; Shi, X.-X.; Tang, Y.; Li, J.; Chen, G.-R. Bioorg. Med. Chem. Lett. 2011, 21, 1092-1096.

68. Kai, H.; Hinou, H.; Nishimura, S.-I. Bioorg. Med. Chem. 2012, 20, 2739-2746.

69. Sandbhor, M. S.; Soya, N.; Albohy, A.; Zheng, R. B.; Cartmell, J.; Bundle, D. R.; Klassen, J. S.; Cairo, C. W. Biochemistry 2011, 50, 6753-6762.

70. Howe, J. D.; Smith, N.; Lee, M. J.-R.; Ardes-Guisot, N.; Vauzeilles, B.; Désiré, J.; Baron, A.; Blériot, Y.; Sollogoub, M.; Alonzi, D. S.; Butters, T. D. Bioorg. Med. Chem. 2013, 21, 4831-4838.

71. Barras, A.; Martin, F. A.; Bande, O.; Baumann, J.-S.; Ghigo, J.-M.; Boukherroub, R.; Beloin, C.; Siriwardena, A.; Szunerits, S. Nanoscale 2013, 5, 2307-2316.

72. Campo, V. L.; Ivanova, I. M.; Carvalho, I.; Lopes, C. D.; Carneiro, Z. A.; Saalbach, G.; Schenkman, S.; da Silva, J. S.; Nepogodiev, S. A.; Field, R. A. Tetrahedron 2015, 71, 7344-7353.

73. Campo, V. L.; Carvalho, I.; Da Silva, C. H. T. P.; Schenkman, S.; Hill, L.; Nepogodiev, S. A.; Field, R. A. Chem. Sci. 2010, 1, 507-514.

74. Hu, X.-L.; Li, D.; Shao, L.; Dong, X.; He, X.-P.; Chen, G.-R.; Chen, D. ACS Med. Chem. Lett. 2015, 6, 793-797.

75. da Rocha, D. R.; Santos, W. C.; Lima, E. S.; Ferreira, V. F. Carbohydr. Res. 2012, 350, 14-19.

76. Bokor, É.; Docsa, T.; Gergely, P.; Somsák, L. Bioorg. Med. Chem. 2010, 18, 11711180.

77. Rossi, L. L.; Basu, A. Bioorg. Med. Chem. Lett. 2005, 15, 3596-3599.

78. McDowell, M.; Gonzales, S. R.; Kumarapperuma, S. C.; Jeselnik, M.; Arterburn, J. B.; Hanley, K. A. Antiviral Res. 2010, 87, 78-80.

79. Chung, D.-H.; Kumarapperuma, S. C.; Sun, Y.; Li, Q.; Chu, Y.-K.; Arterburn, J. B.; Parker, W. B.; Smith, J.; Spik, K.; Ramanathan, H. N.; Schmaljohn, C. S.; Jonsson, C. B. Antiviral Res. 2008, 79, 19-27.

80. Zhang, Q.; He, P.; Zhou, G.; Gu, Y.; Fu, T.; Xue, D.; Liu, H.-M. Carbohydr. Res. 2013, 382, 65-70.

81. Ruddarraju, R. R.; Murugulla, A. C.; Kotla, R.; Chandra Babu Tirumalasetty, M.; Wudayagiri, R.; Donthabakthuni, S.; Maroju, R.; Baburao, K.; Parasa, L. S. Eur. J. Med. Chem. 2016, 123, 379-396.

82. Chaudhary, P. M.; Chavan, S. R.; Shirazi, F.; Razdan, M.; Nimkar, P.; Maybhate, S. P.; 
Likhite, A. P.; Gonnade, R.; Hazara, B. G.; Deshpande, M. V.; Deshpande, S. R. Bioorg. Med. Chem. 2009, 17, 2433-2440.

83. Lolk, L.; Pøhlsgaard, J.; Jepsen, A. S.; Hansen, L. H.; Nielsen, H.; Steffansen, S. I.; Sparving, L.; Nielsen, A. B.; Vester, B.; Nielsen, P. J. Med. Chem. 2008, 51, 49574967.

84. Chen, L.; Wilson, D. J.; Xu, Y.; Aldrich, C. C.; Felczak, K.; Sham, Y. Y.; Pankiewicz, K. W. J. Med. Chem. 2010, 53, 4768-4778.

85. Gupte, A.; Boshoff, H. I.; Wilson, D. J.; Neres, J.; Labello, N. P.; Somu, R. V.; Xing, C.; Barry, C. E.; Aldrich, C. C. J. Med. Chem. 2008, 51, 7495-7507.

86. Györgydeák, Z.; Thiem, J. In Advances in Carbohydrate Chemistry and Biochemistry; Elsevier, 2006; Vol. 60, pp. 103-182.

87. Bertho, A. Berichte der Dtsch. Chem. Gesellschaft 1930, 63, 836-843.

88. Györgydeák, Z.; Szilágyi, L.; Paulsen, H. J. Carbohydr. Chem. 1993, 12, 139-163.

89. Pfleiderer, W.; Bühler, E. Chem. Ber. 1966, 99, 3022-3039.

90. Tropper, F. D.; Andersson, F. O.; Braun, S.; Roy, R. Synthesis (Stuttg). 1992, 1992, 618-620.

91. Paulsen, H.; Györgydeák, Z.; Friedmann, M. Chem. Ber. 1974, 107, 1568-1578.

92. Wilkinson, B. L.; Bornaghi, L. F.; Poulsen, S.-A.; Houston, T. A. Tetrahedron 2006, $62,8115-8125$.

93. Varki, A. Glycobiology 1993, 3, 97-130.

94. Sears, P.; Wong, C.-H. Cell. Mol. Life Sci. 1998, 54, 223-252.

95. Giannis, A. Angew. Chemie Int. Ed. English 1994, 33, 178-180.

96. Yuen, C. T.; Bezouska, K.; O’Brien, J.; Stoll, M.; Lemoine, R.; Lubineau, A.; Kiso, M.; Hasegawa, A.; Bockovich, N. J.; Nicolaou, K. C. J. Biol. Chem. 1994, 269, 15951598.

97. Feizi, T. Curr. Opin. Struct. Biol. 1993, 3, 701-710.

98. Ryan, C. Proc. Natl. Acad. Sci. U. S. A. 1994, 91, 1-2.

99. Rudd, P. M. Science (80-. ). 2001, 291, 2370-2376.

100. Ekholm, F. S.; Schneider, G.; Wölfling, J.; Leino, R. European J. Org. Chem. 2011, 2011, 1064-1077.

101. Hu, K.; Yao, X. Anticancer Drugs 2001, 12, 541-547.

102. Morzycki, J. W.; Wojtkielewicz, A. Phytochem. Rev. 2005, 4, 259-277.

103. Yokosuka, A.; Jitsuno, M.; Yui, S.; Yamazaki, M.; Mimaki, Y. J. Nat. Prod. 2009, 72, 1399-1404.

104. Takechi, M.; Shimada, S.; Tanaka, Y. Phytochemistry 1991, 30, 3943-3944.

105. Mimaki, Y.; Nakamura, O.; Sashida, Y.; Nikaido, T.; Ohmoto, T. Phytochemistry 1995, 38, 1279-1286. 
106. Ekblad, M.; Adamiak, B.; Bergstrom, T.; Johnstone, K. D.; Karoli, T.; Liu, L.; Ferro, V.; Trybala, E. Antiviral Res. 2010, 86, 196-203.

107. Said, J.; Trybala, E.; Andersson, E.; Johnstone, K.; Liu, L.; Wimmer, N.; Ferro, V.; Bergström, T. Antiviral Res. 2010, 86, 286-295.

108. Pellissier, H. Tetrahedron 2004, 60, 5123-5162.

109. Ding, X.; Zhu, F.; Yang, Y.; Li, M. Food Chem. 2013, 141, 1181-1186.

110. Langenhan, J. M.; Peters, N. R.; Guzei, I. A.; Hoffmann, F. M.; Thorson, J. S. Proc. Natl. Acad. Sci. U. S. A. 2005, 102, 12305-12310.

111. De Clercq, E. J. Clin. Virol. 2004, 30, 115-133.

112. McGuigan, C.; Bourdin, C.; Derudas, M.; Hamon, N.; Hinsinger, K.; Kandil, S.; Madela, K.; Meneghesso, S.; Pertusati, F.; Serpi, M.; Slusarczyk, M.; Chamberlain, S.; Kolykhalov, A.; Vernachio, J.; Vanpouille, C.; Introini, A.; Margolis, L.; Balzarini, J. Eur. J. Med. Chem. 2013, 70, 326-340.

113. Pastor-Anglada, M.; Cano-Soldado, P.; Molina-Arcas, M.; Lostao, M. P.; Larráyoz, I.; Martínez-Picado, J.; Casado, F. J. Virus Res. 2005, 107, 151-164.

114. Debnath, J.; Dasgupta, S.; Pathak, T. Bioorg. Med. Chem. 2009, 17, 4921-4927.

115. Zhou, L.; Amer, A.; Korn, M.; Burda, R.; Balzarini, J.; De Clercq, E.; Kern, E. R.; Torrence, P. F. Antivir. Chem. Chemother. 2005, 16, 375-383.

116. Zhang, Y.-X.; Dai, G.-F.; Wang, L.; Tao, J.-C. Bioorg. Med. Chem. Lett. 2007, 17, $1613-1615$.

117. Cho, S. Y.; Polster, J.; Engles, J. M.; Hilton, J.; Abraham, E. H.; Wahl, R. L. J. Nucl. Med. 2006, 47, 837-45.

118. Pérez-Torras, S.; García-Manteiga, J.; Mercadé, E.; Casado, F. J.; Carbó, N.; PastorAnglada, M.; Mazo, A. Biochem. Pharmacol. 2008, 76, 322-329.

119. Poirier, D.; Boivin, R. P.; Bérubé, M.; Lin, S.-X. Synth. Commun. 2003, 33, 31833192.

120. Bérubé, M.; Poirier, D. J. Enzyme Inhib. Med. Chem. 2009, 24, 832-843.

121. Bérubé, M.; Poirier, D. Can. J. Chem. 2009, 87, 1180-1199.

122. Iyer, V. K.; Butler, W. B.; Horwitz, J. P.; Rozhin, J.; Brooks, S. C.; Corombos, J.; Kessel, D. J. Med. Chem. 1983, 26, 162-166.

123. Cheng, K.; Liu, J.; Sun, H.; Xie, J. Synthesis (Stuttg). 2010, 2010, 1046-1052.

124. Herdewijn, P.; Balzarini, J.; Pauwels, R.; Janssen, G.; Aerschot, A. Van; Clercq, E. De Nucleosides and Nucleotides 1989, 8, 1231-1257.

125. Chen, J.-B.; Liu, E. M.; Chern, T.-R.; Yang, C.-W.; Lin, C.-I.; Huang, N.-K.; Lin, Y.L.; Chern, Y.; Lin, J.-H.; Fang, J.-M. ChemMedChem 2011, 6, 1390-1400.

126. Murat, P.; Gennaro, B.; Garcia, J.; Spinelli, N.; Dumy, P.; Defrancq, E. Chem. - A Eur. J. 2011, 17, 5791-5795.

127. Mattarella, M.; Berstis, L.; Baldridge, K. K.; Siegel, J. S. Bioconjug. Chem. 2014, 25, 
$115-128$.

128. Točík, Z.; Dvořáková, I.; Liboska, R.; Buděšínský, M.; Masojídková, M.; Rosenberg, I. Tetrahedron 2007, 63, 4516-4534.

129. Brear, P.; Freeman, G. R.; Shankey, M. C.; Trmčić, M.; Hodgson, D. R. W. Chem. Commun. 2009, 4980-4981.

130. Paredes, E.; Das, S. R. ChemBioChem 2011, 12, 125-131.

131. Yamamoto, I.; Sekine, M.; Hata, T. J. Chem. Soc., Perkin Trans. 1 1980, 306-310.

132. Hui, W.-Q. B.; Sherman, J. C. Tetrahedron Lett. 2014, 55, 1479-1485.

133. Madhuri, V.; Kumar, V. A. Nucleosides Nucleotides \& Nucleic Acids 2012, 31, 97 111.

134. Seio, K.; Miyashita, T.; Sato, K.; Sekine, M. European J. Org. Chem. 2005, 2005, 5163-5170.

135. Nuzzi, A.; Massi, A.; Dondoni, A. QSAR Comb. Sci. 2007, 26, 1191-1199.

136. Liu, F.; Austin, D. J. J. Org. Chem. 2001, 66, 8643-8645.

137. Cui, H.; Carrero-Lérida, J.; Silva, A. P. G.; Whittingham, J. L.; Brannigan, J. a; RuizPérez, L. M.; Read, K. D.; Wilson, K. S.; González-Pacanowska, D.; Gilbert, I. H. J. Med. Chem. 2012, 55, 10948-10957.

138. Mitsunobu, O. Synthesis (Stuttg). 1981, 1981, 1-28.

139. Hughes, D. L. Org. Prep. Proced. Int. 1996, 28, 127-164.

140. Swamy, K. C. K.; Kumar, N. N. B.; Balaraman, E.; Kumar, K. V. P. P. Chem. Rev. 2009, 109, 2551-2651.

141. Viaud, M. C.; Rollin, P. Synthesis (Stuttg). 1990, 1990, 130-132.

142. Hayasi, M.; Kawabata, H. In Recent developments in carbohydrate research.; Research Singpost: Thiruvananthapuram, 2003; pp. 195-208.

143. Beckmann, H. S. G.; Wittmann, V. In Organic Azides: Syntheses and Applications; John Wiley \& Sons, Ltd: Chichester, 2010; pp. 469-490.

144. Sicherl, F.; Wittmann, V. Angew. Chemie Int. Ed. 2005, 44, 2096-2099.

145. Mernyák, E.; Szabó, J.; Bacsa, I.; Huber, J.; Schneider, G.; Minorics, R.; Bózsity, N.; Zupkó, I.; Varga, M.; Bikádi, Z.; Hazai, E.; Wölfling, J. Steroids 2014, 87, 128-136.

146. Zerong, W. (Ed. . In Comprehensive Organic Name Reactions and Reagents; John Wiley \& Sons, Inc.: New York, Chichester, 2010; pp. 3123-3128.

147. Kicsák, M.; Bege, M.; Bereczki, I.; Csávás, M.; Herczeg, M.; Kupihár, Z.; Kovács, L.; Borbás, A.; Herczegh, P. Org. Biomol. Chem. 2016, 14, 3190-3192.

148. Jawalekar, A. M.; Meeuwenoord, N.; Cremers, J. (Sjef) G. O.; Overkleeft, H. S.; van der Marel, G. A.; Rutjes, F. P. J. T.; van Delft, F. L. J. Org. Chem. 2008, 73, 287-290.

149. An, S. H.; West, C. R.; Hong, C. I. Steroids 1986, 47, 413-20.

150. Maiti, S. N.; Singh, M. P.; Micetich, R. G. Tetrahedron Lett. 1986, 27, 1423-1424. 
151. Sechi, M.; Derudas, M.; Dallocchio, R.; Dessì, A.; Bacchi, A.; Sannia, L.; Carta, F.; Palomba, M.; Ragab, O.; Chan, C.; Shoemaker, R.; Sei, S.; Dayam, R.; Neamati, N. J. Med. Chem. 2004, 47, 5298-5310.

152. Borodkin, V. S.; Ferguson, M. A. J.; Nikolaev, A. V. Tetrahedron Lett. 2004, 45, 857862.

153. Enkvist, E.; Lavogina, D.; Raidaru, G.; Vaasa, A.; Viil, I.; Lust, M.; Viht, K.; Uri, A. J. Med. Chem. 2006, 49, 7150-7159.

154. Viht, K.; Schweinsberg, S.; Lust, M.; Vaasa, A.; Raidaru, G.; Lavogina, D.; Uri, A.; Herberg, F. W. Anal. Biochem. 2007, 362, 268-77.

155. Kestav, K.; Lavogina, D.; Raidaru, G.; Chaikuad, A.; Knapp, S.; Uri, A. Bioconjug. Chem. 2015, 26, 225-234.

156. Lerner, C.; Masjost, B.; Ruf, A.; Gramlich, V.; Jakob-Roetne, R.; Zürcher, G.; Borroni, E.; Diederich, F. Org. Biomol. Chem. 2003, 1, 42-49.

157. Fournier, D.; Poirier, D.; Mazumdar, M.; Lin, S.-X. Eur. J. Med. Chem. 2008, 43, 2298-2306.

158. Shi, C.; Tiwari, D.; Wilson, D. J.; Seiler, C. L.; Schnappinger, D.; Aldrich, C. C. ACS Med. Chem. Lett. 2013, 4, 1213-1217.

159. Lavogina, D.; Enkvist, E.; Uri, A. ChemMedChem 2010, 5, 23-34.

160. Nelson, K. M.; Viswanathan, K.; Dawadi, S.; Duckworth, B. P.; Boshoff, H. I.; Barry, C. E.; Aldrich, C. C. J. Med. Chem. 2015, 58, 5459-5475.

161. Pisani, L.; Catto, M.; Giangreco, I.; Leonetti, F.; Nicolotti, O.; Stefanachi, A.; Cellamare, S.; Carotti, A. ChemMedChem 2010, 5, 1616-1630.

162. Laplante, Y.; Cadot, C.; Fournier, M.-A.; Poirier, D. Bioorg. Med. Chem. 2008, 16, 1849-1860.

163. Lippert, B. (Ed. . Cisplatin. Chemistry and Biochemistry Of A Leading Anticancer Drug; Verlag Helvetica Chimica Acta, Wiley-VHC: Zürich, Weinheim, 1999.

164. Ferenc, G.; Pádár, P.; Szolomájer, J.; M. Howarth, N.; Kovács, L. Curr. Org. Chem. 2011, 15, 2871-2892.

165. Herman, B. E.; Szabó, J.; Bacsa, I.; Wölfling, J.; Schneider, G.; Bálint, M.; Hetényi, C.; Mernyák, E.; Szécsi, M. J. Enzyme Inhib. Med. Chem. 2016, 31, 61-69.

166. Dutta, D.; Pulsipher, A.; Yousaf, M. N. Langmuir 2010, 26, 9835-9841.

167. Cottam, H. B.; Wasson, D. B.; Shih, H. C.; Raychaudhuri, A.; Di Pasquale, G.; Carson, D. A. J. Med. Chem. 1993, 36, 3424-3430.

168. Rajaganesh, R.; Jayakumar, J.; Sivaraj, C.; Raaman, N.; Das, T. M. Carbohydr. Res. 2010, 345, 1649-1657.

169. Salunke, S. B.; Babu, N. S.; Chen, C.-T. Chem. Commun. 2011, 47, 10440-10442.

170. Windhorst, A. D.; Klein, P. J.; Eisenbarth, J.; Oeser, T.; Kruijer, P. S.; Eisenhut, M. Nucl. Med. Biol. 2008, 35, 413-423. 
171. Cui, Z.; Zhang, B. Helv. Chim. Acta 2007, 90, 297-310.

172. Singh, S. K.; Sharma, V. K.; Olsen, C. E.; Wengel, J.; Parmar, V. S.; Prasad, A. K. J. Org. Chem. 2010, 75, 7932-7935.

173. Bavaro, T.; Rocchietti, S.; Ubiali, D.; Filice, M.; Terreni, M.; Pregnolato, M. European J. Org. Chem. 2009, 2009, 1967-1975. 


\section{Appendices}


Bodnár B., Mernyák E., Wölfling J., Schneider G., Herman B. E., Szécsi M., Sinka I., Zupkó I., Kupihár Z. and Kovács L. Synthesis and biological evaluation of triazolyl 13a-estronenucleoside bioconjugates, Molecules, 2016, 21, 1212-1228. IF: 2.861 (2016) 
Article

\title{
Synthesis and Biological Evaluation of Triazolyl 13 $\alpha$-Estrone-Nucleoside Bioconjugates
}

\author{
Brigitta Bodnár ${ }^{1}$, Erzsébet Mernyák ${ }^{2}$, János Wölfling ${ }^{2}$, Gyula Schneider ${ }^{2}$, \\ Bianka Edina Herman ${ }^{3}$, Mihály Szécsi ${ }^{3}$, Izabella Sinka ${ }^{4}$, István Zupkó ${ }^{4}$, Zoltán Kupihár ${ }^{1, *}$ \\ and Lajos Kovács ${ }^{1, *}$ \\ 1 Department of Medicinal Chemistry, University of Szeged, Dóm tér 8, H-6720 Szeged, Hungary; \\ bodnar.brigitta@med.u-szeged.hu \\ 2 Department of Organic Chemistry, University of Szeged, Dóm tér 8, H-6720 Szeged, Hungary; \\ bobe@chem.u-szeged.hu (E.M.); wolfling@chem.u-szeged.hu (J.W.); schneider@chem.u-szeged.hu (G.S.) \\ 3 1st Department of Medicine, University of Szeged, Korányi fasor 8-10, H-6720 Szeged, Hungary; \\ herman.bius@gmail.com (B.E.H.); szecsi.mihaly@med.u-szeged.hu (M.S.) \\ 4 Department of Pharmacodynamics and Biopharmacy, University of Szeged, Eötvös u. 6, \\ H-6720 Szeged, Hungary; sinkaiza@gmail.com (I.S.); zupko@pharm.u-szeged.hu (I.Z.) \\ * Correspondence: kupihar.zoltan@med.u-szeged.hu (Z.K.), kovacs.lajos@med.u-szeged.hu (L.K.); \\ Tel.: +36-62-545145 (L.K. \& Z.K.); Fax: +36-62-545971 (L.K. \& Z.K.)
}

Academic Editor: Gyorgy M. Keseru

Received: 28 July 2016; Accepted: 6 September 2016; Published: 10 September 2016

\begin{abstract}
Deoxynucleoside conjugates of $13 \alpha$-estrone were synthesized by applying the copper-catalyzed alkyne-azide click reaction ( $\mathrm{CuAAC}$ ). For the introduction of the azido group the $5^{\prime}$-position of the nucleosides and a propargyl ether functional group on the 3-hydroxy group of $13 \alpha$-estrone were chosen. The best yields were realized in our hands when the $3^{\prime}$-hydroxy groups of the nucleosides were protected by acetyl groups and the $5^{\prime}$-hydroxy groups were modified by the tosyl-azide exchange method. The commonly used conditions for click reaction between the protected-5'-azidonucleosides and the steroid alkyne was slightly modified by using 1.5 equivalent of $\mathrm{Cu}(\mathrm{I})$ catalyst. All the prepared conjugates were evaluated in vitro by means of MTT assays for antiproliferative activity against a panel of human adherent cell lines (HeLa, MCF-7 and A2780) and the potential inhibitory activity of the new conjugates on human $17 \beta$-hydroxysteroid dehydrogenase 1 (17 $\beta$-HSD1) was investigated via in vitro radiosubstrate incubation. Some protected conjugates displayed moderate antiproliferative properties against a panel of human adherent cancer cell lines (the protected cytidine conjugate proved to be the most potent with $\mathrm{IC}_{50}$ value of $9 \mu \mathrm{M}$ ). The thymidine conjugate displayed considerable $17 \beta-H S D 1$ inhibitory activity $\left(\mathrm{IC}_{50}=19 \mu \mathrm{M}\right)$.
\end{abstract}

Keywords: nucleosides; $13 \alpha$-estrone; copper-catalyzed alkyne-azide click reaction; triazoles; antiproliferative; $17 \beta$-HSD1

\section{Introduction}

Estrogens are synthesized biochemically in a multistep process from cholesterol in human body [1], and are responsible for the development of secondary sexual characteristics in females and maintenance of central nervous system, cardiovascular system and bones. Since they play a crucial role in the cell proliferation, overproduction of estrogens may lead to enhanced proliferation of hormone sensitive cells, resulting in hormone dependent cancers: ovarian, uterine, breast, prostate and endometrial [2]. Estrone-based anticancer drugs have been developed as antiproliferative/antihormonal or cytotoxic agents acting on non-hormonal targets [3]. Antiproliferative estrogens exert their activity as enzyme inhibitors or as antiestrogens (acting through their receptors). Although the proliferation process is rather complex, one of potential enzymes which plays crucial role in the proliferation process of 
some cancer cell types is the human $17 \beta$-hydroxysteroid dehydrogenase 1 (17 $\beta$-HSD1). It catalyzes the reduction of estrone to $17 \beta$-estradiol, which enhances the proliferation of certain cancer cells [4]. High activity of this isozyme can be detected in female reproductive tissues, e.g., in the ovaries and in the placenta [5]. 17 $\beta$-HSD1 has been found to be responsible for the local overproduction of $17 \beta$-estradiol in various breast cancers and ovarian cancers [6]. The inhibition of $17 \beta$-HSD1 with suitable pharmacons decreases synthesis of $17 \beta$-estradiol and causes significant estrogen deprivation and antitumor effect in hormone dependent cancers, therefore 17 $\beta$-HSD1 inhibitors could be promising candidates of anti-estrogen therapy $[7,8]$. Regardless of the mechanism of antiproliferative action, there is a general requirement in the development of all estrone-based anticancer drugs: the lack of estrogenic activity. Chemical modifications of estrone may lead to compounds lacking hormonal behavior $[3,9,10]$. Substitution at C-2, opening of ring D or inversion at C-13 of the estrane skeleton usually leads to the loss of estrogenic activity [11-16]. 13 $\alpha$-Estrone may be an excellent scaffold for the design of hormonally inactive agents having antiproliferative activity and fortunately it is readily available from native $13 \beta$-estrone by the method of Yaremenko and Khvat, using 1,2-phenylenediamine and acetic acid [17]. We recently published $13 \alpha$-estrone, 1,2,3-triazolyl $13 \alpha$ - and D-secoestrone derivatives possessing substantial cytostatic and/or 17 $\beta$-HSD1 inhibitory properties [18-22]. 13 $\alpha$-Estrone itself exerted outstanding $17 \beta$-HSD1 inhibitory activity with an $\mathrm{IC}_{50}$ value comparable to that of the reference estrone [22]. Concerning the triazoles, the heterocyclic ring was introduced to C-3 or to C-16 directly or via a short linker. The cell growth-inhibitory potential depended on the position of the triazolyl moiety and on the nature of the functional group at C-3. 3-Hydroxy or 3-ether derivatives displayed lower cytostatic potentials than their 3-O-[(1-benzyl-1H-1,2,3-triazol-4-yl)methyl] counterparts. The latter triazoles displayed one order of magnitude higher activities (submicromolar $\mathrm{IC}_{50}$ values) than the earlier described potent 16-triazolyl 3-O-benzyl ethers [18]. It can be stated that concerning the antiproliferative behaviour of triazolyl $13 \alpha$-estrones, functionalization at C-3 over C-16 seems more preferential. One of the most potent antiproliferative compounds was 3-O-[(1-benzyl-1H-1,2,3-triazol-4-yl)methyl]-13 $\alpha$-estrone bearing intact ring D (1, Figure 1). Based on its remarkable cytostatic potential $\left(\mathrm{IC}_{50}=0.3-0.9 \mu \mathrm{M}\right.$, [20], this $13 \alpha$-estrone triazole conjugate (1) may be used as a model compound for further derivatization with dual aim: to improve its cell growth-inhibitory potential to nanomolar scale, and to enhance its tumor selectivity. A potential route to enhance this selectivity is to prepare bioconjugates. Our recent results suggest that the triazole ring at 3-O should remain to retain the biological activity, but the azide counterpart used in the CuAAC reaction may be another biomolecule, such as a nucleoside.

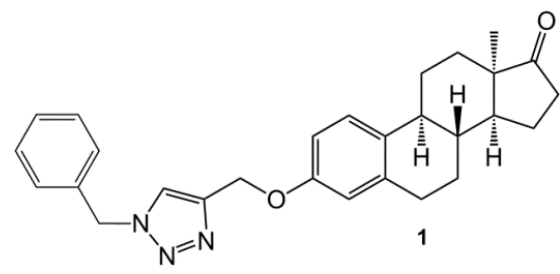

Figure 1. Structure of 3-O-[(1-benzyl-1H-1,2,3-triazol-4-yl)methyl]-13 $\alpha$-estrone.

The advantage of using a nucleoside azide could be either the higher activity on targeted enzymes overrepresented in cancer cells or an enhanced cellular uptake of the bioconjugates in these cells compared to the healthy ones. As the cancer cells require higher amount of nucleoside building blocks for their proliferation, they have significantly higher uptake of nucleosides by the different nucleoside transporters [23-25]. The nucleoside-steroid bioconjugates, which have been synthesized so far for anticancer purposes contain the nucleoside units as the bioactive components, like 2'-deoxy-5-fluorouridine or coenzyme mimics in bisubstrate inhibitors [26,27]. However, to our knowledge nucleosides, which can selectively enhance the transport into the cancer cells, are not used as targeting carriers. 
Therefore our aim was to test this possibility in case of an estrone derivative with established antiproliferative activity. If the coupled nucleoside unit increases the active transport of the steroid molecule without effecting the antiproliferative activity of the steroid part, one should see an increased inhibition of cell growth.

The connection types applied in the nucleoside-steroid conjugates prepared so far are generally ester bonds [26,28-31]. On the other hand, in case of conjugates of polyfunctional biomolecules, the CuAAC method is a widely used alternative [32,33] which forms a stable 1,2,3-triazole ring. 1,2,3-Triazoles (for sake of simplicity hereinafter referred to as "triazoles"; systematic compound names are given in the Materials and Methods section) are extensively used linkers in synthetic bioactive conjugates because of their stability against metabolic degradation and their favourable hydrogen-bonding properties. Incorporation of a triazole ring into the estrane skeleton has additional advantages: it may enhance the water solubility, bioavailability and as mentioned above this structural moiety enhanced the antiproliferative activity of an estrone derivative [18]. The CuAAC is a highly selective coupling method [34] which requires an azide and an alkyne function on the biomolecules and copper(I) ion as a catalyst.

In our case two potential approaches can be considered for the introduction of alkyne and azide moieties suitable for CuAAC reaction: (1) the nucleosides contain the azido group and the steroid has a terminal alkyne function or (2) the nucleosides have the terminal alkyne functional group and the steroid contains the azide. The formation of an alkynyl ether function on the phenolic OH group of an estrone derivative is not problematic, but the derivatization of nucleosides is not as straightforward as it seems. Regarding the first possibility, the preparation of $5^{\prime}$-azido-5'-deoxy nucleosides in the commonly used two-step method (5'-O-activation by introduction of tosylate [35-39], mesylate [38], halogen [35,39-46] or other leaving group [47,48] followed by azide substitution is hampered by several side-reactions and variable yields. The most relevant side-reactions are $3^{\prime}, 5^{\prime}$-bis-O-tosylation, $3^{\prime}, 5^{\prime}$-diazide formation [35], 4',5'-elimination and 2,3' /5'-anhydronucleoside formation (in the case of pyrimidine nucleosides) $[43,47]$. As a rule, the yields of these transformations are highly dependent on the identity of nucleobase (cytidine and especially guanine are troublesome) $[37,41-43,45,47]$, configuration of sugar moiety [35,49], protecting group pattern [36] of the nucleobase and the sugar, steric congestion $[40,44]$ and the actual method used $[39,46,48]$. Hence, the overall yields of these reactions are usually not very high, generally around $40 \%-60 \%$ or even lower (Scheme 1 , path a).

Alternatively, Mitsunobu reaction [50-52] with hydrogen azide, trimethylsilyl azide or zinc azide-pyridine complex [53] is also a possible alternative to prepare azides from nucleosides, provided that the senstive sugar moieties survive these conditions (Scheme 1, path $d$ ).

The second possibility (alkynylation of nucleosides) is also problematic: low yields [54-58], concomintant $\mathrm{O}, \mathrm{N}$-dialkylation hamper the effective derivatization of nucleosides [57,58]; it was also observed that cation chelation and solvents greatly influence the outcome of the reactions [59].

Here we chose the above mentioned $13 \alpha$-estrone as a starting compound with the aim of synthesizing nucleoside bioconjugates and we planned to investigate the antiproliferative properties and potential $17 \beta$-HSD1 inhibitory effect of these conjugates. Based on our earlier experience in the preparation and in vitro biological assays of triazolyl $13 \alpha$-estrone derivatives with anticancer activity, we have opted for the 3-hydroxy group of $13 \alpha$-estrone for the introduction of the terminal alkyne function. On the nucleosides the 5'-hydroxy seems to be the best choice because its chemical reactivity is higher than that of $3^{\prime}$, and also the better biocompatibility, as the nucleosides in the cells are mainly derivatized on their $5^{\prime}$-end. Hence, it is more likely that the recognition of the nucleosides on the receptor, enzyme and transporter proteins are favoured in case the nucleosides are only modified on their $5^{\prime}$-end and the rest of the nucleosides are freely available for the proteins. 

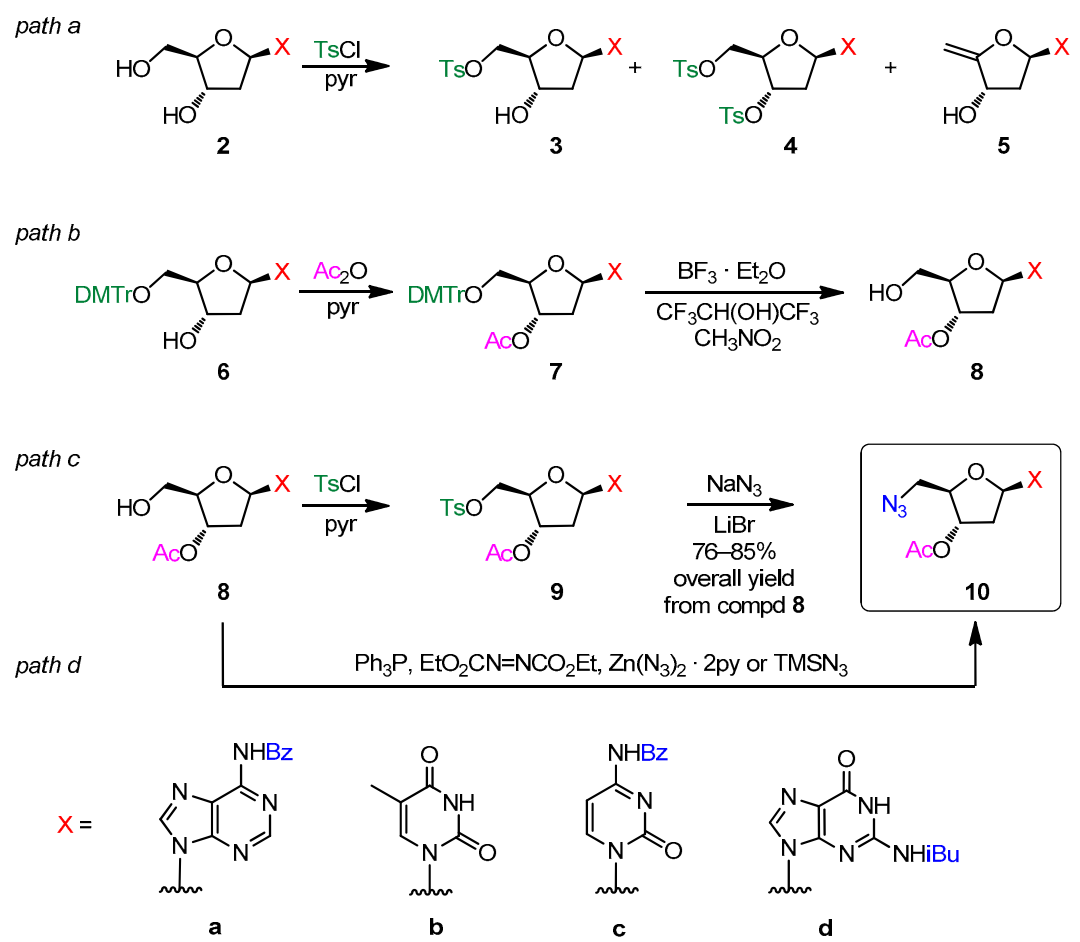

Scheme 1. Synthesis of $5^{\prime}$-azido-2', $5^{\prime}$-dideoxynucleosides.

\section{Results and Discussion}

\subsection{Preparation of $5^{\prime}$-Azido-2', $5^{\prime}$-dideoxynucleosides}

For the preparation of $5^{\prime}$-azido-2', $5^{\prime}$-dideoxynucleosides, first we have followed the tosyl-azide replacement method based on the literature but the isolated yields were significantly lower in our hands (Scheme 1, path a) compared to those described in the literature [35-39] therefore we decided to protect the $3^{\prime}$-hydroxy groups (Scheme 1, path $b$ ). Although the $3^{\prime}$-protection requires two more steps $\left(3^{\prime}-O\right.$-acylation and $5^{\prime}-O$-deprotection when the starting material is a $5^{\prime}-O-\left(4,4^{\prime}\right.$-dimethoxytrityl (DMTr))- $N$-acyl-protected nucleoside), it helps avoid the bis- $3^{\prime}, 5^{\prime}-O$-tosylation and increases the solubility of the nucleosides which might also be a reason of the low yields. We have chosen the acetyl-protection of the $3^{\prime}$-hydroxy because it was considered to be compatible with the final deprotection of the steroid-nucleoside conjugates. The crude acetylated material was used for the 5'-O-DMTr deprotection without chromatographic purification. As a commonly used 3\% trichloroacetic acid/dichloromethane deprotection resulted in a considerable amount of depurination side-products (mainly in the case of 2'-deoxyadenosine) therefore we have changed the reagent to a deprotection mixture containing the Lewis acid boron trifluoride in a 1,1,1,3,3,3-hexafluoroisopropanol-nitromethane solution [60] (Scheme 1, path b).

Using the $5^{\prime}-\mathrm{OH}$ containing, $3^{\prime}$-O-acetyl-protected nucleosides $(\mathbf{8 a}-\mathbf{d})$ we have carried out the $5^{\prime}$-O-tosylation in pyridine at room temperature and after purification the tosyl-azide exchange reaction in DMF at $50{ }^{\circ} \mathrm{C}$ (Scheme 1, path c). We have obtained better yields compared to the ones without $3^{\prime}-O$-protection but the yields were still not too high, around 50\%. Moreover, in case of $2^{\prime}$-deoxguanosine, the tosylation reaction gave a very low yield $(<10 \%)$, probably due to the very poor solubility. Therefore we stopped our attempts to obtain the tosylate $9 \mathbf{d}$ and its further derivatization was also abandoned.

As we were not satisfied with the isolated yields of azidonucleosides we attempted to improve them by applying Mitsunobu reaction to obtain the $5^{\prime}$-azides directly in a one-step reaction from the 3'-O-acetyl-protected nucleosides (Scheme 1, path $d$ ). The Mitsunobu reaction requires an 
acid component which should be $\mathrm{HN}_{3}$ in our case but we did not want to use a Brønsted acid to avoid the potential glycoside bond cleavage therefore, instead of the protic acid, we have tried two Lewis acids, $\mathrm{Zn}\left(\mathrm{N}_{3}\right)_{2} 2$ py or trimethylsilyl azide which were also used for Mitsunobu reactions [50-53]. Although we have tried to optimize the reaction conditions by varying the starting materials ( $2^{\prime}$-deoxyadenosine, thymidine, $2^{\prime}$-deoxycitidine, $2^{\prime}$-deoxyguanosine, $)$, the azodicarboxylate reagents (diethyl or diisopropyl esters), the azide-containing acids and also applying different temperatures $\left(0{ }^{\circ} \mathrm{C}\right.$ and room temperature), we were unable to detect a considerable amount of $5^{\prime}$-azido-2',5'-dideoxynucleosides. Only in case of $2^{\prime}$-deoxyadenosine we have got a $20 \%$ of the desired product, by using trimethylsilyl azide reagent at $0{ }^{\circ} \mathrm{C}$ in a $1 \mathrm{~h}$ reaction time. In all other cases only the $5^{\prime}$-O-trimethylsilylated nucleoside side-products were found by mass spectrometry analyses of the newly appearing TLC spots. These side-products have decomposed during the work up procedure giving back the starting nucleosides. As the Mitsunobu reaction failed to produce the desired 5'-azido-2', $5^{\prime}$-dideoxynucleosides, we eventually have used the $3^{\prime}$-O-protected-tosyl-azide exchange route to prepare the required amounts of $5^{\prime}$-azido- $2^{\prime}, 5^{\prime}$-dideoxynucleosides $10 a-c$ for the conjugation reactions from crude tosylates $\mathbf{9 a}-\mathbf{c}$ (Scheme 1, path c).

\subsection{Optimization of the Click Reaction between $5^{\prime}$-Azido-nucleoside Derivatives and 3-O-Propargyl-13 $\alpha$-estrone}

The 5'-azido-2',5'-dideoxynucleosides $10 \mathrm{a}-\mathbf{c}$ were connected to 3-O-propargyl-13 $\alpha$-estrone (11) [20] in a CuAAC reaction (Scheme 2). The solvent of the click-reaction was toluene (thymidine and adenosine) or anhydrous tetrahydrofuran (cytidine) due to solubility problems. Initially, we have followed the commonly used literature method (catalytic amounts of copper(II) salts in the presence of sodium ascorbate, aq. tert-butanol at room temperature) [32] but to no avail (Table 1). Alternative methods [36,38,61], using 0.01-0.2 equivalent of copper(I) iodide catalyst along with 0.2 equivalent of triphenylphosphane and DIPEA have also been tested but the reaction did not proceed well even if higher temperature, different solvents and prolonged reaction times (3 days) were applied. The highest reaction temperature was limited to as high as $50{ }^{\circ} \mathrm{C}$, to avoid the potential side-reactions on the nucleoside part. We supposed that the reason of the very low yields $(<30 \%$ according to TLC monitoring) could be the high complex-forming affinity of the $N$-acyl-protected nucleosides which trapped the $\mathrm{Cu}(\mathrm{I})$ ion catalysts [54]. Application of inert argone athmosphere did not improve the yield. Therefore we increased the amount of the $\mathrm{Cu}(\mathrm{I})$ catalyst and DIPEA to 1.5 equivalent and eliminated triphenylphosphane from the reaction mixture. With this modified method all conjugation reactions were complete in one day at $50{ }^{\circ} \mathrm{C}$ according to TLC and the final isolated yields of protected conjugates $\mathbf{1 2 a}-\mathbf{c}$ were acceptable (Table 1 ).

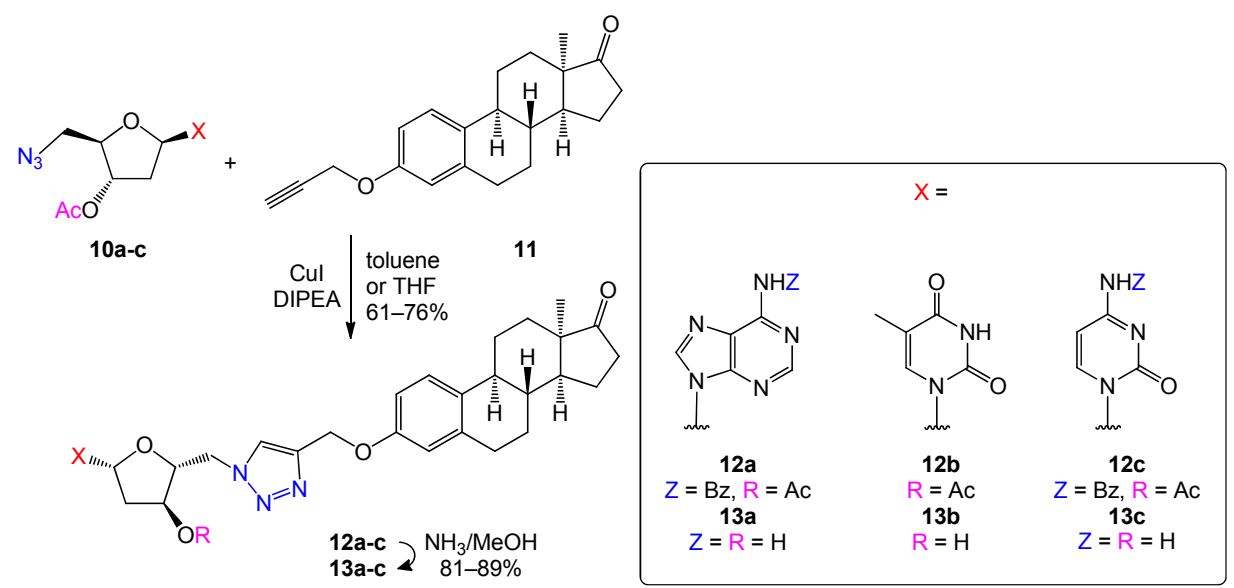

Scheme 2. CuAAC conjugation reaction of $3^{\prime}-O$-acetyl-5'-azido- $2^{\prime}, 5^{\prime}$-dideoxynucleosides and 3-O-propargyl-13 $\alpha$-estrone. 
Table 1. Optimization of CuAAC conjugation reaction of $3^{\prime}$-O-acetyl-5'-azido-2 $2^{\prime}, 5^{\prime}$-dideoxynucleosides and 3-O-propargyl-13 $\alpha$-estrone.

\begin{tabular}{|c|c|c|c|c|c|c|}
\hline \multirow[b]{3}{*}{$\begin{array}{l}\text { Product } \\
\text { Code }\end{array}$} & \multicolumn{6}{|c|}{ Conditions and Yields of CuAAC Reaction } \\
\hline & \multicolumn{2}{|c|}{ Ref. [32] ${ }^{1}$} & \multicolumn{2}{|c|}{ Refs. $[36,38,61]^{2}$} & \multicolumn{2}{|c|}{ This work $^{3}$} \\
\hline & $\begin{array}{l}\text { Product } \\
\text { Yield (\%) }\end{array}$ & $\begin{array}{c}\text { Recovered } \\
\text { Nucleoside (\%) }{ }^{4}\end{array}$ & $\begin{array}{l}\text { Product } \\
\text { Yield (\%) }\end{array}$ & $\begin{array}{c}\text { Recovered } \\
\text { Nucleoside (\%) }\end{array}$ & $\begin{array}{l}\text { Product } \\
\text { Yield (\%) }\end{array}$ & $\begin{array}{c}\text { Recovered } \\
\text { Nucleoside (\%) }{ }^{5}\end{array}$ \\
\hline $12 a$ & 0 & 93 & $18-22$ & $63-68$ & 68 & - \\
\hline $12 b$ & 0 & 92 & $23-28$ & $64-70$ & 76 & - \\
\hline $12 \mathrm{c}$ & 0 & $>95$ & $8-11$ & $78-82$ & 61 & - \\
\hline
\end{tabular}

\subsection{Optimization of the Deprotection of Conjugates (Nucleobase N-Benzoyl and 2'-Deoxy-D-ribose-3'-O- acetyl Deprotection)}

The synthesized bioconjugates contained the $3^{\prime}$-O-acetyl and $\mathrm{N}$-benzoyl protecting groups on the nucleoside moiety which helped increase the solubility in the synthetic reactions but for the biological experiments we needed the unprotected nucleoside conjugates. Aqueous ammonia is commonly used for the deprotection of these protecting groups in the nucleic acid chemistry but the protected conjugates were not soluble in the aqueous media therefore this deprotection method failed. We have tested the Zemplén deacetylation protocol using $0.1 \mathrm{M}$ of sodium methylate in methanol but only the acetyl group was removed from the $3^{\prime}$-hydroxy group. Finally, $4 \mathrm{M}$ ammonia solution in methanol was used at $50{ }^{\circ} \mathrm{C}$ which removed all the acyl protecting groups of the conjugates in $16 \mathrm{~h}$ to yield derivatives 13a-c.

\subsection{Antiproliferative Activities}

The antiproliferative properties of the newly synthesized nucleoside conjugates were characterized in vitro on a panel of human adherent cancer cell lines (HeLa, MCF-7 and A2780) by means of MTT assays. Structurally similar estrone analogs earlier exhibited growth inhibitory activity against these cells $[9,18-21]$. The influence of the nature of the protected or unprotected nucleoside moiety on the cytostatic properties was investigated and the results are shown in Table 2 . The protected cytidine conjugate $12 \mathrm{c}$ proved to be the most potent with $\mathrm{IC}_{50}$ values in the range 9.0-10.4 $\mu \mathrm{M}$, although this value is an order of magnitude higher than the value of the $13 \alpha$-estrone triazole 1 [20]. The removal of the benzoyl and/or acetyl protecting groups from the nucleoside-13 $\alpha$-estrone conjugates 12a-c resulted in unprotected conjugates 13a-c with generally reduced cytostatic properties. Although we do not know the mechanism of action of our conjugates, but compared to the reference steroid $\mathbf{1}$, the non-polar benzyl group was replaced by the polar deoxynucleoside units, therefore the lower activity could be due to the more pronounced steric effect and polar properties of the nucleoside units. Interestingly, the conjugates containing less polar but larger protected nucleosides gave higher antiproliferative activity than the unprotected, more polar but smaller nucleoside-containing ones. This fact highlights the importance of both the limited size and non-polar characteristics of the group at C-3 triazolyl moiety of $13 \alpha$-estrone. On the other hand, this finding also suggests that the hypothesized, potentially selective increase in the uptake of nucleoside conjugates of the estrone derivative might not be operative. The reason of the lower overall uptake could be the decrease of the passive transport of the more polar, nucleoside-estrone derivative through the cell membrane. If the passive transport has much higher contribution to the overall uptake than the nucleoside transporter mediated routes, then the loss of antiproliferative activity of the more polar, unprotected nucleoside-13 $\alpha$-estrone conjugates can be explained by lower concentration of the conjugates inside the cell. Either explanation is true, unfortunately the triazolyl-deoxynucleoside modification of $13 \alpha$-estrone on C-3 position did not help improving the antiproliferative activity of the model compound $\mathbf{1}$. 
Table 2. Antiproliferative properties of the synthesized compounds. Mean value from two independent determinations with five parallel wells; standard deviation $<15 \%$.

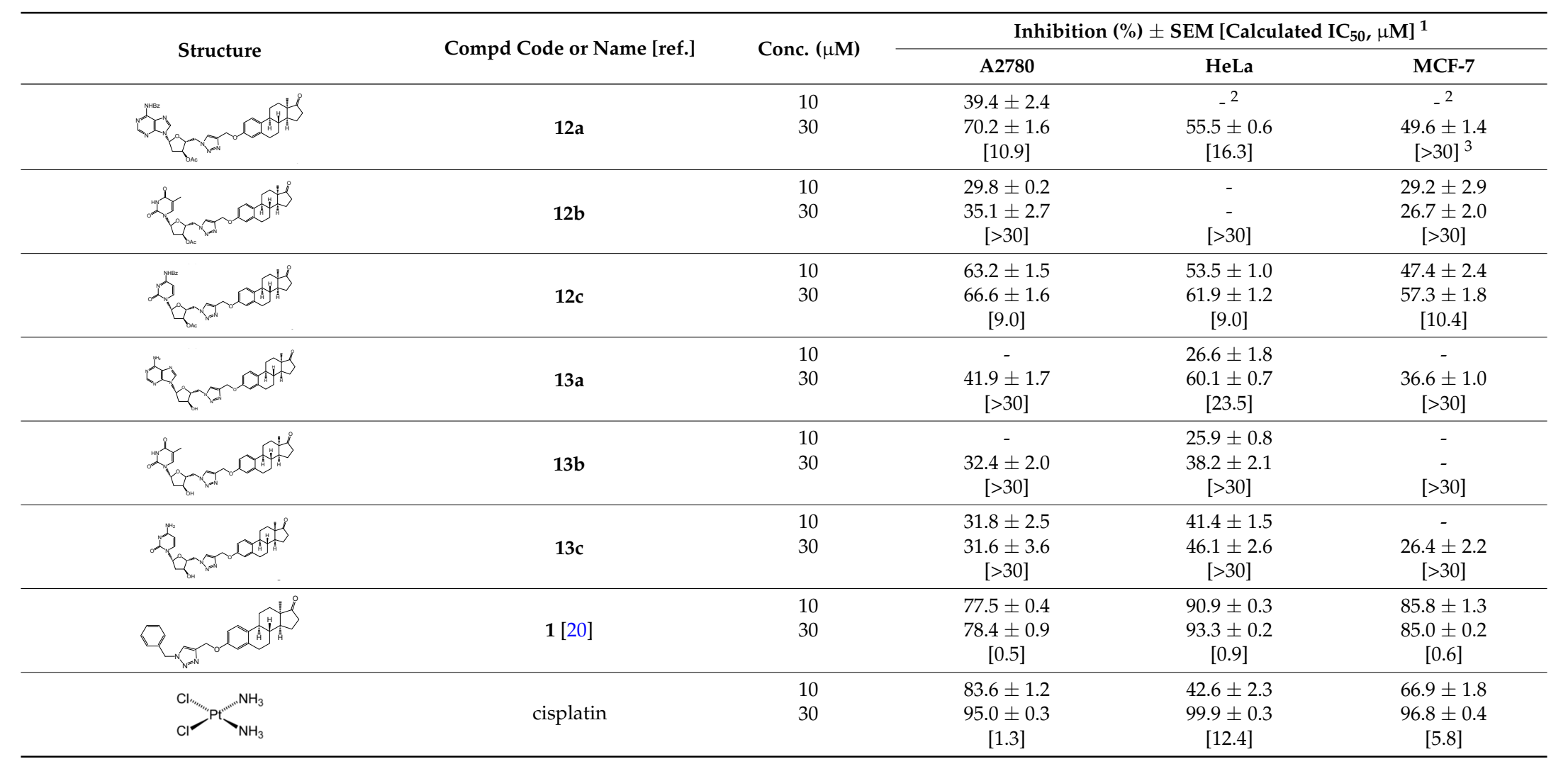

${ }^{1}$ Mean value from two independent determinations with five parallel wells; standard deviation $<15 \%{ }^{2}$ Inhibition values $<20 \%$ are not presented. ${ }^{3}$ IC $_{50}$ values $>30 \mu \mathrm{M}$ are not calculated. 


\subsection{Inhibition of $17 \beta-H S D 1$}

The newly synthesized nucleoside conjugates $12 \mathbf{a}-\mathbf{c}$ and $\mathbf{1 3 a} \mathbf{a}-\mathbf{c}$ of $13 \alpha$-estrone were tested against the human $17 \beta-H S D 1$ in vitro. The results in Table 3 show that only the unprotected thymidine conjugate $\mathbf{1 3 b}$ exerted any substantial inhibition, with an $\mathrm{IC}_{50}$ value of $19 \mu \mathrm{M}$. Other tested conjugates displayed weak inhibition. Compared to our previous results on $13 \alpha$-estrone and its 3-methyl ether, these conjugates showed lower inhibitory effect, similar to those of the 3-benzyl ether of $13 \alpha$-estrone [22]. The decrease in the inhibitory potential of nucleoside conjugates is probably caused by the steric effect of the larger nucleoside-triazolyl unit on the C-3 position.

Table 3. Inhibition results on $17 \beta-H S D 1$. Relative conversions (control incubation with no inhibition is $100 \%$ ) measured in the presence of $10 \mu \mathrm{M}$ of the compound tested. $\mathrm{IC}_{50}$ : The inhibitor concentration that decreases the enzyme activity to $50 \%$. SD: standard deviation (for relative conversion $n=3$ ).

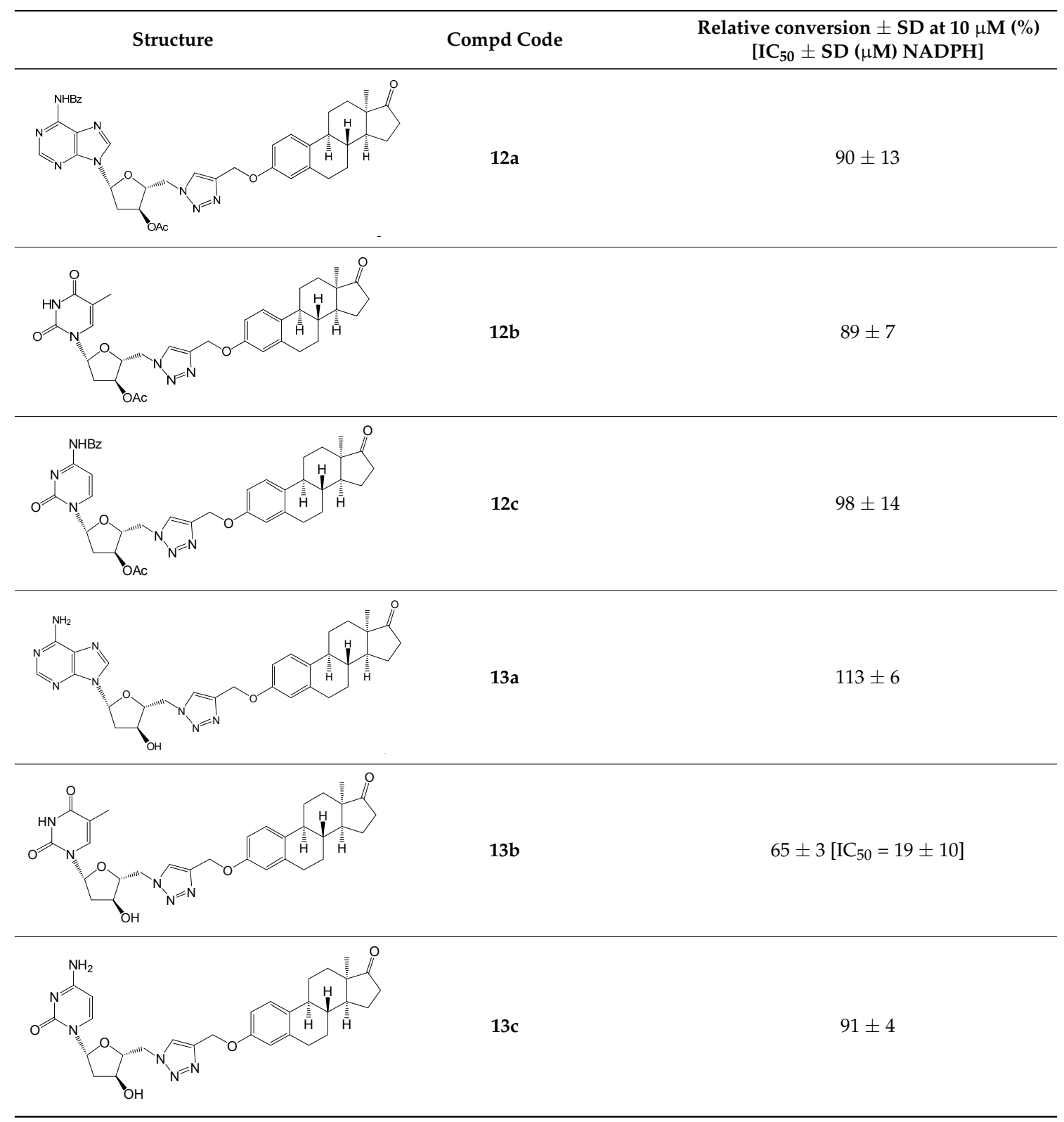




\section{Materials and Methods}

\subsection{Chemistry}

Melting points (mp) were determined on an IA8103 apparatus (Electrothermal, Stone, UK) and are uncorrected. The reactions were monitored by TLC on Kieselgel-G (Si 254 F, Merck, Darmstadt, Germany) layers (0.25 mm thick); solvent systems (ss): (A) EtOAc, (B) EtOAc/methanol (9:1 v/v), (C) toluene/isopropanol $(1: 1 \mathrm{v} / \mathrm{v})$. The conjugates were detected by spraying with $5 \%$ phosphomolybdic acid in 50\% aqueous phosphoric acid. For the identification of azides the TLC was placed in a $10 \%$ solution of triphenylphosphane in $\mathrm{CH}_{2} \mathrm{Cl}_{2}$ for $2 \mathrm{~min}$, then sprayed with ninhydrine solution $(0.5 \%$ ninhydrine and $5 \mathrm{mM} \mathrm{NaOH}$ in ethanol/water 3:1 $\mathrm{v} / \mathrm{v}$ ). The $\mathrm{R}_{\mathrm{f}}$ values were determined for the spots observed by illumination at $254 \mathrm{~nm}$. Flash chromatography: Merck silica gel 60, 40-63 $\mu \mathrm{m}$. All solvents were distilled prior to use. Reagents and materials were obtained from commercial suppliers and were used without purification. Elementary analysis data were determined with a CHN analyzer model 2400 (Perkin Elmer, Waltham, MA, USA). NMR spectra were obtained at room temperature with a DRX 500 instrument (Bruker, Rheinstetten, Germany). Chemical shifts are reported in ppm ( $\delta$ scale), and coupling constants $(J)$ in $\mathrm{Hz}$. For the determination of multiplicities the J-modulated spin-echo pulse sequence was used. Mass spectra were recorded on a MAT TSQ 7000 instrument (Finnigan, Waltham, MA, USA) equipped with an electrospray ion source, using the following parameters: positive ionization mode, nebulizing gas $\mathrm{N}_{2}$ (3.45 bar), capillary temperature: $200{ }^{\circ} \mathrm{C}$, capillary voltage: $4500 \mathrm{~V}$ and an acetonitrile-water $1: 1(\mathrm{v} / \mathrm{v})$ mixture containing $0.1 \%$ trifluoroacetic acid as eluent. The samples were dissolved in acetonitrile and injected directly. The base peaks were usually the $[\mathrm{M}+\mathrm{H}]^{+}$ signals along with far less abundant $[2 \mathrm{M}+\mathrm{H}]^{+}$signals.

\subsubsection{General Procedure for Synthesis of 3'-O-Acetyl-N-acyl-protected-2'-deoxynucleosides 8a-d}

$10 \mathrm{mmol}$ of 5'-O-DMTr- $N$-acyl-protected-2'-deoxynucleoside $\mathbf{6 a}, \mathbf{6 b}, \mathbf{6} \mathbf{c}$ or $\mathbf{6} \mathbf{d}$ was dissolved in pyridine $(50 \mathrm{~mL})$ and $\mathrm{Ac}_{2} \mathrm{O}(10 \mathrm{mmol}, 945 \mu \mathrm{L})$ was added. The reaction mixture was stirred at $0{ }^{\circ} \mathrm{C}$ for $4 \mathrm{~h}$, evaporated in vacuo, redissolved in EtOAc $(100 \mathrm{~mL})$ and extracted with water $(2 \times 100 \mathrm{~mL})$. The combined organic layers were dried over $\mathrm{Na}_{2} \mathrm{SO}_{4}$ and evaporated in vacuo. The resulting crude product $\mathbf{7 a}, \mathbf{7 b}, \mathbf{7 c}$ or $\mathbf{7 d}$ was directly used for the next step without further purifications.

10 mmol of 5'-O-(4,4'-dimethoxytrityl)-3'-O-acetyl- $N$-acyl-protected-2'-deoxynucleoside 7a, 7b, 7c or $\mathbf{7 d}$ was dissolved in nitromethane $(20 \mathrm{~mL})$ and a mixture of 1,1,1,3,3,3-hexafluoroisopropanol (20 $\mathrm{mL}$, $190 \mathrm{mmol})$, boron trifluoride diethyl etherate $(247 \mu \mathrm{L}, 2 \mathrm{mmol})$ and triethylsilane $(6 \mathrm{~mL}, 38 \mathrm{mmol})$ was added. The reaction mixture was stirred at room temperature overnight, then $10 \%$ aqueous $\mathrm{NaHCO}_{3}$ solution was added and evaporated in vacuo. The resulting crude product was purified by column chromatography with EtOAc as eluent to give the corresponding nucleoside $\mathbf{8 a}, \mathbf{8 b}, \mathbf{8 c}$ or $\mathbf{8 d}$.

3.1.2. General Procedure for Synthesis of

3'-O-Acetyl-5'-azido- $N$-acyl-protected-2', $5^{\prime}$-dideoxy-nucleosides 10a-c

3'-O-Acetyl-N-acyl-protected-2'-deoxynucleoside $\mathbf{8 a}, \mathbf{8 b}, \mathbf{8 c}$ or $\mathbf{8 d}$ (1 $\mathbf{m m o l}$ ) was dissolved in pyridine $(15 \mathrm{~mL})$ and p-toluenesulfonyl chloride $(285 \mathrm{mg}, 1.5 \mathrm{mmol})$ was added. The reaction mixture was stirred at room temperature overnight, evaporated in vacuo, redissolved in EtOAc $(100 \mathrm{~mL})$ and extracted with $1 \%$ aqueous $\mathrm{KHSO}_{4}$ solution $(2 \times 100 \mathrm{~mL})$. The combined organic layers were dried over $\mathrm{Na}_{2} \mathrm{SO}_{4}$ and evaporated in vacuo. The resulting crude product was purified by column chromatography with EtOAc as eluent to afford the tosylated nucleoside $9 a, 9 b, 9 c$ or $9 d$.

3'-O-Acetyl-N-acyl-protected-2'-deoxy-5'-O-tosylnucleoside $9 \mathbf{a}, \mathbf{9 b}$ or $9 \mathbf{c}(1 \mathrm{mmol})$ was dissolved in dry DMF $(20 \mathrm{~mL})$ then sodium azide $(195 \mathrm{mg}, 3 \mathrm{mmol})$ and lithium bromide (261 $\mathrm{mg}, 3 \mathrm{mmol})$ were added. The reaction mixture was stirred at $50{ }^{\circ} \mathrm{C}$ for $6 \mathrm{~h}$. The reaction mixture was evaporated in vacuo, redissolved in EtOAc and extracted with water $(2 \times 100 \mathrm{~mL})$. The combined organic layers were dried over $\mathrm{Na}_{2} \mathrm{SO}_{4}$ and evaporated in vacuo. The resulting crude product was recrystallized from EtOAc to yield azidonucleoside $10 a, 10 b$ or $10 c$. 
3'-O-Acetyl-5'-azido-6-N-benzoyl-2' $5^{\prime}$-dideoxyadenosine (10a): After purification, 10a was obtained as a white solid (346 mg, 82\%), m.p. $135-136{ }^{\circ} \mathrm{C}, R_{\mathrm{f}}=0.29$ (ss A); ${ }^{1} \mathrm{H}-\mathrm{NMR}\left(\mathrm{CDCl}_{3}\right) ; \delta[\mathrm{ppm}]=2.11$ $\left(\mathrm{s}, 3 \mathrm{H}, 3^{\prime}-\mathrm{OAc}\right), 2.63(\mathrm{~d}, 1 \mathrm{H}, J=8.0 \mathrm{~Hz})$ and $3.27(\mathrm{~m}, 1 \mathrm{H}): 2^{\prime}-\mathrm{H} 2,3.61(\mathrm{~d}, 1 \mathrm{H}, J=11.5 \mathrm{~Hz})$ and $3.76(\mathrm{~d}, 1 \mathrm{H}$, $J=12.0 \mathrm{~Hz}): 5^{\prime}-\mathrm{H} 2,4.27(\mathrm{~s}, 1 \mathrm{H}), 5.39(\mathrm{~s}, 1 \mathrm{H}), 6.54(\mathrm{~m}, 1 \mathrm{H}): 1^{\prime}-, 3^{\prime}-, 4^{\prime}-\mathrm{H}, 7.55(\mathrm{t}, 2 \mathrm{H}, J=2 \times 7.0 \mathrm{~Hz}), 7.64$ $(\mathrm{d}, 1 \mathrm{H}, J=7.5 \mathrm{~Hz}), 8.06(\mathrm{~d}, 2 \mathrm{H}, J=7 \mathrm{~Hz})$ : benzoyl protons, $8.74(\mathrm{~s}, 1 \mathrm{H})$ and $8.79(\mathrm{~s}, 1 \mathrm{H}): 2-\mathrm{H}$ and $8-\mathrm{H}$, $11.23(\mathrm{~s}, 1 \mathrm{H}, 6-\mathrm{NH}) ;{ }^{13} \mathrm{C}-\mathrm{NMR}\left(\mathrm{CDCl}_{3}\right) ; \delta[\mathrm{ppm}]=20.7\left(3^{\prime}-\mathrm{OAc}\right), 35.0\left(\mathrm{C}-2^{\prime}\right), 51.5\left(\mathrm{C}-5^{\prime}\right), 74.6,82.9,83.8$, 125.9 (C-5), 128.3 (2C), 128.4 (2C), 132.4: benzoyl CHs, 133.2: benzoyl Cq, 143.3 (C-8), 150.4 (C-4), 151.9 (C-6), 152.3 (C-2), 165.5 (Bz-CO), 170.0 (Ac-CO); ESI-MS: 423 [M + H]+; Anal. Calcd for $\mathrm{C}_{19} \mathrm{H}_{18} \mathrm{~N}_{8} \mathrm{O}_{4}$ : C, 54.03; H, 4.30; N, 26.53. Found: C, 53.96; H, 4.47; N, 26.95.

3'-O-Acetyl-5'-azido-5'-deoxythymidine (10b): After purification, $\mathbf{1 0 b}$ was obtained as a white solid (263 mg, 85\%), m.p. $115-116^{\circ} \mathrm{C}, R_{\mathrm{f}}=0.65$ (ss A); ${ }^{1} \mathrm{H}-\mathrm{NMR}\left(\mathrm{CDCl}_{3}\right) ; \delta[\mathrm{ppm}]=1.57$ (s, 3H, 5- $\left.\mathrm{CH}_{3}\right), 1.83$ $\left(\mathrm{s}, 3 \mathrm{H}, 3^{\prime}-\mathrm{OAc}\right), 2.02$ and $2.27\left(2 \times \mathrm{m}, 2 \times 1 \mathrm{H}, 2^{\prime}-\mathrm{H}_{2}\right), 3.40(\mathrm{~m}, 2 \mathrm{H}), 3.86(\mathrm{~d}, 1 \mathrm{H}, J=2.0 \mathrm{~Hz}), 4.91(\mathrm{~d}, 1 \mathrm{H}$, $J=3.5 \mathrm{~Hz}), 5.95(\mathrm{t}, 1 \mathrm{H}, J=10.0 \mathrm{~Hz}, J=5.0 \mathrm{~Hz}): 1^{\prime}-3^{\prime}-4^{\prime}-\mathrm{H}, 5^{\prime}-\mathrm{H} 2,7.33(\mathrm{~s}, 1 \mathrm{H}, 6-\mathrm{H}), 11.16(\mathrm{~s}, 1 \mathrm{H}, 3-\mathrm{NH})$; ${ }^{13} \mathrm{C}-\mathrm{NMR}\left(\mathrm{CDCl}_{3}\right) ; \delta[\mathrm{ppm}]=12.0\left(5-\mathrm{CH}_{3}\right), 20.7\left(3^{\prime}-\mathrm{OAc}\right), 35.0\left(\mathrm{C}-2^{\prime}\right), 51.6\left(\mathrm{C}-5^{\prime}\right), 74.1,81.9,83.9,109.9$ (C-5), 135.9 (C-6), 150.4, 163.6, 170.0 (Ac-CO); ESI-MS: $310[\mathrm{M}+\mathrm{H}]^{+}$; Anal. Calcd for $\mathrm{C}_{12} \mathrm{H}_{15} \mathrm{~N}_{5} \mathrm{O}_{5}$ : C, 46.60; H, 4.89; N, 22.64. Found: C, 46.82; H, 5.02; N, 22.83.

3'-O-Acetyl-5'-azido-4-N-benzoyl-2', $5^{\prime}$-dideoxycytidine (10c): After purification, 10c was obtained as a white solid (302 mg, 76\%), m.p. 146-147 ${ }^{\circ} \mathrm{C}, R_{\mathrm{f}}=0.32$ (ss A); ${ }^{1} \mathrm{H}-\mathrm{NMR}\left(\mathrm{CDCl}_{3}\right) ; \delta[\mathrm{ppm}]=2.11(\mathrm{~s}, 3 \mathrm{H}$, $\left.3^{\prime}-\mathrm{OAc}\right), 2.53\left(\mathrm{~m}, 2 \mathrm{H}, 2^{\prime}-\mathrm{H}_{2}\right), 3.77\left(\mathrm{dd}, 2 \mathrm{H}, J=9.5 \mathrm{~Hz}, J=12.0 \mathrm{~Hz}, 5^{\prime}-\mathrm{H}_{2}\right), 4.25(\mathrm{~s}, 1 \mathrm{H}), 5.21(\mathrm{~s}, 1 \mathrm{H}), 6.24$ $(\mathrm{d}, 1 \mathrm{H}, J=4.5 \mathrm{~Hz}): 1^{\prime}-3^{\prime}-, 4^{\prime}-\mathrm{H}, 7.42\left(\mathrm{~s}, 1 \mathrm{H}, 5^{\prime}-\mathrm{H}\right), 7.54(\mathrm{~d}, 2 \mathrm{H}, J=5.5 \mathrm{~Hz}), 7.65(\mathrm{~d}, 1 \mathrm{H}, J=5.5 \mathrm{~Hz}), 8.04$ $(\mathrm{m}, 2 \mathrm{H})$ : benzoyl protons, $8.24\left(\mathrm{~s}, 1 \mathrm{H}, 66^{\prime}-\mathrm{H}\right), 11.34\left(\mathrm{~s}, 1 \mathrm{H}, 4^{\prime}-\mathrm{NH}\right) ;{ }^{13} \mathrm{C}-\mathrm{NMR}\left(\mathrm{CDCl}_{3}\right) ; \delta[\mathrm{ppm}]=20.7$ (3'-OAc), $36.6\left(\mathrm{C}-2^{\prime}\right), 51.6\left(\mathrm{C}-5^{\prime}\right), 74.3,82.7,86.5,96.6$ (C-5), 128.3 (2C), 128.4 (2C), 132.7: benzoyl CH-s, 133.1: benzoyl Cq, 145.2 (C-6), 154.1 (C-2), 163.6 (C-4), 165.1 (Bz-CO), 170.0 (Ac-CO); ESI-MS: 399 $[\mathrm{M}+\mathrm{H}]^{+}$; Anal. Calcd for $\mathrm{C}_{18} \mathrm{H}_{18} \mathrm{~N}_{6} \mathrm{O}_{5}: \mathrm{C}, 54.27 ; \mathrm{H}, 4.55 ; \mathrm{N}, 21.10$. Found: $\mathrm{C}, 54.18 ; \mathrm{H}, 4.63 ; \mathrm{N}, 19.85$.

\subsubsection{General Procedure for Click Reactions: Preparation of 12a-c}

Azidonucleoside 10a, 10b or 10c $(0.15 \mathrm{mmol})$ was dissolved in toluene $(10 \mathrm{~mL})$ or THF $(10 \mathrm{~mL}), \mathrm{CuI}$ ( $0.225 \mathrm{mmol}, 42.75 \mathrm{mg}$, 1.5 equiv.), DIPEA ( $78 \mu \mathrm{L}, 0.45 \mathrm{mmol}, 3$ equiv.) and 3-O-propargyl-13 $\alpha$-estrone 11 [20] ( $0.165 \mathrm{mmol}, 1.1$ equiv.) were added to the reaction mixture and it was stirred for overnight at $50^{\circ} \mathrm{C}$. Then the mixture was evaporated in vacuo, the resulting crude product was purified by column chromatography with EtOAc as eluent to yield protected conjugate 12a, 12b or 12c.

3-\{[1-(3'-O-Acetyl-6-N-benzoyl-2', 5'-dideoxyadenosine-5'-yl)-1H-1,2,3-triazole-4-yl]methyl-oxy\}-13 $\alpha$-estra1,3,5(10)-trien-17-one (12a): After purification, protected conjugate 12a was obtained as a white solid (78 mg, 68\%), m.p. $141-143{ }^{\circ} \mathrm{C}, R_{\mathrm{f}}=0.55$ (ss B); ${ }^{1} \mathrm{H}-\mathrm{NMR}\left(\mathrm{CDCl}_{3}\right) ; \delta[\mathrm{ppm}]=1.00\left(\mathrm{~s}, 3 \mathrm{H}, 18-\mathrm{CH}_{3}\right), 1.89$ $\left(\mathrm{s}, 3 \mathrm{H}, 3^{\prime}-\mathrm{OAc}\right), 2.27\left(\mathrm{dd}, 2 \mathrm{H}, J=10.5 \mathrm{~Hz}, J=12.5 \mathrm{~Hz}, 2^{\prime}-\mathrm{H}_{2}\right), 2.54(\mathrm{~d}, 1 \mathrm{H}, J=11.0 \mathrm{~Hz})$ and $2.82(\mathrm{~d}, 1 \mathrm{H}$, $J=11.5 \mathrm{~Hz}): 6-\mathrm{H}_{2}, 2.55(\mathrm{~m}, 1 \mathrm{H}), 4.45(\mathrm{~m}, 1 \mathrm{H}), 4.84(\mathrm{dd}, 2 \mathrm{H}, J=13.5 \mathrm{~Hz}, J=14.0 \mathrm{~Hz}), 5.54(\mathrm{~s}, 1 \mathrm{H}): 1^{\prime}-$ - $^{\prime}-$, $4^{\prime}-\mathrm{H}, 5^{\prime}-\mathrm{H}_{2}, 5.04\left(\mathrm{~s}, 2 \mathrm{H}, \mathrm{OCH}_{2}\right), 6.42(\mathrm{~s}, 1 \mathrm{H}, 4-\mathrm{H}), 6.61(\mathrm{~d}, 1 \mathrm{H}, J=6.0 \mathrm{~Hz}, 2-\mathrm{H}) 6.69(\mathrm{~d}, 1 \mathrm{H}, J=8.5 \mathrm{~Hz}$, 1-H), $7.06(\mathrm{~s}, 1 \mathrm{H}), 7.46(\mathrm{~s}, 3 \mathrm{H}), 7.55(\mathrm{~s}, 1 \mathrm{H}), 8.00(\mathrm{~s}, 2 \mathrm{H})$ : benzoyl protons, 2"--, 8"- $\mathrm{H}, 7.59(\mathrm{~s}, 1 \mathrm{H}, \mathrm{HC}=\mathrm{C})$, $8.72\left(\mathrm{~s}, 1 \mathrm{H}, 6\right.$ "'-NH); ${ }^{13} \mathrm{C}-\mathrm{NMR}\left(\mathrm{CDCl}_{3}\right) ; \delta$ [ppm] = 20.7 (C-18), 20.8, 20.9 (3'-OAc), 24.9 (2C), 30.2, 31.9, 33.3, $36.1\left(\mathrm{C}-2^{\prime}\right), 41.2$ (2C, C-8 and C-9), 49.1 (C-14), $50.0(\mathrm{C}-13), 51.4\left(\mathrm{C}-5^{\prime}\right), 61.6\left(\mathrm{OCH}_{2}\right), 74.4,83.1,85.3$, 112.3 (C-2), $114.3(\mathrm{C}-4), 125.3(\mathrm{HC}=\mathrm{C}), 123.8\left(\mathrm{C}-5^{\prime \prime}\right), 126.7(\mathrm{C}-1), 128.1$ (2C). 128.6 (2C), 132.8: benzoyl CH-s, 132.4 (C-10), 135.7: benzoyl Cq, 138.0 (C-5), 139.5 (C-8"), 144.1 (HC=C), 147.1, 151.4, 155.9 (C-3), 153.4, 165.2 (Bz-CO), 170.3 (Ac-CO), 221.7 (C-17); ESI-MS: $731[\mathrm{M}+\mathrm{H}]^{+}$; Anal. Calcd for $\mathrm{C}_{40} \mathrm{H}_{42} \mathrm{~N}_{8} \mathrm{O}_{6}$ : C, 65.74; H, 5.79; N, 15.33. Found: C, 65.67; H, 5.92; N, 15.46 .

3-\{[1-(3'-O-Acetyl-5'-deoxythymidine-5'-yl)-1H-1,2,3-triazole-4-yl]methyloxy\}-13 $\alpha$-estra-1,3,5(10)-trien-17-one (12b): After purification, protected conjugate $\mathbf{1 2 b}$ was obtained as a white solid $(74 \mathrm{mg}, 76 \%)$, m.p. $189-191{ }^{\circ} \mathrm{C}, R_{\mathrm{f}}=0.5(\mathrm{ss} \mathrm{A}) ;{ }^{1} \mathrm{H}-\mathrm{NMR}\left(\mathrm{CDCl}_{3}\right) ; \delta[\mathrm{ppm}]=1.03\left(\mathrm{~s}, 3 \mathrm{H}, 18-\mathrm{CH}_{3}\right), 1.24(\mathrm{~s}, 2 \mathrm{H}), 1.87(\mathrm{~s}, 3 \mathrm{H}$, 
5"- $\left.\mathrm{CH}_{3}\right), 2.09\left(\mathrm{~s}, 3 \mathrm{H}, 3^{\prime}-\mathrm{OAc}\right), 2.20\left(\mathrm{~d}, 2 \mathrm{H}, J=11.0 \mathrm{~Hz}, 2^{\prime}-\mathrm{H}_{2}\right), 2.78\left(\mathrm{~m}, 2 \mathrm{H}, 6-\mathrm{H}_{2}\right), 4.29(\mathrm{~m}, 1 \mathrm{H}), 4.84(\mathrm{dd}$, $2 \mathrm{H}, J=9.5 \mathrm{~Hz}, J=11.5 \mathrm{~Hz}), 5.29(\mathrm{~s}, 1 \mathrm{H}), 6.16(\mathrm{~m}, 1 \mathrm{H}): 1^{\prime}-3^{\prime}-, 4^{\prime}-\mathrm{H}, 5^{\prime}-\mathrm{H}_{2}, 5.17\left(\mathrm{~s}, 2 \mathrm{H}, \mathrm{OCH}_{2}\right), 6.64(\mathrm{~s}, 1 \mathrm{H}$, $4-\mathrm{H}), 6.72(\mathrm{~d}, 1 \mathrm{H}, J=6.0 \mathrm{~Hz}, 2-\mathrm{H}), 6.90\left(\mathrm{~s}, 1 \mathrm{H}, 6^{\prime \prime}-\mathrm{H}\right), 7.14(\mathrm{~d}, 1 \mathrm{H}, J=8.5 \mathrm{~Hz}, 1-\mathrm{H}), 7.79(\mathrm{~s}, 1 \mathrm{H}, \mathrm{HC}=\mathrm{C})$,

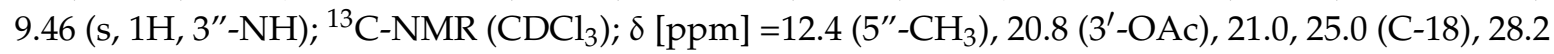
(2C), 30.3, 32.0, 33.4, 36.0 (C-2'), 41.3 (2C, C-8 and C-9), 49.2 (C-14), $50.1(\mathrm{C}-13), 51.6\left(\mathrm{C}-5^{\prime}\right), 61.6\left(\mathrm{OCH}_{2}\right)$, 74.3, 82.0, 85.3, 111.8 (C-5"), 112.4 (C-2), 114.4 (C-4), 124.8 (HC=C), 126.9 (C-1), 132.7 (C-10), 135.6 (C-6"), 138.2 (C-5), 144.2 (HC=C ), 150.3, 163.6, 155.8 (C-3), 170.6 (Ac-CO), 218.8 (C-17); ESI-MS: 618 [M $+\mathrm{H}^{+}$; Anal. Calcd for $\mathrm{C}_{33} \mathrm{H}_{39} \mathrm{~N}_{5} \mathrm{O}_{7}: \mathrm{C}, 64.17 ; \mathrm{H}, 6.37 ; \mathrm{N}, 11.34$. Found: $\mathrm{C}, 64.25 ; \mathrm{H}, 6.52 ; \mathrm{N}, 11.49$.

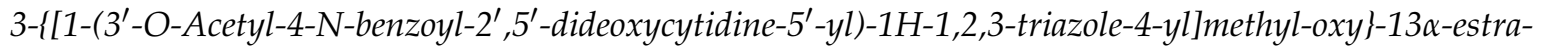
1,3,5(10)-trien-17-one (12c): After purification, protected conjugate 12c was obtained as a white solid (67 mg, 61\%), m.p. $170{ }^{\circ} \mathrm{C}$ (dec.), $R_{\mathrm{f}}=0.47$ (ss B); ${ }^{1} \mathrm{H}-\mathrm{NMR}\left(\mathrm{CDCl}_{3}\right) ; \delta[\mathrm{ppm}]=1.04\left(\mathrm{~s}, 3 \mathrm{H}, 18-\mathrm{CH}_{3}\right), 2.13$ (s, 3H, 3'-OAc), $2.63\left(\mathrm{~d}, 2 \mathrm{H}, J=9.0 \mathrm{~Hz}, 2^{\prime}-\mathrm{H}_{2}\right), 2.78\left(\mathrm{~m}, 2 \mathrm{H}, 6-\mathrm{H}_{2}\right), 4.43(\mathrm{~m}, 1 \mathrm{H}), 4.82(\mathrm{~m}, 2 \mathrm{H}), 5.24-5.26$ (overlapping m, 2H): $1^{\prime}-, 3^{\prime}-, 4^{\prime}-\mathrm{H}, 5^{\prime}-\mathrm{H}_{2}, 5.17\left(\mathrm{~s}, 2 \mathrm{H}, \mathrm{OCH}_{2}\right), 6.68(\mathrm{~s}, 1 \mathrm{H}, 4-\mathrm{H}), 6.76(\mathrm{~d}, 1 \mathrm{H}, J=6.0 \mathrm{~Hz}$, 2-H) $7.15(\mathrm{~d}, 1 \mathrm{H}, J=8.5 \mathrm{~Hz}, 1-\mathrm{H}), 7.53(\mathrm{t}, 3 \mathrm{H}, J=7.0 \mathrm{~Hz}), 7.64(\mathrm{t}, 2 \mathrm{H} J=14.5 \mathrm{~Hz})$ : benzoyl protons, $7.73(\mathrm{~s}, 1 \mathrm{H}, \mathrm{HC}=\mathrm{C}), 7.94\left(\mathrm{~s}, 1 \mathrm{H}, 66^{\prime \prime}-\mathrm{H}\right), 8.04\left(\mathrm{~s}, 1 \mathrm{H}, 4{ }^{\prime \prime}-\mathrm{NH}\right) ;{ }^{13} \mathrm{C}-\mathrm{NMR}\left(\mathrm{CDCl}_{3}\right) ; \delta[\mathrm{ppm}]=20.8(\mathrm{C}-18)$, 21.0, $25.1\left(3^{\prime}-\mathrm{OCH}_{3}\right), 28.2(2 \mathrm{C}), 29.6,30.3,32.0,33.4,37.5\left(\mathrm{C}-2^{\prime}\right), 41.4$ (2C, C-8 and C-9), 49.2 (C-14), 50.1 (C-13), $51.4\left(\mathrm{C}-5^{\prime}\right), 56.3,62.8\left(\mathrm{OCH}_{2}\right), 74.1,84.0,97.3\left(\mathrm{C}-5^{\prime \prime}\right), 112.5(\mathrm{C}-2), 114.5(\mathrm{C}-4), 123.9$ (C-1), 127.0 $(\mathrm{HC}=\mathrm{C}), 129.2(2 \mathrm{C}) .129 .5$ (2C), 132.6: benzoyl CH-s, 132.9 (C-10), 137.6: benzoyl Cq, 138.3 (C-5), 143.5 $(\mathrm{HC}=\underline{\mathrm{C}}), 156.0$ (C-3), 157.5 (C-2"), $162.7\left(\mathrm{C}-4^{\prime \prime}\right), 170.6$ (Bz-CO), 171.2 (Ac-CO), 220.5 (C-17); ESI-MS: 707 $[\mathrm{M}+\mathrm{H}]^{+}$; Anal. Calcd for $\mathrm{C}_{39} \mathrm{H}_{42} \mathrm{~N}_{6} \mathrm{O}_{7}: \mathrm{C}, 66.27 ; \mathrm{H}, 5.99 ; \mathrm{N}, 11.89$. Found: $\mathrm{C}, 66.32 ; \mathrm{H}, 6.13 ; \mathrm{N}, 12.10$.

\subsubsection{General Procedure for Deprotection of Conjugates 13a-c}

Protected conjugate $12 \mathbf{a}, \mathbf{1 2} \mathbf{b}$ or $12 \mathrm{c}(0.1 \mathrm{mmol})$ was deacylated by dissolving in $4 \mathrm{M} \mathrm{NH}_{3}$ in $\mathrm{MeOH}(5 \mathrm{~mL})$, stirring the mixture overnight at room temperature and then the mixture was evaporated in vacuo and the resulting crude product was purified by column chromatography with EtOAc/acetonitrile (9:1) as eluent to afford unprotected conjugate $\mathbf{1 3} \mathbf{a}, \mathbf{1 3 b}$ or $\mathbf{1 3 c}$.

3-\{[1-(2',5'-Dideoxyadenosine-5'-yl)-1H-1,2,3-triazole-4-yl]methyloxy\}-13 $\alpha$-estra-1,3,5(10)-trien-17-one (13a): After purification, conjugate 13a was obtained as a white solid $(50 \mathrm{mg}, 87 \%)$, m.p. $160{ }^{\circ} \mathrm{C}$ (dec.), $R_{\mathrm{f}}=0.33(\mathrm{ss} \mathrm{B}) ;{ }^{1} \mathrm{H}-\mathrm{NMR}\left(\mathrm{DMSO}-d_{6}\right) ; \delta[\mathrm{ppm}]=0.96\left(\mathrm{~s}, 3 \mathrm{H}, 18-\mathrm{CH}_{3}\right), 2.71\left(\mathrm{~m}, 2 \mathrm{H}, 2^{\prime}-\mathrm{H}_{2}\right), 2.83(\mathrm{~m}, 2 \mathrm{H}$, 6- $\left.\mathrm{H}_{2}\right), 4.21(\mathrm{~s}, 1 \mathrm{H}), 4.51(\mathrm{~s}, 1 \mathrm{H}), 4.68-4.77$ (overlapping $\left.\mathrm{m}, 2 \mathrm{H}\right), 4.99(\mathrm{dd}, 2 \mathrm{H} \mathrm{J}=10.0 \mathrm{~Hz}, J=12.0 \mathrm{~Hz}$ ), $5.60(\mathrm{~s}, 1 \mathrm{H}): 1^{\prime}-3^{\prime}-, 4^{\prime}-\mathrm{H}, 5^{\prime}-\mathrm{H}_{2}, \mathrm{OCH}_{2}, 6.63(\mathrm{~s}, 1 \mathrm{H}, 4-\mathrm{H}), 6.70(\mathrm{~d}, 1 \mathrm{H}, J=8.0 \mathrm{~Hz}, 2-\mathrm{H}) 7.12(\mathrm{~d}, 1 \mathrm{H}$, $J=8.5 \mathrm{~Hz}, 1-\mathrm{H}), 7.47\left(\mathrm{~s}, 2 \mathrm{H}, 6^{\prime \prime}-\mathrm{NH}\right), 7.47(\mathrm{~s}, 1 \mathrm{H}, \mathrm{HC}=\mathrm{C}), 8.21(\mathrm{~s}, 1 \mathrm{H}), 8.32(\mathrm{~s}, 1 \mathrm{H}): 2{ }^{\prime \prime}-\mathrm{H}$ and 8"- $\mathrm{H}$; ${ }^{13} \mathrm{C}-\mathrm{NMR}\left(\mathrm{DMSO}-d_{6}\right) ; \delta$ [ppm] = 20.5, $24.6(\mathrm{C}-18), 27.7,28.0,29.7,31.6,32.9,38.0\left(\mathrm{C}-2^{\prime}\right), 40.8(2 \mathrm{C}, \mathrm{C}-8$ and C-9), 48.5 (C-14), 49.4 (C-13), $51.5\left(\mathrm{C}-5^{\prime}\right), 60.8\left(\mathrm{OCH}_{2}\right), 71.1,83.8,84.9,112.4(\mathrm{C}-2), 114.1$ (C-4), 119.1, 125.0 (HC=C), 126.7 (C-1), 132.0 (C-10), 137.9 (C-5), 140.1, 142.8 (HC=C), 150.4, 151.9, 155.6 (C-6"), 155.8 (C-3), 220.7 (C-17); ESI-MS: $585[\mathrm{M}+\mathrm{H}]^{+}$; Anal. Calcd for $\mathrm{C}_{31} \mathrm{H}_{36} \mathrm{~N}_{8} \mathrm{O}_{5}: \mathrm{C}, 63.68 ; \mathrm{H}, 6.21 ; \mathrm{N}, 19.17$. Found: C, 63.84; H, 6.35; N, 19.38 .

3-\{[1-(5'-Deoxythymidine-5'-yl)-1H-1,2,3-triazole-4-yl]methyloxy\}-13 $\alpha$-estra-1,3,5(10)-trien-17-one (13b): After purification, conjugate $\mathbf{1 3 b}$ was obtained as a white solid $(51 \mathrm{mg}, 89 \%)$, m.p. $211-212{ }^{\circ} \mathrm{C}$, $R_{\mathrm{f}}=0.63(\mathrm{ss} \mathrm{B}) ;{ }^{1} \mathrm{H}-\mathrm{NMR}\left(\mathrm{DMSO}-d_{6}\right) ; \delta[\mathrm{ppm}]=0.97\left(\mathrm{~s}, 3 \mathrm{H}, 18-\mathrm{CH}_{3}\right), 1.77\left(\mathrm{~s}, 3 \mathrm{H}, 5^{\prime \prime}-\mathrm{CH}_{3}\right), 1.88(\mathrm{~m}, 1 \mathrm{H})$ and $2.30(\mathrm{~m}, 1 \mathrm{H}): 2^{\prime}-\mathrm{H}_{2}, 2.74\left(\mathrm{~d}, 2 \mathrm{H}, J=3.0 \mathrm{~Hz}, 6-\mathrm{H}_{2}\right), 4.28(\mathrm{~m}, 1 \mathrm{H}), 4.63(\mathrm{~m}, 1 \mathrm{H})$ and $4.71(\mathrm{~m}, 1 \mathrm{H}): 5^{\prime}-\mathrm{H}_{2}$, $5.01\left(\mathrm{~s}, 2 \mathrm{H}, \mathrm{OCH}_{2}\right), 4.09(\mathrm{~d}, 1 \mathrm{H}, J=3.0 \mathrm{~Hz}), 5.50(\mathrm{~s}, 1 \mathrm{H}), 6.16(\mathrm{t}, 1 \mathrm{H}, J=5.0 \mathrm{~Hz}, J=6.0 \mathrm{~Hz}): 1^{\prime}-, 3^{\prime}-, 4^{\prime}-\mathrm{H}$, $6.69(\mathrm{~s}, 1 \mathrm{H}, 4-\mathrm{H}), 6.76(\mathrm{~d}, 1 \mathrm{H}, J=8.5 \mathrm{~Hz}, 2-\mathrm{H}), 7.16(\mathrm{~d}, 1 \mathrm{H}, J=7.5 \mathrm{~Hz}, 1-\mathrm{H}), 7.33(\mathrm{~s}, 1 \mathrm{H}, \mathrm{HC}=\mathrm{C}), 8.16$ $\left(\mathrm{s}, 1 \mathrm{H}, 3\right.$ 3"-NH); ${ }^{13} \mathrm{C}-\mathrm{NMR}$ (DMSO- $\left.d_{6}\right) ; \delta$ [ppm] = $12.0\left(5^{\prime \prime}-\mathrm{CH}_{3}\right), 20.4,24.5(\mathrm{C}-18), 27.6,27.9,29.7,31.5$, 32.5, $37.8\left(\mathrm{C}-2^{\prime}\right), 40.7$ (2C, C-8 and C-9), $48.4(\mathrm{C}-14), 49.4(\mathrm{C}-13), 51.1\left(\mathrm{C}-5^{\prime}\right), 60.8\left(\mathrm{OCH}_{2}\right), 70.7\left(\mathrm{C}-3^{\prime}\right)$, 83.8, 83.9, 109.8 (C-5"), 112.3 (C-2), 114.1 (C-4), 125.0 (HC $=$ C), 126.6 (C-1), 131.9 (C-10), 135.9 (C-6"), 
137.8 (C-5), 142.9 (HC=C ), 150.3, 155.7 (C-3), 163.5, 220.5 (C-17); ESI-MS: 576 [M + H] ${ }^{+}$; Anal. Calcd for $\mathrm{C}_{31} \mathrm{H}_{37} \mathrm{~N}_{5} \mathrm{O}_{6}$ : C, 64.68; $\mathrm{H}, 6.48 ; \mathrm{N}, 12.17$. Found: $\mathrm{C}, 64.53 ; \mathrm{H}, 6.62 ; \mathrm{N}, 12.35$.

3-\{[1-(2',5'-Dideoxycytidine-5'-yl)-1H-1,2,3-triazole-4-yl]methyloxy\}-13 $\alpha$-estra-1,3,5(10)-trien-17-one (13c): After purification, conjugate $13 \mathrm{c}$ was obtained as a white solid ( $45 \mathrm{mg}, 81 \%), \mathrm{m} . \mathrm{p} .170{ }^{\circ} \mathrm{C}\left(\mathrm{dec}\right.$ ), $R_{\mathrm{f}}$ $=0.41(\mathrm{ss} \mathrm{C}) ;{ }^{1} \mathrm{H}-\mathrm{NMR}\left(\mathrm{DMSO}-d_{6}\right) ; \delta[\mathrm{ppm}]=0.96\left(\mathrm{~s}, 3 \mathrm{H}, 18-\mathrm{CH}_{3}\right), 2.29\left(\mathrm{~m}, 2 \mathrm{H}, 2^{\prime}-\mathrm{H}_{2}\right), 2.74(\mathrm{~m}, 2 \mathrm{H}$, 6- $\left.\mathrm{H}_{2}\right), 3.75(\mathrm{~m}, 1 \mathrm{H}), 4.21(\mathrm{~m}, 2 \mathrm{H}), 4.62-4.72$ (overlapping $\left.\mathrm{m}, 2 \mathrm{H}\right): 1^{\prime}-, 3^{\prime}-, 4^{\prime}-\mathrm{H}, 5^{\prime}-\mathrm{H}_{2}, 5.06\left(\mathrm{~s}, 2 \mathrm{H}, \mathrm{OCH}_{2}\right)$, $6.70(\mathrm{~s}, 1 \mathrm{H}, 4-\mathrm{H}), 6.75(\mathrm{~d}, 1 \mathrm{H}, J=6.5 \mathrm{~Hz}, 2-\mathrm{H}) 7.15(\mathrm{~d}, 1 \mathrm{H}, J=8.0 \mathrm{~Hz}, 1-\mathrm{H}), 7.29(\mathrm{~s}, 1 \mathrm{H}, \mathrm{HC}=\mathrm{C}), 8.04$ $\left(\mathrm{d}, 1 \mathrm{H}, J=6.5 \mathrm{~Hz}, 6{ }^{\prime \prime}-\mathrm{H}\right), 8.19$ (s, $\left.1 \mathrm{H}, 4^{\prime \prime}-\mathrm{NH} 2\right) ;{ }^{13} \mathrm{C}-\mathrm{NMR}$ (DMSO- $\left.d_{6}\right) ; \delta[\mathrm{ppm}]=24.6(\mathrm{C}-18), 27.8,28.1$, 29.8, 31.7, 33.0, $36.1\left(\mathrm{C}-2^{\prime}\right), 40.8$ (2C, C-8 and C-9), 43.4, $48.6(\mathrm{C}-14), 50.5(\mathrm{C}-13), 51.5\left(\mathrm{C}-5^{\prime}\right), 61.3\left(\mathrm{OCH}_{2}\right)$, 84.1, 84.9, 87.3, 94.5 (C-5"), 112.5 (C-2), 114.2 (C-4), 125.2 (C-1), 126.8 (HC- =C), 132.1 (C-10), 137.9 (C-5), $141.1\left(\mathrm{C}-6^{\prime \prime}\right), 142.9(\mathrm{HC}=\underline{\mathrm{C}}), 155.0(\mathrm{C}-3), 155.2\left(\mathrm{C}-2^{\prime \prime}\right), 165.6$ (C-4"), 220.7 (C-17); ESI-MS: 561 [M + H] ; Anal. Calcd for $\mathrm{C}_{30} \mathrm{H}_{36} \mathrm{~N}_{6} \mathrm{O}_{5}$ : C, 64.27; $\mathrm{H}, 6.47 ; \mathrm{N}, 14.99$. Found: $\mathrm{C}, 64.42 ; \mathrm{H}, 6.34 ; \mathrm{N}, 15.18$.

\subsection{Cell Cultures and Antiproliferative Assays}

The growth-inhibitory effects of the conjugates $\mathbf{1 2 a}-\mathbf{c}$ and $\mathbf{1 3} \mathbf{a}-\mathbf{c}$ were tested in vitro by means of the MTT assay on a panel of malignant human cell lines of gynecological origin including HeLa, MCF-7 and A2780 cells, isolated from cervical, breast and ovarian cancers. The cell lines were obtained from the European Collection of Cell Cultures (Salisbury, UK). The cells were maintained in minimal essential medium supplemented with 10\% fetal bovine serum (FBS), $1 \%$ nonessential aminoacids and an antibiotic-antimycotic mixture (AAM). All media and supplements were obtained from Lonza Ltd. (Basel, Switzerland). All chemicals, if otherwise not specified, were purchased from Sigma-Aldrich Ltd. (Budapest, Hungary). All cell lines were grown in a humidified atmosphere of $5 \% \mathrm{CO}_{2}$ at $37^{\circ} \mathrm{C}$. For pharmacological investigations, $10 \mathrm{mM}$ stock solutions of the tested conjugates $\mathbf{1 2 a}-\mathbf{c}$ and 13a-c and cisplatin controls were prepared in dimethyl sulfoxide (DMSO). The highest applied DMSO concentration of the medium $(0.3 \%)$ did not exert any substantial effect on the determined cellular functions. All cell types were seeded into 96-well plates at a density of 5000 cells/well and allowed to stand overnight under cell-culturing conditions, then the medium containing the tested compounds (12a-c and 13a-c and cisplatin controls) were added. After a $72 \mathrm{~h}$ incubation with increasing concentrations $(0.03-30 \mu \mathrm{M})$ of the compounds (12a-c and 13a-c and cisplatin controls), viability was determined by the addition of $20 \mu \mathrm{L}$ MTT solution $(5 \mathrm{mg} / \mathrm{mL})$ for $4 \mathrm{~h}$. The precipitated formazan crystals were solubilized in DMSO and the absorbance values were determined at $545 \mathrm{~nm}$ with an ELISA reader [62] utilizing untreated cells as controls. Two independent experiments were performed with 5 parallel wells and cisplatin, a clinically applied anticancer agent, was used as reference compound. For the most effective conjugates (12a, 12c and 13a) sigmoidal dose-response curves were fitted to the measured data in order to determine the $\mathrm{IC}_{50}$ values by means of Graphpad Prism 4.0 (Graphpad Software; San Diego, CA, USA).

\subsection{Determination of $17 \beta-H S D 1$ Inhibition}

The inhibitory effects exerted on $17 \beta$-HSD1 activity by the newly synthesized conjugates were determined via an in vitro radiosubstrate incubation method described in detail earlier $[22,63]$. Conversion of estrone to $17 \beta$-estradiol was measured in the presence of NADPH cofactor and microsomes of human termed placenta served as enzyme source. Relative conversions in the presence of $10 \mu \mathrm{M}$ test compounds were measured. $\mathrm{IC}_{50}$ value (the inhibitor concentration that decreases the enzyme activity to $50 \%$ ) was determined for $\mathbf{1 2 b}$. A reference $\mathrm{IC}_{50}$ value was determined earlier for unlabelled estrone and that was $0.63 \pm 0.11 \mu \mathrm{M}$.

\section{Conclusions}

Triazolyl nucleoside conjugates of $13 \alpha$-estrone have been synthesized succesfully in order to investigate their antiproliferative and $17 \beta-H S D 1$ enzyme inhibitory activity. The CuAAC 
reaction conditions have been optimized for the coupling of the protected azidonucleosides with 3-O-propargyl-13 $\alpha$-estrone. The biological assays showed lower antiproliferative and $17 \beta$-HSD1 enzyme inhibitory activities for the conjugates compared to our earlier synthesized 3-O-[(1-benzyl-1H-1,2,3-triazol-4-yl)methyl]-13 $\alpha$-estrone (1) which is probably due to the steric effect and the polar behavior of the inserted nucleoside units. The protected, cytidine- $13 \alpha$-estrone conjugate 12c showed the best antiproliferative activity with $\mathrm{IC}_{50}$ values of $9.0-10.4 \mu \mathrm{M}$ and the unprotected, thymidine-13 $\alpha$-estrone conjugate $\mathbf{1 3 b}$ displayed the best enzyme inhibitory potential $\left(\mathrm{IC}_{50}=19 \mu \mathrm{M}\right)$. $13 \alpha$-Estrone lost its $17 \beta$-HSD1 inhibitory activity upon attaching the nucleoside moiety to its $3-\mathrm{OH}$ group by a triazolylmethyl linker. The antiproliferative activity was also decreased by changing the benzyl group for the nucleoside unit in our potent model compound $\mathbf{1}$. Concerning that the most active 17 $\beta$-HSD1 inhibitor was different from the best cell growth-inhibitor in this series, it can be stated, that the two biological effects should be attributed to other mechanisms. From the biological results, it seems that neither the improvement in the activity nor the improvement in the selectivity was demonstrated for the synthesized nucleoside- $13 \alpha$-estrone conjugates.

Acknowledgments: The authors are grateful for financial support from the Hungarian Scientific Research Fund (grants OTKA K113150 and K109293).

Author Contributions: Brigitta Bodnár, Edina Bianka Herman and Izabella Sinka performed the experiments; János Wölfling and Gyula Schneider contributed reagents, materials and analysis tools; Zoltán Kupihár, Erzsébet Mernyák, Mihály Szécsi and István Zupkó conceived and designed the experiments; Zoltán Kupihár, Erzsébet Mernyák and István Zupkó analyzed the data; Zoltán Kupihár, Erzsébet Mernyák, Mihály Szécsi, István Zupkó and Lajos Kovács wrote the paper.

Conflicts of Interest: The authors declare no conflict of interest.

\section{References}

1. Miller, W.L.; Auchus, R.J. The molecular biology, biochemistry, and physiology of human steroidogenesis and its disorders. Endocr. Rev. 2010, 32, 81-151. [CrossRef] [PubMed]

2. Chen, G.G.; Zeng, Q.; Tse, G.M. Estrogen and its receptors in cancer. Med. Res. Rev. 2008, 28, 954-974. [CrossRef] [PubMed]

3. Gupta, A.; Kumar, B.S.; Negi, A.S. Current status on development of steroids as anticancer agents. J. Steroid Biochem. Mol. Biol. 2013, 137, 242-270. [CrossRef] [PubMed]

4. Möller, G.; Adamski, J. Integrated view on 17beta-hydroxysteroid dehydrogenases. Mol. Cell. Endocrinol. 2009, 301, 7-19. [CrossRef] [PubMed]

5. Marchais-Oberwinkler, S.; Henn, C.; Möller, G.; Klein, T.; Negri, M.; Oster, A.; Spadaro, A.; Werth, R.; Wetzel, M.; Xu, K.; et al. 17beta-Hydroxysteroid dehydrogenases (17beta-HSDs) as therapeutic targets: Protein structures, functions, and recent progress in inhibitor development. J. Steroid Biochem. Mol. Biol. 2011, 125, 66-82. [CrossRef] [PubMed]

6. Day, J.M.; Tutill, H.J.; Purohit, A.; Reed, M.J. Design and validation of specific inhibitors of 17beta-hydroxysteroid dehydrogenases for therapeutic application in breast and prostate cancer, and in endometriosis. Endocr. Relat. Cancer 2008, 15, 665-692. [CrossRef] [PubMed]

7. Poirier, D. 17beta-Hydroxysteroid dehydrogenase inhibitors: A patent review. Expert Opin. Ther. Pat. 2010, 20, 1123-1145. [CrossRef] [PubMed]

8. Gobec, S.; Brozic, P.; Rizner, T.L. Inhibitors of 17beta-hydroxysteroid dehydrogenase type 1. Curr. Med. Chem. 2008, 15, 137-150. [CrossRef]

9. Minorics, R.; Bózsity, N.; Wölfling, J.; Mernyák, E.; Schneider, G.; Márki, Á.; Falkay, G.; Ocsovszki, I. Zupkó Antiproliferative effect of normal and 13-epi-D-homoestrone and their 3-methyl ethers on human reproductive cancer cell lines. J. Steroid Biochem. Mol. Biol. 2012, 132, 168-175. [CrossRef] [PubMed]

10. Wölfling, J.; Mernyák, E.; Frank, É.; Falkay, G.; Márki, Á.; Minorics, R.; Schneider, G. Synthesis and receptor-binding examinations of the normal and 13-epi-D-homoestrones and their 3-methyl ethers. Steroids 2003, 68, 277-288. [CrossRef] 
11. Cushman, M.; He, H.-M.; Katzenellenbogen, J.A.; Varma, R.K.; Hamel, E.; Lin, C.M.; Ram, S.; Sachdeva, Y.P. Synthesis of analogs of 2-methoxyestradiol with enhanced inhibitory effects on tubulin polymerization and cancer cell growth. J. Med. Chem. 1997, 40, 2323-2334. [CrossRef] [PubMed]

12. Möller, G.; Deluca, D.; Gege, C.; Rosinus, A.; Kowalik, D.; Peters, O.; Droescher, P.; Elger, W.; Adamski, J.; Hillisch, A. Structure-based design, synthesis and in vitro characterization of potent 17beta-hydroxysteroid dehydrogenase type 1 inhibitors based on 2-substitutions of estrone and D-homo-estrone. Bioorg. Med. Chem. Lett. 2009, 19, 6740-6744. [CrossRef] [PubMed]

13. Hillisch, A.; Peters, O.; Gege, C.; Siemeister, G.; Unger, E.; Menzenbach, B. Antitumoral D-homoestra1,3,5(10)-trien-3-yl 2-substituted sulfamates. US Patent 7,244,762, 2007.

14. Ayan, D.; Roy, J.; Maltais, R.; Poirier, D. Impact of estradiol structural modifications (18-methyl and/or 17-hydroxy inversion of configuration) on the in vitro and in vivo estrogenic activity. J. Steroid Biochem. Mol. Biol. 2011, 127, 324-330. [CrossRef] [PubMed]

15. Schönecker, B.; Lange, C.; Kötteritzsch, M.; Gunther, W.; Weston, J.; Anders, E.; Görls, H. Conformational design for 13alpha-steroids. J. Org. Chem. 2000, 65, 5487-5497. [CrossRef] [PubMed]

16. Jovanović-Santa, S.; Petrović, J.; Andrić, S.; Kovačević, R.; Đurendić, E.; Sakač, M.; Lazar, D.; Stanković, S. Synthesis, structure, and screening of estrogenic and antiestrogenic activity of new 3, 17-substituted-16, 17-seco-estratriene derivatives. Bioorg. Chem. 2003, 31, 475-484.

17. Yaremenko, F.G.; Khvat, A.V. A new one-pot synthesis of 17-oxo-13alpha-steroids of the androstane series from their 13beta-analogues. Mendeleev Commun. 1994, 4, 187-188. [CrossRef]

18. Mernyák, E.; Kovács, I.; Minorics, R.; Sere, P.; Czégány, D.; Sinka, I.; Wölfling, J.; Schneider, G.; Újfaludi, Z.; Boros, I.; et al. Synthesis of trans-16-triazolyl-13alpha-methyl-17-estradiol diastereomers and the effects of structural modifications on their in vitro antiproliferative activities. J. Steroid Biochem. Mol. Biol. 2015, 150, 123-134. [CrossRef] [PubMed]

19. Szabó, J.; Jerkovics, N.; Schneider, G.; Wölfling, J.; Bózsity, N.; Minorics, R.; Zupkó, I.; Mernyák, E. Synthesis and in vitro antiproliferative evaluation of C-13 epimers of triazolyl-D-secoestrone alcohols: The first potent $13 \alpha$-D-secoestrone derivative. Molecules 2016, 21, 611-623. [CrossRef] [PubMed]

20. Szabó, J.; Pataki, Z.; Wölfling, J.; Schneider, G.; Bózsity, N.; Minorics, R.; Zupkó, I.; Mernyák, E. Synthesis and biological evaluation of 13alpha-estrone derivatives as potential antiproliferative agents. Steroids 2016, 113, 14-21. [CrossRef] [PubMed]

21. Szabó, J.; Bacsa, I.; Wölfling, J.; Schneider, G.; Zupkó, I.; Varga, M.; Herman, B.E.; Kalmár, L.; Szécsi, M.; Mernyák, E. Synthesis and in vitro pharmacological evaluation of N-[(1-benzyl-1,2,3-triazol4-yl)methyl]-carboxamides on D-secoestrone scaffolds. J. Enzyme Inhib. Med. Chem. 2016, 31, 574-579. [CrossRef] [PubMed]

22. Herman, B.E.; Szabó, J.; Bacsa, I.; Wölfling, J.; Schneider, G.; Bálint, M.; Hetényi, C.; Mernyák, E.; Szécsi, M. Comparative investigation of the in vitro inhibitory potencies of 13-epimeric estrones and D-secoestrones towards 17beta-hydroxysteroid dehydrogenase type 1. J. Enzyme Inhib. Med. Chem. 2016, Early Online, 1-9. [CrossRef] [PubMed]

23. Cho, S.Y.; Polster, J.; Engles, J.M.; Hilton, J.; Abraham, E.H.; Wahl, R.L. In vitro evaluation of adenosine 5'-monophosphate as an imaging agent of tumor metabolism. J. Nucl. Med. 2006, 47, 837-845. [PubMed]

24. Pastor-Anglada, M.; Cano-Soldado, P.; Molina-Arcas, M.; Lostao, M.P.; Larráyoz, I.; Martínez-Picado, J.; Casado, F.J. Cell entry and export of nucleoside analogues. Virus Res. 2005, 107, 151-164. [CrossRef] [PubMed]

25. Pérez-Torras, S.; García-Manteiga, J.; Mercadéd, E.; Casado, F.J.; Carbó, N.; Pastor-Anglada, M.; Mazo, A. Adenoviral-mediated overexpression of human equilibrative nucleoside transporter 1 (hENT1) enhances gemcitabine response in human pancreatic cancer. Biochem. Pharmacol. 2008, 76, 322-329. [CrossRef] [PubMed]

26. Fournier, D.; Poirier, D.; Mazumdar, M.; Lin, S.X. Design and synthesis of bisubstrate inhibitors of type 1 17beta-hydroxysteroid dehydrogenase: Overview and perspectives. Eur. J. Med. Chem. 2008, 43, 2298-2306. [CrossRef] [PubMed]

27. An, S.H.; West, C.R.; Hong, C.I. Nucleoside conjugates. 8. The preparation of 5-fluoro-2'-deoxyuridine conjugates of corticosteroids. Steroids 1986, 47, 413-420. [CrossRef] 
28. Bérubé, M.; Poirier, D. Improved synthesis of EM-1745, preparation of its C17-ketone analogue and comparison of their inhibitory potency on 17beta-hydroxysteroid dehydrogenase type 1. J. Enzyme Inhib. Med. Chem. 2009, 24, 832-843. [CrossRef] [PubMed]

29. Poirier, D. Contribution to the development of inhibitors of 17beta-hydroxysteroid dehydrogenase types 1 and 7: Key tools for studying and treating estrogen-dependent diseases. J. Steroid Biochem. Mol. Biol. 2011, 125, 83-94. [CrossRef] [PubMed]

30. Poirier, D.; Boivin, R.P.; Tremblay, M.R.; Bérubé, M.; Qiu, W.; Lin, S.-X. Estradiol-adenosine hybrid compounds designed to inhibit type 1 17beta-hydroxysteroid dehydrogenase. J. Med. Chem. 2005, 48, 8134-8147. [CrossRef] [PubMed]

31. Iyer, V.K.; Butler, W.B.; Horwitz, J.P.; Rozhin, J.; Brooks, S.C.; Corombos, J.; Kessel, D. Some adenine and adenosine methylene-bridged estrogens. J. Med. Chem. 1983, 26, 162-166. [CrossRef] [PubMed]

32. Rostovtsev, V.V.; Green, L.G.; Fokin, V.V.; Sharpless, K.B. A stepwise Huisgen cycloaddition process: Copper(I)-catalyzed regioselective "ligation" of azides and terminal alkynes. Angew. Chem. Int. Ed. 2002, 41, 2596-2599. [CrossRef]

33. Meldal, M.; Tornøe, C.W. Cu-catalyzed azide-alkyne cycloaddition. Chem. Rev. 2008, 108, 2952-3015. [CrossRef] [PubMed]

34. Liang, L.; Astruc, D. The copper(I)-catalyzed alkyne-azide cycloaddition (CuAAC) "click" reaction and its applications. An overview. Coord. Chem. Rev. 2011, 255, 2933-2945. [CrossRef]

35. Herdewijn, P.; Balzarini, J.; Pauwels, R.; Janssen, G.; Aerschot, A.V.; Clercq, E.D. Synthesis and biological activity of the mono-and diamino analogues of $2^{\prime}$-deoxyadenosine, cordycepin, 9-(3-deoxy-alpha-D-threo-pentofuranosyl)adenine (a structural component of Agrocin 84) and 9-(2-deoxy-alpha-D-threo-pentofuranosyl)adenine. Nucleos. Nucleot. 1989, 8, 1231-1257. [CrossRef]

36. Chen, J.-B.; Liu, E.M.; Chern, T.-R.; Yang, C.-W.; Lin, C.I.; Huang, N.-K.; Lin, Y.-L.; Chern, Y.; Lin, J.-H.; Fang, J.-M. Design and synthesis of novel dual-action compounds targeting the adenosine A2A receptor and adenosine transporter for neuroprotection. ChemMedChem 2011, 6, 1390-1400. [CrossRef] [PubMed]

37. Murat, P.; Gennaro, B.; Garcia, J.; Spinelli, N.; Dumy, P.; Defrancq, E. The use of a peptidic scaffold for the formation of stable guanine tetrads: Control of a H-bonded pattern in water. Chem. Eur. J. 2011, 17, 5791-5795. [CrossRef] [PubMed]

38. Cheng, K.; Liu, J.; Sun, H.; Xie, J. Synthesis of nucleoside conjugates as potential inhibitors of glycogen phosphorylase. Synthesis 2010, 1046-1052. [CrossRef]

39. Mattarella, M.; Berstis, L.; Baldridge, K.K.; Siegel, J.S. Synthesis of bioconjugated sym-pentasubstituted corannulenes: Experimental and theoretical investigations of supramolecular architectures. Bioconj. Chem. 2014, 25, 115-128. [CrossRef] [PubMed]

40. Točík, Z.; Dvořáková, I.; Liboska, R.; Buděšínský, M.; Masojídková, M.; Rosenberg, I. Electrophile-promoted addition of hydroxymethylphosphonate to $4^{\prime}, 5^{\prime}$-didehydronucleosides: A way to novel isosteric analogues of 5'-nucleotides. Tetrahedron 2007, 63, 4516-4534. [CrossRef]

41. Brear, P.; Freeman, G.R.; Shankey, M.C.; Trmčić, M.; Hodgson, D.R.W. Aqueous methods for the preparation of 5'-substituted guanosine derivatives. Chem. Commun. 2009, 4980-4981. [CrossRef] [PubMed]

42. Paredes, E.; Das, S.R. Click chemistry for rapid labeling and ligation of RNA. Chem. Bio. Chem. 2011, 12, 125-131. [CrossRef] [PubMed]

43. Yamamoto, I.; Sekine, M.; Hata, T. One-step synthesis of 5'-azido-nucleosides. J. Chem. Soc. Perkin Trans. 1 1980, 306-310. [CrossRef]

44. Hui, W.B.; Sherman, J.C. Self-assembly of a thymine quartet and quadruplex via an organic template. Tetrahedron Lett. 2014, 55, 1479-1485. [CrossRef]

45. Seio, K.; Miyashita, T.; Sato, K.; Sekine, M. Synthesis and properties of new nucleotide analogues possessing squaramide moieties as new phosphate isosters. Eur. J. Org. Chem. 2005, 5163-5170. [CrossRef]

46. Madhuri, V.; Kumar, V.A. Design and synthesis of dephosphono DNA analogues containing 1, 2, 3-triazole linker and their UV-melting studies with DNA/RNA. Nucleos. Nucleot. Nucl. Acids 2012, 31, 97-111. [CrossRef] [PubMed]

47. Liu, F.; Austin, D.J. A general synthesis of 5'-azido-5'-deoxy-2' ${ }^{\prime} 3^{\prime}-O$-isopropylidene nucleosides. J. Org. Chem. 2001, 66, 8643-8645. [CrossRef] [PubMed] 
48. Nuzzi, A.; Massi, A.; Dondoni, A. Model studies toward the synthesis of thymidine oligonucleotides with triazole internucleosidic linkages via iterative $\mathrm{Cu}(\mathrm{I})$-promoted azide-alkyne ligation chemistry. QSAR Comb. Sci. 2007, 26, 1191-1199. [CrossRef]

49. Cui, H.; Carrero-Lérida, J.; Silva, A.P.; Whittingham, J.L.; Brannigan, J.A.; Ruiz-Pérez, L.M.; Read, K.D.; Wilson, K.S.; González-Pacanowska, D.; Gilbert, I.H. Synthesis and evaluation of alpha-thymidine analogues as novel antimalarials. J. Med. Chem. 2012, 55, 10948-10957. [CrossRef] [PubMed]

50. Mitsunobu, $\mathrm{O}$. The use of diethyl azodicarboxylate and triphenylphosphine in synthesis and transformations of natural products. Synthesis 1981,1-28. [CrossRef]

51. Hughes, D.L. Progress in the Mitsunobu reaction. A review. Org. Prep. Proc. Int. 1996, 28, 127-164. [CrossRef]

52. Kumara Swamy, K.C.; Bhuvan Kumar, N.N.; Balaraman, E.; Pavan Kumar, K.V.P. Mitsunobu and related reactions: Advances and applications. Chem. Rev. 2009, 109, 2551-2651. [CrossRef] [PubMed]

53. Viaud, M.C.; Rollin, P. Zinc azide mediated Mitsunobu substitution. An expedient method for the one-pot azidation of alcohols. Synthesis 1990, 130-132. [CrossRef]

54. Jawalekar, A.M.; Meeuwenoord, N.; Cremers, J.G.O.; Overkleeft, H.S.; van der Marel, G.A.; Rutjes, F.P.J.T.; van Delft, F.L. Conjugation of nucleosides and oligonucleotides by [3+2] cycloaddition. J. Org. Chem. 2008, 73, 287-290. [CrossRef] [PubMed]

55. Lolk, L.; Pøhlsgaard, J.; Jepsen, A.S.; Hansen, L.H.; Nielsen, H.; Steffansen, S.I.; Sparving, L.; Nielsen, A.B.; Vester, B.; Nielsen, P. A click chemistry approach to pleuromutilin conjugates with nucleosides or acyclic nucleoside derivatives and their binding to the bacterial ribosome. J. Med. Chem. 2008, 51, 4957-4967. [CrossRef] [PubMed]

56. Casaschi, A.; Grigg, R.; Sansano, J.M. Palladium catalysed tandem cyclisation-anion capture. Part 6: synthesis of sugar, nucleoside, purine, benzodiazepinone and beta-lactam analogues via capture of in situ generated vinylstannanes. Tetrahedron 2000, 56, 7553-7560. [CrossRef]

57. Tjarks, W.; Anisuzzaman, A.K.; Liu, L.; Soloway, A.H.; Barth, R.F.; Perkins, D.J.; Adams, D.M. Synthesis and in vitro evaluation of boronated uridine and glucose derivatives for boron neutron capture therapy. J. Med. Chem. 1992, 35, 1628-1633. [CrossRef] [PubMed]

58. Fernicola, S.; Torquati, I.; Paiardini, A.; Giardina, G.; Rampioni, G.; Messina, M.; Leoni, L.; Del Bello, F.; Petrelli, R.; Rinaldo, S.; et al. Synthesis of triazole-linked analogues of c-di-GMP and their interactions with diguanylate cyclase. J. Med. Chem. 2015, 58, 8269-8284. [CrossRef] [PubMed]

59. Lucas, R.; Teste, K.; Zerrouki, R.; Champavier, Y.; Guilloton, M. Chelation-controlled regioselective alkylation of pyrimidine 2'-deoxynucleosides. Carbohydr. Res. 2010, 345, 199-207. [CrossRef] [PubMed]

60. Kicsák, M.; Bege, M.; Bereczki, I.; Csávás, M.; Herczeg, M.; Kupihár, Z.; Kovács, L.; Borbás, A.; Herczegh, P. A three-component reagent system for rapid and mild removal of $\mathrm{O}-, \mathrm{N}$ - and S-trityl protecting groups. Org. Biomol. Chem. 2016, 14, 3190-3192. [CrossRef] [PubMed]

61. Kádár, Z.; Molnár, J.; Schneider, G.; Zupkó, I.; Frank, É. A facile 'click' approach to novel 15beta-triazolyl-5alpha-androstane derivatives, and an evaluation of their antiproliferative activities in vitro. Bioorg. Med. Chem. 2012, 20, 1396-1402. [CrossRef] [PubMed]

62. Mosmann, T. Rapid colorimetric assay for cellular growth and survival: Application to proliferation and cytotoxicity assays. J. Immunol. Methods 1983, 65, 55-63. [CrossRef]

63. Bacsa, I.; Jójárt, R.; Schneider, G.; Wölfling, J.; Maróti, P.; Herman, B.E.; Szécsi, M.; Mernyák, E. Synthesis of A-ring halogenated 13alpha-estrone derivatives as potential 17beta-HSD1 inhibitors. Steroids 2015, 104, 230-236. [CrossRef] [PubMed]

Sample Availability: Not available.

(C) 2016 by the authors; licensee MDPI, Basel, Switzerland. This article is an open access article distributed under the terms and conditions of the Creative Commons Attribution (CC-BY) license (http://creativecommons.org/licenses/by/4.0/). 
II.

Bodnár B., Mernyák E., Szabó J., Wölfling J., Schneider G., Zupkó I., Kupihár Z. and Kovács L. Synthesis and in vitro investigation of potential antiproliferative monosaccharideD-secoestrone bioconjugates, Bioorganic and Medicinal Chemistry Letters, 2017, 27, 19381942. IF: 2.454 (2016) 


\title{
Synthesis and in vitro investigation of potential antiproliferative monosaccharide-D-secoestrone bioconjugates
}

\author{
Brigitta Bodnár ${ }^{\mathrm{a}}$, Erzsébet Mernyák ${ }^{\mathrm{b}}$, Johanna Szabó ${ }^{\mathrm{b}}$, János Wölfling ${ }^{\mathrm{b}}$, Gyula Schneider ${ }^{\mathrm{b}}$, István Zupkó ${ }^{\mathrm{c}}$, \\ Zoltán Kupihár ${ }^{\mathrm{a}, *}$, Lajos Kovács ${ }^{\mathrm{a}, *}$
}

a Department of Medicinal Chemistry, University of Szeged, Dóm tér 8, H-6720 Szeged, Hungary

${ }^{\mathrm{b}}$ Department of Organic Chemistry, University of Szeged, Dóm tér 8, H-6720 Szeged, Hungary

${ }^{\mathrm{c}}$ Department of Pharmacodynamics and Biopharmacy, University of Szeged, Eötvös u. 6, H-6720 Szeged, Hungary

\section{A R T I C L E I N F O}

\section{Article history:}

Received 17 January 2017

Revised 11 March 2017

Accepted 14 March 2017

Available online 16 March 2017

\section{Keywords:}

Monosaccharide

D-Secoestrone

Oxime

Bioconjugate

CuAAC

\begin{abstract}
A B S T R A C T
The syntheses of monosaccharide-D-secoestrone conjugates are reported. They were prepared from 3-(prop-2-inyloxy)-D-secoestrone alcohol or oxime and monosaccharide azides via $\mathrm{Cu}(\mathrm{I})$-catalyzed azide-alkyne cycloaddition reactions (CuAAC). The antiproliferative activities of the conjugates were investigated in vitro against a panel of human adherent cancer cell lines (HeLa, A2780 and MCF-7) by means of MTT assays. The protected D-glucose-containing D-secoestrone oxime bioconjugate (24b) proved to be the most effective with an $\mathrm{IC}_{50}$ value in the low micromolar range against $\mathrm{A} 2780$ cell line.
\end{abstract} (C) 2017 Elsevier Ltd. All rights reserved.
Literature precedents reveal that different synthetic modifications of estrone (1, Scheme 1 ) lead to anticancer compounds. ${ }^{1}$ In order to suppress their hormonal action, substitutions at C-2, opening of ring D or inversion of configuration at C-13 are usually carried out. ${ }^{2-7}$ We recently reported that 3-O-benzyl ethers of Dsecoestrone alcohol or oxime (3a and $\mathbf{3 b}$, Scheme 1) display substantial in vitro antiproliferative action against certain cancer cell lines in the low micromolar range. 8,9

The starting compounds bearing phenolic hydroxy groups (2a and $\mathbf{2 b}$ ) did not influence the proliferation of the investigated cell lines. The cytostatic potential of benzyl ethers ( $\mathbf{3 a}$ and $\mathbf{3 b}$ ) was successfully improved by the introduction of a 1,2,3-triazole moiety between the benzyl and the hydroxy groups. The heterocyclic ring was introduced to $\mathrm{C}-3$ via a short oxymethylene group applying copper(I)-catalyzed alkyne-azide click reaction (CuAAC). The resulting 3-O-[(1-benzyl-1H-1,2,3-triazol-4-yl)methyl] derivatives (5a and 5b) displayed submicromolar $\mathrm{IC}_{50}$ values against certain human reproductive adherent cancer cell lines. ${ }^{10}$ There are already a number of literature examples of the synthesis of antiproliferative steroidal triazoles ${ }^{9,11-13}$ and the triazole moiety is also used as a linker arm in bioconjugates owing to its high proteolytic and

\footnotetext{
* Corresponding authors.

E-mail addresses: kupihar.zoltan@med.u-szeged.hu (Z. Kupihár), kovacs.lajos@ med.u-szeged.hu (L. Kovács).
}

metabolic stability. On the other hand, making bioconjugates is a potential strategy to enhance the antiproliferative effect or to increase the selectivity of a compound. Preparation of natural product conjugates is a very promising approach, since the biological potency of the new hybrids may exceed that of the parent compounds. ${ }^{14}$ In general, in the compounds constructed from diverse molecular entities, the components may result in synergic action, with better tolerability or the conjugate may possess more selective cellular uptake or may influence the pharmacokinetic properties. ${ }^{14}$ Based on our previous observations and the potential advantages of modifying our most active D-secoestrones by making bioconjugates, here we aimed at synthesizing novel D-secoestrone bioconjugates, stemming from D-secoestrones, retaining the 3-O[(1,2,3-triazol-4-yl)methyl] moiety, and introducing a monosaccharide unit instead of the previously used benzyl group on the triazole ring. The rationale behind this aim was the fact that although sugars per se have no therapeutic action in glycosylated steroid conjugates, they have a dramatic effect on the physical, chemical and biological properties of bioconjugates and the sugar moieties act as molecular elements that control the pharmacokinetics of a drug, such as absorption, distribution, metabolism and excretion..$^{15}$ As it was reported, the number, location and type of sugars in steroidal glycoalkaloids, even with identical aglycon, play an important role in the antiproliferative activity. ${ }^{16}$ Similarly, subtle sugar modifications can dramatically, and independently, 
<smiles>[R10]Oc1ccc2c(c1)CC[C@@H]1[C@@H]2CC[C@]([R])(C)[C@H]1[R3]</smiles>

$$
\begin{aligned}
& \text { 2a, 2b } \mathrm{R}^{1}=\mathrm{H} ; \mathrm{R}^{3}=n \text {-propyl } \\
& \text { 3a, 3b } \mathrm{R}^{1}=\mathrm{Bn} ; \mathrm{R}^{3}=\text { allyl } \\
& \text { 4a, 4b } \mathrm{R}^{1}=\text { propargyl; } \mathrm{R}^{3}=n \text {-propyl }
\end{aligned}
$$<smiles>[R2][C@]1(C)CC[C@@H]([C@H]2c3ccc(OCc4cn(Cc5ccccc5)nn4)cc3CC[C@H]2C)[C@H]1CCC</smiles>

\section{$5 a, 5 b$}

$$
\begin{aligned}
& \text { series } \mathbf{a}: \mathrm{R}^{2}=\mathrm{CH}_{2} \mathrm{OH} \\
& \text { series } \mathbf{b}: \mathrm{R}^{2}=\mathrm{CH}=\mathrm{NOH}
\end{aligned}
$$

Scheme 1. The synthesis of estrone derivatives 2-5 obtained earlier.

modulate both the cytotoxic properties and the $\mathrm{Na}^{+} / \mathrm{K}^{+}$-ATPase inhibitory properties of cardiac glycosides. ${ }^{17}$ In this vein, we planned to perform CuAAC reactions of steroidal alkynes (4a and 4b) with protected monosaccharide azides and to investigate the in vitro antiproliferative activities of these bioconjugates by means of MTT assays against a panel of human adherent cancer cell lines (HeLa, MCF-7 and A2780).

As our aim was to synthesize carbohydrate-D-secoestrone bioconjugates from our previously reported 3-O-propargyl D-secoestrones using CuAAC, this conjugation reaction required the synthesis of azide-containing carbohydrate building blocks and their CuAAC reaction with propargylated D-secoestrones (4a and 4b, Scheme 1).
Some of the most abundant monosaccharides in the nature, Dglucose, D-mannose, D-galactose and D-ribose were chosen to prepare these building blocks. We aimed at synthesizing their azide derivatives in which the azide group is built into their glycosidic position or in place of their primary hydroxy groups (position 6 in hexopyranoses and position 5 in ribofuranose). The most common ways for the preparation of glycosyl azides are either an $\mathrm{S}_{\mathrm{N}} 2$ substitution of a protected glycosyl halide by sodium azide at high temperature in $\mathrm{DMF}^{18}$ or an $\mathrm{S}_{\mathrm{N}} 1$ substitution of a peracetylated carbohydrate under mild conditions using a Lewis acid catalyst and trimethylsilyl azide. ${ }^{19-21}$ We have chosen the latter method as all of our sugars contained a neighbouring participation group at position 2 ( $O$-acetyl or $O$-benzoyl) that can ensure the desired stereoselectivity. The primary hydroxy groups of the monosaccharides can be replaced to azides in a two-step procedure ${ }^{22}$ involving the introduction of a good leaving group (e.g. a tosyl) to the primary hydroxy and a subsequent azide substitution of the tosylate by sodium azide in DMF.

First, the hexoses studied were peracetylated according to a literature method ${ }^{23}$ to yield compounds 6-8 (Scheme 2). Next, the glycosidic 0 -acetyl groups were replaced with the azide group using tin tetrachloride as a Lewis acid catalyst and trimethylsilyl azide as the source of the nucleophilic azide ion to afford compounds 9-11.

The $\mathrm{S}_{\mathrm{N}} 1$ type substitution resulted in only 1,2-trans products due to the neighbouring group participation of the $O$-acyl group at position 2. For D-glucose and D-galactose the $\beta$-anomer, for Dmannose the $\alpha$-anomer formed in this way in $72-79 \%$ yield. The purity of the azide products and their quantities were sufficient for the subsequent conjugation reactions.

In order to introduce the azide group to positions 6 (hexopyranoses) and 5 (pentofuranose), first the methyl glycosides of D-glucose, D-mannose and D-ribose (12-14, Scheme 3) were selectively tosylated in pyridine on their primary hydroxy groups without the protection of the secondary hydroxy groups. This distinction was allowed by the higher reactivity of the primary hydroxy groups over the secondary ones.

Unfortunately, the direct replacement of the tosyl group with azide in compounds 15-17 was not successful probably due to solubility reasons, therefore the secondary hydroxy groups were benzoylated first, then the tosyl-azide exchange has successfully occurred in all the fully protected monosaccharides 18-20 and resulted in the fully protected 6-azido-6-deoxy- and 5-azido-5deoxymonosaccharides (21-23).

The azide group-containing monosaccharides (9-11 and 21-23) were coupled to the alkyne-containing D-secoalcohol (4a) and Dsecooxime (4b) using similar CuAAC conditions that we used previously (Scheme 4) applying copper(I) iodide, triphenylphosphine and DIPEA as a base with a slight access of propargyl-D-secosteroid in toluene at boiling temperature until TLC showed quantitative conversions. $^{24}$

In case of two glucose-containing bioconjugates (24a and 24b), which showed the best biological activities, the acetyl protecting groups were removed by the Zemplén's method ${ }^{25}$ using sodium methylate in methanol to obtain their unprotected derivatives 30a and 30b.

The antiproliferative properties of the D-secoestrone-carbohydrate conjugates (24-30) were characterized in vitro on a panel of human adherent cancer cell lines (HeLa, A2780 and MCF-7) by means of MTT assays (Table 1).

The antiproliferative properties of some of the presented compounds proved to comparable to that of reference agent cisplatin that is utilized clinically in the treatment of certain gynaecological malignancies. ${ }^{26,27}$ The most potent compounds (24b, 25b and 26b) exhibited remarkable activities with $\mathrm{IC}_{50}$ values in the range 5.3$20.5 \mu \mathrm{M}$, exerting their best effects against A2780 cells. Among 


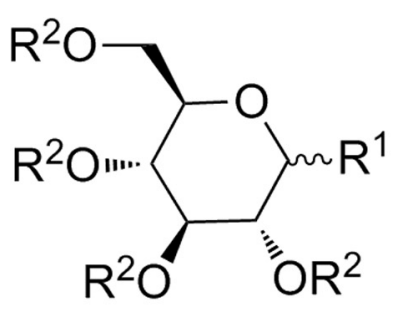

D-glucose

6 $9 \beta$

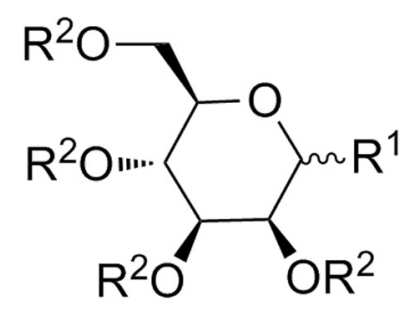

D-mannose

7
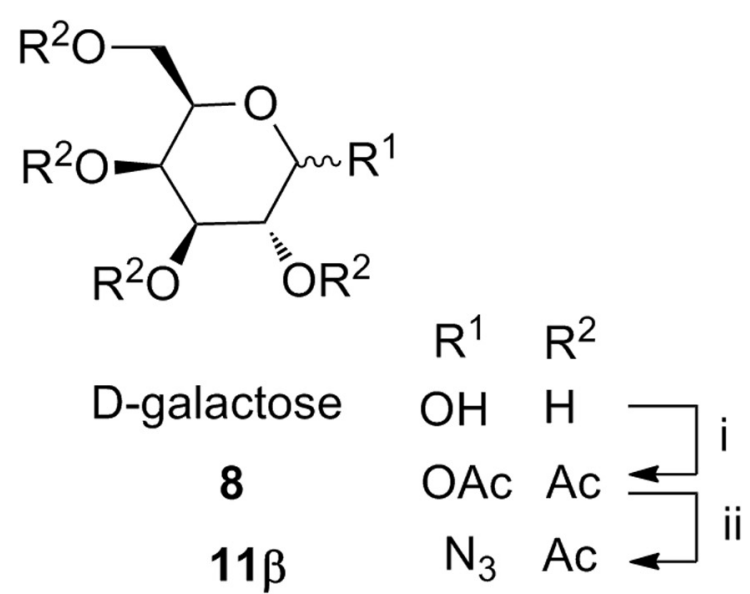

Scheme 2. Synthesis of protected glycosyl azides 9-11. Reagents: (i) $\mathrm{Ac}_{2} \mathrm{O}, \mathrm{NaOAc}$; (ii) $\mathrm{SnCl}_{4}, \mathrm{Me}_{3} \mathrm{SiN}_{3}, \mathrm{CH}_{2} \mathrm{Cl}_{2}$.

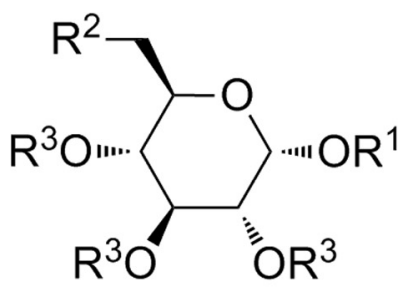

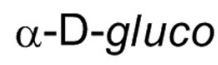

12<smiles>[R]C[C@H]1O[C@H]([R9])[C@@H](O[R10])[C@H]([2H])[C@H]1[R9]</smiles><smiles>O=C[Co]</smiles>

17

20 23

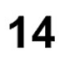<smiles>[R]C[C@H]1O[C@H]([R9])[C@@H]([R9])[C@H]1[R20]</smiles><smiles>[18OH][Pb]</smiles>

$\mathrm{R}^{1} \mathrm{R}^{2} \quad \mathrm{R}^{3}$

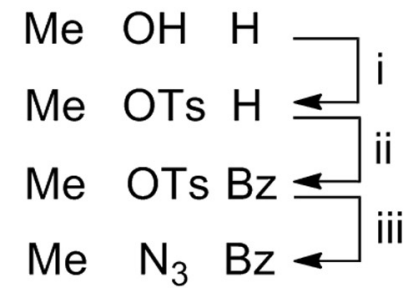

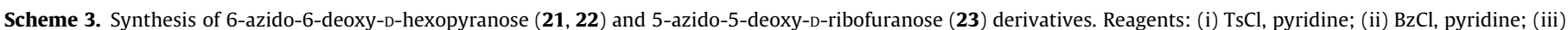
$\mathrm{NaN}_{3}, \mathrm{LiBr}, \mathrm{DMF}$.

the potent compounds the glucoside conjugate (24b) displayed the highest, the mannoside derivative (25b) the lowest cell-line selectivity. Considering the results of Table 1 , important structureactivity relationships appear. The antiproliferative activities of the compounds greatly depend on the attachment site of the monosaccharide unit, and on the nature of the functional group at $\mathrm{C}-13$, but do not really depend on the type of monosaccharide attached. It can be stated that the glycoside derivatives (24-26) are more potent than their methyl glycoside analogues (27-29) which were attached to the triazole ring at the $6^{\prime}$ - or $5^{\prime}$-positions of the carbohydrate units. The removal of the protecting groups from the most potent $\mathbf{2 4 b}$ compound results in a compound (30b) with decreased antiproliferative properties showing the importance of the nonpolar property of the moiety attached to the triazole ring for the bioactivity. Comparison of the results for acetylated conjugates formed from the D-secooxime and the Dsecoalcohol reveals that the presence of the oxime function generally improves the growth-inhibitory properties of the conjugates. Extending the discussion on our recent results, ${ }^{9}$ it seems that both the polarity and the size of the fragment at C-3 position greatly influence the antiproliferative properties. The presence of the less polar, but bulky benzyl function is advantageous over the phenolic hydroxy group, and further enhancement in the activity is achieved by incorporation of a triazole ring between the 3-hydroxy and the benzyl group. An additional determining factor is the nature (type, attachment position and polarity) of the substituent on the triazole ring. The benzyl to monosaccharide exchange decreases the cell growth-inhibition. Even the most potent hexose conjugates (24b, 25b and 26b) displayed one order of magnitude higher $\mathrm{IC}_{50}$ values than certain recently described 3-O-[(1-benzyl-1H-1,2,3-triazol-4-yl)methyl] derivatives (5a and $\mathbf{5 b}$ ). Cancer selectivity is a critical parameter determining the fate of a potential drug candidate. A viability assay on mouse fibroblasts cannot substitute the toxicological evaluation. However, it seems advantageous that our most potent compounds (24b, 25b and 26b) exert substantially less growth inhibiting action on fibroblasts than on cancerous cell lines. ${ }^{9}$

\section{Conclusions}

Fourteen monosaccharide-D-secoestrone bioconjugates were prepared by $\mathrm{CuAAC}$ reaction and their antiproliferative properties were investigated. Although the antiproliferative activities of the bioconjugates were not as high as the activities of the parent compounds, the structure-activity relationships provided by the 


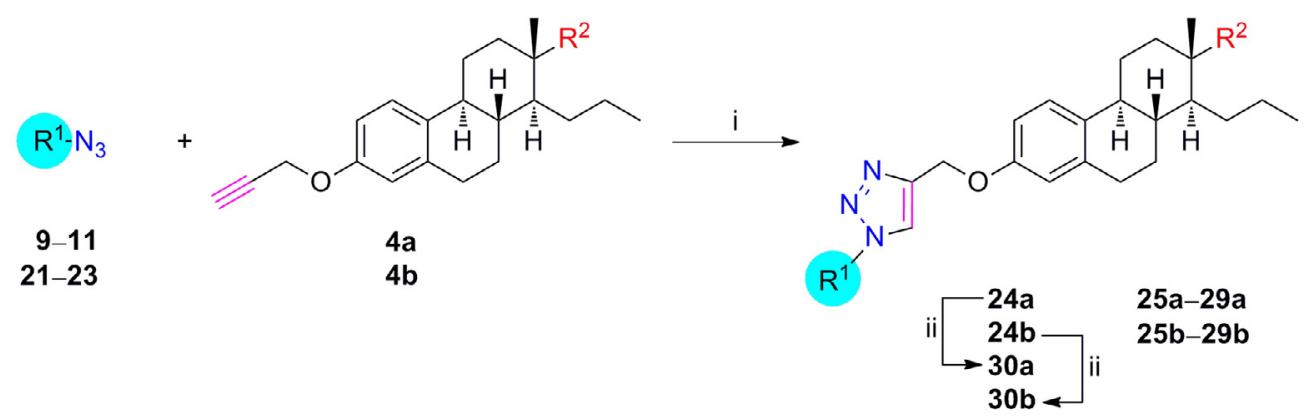

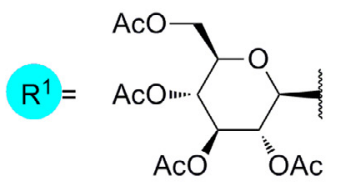<smiles></smiles>

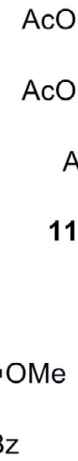

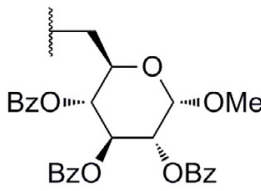

$21,27 a, 27 b$<smiles></smiles>

$11 \beta, 26 a, 26 b$
$22,28 a, 28 b$

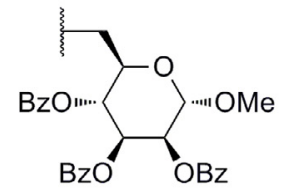<smiles>COC(=O)O[C@H]1[C@@H](OC(=O)c2ccccc2)[C@H](CC(C)C)O[C@H]1OC</smiles>

$23,29 a, 29 b$<smiles>OCC1OC(CI)[C@H](O)[C@H](O)[C@H]1O</smiles>

$30 a, 30 b$

Scheme 4. The synthesis of monosaccharide-D-secoestrone bioconjugates 24-30. Reagents: (i) $\mathrm{Cu}(\mathrm{I}),(\mathrm{Ph})_{3} \mathrm{P}, \mathrm{DIPEA}$, toluene, reflux; (ii) NaOMe, MeOH.

Table 1

Anticancer activity of monosaccharide-D-secoestrone conjugates 24-30 against different cell lines.

\begin{tabular}{|c|c|c|c|c|c|c|c|}
\hline \multirow[t]{2}{*}{$\begin{array}{l}\text { Compd. No. or } \\
\text { name }^{\mathrm{a}}\end{array}$} & \multirow[t]{2}{*}{$\begin{array}{l}\text { Monosaccharide } \\
\text { configuration }\end{array}$} & \multirow[t]{2}{*}{$\begin{array}{l}\text { Attachment site in } \\
\text { monosaccharide }\end{array}$} & \multirow[t]{2}{*}{ Concn. $(\mu \mathrm{M})$} & \multicolumn{4}{|c|}{ 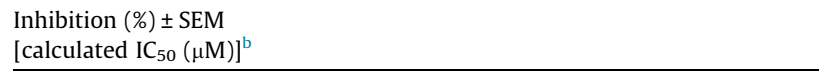 } \\
\hline & & & & HeLa & A 2780 & MCF-7 & $\mathrm{NIH} / 3 \mathrm{~T} 3$ (mouse fibroblast) \\
\hline \multirow[t]{2}{*}{$24 a$} & $\beta$-D-Glcp & $1^{\prime}$ & 10 & $34.5 \pm 0.7$ & $21.0 \pm 1.6$ & $27.4 \pm 2.8$ & \\
\hline & & & 30 & $23.9 \pm 0.9$ & $19.5 \pm 1.4$ & $45.5 \pm 1.5$ & \\
\hline \multirow[t]{3}{*}{$24 b$} & $\beta$-D-Glcp & $1^{\prime}$ & 10 & $20.4 \pm 1.8$ & $69.5 \pm 0.9$ & $46.7 \pm 1.3$ & $<20$ \\
\hline & & & 30 & $40.0 \pm 2.2$ & $76.7 \pm 0.8$ & $67.7 \pm 1.6$ & $28.4 \pm 0.9$ \\
\hline & & & {$\left[\mathrm{IC}_{50}\right]$} & {$[>30]$} & {$[5.3]$} & {$[10.7]$} & \\
\hline \multirow[t]{2}{*}{ 25a } & $\alpha$-D-Manp & $1^{\prime}$ & 10 & $51.9 \pm 1.0$ & $34.9 \pm 2.3$ & $26.3 \pm 2.2$ & \\
\hline & & & 30 & $41.5 \pm 1.7$ & $36.5 \pm 1.4$ & $54.3 \pm 0.6$ & \\
\hline \multirow[t]{3}{*}{ 25b } & $\alpha$-D-Manp & $1^{\prime}$ & 10 & $52.4 \pm 1.7$ & $69.5 \pm 0.6$ & $53.9 \pm 0.9$ & $27.3 \pm 0.5$ \\
\hline & & & 30 & $89.6 \pm 0.5$ & $86.4 \pm 0.8$ & $65.9 \pm 1.2$ & $34.8 \pm 0.3$ \\
\hline & & & {$\left[\mathrm{IC}_{50}\right]$} & [8.9] & {$[6.6]$} & {$[9.4]$} & \\
\hline \multirow[t]{2}{*}{$26 a$} & $\beta$-D-Galp & $1^{\prime}$ & 10 & $23.9 \pm 1.1$ & $<20$ & $<20$ & \\
\hline & & & 30 & $31.8 \pm 1.2$ & $32.7 \pm 1.0$ & $61.9 \pm 0.9$ & \\
\hline \multirow[t]{2}{*}{ 26b } & $\beta-\mathrm{D}-\mathrm{Gal} p$ & $1^{\prime}$ & 10 & $31.5 \pm 2.0$ & $59.3 \pm 0.9$ & $59.1 \pm 2.2$ & $<20$ \\
\hline & & & 30 & $61.9 \pm 2.0$ & $85.2 \pm 0.4$ & $71.5 \pm 1.5$ & $25.5 . \pm 1.4$ \\
\hline \multirow{2}{*}{$27 a$} & $\alpha-\mathrm{D}-\mathrm{Glc} p$ & $6^{\prime}$ & $\begin{array}{l}{\left[\mathrm{IC}_{50}\right]} \\
10\end{array}$ & $\begin{array}{l}{[20.5]} \\
<20\end{array}$ & $\begin{array}{l}{[8.8]} \\
<20\end{array}$ & $\begin{array}{l}{[8.0]} \\
<20\end{array}$ & \\
\hline & & & 30 & $<20$ & $<20$ & $<20$ & \\
\hline \multirow[t]{2}{*}{$27 b$} & $\alpha$-D-Glcp & $6^{\prime}$ & 10 & $<20$ & $28.4 \pm 0.8$ & $<20$ & \\
\hline & & & 30 & $<20$ & $45.7 \pm 2.1$ & $<20$ & \\
\hline \multirow[t]{2}{*}{$28 a$} & $\alpha$-D-Manp & $6^{\prime}$ & 10 & $<20$ & $<20$ & $<20$ & \\
\hline & & & 30 & $<20$ & $<20$ & $<20$ & \\
\hline \multirow[t]{2}{*}{$28 b$} & $\alpha$-D-Manp & $6^{\prime}$ & 10 & $<20$ & $<20$ & $<20$ & \\
\hline & & & 30 & $<20$ & $<20$ & $<20$ & \\
\hline \multirow[t]{2}{*}{$29 a$} & $\beta$-D-Ribf & $5^{\prime}$ & 10 & $<20$ & $<20$ & $<20$ & \\
\hline & & & 30 & $<20$ & $<20$ & $<20$ & \\
\hline \multirow[t]{2}{*}{$29 b$} & $\beta$-D-Rib $f$ & $5^{\prime}$ & 10 & $24.3 \pm 2.6$ & $<20$ & $<20$ & \\
\hline & & & 30 & $<20$ & $<20$ & $<20$ & \\
\hline \multirow[t]{2}{*}{ 30a } & $\beta$-D-Glcp & $1^{\prime}$ & 10 & $<20$ & $<20$ & $<20$ & \\
\hline & & & 30 & $<20$ & $<20$ & $<20$ & \\
\hline \multirow[t]{3}{*}{ 30b } & $\beta-\mathrm{D}-\mathrm{Glc} p$ & $1^{\prime}$ & 10 & $<20$ & $<20$ & $<20$ & \\
\hline & & & 30 & $31.5 \pm 0.4$ & $57.9 \pm 0.6$ & $<20$ & \\
\hline & & & {$\left[\mathrm{IC}_{50}\right]$} & {$[>30]$} & {$[27.4]$} & {$[>30]$} & \\
\hline \multirow[t]{3}{*}{ Cisplatin } & - & - & 10 & $42.6 \pm 2.3$ & $83.6 \pm 1.2$ & $66.9 \pm 1.8$ & $94.2 \pm 0.4$ \\
\hline & & & 30 & $99.9 \pm 0.3$ & $95.0 \pm 0.3$ & $96.8 \pm 0.4$ & $96.4 \pm 0.2$ \\
\hline & & & {$\left[\mathrm{IC}_{50}\right]$} & {$[12.4]$} & {$[1.3]$} & {$[5.8]$} & [3.2] \\
\hline
\end{tabular}

a For structures see Scheme 4 . The compound series a contain hydroxymethyl, series b oxime moieties at C-13 position of the steroid skeleton.

b Mean value from two independent determinations with five parallel wells; standard deviation $<15 \%$. 
results deliver very important information for the design of antiproliferative estrone derivatives in the future.

\section{Acknowledgments}

The authors thank the Hungarian Scientific Research Fund Hungary (OTKA K113150 and K109293), the New Hungary Development Plan (TÁMOP-4.2.2.A-11/1/KONV-2012-0047) for financial support. This research was also supported by the European Union and the State of Hungary, co-financed by the European Social Fund - Belgium and Hungary (TÁMOP-4.2.4.A/2-11/1-2012-0001 'National Excellence Program').

\section{A. Supplementary data}

Supplementary data associated with this article can be found, in the online version, at http://dx.doi.org/10.1016/j.bmcl.2017. 03.029.

\section{References}

1. Gupta A, Kumar BS, Negi AS. Current status on development of steroids as anticancer agents. J Steroid Biochem Mol Biol. 2013;137:242.

2. Cushman M, He H-M, Katzenellenbogen JA, et al. Synthesis of analogs of 2methoxyestradiol with enhanced inhibitory effects on tubulin polymerization and cancer cell growth. J Med Chem. 1997;40:2323.

3. Möller G, Deluca D, Gege C, et al. Structure-based design, synthesis and in vitro characterization of potent 17beta-hydroxysteroid dehydrogenase type 1 inhibitors based on 2-substitutions of estrone and D-homo-estrone. Bioorg Med Chem Lett. 2009;19:6740.

4. Hillisch A, Peters O, Gege C, Siemeister G, Unger E, Menzenbach B. Antitumoral D-homoestra-1,3,5(10)-trien-3-yl 2-substituted sulfamates; 2007. US Patent $7,244,762$.

5. Ayan D, Roy J, Maltais R, Poirier D. Impact of estradiol structural modifications (18-methyl and/or 17-hydroxy inversion of configuration) on the in vitro and in vivo estrogenic activity. J Steroid Biochem Mol Biol. 2011;127:324.

6. Schönecker B, Lange C, Kötteritzsch M, et al. Conformational design for 13alpha-steroids. J Org Chem. 2000;65:5487.

7. Jovanović-Santa S, Petrović J, Andrić S, et al. Synthesis, structure, and screening of estrogenic and antiestrogenic activity of new 3, 17-substituted-16, 17-secoestratriene derivatives. Bioorg Chem. 2003;31:475.

8. Mernyák E, Szabó J, Bacsa I, et al. Syntheses and antiproliferative effects of Dhomo- and D-secoestrones. Steroids. 2014;87:128.
9. Mernyák E, Fiser G, Szabó J, et al. Synthesis and in vitro antiproliferative evaluation of D-secooxime derivatives of $13 \beta$ - and $13 \alpha$-estrone. Steroids. 2014;89:47.

10. Szabó J, Jerkovics N, Schneider G, et al. Synthesis and in vitro antiproliferative evaluation of C-13 epimers of triazolyl-D-secoestrone alcohols: the first potent 13 $\alpha$-D-secoestrone derivative. Molecules. 2016;21:611.

11. Mernyák E, Kovács I, Minorics R, et al. Synthesis of trans-16-triazolyl-13alphamethyl-17-estradiol diastereomers and the effects of structural modifications on their in vitro antiproliferative activities. I Steroid Biochem Mol Biol. 2015; $150: 123$

12. Szabó J, Pataki Z, Wölfling J, et al. Synthesis and biological evaluation of 13alpha-estrone derivatives as potential antiproliferative agents. Steroids. 2016;113:14.

13. Szabó J, Bacsa I, Wölfling J, et al. Synthesis and in vitro pharmacological evaluation of $\mathrm{N}-[(1$-benzyl-1,2,3-triazol-4-yl)methyl]-carboxamides on Dsecoestrone scaffolds. I Enzyme Inhib Med Chem. 2016:31:574.

14. Tietze LF, Bell HP, Chandrasekhar S. Natural product hybrids as new leads for drug discovery. Angew Chem Int Ed. 2003;42:3996.

15. Pellissier H. The glycosylation of steroids. Tetrahedron. 2004:60:5123.

16. Ding X, Zhu F, Yang Y, Li M. Purification, antitumor activity in vitro of steroidal glycoalkaloids from black nightshade (Solanum nigrum L.). Food Chem 2013;141:1181.

17. Langenhan JM, Peters NR, Guzei IA, Hoffmann FM, Thorson JS. Enhancing the anticancer properties of cardiac glycosides by neoglycorandomization. Proc Natl Acad Sci USA. 2005;102:12305.

18. Györgydeák Z, Szilágyi L, Paulsen H. Synthesis, structure and reactions of glycosyl azides. J Carbohydr Chem. 1993;12:139.

19. Hayashi M, Kawabata H. Preparation of 1-azide sugars. In: Anonymous, ed Recent Developments in Carbohydrate Research, Vol. 1. Research Signpost; 2003:195-208.

20. Györgydeák Z, Thiem J. Synthesis and transformation of glycosyl azides. In: Anonymous, ed. Advances in Carbohydrate Chemistry and Biochemistry, Vol. 60. Elsevier; 2006:103-182.

21. Beckmann HSG, Wittmann V. Azides in carbohydrate chemistry. In: Brase S, Banert K, eds. Organic Azides: Syntheses and Applications. Chichester: John Wiley and Sons; 2010:469-490.

22. Sicherl F, Wittmann V. Orthogonally protected sugar diamino acids as building blocks for linear and branched oligosaccharide mimetics. Angew Chem Int Ed. 2005;44:2096.

23. Dutta D, Pulsipher A, Yousaf MN. Selective tethering of ligands and proteins to microfluidically patterned electroactive fluid lipid bilayer array. Langmuir. 2010;26:9835.

24. Bodnár B, Mernyák E, Wölfling J, et al. Synthesis and biological evaluation of triazolyl 13a-estrone-nucleoside bioconjugates. Molecules. 2016;21:1212.

25. Anon. Zemplén Deacetylation. In: Wang Z, ed. Comprehensive Organic Name Reactions and Reagents. Wiley Online Library; 2010:3123-3128.

26. Lippert B, ed. Cisplatin. Chemistry and biochemistry of a leading anticancer drug. Zürich, Weinheim: Verlag Helvetica Chimica Acta, Wiley-VCH; 1999.

27. Ferenc G, Pádár P, Szolomájer J, Howarth NM, Kovács L. Transition metal ion complexes of $N$-alkylguanines. Curr Org Chem. 2011;15:2871. 


\title{
Supporting information
}

\section{Synthesis and in vitro investigation of potential antiproliferative monosaccharide-D-secoestrone bioconjugates}

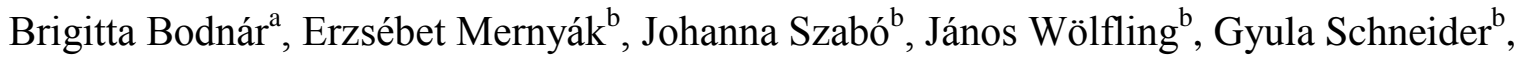 \\ István Zupkóc $^{c}$ Zoltán Kupihár ${ }^{\mathrm{a}^{*}}$, Lajos Kovács ${ }^{\mathrm{a}^{*}}$
}

$\begin{array}{ll}\text { General conditions of syntheses } & \text { S3 }\end{array}$

$\begin{array}{ll}\text { Synthesis of compounds } & \text { S3 }\end{array}$

2,3,4,5-Tetra-O-acetyl- $\beta$-D-glucopyranosyl azide $(\mathbf{9} \beta) \quad$ S4

2,3,4,5-Tetra-O-acetyl- $\alpha$-D-mannopyranosyl azide $(\mathbf{1 0 \alpha}) \quad$ S4

2,3,4,5-Tetra-O-acetyl- $\beta$-D-galactopyranosyl azide $(\mathbf{1 1} \beta) \quad$ S4

General procedure for preparation of 6-azido-6-deoxymonosaccharides $(\mathbf{2 1}, \mathbf{2 2}) \quad$ S5

Methyl 6-azido-6-deoxy-2,3,4-tri-O-benzoyl- $\alpha$-D-glucopyranoside (21) S6

Methyl 6-azido-6-deoxy-2,3,4-tri-O-benzoyl- $\alpha$-D-mannopyranoside (22) S6

Methyl 5-azido-5-deoxy-2,3-di-O-benzoyl- $\beta$-D-ribofuranoside (23) $\quad S 7$

General procedure for click reactions (synthesis of bioconjugates 24a-29a and $24 \boldsymbol{b}-\quad$ S8

$29 b)$

3-(1-(2,3,4,6-Tetra-O-acetyl- $\beta$-D-glucopyranosyl)-1H-1,2,3-triazol-4-yl-methyloxy)- $\quad$ S8

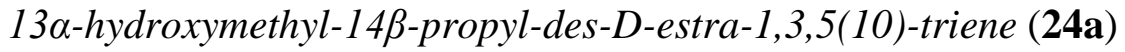

3-(1-(2,3,4,6-tetra-O-acetyl- $\beta$-D-glucopyranosyl)-1H-1,2,3-triazol-4-yl-methyloxy)- $\quad$ S9

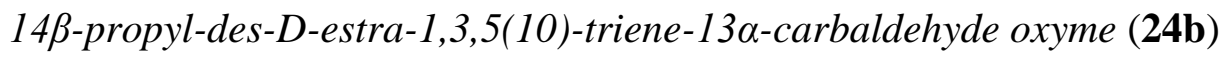

3-(1-(2,3,4,6-Tetra-O-acetyl- $\alpha$-D-mannopyranosyl)-1H-1,2,3-triazol-4-yl-methyloxy)- $\quad$ S9

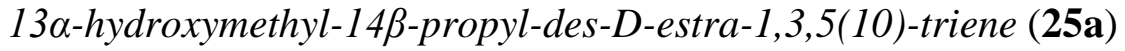

3-(1-(2,3,4,6-tetra-O-acetyl- $\alpha$-D-mannopyranosyl)-1H-1,2,3-triazol-4-yl-methyloxy)- $\quad$ S10

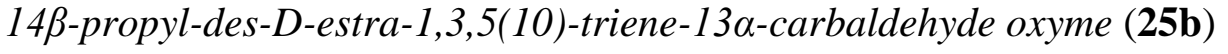

3-(1-(2,3,4,6-Tetra-O-acetyl- $\beta$-D-galactopyranosyl)-1H-1,2,3-triazol-4-yl-methyloxy)- $\quad \mathrm{S} 10$

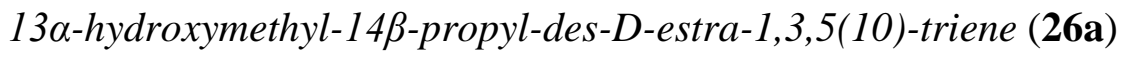


3-(1-(2,3,4,6-Tetra-O-acetyl- $\beta$-D-galactopyranosyl)-1H-1,2,3-triazol-4-yl-methyloxy)-

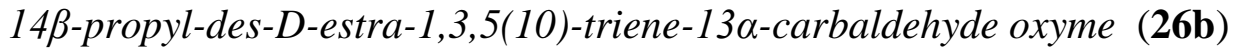

3-(1-(Methyl-6-deoxy-2,3,4-tri-O-benzoyl- $\alpha$-D-glucopyranosid-6-yl)-1H-1,2,3-triazol-

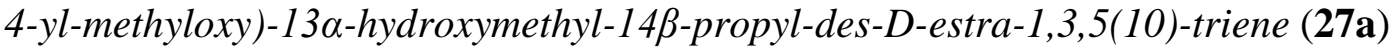

3-(1-(Methyl-6-deoxy-2,3,4-tri-O-benzoyl- $\alpha$-D-glucopyranosid-6-yl)-1H-1,2,3-triazol-

4-yl-methyloxy)-14 $\beta$-propyl-des-D-estra-1,3,5(10)-triene-13 $\alpha$-carbaldehyde oxyme

(27b)

3-(1-(Methyl-6-deoxy-2,3,4-tri-O-benzoyl- $\alpha$-D-mannopyranosid-6-yl)-1H-1,2,3-triazol-

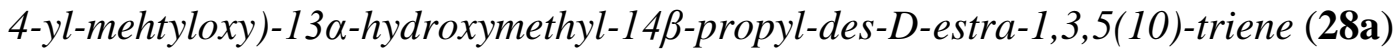

3-(1-(Methyl-6-deoxy-2,3,4-tri-O-benzoyl- $\alpha$-D-mannopyranosid-6-yl)-1H-1,2,3-triazol-

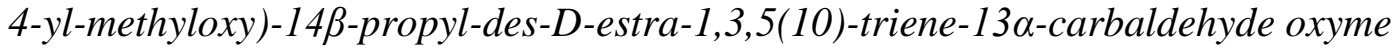

(28b)

3-(1-(Methyl-5-deoxy-2,3-di-O-benzoyl- $\beta$-D-ribofuranosid-5-yl)-1H-1,2,3-triazol-4-yl-

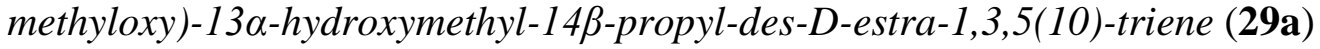

3-(1-(Methyl-5-deoxy-2,3-di-O-benzoyl- $\beta$-D-ribofuranosid-5-yl)-1H-1,2,3-triazol-4-yl-

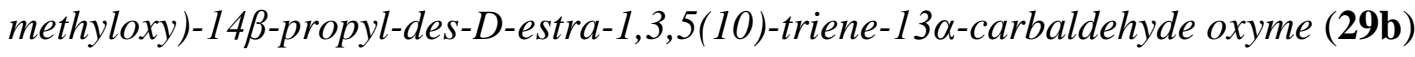

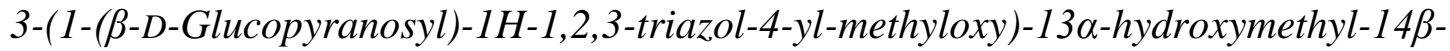
propyl-des-D-estra-1,3,5(10)-triene (30a)

3-(1-( $\beta$-D-Glucopyranosyl)-1H-1,2,3-triazol-4-yl-methyloxy)-14 $\beta$-propyl-des-D-estra-

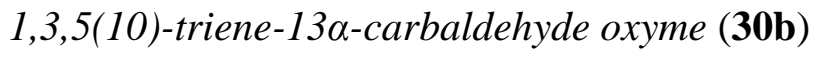

Cell cultures and antiproliferative assays

S16

References

S17 


\section{General conditions of syntheses}

Melting points (mp) were determined on a Kofler block and are uncorrected. The reactions were monitored by TLC on Kieselgel-G (Merck Si $254 \mathrm{~F}$ ) layers (0.25 mm thick); solvent systems (ss): (A) hexane/EtOAc (7:3 v/v), (B) $\mathrm{CH}_{2} \mathrm{Cl}_{2} / \mathrm{EtOAc}(9: 1 \mathrm{v} / \mathrm{v}),(\mathrm{C}) \mathrm{CH}_{2} \mathrm{Cl}_{2} / \mathrm{MeOH}$ (9:1 v/v).

The conjugates were detected by spraying with $5 \%$ phosphomolybdic acid in $50 \%$ aqueous phosphoric acid. For the identification of azides the TLC was placed in a $10 \%$ solution of triphenylphosphine in $\mathrm{CH}_{2} \mathrm{Cl}_{2}$ for 2 minutes, dried and then sprayed with ninhydrine solution (0.5\% ninhydrine and $5 \mathrm{mM} \mathrm{NaOH}$ in ethanol/water $3: 1 \mathrm{v} / \mathrm{v})$.

The $R_{\mathrm{f}}$ values were determined for the spots observed by illumination at $254 \mathrm{~nm}$. Flash chromatography: Merck silica gel 60, 40-63 $\mu \mathrm{m}$. All solvents were distilled prior to use. Reagents and materials were obtained from commercial suppliers and were used without purification. Elementary analysis data were determined with a Perkin Elmer CHN analyzer model 2400. NMR spectra were obtained at room temperature with a Bruker DRX 500 instrument. Chemical shifts are reported in ppm ( $\delta$ scale), and coupling constants $(J)$ in Hz. For the determination of multiplicities, the $J$-MOD pulse sequence was used.

Mass spectra were recorded on a Finnigan MAT TSQ 7000 instrument equipped with an electrospray ion source, using the following parameters: positive ionization mode, nebulizing gas $\mathrm{N}_{2}$ (3.45 bar), capillary temperature: $200{ }^{\circ} \mathrm{C}$, capillary voltage: $4500 \mathrm{~V}$. The samples were dissolved in acetonitrile and injected directly. In case of measuring the monosaccharides the eluent was an isocratic acetonitrile-water mixture 1:1 (v/v) and the samples were dissolved in acetonitrile and mixed with a $10 \mathrm{mM}$ aqueous $\mathrm{NH}_{4} \mathrm{HCO}_{3}$ solution in a 10:1 ratio to increase the sensitivity of the analyses (due to the high affinity of $\mathrm{NH}_{4}{ }^{+}$to carbohydrates). In these cases the base peaks corresponded always to the $\mathrm{NH}_{4}{ }^{+}$adduct ions and the $[\mathrm{M}+\mathrm{H}]^{+}$signals had a relatively low intensities. For the carbohydrate-steroid conjugates an isocratic acetonitrile-water mixture containing $0.1 \%$ trifluoroacetic acid was used. The samples were dissolved only in acetonitrile without any additional adduct-forming agent (due to their existing basic triazole moieties). In these cases the base peaks were always the $[\mathrm{M}+\mathrm{H}]^{+}$signals with the less abundant $[2 \mathrm{M}+\mathrm{H}]^{+}$ signals. 
Penta- $O$-acetylated monosaccharides of D-glucose, D-mannose and D-galactose (compounds 6-8) were prepared according to the literature method. ${ }^{1}$

$1.00 \mathrm{~g}$ (2.56 mmol) of penta- $O$-acetylated monosaccharide $(\mathbf{6}, 7$ or 8$)$ was dissolved in anhydrous $\mathrm{CH}_{2} \mathrm{Cl}_{2}(5 \mathrm{~mL})$, trimethylsilyl azide $(1 \mathrm{~mL}, 7.5 \mathrm{mmol})$ and $2.56 \mathrm{~mL}$ solution of $\mathrm{SnCl}_{4}(2.56$ mmol, $1 \mathrm{M}$ in $\mathrm{CH}_{2} \mathrm{Cl}_{2}$ ) was added. The reaction mixture was stirred for $4 \mathrm{~h}$ at $50{ }^{\circ} \mathrm{C}$ then saturated aqueous solution of $\mathrm{NaHCO}_{3}$ was added until the $\mathrm{pH}$ reached 8 . The emulsion was filtered through a Celite pad three times. The filtrate was extracted with $\mathrm{CH}_{2} \mathrm{Cl}_{2}(2 \times 100 \mathrm{~mL})$, the combined organic layers were dried over $\mathrm{MgSO}_{4}$ and evaporated in vacuo. The resulting crude product was purified by column chromatography, with hexane/EtOAc (6:4) as eluent to give compounds 9-11.

\section{2,3,4,5-Tetra-O-acetyl- $\beta$-D-glucopyranosyl azide $(\mathbf{9} \beta)$}

After purification, $9 \beta$ was obtained as an oil $(680 \mathrm{mg}, 73 \%), R_{\mathrm{f}}=0.36(\mathrm{ss} \mathrm{A}) ;{ }^{1} \mathrm{H}-\mathrm{NMR}\left(\mathrm{CDCl}_{3}\right)$; $\delta[\mathrm{ppm}] 2.02,2.04,2.09$ and 2.11: $(4 \times \mathrm{s}, 4 \times 3 \mathrm{H}, 4 \times \mathrm{OAc}), 3.80(\mathrm{ddd}, 1 \mathrm{H}, J=10.2 \mathrm{~Hz}, J=5.0$ $\mathrm{Hz}, J=2.4 \mathrm{~Hz}, 5-\mathrm{H}), 4.18(\mathrm{dd}, 1 \mathrm{H}, J=12.8 \mathrm{~Hz}, J=2.4 \mathrm{~Hz}, 6 \mathrm{a}-\mathrm{H}), 4.28(\mathrm{dd}, 1 \mathrm{H}, J=12.8 \mathrm{~Hz}, J=$ $4.9 \mathrm{~Hz}, 6 \mathrm{~b}-\mathrm{H}), 4.66(\mathrm{dd}, 1 \mathrm{H}, J=9.1 \mathrm{~Hz}, J=0.5 \mathrm{~Hz}, 1-\mathrm{H}), 4.96(\mathrm{dd}, 1 \mathrm{H}, J=9.2 \mathrm{~Hz}, J=9.2 \mathrm{~Hz}$, 2-H), $5.11(\mathrm{dd}, 1 \mathrm{H}, J=10.2 \mathrm{~Hz}, J=9.7 \mathrm{~Hz}, 4-\mathrm{H}), 5.23(\mathrm{ddd}, 1 \mathrm{H}, J=9.8 \mathrm{~Hz}, J=9.2 \mathrm{~Hz}, J=0.5$ $\mathrm{Hz}, 3-\mathrm{H}) ;{ }^{13} \mathrm{C}-\mathrm{NMR}$ data were consistent with those reported in the literature. ${ }^{2}$ ESI-MS: 374 $[\mathrm{M}+\mathrm{H}]^{+}, 391\left[\mathrm{M}+\mathrm{NH}_{4}\right]^{+}$; Anal. Calcd for $\mathrm{C}_{14} \mathrm{H}_{19} \mathrm{~N}_{3} \mathrm{O}_{9}: \mathrm{C}, 45.04 ; \mathrm{H}, 5.13 ; \mathrm{N}, 11.26$. Found: C, 44.92; H, 5.28; N, 11.41.

\section{2,3,4,5-Tetra-O-acetyl- $\alpha$-D-mannopyranosyl azide $(\mathbf{1 0 \alpha})$}

After purification, $\mathbf{1 0} \alpha$ was obtained as an oil $(736 \mathrm{mg}, 79 \%), R_{\mathrm{f}}=0.36$ (ss A); ${ }^{1} \mathrm{H}-\mathrm{NMR}$ $\left(\mathrm{CDCl}_{3}\right) ; \delta[\mathrm{ppm}] 2.00,2.06,2.12$ and 2.17: $(4 \times \mathrm{s}, 4 \times 3 \mathrm{H}, 4 \times \mathrm{OAc}), 4.16(\mathrm{dd}, 2 \mathrm{H}, J=11.8 \mathrm{~Hz}$, $\left.J=10.8 \mathrm{~Hz}, 6-\mathrm{H}_{2}\right), 4.31(\mathrm{dd}, 1 \mathrm{H}, J=12.5 \mathrm{~Hz}, J=5.8 \mathrm{~Hz}, 5-\mathrm{H}), 5.16(\mathrm{dd}, 1 \mathrm{H}, J=0.5 \mathrm{~Hz}, 1-\mathrm{H})$, 5.23-5.32 (overlapping m, 2H, 2-H and 4-H), 5.39 (dd, $1 \mathrm{H}, J=0.5 \mathrm{~Hz}, 3-\mathrm{H}) ;{ }^{13} \mathrm{C}-\mathrm{NMR}$ data were consistent with those reported in the literature. ${ }^{3}$ ESI-MS: $374[\mathrm{M}+\mathrm{H}]^{+}, 391\left[\mathrm{M}+\mathrm{NH}_{4}\right]^{+}$; Anal. Calcd for $\mathrm{C}_{14} \mathrm{H}_{19} \mathrm{~N}_{3} \mathrm{O}_{9}$ : C, 45.04; H, 5.13; N, 11.26. Found: C, 44.88; H, 5.22; N, 11.32.

2,3,4,5-Tetra-O-acetyl- $\beta$-D-galactopyranosyl azide $(\mathbf{1 1} \beta)$ 
After purification, $\mathbf{1 1} \beta$ was obtained as an oil $(671 \mathrm{mg}, 72 \%), R_{\mathrm{f}}=0.36$ (ss A); ${ }^{1} \mathrm{H}-\mathrm{NMR}$ $\left(\mathrm{CDCl}_{3}\right) ; \delta[\mathrm{ppm}] 2.00,2.07,2.10$ and 2.18: $(4 \times \mathrm{s}, 4 \times 3 \mathrm{H}, 4 \times \mathrm{OAc}), 4.02(\mathrm{dd}, 1 \mathrm{H} . J=6.5 \mathrm{~Hz}$, 5-H), 4.13-4.22 (overlapping m, 2H, 6- $\mathrm{H}_{2}$ ), 4.60 (dd, 1H, $J=9.0 \mathrm{~Hz}, J=0.5 \mathrm{~Hz}, 1-\mathrm{H}$ ), 5.04 (dd, $1 \mathrm{H}, J=10.4 \mathrm{~Hz}, J=3.7 \mathrm{~Hz}, 2-\mathrm{H}), 5.17(\mathrm{dd}, 1 \mathrm{H}, J=10.0 \mathrm{~Hz}, J=9.0 \mathrm{~Hz}, 4-\mathrm{H}), 5.43(\mathrm{~d}, 1 \mathrm{H}, J=$ 3.7 Hz, 3-H); ${ }^{13} \mathrm{C}-\mathrm{NMR}$ data were consistent with those reported in the literature. ${ }^{3} \mathrm{ESI}-\mathrm{MS}: 374$ $[\mathrm{M}+\mathrm{H}]^{+}, 391\left[\mathrm{M}+\mathrm{NH}_{4}\right]^{+}, 396[\mathrm{M}+\mathrm{Na}]^{+}$; Anal. Calcd for $\mathrm{C}_{14} \mathrm{H}_{19} \mathrm{~N}_{3} \mathrm{O}_{9}: \mathrm{C}, 45.04 ; \mathrm{H}, 5.13 ; \mathrm{N}$, 11.26. Found: C, 45.12; H, 5.08; N, 11.17.

Methyl glycosides 12, 13 and 14 were purchased as pure $\alpha$-, $\alpha$ - and $\beta$-anomers, respectively.

General procedure for preparation of 6-azido-6-deoxymonosaccharides $(\mathbf{2 1}, \mathbf{2 2})$

Methyl glycoside 12 or 13 (5 mmol, $0.97 \mathrm{~g}$ ) was dissolved in pyridine (20 mL) and $p$-toluenesulfonyl chloride (0.95 $\mathrm{g}, 5 \mathrm{mmol}, 1$ equiv) was added. The reaction mixture was stirred overnight, at room temperature, then evaporated in vacuo, redissolved in $\mathrm{CH}_{2} \mathrm{Cl}_{2}(100 \mathrm{~mL})$ and extracted with water $(2 \times 100 \mathrm{~mL})$. The combined organic layers were dried over $\mathrm{Na}_{2} \mathrm{SO}_{4}$ and evaporated in vacuo. The resulting crude product was purified by column chromatography, with $\mathrm{CH}_{2} \mathrm{Cl}_{2}$ /methanol (9:1) as eluent to give compounds $\mathbf{1 5}$ or $\mathbf{1 6}$.

Methyl 6- $O$-(p-toluenesulfonyl) glycoside 15 or 16 (1.00 g, $2.9 \mathrm{mmol})$ was dissolved in pyridine $(20 \mathrm{~mL})$ and benzoyl chloride $(1.16 \mathrm{~mL}, 10 \mathrm{mmol})$ was added. The reaction was complete in $1 \mathrm{~h}$ at room temperature. The reaction mixture was evaporated in vacuo, redissolved in $\mathrm{CH}_{2} \mathrm{Cl}_{2}(100$ $\mathrm{mL})$ and extracted with $5 \%$ aqueous $\mathrm{KHSO}_{4}$ solution $(2 \times 100 \mathrm{~mL})$. The combined organic layers were dried over $\mathrm{Na}_{2} \mathrm{SO}_{4}$ and evaporated in vасио. The resulting crude product was purified by column chromatography with hexane/EtOAc (5:5) as eluent to give compound 18 or 19.

Methyl 6- $O$-( $p$-toluenesulfonyl)-2,3,4-tri- $O$-benzoyl glycoside 18 or 19 (1.00 g, $1.5 \mathrm{mmol}$ ) was dissolved in dry DMF $(5 \mathrm{~mL})$ then sodium azide $(0.49 \mathrm{~g}, 7.5 \mathrm{mmol})$ and lithium bromide $(0.65 \mathrm{~g}$, $7.5 \mathrm{mmol}$ ) were added. The reaction mixture was stirred at $120^{\circ} \mathrm{C}$ for $6 \mathrm{~h}$. The reaction mixture was evaporated in vacuo, redissolved in $\mathrm{CH}_{2} \mathrm{Cl}_{2}$ and extracted with $1 \%$ aqueous $\mathrm{KHSO}_{4}$ solution $(2 \times 100 \mathrm{~mL})$. The combined organic layers were dried over $\mathrm{Na}_{2} \mathrm{SO}_{4}$ and evaporated in vacuo. 
The resulting crude product was purified by column chromatography, with hexane/EtOAc $(8: 2)$ as eluent to give compound $\mathbf{2 1}$ or $\mathbf{2 2}$.

Methyl 6-azido-6-deoxy-2,3,4-tri-O-benzoyl- $\alpha$-D-glucopyranoside (21).

After purification, compound 21 was obtained as an oil (289 mg, 68\%), $R_{\mathrm{f}}=0.67$ (ss A); ${ }^{1} \mathrm{H}-$ $\operatorname{NMR}\left(\mathrm{CDCl}_{3}\right) ; \delta[\mathrm{ppm}] 3.42(\mathrm{dd}, 1 \mathrm{H}, J=13.5 \mathrm{~Hz}, J=3.0 \mathrm{~Hz}, 6 \mathrm{a}-\mathrm{H}), 3.49-3.55$ (overlapping m, $4 \mathrm{H}, 6 \mathrm{~b}-\mathrm{H}$ and $\left.\mathrm{OCH}_{3}\right), 4.25(\mathrm{ddd}, 1 \mathrm{H}, J=10.1 \mathrm{~Hz}, J=7.0 \mathrm{~Hz}, J=3.1 \mathrm{~Hz}, 5-\mathrm{H}), 5.25-5.32$ (overlapping m, 2H, 1-H and 2-H), $5.51(\mathrm{dd}, 1 \mathrm{H}, J=9.8 \mathrm{~Hz}, 3-\mathrm{H}), 6.12-6.19(\mathrm{~m}, 1 \mathrm{H}, 4-\mathrm{H})$, benzoyl protons: $7.30(\mathrm{~m}, 2 \mathrm{H}), 7.41(\mathrm{~m}, 5 \mathrm{H}), 7.53(\mathrm{~m}, 2 \mathrm{H}), 7.87(\mathrm{~m}, 2 \mathrm{H}), 7.96(\mathrm{~m}, 2 \mathrm{H}), 7.99(\mathrm{~m}$, $2 \mathrm{H}) ;{ }^{13} \mathrm{C}-\mathrm{NMR}\left(\mathrm{CDCl}_{3}\right) ; \delta[\mathrm{ppm}] 51.2(\mathrm{C}-6), 55.8\left(\mathrm{OCH}_{3}\right), 69.1(\mathrm{C}-2), 70.1(\mathrm{C}-3), 70.2(\mathrm{C}-4)$, 71.9 (C-5), 97.0 (C-1), 128.3 (2C), 128.4 (2C), 128.5 (2C), 129.6 (2C), 129.8 (2C), 129.9 (2C), 133.1, 133.4, 133.6: benzoyl CHs, 128.6, 128.9, 129.1: benzoyl Cq, 165.8, 166.5 and 167.0: (3 $\times$ s, $3 \times 1 \mathrm{C}, \mathrm{Bz}-\mathrm{CO})$; ESI-MS: $532[\mathrm{M}+\mathrm{H}]^{+}, 549\left[\mathrm{M}+\mathrm{NH}_{4}\right]^{+}$; Anal. Calcd for $\mathrm{C}_{28} \mathrm{H}_{25} \mathrm{~N}_{3} \mathrm{O}_{8}: \mathrm{C}$, 63.27; H, 4.74; N, 7.91. Found: C, 63.42; H, 4.58; N, 8.05.

\section{Methyl 6-azido-6-deoxy-2,3,4-tri-O-benzoyl- $\alpha$-D-mannopyranoside (22)}

After purification, compound 22 was obtained as an oil $(301 \mathrm{mg}, 71 \%), R_{\mathrm{f}}=0.67$ (ss A); ${ }^{1} \mathrm{H}-$ $\operatorname{NMR}\left(\mathrm{CDCl}_{3}\right) ; \delta[\mathrm{ppm}] 3.46(\mathrm{ddd}, 1 \mathrm{H}, J=13.0 \mathrm{~Hz}, J=3.0 \mathrm{~Hz}, J=1.0 \mathrm{~Hz}, 6 \mathrm{a}-\mathrm{H}), 3.51-3.59$ (overlapping m, 4H, 6b-H and $\mathrm{OCH}_{3}$ ), 4.26 (ddd, $1 \mathrm{H}, J=11.0 \mathrm{~Hz}, J=7.0 \mathrm{~Hz}, J=1.0 \mathrm{~Hz}, 5-\mathrm{H}$ ), $5.01(\mathrm{dd}, 1 \mathrm{H}, J=2.5 \mathrm{~Hz}, 1-\mathrm{H}), 5.69(\mathrm{dd}, 1 \mathrm{H}, J=3.5 \mathrm{~Hz}, J=2.5 \mathrm{~Hz}, 2-\mathrm{H}), 5.83-5.92$ (overlapping m, 2H, 3-H and 4-H), benzoyl protons: $7.25(\mathrm{~m}, 1 \mathrm{H}), 7.29(\mathrm{~m}, 1 \mathrm{H}), 7.41(\mathrm{~m}, 3 \mathrm{H})$, $7.52(\mathrm{~m}, 3 \mathrm{H}), 7.63(\mathrm{~m}, 1 \mathrm{H}), 7.83(\mathrm{~m}, 2 \mathrm{H}), 7.96(\mathrm{~m}, 2 \mathrm{H}), 8.12(\mathrm{~m}, 2 \mathrm{H}) ;{ }^{13} \mathrm{C}-\mathrm{NMR}\left(\mathrm{CDCl}_{3}\right) ; \delta$ [ppm] $51.9(\mathrm{C}-6), 56.3\left(\mathrm{OCH}_{3}\right), 68.4$ (C-2), 70.3 (C-3), 70.9 (C-4), 71.0 (C-5), 99.2 (C-1), 128.2 (2C), 128.4 (2C), 128.5 (2C), 129.6 (2C), 129.7 (2C), 129.8 (2C), 133.1, 133.5 (2C): benzoyl CHs, 128.9, 129.1, 129.2: benzoyl Cq, 166.2, 167.3 and 167.7: (3 × s, $3 \times 1 \mathrm{C}$, Bz-CO); ESI-MS: $532[\mathrm{M}+\mathrm{H}]^{+}, 549\left[\mathrm{M}+\mathrm{NH}_{4}\right]^{+}$; Anal. Calcd for $\mathrm{C}_{28} \mathrm{H}_{25} \mathrm{~N}_{3} \mathrm{O}_{8}: \mathrm{C}, 45.04 ; \mathrm{H}, 5.13 ; \mathrm{N}, 11.26$. Found: C, 63.38; H, 4.63; N, 7.85. 
Preparation of 5-azido-5-deoxymonosaccharide (23)

Methyl $\beta$-D-ribofuranoside (14) (1.00 g, $6.1 \mathrm{mmol})$ was dissolved in pyridine $(20 \mathrm{~mL})$ and $p$ toluenesulfonyl chloride $(1.20 \mathrm{~g}, 6.1 \mathrm{mmol})$ was added. The reaction mixture was stirred overnight at room temperature, then evaporated in vacuo, redissolved in $\mathrm{CH}_{2} \mathrm{Cl}_{2}(100 \mathrm{~mL})$, and extracted with water $(2 \times 100 \mathrm{~mL})$. The combined organic layers were dried over $\mathrm{Na}_{2} \mathrm{SO}_{4}$ and evaporated in vacuo. The resulting crude product was purified by column chromatography, with $\mathrm{CH}_{2} \mathrm{Cl}_{2} /$ methanol (9:1) as eluent to give compound 17.

Methyl 5-O-toluenesulfonyl- $\beta$-D-ribofuranoside (17) $(1.00 \mathrm{~g}, 3.1 \mathrm{mmol})$ was dissolved in pyridine $(20 \mathrm{~mL})$ and benzoyl chloride $(1.08 \mathrm{~mL}, 9.3 \mathrm{mmol})$ was added. The reaction was completed in $1 \mathrm{~h}$ at room temperature. The reaction mixture was evaporated in vacuo, redissolved in EtOAc $(100 \mathrm{~mL})$ and extracted with 5\% aqueous $\mathrm{KHSO}_{4}$ solution $(2 \times 100 \mathrm{~mL})$. The combined organic layers were dried over $\mathrm{Na}_{2} \mathrm{SO}_{4}$ and evaporated in vacuo. The resulting crude product was purified by column chromatography with hexane/EtOAc (5:5) as eluent to give compound $\mathbf{2 0}$.

Methyl 5-O-toluenesulfonyl-2,3-di- $O$-benzoyl- $\beta$-D-ribofuranoside (20) $(1.00 \mathrm{~g}, 1.9 \mathrm{mmol})$ was dissolved in dry DMF $(5 \mathrm{~mL})$ then sodium azide $(0.62 \mathrm{~g}, 9.5 \mathrm{mmol})$ and lithium bromide $(0.83 \mathrm{~g}$, $9.5 \mathrm{mmol}$ ) were added. The reaction mixture was stirred at $120^{\circ} \mathrm{C}$ for 6 hours, then the reaction mixture was evaporated in vacuo, redissolved in $\mathrm{CH}_{2} \mathrm{Cl}_{2}(100 \mathrm{~mL})$ and extracted with $1 \%$ aqueous $\mathrm{KHSO}_{4}$ solution $(2 \times 100 \mathrm{~mL})$. The combined organic layers were dried over $\mathrm{Na}_{2} \mathrm{SO}_{4}$ and evaporated in vacuo. The resulting crude product was purified by column chromatography with hexane/EtOAc (8:2) as eluent to give compound 23.

\section{Methyl 5-azido-5-deoxy-2,3-di-O-benzoyl- $\beta$-D-ribofuranoside $\mathbf{2 3}$}

After purification, 23 was obtained as an oil (195 mg, 65\%), $R_{\mathrm{f}}=0.71$ (ss A); ${ }^{1} \mathrm{H}-\mathrm{NMR}\left(\mathrm{CDCl}_{3}\right)$; $\delta[\mathrm{ppm}] 3.52-3.58$ (overlapping $\mathrm{m}, 4 \mathrm{H}, \mathrm{OCH}_{3}$ and $5 \mathrm{a}-\mathrm{H}$ ), $3.66(\mathrm{dd}, 1 \mathrm{H}, J=13.0 \mathrm{~Hz}, J=4.0 \mathrm{~Hz}$, $5 \mathrm{~b}-\mathrm{H}), 4.53$ (ddd, 1H, $J=6.3 \mathrm{~Hz}, J=4.0 \mathrm{~Hz}, 4-\mathrm{H}), 5.17$ (d, 1H, $J=1.0 \mathrm{~Hz}, 1-\mathrm{H}), 5.64$ (overlapping $\mathrm{m}, 2 \mathrm{H}, 3-\mathrm{H}$ and 4-H), benzoyl protons: $7.34(\mathrm{~m}, 2 \mathrm{H}), 7.44(\mathrm{~m}, 2 \mathrm{H}), 7.52(\mathrm{~m}, 1 \mathrm{H})$, $7.59(\mathrm{~m}, 1 \mathrm{H}), 7.88(\mathrm{~m}, 2 \mathrm{H}), 8.03(\mathrm{~m}, 2 \mathrm{H}) ;{ }^{1} \mathrm{H}-\mathrm{NMR}$ data were consistent with those reported in 
the literature. ${ }^{4}{ }^{13} \mathrm{C}-\mathrm{NMR}\left(\mathrm{CDCl}_{3}\right) ; \delta[\mathrm{ppm}] 54.1(\mathrm{C}-5), 55.9\left(\mathrm{OCH}_{3}\right), 73.0(\mathrm{C}-2), 75.6(\mathrm{C}-3), 80.7$ (C-4), 106.9 (C-1), 128.2 (2C), 128.3 (2C), 129.5 (2C), 129.6 (2C), 133.2, 133.3: benzoyl CHs, 128.7, 129.0: benzoyl Cq, 165.4 and 165.5: $\left(2 \times\right.$ s, 2C, Bz-CO); ESI-MS: $398[\mathrm{M}+\mathrm{H}]^{+}, 415$ $\left[\mathrm{M}+\mathrm{NH}_{4}\right]^{+}$; Anal. Calcd for $\mathrm{C}_{20} \mathrm{H}_{19} \mathrm{~N}_{3} \mathrm{O}_{6}: \mathrm{C}, 60.45 ; \mathrm{H}, 4.82 ; \mathrm{N}, 10.57$. Found: $\mathrm{C}, 60.54 ; \mathrm{H}, 4.98$; $\mathrm{N}, 10.36$.

General procedure for click reactions (synthesis of bioconjugates $24 a-29 a$ and $24 b-29 b$ )

$50 \mathrm{mg}(0.094-0.134 \mathrm{mmol}$ ) of an azido saccharide (compound 9-11 or 21-23) was dissolved in toluene $(10 \mathrm{~mL})$, then triphenylphosphine $(6.8 \mathrm{mg}, 0.026 \mathrm{mmol}), \mathrm{CuI}(2.5 \mathrm{mg}, 0.013 \mathrm{mmol})$, DIPEA (70 $\mu \mathrm{L}, 0.4 \mathrm{mmol})$ and the terminal alkyne-containing steroid (4a and $\mathbf{4 b}, 1.1$ equiv) were added to the reaction mixture, and it was boiled for $6 \mathrm{~h}$. Then the mixture was evaporated in vacuo and the resulting crude product was purified by column chromatography, with EtOAc/ $\mathrm{CH}_{2} \mathrm{Cl}_{2}$ (5:5) as eluent to furnish derivatives $24 \mathbf{a}-29 \mathbf{a}$ and $\mathbf{2 4 b}-\mathbf{2 9 b}$, respectively.

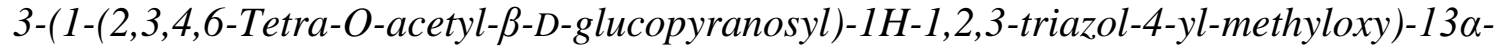
hydroxymethyl-14ß-propyl-des-D-estra-1,3,5(10)-triene (24a)

After purification, 24a was obtained as a white solid (76 mg, 81\%), $\mathrm{mp} 158-160{ }^{\circ} \mathrm{C}, R_{\mathrm{f}}=0.33$ (ss B); ${ }^{1} \mathrm{H}-\mathrm{NMR}\left(\mathrm{CDCl}_{3}\right) ; \delta[\mathrm{ppm}] 0.77\left(\mathrm{~s}, 3 \mathrm{H}, 18-\mathrm{H}_{3}\right), 0.91\left(\mathrm{t}, 3 \mathrm{H}, J=6.3 \mathrm{~Hz}, 16 \mathrm{a}-\mathrm{H}_{3}\right), 1.85,2.03$, 2.07 and $2.08\left(4 \times \mathrm{s}, 4 \times 3 \mathrm{H}, 4 \times \mathrm{Ac}^{-\mathrm{CH}_{3}}\right), 2.85\left(\mathrm{~m}, 2 \mathrm{H}, 6-\mathrm{H}_{2}\right), 3.34$ and $3.51(2 \times \mathrm{d}, 2 \times 1 \mathrm{H}, J=$ $\left.2 \times 10.8 \mathrm{~Hz}, 17-\mathrm{H}_{2}\right), 3.99\left(\mathrm{~m}, 1 \mathrm{H}, 5^{\prime}-\mathrm{H}\right), 4.15$ and $4.29\left(2 \times \mathrm{m}, 2 \times 1 \mathrm{H}, 6^{\prime}-\mathrm{H}_{2}\right), 5.17-5.25$ (overlapping m, 3H), 5.39-5.47 (overlapping m, 2H), 5,88 (d, 1H, J= 8.9 Hz): 1'-, 2'-, 3'-, 4'-H, $\mathrm{OCH}_{2} ; 6.70(\mathrm{~d}, 1 \mathrm{H}, J=2.2 \mathrm{~Hz}, 4-\mathrm{H}), 6.78(\mathrm{dd}, 1 \mathrm{H}, J=8.6 \mathrm{~Hz}, J=2.2 \mathrm{~Hz}, 2-\mathrm{H}), 7.22(\mathrm{~d}, 1 \mathrm{H}, J=$ $8.6 \mathrm{~Hz}, 1-\mathrm{H}), 7.84$ (s, 1H, HC=C); ${ }^{13} \mathrm{C}-\mathrm{NMR}\left(\mathrm{CDCl}_{3}\right) ; \delta[\mathrm{ppm}] 14.6$ (C-16a), $16.0(\mathrm{C}-18), 20.1$, 20.5 (2C) and 20.7 (4 × $\left.\mathrm{Ac}-\mathrm{CH}_{3}\right), 25.0,26.4,27.4,30.6,31.2,35.6,41.7,42.3,43.5,45.2,61.5$ and $61.9\left(\mathrm{OCH}_{2}\right.$ and $\mathrm{C}-6$ '), 67.7, 70.2, 71.3 (C-17), 72.7, 75.1, 85.7 (C-1'), 112.3 (C-2), 114.4 (C-4), 120.9 (Hㄷ=), 126.6 (C-1), 133.6 (C-10), 138.2 (C-5), 145.4 (HC=ㅡ), 152.0 (C-3), 168.8, 169.3, 169.9 and $170.8\left(4 \times\right.$ Ac-CO); ESI-MS: $700[\mathrm{M}+\mathrm{H}]^{+}, 1399[2 \mathrm{M}+\mathrm{H}]^{+}$; Anal. Calcd for $\mathrm{C}_{36} \mathrm{H}_{49} \mathrm{~N}_{3} \mathrm{O}_{11}: \mathrm{C}, 61.79 ; \mathrm{H}, 7.06 ; \mathrm{N}, 6.00$. Found: C, 61.87; H, 6.92; N, 6.15 . 
3-(1-(2,3,4,6-tetra-O-acetyl- $\beta$-D-glucopyranosyl)-1H-1,2,3-triazol-4-yl-methyloxy)-14 $\beta$-propyldes-D-estra-1,3,5(10)-triene-13 $\alpha$-carbaldehyde oxyme (24b)

After purification, 24b was obtained as a white solid (78 mg, 82\%), $\mathrm{mp} 146-148{ }^{\circ} \mathrm{C}, R_{\mathrm{f}}=0.35$ (ss B); ${ }^{1} \mathrm{H}-\mathrm{NMR}\left(\mathrm{CDCl}_{3}\right) ; \delta[\mathrm{ppm}] 0.87\left(\mathrm{t}, 3 \mathrm{H}, J=6.3 \mathrm{~Hz}, 16 \mathrm{a}-\mathrm{H}_{3}\right), 1.08\left(\mathrm{~s}, 3 \mathrm{H}, 18-\mathrm{H}_{3}\right), 1.85,2.02$, 2.06 and $2.07\left(4 \times \mathrm{s}, 4 \times 3 \mathrm{H}, 4 \times \mathrm{Ac}^{\left.-\mathrm{CH}_{3}\right)}, 2.85\left(\mathrm{~m}, 2 \mathrm{H}, 6-\mathrm{H}_{2}\right), 4.09-4.15\right.$ (overlapping m, $2 \mathrm{H}$ ), 4.28-4.31 (m, 1H), $5.23(\mathrm{~m}, 1 \mathrm{H})$, 5.39-5.45 (overlapping $\mathrm{m}, 2 \mathrm{H}), 5.89$ (m, 1H): 1'-, 2'-, 3'-, 4'-, 5'-H, 6'- $\mathrm{H}_{2}, 5.17$ (s, 2H, OCH $\left.{ }_{2}\right), 6.70(\mathrm{~d}, 1 \mathrm{H}, J=2.2 \mathrm{~Hz}, 4-\mathrm{H}), 6.79$ (dd, $1 \mathrm{H}, J=8.6 \mathrm{~Hz}, J=2.2$ $\mathrm{Hz}, 2-\mathrm{H}), 7.19$ (d, 1H, J = 8.6 Hz, 1-H), $7.32(\mathrm{~s}, 1 \mathrm{H}, 17-\mathrm{H}), 7.85$ (s, 1H, HC=C); ${ }^{13} \mathrm{C}-\mathrm{NMR}$ $\left(\mathrm{CDCl}_{3}\right) ; \delta[\mathrm{ppm}] 14.1$ (C-16a), $15.0(\mathrm{C}-18), 19.7,20.0,20.1$ and $20.3\left(4 \times \mathrm{Ac}^{-\mathrm{CH}_{3}}\right), 23.9,25.5$, 26.8, 30.0, 31.8, 36.9, 40.4, 41.1, 42.9, 47.5, 61.1 and $61.5\left(\mathrm{OCH}_{2}\right.$ and $\mathrm{C}-6$ ' $), 67.3,69.9,72.3$, 74.7, 85.4 (C-1'), 112.1 (C-2), 114.1 (C-4), 120.6 (Hㅌ= $)$ ), 126.2 (C-1), 132.5 (C-10), 137.6 (C5), $144.9(\mathrm{HC}=\underline{\mathrm{C}}), 155.7$ (C-3), 160.6 (C-17), 168.5, 168.9, 169.5 and 170.1 (4 × Ac-CO); ESIMS: $713[\mathrm{M}+\mathrm{H}]^{+}, 1425[2 \mathrm{M}+\mathrm{H}]^{+}$; Anal. Calcd for $\mathrm{C}_{36} \mathrm{H}_{48} \mathrm{~N}_{4} \mathrm{O}_{11}: \mathrm{C}, 60.66 ; \mathrm{H}, 6.79 ; \mathrm{N}, 7.86$. Found: C, 60.53; H, 6.85; N, 7.74 .

3-(1-(2,3,4,6-Tetra-O-acetyl- $\alpha$-D-mannopyranosyl)-1H-1,2,3-triazol-4-yl-methyloxy)-13 $\alpha$ hydroxymethyl-14ß-propyl-des-D-estra-1,3,5(10)-triene (25a)

After purification, 25a was obtained as a white solid (73 mg, 78\%), mp $65-67{ }^{\circ} \mathrm{C}, R_{\mathrm{f}}=0.37$ (ss B); ${ }^{1} \mathrm{H}-\mathrm{NMR}\left(\mathrm{CDCl}_{3}\right) ; \delta[\mathrm{ppm}] 0.76\left(\mathrm{~s}, 3 \mathrm{H}, 18-\mathrm{H}_{3}\right), 0.85\left(\mathrm{t}, 3 \mathrm{H}, \mathrm{J}=6.3 \mathrm{~Hz}, 16 \mathrm{a}-\mathrm{H}_{3}\right), 2.05,2.06$, 2.07 and $2.18\left(4 \times \mathrm{s}, 4 \times 3 \mathrm{H}, 4 \times \mathrm{Ac}^{-\mathrm{CH}_{3}}\right), 2.85\left(\mathrm{~m}, 2 \mathrm{H}, 6-\mathrm{H}_{2}\right), 3.34$ and $3.52(2 \times \mathrm{d}, 2 \times 1 \mathrm{H}, \mathrm{J}=$ $\left.2 \times 10.8 \mathrm{~Hz}, 17-\mathrm{H}_{2}\right), 4.03-4.06$ (overlapping m, 2H, 6'- $\left.\mathrm{H}_{2}\right), 4.36(\mathrm{dd}, 1 \mathrm{H}, \mathrm{J}=12.5 \mathrm{~Hz}, \mathrm{~J}=5.4$ $\mathrm{Hz}, 5$ '-H), 5.22 (s, 2H, $\mathrm{OCH}_{2}$ ), 5.37 (m, 1H), 5.91-5.99 (overlapping m, 3H): 1'-, 2'-, 3'-, 4'-H, $6.71(\mathrm{~d}, 1 \mathrm{H}, \mathrm{J}=2.2 \mathrm{~Hz}, 4-\mathrm{H}), 6.78(\mathrm{dd}, 1 \mathrm{H}, \mathrm{J}=8.6 \mathrm{~Hz}, \mathrm{~J}=2.2 \mathrm{~Hz}, 2-\mathrm{H}), 7.22(\mathrm{~d}, 1 \mathrm{H}, \mathrm{J}=8.6 \mathrm{~Hz}$, 1-H), 7.79 (s, 1H, HC=C); ${ }^{13} \mathrm{C}-\mathrm{NMR}\left(\mathrm{CDCl}_{3}\right) ; \delta$ [ppm] 14.3 (C-16a), 15.6 (C-18), 20.1, 20.2 (2C) and $20.3\left(4 \times \mathrm{Ac}^{-} \mathrm{CH}_{3}\right), 24.6,26.0,27.0,30.3,30.8,35.2,38.3,41.3,43.1,44.9,61.1$ and $64.1\left(\mathrm{OCH}_{2}\right.$ and C-6'), 65.7, 67.9, 68.3, 70.9 (C-17), 71.8, 83.2 (C-1'), 111.9 (C-2), 113.9 (C-4), 122.5 (HC=C), 126.3 (C-1), 133.3 (C-10), 137.8 (C-5), 145.0 (HC= - ), 155.5 (C-3), 168.8, 169.2, 170.0 and $173.3\left(4 \times\right.$ Ac-CO); ESI-MS: $700[\mathrm{M}+\mathrm{H}]^{+}, 1399[2 \mathrm{M}+\mathrm{H}]^{+}$; Anal. Calcd for $\mathrm{C}_{36} \mathrm{H}_{49} \mathrm{~N}_{3} \mathrm{O}_{11}: \mathrm{C}, 61.79 ; \mathrm{H}, 7.06 ; \mathrm{N}, 6.00$. Found: C, 61.63; H, 6.94; N, 6.25. 
3-(1-(2,3,4,6-tetra-O-acetyl- $\alpha$-D-mannopyranosyl)-1H-1,2,3-triazol-4-yl-methyloxy)-14 $\beta$-propyldes-D-estra-1,3,5(10)-triene-13 $\alpha$-carbaldehyde oxyme (25b)

After purification, 25b was obtained as a white solid ( $79 \mathrm{mg}, 83 \%$ ), $\mathrm{mp} 105-107{ }^{\circ} \mathrm{C}, R_{\mathrm{f}}=0.35$ (ss B); ${ }^{1} \mathrm{H}-\mathrm{NMR}\left(\mathrm{CDCl}_{3}\right) ; \delta[\mathrm{ppm}] 0.87\left(\mathrm{t}, 3 \mathrm{H}, J=6.3 \mathrm{~Hz}, 16 \mathrm{a}-\mathrm{H}_{3}\right), 1.07$ (s, $\left.3 \mathrm{H}, 18-\mathrm{H}_{3}\right), 2.03,2.04$, 2.05 and $2.17\left(4 \times \mathrm{s}, 4 \times 3 \mathrm{H}, 4 \times \mathrm{Ac}_{-} \mathrm{CH}_{3}\right), 2.85\left(\mathrm{~m}, 2 \mathrm{H}, 6-\mathrm{H}_{2}\right), 4.05(\mathrm{~m}, 1 \mathrm{H}), 4.07-4.13$ (overlapping m, 2H), 4.35 (m, 1H), $5.36(1 \mathrm{H}): 1^{\prime}-, 2^{\prime}-, 3^{\prime}-, 4^{\prime}-, 5^{\prime}-\mathrm{H}, 5.22\left(\mathrm{~s}, 2 \mathrm{H}, \mathrm{OCH}_{2}\right), 6.70$ $(\mathrm{d}, 1 \mathrm{H}, J=2.2 \mathrm{~Hz}, 4-\mathrm{H}), 6.79$ (dd, $1 \mathrm{H}, J=8.6 \mathrm{~Hz}, J=2.2 \mathrm{~Hz}, 2-\mathrm{H}), 7.19$ (d, $1 \mathrm{H}, J=8.6 \mathrm{~Hz}, 1-$ $\mathrm{H}), 7.31(\mathrm{~s}, 1 \mathrm{H}, 17-\mathrm{H}), 7.80(\mathrm{~s}, 1 \mathrm{H}, \mathrm{HC}=\mathrm{C}) ;{ }^{13} \mathrm{C}-\mathrm{NMR}\left(\mathrm{CDCl}_{3}\right) ; \delta[\mathrm{ppm}] 14.5(\mathrm{C}-16 \mathrm{a}), 15.3(\mathrm{C}-$ 18), 20.5, 20.6 (2C) and 20.7 (4 $\left.\times \mathrm{Ac}^{-} \mathrm{CH}_{3}\right), 24.3,25.9,27.1,29.6,32.1,37.3,40.8,41.4,43.2$, 47.8, 61.5 and $61.8\left(\mathrm{OCH}_{2}\right.$ and $\left.\mathrm{C}-6{ }^{\prime}\right), 66.0,68.2,68.7,72.1,83.6\left(\mathrm{C}^{\prime}{ }^{\prime}\right), 112.4(\mathrm{C}-2), 114.3(\mathrm{C}-$

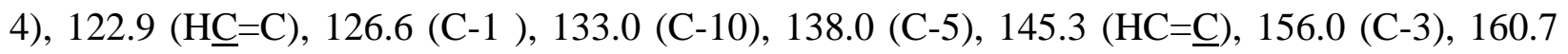
(C-17), 169.3, $169.6(2 \mathrm{C})$ and $170.4\left(4 \times\right.$ Ac-CO); ESI-MS: $713[\mathrm{M}+\mathrm{H}]^{+}, 1425[2 \mathrm{M}+\mathrm{H}]^{+}$; Anal. Calcd for $\mathrm{C}_{36} \mathrm{H}_{48} \mathrm{~N}_{4} \mathrm{O}_{11}$ : C, 60.66; H, 6.79; N, 7.86. Found: C, 60.72; H, 6.85; N, 8.02.

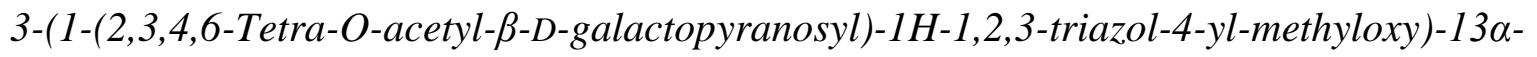
hydroxymethyl-14 $\beta$-propyl-des-D-estra-1,3,5(10)-triene (26a)

After purification, 26a was obtained as an oil (71 mg, 76\%), $R_{\mathrm{f}}=0.30$ (ss B); ${ }^{1} \mathrm{H}-\mathrm{NMR}\left(\mathrm{CDCl}_{3}\right)$; $\delta[\mathrm{ppm}] 0.77\left(\mathrm{~s}, 3 \mathrm{H}, 18-\mathrm{H}_{3}\right), 0.91\left(\mathrm{t}, 3 \mathrm{H}, J=6.3 \mathrm{~Hz}, 16 \mathrm{a}-\mathrm{H}_{3}\right), 1.87,2.00,2.05$ and $2.22(4 \times \mathrm{s}, 4$ $\left.\times 3 \mathrm{H}, 4 \times \mathrm{Ac}^{-\mathrm{CH}_{3}}\right), 2.85\left(\mathrm{~m}, 2 \mathrm{H}, 6-\mathrm{H}_{2}\right), 3.34$ and $3.52\left(2 \times \mathrm{d}, 2 \times 1 \mathrm{H}, J=2 \times 10.7 \mathrm{~Hz}, 17-\mathrm{H}_{2}\right)$, 4.13-4.22 (overlapping $\mathrm{m}, 3 \mathrm{H}$ ), 5.18-5.26 (overlapping $\mathrm{m}, 3 \mathrm{H}$ ), 5.54-5.59 (overlapping $\mathrm{m}, 2 \mathrm{H}$ ), 5.84 (m, 1H): 1'-, 2'-, 3'-, 4'-, 5'-H, 6'- $\mathrm{H}_{2}, \mathrm{OCH}_{2} ; 6.72$ (d, 1H, $\left.J=2.2 \mathrm{~Hz}, 4-\mathrm{H}\right), 6.79$ (dd, 1H, $J$ $=8.6 \mathrm{~Hz}, J=2.2 \mathrm{~Hz}, 2-\mathrm{H}), 7.23(\mathrm{~d}, 1 \mathrm{H}, J=8.6 \mathrm{~Hz}, 1-\mathrm{H}), 7.92(\mathrm{~s}, 1 \mathrm{H}, \mathrm{HC}=\mathrm{C}) ;{ }^{13} \mathrm{C}-\mathrm{NMR}$ $\left(\mathrm{CDCl}_{3}\right) ; \delta[\mathrm{ppm}] 14.7(\mathrm{C}-16 \mathrm{a}), 16.0(\mathrm{C}-18), 20.2,20.5(2 \mathrm{C})$ and $20.6\left(4 \times \mathrm{Ac}^{-\mathrm{CH}_{3}}\right), 25.0,26.4$, 27.4, 30.7, 31.2, 35.6, 38.7, 41.7, 43.5, 45.2, 61.2 and $62.0\left(\mathrm{OCH}_{2}\right.$ and $\left.\mathrm{C}-6{ }^{\prime}\right), 66.8,67.8,70.8$, 71.4 (C-17), 74.1, 86.3 (C-1'), 112.3 (C-2), 114.5 (C-4), 120.9 (Hㅌ=) $) 126.6$ (C-1), 133.5 (C10), $138.2(\mathrm{C}-5), 145.3$ (HC=ㄷ), $156.2(\mathrm{C}-3), 169.0,169.8,169.9$ and $170.4(4 \times \mathrm{Ac}-\mathrm{CO})$; ESIMS: $700[\mathrm{M}+\mathrm{H}]^{+}, 1399[2 \mathrm{M}+\mathrm{H}]^{+}$; Anal. Calcd for $\mathrm{C}_{36} \mathrm{H}_{49} \mathrm{~N}_{3} \mathrm{O}_{11}: \mathrm{C}, 61.79 ; \mathrm{H}, 7.06 ; \mathrm{N}, 6.00$. Found: C, 61.75; H, 7.18; N, 5.94 .

3-(1-(2,3,4,6-Tetra-O-acetyl- $\beta$-D-galactopyranosyl)-1H-1,2,3-triazol-4-yl-methyloxy)-14 $\beta$ propyl-des-D-estra-1,3,5(10)-triene-13 $\alpha$-carbaldehyde oxyme (26b) 
After purification, 26b was obtained as a white solid (76 mg, 80\%), mp 98-101 ${ }^{\circ} \mathrm{C}, R_{\mathrm{f}}=0.28$ (ss B); ${ }^{1} \mathrm{H}-\mathrm{NMR}\left(\mathrm{CDCl}_{3}\right) ; \delta[\mathrm{ppm}] 0.88\left(\mathrm{t}, 3 \mathrm{H}, J=6.3 \mathrm{~Hz}, 16 \mathrm{a}-\mathrm{H}_{3}\right), 1.06\left(\mathrm{~s}, 3 \mathrm{H}, 18-\mathrm{H}_{3}\right), 1.88,2.01$, 2.05 and $2.22\left(4 \times \mathrm{s}, 4 \times 3 \mathrm{H}, 4 \times \mathrm{Ac}^{-} \mathrm{CH}_{3}\right), 2.86\left(\mathrm{~m}, 2 \mathrm{H}, 6-\mathrm{H}_{2}\right), 4.15-4.22$ (overlapping m, 3H), 5.16-5.19 (overlapping m, 2H), 5.24 (m, 1H), 5.55 (m, 1H), 5.58 (m, 1H), 5,84 (m, 1H): 1'-, 2'-, 3'-, 4'-, 5'-H, 6'- $\mathrm{H}_{2}, \mathrm{OCH}_{2}, 6.72$ (d, 1H, J = 2.2 Hz, 4-H), 6.79 (dd, 1H, J = 8.6 Hz, J = 2.2 Hz, 2-H), $7.21(\mathrm{~d}, 1 \mathrm{H}, J=8.6 \mathrm{~Hz}, 1-\mathrm{H}), 7,30(\mathrm{~s}, 1 \mathrm{H}, 17-\mathrm{H}), 7,91(\mathrm{~s}, 1 \mathrm{H}, \mathrm{HC}=\mathrm{C}) ;{ }^{13} \mathrm{C}-\mathrm{NMR}\left(\mathrm{CDCl}_{3}\right)$;

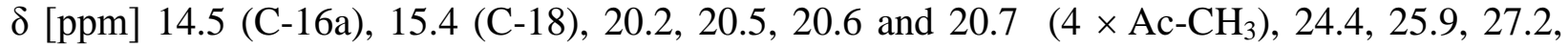
29.7, 30.4, 32.2, 37.4, 40.9, 43.3, 47.9, 61.2 and $62.0\left(\mathrm{OCH}_{2}\right.$ and $\mathrm{C}-6$ '), 66.8, 67.8, 70.8, 74.1, 86.3 (C-1'), 112.5 (C-2), 114.5 (C-4), 120.1 (HC=C), 126.6 (C-1 ), 133.0 (C-10), 138.0 (C-5), $144.6(\mathrm{HC}=\underline{\mathrm{C}}), 156.2(\mathrm{C}-3), 160.8(\mathrm{C}-17), 169.0$ and 169.9 (4C, $4 \times$ Ac-CO); ESI-MS: 713 $[\mathrm{M}+\mathrm{H}]^{+}, 1425[2 \mathrm{M}+\mathrm{H}]^{+}$; Anal. Calcd for $\mathrm{C}_{36} \mathrm{H}_{48} \mathrm{~N}_{4} \mathrm{O}_{11}: \mathrm{C}, 60.66 ; \mathrm{H}, 6.79 ; \mathrm{N}, 7.86$. Found: C, 60.78; H, 6.92; N, 7.93.

3-(1-(Methyl-6-deoxy-2,3,4-tri-O-benzoyl- $\alpha$-D-glucopyranosid-6-yl)-1H-1,2,3-triazol-4-yl-

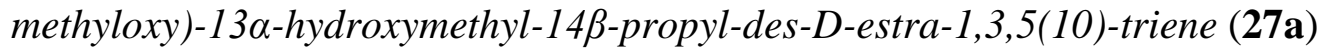

After purification, 27a was obtained as a white solid (63 mg, 78\%), mp 109-111 ${ }^{\circ} \mathrm{C}, R_{\mathrm{f}}=0.61$ (ss B); ${ }^{1} \mathrm{H}-\mathrm{NMR}\left(\mathrm{CDCl}_{3}\right) ; \delta[\mathrm{ppm}] 0.73\left(\mathrm{~s}, 3 \mathrm{H}, 18-\mathrm{H}_{3}\right), 0.88\left(\mathrm{t}, 3 \mathrm{H}, J=6.3 \mathrm{~Hz}, 16 \mathrm{a}-\mathrm{H}_{3}\right), 2.81(\mathrm{~m}$, $\left.2 \mathrm{H}, 6-\mathrm{H}_{2}\right), 3.01\left(\mathrm{~s}, 3 \mathrm{H}, 1^{\prime}-\mathrm{OCH}_{3}\right), 3.31$ and $3.48\left(2 \times \mathrm{d}, 2 \times 1 \mathrm{H}, J=2 \times 10.9 \mathrm{~Hz}, 17-\mathrm{H}_{2}\right), 4.10(\mathrm{~m}$, $1 \mathrm{H}), 4.40-4.48$ (overlapping $\mathrm{m}, 2 \mathrm{H}), 4.70(\mathrm{~m}, 1 \mathrm{H}), 5.13(\mathrm{~m}, 1 \mathrm{H}), 5.20(\mathrm{~m}, 1 \mathrm{H}), 5.27(\mathrm{~m}, 1 \mathrm{H})$, $5.40(\mathrm{t}, 1 \mathrm{H}, J=9.4 \mathrm{~Hz}), 6.13$ (t, 1H, J = 9.4 Hz): 1'-, 2'-, 3'-, 4'-, 5'-H, 6'- $\mathrm{H}_{2}, \mathrm{OCH}_{2}, 6.67$ (d, $1 \mathrm{H}, J=2.2 \mathrm{~Hz}, 4-\mathrm{H}), 6.73(\mathrm{dd}, 1 \mathrm{H}, J=8.6 \mathrm{~Hz}, J=2.2 \mathrm{~Hz}, 2-\mathrm{H}), 7.17$ (d, 1H, $J=8.6 \mathrm{~Hz}, 1-\mathrm{H})$, 7.28 (t, 2H, $J=7.7 \mathrm{~Hz}$ ), 7.33-7.4, (overlapping m, 5H), 7.47-7.54 (overlapping m, 2H), 7.84 (d, $2 \mathrm{H}, \mathrm{J}=7.7 \mathrm{~Hz}$ ), 7,95-7,99 (overlapping m, 4H): benzoyl protons, 7.77 (s, 1H, HC=C); ${ }^{13} \mathrm{C}-\mathrm{NMR}$ $\left(\mathrm{CDCl}_{3}\right) ; \delta[\mathrm{ppm}] 14.6(\mathrm{C}-16 \mathrm{a}), 15.9$ (C-18), 25.0, 26.4, 27.4, 30.6, 31.2, 35.6, 38.7, 41.7, 43.5, 45.2, 51.1 (C-6'), 55.4 (1'- $\left.\mathrm{OCH}_{3}\right), 61.9\left(\mathrm{OCH}_{2}\right), 68.4$, 69.9, 70.6, $71.3(\mathrm{C}-17), 71.8,96.8(\mathrm{C}-1$ ') 112.3 (C-2), 114.4 (C-4), 124.2 (HC=C), 126.5 (C-1), 128.3 (2C), 128.4 (2C), 128.5 (2C), 129.6 (2C), 129.9 (2C), 130.0 (2C), 133.2, 133.4, 133.8: benzoyl CHs, 128.3, 128.8, 129.0: benzoyl Cq, $133.4(\mathrm{C}-10), 138.1(\mathrm{C}-5), 144.7(\mathrm{HC}=\underline{\mathrm{C}}), 155.8(\mathrm{C}-3), 165.3,165.4$ and $165.9(3 \times \mathrm{Bz}-\mathrm{CO})$; ESI-MS: $858[\mathrm{M}+\mathrm{H}]^{+}, 1715[2 \mathrm{M}+\mathrm{H}]^{+}$; Anal. Calcd for $\mathrm{C}_{50} \mathrm{H}_{55} \mathrm{~N}_{3} \mathrm{O}_{10}$ : C, 69.99; H, 6.46; N, 4.90. Found: C, 70.14; H, 6.37; N, 5.07. 
3-(1-(Methyl-6-deoxy-2,3,4-tri-O-benzoyl- $\alpha$-D-glucopyranosid-6-yl)-1H-1,2,3-triazol-4-yl-

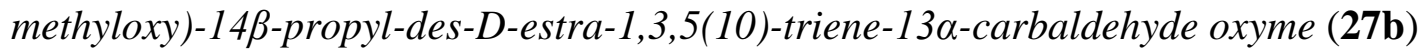
After purification, 27b was obtained as a white solid (61 mg, 75\%), $\mathrm{mp} 119-123^{\circ} \mathrm{C}, R_{\mathrm{f}}=0.70$ (ss B); ${ }^{1} \mathrm{H}-\mathrm{NMR}\left(\mathrm{CDCl}_{3}\right) ; \delta[\mathrm{ppm}] 0.87\left(\mathrm{t}, 3 \mathrm{H}, J=6.3 \mathrm{~Hz}, 16 \mathrm{a}-\mathrm{H}_{3}\right), 1.05\left(\mathrm{~s}, 3 \mathrm{H}, 18-\mathrm{H}_{3}\right), 2.84(\mathrm{~m}$, $2 \mathrm{H}, 6-\mathrm{H}_{2}$ ), 3.04 (s, 3H, 1'- $-\mathrm{OCH}_{3}$ ), 4.43-4.47 (overlapping m, 3H), 5.14-5.24 (overlapping m, $4 \mathrm{H}), 5.41(\mathrm{t}, 1 \mathrm{H}, J=9.7 \mathrm{~Hz}), 6.15$ (t, 1H, $J=9.7 \mathrm{~Hz}): 1^{\prime}-, 2^{\prime}-, 3^{\prime}-, 4^{\prime}-, 5^{\prime}-\mathrm{H}, 6{ }^{\prime}-\mathrm{H}_{2}, \mathrm{OCH}_{2}, 6.7$ (d, $1 \mathrm{H}, J=2.2 \mathrm{~Hz}, 4-\mathrm{H}), 6.77$ (dd, $1 \mathrm{H}, J=8.6 \mathrm{~Hz}, J=2.2 \mathrm{~Hz}, 2-\mathrm{H}) .7 .17$ (d, $1 \mathrm{H}, J=8.6 \mathrm{~Hz}, 1-$ H), 7.29 (t, 2H, $J=7.5 \mathrm{~Hz}$ ), 7.37-7.44 (overlapping m, 5H), 7.50-7.57 (overlapping m, 2H), 7.86 $(\mathrm{m}, 2 \mathrm{H}), 7.95-7.99$ (overlapping $\mathrm{m}, 4 \mathrm{H})$ : benzoyl protons, $7.36(\mathrm{~s}, 1 \mathrm{H}, 17-\mathrm{H}), 7.84(\mathrm{~s}, 1 \mathrm{H}$, $\mathrm{HC}=\mathrm{C}) ;{ }^{13} \mathrm{C}-\mathrm{NMR}\left(\mathrm{CDCl}_{3}\right) ; \delta[\mathrm{ppm}] 14.5$ (C-16a), 15.3 (C-18), 24.3, 26.0, 27.2, 30.5, 32.2, 37.4, 40.9, 41.3, 43.3, 47.9, 51.9 (C-6'), $55.5\left(1\right.$ '- $\left.\mathrm{OCH}_{3}\right), 61.8\left(\mathrm{OCH}_{2}\right), 68.4,69.9,70.6,71.8,96.9$ (C1'), 112.4 (C-2), 114.5 (C-4), 124.9 (HC=C), 126.5 (C-1), 128.3 (2C), 128.4 (2C), 128.6 (2C), 129.6 (2C), 129.9 (2C), 130.0 (2C), 133.2, 133.5, 133.8: benzoyl CHs, 128.3, 128.8, 129.0: benzoyl Cq, 132.9 (C-10), 137.9 (C-5), 145.2 (HC=), 156.0 (C-3), 160.7 (C-17), 165.6, 165.7 and $165.8(3 \times \mathrm{Bz}-\mathrm{CO})$; ESI-MS: $871[\mathrm{M}+\mathrm{H}]^{+}, 1741[2 \mathrm{M}+\mathrm{H}]^{+}$; Anal. Calcd for $\mathrm{C}_{50} \mathrm{H}_{54} \mathrm{~N}_{4} \mathrm{O}_{10}: \mathrm{C}$, 68.95; H, 6.25; N, 6.43. Found: C, 69.14; H, 6.13; N, 6.42.

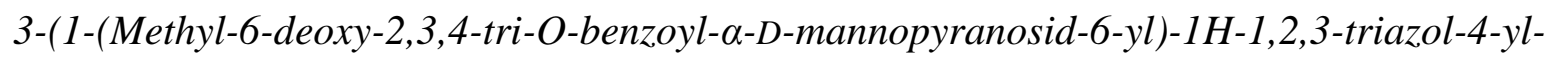

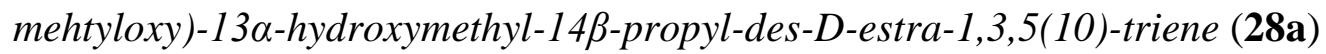

After purification, 28a was obtained as a white solid (64 mg, 79\%), $\mathrm{mp} 101-103{ }^{\circ} \mathrm{C}, R_{\mathrm{f}}=0.63$ (ss B); ${ }^{1} \mathrm{H}-\mathrm{NMR}\left(\mathrm{CDCl}_{3}\right) ; \delta[\mathrm{ppm}] 0.77\left(\mathrm{~s}, 3 \mathrm{H}, 18-\mathrm{H}_{3}\right), 0.91\left(\mathrm{t}, 3 \mathrm{H}, J=6.3 \mathrm{~Hz}, 16 \mathrm{a}-\mathrm{H}_{3}\right), 2.82(\mathrm{~m}$, $\left.2 \mathrm{H}, 6-\mathrm{H}_{2}\right), 3.11\left(\mathrm{~s}, 3 \mathrm{H}, 1^{\prime}-\mathrm{OCH}_{3}\right), 3.34$ and $3.52\left(2 \times \mathrm{d}, 2 \times 1 \mathrm{H}, J=2 \times 10.9 \mathrm{~Hz}, 17-\mathrm{H}_{2}\right), 4.45(\mathrm{~m}$, 1H), $4.55(\mathrm{~m}, 1 \mathrm{H}), 4.76(\mathrm{~m}, 1 \mathrm{H}), 4.91(\mathrm{~s}, 1 \mathrm{H}), 5.17(\mathrm{~m}, 2 \mathrm{H}), 5.63(\mathrm{~m}, 1 \mathrm{H}), 5.74(\mathrm{~m}, 1 \mathrm{H}), 5.87$ (m, 1H): 1'-, 2'-, 3'-, 4'-, 5'-H, 6'- $\mathrm{H}_{2}, \mathrm{OCH}_{2}, 6.66$ (d, 1H, $\left.J=2.2 \mathrm{~Hz}, 4-\mathrm{H}\right), 6.73$ (dd, 1H, $J=8.6$ $\mathrm{Hz}, J=2.2 \mathrm{~Hz}, 2-\mathrm{H}), 7.18(\mathrm{~d}, 1 \mathrm{H}, J=8.6 \mathrm{~Hz}, 1-\mathrm{H}), 7.26(\mathrm{t}, 2 \mathrm{H}, J=7.5 \mathrm{~Hz}), 7.39-7.42$ (overlapping m, 3H), $7.51(\mathrm{t}, 2 \mathrm{H}, J=7.5 \mathrm{~Hz}), 7,55(\mathrm{t}, 1 \mathrm{H}, J=7.5 \mathrm{~Hz}), 7.63(\mathrm{t}, 1 \mathrm{H}, J=7.5 \mathrm{~Hz}$ ), $7.82(\mathrm{~d}, 2 \mathrm{H}, J=7.5 \mathrm{~Hz}), 7.99(\mathrm{~d}, 2 \mathrm{H}, J=7.5 \mathrm{~Hz}), 8.06(\mathrm{~d}, 2 \mathrm{H}, J=7.5 \mathrm{~Hz})$ : benzoyl protons, 7.80 (s, 1H, HC=C); ${ }^{13} \mathrm{C}-\mathrm{NMR}\left(\mathrm{CDCl}_{3}\right) ; \delta[\mathrm{ppm}] 14.6$ (C-16a), 16.0 (C-18), 25.0, 26.4, 27.4, 30.7, 31.2, 35.6, 38.7, 41.8, 43.5, 45.3, $51.2\left(\mathrm{C}-6\right.$ '), $55.4\left(1^{\prime}-\mathrm{OCH}_{3}\right), 61.9\left(\mathrm{OCH}_{2}\right), 68.2,69.4,69.5$, 70.4, 71.3 (C-17), 98.5 (C-1'), 112.3 (C-2), 114.4 (C-4), 124.2 (Hㅌ=C), 126.6 (C-1), 128.3 (2C), 128.6 (2C), 128.7 (2C), 129.7 (2C), 129.8 (2C), 129.9 (2C), 133.2, 133.6, 133.8: benzoyl 
CHs, 128.5, 128.9, 129.2: benzoyl Cq, 133.4 (C-10), 138.1 (C-5), 146.0 (HC=ㅡ), 155.9 (C-3), 165.3, 165.4 and 165.9: $(3 \times \mathrm{Bz}-\mathrm{CO})$; ESI-MS: $858[\mathrm{M}+\mathrm{H}]^{+}$; Anal. Calcd for $\mathrm{C}_{50} \mathrm{H}_{55} \mathrm{~N}_{3} \mathrm{O}_{10}: \mathrm{C}$, 69.99; H, 6.46; N, 4.90. Found: C, 70.12; H, 6.56; N, 5.08.

3-(1-(Methyl-6-deoxy-2,3,4-tri-O-benzoyl-a-D-mannopyranosid-6-yl)-1H-1,2,3-triazol-4-yl-

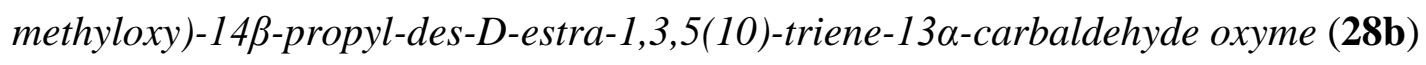

After purification, $\mathbf{2 8 b}$ was obtained as a white solid (59 mg, 72\%), $\mathrm{mp} 112-115^{\circ} \mathrm{C}, R_{\mathrm{f}}=0.72$ (ss B); ${ }^{1} \mathrm{H}-\mathrm{NMR}\left(\mathrm{CDCl}_{3}\right) ; \delta[\mathrm{ppm}] 0.88\left(\mathrm{t}, 3 \mathrm{H}, J=6.3 \mathrm{~Hz}, 16 \mathrm{a}-\mathrm{H}_{3}\right), 1.06\left(\mathrm{~s}, 3 \mathrm{H}, 18-\mathrm{H}_{3}\right), 2.82(\mathrm{~m}$, 2H, 6- $\left.\mathrm{H}_{2}\right), 3.11\left(\mathrm{~s}, 3 \mathrm{H}, 1^{\prime}-\mathrm{OCH}_{3}\right), 4.45(\mathrm{~m}, 1 \mathrm{H}), 4.57(\mathrm{~m}, 1 \mathrm{H}), 4.76(\mathrm{~m}, 1 \mathrm{H}), 4.91(\mathrm{~s}, 1 \mathrm{H}), 5.17$ (m, 2H), $5.63(\mathrm{~m}, 1 \mathrm{H}), 5.74(\mathrm{t}, 1 \mathrm{H}, J=9.0 \mathrm{~Hz}), 5.88(\mathrm{dd}, 1 \mathrm{H}, J=9.0 \mathrm{~Hz}, J=3.2 \mathrm{~Hz}): 1^{\prime}-, 2^{\prime}-, 3^{\prime}-$ , 4'-, 5'- $-\mathrm{H}, 6^{\prime}-\mathrm{H}_{2}, \mathrm{OCH}_{2}, 6.67$ (d, $\left.1 \mathrm{H}, J=2.2 \mathrm{~Hz}, 4-\mathrm{H}\right), 6.74(\mathrm{dd}, 1 \mathrm{H}, J=8.6 \mathrm{~Hz}, J=2.2 \mathrm{~Hz}, 2-$ $\mathrm{H}), 7.16(\mathrm{~d}, 1 \mathrm{H}, J=8.6 \mathrm{~Hz}, 1-\mathrm{H}), 7.26(\mathrm{~m}, 2 \mathrm{H}), 7.40-7.44$ (overlapping $\mathrm{m}, 3 \mathrm{H}), 7.51(\mathrm{t}, 2 \mathrm{H}, J=$ $7.5 \mathrm{~Hz}), 7.55(\mathrm{t}, 1 \mathrm{H}, J=7.5 \mathrm{~Hz}), 7.63(\mathrm{t}, 1 \mathrm{H}, J=7.5 \mathrm{~Hz}), 7.80(\mathrm{~d}, 2 \mathrm{H}, J=7.5 \mathrm{~Hz}), 7.99(\mathrm{~d}, 2 \mathrm{H}, J$ $=7.5 \mathrm{~Hz}), 8.06(\mathrm{~d}, 2 \mathrm{H}, J=7.5 \mathrm{~Hz})$ : benzoyl protons, $7.39(\mathrm{~s}, 1 \mathrm{H}, 17-\mathrm{H}), 7.88(\mathrm{~s}, 1 \mathrm{H}, \mathrm{HC}=\mathrm{C})$; ${ }^{13} \mathrm{C}-\mathrm{NMR}\left(\mathrm{CDCl}_{3}\right) ; \delta$ [ppm] 14.5 (C-16a), 15.4 (C-18), 24.4, 26.0, 27.2, 30.5, 32.2, 37.4, 40.9, 41.3, 43.3, 47.8, 51.2 (C-6'), $55.4\left(1^{\prime}-\mathrm{OCH}_{3}\right), 61.9\left(\mathrm{OCH}_{2}\right), 68.2,69.4,69.5,70.4,98.5(\mathrm{C}-1$ ') 112.4 (C-2), 114.4 (C-4), $124.2(\mathrm{HC}=\mathrm{C}), 126.51(\mathrm{C}-1), 128.3$ (2C), $128.6(2 \mathrm{C}), 128.7(2 \mathrm{C})$, 129.7 (2C), 129.8 (2C), 129.9 (2C), 133.2, 133.7, 133.8: benzoyl CHs, 128.5, 128.9, 129.1: benzoyl Cq, 132.8 (C-10), 137.9 (C-5), 144.6 (HC=ㄷ), 156.0 (C-3), 160.6 (C-17), 165.3, 165.4 and $165.9(3 \times \mathrm{Bz}-\mathrm{CO})$; ESI-MS: $871[\mathrm{M}+\mathrm{H}]^{+}, 1741[2 \mathrm{M}+\mathrm{H}]^{+}$; Anal. Calcd for $\mathrm{C}_{50} \mathrm{H}_{55} \mathrm{~N}_{4} \mathrm{O}_{10}: \mathrm{C}$, 68.95; H, 6.25; N, 6.43. Found: C, 68.73; H, 6.38; N, 6.51.

3-(1-(Methyl-5-deoxy-2,3-di-O-benzoyl- $\beta$-D-ribofuranosid-5-yl)-1H-1,2,3-triazol-4-yl-

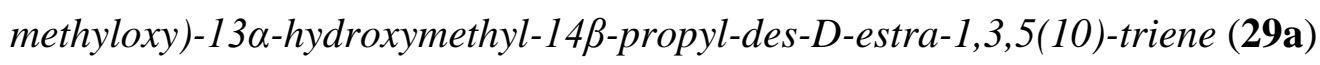

After purification, 29a was obtained as an oil (62 mg, 76\%), $R_{\mathrm{f}}=0.54$ (ss B); ${ }^{1} \mathrm{H}-\mathrm{NMR}\left(\mathrm{CDCl}_{3}\right)$; $\delta[\mathrm{ppm}] 0.77\left(\mathrm{~s}, 3 \mathrm{H}, 18-\mathrm{H}_{3}\right), 0.91\left(\mathrm{t}, 3 \mathrm{H}, J=6.3 \mathrm{~Hz}, 16 \mathrm{a}-\mathrm{H}_{3}\right), 2.85\left(\mathrm{~m}, 2 \mathrm{H}, 6-\mathrm{H}_{2}\right), 3.33$ and 3.52 $\left(2 \times \mathrm{d}, 2 \times 1 \mathrm{H}, J=2 \times 10.9 \mathrm{~Hz}, 17-\mathrm{H}_{2}\right), 3.48\left(\mathrm{~s}, 3 \mathrm{H}, 1^{\prime}-\mathrm{OCH}_{3}\right), 4.58(\mathrm{~m}, 1 \mathrm{H}), 4.71(\mathrm{~m}, 1 \mathrm{H}), 4.99$ (m, $1 \mathrm{H}), 5.18(\mathrm{~m}, 2 \mathrm{H}), 5.12(\mathrm{~s}, 1 \mathrm{H}), 5.63-5.66$ (overlapping $\mathrm{m}, 2 \mathrm{H}): 1^{\prime}-, 2^{\prime}-3^{\prime}-, 4^{\prime}-\mathrm{H}, 5^{\prime}-\mathrm{H}_{2}$, $\mathrm{OCH}_{2} ; 6.72(\mathrm{~d}, 1 \mathrm{H}, J=2.2 \mathrm{~Hz}, 4-\mathrm{H}), 6.79(\mathrm{dd}, 1 \mathrm{H}, J=8.6 \mathrm{~Hz}, J=2.2 \mathrm{~Hz}, 2-\mathrm{H}), 7.22(\mathrm{~d}, 1 \mathrm{H}, J=$ $8.6 \mathrm{~Hz}, 1-\mathrm{H}), 7.33$ (t, 2H, $J=7.6 \mathrm{~Hz}), 7.43$ (t, 2H, $J=7.6 \mathrm{~Hz}), 7.53$ (t, 1H, $J=7.6 \mathrm{~Hz}), 7.59$ (t, $1 \mathrm{H}, J=7.6 \mathrm{~Hz}), 7.86(\mathrm{~d}, 2 \mathrm{H}, J=7.6 \mathrm{~Hz}), 8.01(\mathrm{~d}, 2 \mathrm{H}, J=7.6 \mathrm{~Hz})$ : benzoyl protons, $7.86(\mathrm{~s}, 1 \mathrm{H}$, 
$\mathrm{HC}=\mathrm{C}) ;{ }^{13} \mathrm{C}-\mathrm{NMR}\left(\mathrm{CDCl}_{3}\right) ; \delta[\mathrm{ppm}] 14.7$ (C-16a), 16.0 (C-18), 25.0, 26.4, 27.4, 30.7, 31.2, 35.6, 38.7, 41.7, 43.5, 45.3, $54.0\left(\mathrm{C}-5^{\prime}\right), 55.9\left(1^{\prime}{ }^{\prime}-\mathrm{OCH}_{3}\right), 62.0\left(\mathrm{OCH}_{2}\right), 71.3(\mathrm{C}-17), 73.1,75.1,79.7$, 106.8 (C-1'), 112.4 (C-2), 114.4 (C-4), 124.1 (HC- =C), 126.6 (C-1), 128.4 (2C), 128.5 (2C), 129.8 (4C), 133.6 (2C): benzoyl CHs, 128.3, 129.0: benzoyl Cq, 133.5 (C-10), 138.1 (C-5), $147.8(\mathrm{HC}=\underline{\mathrm{C}}), 156.1(\mathrm{C}-3), 165.2$ and $165.5(2 \times \mathrm{Bz}-\mathrm{CO})$; ESI-MS: $724[\mathrm{M}+\mathrm{H}]^{+}, 1447$ $[2 \mathrm{M}+\mathrm{H}]^{+}$; Anal. Calcd for $\mathrm{C}_{42} \mathrm{H}_{49} \mathrm{~N}_{3} \mathrm{O}_{8}: \mathrm{C}, 69.69 ; \mathrm{H}, 6.82 ; \mathrm{N}, 5.81$. Found: C, 69.72; H, 6.94; N, 6.03 .

3-(1-(Methyl-5-deoxy-2,3-di-O-benzoyl- $\beta$-D-ribofuranosid-5-yl)-1H-1,2,3-triazol-4-yl-

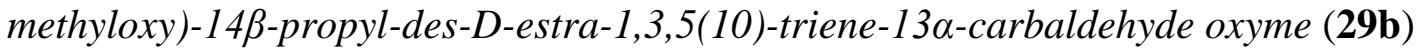
After purification, 29b was obtained as a white solid (65 mg, 70\%), mp 95-98 ${ }^{\circ} \mathrm{C}, R_{\mathrm{f}}=0.78$ (ss B); ${ }^{1} \mathrm{H}-\mathrm{NMR}\left(\mathrm{CDCl}_{3}\right) ; \delta[\mathrm{ppm}] 0.88\left(\mathrm{t}, 3 \mathrm{H}, J=6.3 \mathrm{~Hz}, 16 \mathrm{a}-\mathrm{H}_{3}\right), 1.06\left(\mathrm{~s}, 3 \mathrm{H}, 18-\mathrm{H}_{3}\right), 2.85(\mathrm{~m}$, 2H, 6-H $), 3.48\left(\mathrm{~s}, 3 \mathrm{H}, 1\right.$ ' $\left.-\mathrm{OCH}_{3}\right), 4.60(\mathrm{~m}, 1 \mathrm{H}), 4.73(\mathrm{~m}, 1 \mathrm{H}), 4.99(\mathrm{~m}, 1 \mathrm{H}), 5,18(\mathrm{~m}, 2 \mathrm{H}), 5.12$ (s, 1H), 5.63-5.66 (overlapping m, 2H), 1'-,2'-, 3'-,4'-H, 5'- $\mathrm{H}_{2}, \mathrm{OCH}_{2} ; 6.73$ (d, 1H, J = 2.2 Hz, 4-H), $6.81(\mathrm{dd}, 1 \mathrm{H}, J=8.6 \mathrm{~Hz}, J=2.2 \mathrm{~Hz}, 2-\mathrm{H}), 7.20(\mathrm{~d}, 1 \mathrm{H}, J=8.6 \mathrm{~Hz}, 1-\mathrm{H}), 7.33(\mathrm{t}, 2 \mathrm{H}, J=$ $7.5 \mathrm{~Hz}), 7.43(\mathrm{t}, 2 \mathrm{H}, J=7.5 \mathrm{~Hz}), 7.53(\mathrm{t}, 1 \mathrm{H}, J=7.5 \mathrm{~Hz}), 7.59(\mathrm{t}, 1 \mathrm{H}, J=7.5 \mathrm{~Hz}), 7.86(\mathrm{~d}, 2 \mathrm{H}, J$ $=7.5 \mathrm{~Hz}), 8.01(\mathrm{~d}, 2 \mathrm{H}, J=7.5 \mathrm{~Hz})$ : benzoyl protons, $7.35(\mathrm{~s}, 1 \mathrm{H}, 17-\mathrm{H}), 7.87(\mathrm{~s}, 1 \mathrm{H}, \mathrm{HC}=\mathrm{C})$; ${ }^{13} \mathrm{C}-\mathrm{NMR}\left(\mathrm{CDCl}_{3}\right) ; \delta$ [ppm] 14.5 (C-16a), 15.4 (C-18), 24.3, 26.0, 27.2, 30.5, 32.1, 37.4, 40.9, 41.3, 43.3, 47.9, 53.8 (C-5'), 55.9 (1'- $\left.\mathrm{OCH}_{3}\right), 62.0\left(\mathrm{OCH}_{2}\right), 73.1,75.1,79.6,106.8$ (C-1'), 112.5 (C-2), 114.5 (C-4), 124.8 (Hㄷ=), 126.5 (C-1), 128.4 (2C), 128.5 (2C), 129.8 (4C), 133.6 (2C): benzoyl CHs, 129.0 (2C): benzoyl Cq, 132.9 (C-10), 137.9 (C-5), 148.9 (HC=ㄷ), 156.2 (C-3), $161.0(\mathrm{C}-17), 165.2$ and $165.5(2 \times \mathrm{Bz}-\mathrm{CO})$; ESI-MS: $737[\mathrm{M}+\mathrm{H}]^{+}, 1473[2 \mathrm{M}+\mathrm{H}]^{+}$; Anal. Calcd for $\mathrm{C}_{42} \mathrm{H}_{48} \mathrm{~N}_{4} \mathrm{O}_{8}$ : C, 68.46; H, 6.57; N, 7.60. Found: C, 68.31; H, 6.73; N, 7.45.

\section{Removal of acetyl protecting groups of bioconjugates $24 a$ and $24 b$}

$0.45 \mathrm{mmol}$ of conjugates (24a or $\mathbf{2 4 b})$ was dissolved in $10 \mathrm{ml}$ of methanol and $2.4 \mathrm{mg}(0.045$ mmol, 0.1 equiv.) of sodium methylate was added. The reaction was monitored by TLC and showed a perfect conversion in 30 minutes. After evaporation, the crude product was purified by column chromatography using a $\mathrm{CH}_{2} \mathrm{Cl}_{2} / \mathrm{MeOH}$ (9:1) as eluent to give compound 30a or 30b. 


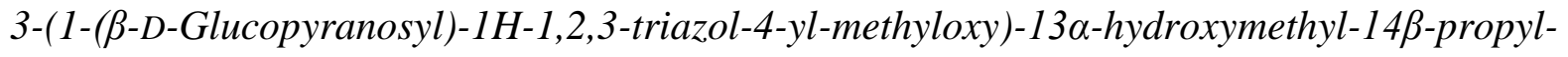
des-D-estra-1,3,5(10)-triene (30a)

After purification, 30a was obtained as a white solid (182 mg, 76\%), mp 102-104 ${ }^{\circ} \mathrm{C}, R_{\mathrm{f}}=0.2$ (ss C); ${ }^{1} \mathrm{H}-\mathrm{NMR}\left(\mathrm{DMSO}_{\mathrm{d}}\right) ; \delta[\mathrm{ppm}] 0.68\left(\mathrm{~s}, 3 \mathrm{H}, 18-\mathrm{H}_{3}\right), 0.87$ (t, 3H, $\left.J=6.7 \mathrm{~Hz}, 16 \mathrm{a}-\mathrm{H}_{3}\right), 2.79(\mathrm{~m}$, 2H, 6- $\left.\mathrm{H}_{2}\right), 3.11(\mathrm{~m}, 1 \mathrm{H}), 3.24(\mathrm{~m}, 1 \mathrm{H}), 3.39(\mathrm{~m}, 1 \mathrm{H}), 3.44(\mathrm{~m}, 2 \mathrm{H}), 3.69(\mathrm{~m}, 1 \mathrm{H}), 3.77(\mathrm{~m}, 1 \mathrm{H})$, $4.03(\mathrm{~m}, 1 \mathrm{H}), 4.39(\mathrm{~m}, 1 \mathrm{H}), 4.63(\mathrm{~m}, 1 \mathrm{H}), 5.14(\mathrm{~m}, 1 \mathrm{H}), 5.27(\mathrm{~m}, 1 \mathrm{H}), 5.38(\mathrm{~m}, 1 \mathrm{H}), 5.54(\mathrm{~m}$, 1H): 1'-, 2'-, 3'-, 4'-, 5'-H, 6'- $\mathrm{H}_{2}, 17-\mathrm{H}_{2}, 5 \times \mathrm{OH}$; 5.08 (s, 2H, $\left.\mathrm{OCH}_{2}\right), 6.72$ (d, 1H, J = 8.5 Hz, 4H), $6.78(\mathrm{dd}, 1 \mathrm{H}, J=8.5 \mathrm{~Hz}, J=2.4 \mathrm{~Hz}, 2-\mathrm{H}), 7.19(\mathrm{~d}, 1 \mathrm{H}, J=8.5 \mathrm{~Hz}, 1-\mathrm{H}), 8.4(\mathrm{~s}, 1 \mathrm{H}, \mathrm{HC}=\mathrm{C})$; ${ }^{13}$ C-NMR (DMSO-d ${ }_{6}$ ); $\delta$ [ppm] 14.5 (C-16a), 16.0 (C-18), 24.2, 26.1, 27.0, 30.1, 30.8, 35.5, 38.2, 41.4, 43.1, 44.6, 60.6 and $60.7\left(\mathrm{OCH}_{2}\right.$ and C-6'), 69.3 (C-17), 69.5, 71.9, 76.9, 79.7, 87.4 (C-1'), 112.2 (C-2), 113.8 (C-4), 123.6 (HE- =C), 126.4 (C-1), 132.7 (C-10), 137.5 (C-5), 141.8 $(\mathrm{HC}=\underline{\mathrm{C}}), 155.7(\mathrm{C}-3)$; ESI-MS: $532[\mathrm{M}+\mathrm{H}]^{+}, 1063[2 \mathrm{M}+\mathrm{H}]^{+}$; Anal. Calcd for $\mathrm{C}_{28} \mathrm{H}_{41} \mathrm{~N}_{3} \mathrm{O}_{7}: \mathrm{C}$, 63.26; H, 7.77; N, 7.90. Found: C, 63.38; H, 7.61; N, 8.05.

3-(1-( $\beta$-D-Glucopyranosyl)-1H-1,2,3-triazol-4-yl-methyloxy)-14 $\beta$-propyl-des-D-estra-1,3,5(10)-

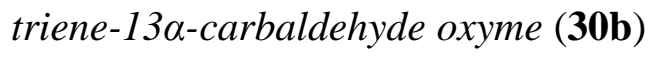

After purification, 30b was obtained as a white solid (201 mg, 82\%), mp 99-101 ${ }^{\circ} \mathrm{C}, R_{\mathrm{f}}=0.24$ (ss C); ${ }^{1} \mathrm{H}-\mathrm{NMR}\left(\right.$ DMSO-d $\left._{6}\right) ; \delta[\mathrm{ppm}] 0.83\left(\mathrm{t}, 3 \mathrm{H}, J=6.3 \mathrm{~Hz}, 16 \mathrm{a}-\mathrm{H}_{3}\right), 0.98\left(\mathrm{~s}, 3 \mathrm{H}, 18-\mathrm{H}_{3}\right), 2.80(\mathrm{~m}$, $\left.2 \mathrm{H}, 6-\mathrm{H}_{2}\right), 3.25(\mathrm{~d}, 1 \mathrm{H}, J=4.5 \mathrm{~Hz}), 3.40(\mathrm{t}, 1 \mathrm{H}, J=2 \times 9.0 \mathrm{~Hz}), 3.46(\mathrm{~d}, 2 \mathrm{H}, J=8.0 \mathrm{~Hz}), 3.71$ $(\mathrm{dd}, 1 \mathrm{H}, J=2 \times 5.5 \mathrm{~Hz}), 3.80(\mathrm{dd}, 1 \mathrm{H}, J=8.5 \mathrm{~Hz}, J=6.5 \mathrm{~Hz}), 4.63(\mathrm{~m}, 1 \mathrm{H}), 5.15(\mathrm{~m}, 1 \mathrm{H}), 5.27$ $(\mathrm{m}, 1 \mathrm{H}), 5.40(\mathrm{~d}, 1 \mathrm{H}, J=5.5 \mathrm{~Hz}), 5.60(\mathrm{~d}, 1 \mathrm{H}, J=9.0 \mathrm{~Hz}): 1^{\prime}-, 2^{\prime}-, 3^{\prime}-, 4^{\prime}-, 5^{\prime}-\mathrm{H}, 6^{\prime}-\mathrm{H}_{2}, 4 \times \mathrm{OH}$; 5.09 (s, 2H, $\left.\mathrm{OCH}_{2}\right), 6.74(\mathrm{~d}, 1 \mathrm{H}, J=2.2 \mathrm{~Hz}, 4-\mathrm{H}), 6.80(\mathrm{dd}, 1 \mathrm{H}, J=8.6 \mathrm{~Hz}, J=2.2 \mathrm{~Hz}, 2-\mathrm{H})$, $7.18(\mathrm{~d}, 1 \mathrm{H}, J=8.6 \mathrm{~Hz}, 1-\mathrm{H}), 7.20(\mathrm{~s}, 1 \mathrm{H}, 17-\mathrm{H}), 8.40$ (s, 1H, HC=C); ${ }^{13} \mathrm{C}-\mathrm{NMR}$ (DMSO-d $\mathrm{d}_{6}$ ); $\delta$ [ppm] 14.4 (C-16a), 15.4 (C-18), 23.8, 25.7, 26.8, 29.9, 31.5, 37.2, 40.5, 40.6, 42.8, 47.0, 60.6 and $60.7\left(\mathrm{OCH}_{2}\right.$ and $\mathrm{C}-6$ ') $69.5,71.9,76.9,79.9,87.4(\mathrm{C}-1$ ') $, 112.3(\mathrm{C}-2), 113.9(\mathrm{C}-4), 123.7$ $(\mathrm{H} \underline{\mathrm{C}}=\mathrm{C}), 126.4$ (C-1), 132.2 (C-10), 137.4 (C-5), 142.8 (HC=$), 155.8$ (C-3), 157.8 (C-17); ESIMS: $545[\mathrm{M}+\mathrm{H}]^{+}, 1089[2 \mathrm{M}+\mathrm{H}]^{+}$; Anal. Calcd for $\mathrm{C}_{28} \mathrm{H}_{40} \mathrm{~N}_{4} \mathrm{O}_{7}: \mathrm{C}, 61.75 ; \mathrm{H}, 7.40 ; \mathrm{N}, 10.29$. Found: C, 61.88; H, 7.31; N, 10.35. 


\section{Cell cultures and antiproliferative assays}

Human cancer cell lines (HeLa and MCF-7 isolated from cervical adenocarcinoma and breast adenocarcinoma, respectively) and noncancerous mouse fibroblasts (NIH/3T3) were maintained in minimal essential medium supplemented with $10 \%$ fetal bovine serum (FBS), $1 \%$ nonessential amino-acids and an antibiotic-antimycotic mixture (AAM). A2780 cells (isolated from ovarial cancer) were maintained in RPMI medium supplemented with 10\% FBS, 1\% AAM and 1\% L-glutamine. All cancer cell lines were purchased from the European Collection of Cell Cultures (Salisbury, U.K.) while NIH/3T3 cell line was a generous gift from Dr. Gabriella Spengler (Department of Medical Microbiology and Immunbiology, University of Szeged). For pharmacological investigations, $10 \mathrm{mM}$ stock solutions of the tested compounds were prepared with dimethyl sulfoxide (DMSO). The highest applied DMSO concentration of the medium $(0.3 \%)$ did not have any substantial effect on the determined cellular functions. All the chemicals, if otherwise not specified, were purchased from Sigma-Aldrich Ltd. (Budapest, Hungary). The antiproliferative effects were determined in vitro on three cell lines: HeLa, MCF7 and A2780. The cells were grown in a humidified atmosphere of $5 \% \mathrm{CO}_{2}$ at $37^{\circ} \mathrm{C}$. Cells were seeded onto 96-well plates at a density of 5000 cells/well and allowed to stand overnight, after which the medium containing the tested compound was added. After a 72-h incubation, viability was determined by the addition of $20 \mu \mathrm{L}$ of [3-(4,5-dimethylthiazol-2-yl)-2,5diphenyltetrazolium bromide] solution $(5 \mathrm{mg} / \mathrm{mL})$. The precipitated formazan crystals were solubilized in DMSO and the absorbance was determined at $545 \mathrm{~nm}$ with an ELISA reader [20]. Two independent experiments were performed with 5 parallel wells; cisplatin, an agent administered clinically in the treatment of certain gynaecological malignancies, was used as a positive control. Sigmoidal dose-response curves were fitted to the measured data. Calculations of $\mathrm{IC}_{50}$ values and statistical analyses (ANOVA) were performed by means of GraphPad Prism 4.0 (GraphPad Software; San Diego, CA, USA). 


\section{References:}

1. Dutta D; Pulsipher A; Yousaf MN. Selective tethering of ligands and proteins to a microfluidically patterned electroactive fluid lipid bilayer array. Langmuir. 2010;26:9835.

2. Rajaganesh R; Jayakumar J; Sivaraj C; Raaman N; Das TM. Synthesis and antioxidant activity of a novel class of 4, 6-O-protected O-glycosides and their utility in disaccharide synthesis. Carbohydr Res. 2010;345:1649.

3. Salunke SB; Babu NS; Chen C-T. Iron(III) chloride as an efficient catalyst for stereoselective synthesis of glycosyl azides and a cocatalyst with $\mathrm{Cu}(0)$ for the subsequent click chemistry. Chem Commun. 2011;47:10440.

4. Cottam HB; Wasson DB; Shih HC; Raychaudhuri A; Di Pasquale G; Carson DA. New adenosine kinase inhibitors with oral antiinflammatory activity: synthesis and biological evaluation. J Med Chem. 1993;36:3424. 
III.

Kupihár Z., Bodnár B., Kovács L. 5'-Linker modified nucleosides, Hungarian patent P1700542, 2017.12.19. (5'-Linkerrel módosított nukleozidok, magyar szabadalmi bejelentés) 


\section{5'-LINKERREL MÓDOSÍTOTT NUKLEOZIDOK}

A találmány tárgyát képezik olyan természetes, purintartalmú nukleozidokból előállított (adott esetben a cukorrészek 2'- és/vagy 3'-hidroxicsoporjain védett, és adott esetben a nukleobázisok aminocsoportjain védett) nukleozidszármazékok, amelyeknek 5'szénatomjához karbamát/tiokarbamát csoporton keresztül egy nem ionos jellegü (alkilamidoalkil-, alkilén-, vagy polietilénglikol tartalmú) linker egység kapcsolódik, amelynek másik végén egy terminális (azaz láncvégi) alkin vagy azidometil funkciós csoport található. A találmány szerinti, purintartalmú nukleozidszármazékok biológiailag aktív vagy potencionálisan aktív, purintartalmú nukleozidtartalmú biokonjugátumok, elönyösen enzimek biszubsztrát inhibitorainak gyors, egyszerü és hatékony előállítására alkalmazhatók.

\section{A TECHNIKA ÁLLÁSA}

A gyógyszerhatóanyagok jelentős része fehérjékhez, igen gyakran transzportfehérjékhez vagy enzimekhez kötődve fejti ki hatását azáltal, hogy pl. a hatóanyag az enzim természetes szubsztrátjával versengve kiszorítja azt az enzim aktív centrumából, és saját maga kötődik a fehérje ezen szubsztrátkötő helyére. A hagyományos enziminhibitorok csak az enzim ezen B1 szubsztrátkötő helyét (aktív centrumát) veszik célba, miközben az úgynevezett biszubsztrát enziminhibitorok a célzott enzimhez történő kötődés során az enzim felületén a szubsztrát kötőhely mellett a B2 koenzim kötőhelyhez is kötődnek az I inhibitormolekulához egy linkeren (L) keresztül kapcsolt koenzimmimikáló molekularésszel (C) (1. ábra). Ezáltal lényegesen erősebb kötődés érhető el, azaz hatékonyabb enzimgátlásra képesek az ilyen kettős kötődésű, úgynevezett biszubsztrát inhibitorok az irodalmi hivatkozások alapján. [111]. Mivel a nukleotid koenzimek/koenzimmimikálók általában purinalapú nukleozidokat, legjellemzőbben adenozin nukleozidot tartalmaznak az enzim koenzim-kötőhelye által felismerendő molekularészletként, ezért ezen természetes szerkezetü, purinvázas nukleozidok a legfontosabbak a biszubsztrát inhibitorok tervezésénél, előállításánál.

A biszubsztrát inhibitorok elöállítása hagyományosan [1-2,6,8,10-11] úgy történik, hogy a már valamilyen mértékü enzimgátlásra képes I inhibitormolekulához egy egyedileg tervezett szintézisúton hozzákapcsolják a C koenzimmimikáló molekularészt. Ez általában minden egyes I inhibitormolekula esetében egyedi reakcióútvonal tervezését és általában 
többlépéses, hosszadalmas szintetikus kivitelezést igényel, ahol a két molekularészt összekötő L linkerrész módosításához a teljes szintézisutat újra el kell végezni, akár újraoptimalizált szintéziskörülmények között, ami idö- és erőforrás-igényes eljárás (2. ábra 2A része). Ezzel szemben az általunk is előnyben részesített eljárásmód esetén (építőelem módszer, 2. ábra $2 \mathrm{~B}$ része) az I inhibitormolekulán mindössze egyetlen F1 kapcsoló funkciós csoport kialakítását kell elvégezni, amely a molekula szerkezetétől függően lehet terminális alkin- vagy azidcsoport. Ezután az előre elkészített, purintartalmú nukleozid típusú C koenzimmimikáló molekuláris építőelemmel (amely különböző szerkezetü és tulajdonságú lehet) az I inhibitormolekula kovalensen összekapcsolható az úgynevezett alkin-azid klikkreakció segítségével (3. ábra, [17-19]), mivel a C koenzimmimikáló molekuláris építőelem tartalmaz egy F2 „komplementer” azido vagy terminális alkin kapcsoló funkciós csoportot, amely az említett alkin-azid klikkreakcióval az F1 kapcsoló funkciós csoporthoz egyszerủen hozzákapcsolható (itt jegyezzük meg, a jelen találmány szerinti képletben az azidocsoport mindig azidometil-csoport formájában van jelen az F2-nek megfelelő $F$ részen). Ehhez mindössze arra van szükség, hogy az összekapcsolandó két molekulából az egyik egy terminális alkin, a másik egy azid funkciós csoportot tartalmazzon. Az eljárás során az alkinazid klikkreakció optimalizálása nem túl időigényes, mivel az irodalomban leírt eljárások [2024] általában univerzálisan alkalmazhatók, ráadásul az eljárás egyszerre többféle, előre elkészített nukleozid koenzimmimikáló molekuláris építőelemmel párhuzamosan is elvégezhető az adott inhibitorhoz történő kapcsolás, tehát a szokásos módszerhez képest lényegesen rövidebb idő alatt kivitelezhető akár igen nagyszámú számú biszubsztrát inhibitor molekula párhuzamos szintézise.

Ezen építőelem módszerhez hasonló módszerek ismertek a szakirodalomban és az alkinazid klikkreakciót is alkalmazzák a fent leírt módon különféle szerkezeti elemek kapcsolására. Koenzimtartalmú biszubsztrát inhibitorokat ismertet a [13] cikk, ahol egy konkrét enzim (Abelson tirozin kináz) gátlását tüzték ki célul. A [12] cikkben ismertetnek hasonló, klikkeléses reakcióban alkalmazható nukleozidszármazékokat, azonban ezen tudományos közleményekben leírt molekuláris építőelemek a természetes nukleotid koenzimekkel tökéletesen megegyező, fiziológiás körülmények között negatív töltésű 5'-mono-/di-/tri/tetrafoszfát csoportot tartalmaznak, ahol az alkin (konkrétan etinil) csoport közvetlenül egy P-atomhoz kapcsolódik (a [12] cikk ezen C-P kötés kialakítására nagy hangsúlyt fektet). 
Aláhúzzuk, hogy a jelen találmány szerinti vegyületek foszfátmentesek, ami komoly gyakorlati előnnyel bír. Ugyanis a foszfát funkciós csoport jelenlétének hátránya, hogy ezáltal a molekula negatív töltésű lesz fiziológiás körülmények között, ami a sejtmembránon történő áthatolást, azaz a hatóanyag sejtekbe történő bejutását jelentősen megnehezíti, ezáltal a hatásosság csökkenhet egy hasonló szerkezetü, de állandó negatív töltést nem hordozó molekulával szemben. További hátrányt okozhat a foszfáttartalmú molekulák esetében az, hogy a foszfátcsoport réz(I)-ionokkal komplexet képez, amely a tervezett klikkreakciók kivitelezését (melynek során réz(I)-katalizátort szokás használni), azaz magának a biszubsztrát inhibitor molekulának az előállítását is nehezíti. A foszfátcsoportok jelenléte ráadásul a molekula hidrofobicitását jelentősen csökkenti, amely az apoláros oldószerekben történő szintetikus lépések kivitelezését jelentősen nehezítheti. A szakirodalomban találunk semleges módon, karbonsavészterként kapcsolt nukleozid biokonjugátumokat is [1], azonban ezek hátránya a foszfátészterekhez hasonlóan az, hogy a sejtekben található észteráz enzimek elbonthatják őket, miáltal a sejtekben a felezési idejük alacsony lesz, azaz ismét csökkenhet a biológiai hatásosságuk. Ráadásul az észterkötés jelenléte a biokonjugátumok szintetikus kémiai előállításaihoz szükséges bázisérzékeny védőcsoportok alkalmazását nem engedi meg, mivel maga is bázisérzékeny.

A találmány szerinti vegyületekhez hasonló, észterkötés- és foszfátmentes molekulát ismertet a [16] cikk, amelyek azonban csak köztitermékként szerepelnek, mert azokból foszfortartalmú uridin-foszfoamiditeket állítanak elő (lásd az 1. reakcióvázlatban). Továbbá a végcél foszfátcsoportokkal kapcsolt származékolt oligonukleotidok előállítása, lásd a Kivonatban, illetve 4. és 5. a reakcióvázlatokban, vagyis a cikkben nem található utalás arra, hogy a feltárt foszfátmentes uridinszármazékok biszubsztrát inhibitorok előállítására lennének alkalmazhatók. Ez a tény teljes összhangban áll azzal, hogy csak pirimidinvázas nukleotidot alkalmaznak a cikkben, amelyek lényegében nem bírnak jelentőséggel koenzim kötőhely szubsztrátként, azaz nem tekinthetők célszerü biszubsztrát inhibitor alkotónak, ugyanis a leggyakoribb nukleotid koenzimek purin bázisokat (elsősorban adenint tartalmaznak), mint pl. az ATP, NAD, NADH,. FAD, FADH, AcCoA.

Hasonló észterkötés- és foszfátmentes molekulákat ismertet az US20120035515 A1 sz. amerikai szabadalmi irat (uridin és timidin nukleotid részekkel, azaz ezek szintén pirimidinvázas nukleotidokon alapulnak), egyrészt szintén foszfortartalmú vegyületek 
intermediereként (lásd 5. példa a 49. leírásoldaltól), másrészt szilárd hordozóhoz kötött végtermék intermediereként (lásd 17. példa a 106. leírásoldaltól). A találmány célkitüzése RNS-t célzó oligonukleotidok előállítása, azaz célkitüzésében megegyezik a [16] cikkel. Ezzel összhangban itt sem kerül említésre, hogy a feltárt foszfátmentes uridinszármazékok biszubsztrát inhibitorok előállítására lennének alkalmazhatók.

Aláhúzzuk továbbá, hogy a fenti, a találmány szerinti vegyületekhez legközelebb álló molekulák esetében kizárólag az etinilcsoport beépítését tudták megvalósítani.

Az alábbiakban olyan megoldásokat ismertetünk, amelyek már távolabb állnak a jelen találmány szerinti megoldástól, de a szakterülethez tartozónak tekinthetők.

Az US 2012071641 sz. amerikai szabadalmi irat olyan módosított nukleozidokat ismertet, amelyek 5' helyzetü hidroxicsoportját valamilyen hidroxicsoportot védő csoporttal vagy egy reaktív foszfortartalmú csoporttal (pl. foszforamidit, H-foszfonát) szubsztituálják. A reaktív foszfortartalmú csoportok célja nukleozidok összekapcsolása pl. foszfodiészter vagy foszforotioát linkerek segítségével. A módosított nukleozidokat génexpresszió gátlására alkalmas oligonukleotidok előállítására alkalmazzák.

Az US 2014220573 sz. amerikai szabadalmi irat módosított nukleozidokat mint oligonukleotidok monomerjeit ismerteti, ahol egy kiviteli alak szerint a módosítást azid-alkin klikkreakcióval végzik el. A klikkreakció kiindulásakor azonban olyan nukleozidból indulnak ki, melyben az azidcsoport közvetlenül, linker nélkül kapcsolódik a nukleozid cukorrészéhez.

A WO 2011032034 sz. nemzetközi szabadalmi irat C5 pozícióban funkcionalizált nukleinsavakat ismertet, vagyis a monomer módosítása a nukleobázist célozza, nem pedig a cukorrészt. A hivatkozott dokumentum szerint a nukleobázis linkerként tartalmazhat alkincsoportot (tehát az alkincsoport nem terminális helyzetü) vagy triazolcsoportot. A triazolcsoportot azid-alkin klikkreakcióval alakítják ki. A klikkreakció elvégzéséhez olyan nukleozidból indulnak ki, amelyben az alkincsoport közvetlenül kapcsolódik a nukleobázishoz, tehát szintén nem a nukleozid cukor részéhez.

A US 20130184160 sz. amerikai szabadalmi irat oligonukleotidok monomerjeiként olyan módosított nukleozidokat ismertet, amelyekben a nukleobázisok bórsavszármazékkal szubsztituáltak, a cukorrész pedig az 5' pozícióban mono-, di- vagy trifoszfát-észtercsoporttal szubsztituáltak. A hivatkozott dokumentum utal az azid-alkin klikkreakcióra, azonban itt a bórsavszármazéknak a nukleobázishoz való kapcsolására használják. A 
hivatkozott dokumentum ismerteti, hogy a klikkreakcióhoz szükséges azid- vagy alkincsoportok linkeren keresztül kapcsolódnak a nukleobázishoz, de a lehetséges linkerek, kapcsolórészek között nem említi a karbamát- [-O(CO)NH-] vagy tiokarbamátcsoportot [$\mathrm{O}(\mathrm{CS}) \mathrm{NH}-]$.

A WO 2011156690 nemzetközi szabadalmi iratban oligoszacharid-oligonukleotid konjugátumokat és azok előállítására alkalmas eljárást ismertetnek. Az oligoszacharid és az oligonukleotid építőelemeket azid-alkin klikkreakcióval kapcsolják össze úgy, hogy az azidcsoportot az oligoszacharid egység tartalmazza, az alkincsoport pedig közvetlenül valamelyik nukleobázishoz kapcsolódik.

Az US 20150307550 sz. amerikai szabadalmi iratban módosított peptideket és előállítási eljárásukat ismertetik. Említik, hogy bizonyos aminosavak oldalláncait pl. azid-alkin klikkreakció segítségével módosítják.

Összefoglalva, az említett iratok egyike sem ismerteti a találmány szerinti vegyületeket, továbbá a legközelebbi szerkezeti analógokat más célból állították elő, és a vonatkozó iratokban nem utaltak azok biszubsztrát inhibitorok előállítására való alkalmazhatóságára.

Hivatkozott nem szabadalmi referenciák:

[1] Fournier D et al. Eur. J. Med. Chem. 2008, 43, 2298-2306.

[2] Lerner C et al. Org. Biomol. Chem. 2003, 1, 42-49.

[3] Xia Ge et al. Biochemistry 2008, 47, 9966-9980.

[4] Kaido Viht et al. Anal. Biochem. 2007, 362, 268-277.

[5] Erki Enkvist et al. J. Med. Chem. 2006, 49, 7150-7159.

[6] Leonardo Pisani et al. Chem. Med. Chem. 2010, 5, 1616-1630.

[7] Darja Lavogina et al. Chem. Med. Chem. 2010, 5, 23-34.

[8] Kathryn M. Nelson et al. J. Med. Chem. 2015, 58(14), 5459-5475.

[9] Katrin Kestav et al. Bioconjug. Chem. 2015, 26(2), 225-234.

[10] Vladimir S. Borodkin et al. Tetrahedron Letters 2004, 45, 857-862.

[11] Ce Shi et al. Med. Chem. Lett. 2013, 4(12), 1213-1217

[12] Przemyslaw Wanat et al. Org. Lett. 2015, 17(12), 3062-3065.

[13] Karunakaran A. Kalesh et al. Org. Biomol. Chem. 2009, 7, 5129-5136.

[14] Stephan M. Hacker et al. Angew. Chem. Int. Ed. 2013, 52, 11916-11919. 
[15] Nick Cox et al. Angew. Chem. Int. Ed. 2016, 55, 9894-9897.

[16] Takeshi Yamada et al. J. Org. Chem. 2011, 76, 1198-1211.

[17] Huisgen, R. Angew. Chemie Int. Ed. English 1963, 2, 565-598.

[18] Rostovtsev, V. V.; Green, L. G.; Fokin, V. V.; Sharpless, K. B. Angew. Chemie Int. Ed. 2002, 41, 2596-2599.

[19] Tornøe, C. W.; Christensen, C.; Meldal, M. J. Org. Chem. 2002, 67, 3057-3064.

[20] Liang, L.; Astruc, D. Coord. Chem. Rev. 2011, 255, 2933-2945.

[21] Malkoch, M.; Thibault, R. J.; Drockenmuller, E.; Messerschmidt, M.; Voit, B.; Russell, T. P.; Hawker, C. J. J. Am. Chem. Soc. 2005, 127, 14942-14949.

[22] Liang, C.-H.; Yao, S.; Chiu, Y.-H.; Leung, P. Y.; Robert, N.; Seddon, J.; Sears, P.; Hwang, C.-K.; Ichikawa, Y.; Romero, A. Bioorg. Med. Chem. Lett. 2005, 15, 1307-1310.

[23] Dondoni, A.; Marra, A. J. Org. Chem. 2006, 71, 7546-7557.

[24] Bock, V. D.; Hiemstra, H.; van Maarseveen, J. H. European J. Org. Chem. 2006, 2006, 51-68.

[25] Cheng, K.; Liu, J.; Sun, H.; Xie, J. Synthesis (Stuttg). 2010, 2010, 1046-1052.

[26] Herdewijn, P.; Balzarini, J.; Pauwels, R.; Janssen, G.; Aerschot, A. Van; Clercq, E. De Nucleosides and Nucleotides 1989, 8, 1231-1257.

[27] Chen, J.-B.; Liu, E. M.; Chern, T.-R.; Yang, C.-W.; Lin, C.-I.; Huang, N.-K.; Lin, Y.-L.; Chern, Y.; Lin, J.-H.; Fang, J.-M. ChemMedChem 2011, 6, 1390-1400.

[28] Murat, P.; Gennaro, B.; Garcia, J.; Spinelli, N.; Dumy, P.; Defrancq, E. Chem. - A Eur. J. 2011, 17, 5791-5795.

[29] Mattarella, M.; Berstis, L.; Baldridge, K. K.; Siegel, J. S. Bioconjug. Chem. 2014, 25, $115-128$.

\section{AZ ÁBRÁK RÖVID ISMERTETÉSE}

1. ábra: Tradícionális (monoszubsztrát) inhibitorok és biszubsztrát inhibitorok bemutatása az I inhibitormolekulával mint szubsztrátmimikáló molekulával, a C nukleozidtartalmú koenzimmimikáló molekularésszel, a B1 szubsztrát kötőhellyel, a B2 koenzim kötőhellyel, továbbá az LN linkerrel.

2. ábra: Biszubsztrát inhibitorok előállítása hagyományos módszerrel (2A ábra) és építőelem módszerrel (2B ábra). A hagyományos módszer esetén első lépésben minden egyes 
I inhibitormolekulához az LN linker hozzákapcsolása egyedileg tervezett eljárással történik. A hagyományos módszer második lépésében a nukleozidtartalmú C koenzimmimikáló molekularész hozzákapcsolása az LN linkerhez egyedileg tervezett szintézismódszerrel történik az I inhibitormolekula és a nukleozidtartalmú C koenzimmimikáló molekularész szerkezetétől függően. $\mathrm{Az}$ építőelem módszer kiindulásaként egyrészt az I inhibitormolekulába egy speciális F1 funkciós csoportot (terminális alkin- vagy azidcsoportot) építünk be, másrészt előzetesen elkészítünk egy univerzálisan alkalmazható, koenzim vagy annak egy részletét tartalmazó koenzimmimikáló molekuláris építőelemet, amely egy speciális (terminális alkin vagy azido, esetünkben azidometil) F2 funkciós csoportot, egy L linkert, egy $\mathrm{K}$ kapcsolórészt, valamint egy nukleozidrészt is tartalmaz. Az építőelem módszer során az így előkészített molekuláris építőelemekből az igen szelektív alkin-azid klikkreakcióval hozzuk létre a biszubsztrát inhibitort.

3. ábra: Az alkin-azid klikkreakció bemutatása az „egyik horgony” F1 funkciós csoporttal és a „másik horgony” F2 funkciós csoporttal, ahol a két funkciós csoport igen szelektív és hatékony kapcsolásával jön létre a triazolgyürüt tartalmazó biokonjugátum.

4. ábra: A találmány szerinti, univerzálisan alkalmazható koenzimmimikáló molekuláris építőelemek szerkezeti elemei a ,horgony” $\mathrm{F}$ funkciós csoporttal, az L linkerrel, a K kapcsolórésszel és a purinalapú, nukleozidtartalmú C koenzimmimikáló molekularésszel, ahol $\mathrm{X}=$ oxigén- vagy kénatom, $\mathrm{NB}=\mathrm{az}$ aminocsoportokon $\mathrm{PG}_{3}$ védőcsoporttal védett vagy védetlen adenin /guanin nukleobázis, $R_{1}=$ hidrogénatom vagy $P_{2}$ védőcsoport és $R_{2}=$ hidrogénatom $(\mathrm{H})$, hidroxicsoport $(\mathrm{OH})$ vagy $\mathrm{O}-\mathrm{PG}_{2}$ (ahol $\mathrm{PG}_{2}$ védőcsoport).

\section{A TALÁLMÁNNYAL MEGOLDANDÓ PROBLÉMA}

Stabilabb biszubsztrát inhibitorok gyorsabb és hatékonyabb előállítása, valamint olyan, purinalapú, előnyösen természetes nukleozid koenzimmimikáló molekuláris építőelemek tervezése és szintézise, melyek a fenti irodalmi részben említett módon alkin-azid klikkreakcióval hozzákapcsolhatók megfelelő komplementer funkciós csoportot (azid/alkin) tartalmazó enziminhibitor molekulákhoz olyan módon, hogy a korábbi, hasonló célra alkalmazott karbonsav- és foszforsavésztert tartalmazó molekulák fent említett hátrányait (lúgos közeggel és észteráz enzimekkel szembeni érzékenység, negatív töltés miatti gyengébb 
sejtmembránpenetráció, az észtercsoport jelenléte, illetve a negatív töltés okozta szintetikus kémiai műveletek nehézségei) kiküszöböljék.

\section{A TALÁLMÁNY ALAPJÁT KÉPEZÖ FELISMERÉS}

Az említett célokat a találmány azon a felismerésen alapuló megoldással éri el, hogy a foszfátmentes, azaz állandó negatív töltést nem tartalmazó biszubsztrát inhibitorok stabilabbak, továbbá hogy ezek előállíthatók a korábban alkalmazott enzimatikusan kevéssé stabil észterkötés kiváltásával, és az általunk alkalmazott előállítási eljárással.

A purin nukleozidok 5'-helyzetű szénatomjához nem a korábban alkalmazott enzimatikusan és kémiailag kevéssé stabil észterkötéssel, hanem karbamát/tiokarbamátcsoporttal kapcsolódik a terminális azidometil vagy alkin funkciós csoportot tartalmazó linker molekularész. Ezen (karbamát/tiokarbamát) kötés jóval ellenállóbb a szintetikus lépések során általánosan alkalmazott bázikus kezelésekkel és a sejtek lebontó enzimjeivel szemben is. Emellett a nukleozidok 5'-helyzetében kapcsolódó, terminális azid- vagy alkincsoportot hordozó találmány szerinti csoport kialakítását is megkönnyíti a hagyományos megoldásokhoz képest, mivel a kevéssé hatékony és sok mellékreakcióval járó 5'-alkilezés és azidálás [25-29] helyett egy jóval kevesebb mellékreakcióval járó és nagyobb hatékonyságú (jobb hozamú, könnyebben tisztítható terméket szolgáltató) acilezési reakcióval lehet beépíteni a funkciós csoportokat a molekula 5' pozíciójába. További előnye az így kialakított vegyületeknek, hogy a nukleozidrész és a terminális azidometil/ alkin funkcióscsoport távolsága, valamint fizikokémiai tulajdonságai tetszés szerint szabályozhatók a megfelelő linkerrész beépítésével, amelyek a későbbi biológiai hatásnál kulcsfontosságú szempontok lehetnek. Továbbá különféle típusú linkerek alkalmazhatóságán keresztül „finomhangolni” lehet a találmány szerinti molekulák hidrofobicitását.

\section{A TALÁLMÁNY RÖVID ISMERTETÉSE}

1. Az (I) általános képletü, purinalapú, nukleozid koenzimmimikáló molekuláris építőelemek biokonjugátumok, elsősorban biszubsztrát inhibitorok előállításához,

$$
\mathrm{F}-\mathrm{L}-\mathrm{K}-\mathrm{C}
$$


ahol a képletben

C jelentése az alábbi általános képlettel jellemzett nukleozid molekularész:

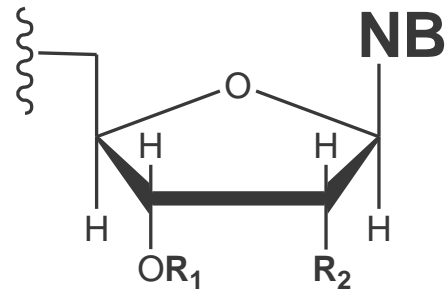

ahol a képletben $R_{1}$ jelentése $H$ vagy $P_{1}$ védőcsoport;

$R_{2}$ jelentése $H, O H$ vagy $O-P_{2}$, ahol $P_{2}$ védőcsoport;

NB jelentése az alábbi csoportok közül választott:<smiles>[Y]N(C(=O)O)c1ncnc2c1ncn2C</smiles>

adenin<smiles>CN(C(=O)O)c1nc2c(ncn2C)c(=O)[nH]1</smiles>

guanin

ahol $\mathrm{PG}_{3}$ jelentése $\mathrm{H}$ vagy védőcsoport;

A jelentése $\mathrm{H}$ vagy a $\mathrm{PG}_{3}$ védőcsoporttal együtt $\mathrm{N}$-dimetilformamidin csoportot jelöl;

$\mathrm{K}$ jelentése a $\mathrm{C}$ nukleozid molekularész 5'-szénatomjához kapcsolódó karbamátvagy tiokarbamát-csoport, amely karbamát- vagy tiokarbamát-csoport oxigénatomján keresztül kapcsolódik a C nukleozid molekularészhez;

L jelentése a K karbamát- vagy tiokarbamát-csoport nitrogénatomján keresztül kapcsolódó linkerrész, amely a következők közül választott: - $\left(\mathrm{CH}_{2}\right)_{\mathrm{n}}(\mathrm{CO}) \mathrm{NH}\left(\mathrm{CH}_{2}\right)_{\mathrm{m}}$ - képletü alkil-amidoalkil-csoport, - $\left(\mathrm{CH}_{2}\right)_{\mathrm{p}^{-}}$képletü alkiléncsoport vagy - $\left(\mathrm{CH}_{2}\right)_{\mathrm{q}}\left(\mathrm{OCH}_{2} \mathrm{CH}_{2}\right)_{\mathrm{r}^{-}}$képletü oligo-etilénoxi-csoport, ahol a képletekben n jelentése 0-10 értékủ egész szám, m jelentése 212 értékủ egész szám, p jelentése 1-16 értékü egész szám, q jelentése 1-6 értékü egész szám és r jelentése 1-6 értékü egész szám;

F jelentése az L linkerrész másik végéhez kapcsolódó etinil- vagy azidometilcsoport;

és ezen vegyületek sói, hidrátjai és szeteroizomer formái.

2. Az 1. pont szerinti purinalapú, nukleozid koenzimmimikáló molekuláris építőelemek, ahol NB jelentése elönyösen adenin. 
3. Az 1-2. igénypontok bármelyike szerinti nukleozid koenzimmimikáló molekuláris építőelemek, ahol L jelentése - $\left(\mathrm{CH}_{2}\right)_{\mathrm{n}}(\mathrm{CO}) \mathrm{NH}\left(\mathrm{CH}_{2}\right)_{\mathrm{m}}$ - képletű alkil-amidoalkil-csoport.

4. Az 1-2. igénypontok bármelyike szerinti purinalapú, nukleozid koenzimmimikáló molekuláris építőelemek, ahol L jelentése - $\left(\mathrm{CH}_{2}\right)_{\mathrm{q}}\left(\mathrm{OCH}_{2} \mathrm{CH}_{2}\right)_{\mathrm{r}^{-}}$képletü oligoetilénoxicsoport.

5. Az 1-2. pontok bármelyike szerinti nukleozid koenzimmimikáló molekuláris építőelemek, ahol L jelentése - $\left(\mathrm{CH}_{2}\right)_{\mathrm{p}}$ - képletü alkiléncsoport.

6. Az 1-5. pont bármelyike szerinti nukleozid koenzimmimikáló molekuláris építőelemek, ahol K jelentése karbamátcsoport.

7. Az 1-6. pont bármelyike szerinti nukleozid koenzimmimikáló molekuláris építőelemek, ahol F jelentése azidometil-csoport.

8. Az 1-6. pont bármelyike szerinti nukleozid koenzimmimikáló molekuláris építőelemek, ahol F jelentése etinilcsoport.

9. Az 1. pont szerinti nukleozid koenzimmimikáló molekuláris építőelem a következő vegyületek köréből választva:

3'-O-acetil-5' - $O$-((3-(2-azidoacetamido)propil)karbamoil)- $N^{6}$-benzoil-2'dezoxiadenozin,

3'-O-acetil-5'-O-((3-(2-azidoacetamido)propil)karbamoil)-2'-dezoxi- $N^{2}$ izobutirilguanozin,

2',3'-di-O-acetil-5'-O-((3-(2-azidoacetamido)propil)karbamoil)- $N^{6}$-benzoiladenozin, 2',3'-di- $O$-acetil-5' '-O-((3-(2-azidoacetamido)propil)karbamoil)- $N^{2}$-izobutirilguanozin, 3'-O-acetil-5'-O-((3-azidopropil)karbamoil)- $N^{6}$-benzoil-2'-dezoxiadenozin, 3'-O-acetil-5'-O-((prop-2-in-1-il)karbamoil)- $N^{6}$-benzoil-2'-dezoxiadenozin, 3'-O-acetil-5'-O-((8-azido-3,6-dioxaoktil)karbamoil)- $N^{6}$-benzoil-2'-dezoxiadenozin, 3'-O-acetil-5'-O-((3,6-dioxanon-8-in-1-il)karbamoil)- $N^{6}$-benzoil-2'-dezoxiadenozin, 3'-O-acetil-5' -O-((3-propiolamidopropil)karbamoil)- $N^{6}$-benzoil-2' -dezoxiadenozin, 3'-O-acetil-5' - $O$-((3-azidopropil)tiokarbamoil)- $N^{6}$-benzoil-2'-dezoxiadenozin, 3'-O-acetil-5' - $O$-(prop-2-in-1-iltiokarbamoil)- $N^{6}$-benzoil-2'-dezoxiadenozin, 3'-O-acetil-5' -O-((8-azido-3,6-dioxaoktil)tiokarbamoil)- $N^{6}$-benzoil-2' -dezoxiadenozin, 3'-O-acetil-5' - $O$-((3,6-dioxanon-8-in-1-il)tiokarbamoil)- $N^{6}$-benzoil-2' -dezoxiadenozin, 2',3'-di-O-acetil-5'-O-((3-azidopropil)karbamoil)- $N^{2}$-izobutirilguanozin, 
2',3'-di-O-acetil-5'-O-(prop-2-in-1-ilkarbamoil)- $N^{2}$-izobutirilguanozin,

2',3'-di-O-acetil-5' - $O$-((8-azido-3,6-dioxaoktil)karbamoil)- $N^{2}$-izobutirilguanozin,

2',3'-di- $O$-acetil-5'-O-((3,6-dioxanon-8-in-1-il)karbamoil)- $N^{2}$-izobutirilguanozin,

2',3'-di-O-acetil-5'-O-((3-propiolamidopropil)karbamoil)- $N^{2}$-izobutirilguanozin,

5'-O-((3-(2-azidoacetamido)propil)karbamoil)-2'-dezoxiadenozin,

5'-O-((3-(2-azidoacetamido)propil)karbamoil)-2'-dezoxiguanozin,

5'-O-((3-(2-azidoacetamido)propil)karbamoil)-adenozin,

5'-O-((3-(2-azidoacetamido)propil)karbamoil)-guanozin,

5'-O-((3-azidopropil)karbamoil)-2'-dezoxiadenozin),

5'-O-((Prop-2-in-1-il)karbamoil)-2'-dezoxiadenozin,

5'-O-((8-azido-3,6-dioxaoktil)karbamoil)-2'-dezoxiadenozin,

5'-O-((3,6-dioxanon-8-in-1-il)karbamoil)-2'-dezoxiadenozin,

5'-O-((3-Propiolamidopropil)karbamoil)-2'-dezoxiadenozin,

5'-O-((3-azidopropil)tiokarbamoil)-2'-dezoxiadenozin,

5'-O-((Prop-2-in-1-il)tiokarbamoil)-2'-dezoxiadenozin,

5'-O-((8-azido-3,6-dioxaoktil)tiokarbamoil)-2'-dezoxiadenozin,

5'-O-((3,6-dioxanon-8-in-1-il)tiokarbamoil)-2'-dezoxiadenozin,

5'-O-((3-azidopropil)karbamoil)guanozin,

5'-O-(Prop-2-in-1-ilkarbamoil)guanozin,

5'-O-((8-azido-3,6-dioxaoktil)karbamoil)guanozin,

5'-O-((3,6-dioxanon-8-in-1-il)karbamoil)guanozin,

5'-O-((3-Propiolamidopropil)karbamoil)guanozin

és ezen vegyületek sói, hidrátjai és szeteroizomer formái.

10. Az 1-9. pontok szerinti vegyületek alkalmazása biokonjugátumok, elönyösen enzimek biszubsztrát inhibitorainak előállítására.

\section{A TALÁMÁNY RÉSZLETES ISMERTETÉSE}

A találmány szerinti vegyületek (purinbázisú, nukleozid koenzimmimikáló molekuláris építőelemek) 4 fő részt tartalmaznak (4. ábra): egy purintartalmú nukleobázison, illetve cukorrészen védett vagy védetlen nukleozid molekularészt (a 4. ábrán C-vel jelölve), másrészt ezen nukleozidrész 5'-szénatomjához kapcsolódó karbamát vagy tiokarbamát csoportot (a 4. 
ábrán K-val jelölve), ahol a kapcsolódás karbamát/tiokarbamát csoport oxigénatomján keresztül történik), harmadrészt a karbamát/tiokarbamát csoport nitrogén atomján keresztül kapcsolódó linkerrészt (a 4. ábrán L-lel jelölve), amely háromféle szerkezettel írható le (1. alkil-amidoalkil, 2. alkilén, 3. oligo-etilénglikol). A negyedik szerkezeti elem a linkerrész másik végéhez kapcsolódó terminális alkin (ami esetünkben etinil) vagy azidometil funkciós csoport (a 4. ábrán F-fel jelölve). Mindezen négy szerkezeti elem együttes jelenléte szükséges ahhoz, hogy az irodalomban korábban leírt és alkalmazott építőelemeknél hatékonyabb, könnyebben előállítható olyan nukleozid koenzimmimikáló molekuláris építőelemeket kapjunk, amelyekkel potenciálisan biológiailag hatásos biokonjugátumokat, elsősorban biszubsztrát inhibitorokat lehet gyorsan és hatékonyan előállítani. A korábbi megoldásokkal szemben a leírt szerkezeteknek az előnyei közé tartozik, hogy:

1. ezen vegyületek előállítása viszonylag egyszerü a korábbi, hasonló célra készített analóg vegyületekhez képest;

2. a segítségükkel felépített biokonjugátumok lényegesen ellenállóbbak az élő szervezetek enzimatikus lebontó folyamataival szemben, tehát átlagos felezési idejük a szervezetben hosszabb, azaz hosszabb hatást fejthetnek ki;

3. az irodalomban található és hasonló célra alkalmas, de ionos karakterü, foszfáttartalmú vegyületekkel szemben nem ionos karakterüek, ezáltal a felhasználásuk során alkalmazott alkin-azid klikk kapcsolási reakciók kivitelezése és a kapott apolárosabb termékek tisztítása elönyösebben megoldható;

4. az irodalomban található és hasonló célra alkalmas, de ionos karakterü, és negatív töltést hordozó foszfáttartalmú vegyületekkel szemben nem ionos karakterüek, ezáltal a belölük készített biokonjugátumok (például biszubsztrát inhibitorok) farmakokinetikai tulajdonságai (membránpenetráció) sokkal előnyösebbek lesznek, azaz várhatóan sokkal könnyebben fognak átjutni a sejtmembránon ezen biokonjugátumok, mint a jelenleg alkalmazott, foszfátcsoportot is tartalmazó, negatív töltésü analóg vegyületek, ezért várhatóan ez is növelni fogja hatásosságukat;

5. ezen vegyületek felhasználásával az építőelem módszer segítségével egy univerzalizált kombinatórikus kémiai megközelítéssel sokkal rövidebb idő alatt, sokkal több potenciális biszubsztrát inhibitor molekula állítható elö, mint a hagyományos 
módszerrel, ahol a biszubsztrát inhibitorok előállítása egyedileg tervezett szintézisutakon történik.

A találmány szerinti vegyületek előállításának célja, hogy potenciálisan bioaktív, purinalapú nukleozidtartalmú biokonjugátumokat lehessen könnyen, gyorsan, hatékonyan nagy mennyiségben előállítani, melyek a fenti 2. és 3. pontban írtak alapján előnyösebb biológiai hatással rendelkeznek, mint a korábban hasonló célra készült vegyületek.

A nukleozidtartalmú biokonjugátumok két részből állnak: egy, a biológiai hatásért elsősorban felelős, azaz egy fehérjemolekulához történő kapcsolódásért és a fehérjemolekula funkciójának módosításáért felelős, úgynevezett inhibitorrészből, valamint az említett inhibíciós hatást a fehérjemolekula egy másik részéhez (vagy akár egy másik fehérjemolekulához) történő kötődésével megnövelő nukleozid koenzimmimikáló molekularészből (molekuláris építőelemből). A két rész összekapcsolása kovalens kötés kialakításával történik, melynek általunk célzott módja, hogy a biokonjugátum inhibitorrészén előzetesen kialakított (terminális alkin vagy azid) funkciós csoportot kapcsoljuk össze a nukleozidrészen szintén előzetesen kialakított (terminális azidometil vagy alkin) komplementer funkciós csoporttal. Ehhez a természetes, purintartalmú nukleozidokból kialakított és előzetesen megfelelő funkciós csoporttal ellátott találmány szerinti nukleozid koenzimmimikáló molekuláris építőelemre van szükség.

A találmány szerinti nukleozid koenzimmimikáló molekuláris építőelemek 4 fő szerkezeti egységet tartalmaznak, melyek sorban kapcsolódnak egymáshoz az alábbi sorrendben: F-L-K-C, (jelentésük F = kapcsolódást biztosító („horgony”) funkciós csoport, L $=$ linkerrész, $\mathrm{K}=$ kapcsolórész a linker és nukleozidrész között, $\mathrm{C}=$ nukleozid koenzimmimikáló molekularész), amelyek együttes jelenlétére van szükség ahhoz, hogy a találmányban leírt szerkezetek a tervezett célra a lehető legalkalmasabbak legyenek. Részletesebben:

C jelentése természetes, purinalapú nukleozid, azaz adenozin, guanozin valamint 2'dezoxiadenozin, 2'-dezoxiguanozin adott esetben védett formában, ahol a védelem történhet a szénhidrátrész 2' és/vagy 3' hidroxicsoportjain, és/vagy a nukleobázisok aromás aminocsoportjain lévő egy vagy több védőcsoporttal. 
C jelentésében különösen előnyös az adenozin nukleozid, mivel a nukleotid koenzimek/koenzimmimikálók leggyakrabban adenozin nukleozidot tartalmaznak az enzim koenzim-kötőhelye által felismerendő molekularészletként.

A C nukleozid szénhidrát részének védőcsoportjai (melyek az ábrákon és reakciósémákon $\mathrm{PG}_{1}$ és $\mathrm{PG}_{2}$ jelöléssel szerepelnek) jellemzően acil típusú védőcsoportok, előnyösen az acetil, benzoil, metoxiacetil fenoxiacetil, fenilacetil körből egymástól függetlenül választva, de legjellemzőbben/legelőnyösebben acetil vagy benzoil csoportot jelölnek. A nukleobázisok esetében az ábrákon $\mathrm{PG}_{3}$-mal jelzett védőcsoport előnyösen $\mathrm{az}$ alábbiak köréből kerülhet ki: acetil, benzoil, izobutiril, fenoxiacetil, para-izopropilfenoxiacetil, para-terc-butil-fenoxiacetil, fluorenilmetiloxikarbonil vagy $\mathrm{N}$-dimetilformamidin csoport, legelőnyösebben benzoil vagy izobutiril csoport. Megjegyezzük, hogy a két kötéssel kapcsolódó N-dimetilformamidin csoport esetén a megadott képletben szereplö $-\mathrm{NAPG}_{3}$ részt úgy kell értelmezni, hogy az $A$ és a $\mathrm{PG}_{3}$ jelölések együtt jelentik az $\mathrm{N}$ dimetilformamidin csoportot, azaz ebben az esetben a $\mathrm{N}$-atomhoz nem kapcsolódik hidrogén.

Szükség esetén a fenti védőcsoportokat a szakterületen ismert módon távolítjuk el, előnyösen lúgos hidrolízissel.

K jelentése a nukleozidok 5'-helyzetű szénatomjához kapcsolódó karbamát vagy tiokarbamát funkciós csoport, azaz - $\mathrm{NH}(\mathrm{CO}) \mathrm{O}$ - vagy - $\mathrm{NH}(\mathrm{CS}) \mathrm{O}$ - csoport. Ezen funkciós csoport egy lényeges eleme a találmány szerinti vegyületeknek, és alkalmazása azért elönyös, mert a felhasználás során előállítandó biokonjugátumok szintézisét jelentősen megkönnyíti ezen szerkezeti elem, ugyanis a szintézislépések során alkalmazott védőcsoportok eltávolítására gyakran alkalmazott savas, illetve bázikus körülményeknek is ellenáll (szemben pl. a korábbi irodalmakban alkalmazott észterkötéssel). Másrészt a kialakítása acilezési típusú reakciót igényel, amelynek óriási előnye, hogy kompatibilis a szokásos nukleozidkémiai funkciós csoportok alkalmazásával és kialakítása jóval kevesebb mellékreakcióval jár, mint a korábban azidonukleozidok előállítására használt 5'-tozil-azid szubsztitúciós eljárások, így a nukleozidtartalmú koenzimmimikáló molekuláris építőelem magasabb hozammal állítható elő, valamint a végtermék megtisztítása is lényegesen könnyebb.

L jelentése a karbamát/tiokarbamát funkciós csoport nitrogén atomjához kapcsolódó linkerrész, amely előnyösen a következök közül választott:, alkil-amidoalkil-, alkilén- és oligoetilénglikol-csoport. A három különböző előnyös linkertípus különböző fizikokémiai és 
farmakokinetikai tulajdonságokat kölcsönöz a felhasználás során előállítani tervezett biokonjugátumnak, melyek a végső biológiai hatást erősíthetik a különböző esetekben. A 4. ábrán láthatóak az általánosan megadott szerkezetek, melyben az alkil-amidoalkil linker esetében $\left(\mathrm{L}=-\left(\mathrm{CH}_{2}\right)_{\mathrm{n}}(\mathrm{CO}) \mathrm{NH}\left(\mathrm{CH}_{2}\right)_{\mathrm{m}^{-}}\right)$az amidcsoport karbonilcsoport melletti részén 0-10 $\mathrm{db}$ metiléncsoportot tartalmazó alkillánc $(\mathrm{n}=0-10)$, az amidocsoport és a karbamátcsoport közötti részen pedig 2-12 db metiléncsoportot tartalmazó alkillánc található $(m=2-12)$. Az $n=0$ érték esetében az F jelentésében szereplő etinilcsoport közvetlenül kapcsolódik az alkilamidoalkil linker karbonilcsoportjához. Megjegyezzük hogy n esetében előnyös értékei a következők lehetnek: 0-8, 0-6, 0-4, 0-3, 0-2, 1-8, 1-6, 1-4, 1-3, 1-2, ahol még előnyösebb az 1, 1-2 és 1-3. Továbbá m esetében előnyös értékek lehetnek a következők: 2-10, 2-8, 2-6, 2-4, 23, 3-8, 3-6, 3-4, ahol még elönyösebb a 2, 2-3 és 2-4. Az n és m jelentései egymástól függetlenek.

Az alkilén linker esetében $\left(\mathrm{L}=-\left(\mathrm{CH}_{2}\right)_{\mathrm{p}^{-}}\right)$1-16 szénatomszámú alkiléncsoportból áll a linker rész $(p=1-16)$. Megjegyezzük hogy $p$ esetében előnyös értékek a következők lehetnek: 1-14, 1-12, 1-10, 1-8, 1-6, 1-4, 1-3, 1-2, ahol még előnyösebb az 1, 1-2, 1-3 és 1-4.

Az oligo-etilénoxi linker esetén $\left(\mathrm{L}=-\left(\mathrm{CH}_{2}\right)_{\mathrm{q}}\left(\mathrm{OCH}_{2} \mathrm{CH}_{2}\right)_{\mathrm{r}^{-}}\right)$a karbamát csoporthoz 1-6 etilénoxiegység kapcsolódik ( $\mathrm{r}=1-6)$, melyet az oligo-etilénoxi lánc végének oxigénjéhez kapcsolódó 1-6 db metiléncsoportból álló alkilrész követ (q=1-6). Megjegyezzük hogy q esetében előnyös értékei a következők lehetnek: 1-4, 1-3, 1-2, ahol még elönyösebb az 1, 1-2 és 1-3. Továbbá $r$ esetében előnyös értékek lehetnek a következők: 1-4, 1-3, 1-2, ahol még előnyösebb az 1, 1-2 és 1-3. Az r és q jelentései egymástól függetlenek.

Aláhúzzuk, hogy $n, m, p, q$ és $r$ gyakorlatban jelentőséggel bíró értékei függnek a megcélzott biokonjugátum ideális méretétől, ezen belül a linker rész ideális hosszától. Továbbá a különféle típusú linkerek alkalmazhatóságán keresztül „finomhangolni” lehet a találmány szerinti molekulák hidrofobicitását.

F jelentése kapcsoló (horgony) funkciós csoport, amely a linkernek a karbamátcsoporttal ellentétes végéhez kapcsolódó etinilcsoportot vagy az ugyanide kapcsolódó azidometil-csoportot jelenti. Ezen funkciós csoport felelős a felhasználás során alkin-azid klikkreakcióval történő kapcsolásért, amellyel a kívánt biokonjugátumok állíthatók elö. 
A technika állásának fényében előnyösként kiemelendők azok a vegyületek, amelyekben $\mathrm{F}$ jelentése azidometil-csoport, mivel a szerkezetileg közelálló vegyületekben etinilcsoportot alkalmaztak kapcsoló (horgony) funkciós csoportként, azaz nem oldották meg az azidometil-csoport beépítését.

A találmány tárgya továbbá a (I) általános képletű vegyületek alkalmazása biokonjugátumok, előnyösen enzimek biszubsztrát inhibitorainak előállítására.

\section{SZINTÉZISUTAK}

\section{Az F-L-NH $\mathrm{N}_{2}$ képletủ kiindulási anyag}

1. Az alkilén típusú $\mathrm{L}$ linkerek esetében mind az $\mathrm{F}=$ etinil, mind az $\mathrm{F}=$ azidometil végü linkermolekulák kereskedelmi forgalomban elérhetők. Például a 2-4 szénatomos azidometil linkerek megvásárolhatók a BOC Sciences cégtől (45-16 Ramsey Road Shirley, 11967 New York, UNITED STATES), az alábbi katalógusszámokon: \#87156-40-9, \#88192-19-2, \#88192-20-5), az 5-6 szénatomos azidometil linkerek pedig például a Matrix Scientific cégtől (PO BOX 25067, Columbia, SC 29224-5067) az alábbi katalógusszámokon: \#115307, \#069405. Alkinil típusú linkerek beszerezhetők például a GFS Chemicals Inc. nevű cégtől (3041 Home Road, P.O. Box 245, Powell, OH 43065) 3-6 szénatomszámú esetekben az alábbi katalógusszámokon: \#62611, \#17621,\#17631).

2. Oligo-etilénoxi típusú L linkerek esetében mind az F = etinil, mind az F = azidometil végü linkermolekulák kereskedelmi forgalomban elérhetők és beszerezhetők például a BroadPharm nevü cégtől (9380 Waples Street, Suite 101, San Diego, CA 92121, USA) a következő katalógusszámokon: 1. alkinil végü linkerek (\#BP-22770, \#BP-22519, \#BP-21683, \#BP-22520, \#BP-22103, \#BP-22876), 2. azidometil végü linkerek (\#BP-21611, \#BP-20692, \#BP-20580, \#ВP-21615, \#BP-20590, \#BP-22224).

3. Alkil-amidoalkil típusú L linkerek esetében pl. az alábbi módon szintetizálhatók az F-L$\mathrm{NH}_{2}$ linkerek (illetve etinilcsoport esetén sóik):

a) $\mathrm{F}=$ azidometil-csoport esetén: 
1. reakcióvázlat:<smiles>COC(=O)C(C)(CC(C)(C)Br)CC(C)(N)CC(I)(CC(C)(C)Br)C(=O)OC</smiles>

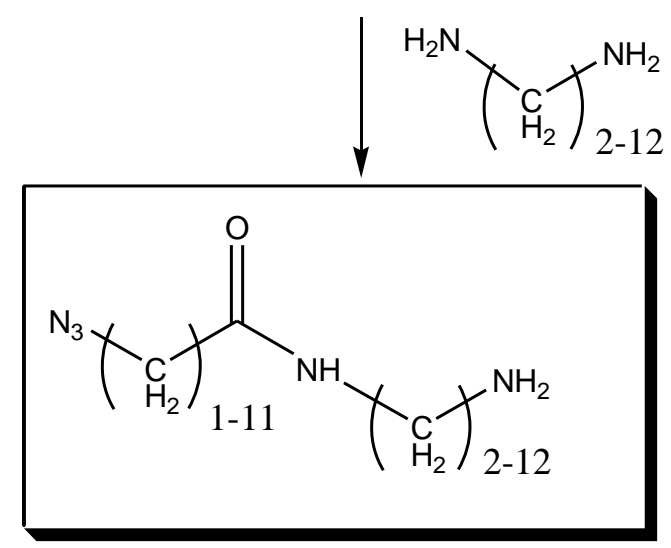

b) F = etinilcsoport esetén:

\section{2. reakcióvázlat}

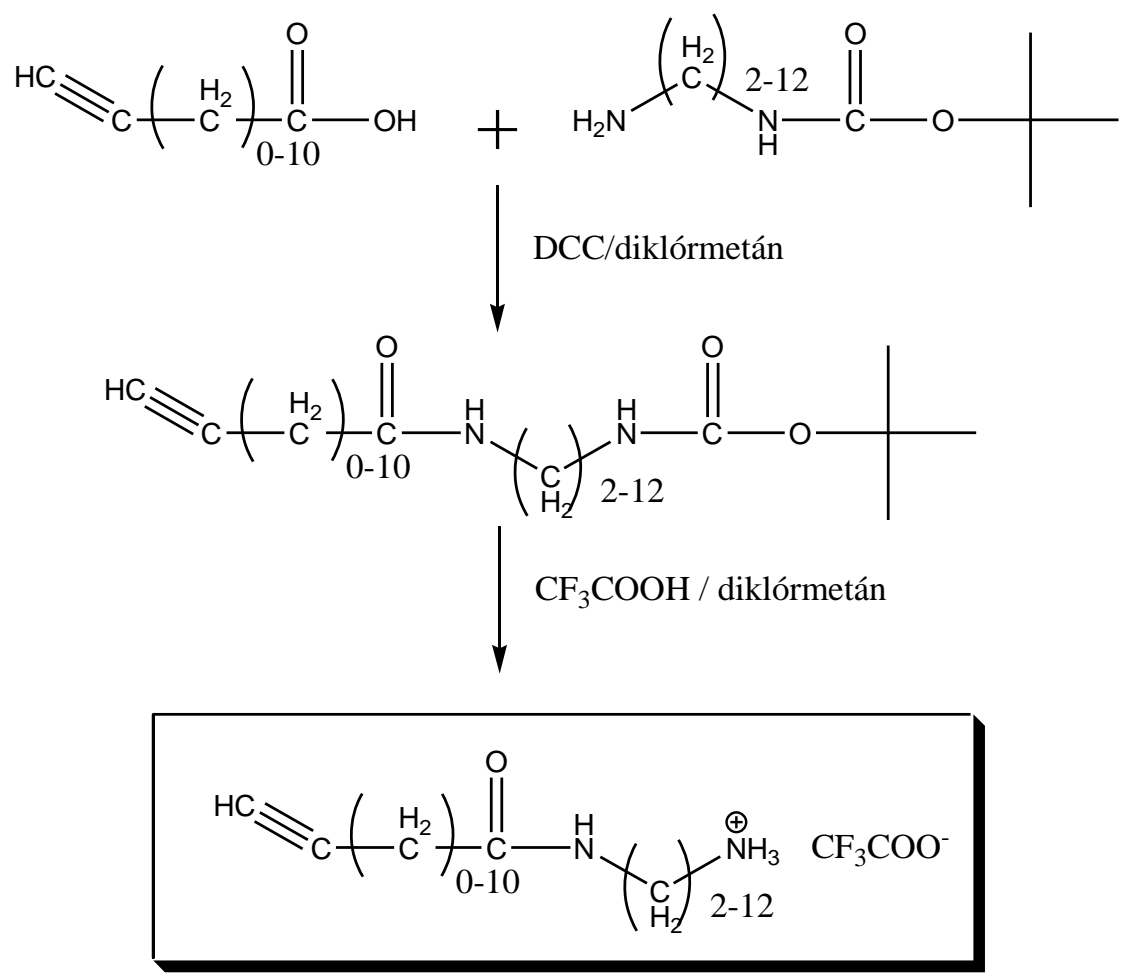


II. Védett nukleozid koenzimmimikáló molekuláris építőelemek általános szintézise:

3. reakcióvázlat
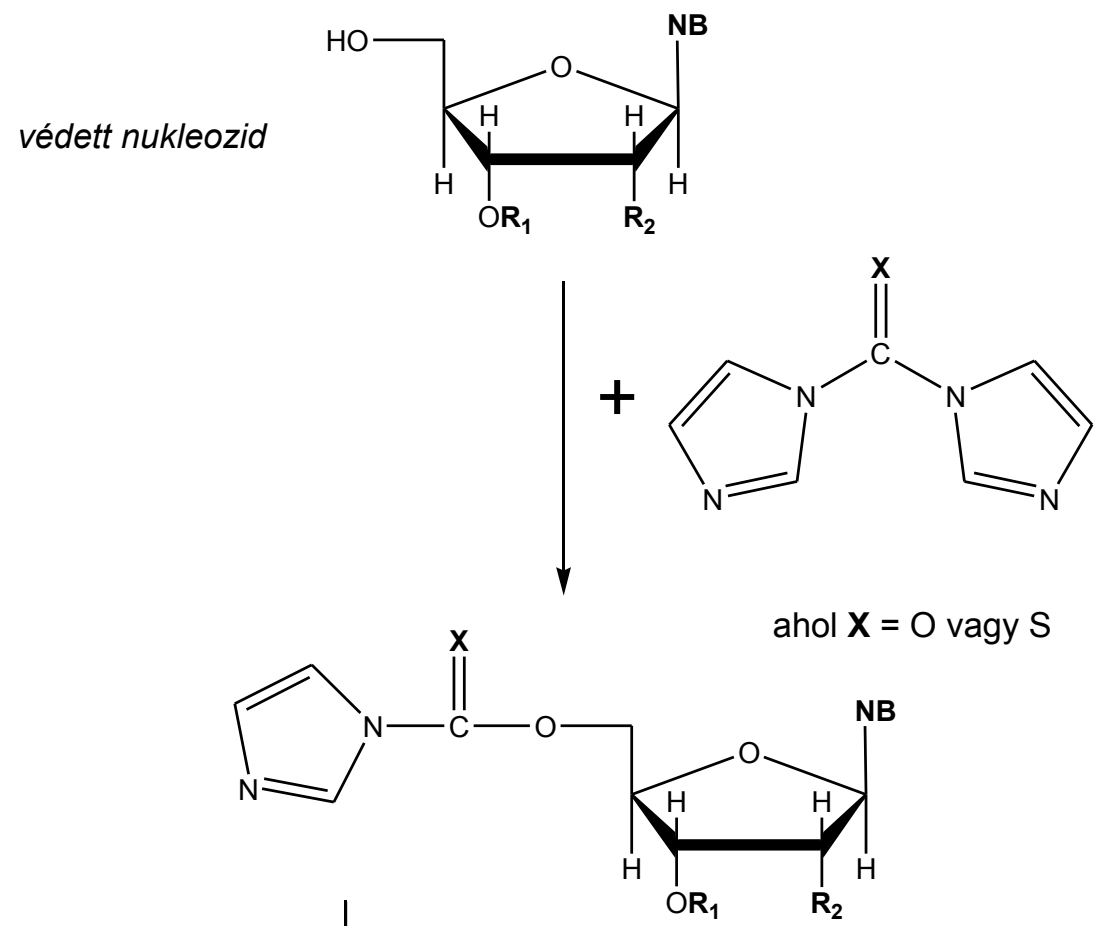

$+\quad \mathrm{F}-\mathrm{L}-\mathrm{NH}_{2}$

horgony funkciós csoportot $(F)$ tartalmazó, másik végén aminocsoportot hordozó linker $(\mathrm{L})$

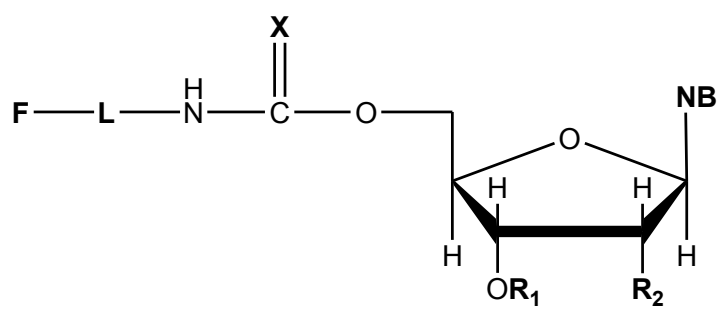

kész, védett nukleozid koenzimmimikáló építőelem

$\mathbf{R}_{\mathbf{1}}=\mathrm{PG}_{1}$ védőcsoport

$\mathbf{R}_{\mathbf{2}}=\mathrm{H}$ vagy $\mathrm{O}-\mathrm{PG}_{2}$, ahol $P \mathrm{PG}_{2}=$ védőcsoport

$\mathbf{X}=\mathrm{O}$ vagy $\mathrm{S}$

NB = a korábban már említett védett nukleobázisok egyike 
III. A nem védett nukleozid építőelemek megkaphatók a fenti védett nukleozidok lúgos hidrolízisével, amit például végrehajthatunk metanolban készült 2M ammónia oldattal, melynek során a nukleozid 2' és/vagy 3' hidroxicsoportjait, valamint a nukleobázis aromás aminocsoportjait szabadítjuk fel az alkalmazott $\mathrm{PG}_{1}, \mathrm{PG}_{2}, \mathrm{PG}_{3}$ védőcsoportok eltávolításával.

\section{PÉLDÁK}

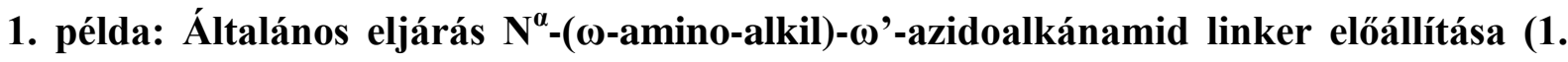 reakcióvázlat)}

0,1 mol $\omega$-Brómalkánsav-metilésztert és $0,11 \mathrm{~mol}$ (1,1 ekvivalens) nátrium-azidot $50 \mathrm{ml}$ $N, N$-dimetil-formamidban szobahőmérsékleten, 2,5 órán át kevertetünk, majd ekvivalens mennyiségű vizet hozzáadva, a kapott elegyet extraháljuk háromszor etil-acetáttal. A szerves fázist hatszor mossuk vízzel, majd nátrium-szulfáton szárítjuk és vákuumban bepároljuk.

A kapott nyerstermékhez 10 ekvivalens $\alpha, \omega$-diaminoalkánt adunk $50 \mathrm{ml}$ metanolban oldva, melyet egy éjszakán át szobahőmérsékleten kevertetünk. Ezután vákuumban bepároljuk az oldatot, majd háromszor $50 \mathrm{ml}$ acetonitrillel is, majd feloldjuk $100 \mathrm{ml}$ etil-acetátban és $10 \%$ os vizes nátrium-hidrogén-karbonát oldattal hatszor extraháljuk. A szerves fázist nátriumszulfáton szárítjuk, majd vákuumban bepároljuk és rövid szénláncú diamin (szénatomszám: 23) alkalmazása esetén további tisztítás nélkül használjuk, hosszabb szénláncú diamin esetén pedig szilikagél oszlopkromatográfiával tisztítjuk.

A fenti általános példa szerinti előállítást ismertet az 2. példa.

2. példa: $N$-(3-amino-propil)-2-azido-acetamid előállítása (Konkrét példa az 1. példában említett azido-alkilamido-alkilamin linkermolekula előállítására.)

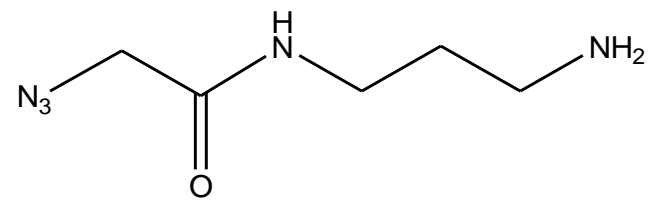

$13 \mathrm{~g}$ (85 mmol) Brómecetsav-metilésztert és 5,85 g (90 mmol, 1,06 ekv.) nátrium-azidot $20 \mathrm{ml} N, N$-dimetil-formamidban szobahőmérsékleten, 2,5 órán át kevertettünk, majd ekvivalens mennyiségü vizet hozzáadva, a kapott elegyet extraháltuk háromszor etil-acetáttal. A szerves fázist hatszor mostuk vízzel, majd nátrium-szulfáton szárítottuk és vákuumban bepároltuk. 
A kapott nyerstermék metil-azidoacetáthoz (3,6 g, $31 \mathrm{mmol}) 10$ ekvivalens (26 ml) 1,3diamino-propánt adtunk $25 \mathrm{ml}$ metanolban oldva, melyet egy éjszakán át szobahőmérsékleten kevertettünk. Ezután vákuumban bepároltuk az oldatot, majd háromszor $50 \mathrm{ml}$ acetonitrillel is, hogy a maradék amint eltávolítsuk, majd feloldottuk $100 \mathrm{ml}$ etil-acetátban és 10\%-os vizes nátrium-hidrogén-karbonát oldattal hatszor extraháltuk. A szerves fázist nátrium-szulfáton szárítottuk, majd vákuumban bepároltuk.

A tisztítás után kapott termék egy olaj $(4,4 \mathrm{~g}, 90 \%) ;{ }^{1} \mathrm{H}-\mathrm{NMR}\left(\mathrm{DMSO}-\mathrm{d}_{6}\right) ; \delta[\mathrm{ppm}]=1.51$ $(\mathrm{t}, 2 \mathrm{H}, J=6.0 \mathrm{~Hz}, J=6.5 \mathrm{~Hz})$ és $2.56(\mathrm{~m}, 2 \mathrm{H})$ és $3.13(\mathrm{~m}, 2 \mathrm{H})$ és $3.79(\mathrm{~s}, 2 \mathrm{H}): 4 \times \mathrm{CH}_{2}, 6.30(\mathrm{br}$ $\left.\mathrm{s}, 2 \mathrm{H}, \mathrm{NH}_{2}\right), 8.19(\mathrm{~s}, 1 \mathrm{H}, \mathrm{CO}-\underline{\mathrm{NH}}) ;{ }^{13} \mathrm{C}-\mathrm{NMR}\left(\mathrm{DMSO}-\mathrm{d}_{6}\right) ; \delta[\mathrm{ppm}]=31.9$ és 36.3 és 38.5 és 50.8: $4 \times \mathrm{CH}_{2}, 167.0(\underline{\mathrm{CO}}-\mathrm{NH})$; ESI-MS: $158[\mathrm{M}+\mathrm{H}]^{+}$

\section{3. példa: Általános eljárás $\mathbf{N}^{\alpha}$-( $\omega$-aminoalkil)- $\omega$-alkinamid linker előállítása (2. reakcióvázlat)}

Argon atmoszférában $-40^{\circ} \mathrm{C}$-ra hütött $0,01 \mathrm{~mol} \omega$-alkinsav $10 \mathrm{ml}$ vízmentes diklórmetános oldatához 1 ekvivalens $(0,01 \mathrm{~mol})$ diciklohexilkarbodiimidet adunk szeptumon keresztül, melyet előzetesen $10 \mathrm{ml}$ vízmentes diklórmetánban oldunk és szintén argon alatt $-40^{\circ} \mathrm{C}$-ra hütünk, majd 5 perc múlva hozzáadjuk folyamatos kevertetés mellett, szeptumon keresztül az $\alpha$-N-tercbutiloxikarbonil, $\omega$-diaminoalkán $\quad(0,0085$ mol, 0,085 ekvivalens $) \quad$ vízmentes diklórmetános oldatát $(10 \mathrm{ml})$, melyet előzetesen argon alatt $-40^{\circ} \mathrm{C}$-ra hütöttünk és 3 órán át kevertetjük, miközben a reakcióelegy hőmérséklete szobahőmérsékletre melegszik. A kapott csapadékos oldathoz $100 \mathrm{ml}$ dietilétert adunk, majd a kapott elegyet leszürjük és a szürletet bepároljuk. A kapott halványsárga olajos nyersterméket szilikagél oszlopkromatográfiával tisztítjuk etilacetát/diklórmetán eluenselegyel 20-60\% etilacetát gradiens alkalmazásával.

A kapott tercbutiloxikarbonil-védett linkert $50 \mathrm{ml} 50 \%$-os diklórmetános trifluorecetsavoldatban oldjuk, majd 1,5 óra múlva a reakcióelegyet bepároljuk. Ezáltal megkapjuk a kívánt $\mathrm{N}^{\alpha}$-( $\omega$-aminoalkil)- $\omega$ '-alkinamid linker trifluorecetsavas sóját, melyet a nukleozidok szintéziséhez úgy használunk, hogy 1,5 ekvivalens diizopropiletilaminnal szabadítjuk fel a sójából a linker-só közvetlenül a reakcióelegyhez történő hozzáadása után.

A fenti általános példa szerinti előállítást ismertet a 4. példa. 
4. példa: $N$-(3-aminopropil)-2-propinamid előállítása (Konkrét példa az 3. példában említett $\mathrm{N}^{\alpha}$-( $\omega$-aminoalkil)- $\omega$ '-alkinamid linker linkermolekula előállítására.)

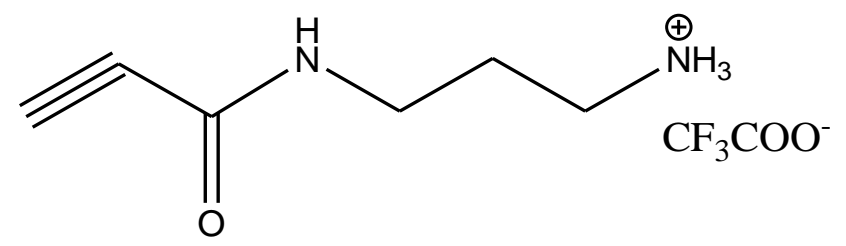

Argon atmoszférában $-40^{\circ} \mathrm{C}$-ra hütött $0,7 \mathrm{~g}(0,01 \mathrm{~mol})$ 2-propinsav $10 \mathrm{ml}$ vízmentes diklórmetános oldatához 2,06g (0,01 mol, 1 ekvivalens) diciklohexilkarbodiimidet adunk szeptumon keresztül, melyet előzetesen $10 \mathrm{ml}$ vízmentes diklórmetánban oldunk és szintén argon alatt $-40^{\circ} \mathrm{C}$-ra hủtünk, majd 5 perc múlva hozzáadjuk folyamatos kevertetés mellett, szeptumon keresztül az N-tercbutiloxikarbonil-diaminopropán (1.48 g, 0,0085 mol, 0,085 ekvivalens) vízmentes diklórmetános oldatát $(10 \mathrm{ml})$, melyet előzetesen argon alatt $-40^{\circ} \mathrm{C}$-ra hütöttünk és 3 órán át kevertetjük, miközben a reakcióelegy hőmérséklete szobahőmérsékletre melegszik. A kapott csapadékos oldathoz $100 \mathrm{ml}$ dietilétert adunk, majd a kapott elegyet leszürjük és a szürletet bepároljuk. A kapott halványsárga olajos nyersterméket szilikagél oszlopkromatográfiával tisztítjuk etilacetát/diklórmetán eluenselegyel 20-60\% etilacetát gradiens alkalmazásával.

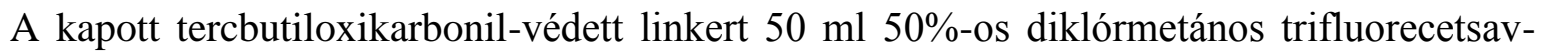
oldatban oldjuk, majd 1,5 óra múlva a reakcióelegyet bepároljuk. Ezáltal megkapjuk a kívánt N-(3-aminopropil)-2-propinamid linker trifluorecetsavas sóját, melyet a nukleozidok szintéziséhez úgy használunk, hogy 1,5 ekvivalens diizopropiletilaminnal szabadítjuk fel a sójából a linker-só közvetlenül a reakcióelegyhez történő hozzáadása után.

A tisztítás után kapott termék egy olaj $(1.5 \mathrm{~g}, 74 \%) ;{ }^{1} \mathrm{H}$ NMR $\left(\mathrm{CD}_{3} \mathrm{CN}\right) \delta[\mathrm{ppm}]=7.44(\mathrm{~s}$, $1 \mathrm{H}, \mathrm{CON} \underline{\mathrm{H}}$ ), $3.33\left(\mathrm{~m}, 3 \mathrm{H}, \mathrm{CONHC}_{2}\right.$ és $\underline{\mathrm{H}}$ ), 2.95 (ddt, $2 \mathrm{H}, J=13.0 \mathrm{~Hz}, J=7.0 \mathrm{~Hz}, J=6.0 \mathrm{~Hz}$, $\left.\mathrm{CH}_{2} \mathrm{NH}_{2}\right), 1.89\left(\mathrm{~m}, 2 \mathrm{H}, \mathrm{CH}_{2} \mathrm{CH}_{2} \mathrm{CH}_{2}\right) ;{ }^{13} \mathrm{C}-\mathrm{NMR}\left(\mathrm{CD}_{3} \mathrm{CN}\right) ; \delta[\mathrm{ppm}]=27.5,36.6,38.3: 3 \times \mathrm{CH}_{2}$, $75.7(\mathrm{C} \equiv \underline{\mathrm{CH}}), 77.5(\underline{\mathrm{C}} \equiv \mathrm{CH}), 115.4\left(\underline{\mathrm{CF}}_{3} \mathrm{COOH}\right), 154.5(\mathrm{CO}), 160.2$ és 160.6: $\left(\mathrm{CF}_{3} \underline{\mathrm{COOH}}\right)$; ESI-MS: $127[\mathrm{M}+\mathrm{H}]^{+}$

5. példa: Általános eljárás 5'-hidroxicsoportot tartalmazó, védett nukleozidok kapcsolására F-L- $\mathrm{NH}_{2}$ általános képletű linkerrel (3. reakcióvázlat; találmány szerinti védett nukleozid koenzimmimikáló molekuláris építőelemek általános előállítása) 
0,5 mmol Nukleozidot $5 \mathrm{ml}$ vízmentes $N, N$-dimetil-formamidban feloldunk, majd 1,4 ekvivalens $(0,7 \mathrm{mmol}) N, N^{\prime}$-karbonil-diimidazolt (tiokarbamát kötés létesítése esetén ehelyett $N, N$ '-tiokarbonil-diimidazolt) és 0,1 ekvivalens $(0,05 \mathrm{mmol}, 6,1 \mathrm{mg}) 4-N, N$-dimetilaminopiridint adunk hozzá, majd 6 órán át szobahőmérsékleten kevertetjük. Ezután 2 ekvivalens (1 mmol) F-L- $\mathrm{NH}_{2}$ linkert adunk az elegyhez és további 16 órán át kevertetjük. A reakciót az alkalmazott aminnal ekvivalens mennyiségü vizes kálium-hidrogén-szulfát-oldat hozzáadásával állítjuk le, majd az elegyet vákuumban bepároljuk, amit megismételünk acetonitril hozzáadásával is három alkalommal. A kapott olajszerű anyagot etil-acetátban oldjuk és 5\%-os vizes kálium-hidrogén-szulfát-oldattal háromszor extraháljuk, majd a szerves fázist egy nátrium-szulfátos szárítás után vákuumban bepároljuk. A kapott nyersterméket szilikagél oszlopkromatográfiával tisztítjuk etil-acetát/acetonitril $(9: 1 \mathrm{v} / \mathrm{v})$ vagy etilacetát/metanol $(9: 1 \mathrm{v} / \mathrm{v})$ eluenssel.

A fenti általános példát a 6. példa tovább specifikálja N-(3-amino-propil)-2-azido-acetamid linkerre.

A 8-25. példákban bemutatott vegyületek előállítása a fenti általános eljárással történt (a megfelelő nukleozid és F-L-NH $\mathbf{N H}_{2}$ linker alkalmazása mellett).

\section{6. példa: Általános eljárás 5'-hidroxicsoportot tartalmazó, védett nukleozidok kapcsolására $N$-(3-amino-propil)-2-azido-acetamid linkerrel}

0,5 mmol Nukleozidot $5 \mathrm{ml}$ vízmentes $N, N$-dimetil-formamidban oldottunk, majd 1,4 ekvivalens $(0,7 \mathrm{mmol}, 113 \mathrm{mg}) N, N^{\prime}$-karbonil-diimidazolt és 0,1 ekvivalens $(0,05 \mathrm{mmol}, 6,1$ mg) 4-N,N-dimetilamino-piridint adtunk hozzá és 6 órán át szobahőmérsékleten kevertettük. Ezután 2 ekvivalens (1 mmol, $157 \mathrm{mg})$ 2. példa szerinti $N$-(3-amino-propil)-2-azido-acetamid linkert adtunk hozzá és további 16 órán át kevertettük. A reakciót az alkalmazott aminnal ekvivalens mennyiségü vizes kálium-hidrogén-szulfát-oldat hozzáadásával állítottuk le, majd az elegyet vákuumban bepároltuk, amit megismételtünk acetonitril hozzáadásával is három alkalommal. A kapott olajszerü anyagot etil-acetátban oldottuk és 5\%-os vizes káliumhidrogén-szulfát-oldattal háromszor extraháltuk, majd a szerves fázist egy nátrium-szulfátos szárítás után vákuumban bepároltuk. A kapott nyersterméket szilikagél oszlopkromatográfiával tisztítottuk etil-acetát/acetonitril $(9: 1 \mathrm{v} / \mathrm{v})$ vagy etil-acetát/metanol (9:1 v/v) eluenssel. 
A 8-11. példákban bemutatott vegyületek elöállítása a fenti általános eljárással történt (a megfelelő nukleozid alkalmazása mellett).

\section{7. példa: Általános eljárás linkertartalmú nukleozidszármazékok védőcsoportjainak} eltávolítására (találmány szerinti nem védett nukleozid koenzimmimikáló molekuláris építőelemek általános előállítása)

Az 5. illetve 6. példa szerint előállított $0,2 \mathrm{mmol}$ acilvédőcsoportokat tartalmazó linkertartalmú nukleozidszármazékot feloldunk $10 \mathrm{ml} 2 \mathrm{M}$ koncentrációjú metanolos ammóniaoldatban, majd az elegyet lezárjuk és egy éjszakán át kevertetjük szobahőmérsékleten. Ezután az elegyet vákuumban bepároljuk és a kapott nyersterméket szilikagél oszlopkromatográfiával tisztítjuk etil-acetát/acetonitril vagy etil-acetát/metanol eluenssel. Guanin tartalmú nukleozidok esetében ahol szükséges, ott izopropanol/víz/acetonitril 2:1:8 elegyet használunk a kromatográfiához.

A 26-43. példákban bemutatott vegyületek előállítása a fenti általános eljárással történt.

\section{8. példa:}

\section{3'-O-Acetil-5'-O-((3-(2-azidoacetamido)propil)karbamoil)- $N^{6}$-benzoil-2'-dezoxiadenozin}

Védett 2'-dezoxiadenozin alapú, azidometil végü, karbamát kötésű, alkil-amidoalkil linkeres építőelem.

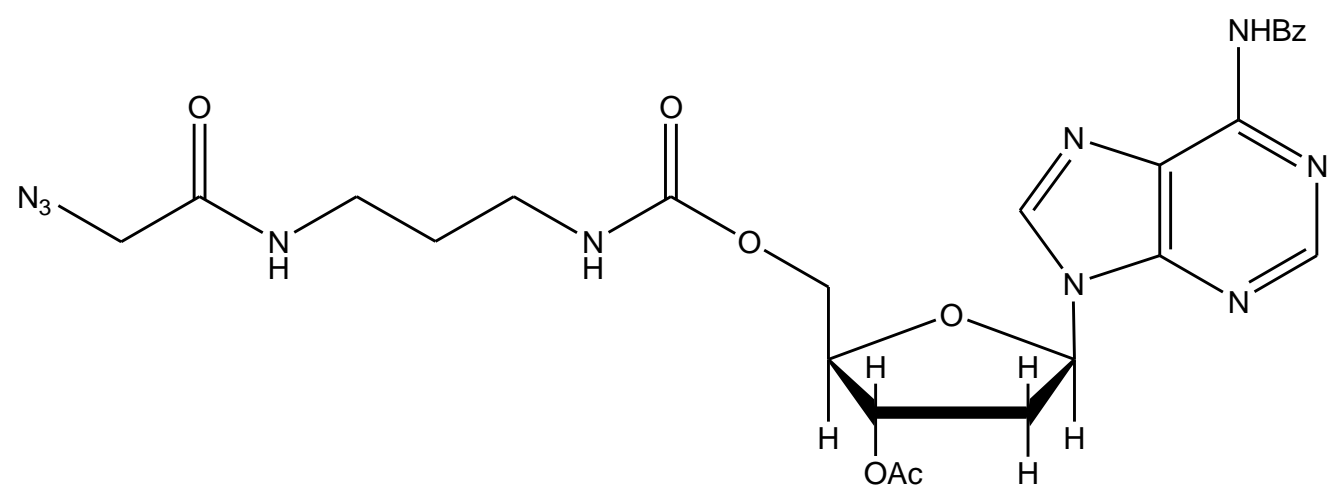

Amorf hab (232 mg, 80\%), $R_{\mathrm{f}}=0.43$ (EtOAc:MeOH/95:5); ${ }^{1} \mathrm{H}-\mathrm{NMR}\left(\mathrm{DMSO}-\mathrm{d}_{6}\right) ; \delta[\mathrm{ppm}]=2.12$ (s, 3H, OAc), $1.55(\mathrm{~m}, 2 \mathrm{H})$ és $2.99(\mathrm{~m}, 2 \mathrm{H})$ és $3.08(\mathrm{~m}, 2 \mathrm{H})$ és $3.79(\mathrm{~s}, 2 \mathrm{H})$ : linker $4 \times \mathrm{CH}_{2}, 2.62$ (d, 2H, J=12.0 Hz, 2'- $\mathrm{H}_{2}$ ), 4.17 (dd, 1H, J=6.5 Hz, J=10.0 Hz, 3'-H), 4.28 (m, 2H, 5'- $\mathrm{H}_{2}$ ), 5.40 $\left(\mathrm{m}, 1 \mathrm{H}, 4^{\prime}-\mathrm{H}\right), 6.52\left(\mathrm{~m}, 1 \mathrm{H}, 1^{\prime}-\mathrm{H}\right), 7.30(\mathrm{~m}, 1 \mathrm{H})$ és $7.57(\mathrm{dd}, 2 \mathrm{H}, J=2 \times 7.0 \mathrm{~Hz})$ és $7.66(\mathrm{dd}, 1 \mathrm{H}$, 
$J=6.0 \mathrm{~Hz}, J=7.0 \mathrm{~Hz})$ és $8.06(\mathrm{~d}, 3 \mathrm{H}, J=6.5 \mathrm{~Hz})$ : benzoil protonok és linker $2 \times \mathrm{NH}, 8.68(\mathrm{~s}, 1 \mathrm{H})$ és $8.78(\mathrm{~s}, 1 \mathrm{H})$ : 2-H és $8-\mathrm{H}, 11.22(\mathrm{~s}, 1 \mathrm{H}, 6-\mathrm{NH}) ;{ }^{13} \mathrm{C}-\mathrm{NMR}\left(\mathrm{DMSO}_{\mathrm{d}}\right) ; \delta[\mathrm{ppm}]=20.8(\mathrm{OAc})$, 29.2 és 35.6 és 38.0 és 50.7: linker $4 \times \mathrm{CH}_{2}, 36.3$ (C-2'), 63.7 (C-5'), 74.5 (C-3’), 82.2 (C-4'), 83.4 (C-1'), 125.7 (C-5), 128.4 (2C), 128.5 (2C), 132.4, 133.2, 142.5 (C-8), 150.4 (C-4), 151.7 (C-2), 152.0 (C-6), 155.7 és 159.3: 2×linker-CO, 167.1 (Bz-CO), 169.9 (Ac-CO); ESI-MS: 581 $[\mathrm{M}+\mathrm{H}]^{+}$.

A fenti és a további képletekben Ac jelentése acetil, illetve Bz jelentése benzoil.

\section{9. példa:}

3'-O-Acetil-5'-O-((3-(2-azidoacetamido)propil)karbamoil)-2'-dezoxi- $\boldsymbol{N}^{2}$-izobutirilguanozin

Védett 2'-dezoxiguanozin alapú, azidometil végü, karbamát kötésü, alkil-amidoalkil linkeres építőelem.

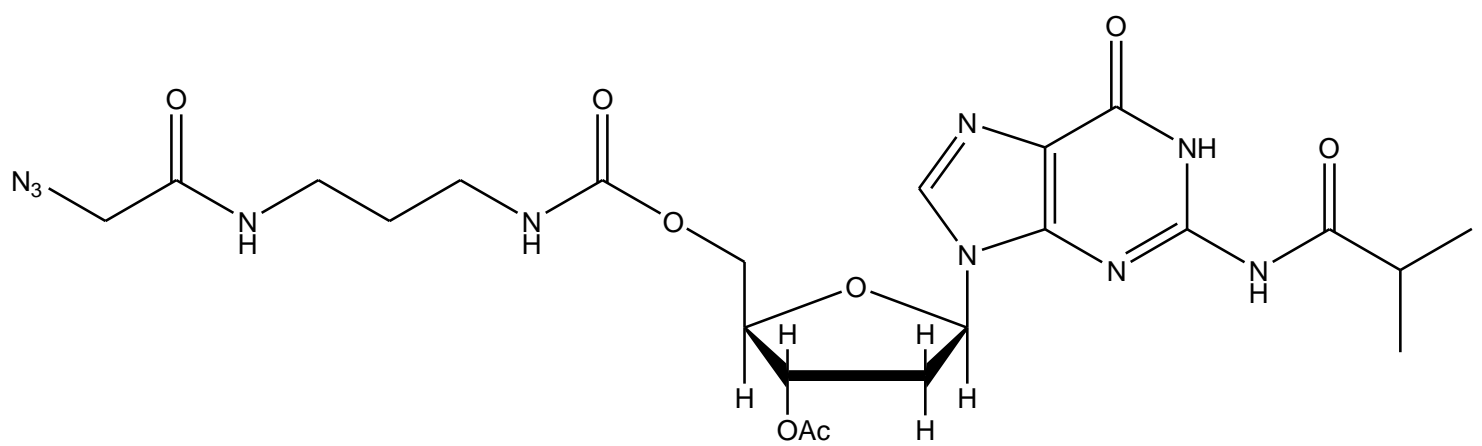

Amorf hab (233 mg, 83\%), $R_{\mathrm{f}}=0.2$ (EtOAc:MeOH/95:5); ${ }^{1} \mathrm{H}-\mathrm{NMR}\left(\mathrm{DMSO}-\mathrm{d}_{6}\right) ; \delta[\mathrm{ppm}]=1.13$ (d, $\left.6 \mathrm{H}, J=6.5 \mathrm{~Hz}, 2 \times \mathrm{iBu}_{-} \mathrm{CH}_{3}\right), 2.08(\mathrm{~s}, 3 \mathrm{H}, \mathrm{OAc}), 1.57(\mathrm{dd}, 2 \mathrm{H}, J=6.5 \mathrm{~Hz}, J=7.0 \mathrm{~Hz}$ ) és 3.00 $(\mathrm{m}, 3 \mathrm{H})$ és $3.10(\mathrm{~m}, 2 \mathrm{H})$ és $3.80(\mathrm{~s}, 2 \mathrm{H})$ : linker $4 \times \mathrm{CH}_{2}$ és 3'- $\mathrm{H}, 2.79(\mathrm{~m}, 1 \mathrm{H})$ és $2.94(\mathrm{~m}, 1 \mathrm{H})$ : 2'- $\mathrm{H}_{2}, 4.13(\mathrm{~m}, 1 \mathrm{H})$ és 4.21 (m, 2H): iBu-CH és 5'- $\mathrm{H}_{2}, 5.29$ (d, 1H, $J=4.5 \mathrm{~Hz}, 4$ '- $\left.-\mathrm{H}\right), 6.23$ (dd, $1 \mathrm{H}, J=7.0 \mathrm{~Hz}, J=7.5 \mathrm{~Hz}, 1$ '-H), 7.33 (m, 1H) és 8.08 (m, 1H): linker 2×NH, $8.22(\mathrm{~s}, 1 \mathrm{H}, 8-\mathrm{H})$, $11.66(\mathrm{~s}, 1 \mathrm{H}, \mathrm{iBu}-\mathrm{NH}), 12.07$ (s, 1H, 1-NH); ${ }^{13} \mathrm{C}-\mathrm{NMR}\left(\mathrm{DMSO}_{6}\right) ; \delta[\mathrm{ppm}]=18.9(2 \mathrm{C}, 2 \times \mathrm{iBu}-$ $\mathrm{CH}_{3}$ ), 20.9 (OAc), 29.4 és 36.0 és 38.1 és 50.9: linker $4 \times \mathrm{CH}_{2}, 34.8(\mathrm{iBu}-\mathrm{CH}), 36.4(\mathrm{C}-2$ '), 63.7 (C-5'), 74.7 (C-3'), 82.3 (C-4'), 82.8 (C-1'), 120.3 (C-5), 137.2 (C-8), 148.3 (C-4), 148.7 (C-2), 154.8 és 167.2: 2×linker-CO, 155.8 (C-6), 170.0 (Ac-CO), 180.2 (iBu-CO); ESI-MS: 563 $[\mathrm{M}+\mathrm{H}]^{+}$. 
10. példa:

\section{2',3'-Di- $O$-acetil-5' $-O$-((3-(2-azidoacetamido)propil)karbamoil)- $N^{6}$-benzoiladenozin}

Védett adenozin alapú, azidometil végü, karbamát kötésü, alkil-amidoalkil linkeres építőelem.

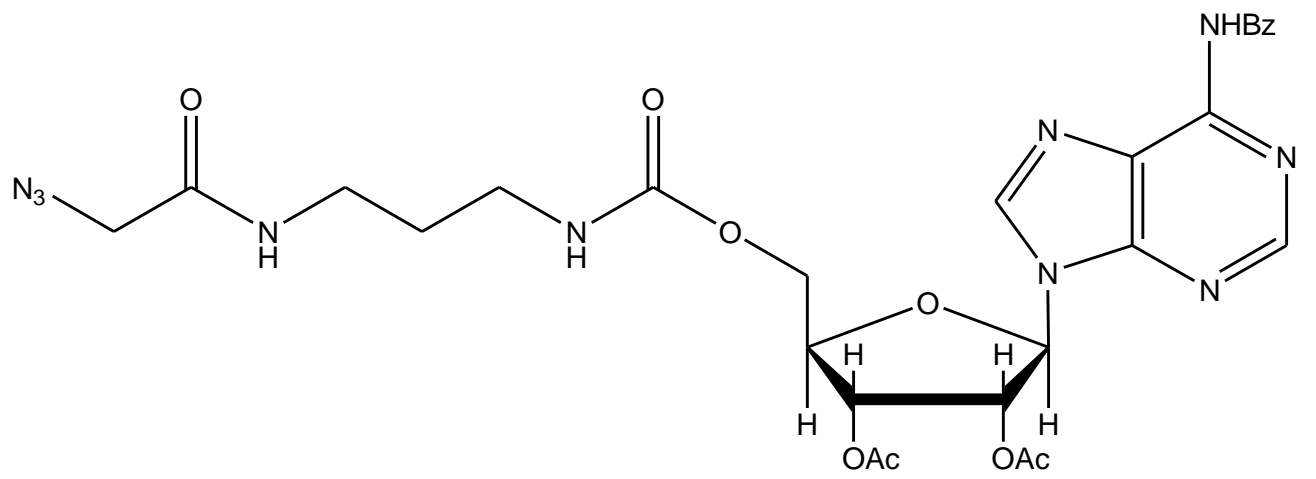

Amorf hab (255 mg, 80\%), $R_{\mathrm{f}}=0.41$ (EtOAc); ${ }^{1} \mathrm{H}-\mathrm{NMR}\left(\mathrm{DMSO}_{\mathrm{d}}\right.$ ); $\delta$ [ppm]=2.04 és 2.15 $(2 \times \mathrm{s}, 2 \times 3 \mathrm{H}, 2 \times \mathrm{OAc}), 1.57(\mathrm{t}, 2 \mathrm{H}, J=2 \times 6.0 \mathrm{~Hz})$ és $2.73(\mathrm{~s}, 1 \mathrm{H})$ és $2.89(\mathrm{~s}, 1 \mathrm{H})$ és $3.09(\mathrm{~d}, 2 \mathrm{H}$, $J=5.5 \mathrm{~Hz})$ és $3.79(\mathrm{~s}, 2 \mathrm{H})$ : linker $4 \times \mathrm{CH}_{2}, 3.00\left(\mathrm{~d}, 2 \mathrm{H}, J=5.0 \mathrm{~Hz}, 5^{\prime}-\mathrm{H}_{2}\right), 4.26(\mathrm{dd}, 1 \mathrm{H}, J=2.5$ $\left.\mathrm{Hz}, J=5.0 \mathrm{~Hz}, 4^{\prime}-\mathrm{H}\right), 5.60(\mathrm{~m}, 1 \mathrm{H})$ és $6.03(\mathrm{~m}, 1 \mathrm{H})$ : 2'-H és 3'-H, 6.37 (d, 1H, J=4.0 Hz, 1'$\mathrm{H}), 7.33(\mathrm{~m}, 1 \mathrm{H})$ és $7.57(\mathrm{dd}, 2 \mathrm{H}, J=7.0 \mathrm{~Hz}, J=7.5 \mathrm{~Hz})$ és $7.67(\mathrm{dd}, 1 \mathrm{H}, J=7.0 \mathrm{~Hz}, J=7.5 \mathrm{~Hz})$ és $8.06(\mathrm{~d}, 3 \mathrm{H}, J=7,0 \mathrm{~Hz})$ : benzoil protonok és linker $2 \times \mathrm{NH}, 8.71(\mathrm{~s}, 1 \mathrm{H})$ és $8.79(\mathrm{~s}, 1 \mathrm{H}): 2-\mathrm{H}$ és 8-H, $11.26(\mathrm{~s}, 1 \mathrm{H}, 6-\mathrm{NH}) ;{ }^{13} \mathrm{C}-\mathrm{NMR}\left(\mathrm{DMSO}_{-} \mathrm{d}_{6}\right) ; \delta[\mathrm{ppm}]=20.1$ és $20.3(2 \times \mathrm{OAc}), 29.2$ és 36.3 és 38.0 és 50.7: linker $4 \times \mathrm{CH}_{2}, 62.9$ (C-5’), 70.3 (C-2’), 72.0 (C-3'), 80.2 (C-4'), 85.1 (C1'), 125.6 (C-5), 128.40 (2C), 128.42 (2C), 132.4, 133.1, 139.2 (C-8), 150.5 (C-4), 151.9 és 167.1: 2×linker-CO, 154.3 (C-2), 155.6 (C-6), 165.1 (Bz-CO), 169.2 és 169.4 (2×Ac-CO); ESI-MS: $639[\mathrm{M}+\mathrm{H}]^{+}$.

11. példa:

2',3'-Di-O-acetil-5'-O-((3-(2-azidoacetamido)propil)karbamoil)- $N^{2}$-izobutirilguanozin

Védett guanozin alapú, azidometil végü, karbamát kötésü, alkil-amidoalkil linkeres építőelem.<smiles>CC(C)C(=O)Nc1nc2c(ncn2[C@H]2O[C@H](COC(=O)NCCCNC(=O)CN)[C@@H](O)[C@H](O)[C@H]2O)c(=O)[nH]1</smiles> 
Amorf hab (236 mg, 76\%), $R_{\mathrm{f}}=0.14$ (EtOAc:MeOH/95:5); ${ }^{1} \mathrm{H}-\mathrm{NMR} \quad\left(\mathrm{DMSO}-\mathrm{d}_{6}\right) ; \delta$ $[\mathrm{ppm}]=1.14\left(\mathrm{~d}, 6 \mathrm{H}, J=6.5 \mathrm{~Hz}, 2 \times \mathrm{iBu}-\mathrm{CH}_{3}\right), 2.02$ és $2.13(2 \times \mathrm{s}, 2 \times 3 \mathrm{H}, 2 \times \mathrm{OAc}), 1.59(\mathrm{t}, 2 \mathrm{H}$, $J=6.5 \mathrm{~Hz}, J=7.0 \mathrm{~Hz})$ és $3.03(\mathrm{dd}, 2 \mathrm{H}, J=2 \times 6.5 \mathrm{~Hz})$ és $3.12(\mathrm{~m}, 3 \mathrm{H})$ és $3.81(\mathrm{~m}, 2 \mathrm{H})$ : linker $4 \times \mathrm{CH}_{2}$ és iBu-CH, $4.33\left(\mathrm{~m}, 2 \mathrm{H}, 5^{\prime}-\mathrm{H}_{2}\right), 5.45$ (m, 1H, 2'-H), 5.78 (dd, $1 \mathrm{H}, J=6.0 \mathrm{~Hz}, J=7.0 \mathrm{~Hz}$, 3'-H), 6.09 (d, 1H, J=7.0 Hz, 4'-H), 7.43 (dd, 1H, J=5.0 Hz, J=5.5 Hz, 1'-H), 8.08 (s, 2H,

linker $2 \times \mathrm{NH}), 8.28(\mathrm{~s}, 1 \mathrm{H}, 8-\mathrm{H}), 11.62(\mathrm{~s}, 1 \mathrm{H}, \mathrm{iBu}-\mathrm{NH}), 12.11(\mathrm{~s}, 1 \mathrm{H}, 1-\mathrm{NH}) ;{ }^{13} \mathrm{C}-\mathrm{NMR}$

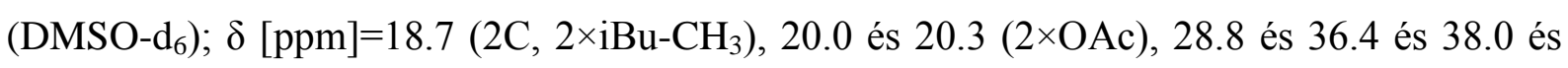
50.7: linker 4× $\mathrm{CH}_{2}, 34.7$ (iBu-CH), 63.0 (C-5'), 70.6 (C-2'), 72.1 (C-3'), 80.6 (C-4'), 83.7 (C1'), 120.1 (C-5), 137.0 (C-8), 148.4 (C-4), 148.7 (C-2), 154.6 (C-6), 155.6 és 167.1: 2×linkerCO, 169.1 és 169.3 (2×Ac-CO), $180.0(\mathrm{iBu}-\mathrm{CO})$; ESI-MS: $621[\mathrm{M}+\mathrm{H}]^{+}$.

\section{2. példa:}

\section{3'-O-Acetil-5'-O-((3-azidopropil)karbamoil)- $N^{6}$-benzoil-2'-dezoxiadenozin}

Védett 2'-dezoxiadenozin alapú, azidometil végü, karbamát kötésű, alkilén linkeres építőelem.

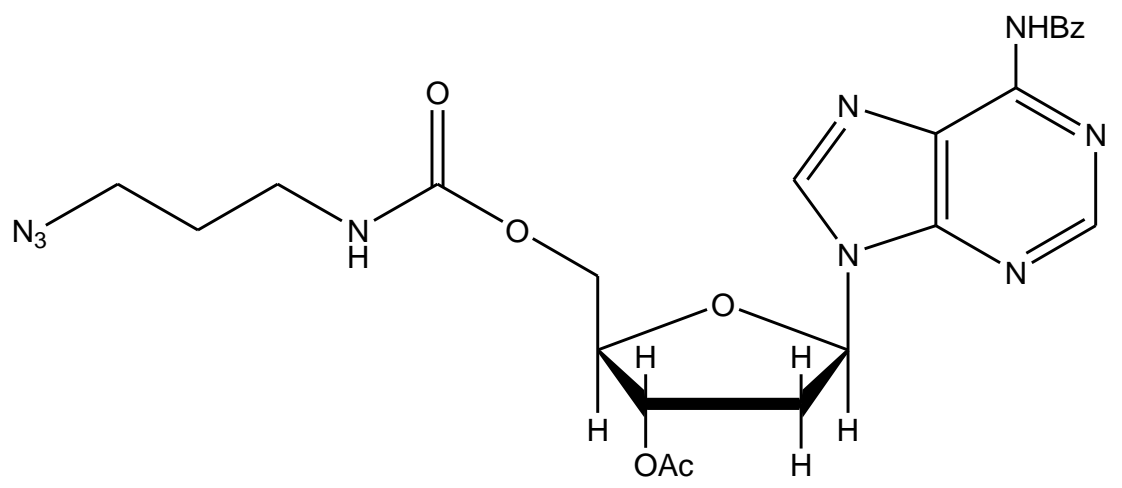

Színtelen olaj (212 mg, 81\%), $R_{\mathrm{f}}=0,57$ (EtOAc:MeOH/9:1); ${ }^{1} \mathrm{H}-\mathrm{NMR}\left(\mathrm{CD}_{3} \mathrm{CN}\right) ; \delta[\mathrm{ppm}] 1.65$ $\left(\mathrm{p}, 2 \mathrm{H}, J=6.5 \mathrm{~Hz}\right.$ ) és $3.10(\mathrm{q}, 2 \mathrm{H}, J=6.5 \mathrm{~Hz})$ és $3.29\left(\mathrm{t}, 2 \mathrm{H}, J=6.5 \mathrm{~Hz}\right.$ ): linker $3 \times \mathrm{CH}_{2}, 2.07$ (s, $3 \mathrm{H}, \mathrm{OAc}), 2.59(\mathrm{~m}, 1 \mathrm{H})$ és $2.95(\mathrm{~m}, 1 \mathrm{H}): 2^{\prime}-\mathrm{H}_{2}, 4.22(\mathrm{dd}, 1 \mathrm{H}, J=12.5 \mathrm{~Hz}, J=5.5 \mathrm{~Hz})$ és 4.32 (m, 1H): 5'- $\mathrm{H}_{2}, 5.40$ (dt, 1H, J=6.0 Hz, J=2.5 Hz, 4'-H), 5.86 (dd, $\left.1 \mathrm{H}, J=2 \times 6.0 \mathrm{~Hz}, 3^{\prime}-\mathrm{H}\right)$, $6.46\left(\mathrm{dd}, 1 \mathrm{H}, J=7.5 \mathrm{~Hz}, J=6.0 \mathrm{~Hz}, 1^{\prime}-\mathrm{H}\right), 7.50(\mathrm{t}, J=7.5 \mathrm{~Hz}, 2 \mathrm{H})$ és 7.65 (m, 1H) és 7.98 (d, $J=7.5 \mathrm{~Hz}, 2 \mathrm{H})$ : benzoil protonok, $7.33(\mathrm{~s}, 1 \mathrm{H}$, linker-NH), $8.33(\mathrm{~s}, 1 \mathrm{H})$ és $8.64(\mathrm{~s}, 1 \mathrm{H})$ : 2-H és 8-H, $9.53(\mathrm{~s}, 1 \mathrm{H}, 6-\mathrm{NH}) .{ }^{13} \mathrm{C}-\mathrm{NMR}\left(\mathrm{CD}_{3} \mathrm{CN}\right) ; \delta[\mathrm{ppm}]=21.2(\mathrm{OAc}), 29.7$ és 38.9 és 49.6: linker $3 \times \mathrm{CH}_{2}, 37.8$ (C-2'), 64.8 (C-5'), 75.3 (C-3'), 83.9 (C-4'), 85.1 (C-1'), 125.6 (C-5), 
129.1 (2C), 129.6 (2C), 133.5, 134.7, 143.0 (C-8), 150.8 (C-4), 151.3 (C-2), 152.7 (C-6), 157.0 (linker-CO), 166.3 (Bz-CO), 171.3 (Ac-CO). ESI-MS: 530 [M+Li] ${ }^{+}$.

\section{3. példa:}

\section{3'-O-Acetil-5'-O-((prop-2-in-1-il)karbamoil)- $N^{6}$-benzoil-2'-dezoxiadenozin}

Védett 2'-dezoxiadenozin alapú, etinil végü, karbamát kötésủ, alkilén linkeres építőelem.

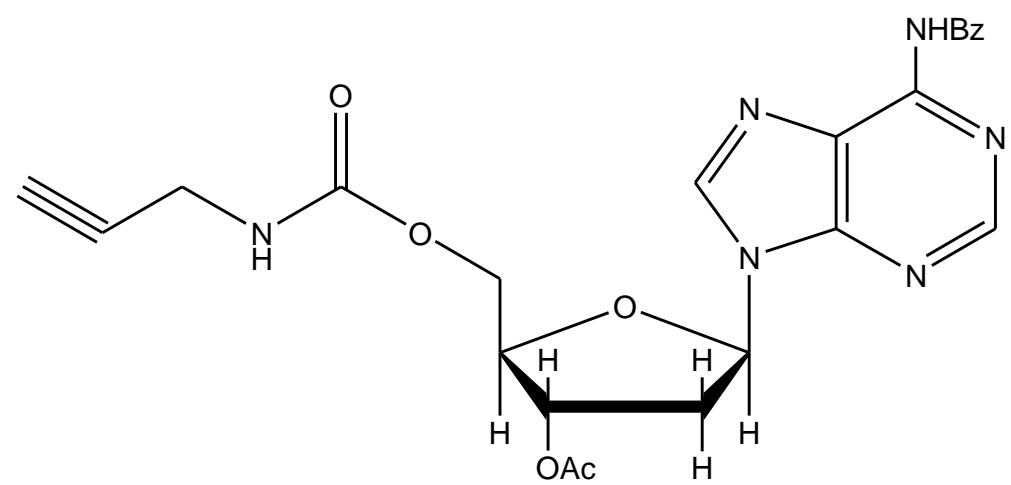

Színtelen olaj (186 mg, 78\%), $R_{\mathrm{f}}=0,54$ (EtOAc:MeOH/9:1); ${ }^{1} \mathrm{H}-\mathrm{NMR} \quad\left(\mathrm{CD}_{3} \mathrm{CN}\right) ; \delta$ $[\mathrm{ppm}]=2.07$ (s, 3H, OAc), $2.43(\mathrm{t}, 1 \mathrm{H}, J=2.5 \mathrm{~Hz}, \mathrm{C} \equiv \underline{\mathrm{CH}}), 2.63(\mathrm{~m}, 1 \mathrm{H})$ és 2.95 (dt, $1 \mathrm{H}$, $J=14.0 \mathrm{~Hz}, J=7.0 \mathrm{~Hz}$ ): 2'- $\mathrm{H}_{2}, 3.83$ (dd, $2 \mathrm{H}, J=6.0 \mathrm{~Hz}, J=2.5 \mathrm{~Hz}$, linker $\left.\mathrm{CH}_{2}\right), 4.37$ (m, 2H, 5'$\left.\mathrm{H}_{2}\right), 5.40\left(\mathrm{dt}, 1 \mathrm{H}, J=6.0 \mathrm{~Hz}, J=2.5 \mathrm{~Hz}, 4^{\prime}-\mathrm{H}\right), 6.22\left(\mathrm{~d}, 1 \mathrm{H}, J=6.5 \mathrm{~Hz}, 3^{\prime}-\mathrm{H}\right), 6.44(\mathrm{t}, 1 \mathrm{H}, J=7.0$ $\left.\mathrm{Hz}, 1^{\prime}-\mathrm{H}\right), 7.53(\mathrm{~m}, 2 \mathrm{H})$ és $7.63(\mathrm{~m}, 1 \mathrm{H})$ és 7.97 (d, 2H, $\left.J=7.5 \mathrm{~Hz}\right)$ : benzoil protonok, 7.31 (s, $1 \mathrm{H}$, linker-NH), $8.31(\mathrm{~s}, 1 \mathrm{H})$ és $8.65(\mathrm{~s}, 1 \mathrm{H}): 2-\mathrm{H}$ és $8-\mathrm{H}, 9.62(\mathrm{~s}, 1 \mathrm{H}, 6-\mathrm{NH}) .{ }^{13} \mathrm{C}-\mathrm{NMR}$ $\left(\mathrm{CD}_{3} \mathrm{CN}\right) ; \delta[\mathrm{ppm}]=21.2(\mathrm{OAc}), 31.0\left(\right.$ linker $\left.\mathrm{CH}_{2}\right), 37.7\left(\mathrm{C}-2^{\prime}\right), 65.2\left(\mathrm{C}-5^{\prime}\right), 72.0(\mathrm{C} \equiv \mathrm{CH})$, 75.3 (C-3'), $81.4(\underline{\mathrm{C}} \equiv \mathrm{CH}), 83.7$ (C-4'), 85.1 (C-1'), 125.5 (C-5), 129.1 (2C), 129.5 (2C), 133.5, 134.1, 143.1 (C-8), 150.8 (C-4), 151.2 (C-2), 152.3 (C-6), 156.7 (linker-CO), 166.4 (Bz-CO), 171.3 (Ac-CO). ESI-MS: 485 [M+Li] ${ }^{+}$.

\section{4. példa:}

\section{3'-O-Acetil-5'-O-((8-azido-3,6-dioxaoktil)karbamoil)- $N^{6}$-benzoil-2'-dezoxiadenozin}

Védett 2'-dezoxiadenozin alapú, azidometil végü, karbamát kötésű, oligo-etilénoxi linkeres építőelem. 


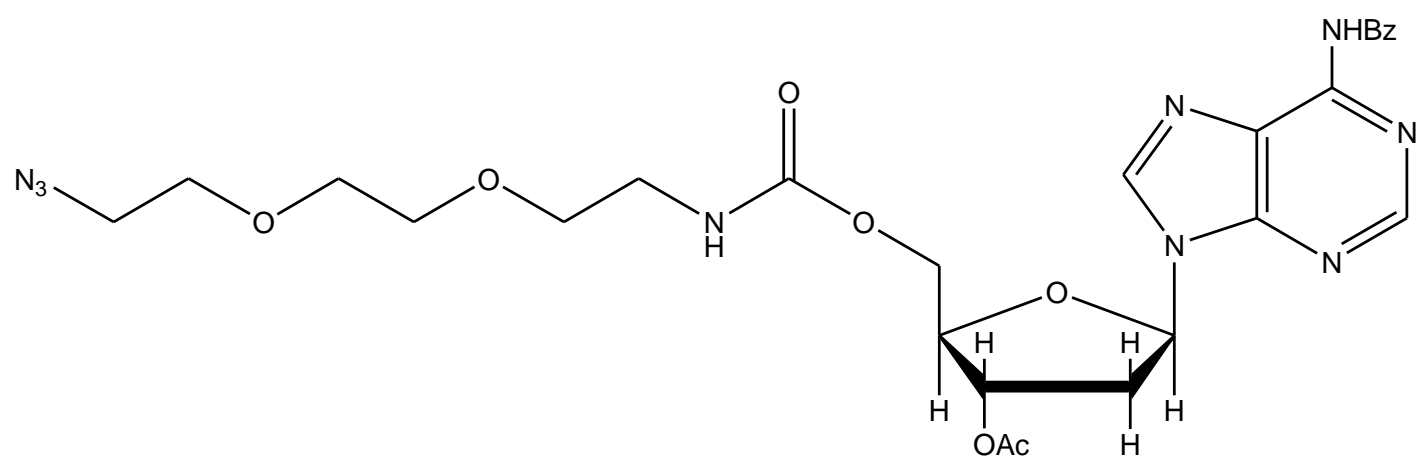

Színtelen olaj (224 mg, 75\%), $R_{\mathrm{f}}=0,48 \quad$ (EtOAc:MeOH/9:1); ${ }^{1} \mathrm{H}-\mathrm{NMR} \quad\left(\mathrm{CD}_{3} \mathrm{CN}\right) ; \delta$ $[\mathrm{ppm}]=2.07(\mathrm{~s}, 3 \mathrm{H}, \mathrm{OAc}), 2.58(\mathrm{~m}, 1 \mathrm{H})$ és $2.96(\mathrm{~m}, 1 \mathrm{H}): 2^{\prime}-\mathrm{H}_{2}, 3.25(\mathrm{~m}, 2 \mathrm{H})$ és $3.30(\mathrm{t}, 2 \mathrm{H}$, $\mathrm{J}=5.0 \mathrm{~Hz}$ ) és $3.44(\mathrm{t}, 2 \mathrm{H}, \mathrm{J}=5.5 \mathrm{~Hz}), 3.61(\mathrm{~m}, 6 \mathrm{H})$ : linker $6 \times \mathrm{CH}_{2}, 4.34\left(\mathrm{~m}, 2 \mathrm{H}, 5\right.$ ' $\left.-\mathrm{H}_{2}\right), 5.40$ (dt, $\left.1 \mathrm{H}, J=6.0 \mathrm{~Hz}, J=2.5 \mathrm{~Hz}, 4^{\prime}-\mathrm{H}\right), 5.90$ (dd, $\left.1 \mathrm{H}, J=2 \times 6.0 \mathrm{~Hz}, 3^{\prime}-\mathrm{H}\right), 6.46$ (dd, $1 \mathrm{H}, J=7.5 \mathrm{~Hz}$, $\left.J=6.0 \mathrm{~Hz}, 1^{\prime}-\mathrm{H}\right), 7.50(\mathrm{dd}, 2 \mathrm{H}, J=8.5 \mathrm{~Hz}, J=7.0 \mathrm{~Hz})$ és $7.56(\mathrm{~m}, 1 \mathrm{H})$ és $7.98(\mathrm{~d}, J=7.5 \mathrm{~Hz}$, 2H): benzoil protonok, 7.31 (s, 1H, linker-NH), 8.32 (s, 1H) és 8.64 (s, 1H): 2-H és 8-H, 9.56 $(\mathrm{s}, 1 \mathrm{H}, 6-\mathrm{NH}) .{ }^{13} \mathrm{C}-\mathrm{NMR}\left(\mathrm{CD}_{3} \mathrm{CN}\right) ; \delta[\mathrm{ppm}]=21.2(\mathrm{OAc}), 37.7(\mathrm{C}-2$ '), 41.5 és 51.4 és 70.3 és 70.5 és 70.9 és 71.0: linker $6 \times \mathrm{CH}_{2}, 64.9$ (C-5'), 75.4 (C-3'), 83.9 (C-4'), 85.1 (C-1'), 125.6 (C-5), 129.1 (2C), 129.6 (2C), 133.5, 134.7, 143.1 (C-8), 150.8 (C-4), 151.3 (C-2), 153.0 (C6), 157.0 (linker-CO), 166.3 (Bz-CO), 171.3 (Ac-CO). ESI-MS: 604 [M+Li] ${ }^{+}$.

\section{5. példa:}

\section{3'-O-Acetil-5' - $O$-((3,6-dioxanon-8-in-1-il)karbamoil)- $N^{6}$-benzoil-2'-dezoxiadenozin}

Védett 2'-dezoxiadenozin alapú, etinil végű, karbamát kötésű, oligo-etilénoxi linkeres építőelem.

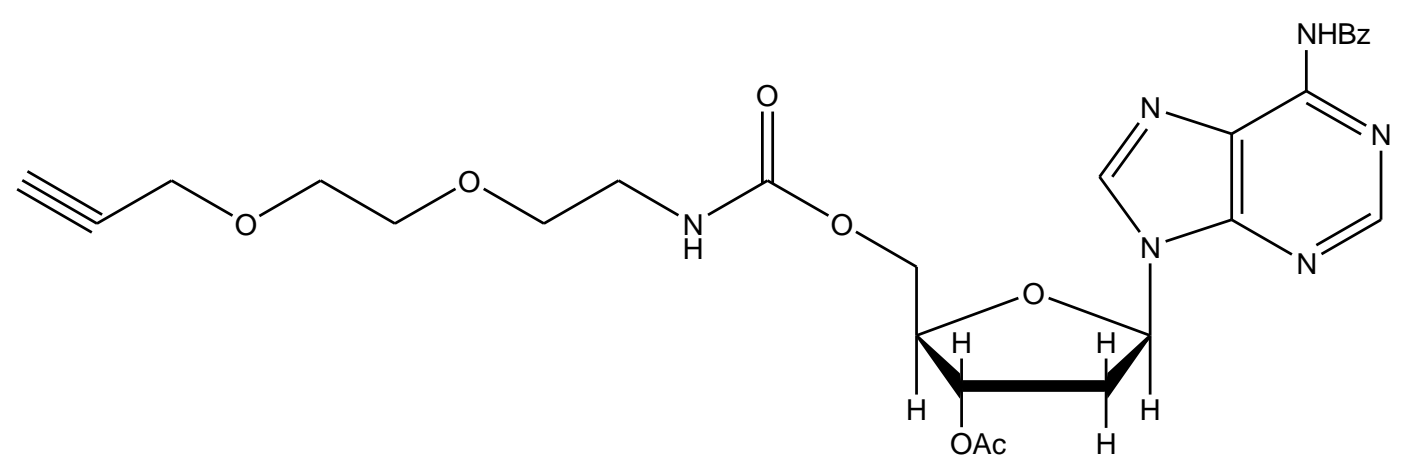

Színtelen olaj (224 mg, 79\%), $R_{\mathrm{f}}=0,52 \quad$ (EtOAc:MeOH/9:1); ${ }^{1} \mathrm{H}-\mathrm{NMR} \quad\left(\mathrm{CD}_{3} \mathrm{CN}\right) ; \delta$ $[\mathrm{ppm}]=2.08(\mathrm{~s}, 3 \mathrm{H}, \mathrm{OAc}), 2.68(\mathrm{t}, 1 \mathrm{H}, J=2.5 \mathrm{~Hz}, \mathrm{C} \equiv \underline{\mathrm{CH}}), 2.58(\mathrm{~m}, 1 \mathrm{H})$ és $3.02(\mathrm{~m}, 1 \mathrm{H}): 2$ '$\mathrm{H}_{2}, 3.30(\mathrm{~m}, 2 \mathrm{H})$ és $3.43(\mathrm{t}, 2 \mathrm{H}, J=5.6 \mathrm{~Hz})$ és $3.63(\mathrm{~m}, 4 \mathrm{H})$ és $4.13(\mathrm{~m}, 2 \mathrm{H})$ : linker $5 \times \mathrm{CH}_{2}$, 
$4.22\left(\mathrm{dd}, 2 \mathrm{H}, J=13.0 \mathrm{~Hz}, J=6.0 \mathrm{~Hz}, 5^{\prime}-\mathrm{H}_{2}\right), 5.41$ (dt, 1H, J=6.0 Hz, J=2.5 Hz, 4'-H), 5.89 (dd, $\left.1 \mathrm{H}, J=2 \times 6.0 \mathrm{~Hz}, 3^{\prime}-\mathrm{H}\right), 6.46\left(\mathrm{dd}, 1 \mathrm{H}, J=8.0 \mathrm{~Hz}, J=6.0 \mathrm{~Hz}, 1^{\prime}-\mathrm{H}\right), 7.55$ (m, 2H) és 7.66 (m, $1 \mathrm{H})$ és $7.98(\mathrm{~d}, 2 \mathrm{H}, J=7.5 \mathrm{~Hz})$ : benzoil protonok, $7.30(\mathrm{~s}, 1 \mathrm{H}$, linker-NH), $8.32(\mathrm{~s}, 1 \mathrm{H})$ és 8.65 (s, 1H): 2-H és 8-H, $9.53(\mathrm{~s}, 1 \mathrm{H}, 6-\mathrm{NH}) .{ }^{13} \mathrm{C}-\mathrm{NMR}\left(\mathrm{CD}_{3} \mathrm{CN}\right) ; \delta[\mathrm{ppm}]=21.2(\mathrm{OAc}), 37.7(\mathrm{C}-$ 2'), 41.5 és 58.6 és 69.8 és 70.3 és 70.6: linker $5 \times \mathrm{CH}_{2}, 64.9\left(\mathrm{C}-5\right.$ '), $75.4(\mathrm{C} \equiv \underline{\mathrm{CH}}), 75.7\left(\mathrm{C}-3^{\prime}\right)$, $80.9(\underline{\mathrm{C}} \equiv \mathrm{CH}), 83.9$ (C-4'), 85.1 (C-1'), 125.6 (C-5), 129.1 (2C), 129.6 (2C), 133.5, 134.7, 143.1 (C-8), 150.8 (C-4), 151.3 (C-2), 152.5 (C-6), 157.0 (linker-CO), 166.3 (Bz-CO), 171.3 (Ac-CO). ESI-MS: 573 [M+Li] $]^{+}$.

\section{6. példa:}

\section{3'-O-Acetil-5'-O-((3-propiolamidopropil)karbamoil)- $N^{6}$-benzoil-2'-dezoxiadenozin}

Védett 2'-dezoxiadenozin alapú, etinil végű, karbamát kötésű, alkil-amidoalkil linkeres építőelem.

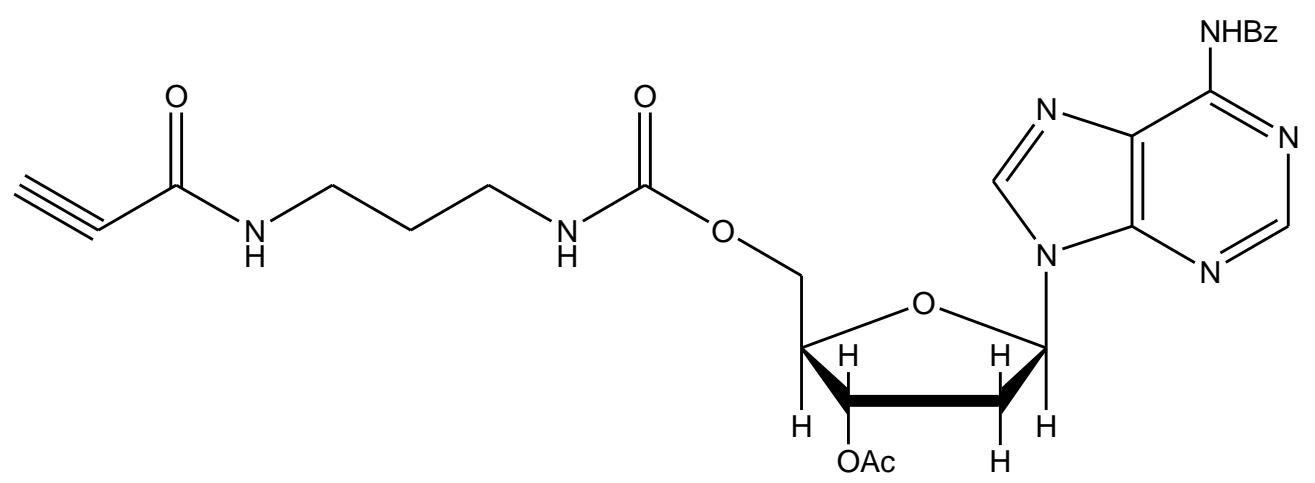

Színtelen olaj (200 mg, 71\%), $R_{\mathrm{f}}=0,35$ (EtOAc:MeOH/9:1); ${ }^{1} \mathrm{H}-\mathrm{NMR} \quad\left(\mathrm{CD}_{3} \mathrm{CN}\right) ; \delta$ $[\mathrm{ppm}]=1.57(\mathrm{p}, 2 \mathrm{H}, J=7.0 \mathrm{~Hz})$ és $3.03(\mathrm{t}, 2 \mathrm{H}, J=7.0 \mathrm{~Hz})$ és $3.14(\mathrm{~m}, 2 \mathrm{H}): 3 \times \operatorname{linker} \mathrm{CH}_{2}, 2.08$ (s, 3H, OAc), 2.63 (ddd, 1H, $J=14.5 \mathrm{~Hz}, J=6.0 \mathrm{~Hz}, J=3.0 \mathrm{~Hz}$ ) és 2.93 (ddd, $1 \mathrm{H}, J=14.0 \mathrm{~Hz}$, $J=8.0 \mathrm{~Hz}, J=6.5 \mathrm{~Hz}): 2{ }^{\prime}-\mathrm{H}_{2}, 3.23(\mathrm{~s}, 1 \mathrm{H}, \mathrm{C} \equiv \underline{\mathrm{CH}}), 4.21$ (dd, 1H, J=12.5 Hz, J=5.0 Hz, 3'-H), 4.35 (m, 2H, 5'- $\left.-\mathrm{H}_{2}\right), 5.40$ (dt, 1H, J=6.0 Hz, J=2.5 Hz, 4'-H), 6.47 (dd, 1H, J=7.5 Hz, J=6.0 $\left.\mathrm{Hz}, 1^{\prime}-\mathrm{H}\right), 7.56(\mathrm{~m}, 2 \mathrm{H})$ és $7.66(\mathrm{~m}, 1 \mathrm{H})$ és $8.04(\mathrm{~d}, 2 \mathrm{H}, J=7.5 \mathrm{~Hz})$ : benzoil protonok, $7.30(\mathrm{t}$, $1 \mathrm{H}, J=5.5 \mathrm{~Hz})$ és $8.74(\mathrm{t}, 1 \mathrm{H}, J=5.5 \mathrm{~Hz}): 2 \times$ linker-NH, $8.42(\mathrm{~s}, 1 \mathrm{H})$ és $8.68(\mathrm{~s}, 1 \mathrm{H}): 2-\mathrm{H}$ és 8 $\mathrm{H}, 9.63(\mathrm{~s}, 1 \mathrm{H}, 6-\mathrm{NH}) .{ }^{13} \mathrm{C}-\mathrm{NMR}\left(\mathrm{CD}_{3} \mathrm{CN}\right) ; \delta[\mathrm{ppm}]=21.2(\mathrm{OAc}), 29.7$ és 37.9 és 38.8: $3 \times$ linker $\mathrm{CH}_{2}, 37.6\left(\mathrm{C}-2^{\prime}\right), 64.9\left(\mathrm{C}-5^{\prime}\right.$ ), $75.1(\mathrm{C} \equiv \underline{\mathrm{CH}}), 75.4\left(\mathrm{C}-3^{\prime}\right), 77.9(\underline{\mathrm{C}} \equiv \mathrm{CH}), 84.0\left(\mathrm{C}-4^{\prime}\right)$, 85.4 (C-1'), 124.5 (C-5), 129.3 (2C), 129.6 (2C), 133.8, 134.5, 143.3 (C-8), 150.5 (C-4), 
152.6 (C-2), 152.7 (C-6), 153.5 és 157.5: 2×linker-CO, 167.2 (Bz-CO), 172.0 (Ac-CO). ESIMS: $556[\mathrm{M}+\mathrm{Li}]^{+}$.

\section{7. példa:}

\section{3'-O-Acetil-5'-O-((3-azidopropil)tiokarbamoil)- $N^{6}$-benzoil-2'-dezoxiadenozin}

Védett 2'-dezoxiadenozin alapú, azidometil végü, tiokarbamát kötésü, alkilén linkeres építőelem.

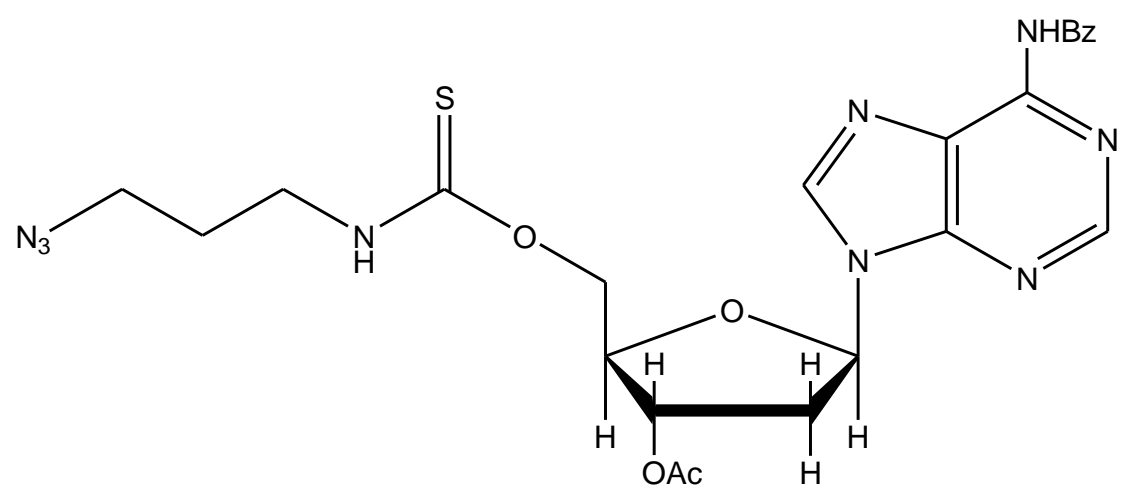

Színtelen olaj (218 mg, 80\%), $R_{\mathrm{f}}=0,64 \quad$ (EtOAc:MeOH/9:1); ${ }^{1} \mathrm{H}-\mathrm{NMR} \quad\left(\mathrm{CD}_{3} \mathrm{CN}\right) ; \delta$ $[\mathrm{ppm}]=1.79(\mathrm{p}, 2 \mathrm{H}, J=6.5 \mathrm{~Hz})$ és $3.33(\mathrm{~d}, 2 \mathrm{H}, J=6.5 \mathrm{~Hz})$ és 3.50 (q, 2H, $J=6.5 \mathrm{~Hz})$ : linker $3 \times \mathrm{CH}_{2}, 2.08$ (s, 3H, OAc), $2.68(\mathrm{~m}, 1 \mathrm{H})$ és 3.01 (dt, $1 \mathrm{H}, J=14.0 \mathrm{~Hz}, J=7.0 \mathrm{~Hz}$ ): 2'- $\mathrm{H}_{2}, 4.45$ (m, 1H, 4'-H), $4.61(\mathrm{dd}, 1 \mathrm{H}, J=11.0 \mathrm{~Hz}, J=4.5 \mathrm{~Hz})$ és $4.79(\mathrm{~m}, 1 \mathrm{H}): 5$ '- $\mathrm{H}_{2}, 5.44(\mathrm{dd}, 1 \mathrm{H}$, $J=6.0 \mathrm{~Hz}, J=2.5 \mathrm{~Hz}, 3$ '-H), 6.45 (dd, 1H, $\left.J=8.5 \mathrm{~Hz}, J=6.0 \mathrm{~Hz}, 1^{\prime}-\mathrm{H}\right), 7.52$ (t, $\left.J=7.5 \mathrm{~Hz}, 2 \mathrm{H}\right)$ és $7.67(\mathrm{~m}, 1 \mathrm{H})$ és $7.99(\mathrm{~d}, J=7.5 \mathrm{~Hz}, 2 \mathrm{H})$ : benzoil protonok, 7.31 (s, 1H, linker-NH), 8.30 (s, $1 \mathrm{H})$ és $8.65(\mathrm{~s}, 1 \mathrm{H}): 2-\mathrm{H}$ és $8-\mathrm{H}, 9.46(\mathrm{~s}, 1 \mathrm{H}, 6-\mathrm{NH}) .{ }^{13} \mathrm{C}-\mathrm{NMR}\left(\mathrm{CD}_{3} \mathrm{CN}\right) ; \delta[\mathrm{ppm}]=21.2$ (OAc), 28.2 és 43.3 és 49.6: 3×linker $\mathrm{CH}_{2}, 37.8$ (C-2'), 69.9 (C-5'), 75.3 (C-3’), 83.6 (C-4'), 85.3 (C-1'), 125.6 (C-5), 129.1 (2C), 129.6 (2C), 133.5, 133.6, 143.1 (C-8), 150.7 (C-4), 151.2 (C-2), 152.9 (C-6), 166.4 (Bz-CO), 171.3 (Ac-CO), 190.9 (linker-C=S). ESI-MS: 546 $[\mathrm{M}+\mathrm{Li}]^{+}$.

18. példa:

3'-O-Acetil-5' $O$ - -(prop-2-in-1-iltiokarbamoil)- $N^{6}$-benzoil-2'-dezoxiadenozin

Védett 2'-dezoxiadenozin alapú, etinil végü, tiokarbamát kötésű, alkilén linkeres építőelem. 


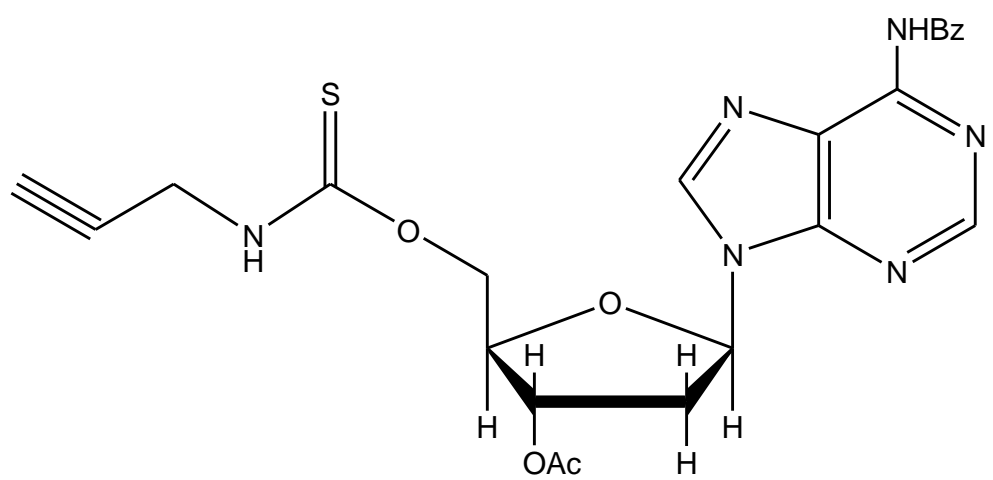

Színtelen olaj (183 mg, 74\%), $R_{\mathrm{f}}=0,66 \quad$ (EtOAc:MeOH/9:1); ${ }^{1} \mathrm{H}-\mathrm{NMR} \quad\left(\mathrm{CD}_{3} \mathrm{CN}\right) ; \delta$ $[\mathrm{ppm}]=2.08(\mathrm{~s}, 3 \mathrm{H}, \mathrm{OAc}), 2.48(\mathrm{t}, 1 \mathrm{H}, J=2.5 \mathrm{~Hz}, \mathrm{C} \equiv \underline{\mathrm{CH}}), 2.60(\mathrm{~m}, 1 \mathrm{H})$ és 3.01 (dt, $1 \mathrm{H}, J=14.0$ $\mathrm{Hz}, J=7.0 \mathrm{~Hz}$ ): 2'- $\mathrm{H}_{2}, 4.25$ (dd, 2H, J=6.0 Hz, J=2.5 Hz, linker $\mathrm{CH}_{2}$ ), 4.45 (m, 1H, 4'-H), 4.79 (m, 2H, 5'- $\mathrm{H}_{2}$ ), 5.44 (dd, 1H, J=6.5 Hz, J=3.0 Hz, 3'-H), 6.44 (t, 1H, J=6.5 Hz, 1'-H), 7.52 (t, $2 \mathrm{H}, J=7.5 \mathrm{~Hz})$ és $7.66(\mathrm{~m}, 1 \mathrm{H})$ és $7.99(\mathrm{~d}, 2 \mathrm{H}, J=7.5 \mathrm{~Hz})$ : benzoil protonok, $7.31(\mathrm{~s}, 1 \mathrm{H}$, linker-NH), $8.30(\mathrm{~s}, 1 \mathrm{H})$ és $8.65(\mathrm{~s}, 1 \mathrm{H}): 2-\mathrm{H}$ és $8-\mathrm{H}, 9.45(\mathrm{~s}, 1 \mathrm{H}, 6-\mathrm{NH}) .{ }^{13} \mathrm{C}-\mathrm{NMR}\left(\mathrm{CD}_{3} \mathrm{CN}\right)$; $\delta[\mathrm{ppm}]=21.2(\mathrm{OAc}), 35.3\left(\right.$ linker $\left.\mathrm{CH}_{2}\right), 37.7\left(\mathrm{C}-2^{\prime}\right), 70.5(\mathrm{C}-5$ ') $, 72.8(\mathrm{C} \equiv \underline{\mathrm{CH}}), 75.2$ (C-3'), $79.7(\underline{\mathrm{C}} \equiv \mathrm{CH}), 83.4(\mathrm{C}-4$ '), 85.2 (C-1'), 125.6 (C-5), 129.1 (2C), 129.6 (2C), 133.6, 134.2, 143.2 (C-8), 150.6 (C-4), 151.2 (C-2), 153.0 (C-6), 165.9 (Bz-CO), 171.3 (Ac-CO), 191.2 (linker $\mathrm{C}=\mathrm{S}$ ). ESI-MS: $501[\mathrm{M}+\mathrm{Li}]^{+}$.

19. példa:

\section{3'-O-Acetil-5'-O-((8-azido-3,6-dioxaoktil)tiokarbamoil)- $N^{6}$-benzoil-2'-dezoxiadenozin}

Védett 2'-dezoxiadenozin alapú, azidometil végü, tiokarbamát kötésű, oligo-etilénoxi linkeres építőelem.

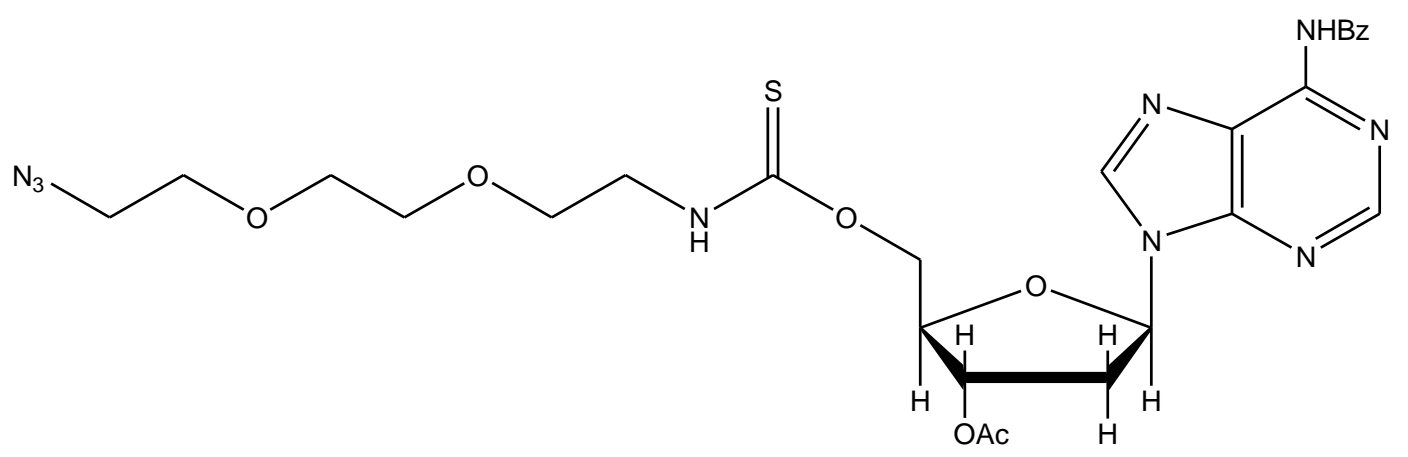

Színtelen olaj (224 mg, 73\%), $R_{\mathrm{f}}=0,57 \quad$ (EtOAc:MeOH/9:1); ${ }^{1} \mathrm{H}-\mathrm{NMR} \quad\left(\mathrm{CD}_{3} \mathrm{CN}\right) ; \delta$ $[\mathrm{ppm}]=2.08(\mathrm{~s}, 3 \mathrm{H}, \mathrm{OAc}), 2.60(\mathrm{~m}, 1 \mathrm{H})$ és $3.17(\mathrm{~m}, 1 \mathrm{H}): 2^{\prime}-\mathrm{H}_{2}, 3.41(\mathrm{~m}, 2 \mathrm{H})$ és $3.46(\mathrm{t}, 2 \mathrm{H}$, $J=5.5 \mathrm{~Hz})$ és $3.65(\mathrm{~m}, 2 \mathrm{H}), 3.71(\mathrm{~m}, 6 \mathrm{H})$ : linker $6 \times \mathrm{CH}_{2}, 4.44(\mathrm{~m}, 1 \mathrm{H}, 4$ '-H), $4.71(\mathrm{dd}, 2 \mathrm{H}$, 
$J=12.0 \mathrm{~Hz}, J=5.0 \mathrm{~Hz}, 5$ '- $\left.\mathrm{H}_{2}\right), 5.47$ (m, 1H, 3'-H), 6.49 (m, 1H, 1'-H), 7.55 (m, 2H) és 7.78 $(\mathrm{dd}, J=2 \times 5.0 \mathrm{~Hz}, 1 \mathrm{H})$ és $7.98(\mathrm{dd}, J=2 \times 7.5 \mathrm{~Hz}, 2 \mathrm{H})$ : benzoil protonok, $7.33(\mathrm{~d}, 1 \mathrm{H}, J=1.5 \mathrm{~Hz}$, linker-NH), $8.30(\mathrm{~s}, 1 \mathrm{H})$ és $8.65(\mathrm{~s}, 1 \mathrm{H}): 2-\mathrm{H}$ és $8-\mathrm{H}, 9.46(\mathrm{~s}, 1 \mathrm{H}, 6-\mathrm{NH}) .{ }^{13} \mathrm{C}-\mathrm{NMR}\left(\mathrm{CD}_{3} \mathrm{CN}\right)$; $\delta[\mathrm{ppm}]=21.2(\mathrm{OAc}), 37.6\left(\mathrm{C}-2\right.$ '), 46.0 és 51.4 és 70.0 és 70.5 és 70.8 és 70.9: linker $6 \times \mathrm{CH}_{2}$, 68.9 (C-5'), 75.3 (C-3'), 83.5 (C-4'), 85.3 (C-1'), 125.7 (C-5), 129.1 (2C), 129.6 (2C), 133.5, 134.7, 143.2 (C-8), 150.8 (C-4), 151.3 (C-2), 152.9 (C-6), 166.3 (Bz-CO), 171.4 (Ac-CO), 190.9 (linker-C=S). ESI-MS: $620[\mathrm{M}+\mathrm{Li}]^{+}$.

\section{0. példa:}

\section{3'-O-Acetil-5' $O$-((3,6-dioxanon-8-in-1-il)tiokarbamoil)- $N^{6}$-benzoil-2'-dezoxiadenozin}

Védett 2'-dezoxiadenozin alapú, etinil végü, tiokarbamát kötésü, oligo-etilénoxi linkeres építőelem.

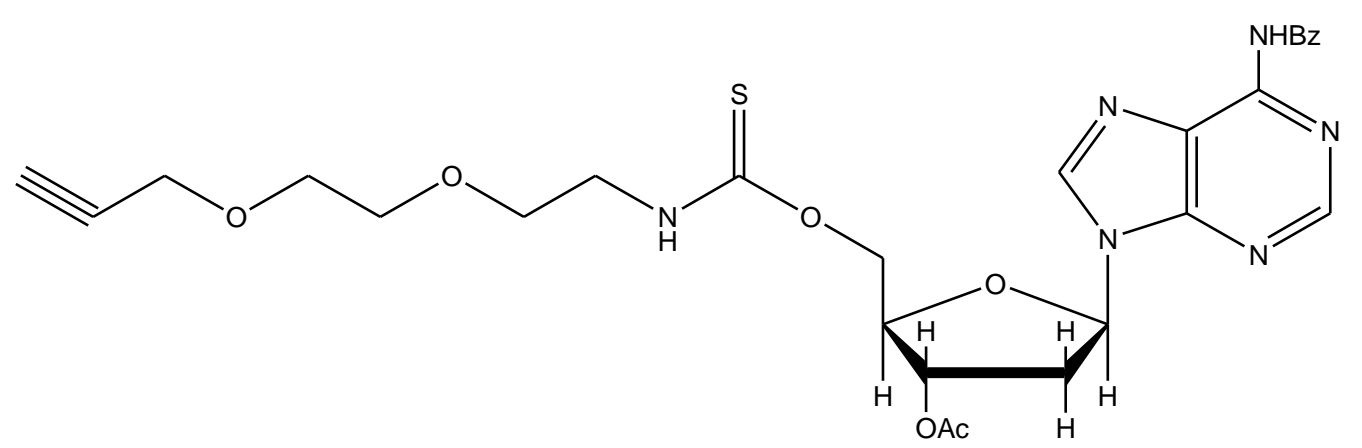

Színtelen olaj (244 mg, 84\%), $R_{\mathrm{f}}=0,64 \quad$ (EtOAc:MeOH/9:1); ${ }^{1} \mathrm{H}-\mathrm{NMR} \quad\left(\mathrm{CD}_{3} \mathrm{CN}\right) ; \delta$ $[\mathrm{ppm}]=2.08$ (s, 3H, OAc), $2.65(\mathrm{t}, 1 \mathrm{H}, J=2.5 \mathrm{~Hz}, \mathrm{C} \equiv \underline{\mathrm{CH}}), 2.53(\mathrm{~m}, 1 \mathrm{H})$ és $3.09(\mathrm{~m}, 1 \mathrm{H}): 2$ ' $\mathrm{H}_{2}, 3.51(\mathrm{~m}, 2 \mathrm{H})$ és $3.65(\mathrm{~m}, 6 \mathrm{H})$ és $4.14(\mathrm{~m}, 2 \mathrm{H})$ : linker $5 \times \mathrm{CH}_{2}, 4.45\left(\mathrm{~m}, 1 \mathrm{H}, 4{ }^{\prime}-\mathrm{H}\right), 4.61(\mathrm{dd}$, $1 \mathrm{H}, J=12.0 \mathrm{~Hz}, J=5.0 \mathrm{~Hz}$ ) és $4.76(\mathrm{~m}, 1 \mathrm{H}): 5^{\prime}-\mathrm{H}_{2}, 5.48\left(\mathrm{dd}, 1 \mathrm{H}, J=2 \times 6.0 \mathrm{~Hz}, 3^{\prime}-\mathrm{H}\right), 6.44$ (dt, $\left.1 \mathrm{H}, J=8.0 \mathrm{~Hz}, J=6.0 \mathrm{~Hz}, 1^{\prime}-\mathrm{H}\right), 7.51(\mathrm{dd}, 2 \mathrm{H}, J=2 \times 8.0 \mathrm{~Hz})$ és $7.62(\mathrm{dd}, 1 \mathrm{H}, J=2 \times 7.5 \mathrm{~Hz})$ és $7.98(\mathrm{~d}, 2 \mathrm{H}, J=7.5 \mathrm{~Hz})$ : benzoil protonok, $7.35(\mathrm{~d}, 1 \mathrm{H}, J=2.5 \mathrm{~Hz}$, linker-NH), $8.30(\mathrm{~s}, 1 \mathrm{H})$ és 8.65 (s, 1H): 2-H és 8-H, 9.49 (s, 1H, 6-NH). ${ }^{13} \mathrm{C}-\mathrm{NMR}\left(\mathrm{CD}_{3} \mathrm{CN}\right) ; \delta[\mathrm{ppm}]=21.2(\mathrm{OAc}), 37.6$ (C-2'), 46.0 és 58.7 és 68.8 és 70.0 és 70.7: linker $5 \times \mathrm{CH}_{2}, 69.8\left(\mathrm{C}-5^{\prime}\right), 75.3(\mathrm{C} \equiv \underline{\mathrm{CH}}), 75.7(\mathrm{C}-$

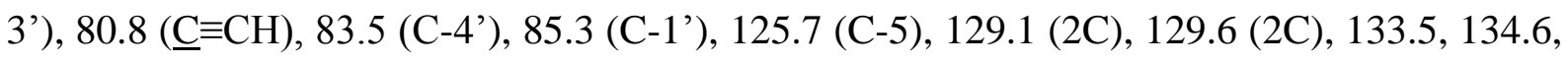
143.2 (C-8), 150.9 (C-4), 151.4 (C-2), 153.0 (C-6), 166.1 (Bz-CO), 171.3 (Ac-CO), 191.0 (linker-C=S). ESI-MS: $589[\mathrm{M}+\mathrm{Li}]^{+}$. 
21. példa:

\section{2',3'-Di- $O$-acetil-5'-O-((3-azidopropil)karbamoil)- $N^{2}$-izobutirilguanozin}

Védett guanozin alapú, azidometil végü, karbamát kötésü, alkilén linkeres építőelem.

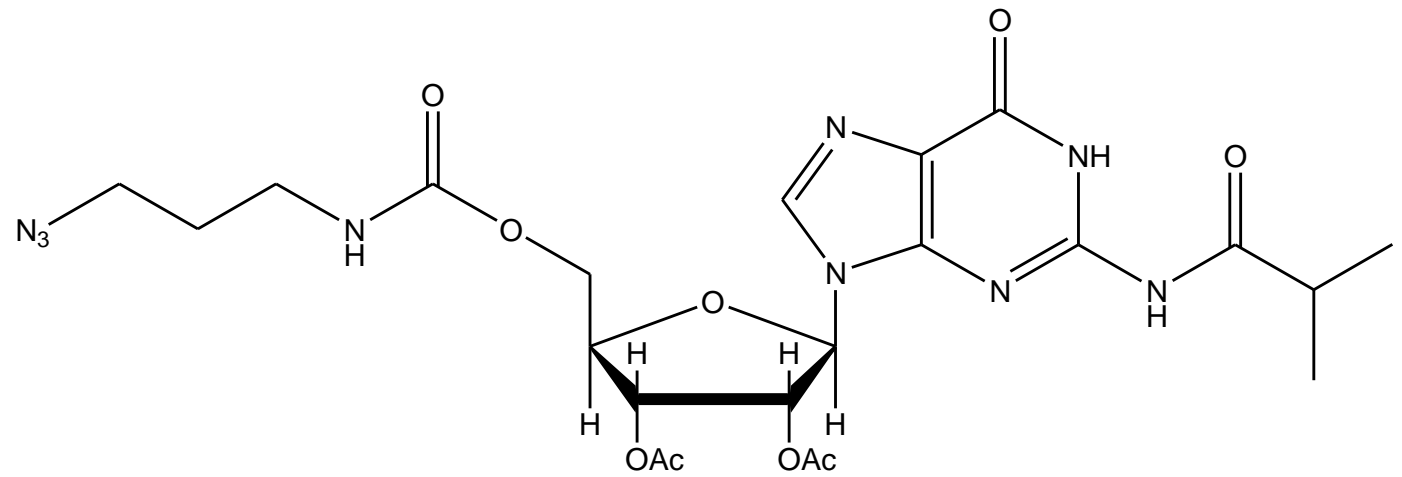

Színtelen olaj $(231 \mathrm{mg}, \quad 81 \%), \quad R_{\mathrm{f}}=0,55 \quad$ (EtOAc:MeOH/9:1); ${ }^{1} \mathrm{H}-\mathrm{NMR} \quad\left(\mathrm{CD}_{3} \mathrm{CN}\right) ; \delta$ $[\mathrm{ppm}]=1.19\left(\mathrm{~d}, 6 \mathrm{H}, J=7.0 \mathrm{~Hz}, 2 \times \mathrm{iBu}-\mathrm{CH}_{3}\right), 1.69(\mathrm{~m}, 2 \mathrm{H})$ és $3.22(\mathrm{~m}, 2 \mathrm{H})$ és $3.33(\mathrm{dd}, 2 \mathrm{H}$, $J=9.5 \mathrm{~Hz}, J=5.0 \mathrm{~Hz})$ : linker $3 \times \mathrm{CH}_{2}, 2.08(2 \times \mathrm{s}, 2 \times 3 \mathrm{H}, 2 \times \mathrm{OAc}), 2.75(\mathrm{~m}, 1 \mathrm{H}, \mathrm{iBu}-\mathrm{CH}), 4.44$ (m, 2H, 5'- $-\mathrm{H}_{2}$ ), 4.52 (dd, 1H, J=11.5 Hz, J=3.5 Hz, 4'-H), 5.62 (dd, 1H, J=5.5 Hz, J=3.0 Hz, 3'-H), 5.74 (dd, 1H, J=5.5 Hz, J=2.0 Hz, 2'-H), 5.99 (dd, 1H, J=5.5 Hz, J=2.0 Hz, 1'-H), 7.83 (d, 1H, J=2.5 Hz, linker-NH), $10.08(\mathrm{~s}, 1 \mathrm{H}, 8-\mathrm{H}), 11.96(\mathrm{~s}, 1 \mathrm{H}, \mathrm{iBu}-\mathrm{NH}) .{ }^{13} \mathrm{C}-\mathrm{NMR}\left(\mathrm{CD}_{3} \mathrm{CN}\right)$; $\delta[\mathrm{ppm}]=19.1$ és 19.3: $2 \times \mathrm{iBu}-\mathrm{CH}_{3}, 20.6$ és 20.8: $2 \times \mathrm{OAc}, 29.7$ és 39.0 és 49.6: $3 \times$ linker $\mathrm{CH}_{2}$, 36.7 (iBu-CH), 64.2 (C-5'), 72.7 (C-2'), 74.0 (C-3'), 81.6 (C-4'), 87.6 (C-1'), 122.5 (C-5), 139.1 (C-8), 149.3 (C-4), 149.4 (C-2), 156.3 (linker-CO), 157.2 (C-6), 170.5 és 170.7: 2×AcCO, 181.1 (iBu-CO). ESI-MS: $570[\mathrm{M}+\mathrm{Li}]^{+}$.

22. példa:

2',3'-Di- $O$-acetil-5'-O-(prop-2-in-1-ilkarbamoil)- $N^{2}$-izobutirilguanozin

Védett guanozin alapú, etinil végü, karbamát kötésü, alkilén linkeres építőelem.

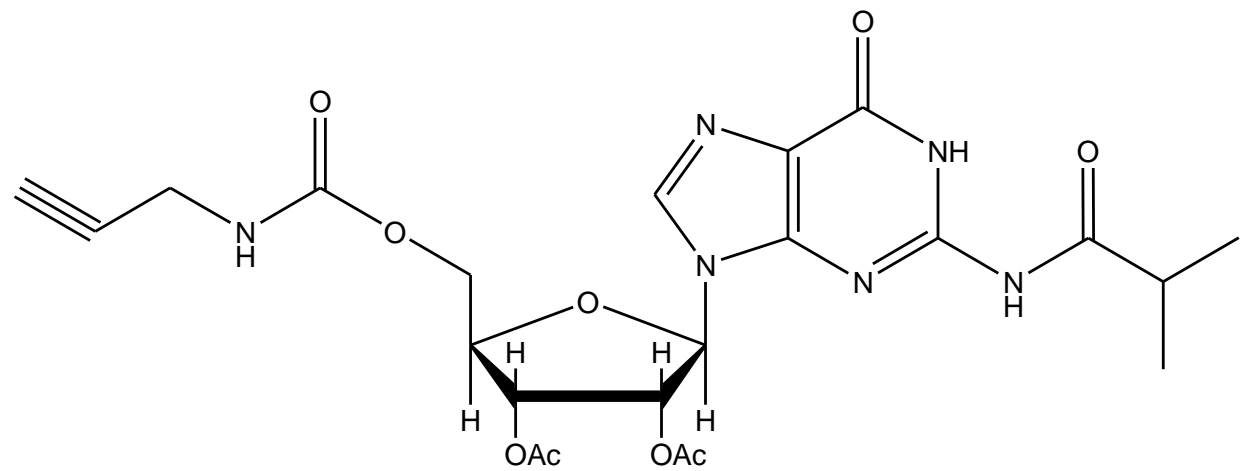


Színtelen olaj (197 mg, 76\%), $R_{\mathrm{f}}=0,55$ (EtOAc:MeOH/9:1); ${ }^{1} \mathrm{H}-\mathrm{NMR} \quad\left(\mathrm{CD}_{3} \mathrm{CN}\right) ; \delta$ $[\mathrm{ppm}]=1.18\left(\mathrm{~d}, 6 \mathrm{H}, J=7.0 \mathrm{~Hz}, 2 \times \mathrm{iBu}-\mathrm{CH}_{3}\right), 2.00$ (s, 3H, OAc), 2.07 (s, 3H, OAc), 2.49 (t, 1H, $J=2.5 \mathrm{~Hz}, \mathrm{C} \equiv \underline{\mathrm{CH}}), 2.76(\mathrm{~m}, 1 \mathrm{H}, \mathrm{iBu}-\mathrm{CH}), 3.93\left(\mathrm{~m}, 2 \mathrm{H}\right.$, linker $\left.\mathrm{CH}_{2}\right), 4.40\left(\mathrm{~m}, 2 \mathrm{H}, 5^{\prime}-\mathrm{H}_{2}\right), 4.58$ (m, 1H, 4'-H), 5.65 (m, 1H, 3'-H), 5.75 (t, 1H, J=5.5 Hz, 2'-H), 5.99 (d, 1H, J=5.5 Hz, 1'-H), $7.84\left(\mathrm{~s}, 1 \mathrm{H}\right.$, linker-NH), $9.82(\mathrm{~s}, 1 \mathrm{H}, 8-\mathrm{H}), 12.07(\mathrm{~s}, 1 \mathrm{H}, \mathrm{iBu}-\mathrm{NH}) .{ }^{13} \mathrm{C}-\mathrm{NMR}\left(\mathrm{CD}_{3} \mathrm{CN}\right) ; \delta$ $[\mathrm{ppm}]=19.2$ és 19.3: $2 \times \mathrm{iBu}-\mathrm{CH}_{3}, 20.6$ és 20.8: $2 \times \mathrm{OAc}, 31.0\left(\right.$ linker $\left.\mathrm{CH}_{2}\right), 36.7(\mathrm{iBu}-\mathrm{CH}), 64.6$ (C-5'), 71.6 (C-2'), $72.1(\mathrm{C} \equiv \underline{\mathrm{CH}}), 73.9$ (C-3'), $81.2(\underline{\mathrm{C}} \equiv \mathrm{CH}), 81.3$ (C-4'), 87.6 (C-1'), 122.3 (C-5), 137.2 (C-8), 149.3 (C-4), 149.4 (C-2), 156.3 (linker-CO), 156.9 (C-6), 170.5 és 170.7: $2 \times$ Ac-CO, 181.1 (iBu-CO). ESI-MS: $525[\mathrm{M}+\mathrm{Li}]^{+}$.

\section{3. példa:}

\section{2',3'-Di- $O$-acetil-5'-O-((8-azido-3,6-dioxaoktil)karbamoil $)-N^{2}$-izobutirilguanozin}

Védett guanozin alapú, azidometil végü, karbamát kötésü, oligo-etilénoxi linkeres építőelem.

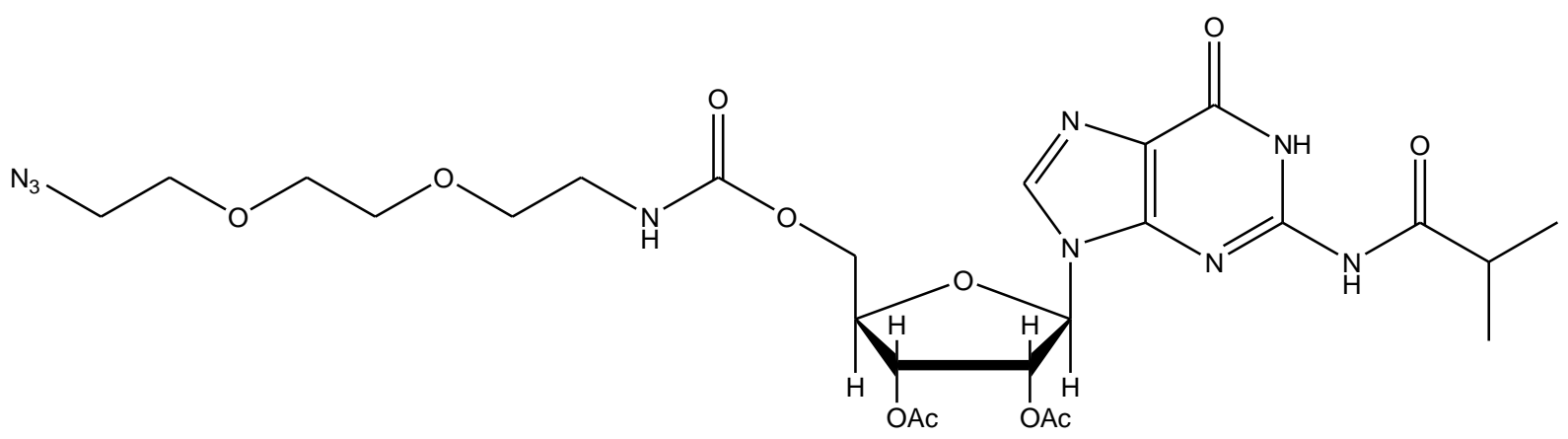

Színtelen olaj (252 mg, 79\%), $R_{\mathrm{f}}=0,46$ (EtOAc:MeOH/9:1); ${ }^{1} \mathrm{H}-\mathrm{NMR} \quad\left(\mathrm{CD}_{3} \mathrm{CN}\right) ; \delta$ $[\mathrm{ppm}]=1.19\left(\mathrm{~d}, 6 \mathrm{H}, J=7.0 \mathrm{~Hz}, 2 \times \mathrm{iBu}-\mathrm{CH}_{3}\right), 2.01$ (s, 3H, OAc), 2.08 (s, 3H, OAc), 2.75 (m, $1 \mathrm{H}, \mathrm{iBu}-\mathrm{CH}), 3.33(\mathrm{~m}, 2 \mathrm{H})$ és $3.34(\mathrm{~d}, 2 \mathrm{H}, J=5.0 \mathrm{~Hz})$ és $3.48(\mathrm{t}, 2 \mathrm{H}, J=5.5 \mathrm{~Hz})$ és $3.65(\mathrm{~m}$, $6 \mathrm{H})$ : linker $6 \times \mathrm{CH}_{2}, 4.41\left(\mathrm{~m}, 2 \mathrm{H}, 5^{\prime}-\mathrm{H}_{2}\right), 4.52$ (dd, $\left.1 \mathrm{H}, J=11.0 \mathrm{~Hz}, J=3.5 \mathrm{~Hz}, 4^{\prime}-\mathrm{H}\right), 5.62$ (dd, $\left.1 \mathrm{H}, J=6.0 \mathrm{~Hz}, J=4.0 \mathrm{~Hz}, 3^{\prime}-\mathrm{H}\right), 5.75$ (dd, 1H, J=5.5 Hz, 2'-H), 5.99 (t, 1H, J=5.0 Hz, 1'-H), $7.83\left(\mathrm{~d}, 1 \mathrm{H}, J=2.5 \mathrm{~Hz}\right.$, linker-NH), $9.84(\mathrm{~s}, 1 \mathrm{H}, 8-\mathrm{H}), 12.05(\mathrm{~s}, 1 \mathrm{H}, \mathrm{iBu}-\mathrm{NH}) .{ }^{13} \mathrm{C}-\mathrm{NMR}$

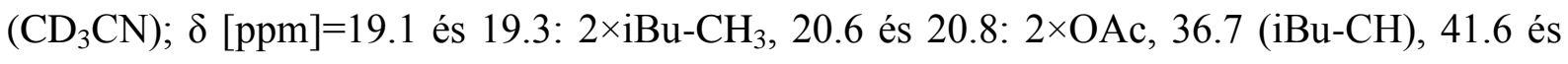
51.4 és 70.2 és 70.5 és 70.9 és 71.0 : $6 \times$ linker $\mathrm{CH}_{2}, 64.4$ (C-5'), 71.7 (C-2'), 73.9 (C-3'), 81.5 (C-4'), 87.6 (C-1'), 122.5 (C-5), 139.1 (C-8), 149.3 (C-4), 149.4 (C-2), 156.3 (linker-CO), 157.2 (C-6), 170.5 és 170.7: 2×Ac-CO, 181.0 (iBu-CO). ESI-MS: 644 [M+Li] $]^{+}$. 
24. példa:

2',3'-Di-O-acetil-5'-O-((3,6-dioxanon-8-in-1-il)karbamoil)- $\mathrm{N}^{2}$-izobutirilguanozin

Védett guanozin alapú, etinil végü, karbamát kötésű, oligo-etilénoxi linkeres építőelem.

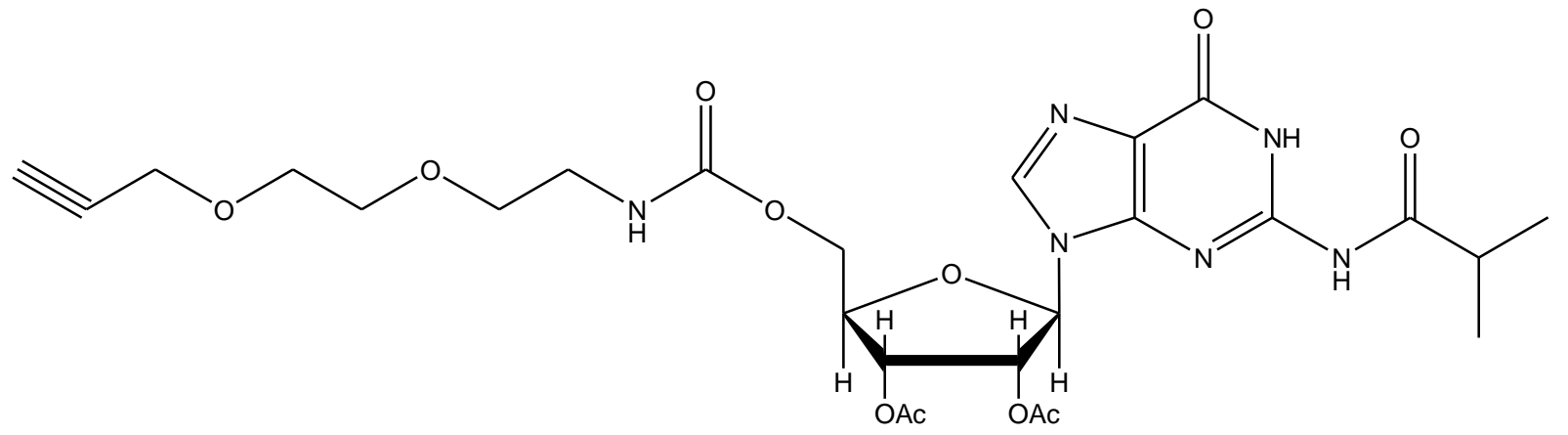

Színtelen olaj (233 mg, 77\%), $R_{\mathrm{f}}=0,52 \quad$ (EtOAc:MeOH/9:1); ${ }^{1} \mathrm{H}-\mathrm{NMR} \quad\left(\mathrm{CD}_{3} \mathrm{CN}\right) ; \delta$ $[\mathrm{ppm}]=1.19\left(\mathrm{~d}, 6 \mathrm{H}, J=7.0 \mathrm{~Hz}, 2 \times \mathrm{iBu}-\mathrm{CH}_{3}\right), 1.97$ (s, 3H, OAc), 2.04 (s, 3H, OAc), 2.67 (t, 1H, $J=2.5 \mathrm{~Hz}, \mathrm{C} \equiv \underline{\mathrm{CH}}), 2.83(\mathrm{~m}, 1 \mathrm{H}, \mathrm{iBu}-\mathrm{CH}), 3.46(\mathrm{dd}, 2 \mathrm{H}, J=6.0 \mathrm{~Hz}, J=4.0 \mathrm{~Hz})$ és $3.63(\mathrm{~m}, 6 \mathrm{H})$ és $4.14(\mathrm{~m}, 2 \mathrm{H})$ : linker $5 \times \mathrm{CH}_{2}, 4.40\left(\mathrm{~m}, 2 \mathrm{H}, 5^{\prime}-\mathrm{H}_{2}\right), 4.51\left(\mathrm{dd}, 1 \mathrm{H}, J=11.0 \mathrm{~Hz}, J=4.0 \mathrm{~Hz}, 4^{\prime}-\right.$ H), 5.62 (dd, 1H, J=6.0 Hz, J=4.0 Hz, 3'-H), 5.75 (t, 1H, J=5.5 Hz, 2'-H), 5.99 (d, 1H, J=5.5 $\mathrm{Hz}, 1$ '-H), 7.84 (s, 1H, linker-NH), 9.91 (s, 1H, 8-H), 12.07 (s, 1H, iBu-NH). ${ }^{13} \mathrm{C}-\mathrm{NMR}$ $\left(\mathrm{CD}_{3} \mathrm{CN}\right) ; \delta[\mathrm{ppm}]=19.1$ és 19.3: $2 \times 1 \mathrm{Bu}-\mathrm{CH}_{3}, 20.6$ és 20.8: $2 \times \mathrm{OAc}, 36.7(\mathrm{iBu}-\mathrm{CH}), 41.6$ és 58.7 és 69.8 és 69.9 és 70.1: linker $5 \times \mathrm{CH}_{2}, 64.3\left(\mathrm{C}-5^{\prime}\right), 71.2\left(\mathrm{C}-2^{\prime}\right), 71.7(\mathrm{C} \equiv \underline{\mathrm{CH}}), 73.9(\mathrm{C}-$ 3'), 80.9 ( $\underline{\mathrm{C}} \equiv \mathrm{CH}), 81.5$ (C-4'), 87.6 (C-1'), 122.5 (C-5), 139.1 (C-8), 149.3 (C-4), 149.4 (C2), 156.3 (linker-CO), 157.2 (C-6), 170.5 és 170.7: 2×Ac-CO, 181.1 (iBu-CO). ESI-MS: 613 $[\mathrm{M}+\mathrm{Li}]^{+}$.

\section{5. példa:}

\section{2',3'-Di- $O$-acetil-5' $O$-((3-propiolamidopropil)karbamoil)- $N^{2}$-izobutirilguanozin}

Védett guanozin alapú, etinil végü, karbamát kötésü, alkil-amidoalkil linkeres építőelem.

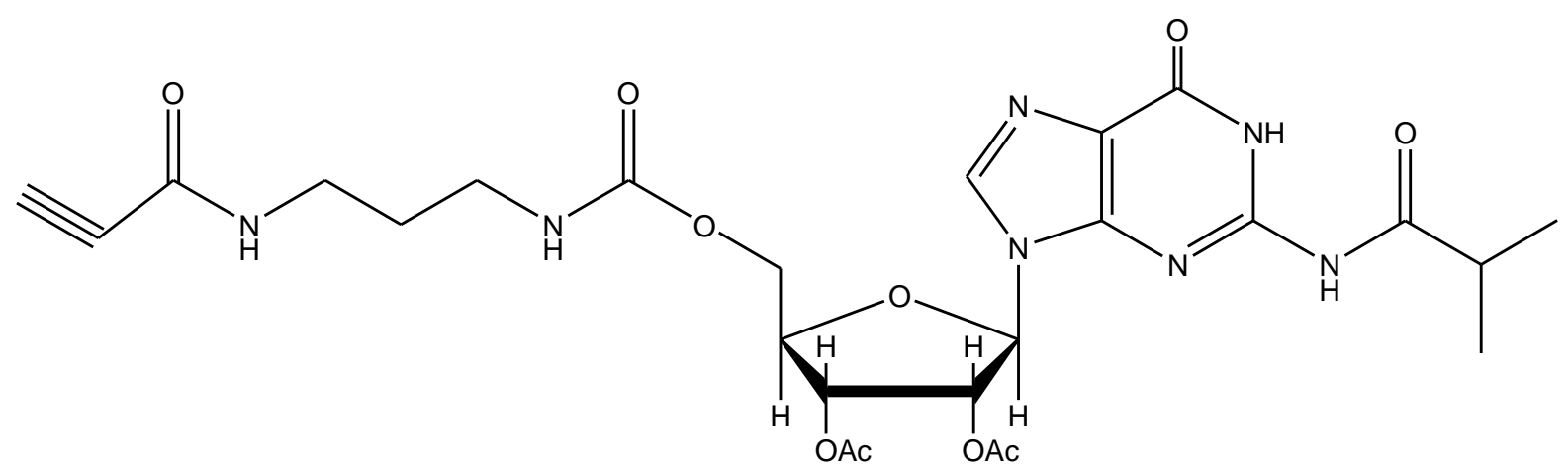


Színtelen olaj (212 mg, 72\%), $R_{\mathrm{f}}=0,25$ (EtOAc:MeOH/9:1); ${ }^{1} \mathrm{H}-\mathrm{NMR} \quad\left(\mathrm{CD}_{3} \mathrm{CN}\right) ; \delta$ $[\mathrm{ppm}]=1.12\left(\mathrm{dd}, 6 \mathrm{H}, J=7.0 \mathrm{~Hz}, J=1.5 \mathrm{~Hz}, 2 \times \mathrm{iBu}_{-} \mathrm{CH}_{3}\right), 1.55(\mathrm{p}, 2 \mathrm{H}, J=7.0 \mathrm{~Hz})$ és $3.03(\mathrm{t}, 2 \mathrm{H}$, $J=7.0 \mathrm{~Hz}$ ) és $3.11(\mathrm{~d}, 2 \mathrm{H}, J=7.0 \mathrm{~Hz}): 3 \times$ linker $\mathrm{CH}_{2}, 2.01(\mathrm{~s}, 3 \mathrm{H}, \mathrm{OAc}), 2.08$ (s, 3H, OAc), $2.68(\mathrm{~m}, 1 \mathrm{H}, \mathrm{iBu}-\mathrm{CH}), 3.21(\mathrm{~s}, 1 \mathrm{H}, \mathrm{C} \equiv \underline{\mathrm{CH}}), 4.23(\mathrm{dd}, 1 \mathrm{H}, J=11.5 \mathrm{~Hz}, J=7.5 \mathrm{~Hz}$,) és 4.45 (dd, $1 \mathrm{H}, J=11.5 \mathrm{~Hz}, J=4.0 \mathrm{~Hz}$ ): 5'-H $\mathrm{H}_{2}, 4.29$ (td, $1 \mathrm{H}, J=5.0 \mathrm{~Hz}, J=3.5 \mathrm{~Hz}, 4$ '-H), 5.56 (dd, 1H, $J=6.0 \mathrm{~Hz}, J=5.0 \mathrm{~Hz}, 3$ '-H), 5.68 (t, 1H, J=5.5 Hz, 2'-H), 5.93 (d, 1H, J=5.0 Hz, 1'-H), 7.16 (t, $1 \mathrm{H}, J=5.5 \mathrm{~Hz})$ és $7.77(\mathrm{t}, 1 \mathrm{H}, J=5.5 \mathrm{~Hz}): 2 \times \operatorname{linker-NH}, 9.75(\mathrm{~s}, 1 \mathrm{H}, 8-\mathrm{H}), 11.98(\mathrm{~s}, 1 \mathrm{H}, \mathrm{iBu}-$ $\mathrm{NH}) .{ }^{13} \mathrm{C}-\mathrm{NMR}\left(\mathrm{CD}_{3} \mathrm{CN}\right) ; \delta[\mathrm{ppm}]=19.1$ és 19.2: $2 \times \mathrm{iBu}-\mathrm{CH}_{3}, 20.6$ és 20.8: $2 \times \mathrm{OAc}, 29.9$ és 37.5 és 38.9: $3 \times$ linker $\mathrm{CH}_{2}, 36.7(\mathrm{iBu}-\mathrm{CH}), 64.2\left(\mathrm{C}-5^{\prime}\right), 71.7\left(\mathrm{C}-2^{\prime}\right), 74.0(\mathrm{C} \equiv \underline{\mathrm{CH}}), 74.3(\mathrm{C}-$ 3’), 78.3 ( $\underline{\mathrm{C}} \equiv \mathrm{CH}), 81.6$ (C-4'), 87.6 (C-1'), 122.3 (C-5), 139.1 (C-8), 149.3 (C-4), 149.4 (C2), 153.0 és 156.3: $2 \times$ linker-CO, 157.3 (C-6), 170.5 és 170.7: 2×Ac-CO, 181.0 (iBu-CO). ESI-MS: $596[\mathrm{M}+\mathrm{Li}]^{+}$.

\section{6. példa:}

\section{5'-O-((3-(2-Azidoacetamido)propil)karbamoil)-2'-dezoxiadenozin}

Védetlen 2'-dezoxiadenozin alapú, azidometil végü, karbamát kötésü, alkil-amidoalkil linkeres építőelem.

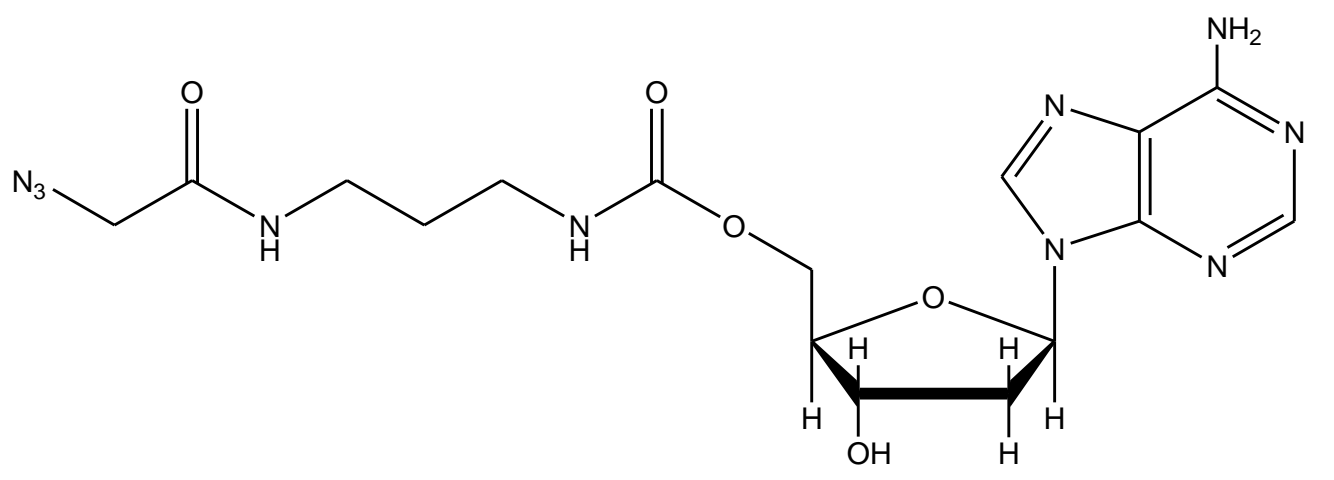

Amorf hab (70 mg, 81\%), $R_{\mathrm{f}}=0.26$ (EtOAc:MeOH/8:2); ${ }^{1} \mathrm{H}-\mathrm{NMR}\left(\mathrm{DMSO}-\mathrm{d}_{6}\right) ; \delta[\mathrm{ppm}]=1.56$ $(\mathrm{m}, 2 \mathrm{H})$ és $3.00(\mathrm{~m}, 2 \mathrm{H})$ és $3.11(\mathrm{~m}, 2 \mathrm{H})$ és $3.82(\mathrm{~s}, 2 \mathrm{H})$ : linker $4 \times \mathrm{CH}_{2}, 2.58(\mathrm{~d}, 2 \mathrm{H}, J=11.0$ $\left.\mathrm{Hz}, 2^{\prime}-\mathrm{H}_{2}\right), 4.17$ (dd, 1H, J=7.0 Hz, J=10.0 Hz, 3'-H), 4.20 (m, 2H, 5'-H $), 4.82$ (s, 1H, 4'-H), $5.91(\mathrm{~m}, 1 \mathrm{H}, 1$ '-H), $7.25(\mathrm{~m}, 1 \mathrm{H})$ és $8.29(\mathrm{~m}, 1 \mathrm{H})$ : linker $2 \times \mathrm{NH}, 8.64(\mathrm{~s}, 1 \mathrm{H})$ és $8.75(\mathrm{~s}, 1 \mathrm{H})$ : 2-H és $8-\mathrm{H}, 10.28(\mathrm{~s}, 1 \mathrm{H}, 6-\mathrm{NH}) ;{ }^{13} \mathrm{C}-\mathrm{NMR}\left(\mathrm{DMSO}_{6}\right) ; \delta[\mathrm{ppm}]=28.7$ és 37.2 és 39.0 és

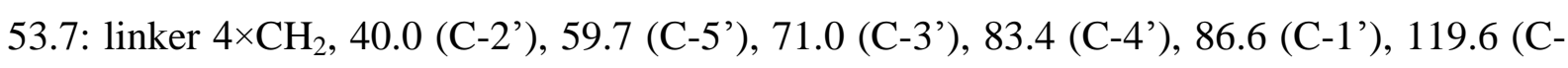
5), 143.5 (C-8), 152.6 (C-4), 155.7 (C-2), 156.2 (C-6), 156.0 és 162.4: 2×linker-CO; ESI-MS: $435[\mathrm{M}+\mathrm{H}]^{+}$. 
27. példa:

5'-O-((3-(2-Azidoacetamido)propil)karbamoil)-2'-dezoxiguanozin

Védetlen 2'-dezoxiguanozin alapú, azidometil végü, karbamát kötésü, alkil-amidoalkil linkeres építőelem.

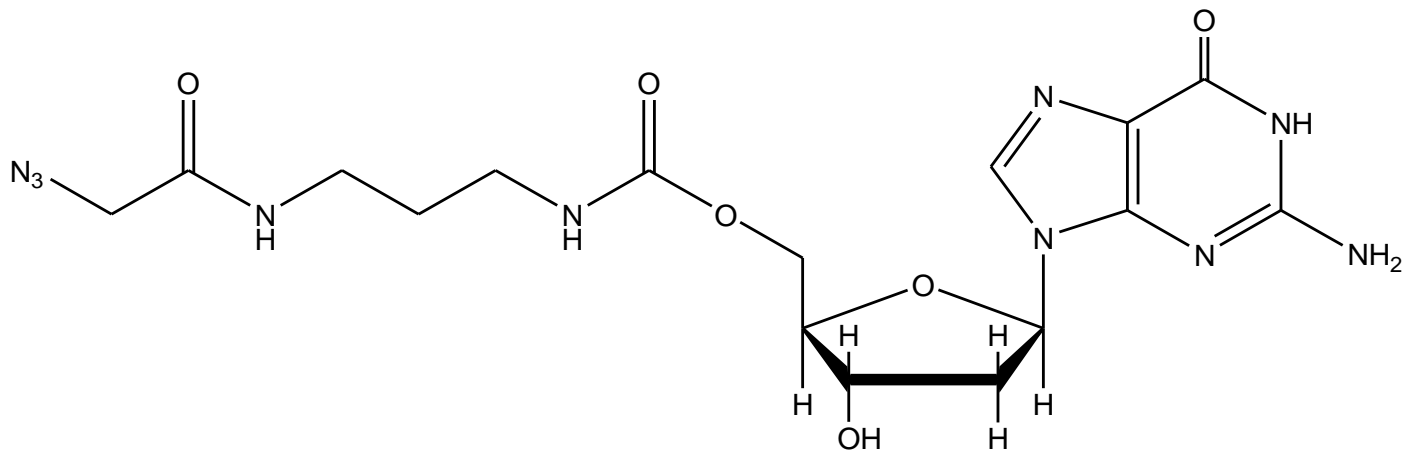

Amorf hab (74 mg, 82\%), $R_{\mathrm{f}}=0.34$ (EtOAc:MeOH/7:3); ${ }^{1} \mathrm{H}-\mathrm{NMR}\left(\mathrm{DMSO}-\mathrm{d}_{6}\right) ; \delta[\mathrm{ppm}]=1.57$ $(\mathrm{t}, 2 \mathrm{H}, J=7.0 \mathrm{~Hz})$ és $3.00(\mathrm{~m}, 3 \mathrm{H})$ és $3.11(\mathrm{~m}, 2 \mathrm{H})$ és $3.81(\mathrm{~s}, 2 \mathrm{H})$ : linker $4 \times \mathrm{CH}_{2}$ és 3'- $\mathrm{H}, 2.21$ $(\mathrm{m}, 1 \mathrm{H})$ és $2.60(\mathrm{~m}, 1 \mathrm{H}): 2^{\prime}-\mathrm{H}_{2}, 4.04(\mathrm{dd}, 1 \mathrm{H}, \mathrm{dd}, 1 \mathrm{H}, J=4.5 \mathrm{~Hz}, J=11.5 \mathrm{~Hz})$ és $4.20(\mathrm{dd}, 1 \mathrm{H}$, dd, 1H, J=3.5 Hz, J=11.5 Hz): 5'-H, 6.11 (t, 1H, J=7.5 Hz, 4'-H), 6.49 (s, 1H, 1'-H), 7.28 (t, $1 \mathrm{H}, J=5.5 \mathrm{~Hz})$ és $7.87(\mathrm{~m}, 1 \mathrm{H})$ : linker $2 \times \mathrm{NH}, 8.10(\mathrm{~s}, 1 \mathrm{H}, 8-\mathrm{H}), 9.65(\mathrm{~s}, 1 \mathrm{H}, 1-\mathrm{NH}) ;{ }^{13} \mathrm{C}-\mathrm{NMR}$ $\left(\mathrm{DMSO}_{6}\right) ; \delta[\mathrm{ppm}]=29.3$ és 36.3 és 37.9 és 50.7: linker $4 \times \mathrm{CH}_{2}, 35.8\left(\mathrm{C}-2^{\prime}\right), 64.1$ (C-5'), 70.8 (C-3’), 82.3 (C-4'), 84.5 (C-1'), 116.6 (C-5), 135.1 (C-8), 151.0 (C-4), 153.7 (C-2), 155.9 és 167.1: 2×linker-CO, $156.7(\mathrm{C}-6)$; ESI-MS: $451[\mathrm{M}+\mathrm{H}]^{+}$.

\section{8. példa:}

\section{5'-O-((3-(2-Azidoacetamido)propil)karbamoil)-adenozin}

Védetlen adenozin alapú, azidometil végü, karbamát kötésű, alkil-amidoalkil linkeres építőelem.

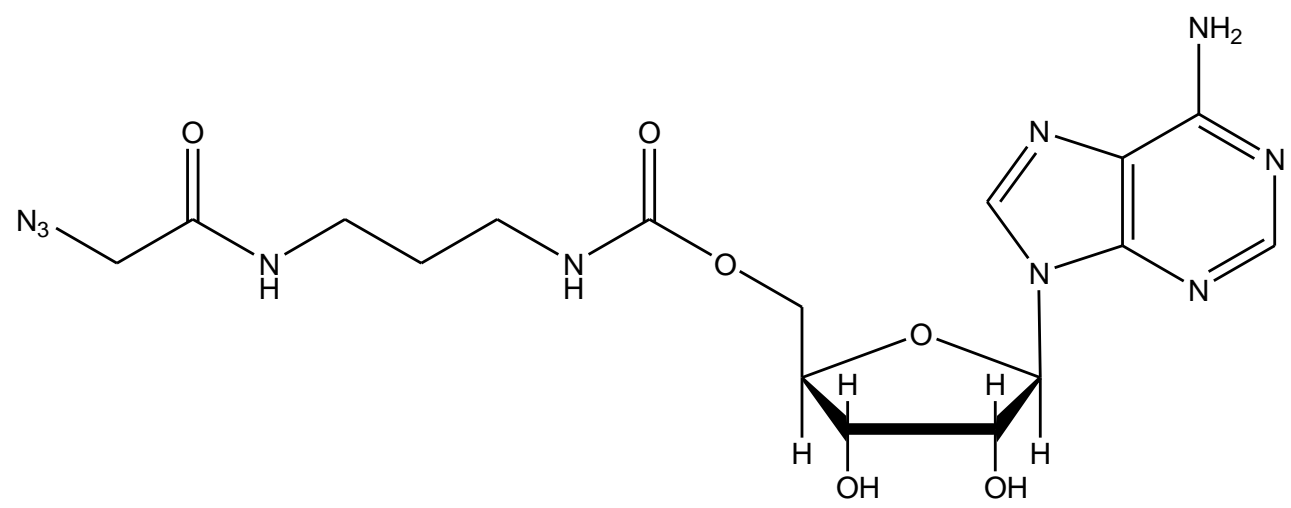


Amorf hab (75 mg, 83\%), $R_{\mathrm{f}}=0.26$ (EtOAc:MeOH/8:2); ${ }^{1} \mathrm{H}-\mathrm{NMR}\left(\mathrm{DMSO}-\mathrm{d}_{6}\right) ; \delta[\mathrm{ppm}]=1.57$ $(\mathrm{t}, 2 \mathrm{H}, J=6.0 \mathrm{~Hz})$ és $3.01(\mathrm{~m}, 2 \mathrm{H})$ és $3.09(\mathrm{~d}, 2 \mathrm{H}, J=5.5 \mathrm{~Hz})$ és $3.79(\mathrm{~s}, 2 \mathrm{H})$ : linker $4 \times \mathrm{CH}_{2}$, $4.32\left(\mathrm{~d}, 2 \mathrm{H}, J=5.0 \mathrm{~Hz}, 5^{\prime}-\mathrm{H}_{2}\right), 4.42\left(\mathrm{dd}, 1 \mathrm{H}, J=2.5 \mathrm{~Hz}, J=5.0 \mathrm{~Hz}, 4^{\prime}-\mathrm{H}\right), 5.60$ (m, 2H): 2'-H és 3'-H, $6.02(\mathrm{~d}, 1 \mathrm{H}, J=4.0 \mathrm{~Hz}, 1$ '-H), 7.55 (t, 1H, J=6.0 Hz) és $8.06(\mathrm{~m}, 1 \mathrm{H})$ : linker $2 \times \mathrm{NH}, 8.22$ $(\mathrm{s}, 1 \mathrm{H})$ és $8.76(\mathrm{~s}, 1 \mathrm{H})$ : 2-H és $8-\mathrm{H}, 10.21(\mathrm{~s}, 1 \mathrm{H}, 6-\mathrm{NH}) ;{ }^{13} \mathrm{C}-\mathrm{NMR}\left(\mathrm{DMSO}-\mathrm{d}_{6}\right) ; \delta[\mathrm{ppm}]=$ 28.7 és 36.0 és 38.0 és 51.2: linker $4 \times \mathrm{CH}_{2}, 61.9$ (C-5'), 71.5 (C-2'), 72.4 (C-3'), 84.8 (C-4'), 87.3 (C-1'), 125.0 (C-5), 138.4 (C-8), 151.5 (C-4), 153.7 és 166.8: 2×linker-CO, 155.3 (C-2), $157.6(\mathrm{C}-6)$; ESI-MS: $451[\mathrm{M}+\mathrm{H}]^{+}$.

\section{9. példa:}

\section{5'-O-((3-(2-Azidoacetamido)propil)karbamoil)-guanozin}

Védetlen guanozin alapú, azidometil végü, karbamát kötésü, alkil-amidoalkil linkeres építőelem.

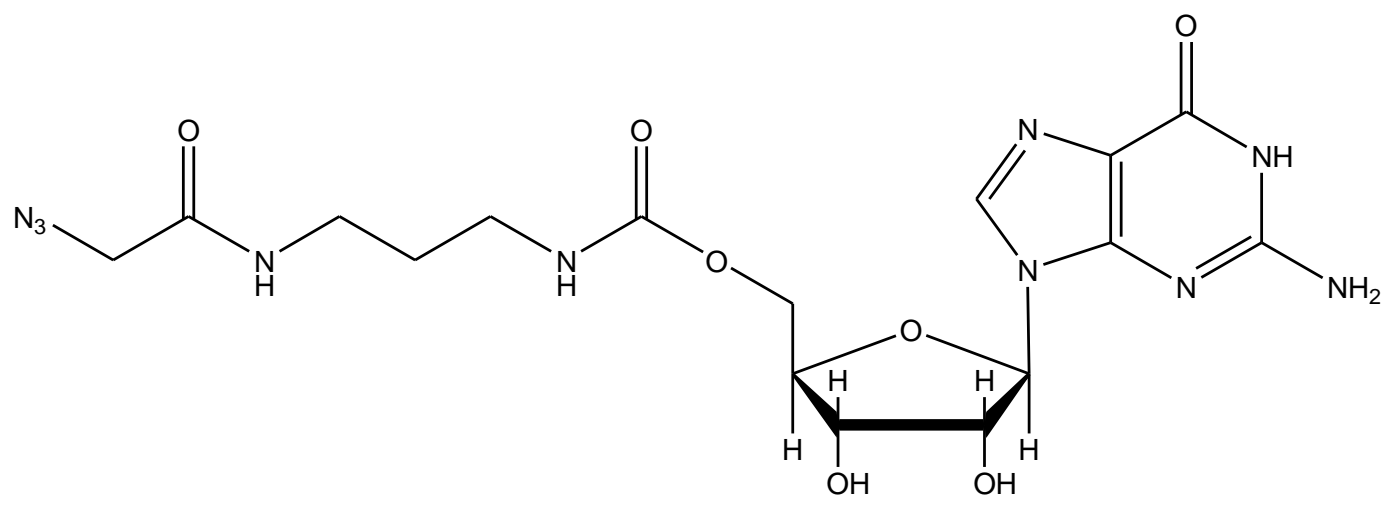

Amorf hab (80 mg, 86\%), $R_{\mathrm{f}}=0.39$ (EtOAc:MeOH/8:2); ${ }^{1} \mathrm{H}-\mathrm{NMR}\left(\right.$ DMSO-d $\left._{6}\right) ; \delta[\mathrm{ppm}]=1.59$ $\left(\mathrm{dd}, 2 \mathrm{H}, J=7.0 \mathrm{~Hz}, J=14.0 \mathrm{~Hz}\right.$ ) és $3.01(\mathrm{~m}, 2 \mathrm{H})$ és $3.12(\mathrm{~m}, 2 \mathrm{H})$ és $4.00(\mathrm{~s}, 2 \mathrm{H})$ : linker $4 \times \mathrm{CH}_{2}$, $4.22(\mathrm{dd}, 1 \mathrm{H}, J=3.0 \mathrm{~Hz}, J=12.0 \mathrm{~Hz}) 4.49(\mathrm{dd}, 1 \mathrm{H}, J=6.0 \mathrm{~Hz}, J=11.5 \mathrm{~Hz}) 5^{\prime}-\mathrm{H}_{2}, 5.29(\mathrm{~d}, 1 \mathrm{H}$, $\left.J=4.5 \mathrm{~Hz}, 2^{\prime}-\mathrm{H}\right), 5.48$ (d, 1H, J=6.0 Hz, 3'-H), 5.71 (d, 1H, J=6.0 Hz, 4'-H), 6.48 (m, 1H, 1'$\mathrm{H}), 7.32(\mathrm{t}, 1 \mathrm{H}, J=6.0 \mathrm{~Hz})$ és $8.09(\mathrm{~m}, 1 \mathrm{H})$ : linker $2 \times \mathrm{NH}, 7.89(\mathrm{~s}, 1 \mathrm{H}, 8-\mathrm{H}), 10.36(\mathrm{~s}, 1 \mathrm{H}, 1-$ $\mathrm{NH}) ;{ }^{13} \mathrm{C}-\mathrm{NMR}\left(\mathrm{DMSO}-\mathrm{d}_{6}\right) ; \delta[\mathrm{ppm}]=28.8$ és 36.4 és 37.9 és 50.7: linker $4 \times \mathrm{CH}_{2}, 63.9\left(\mathrm{C}-5{ }^{\prime}\right)$, 70.5 (C-2'), 72.8 (C-3’), 82.2 (C-4'), 85.9 (C-1'), 116.5 (C-5), 136.4 (C-8), 150.6 (C-4), 153.6 (C-2), 156.6 (C-6), 155.8 és 167.1: $2 \times$ linker-CO; ESI-MS: $467[\mathrm{M}+\mathrm{H}]^{+}$. 
30. példa:

\section{5'-O-((3-Azidopropil)karbamoil)-2'-dezoxiadenozin)}

Védetlen 2'-dezoxiadenozin alapú, azidometil végü, karbamát kötésű, alkilén linkeres építőelem.

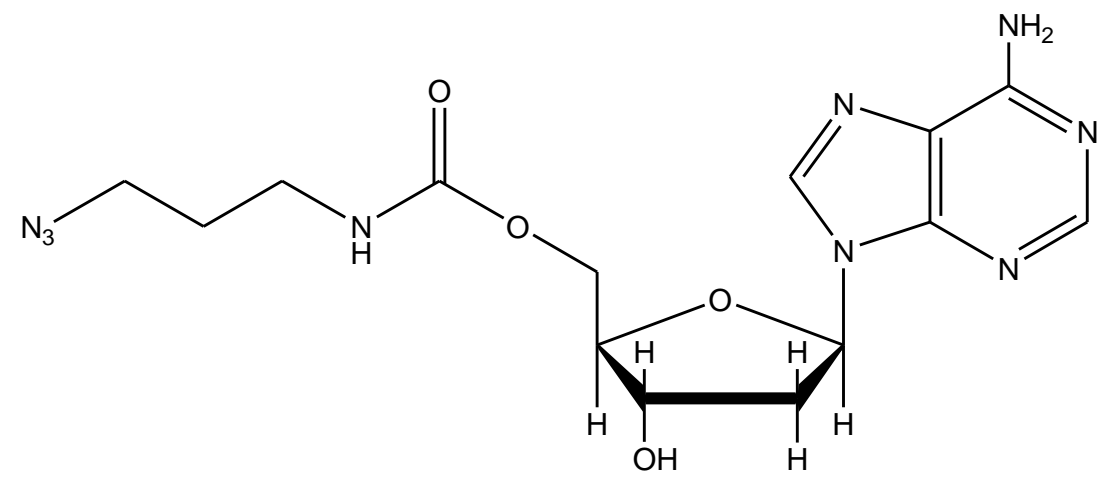

Amorf hab (66 mg, 88\%), $R_{\mathrm{f}}=0,39$ (EtOAc:MeOH/8:2); ${ }^{1} \mathrm{H}-\mathrm{NMR}\left(\mathrm{CD}_{3} \mathrm{OD}\right) ; \delta[\mathrm{ppm}]=1.71$ (p, $2 \mathrm{H}, J=7.0 \mathrm{~Hz}$ ) és $3.15(\mathrm{t}, 2 \mathrm{H}, J=7.0 \mathrm{~Hz})$ és $3.15(\mathrm{t}, 2 \mathrm{H}, J=7.0 \mathrm{~Hz})$ : linker $3 \times \mathrm{CH}_{2}, 2.49$ (ddd, $1 \mathrm{H}, J=13.5 \mathrm{~Hz}, J=6.5 \mathrm{~Hz}, J=3.5 \mathrm{~Hz}$ ) és $2.95(\mathrm{ddd}, 1 \mathrm{H}, J=13.5 \mathrm{~Hz}, J=7.0 \mathrm{~Hz}, J=6.0 \mathrm{~Hz}): 2$ '$\mathrm{H}_{2}, 4.15$ (dd, 1H, J=5.0 Hz, J=3.5 Hz, 4'-H), 4.23 (dd, 1H, $J=12.0 \mathrm{~Hz}, J=5.0 \mathrm{~Hz}$ ) és 4.35 (dd, $1 \mathrm{H}, J=12.0 \mathrm{~Hz}, J=4.0 \mathrm{~Hz}$ ): 5'- $\mathrm{H}_{2}, 4.57$ (dd, $\left.1 \mathrm{H}, J=6.5 \mathrm{~Hz}, J=3.5 \mathrm{~Hz}, 3^{\prime}-\mathrm{H}\right), 6.44$ (t, 1H, $J=6.5$ $\mathrm{Hz}, 1$ '-H), 8.13 (s, 1H, linker-NH), $8.20(\mathrm{~s}, 1 \mathrm{H})$ és 8.27 (s, 1H): 2-H és 8-H. ${ }^{13} \mathrm{C}-\mathrm{NMR}$ $\left(\mathrm{CD}_{3} \mathrm{OD}\right) ; \delta[\mathrm{ppm}]=30.1$ és 40.9 és 49.9: linker $3 \times \mathrm{CH}_{2}, 39.1$ (C-2'), $65.4(\mathrm{C}-5$ '), 72.7 (C-3'), 85.6 (C-4'), 86.6 (C-1'), 120.4 (C-5), 140.7 (C-8), 150.3 (C-4), 153.8 (C-2), 157.2 (C-6), 158.5 (linker-CO). ESI-MS: $384[\mathrm{M}+\mathrm{Li}]^{+}$.

\section{1. példa:}

\section{5'-O-((Prop-2-in-1-il)karbamoil)-2'-dezoxiadenozin}

Védetlen 2'-dezoxiadenozin alapú, etinil végü, karbamát kötésű, alkilén linkeres építőelem.<smiles>C#CCNC(=O)OC[C@H]1O[C@@H]2CO[C@@H](n3cnc4c(N)ncnc43)[C@H]1O2</smiles> 
Amorf hab (54 mg, 88\%), $R_{\mathrm{f}}=0,41$ (EtOAc:MeOH/8:2); ${ }^{1} \mathrm{H}-\mathrm{NMR}\left(\mathrm{CD}_{3} \mathrm{OD}\right) ; \delta[\mathrm{ppm}]=2.48$ (ddd, $1 \mathrm{H}, J=13.5 \mathrm{~Hz}, J=6.5 \mathrm{~Hz}, J=3.5 \mathrm{~Hz}$ ) és $2.86(\mathrm{~m}, 1 \mathrm{H}): 2^{\prime}-\mathrm{H}_{2}, 2.58(\mathrm{t}, 1 \mathrm{H}, J=2.5 \mathrm{~Hz}$, $\mathrm{C} \equiv \underline{\mathrm{CH}}), 3.87\left(\mathrm{~d}, 2 \mathrm{H}, J=2.5 \mathrm{~Hz}\right.$, linker $\left.\mathrm{CH}_{2}\right), 4.16\left(\mathrm{~m}, 1 \mathrm{H}, 4^{\prime}-\mathrm{H}\right), 4.25$ (dd, 1H, J=12.0 Hz, $J=5.0 \mathrm{~Hz}$ ) és $4.37(\mathrm{dd}, 1 \mathrm{H}, J=12.0 \mathrm{~Hz}, J=4.0 \mathrm{~Hz}): 5^{\prime}-\mathrm{H}_{2}, 4.57(\mathrm{dd}, 1 \mathrm{H}, J=6.5 \mathrm{~Hz}, J=3.5 \mathrm{~Hz}$, 3'-H), 6.44 (t, 1H, J=7.0 Hz, 1'-H), 7.88 (s, 1H, linker-NH), 8.20 (s, 1H) és 8.27 (s, 1H): 2-H és 8-H. ${ }^{13} \mathrm{C}-\mathrm{NMR}\left(\mathrm{CD}_{3} \mathrm{OD}\right) ; \delta[\mathrm{ppm}]=31.1$ (linker $\left.\mathrm{CH}_{2}\right), 40.9(\mathrm{C}-2$ '), $65.7(\mathrm{C}-5$ ') 72.2 $(\mathrm{C} \equiv \underline{\mathrm{CH}}), 72.7\left(\mathrm{C}-3^{\prime}\right), 81.0(\underline{\mathrm{C}} \equiv \mathrm{CH}), 85.6\left(\mathrm{C}^{-4}{ }^{\prime}\right), 86.6$ (C-1'), 120.4 (C-5), $140.7(\mathrm{C}-8), 150.3$ (C-4), 153.8 (C-2), 157.2 (C-6), 158.1 (linker-CO). ESI-MS: 339 [M+Li] ${ }^{+}$.

\section{2. példa:}

\section{5'-O-((8-Azido-3,6-dioxaoktil)karbamoil)-2'-dezoxiadenozin}

Védetlen 2'-dezoxiadenozin alapú, azidometil végü, karbamát kötésű, oligo-etilénoxi linkeres építőelem.

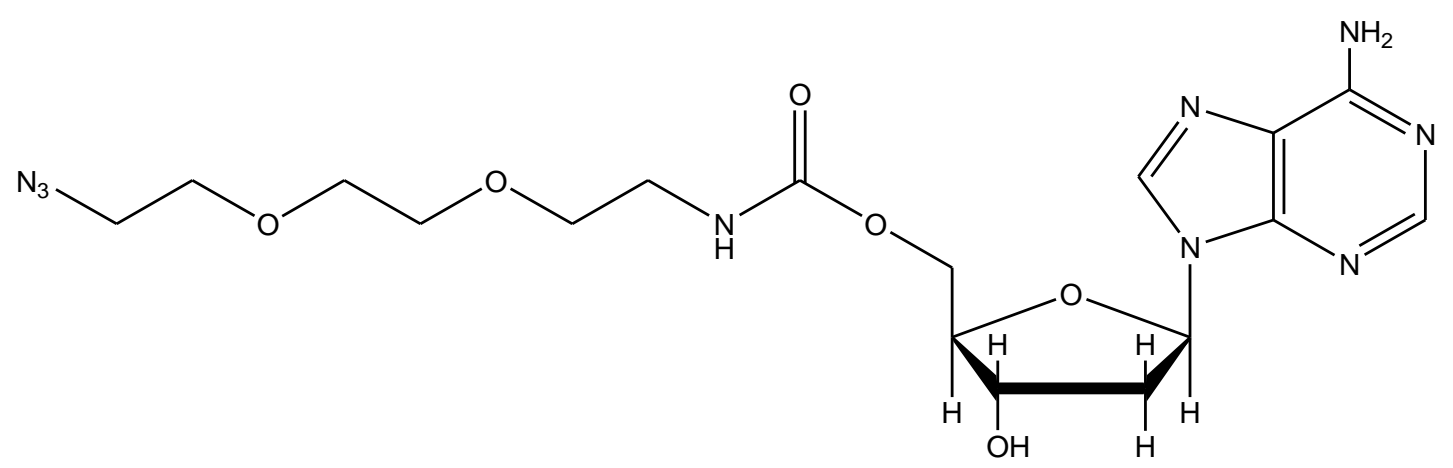

Amorf hab (71 mg, 79\%), $R_{\mathrm{f}}=0,36$ (EtOAc:MeOH/8:2); ${ }^{1} \mathrm{H}-\mathrm{NMR}\left(\mathrm{CD}_{3} \mathrm{OD}\right) ; \delta[\mathrm{ppm}]=2.50$ (ddd, $1 \mathrm{H}, J=13.5 \mathrm{~Hz}, J=6.5 \mathrm{~Hz}, J=3.5 \mathrm{~Hz}$ ) és 2.82 (ddd, $1 \mathrm{H}, J=13.5 \mathrm{~Hz}, J=7.0 \mathrm{~Hz}, J=6.5 \mathrm{~Hz}$ ): 2'- $\mathrm{H}_{2}, 3.39(\mathrm{~m}, 4 \mathrm{H})$ és $3.53(\mathrm{t}, 2 \mathrm{H}, J=5.5 \mathrm{~Hz})$ és $3.67(\mathrm{~m}, 6 \mathrm{H})$ : linker $6 \times \mathrm{CH}_{2}, 4.18(\mathrm{dt}, 1 \mathrm{H}$, $\left.J=5.0 \mathrm{~Hz}, J=3.5 \mathrm{~Hz}, 4^{\prime}-\mathrm{H}\right), 4.26(\mathrm{dd}, 1 \mathrm{H}, J=12.0 \mathrm{~Hz}, J=5.0 \mathrm{~Hz})$ és $4.36(\mathrm{dd}, 1 \mathrm{H}, J=12.0 \mathrm{~Hz}$, $J=4.0 \mathrm{~Hz}$ ): 5'- $-\mathrm{H}_{2}, 4.59$ (dd, $1 \mathrm{H}, J=6.5 \mathrm{~Hz}, J=3.5 \mathrm{~Hz}, 3$ '-H), 6.46 (dd, 1H, $\left.J=2 \times 7.0 \mathrm{~Hz}, 1^{\prime}-\mathrm{H}\right)$, $7.31\left(\mathrm{~s}, 1 \mathrm{H}\right.$, linker-NH), $8.23(\mathrm{~s}, 1 \mathrm{H})$ és $8.27(\mathrm{~s}, 1 \mathrm{H}): 2-\mathrm{H}$ és $8-\mathrm{H} .{ }^{13} \mathrm{C}-\mathrm{NMR}\left(\mathrm{CD}_{3} \mathrm{OD}\right) ; \delta$ $[\mathrm{ppm}]=40.9\left(\mathrm{C}-2^{\prime}\right), 41.7$ és 51.7 és 70.9 és 71.1 és 71.3 és 71.4 : linker $6 \times \mathrm{CH}_{2}, 65.5\left(\mathrm{C}-5^{\prime}\right)$, 72.7 (C-3'), 85.6 (C-4'), 86.6 (C-1'), 120.4 (C-5), 140.7 (C-8), 150.3 (C-4), 153.9 (C-2), 157.2 (C-6), 158.5 (linker-CO). ESI-MS: 458 [M+Li $]^{+}$. 
33. példa:

\section{5'-O-((3,6-Dioxanon-8-in-1-il)karbamoil)-2'-dezoxiadenozin}

Védetlen 2'-dezoxiadenozin alapú, etinil végü, karbamát kötésű, oligo-etilénoxi linkeres építőelem.

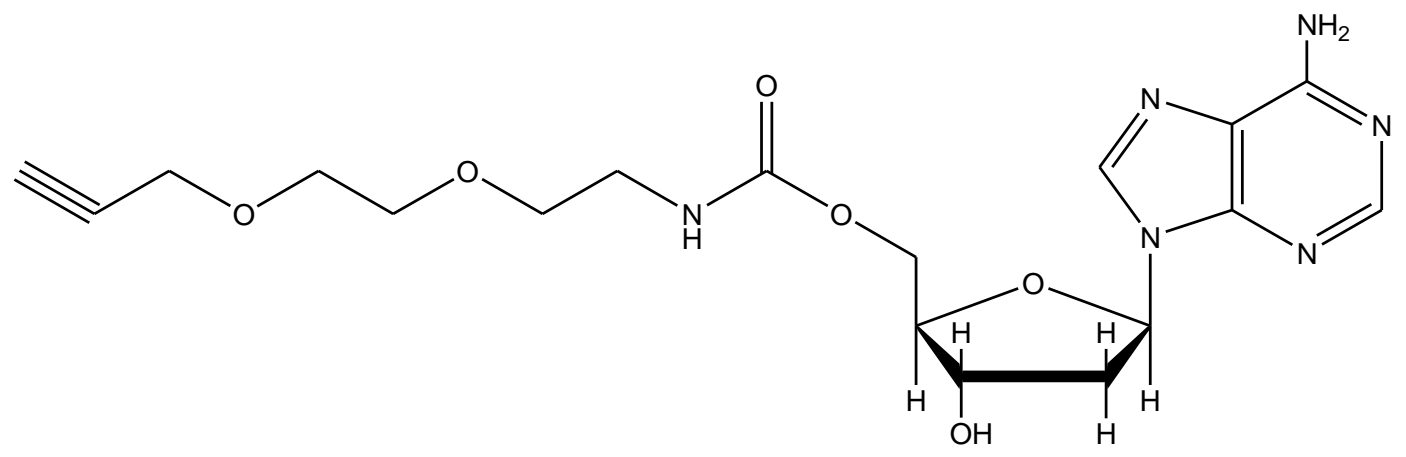

Amorf hab (71 mg, 84\%), $R_{\mathrm{f}}=0,38$ (EtOAc:MeOH/8:2); ${ }^{1} \mathrm{H}-\mathrm{NMR}\left(\mathrm{CD}_{3} \mathrm{OD}\right) ; \delta[\mathrm{ppm}]=2.48$ (ddd, $1 \mathrm{H}, J=13.5 \mathrm{~Hz}, J=6.5 \mathrm{~Hz}, J=3.5 \mathrm{~Hz})$ és $2.83(\mathrm{~m}, 1 \mathrm{H}): 2^{\prime}-\mathrm{H}_{2}, 2.85(\mathrm{t}, 1 \mathrm{H}, J=2.5 \mathrm{~Hz}$, $\mathrm{C} \equiv \underline{\mathrm{CH}}), 3.27(\mathrm{dt}, 2 \mathrm{H}, J=5.5 \mathrm{~Hz}, J=1.5 \mathrm{~Hz})$ és $3.50(\mathrm{t}, 2 \mathrm{H}, J=5.5 \mathrm{~Hz})$ és $3.61(\mathrm{~m}, 4 \mathrm{H})$ és 4.15 $(\mathrm{m}, 3 \mathrm{H}, J=2.0 \mathrm{~Hz})$ : linker $5 \times \mathrm{CH}_{2}$ és 3'-H, $4.23(\mathrm{dd}, 1 \mathrm{H}, J=12.0 \mathrm{~Hz}, J=5.0 \mathrm{~Hz})$ és $4.35(\mathrm{dd}, 1 \mathrm{H}$, $J=12.0 \mathrm{~Hz}, J=4.0 \mathrm{~Hz}): 5^{\prime}-\mathrm{H}_{2}, 4.57\left(\mathrm{dd}, 1 \mathrm{H}, J=6.5 \mathrm{~Hz}, J=3.5 \mathrm{~Hz}, 4^{\prime}-\mathrm{H}\right), 6.44$ (dd, $1 \mathrm{H}, J=2 \times$ $6.5 \mathrm{~Hz}, 1$ '-H), 8.32 (s, 1H, linker-NH), 8.21 (s, 1H) és $8.28(\mathrm{~s}, 1 \mathrm{H}): 2-\mathrm{H}$ és $8-\mathrm{H} .{ }^{13} \mathrm{C}-\mathrm{NMR}$ $\left(\mathrm{CD}_{3} \mathrm{OD}\right) ; \delta[\mathrm{ppm}]=40.9\left(\mathrm{C}-2^{\prime}\right), 41.7$ és 59.0 és 70.1 és 70.9 és 71.0 : linker $5 \times \mathrm{CH}_{2}, 65.5(\mathrm{C}$ 5’), $72.7(\mathrm{C} \equiv \underline{\mathrm{CH}}), 76.1\left(\mathrm{C}-3^{\prime}\right), 80.5(\underline{\mathrm{C}} \equiv \mathrm{CH}), 85.6$ (C-4'), $86.7\left(\mathrm{C}-1^{\prime}\right), 120.5$ (C-5), 140.7 (C8), 150.3 (C-4), 153.8 (C-2), 157.2 (C-6), 158.5 (linker-CO). ESI-MS: 427 [M+Li] ${ }^{+}$.

\section{4. példa:}

\section{5'-O-((3-Propiolamidopropil)karbamoil)-2'-dezoxiadenozin}

Védetlen 2'-dezoxiadenozin alapú, etinil végü, karbamát kötésű, alkil-amidoalkil linkeres építőelem.

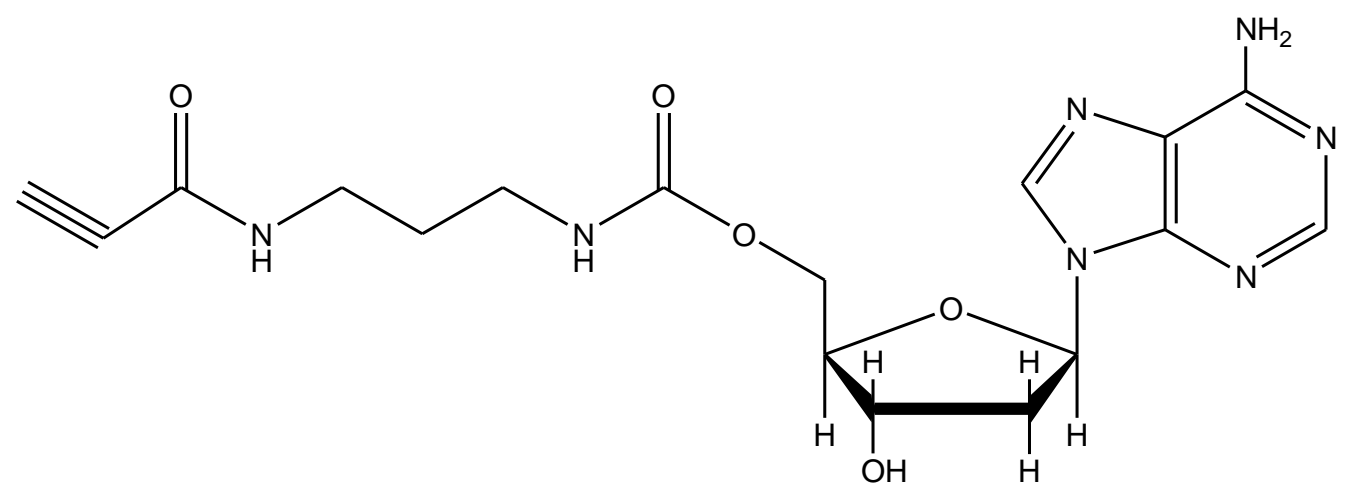


Amorf hab (58 mg, 72\%), $R_{\mathrm{f}}=0,21$ (EtOAc:MeOH/8:2); ${ }^{1} \mathrm{H}-\mathrm{NMR}\left(\mathrm{DMSO}-\mathrm{d}_{6}\right) ; \delta[\mathrm{ppm}]=1.56$ $(\mathrm{m}, 2 \mathrm{H})$ és $2.95(\mathrm{q}, 2 \mathrm{H}, J=6.5 \mathrm{~Hz})$ és $3.10(\mathrm{~m}, 2 \mathrm{H}): 3 \times$ linker $\mathrm{CH}_{2}, 2.30(\mathrm{ddd}, 1 \mathrm{H}, J=13.5 \mathrm{~Hz}$, $J=6.5 \mathrm{~Hz}, J=3.5 \mathrm{~Hz}$ ) és $2.78(\mathrm{ddd}, 1 \mathrm{H}, J=13.5 \mathrm{~Hz}, J=7.5 \mathrm{~Hz}, J=6.0 \mathrm{~Hz}): 2^{\prime}-\mathrm{H}_{2}, 4.08(\mathrm{~m}, 2 \mathrm{H}$, $\left.5^{\prime}-\mathrm{H}_{2}\right), 4.14(\mathrm{~s}, 1 \mathrm{H}, \mathrm{C} \equiv \underline{\mathrm{CH}}), 4.20\left(\mathrm{dd}, 1 \mathrm{H}, J=11.0 \mathrm{~Hz}, J=3.5 \mathrm{~Hz}, 3^{\prime}-\mathrm{H}\right), 4.40$ (dt, 1H, J=6.0 $\left.\mathrm{Hz}, J=3.0 \mathrm{~Hz}, 4^{\prime}-\mathrm{H}\right), 6.38\left(\mathrm{t}, 1 \mathrm{H}, J=7.0 \mathrm{~Hz}, 1^{\prime}-\mathrm{H}\right), 7.26(\mathrm{t}, 1 \mathrm{H}, J=5.5 \mathrm{~Hz})$ és $8.76(\mathrm{t}, 1 \mathrm{H}, J=5.5$ $\mathrm{Hz}): 2 \times$ linker-NH, $8.14(\mathrm{~s}, 1 \mathrm{H})$ és $8.30(\mathrm{~s}, 1 \mathrm{H}): 2-\mathrm{H}$ és $8-\mathrm{H} .{ }^{13} \mathrm{C}-\mathrm{NMR}\left(\mathrm{DMSO}_{6}\right) ; \delta$ $[\mathrm{ppm}]=29.1$ és 36.7 és 38.1: $3 \times$ linker $\mathrm{CH}_{2}, 38.7\left(\mathrm{C}-2^{\prime}\right), 64.3\left(\mathrm{C}-5^{\prime}\right), 71.0(\mathrm{C} \equiv \underline{\mathrm{CH}}), 75.6(\mathrm{C}-$ 3'), $78.4(\underline{\mathrm{C}} \equiv \mathrm{CH}), 83.2$ (C-4'), 84.8 (C-1'), 119.1 (C-5), 139.4 (C-8), 149.3 (C-4), 152.7 (C2), 156.0 (C-6), 151.6 és 156.1: $2 \times$ linker-CO. ESI-MS: $410[\mathrm{M}+\mathrm{Li}]^{+}$.

\section{5. példa:}

\section{5'-O-((3-Azidopropil)tiokarbamoil)-2'-dezoxiadenozin}

Védetlen 2'-dezoxiadenozin alapú, azidometil végü, tiokarbamát kötésű, alkilén linkeres építőelem.

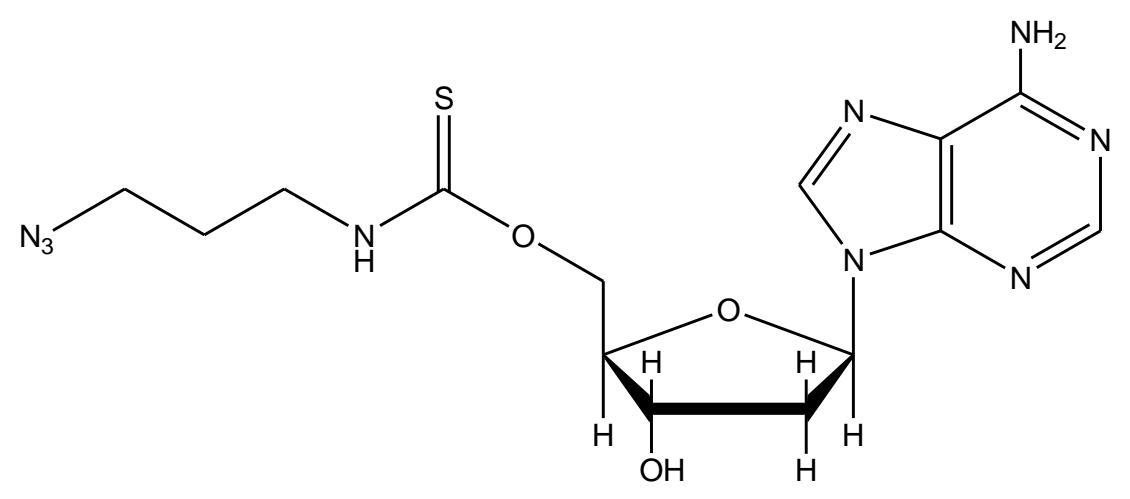

Amorf hab (53 mg, 67\%), $R_{\mathrm{f}}=0,50$ (EtOAc:MeOH/8:2); ${ }^{1} \mathrm{H}-\mathrm{NMR}\left(\mathrm{CD}_{3} \mathrm{OD}\right) ; \delta[\mathrm{ppm}]=1.84$ (p, $2 \mathrm{H}, J=6.5 \mathrm{~Hz})$ és $3.38(\mathrm{~m}, 2 \mathrm{H})$ és $3.54(\mathrm{t}, 2 \mathrm{H}, J=7.0 \mathrm{~Hz})$ : linker $3 \times \mathrm{CH}_{2}, 2.50(\mathrm{ddd}, 1 \mathrm{H}, J=13.5$ $\mathrm{Hz}, J=6.5 \mathrm{~Hz}, J=3.5 \mathrm{~Hz}$ ) és 2.84 (ddd, $1 \mathrm{H}, J=13.5 \mathrm{~Hz}, J=7.5 \mathrm{~Hz}, J=6.0 \mathrm{~Hz}$ ): 2'- $\mathrm{H}_{2}, 3.23$ (m, 1H, 3'-H), $4.32\left(\mathrm{~m}, 1 \mathrm{H}, 4^{\prime}-\mathrm{H}\right), 4.60(\mathrm{dd}, 1 \mathrm{H}, J=6.0 \mathrm{~Hz}, J=3.0 \mathrm{~Hz})$ és 4.81 (m, 1H): 5'- $\mathrm{H}_{2}, 6.45$ (dd, 1H, J=7.0 Hz, J=6.0 Hz, 1'-H), 7.45 (s, 1H, linker-NH), 8.21 (s, 1H) és 8.27 (s, 1H): 2-H és 8-H. ${ }^{13} \mathrm{C}-\mathrm{NMR}\left(\mathrm{CD}_{3} \mathrm{OD}\right) ; \delta[\mathrm{ppm}]=28.7$ és 43.4 és 49.8 : linker $3 \times \mathrm{CH}_{2}, 40.1(\mathrm{C}-2$ '), 70.4 (C-5'), 72.8 (C-3'), 85.9 (C-4'), 86.5 (C-1'), 120.6 (C-5), 140.7 (C-8), 150.3 (C-4), 153.8 (C2), 157.2 (C-6), 190.6 (linker-C=S). ESI-MS: $400[\mathrm{M}+\mathrm{Li}]^{+}$. 
36. példa:

\section{5'-O-((Prop-2-in-1-il)tiokarbamoil)-2'-dezoxiadenozin}

Védetlen 2'-dezoxiadenozin alapú, etinil végü, tiokarbamát kötésű, alkilén linkeres építőelem.

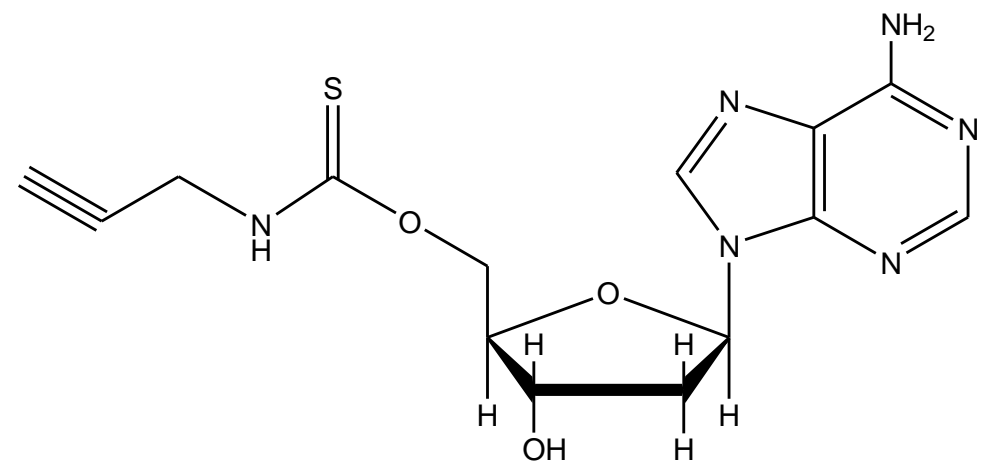

Amorf hab (31 mg, 45\%), $R_{\mathrm{f}}=0,35$ (EtOAc:MeOH/9:1); ${ }^{1} \mathrm{H}-\mathrm{NMR}\left(\mathrm{DMSO}-\mathrm{d}_{6}\right) ; \delta[\mathrm{ppm}]=2.32$ (ddd, $J=13.5 \mathrm{~Hz}, J=6.5 \mathrm{~Hz}, J=3.5 \mathrm{~Hz}, 1 \mathrm{H})$ és $2.78(\mathrm{~m}, 1 \mathrm{H}): 2^{\prime}-\mathrm{H}_{2}, 3.11(\mathrm{t}, J=2.5 \mathrm{~Hz}, 1 \mathrm{H}$, $\mathrm{C} \equiv \underline{\mathrm{CH}}), 4.10\left(\mathrm{dq}, J=6.5 \mathrm{~Hz}, J=3.5 \mathrm{~Hz}, 1 \mathrm{H}, 4^{\prime}-\mathrm{H}\right), 4.17\left(\mathrm{~d}, J=2.5 \mathrm{~Hz}, 2 \mathrm{H}\right.$, linker $\left.\mathrm{CH}_{2}\right), 4.45$ (m, 2H, 5'- $\left.\mathrm{H}_{2}\right)$, ), 4.61 (m, 1H, 3'-H), 6.31 (m, 1H, 1'-H), 8.14 (s, 1H) és 8.31 (s, 1H): 2-H és 8-H. ${ }^{13} \mathrm{C}-\mathrm{NMR}\left(\mathrm{DMSO}_{6}\right) ; \delta[\mathrm{ppm}]=34.2\left(\right.$ linker $\left.\mathrm{CH}_{2}\right), 38.7$ (C-2'), $70.2(\mathrm{C}-5$ '), 70.9 $(\mathrm{C} \equiv \underline{\mathrm{CH}}), 74.0\left(\mathrm{C}^{\prime} 3^{\prime}\right), 79.6(\underline{\mathrm{C}} \equiv \mathrm{CH}), 83.1$ (C-4'), 84.2 (C-1'), 119.1 (C-5), 139.4 (C-8), 149.2 (C-4), 152.7 (C-2), 156.1 (C-6), 189.8 (linker-C=S). ESI-MS: 355 [M+Li] ${ }^{+}$.

37. példa:

\section{5'-O-((8-Azido-3,6-dioxaoktil)tiokarbamoil)-2'-dezoxiadenozin}

Védetlen 2'-dezoxiadenozin alapú, azidometil végü, tiokarbamát kötésü, oligo-etilénoxi linkeres építőelem.

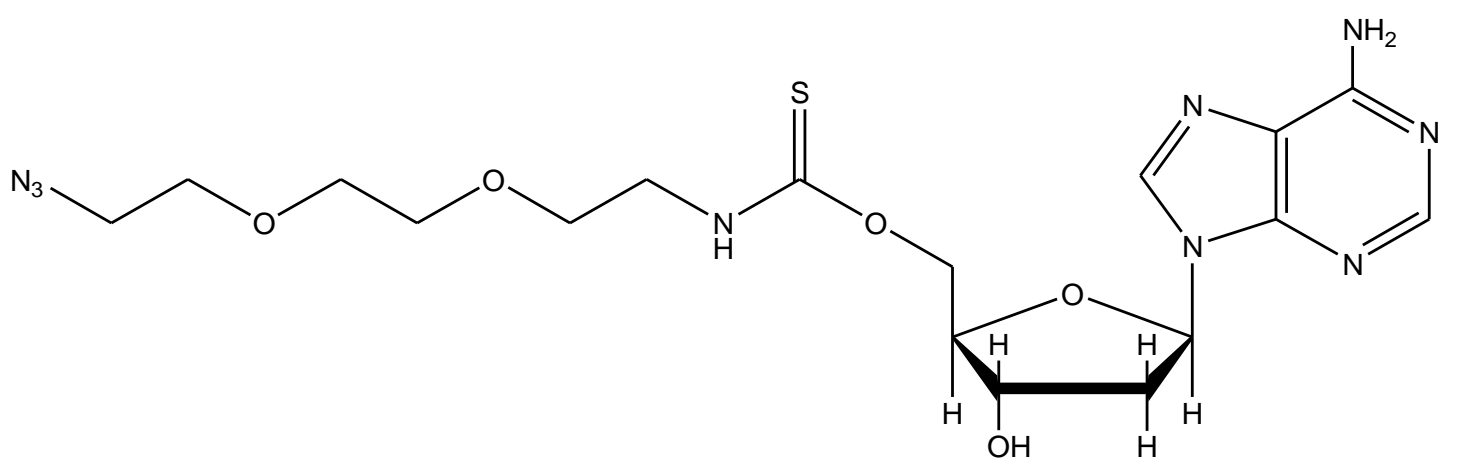

Amorf hab (68 mg, 73\%), $R_{\mathrm{f}}=0,45$ (EtOAc:MeOH/8:2); ${ }^{1} \mathrm{H}-\mathrm{NMR}\left(\mathrm{CD}_{3} \mathrm{OD}\right) ; \delta[\mathrm{ppm}]=2.51$ (ddd, $1 \mathrm{H}, J=13.5 \mathrm{~Hz}, J=6.5 \mathrm{~Hz}, J=3.5 \mathrm{~Hz}$ ) és $2.86(\mathrm{ddd}, 1 \mathrm{H}, J=13.5 \mathrm{~Hz}, J=7.5 \mathrm{~Hz}, J=6.0 \mathrm{~Hz}$ ): 2'- $\mathrm{H}_{2}, 3.33(\mathrm{~m}, 4 \mathrm{H})$ és $3.62(\mathrm{~m}, 8 \mathrm{H})$ : linker $6 \times \mathrm{CH}_{2}, 4.25\left(\mathrm{~m}, 1 \mathrm{H}, 4^{\prime}-\mathrm{H}\right), 4.63\left(\mathrm{~m}, 2 \mathrm{H}, 5^{\prime}-\mathrm{H}_{2}\right)$, 
4.75 (dd, 1H, J=12.0 Hz, J=4.0 Hz, 3'-H), 6.49 (m, 1H, 1'-H), 7.45 (d, 1H, J=1.5 Hz, linker$\mathrm{NH}), 8.22(\mathrm{~s}, 1 \mathrm{H})$ és 8.29 (s, 1H): 2-H és 8-H. ${ }^{13} \mathrm{C}-\mathrm{NMR}\left(\mathrm{CD}_{3} \mathrm{OD}\right) ; \delta[\mathrm{ppm}]=40.8\left(\mathrm{C}-2{ }^{\prime}\right), 46.2$ és 51.7 és 70.0 és 70.6 és 71.0 és 71.1: linker $6 \times \mathrm{CH}_{2}, 69.6$ (C-5’), 72.9 (C-3’), 85.8 (C-4'), 86.5 (C-1'), 120.5 (C-5), 140.8 (C-8), 150.3 (C-4), 153.9 (C-2), 157.2 (C-6), 190.6 (linker$\mathrm{C}=\mathrm{S})$. ESI-MS: $474[\mathrm{M}+\mathrm{Li}]^{+}$.

\section{8. példa:}

\section{5'-O-((3,6-Dioxanon-8-in-1-il)tiokarbamoil)-2'-dezoxiadenozin}

Védetlen 2'-dezoxiadenozin alapú, etinil végü, tiokarbamát kötésü, oligo-etilénoxi linkeres építőelem.

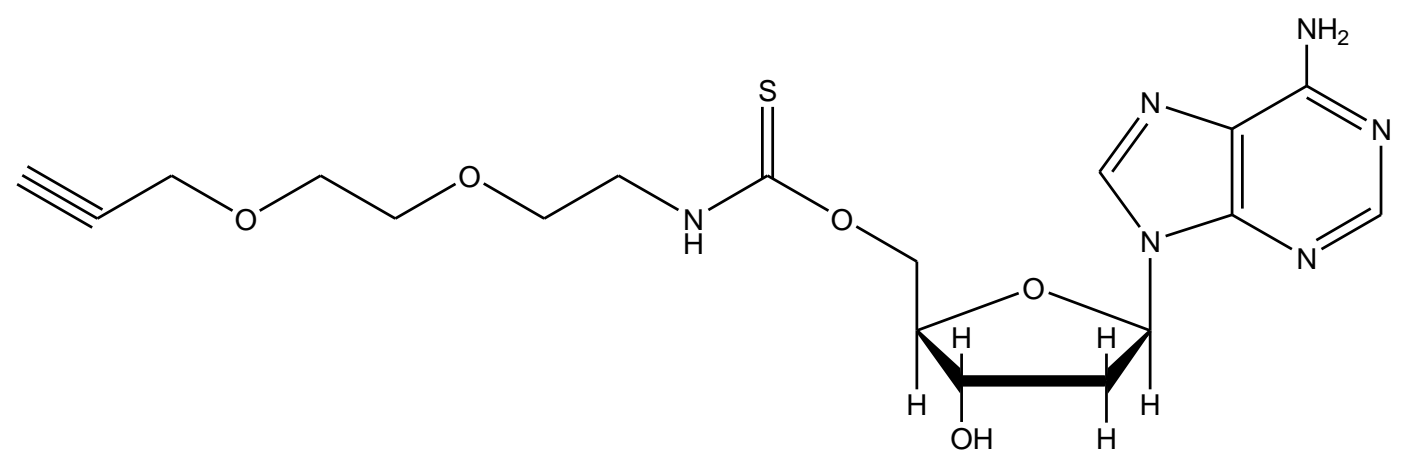

Amorf hab (65 mg, 75\%), $R_{\mathrm{f}}=0,46$ (EtOAc:MeOH/8:2); ${ }^{1} \mathrm{H}-\mathrm{NMR}\left(\mathrm{CD}_{3} \mathrm{OD}\right) ; \delta[\mathrm{ppm}]=2.57$ $(\mathrm{m}, 1 \mathrm{H})$ és $2.99(\mathrm{~m}, 1 \mathrm{H}): 2$ '- $\mathrm{H}_{2}, 2.75(\mathrm{t}, 1 \mathrm{H}, J=2.5 \mathrm{~Hz}, \mathrm{C} \equiv \underline{\mathrm{CH}}), 3.48(\mathrm{~m}, 2 \mathrm{H})$ és $3.70(\mathrm{~m}, 6 \mathrm{H})$ és $4.15(\mathrm{dd}, 2 \mathrm{H}, J=3.0 \mathrm{~Hz}, J=2.5 \mathrm{~Hz})$ : linker $5 \times \mathrm{CH}_{2}, 4.30\left(\mathrm{~m}, 1 \mathrm{H}, 4^{\prime}-\mathrm{H}\right), 4.64\left(\mathrm{~m}, 2 \mathrm{H}, 5^{\prime}-\mathrm{H}_{2}\right)$, 4.79 (m, 1H, 3'-H), 6.44 (dd, 1H, J=6.5 Hz, J=6.0 Hz, 1'-H), 7.36 (d, 1H, J=2.5 Hz, linker$\mathrm{NH}), 8.21(\mathrm{~s}, 1 \mathrm{H})$ és 8.27 (s, 1H): 2-H és 8-H. ${ }^{13} \mathrm{C}-\mathrm{NMR}\left(\mathrm{CD}_{3} \mathrm{OD}\right) ; \delta[\mathrm{ppm}]=40.8\left(\mathrm{C}-2^{\prime}\right), 46.2$ és 59.1 és 70.0 és 70.1 és 70.5: linker $5 \times \mathrm{CH}_{2}, 69.6\left(\mathrm{C}-5^{\prime}\right), 76.1(\mathrm{C} \equiv \underline{\mathrm{CH}}), 76.2\left(\mathrm{C}-3^{\prime}\right), 80.4$ $(\underline{\mathrm{C}} \equiv \mathrm{CH}), 85.8$ (C-4'), 86.5 (C-1'), 120.4 (C-5), 140.8 (C-8), 150.3 (C-4), 153.8 (C-2), 157.2 (C-6), 191.7 (linker-C=S). ESI-MS: $443[\mathrm{M}+\mathrm{Li}]^{+}$.

\section{9. példa:}

\section{5'-O-((3-Azidopropil)karbamoil)guanozin}

Védetlen guanozin alapú, azidometil végü, karbamát kötésü, alkilén linkeres építőelem. 


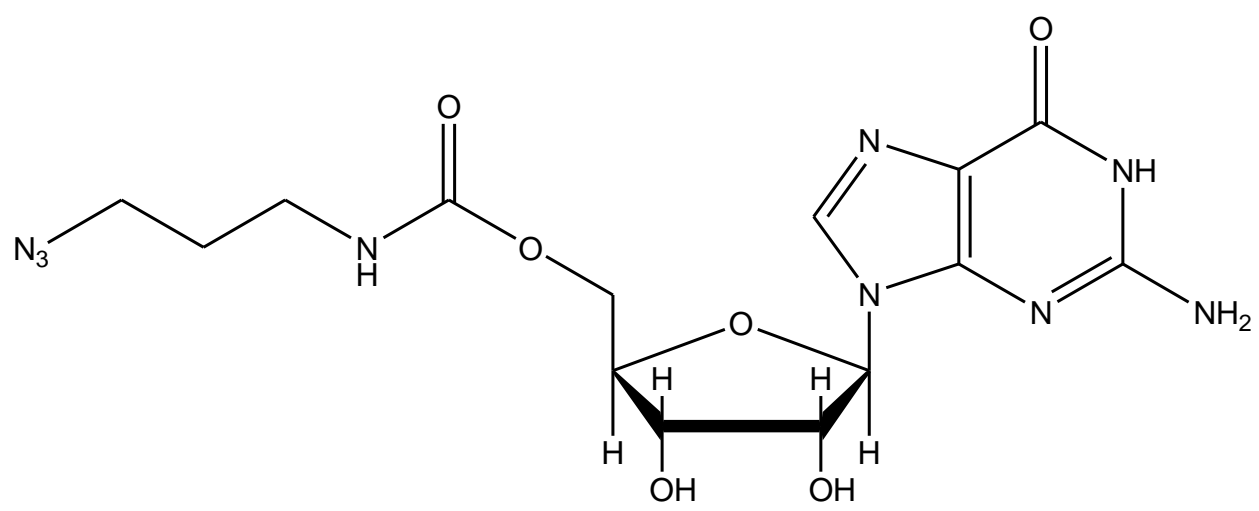

Amorf hab (67 mg, 82\%), $R_{\mathrm{f}}=0,49$ (EtOAc:iPrOH: $\left.\mathrm{H}_{2} \mathrm{O} / 8: 2: 1\right) ;{ }^{1} \mathrm{H}-\mathrm{NMR}\left(\right.$ DMSO $\left.\mathrm{d}_{6}\right) ; \delta$ $[\mathrm{ppm}]=1.64(\mathrm{p}, 2 \mathrm{H}, J=7.0 \mathrm{~Hz})$ és $3.09(\mathrm{~m}, 2 \mathrm{H})$ és $3.36(\mathrm{~m}, 2 \mathrm{H})$ : linker $3 \times \mathrm{CH}_{2}, 4.00(\mathrm{dt}, 1 \mathrm{H}$, $J=6.0 \mathrm{~Hz}, J=3.5 \mathrm{~Hz}, 3$ '-H), 4.12 (m, 2H, 5'-H $), 4.19$ (dd, 1H, J=12.0 Hz, J=3.5 Hz, 4'-H), $4.47\left(\mathrm{dd}, 1 \mathrm{H}, J=2 \times 6.0 \mathrm{~Hz}, 2^{\prime}-\mathrm{H}\right), 5.53\left(\mathrm{dd}, 1 \mathrm{H}, J=5.0 \mathrm{~Hz}, J=2.0 \mathrm{~Hz}, 1^{\prime}-\mathrm{H}\right), 7.42$ (t, $1 \mathrm{H}, J=6.0$ $\mathrm{Hz}$, linker-NH), 7.90 (s, 1H, 8-H), 10.72 (s, 1H, 1-NH). ${ }^{13} \mathrm{C}-\mathrm{NMR}\left(\mathrm{DMSO}-\mathrm{d}_{6}\right) ; \delta[\mathrm{ppm}]=28.7$ és 37.6 és 48.3: 3×linker $\mathrm{CH}_{2}, 64.1$ (C-5’), 70.6 (C-2'), 73.1 (C-3'), 82.3 (C-4'), 86.0 (C-1'), 116.7 (C-5), 135.5 (C-8), 151.6 (C-4), 153.8 (C-2), 156.1 (linker-CO), 156.8 (C-6). ESI-MS: $416[\mathrm{M}+\mathrm{Li}]^{+}$.

\section{0. példa:}

\section{5'-O-(Prop-2-in-1-ilkarbamoil)guanozin}

Védetlen guanozin alapú, etinil végü, karbamát kötésű, alkilén linkeres építőelem.

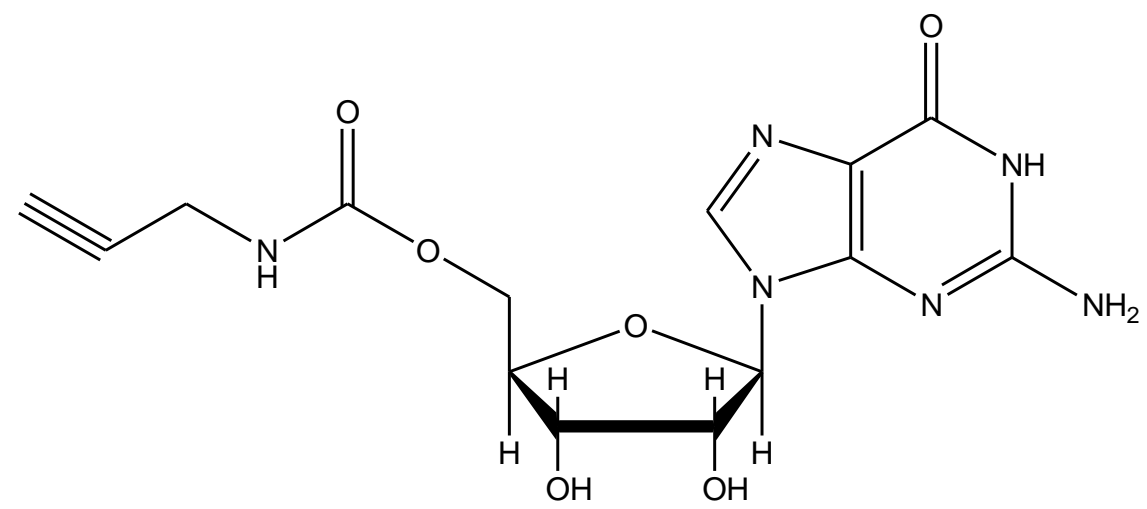

Amorf hab (58 mg, 80\%), $R_{\mathrm{f}}=0,47$ (EtOAc:iPrOH: $\left.\mathrm{H}_{2} \mathrm{O} / 8: 2: 1\right) ;{ }^{1} \mathrm{H}-\mathrm{NMR}\left(\right.$ DMSO-d $_{6}$ ); $\delta$ $[\mathrm{ppm}]=3.13(\mathrm{t}, 1 \mathrm{H}, J=2.5 \mathrm{~Hz}, \mathrm{C} \equiv \underline{\mathrm{CH}}), 3.79\left(\mathrm{dd}, 2 \mathrm{H}, J=6.0 \mathrm{~Hz}, J=2.5 \mathrm{~Hz}\right.$, linker $\left.\mathrm{CH}_{2}\right), 4.01$

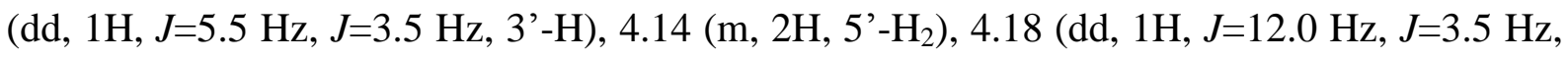
4'-H), 4.46 (dd, 1H, J=6.5 Hz, J=5.0 Hz, 2'-H), 5.69 (d, 1H, J=6.5 Hz, 1'-H), 7.84 (t, 1H, $J=6.0 \mathrm{~Hz}$, linker-NH), $7.92(\mathrm{~s}, 1 \mathrm{H}, 8-\mathrm{H}), 10.28(\mathrm{~s}, 1 \mathrm{H}, 1-\mathrm{NH}) \cdot{ }^{13} \mathrm{C}-\mathrm{NMR}\left(\mathrm{DMSO}_{\mathrm{d}}\right) ; \delta$ 


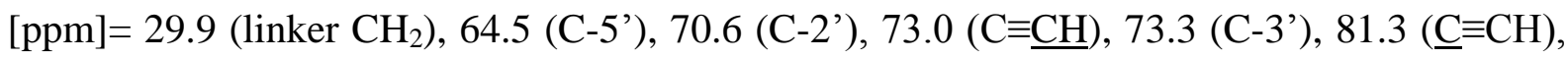
82.2 (C-4'), 86.0 (C-1'), 116.7 (C-5), 135.6 (C-8), 151.6 (C-4), 153.8 (C-2), 155.9 (linkerCO), 156.9 (C-6). ESI-MS: 371 [M+Li] $]^{+}$

\section{1. példa:}

\section{5'-O-((8-Azido-3,6-dioxaoktil)karbamoil)guanozin}

Védetlen guanozin alapú, azidometil végü, karbamát kötésű, oligo-etilénoxi linkeres építőelem.

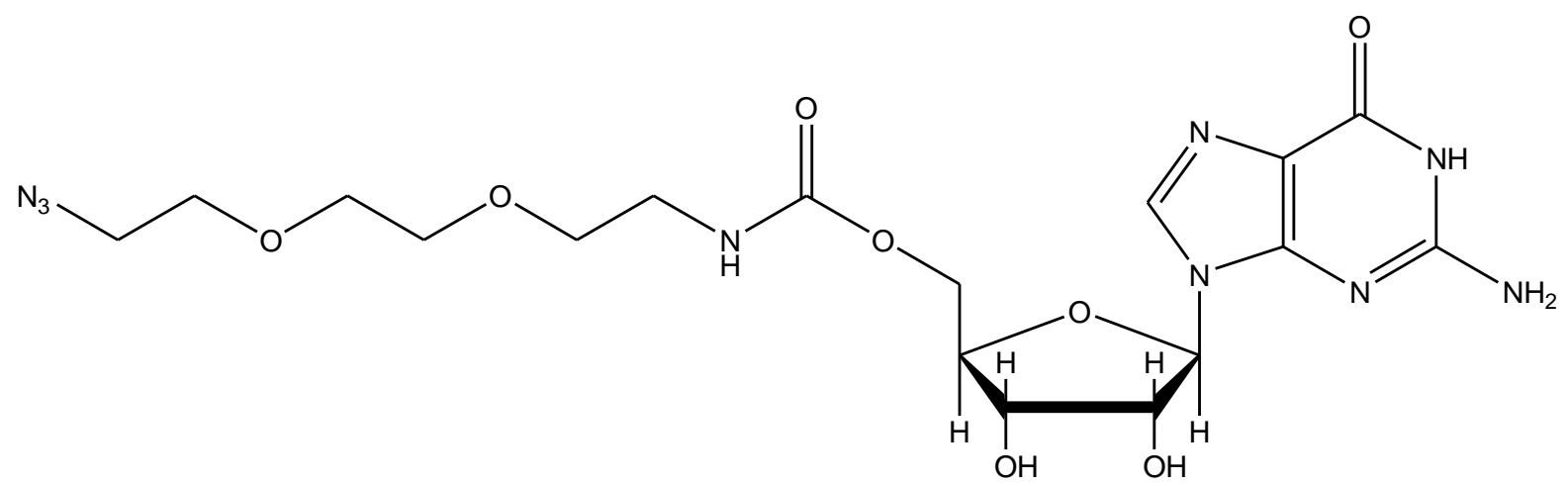

Amorf hab (82 mg, 85\%), $R_{\mathrm{f}}=0,42$ (EtOAc:iPrOH: $\left.\mathrm{H}_{2} \mathrm{O} / 8: 2: 1\right) ;{ }^{1} \mathrm{H}-\mathrm{NMR}\left(\right.$ DMSO-d $_{6}$ ); $\delta$ $[\mathrm{ppm}]=3.13(\mathrm{q}, 2 \mathrm{H}, J=6.0 \mathrm{~Hz})$ és $3.45(\mathrm{~m}, 4 \mathrm{H})$ és $3.53(\mathrm{~m}, 2 \mathrm{H})$ és $3.55(\mathrm{ddd}, 2 \mathrm{H}, J=5.5 \mathrm{~Hz}$, $J=3.0 \mathrm{~Hz}, J=1.5 \mathrm{~Hz}$ ) és $3.63(\mathrm{~m}, 2 \mathrm{H})$ : linker $6 \times \mathrm{CH}_{2}, 3.99\left(\mathrm{dt}, 1 \mathrm{H}, J=5.5 \mathrm{~Hz}, J=3.5 \mathrm{~Hz}, 3^{\prime}-\mathrm{H}\right)$, 4.12 (m, 2H, 5'-H $), 4.17$ (dd, $1 \mathrm{H}, J=12.0 \mathrm{~Hz}, J=3.5 \mathrm{~Hz}, 4$ '-H), 4.47 (dd, 1H, $J=2 \times 6.0 \mathrm{~Hz}, 2^{\prime}-$ H), 5.70 (d, 1H, J=6.5 Hz, 1'-H), 7.40 (t, 1H, J=6.0 Hz, linker-NH), 7.92 (s, 1H, 8-H), 10.38 $(\mathrm{s}, 1 \mathrm{H}, 1-\mathrm{NH}) .{ }^{13} \mathrm{C}-\mathrm{NMR}\left(\mathrm{DMSO}-\mathrm{d}_{6}\right) ; \delta[\mathrm{ppm}]=40.2$ és 50.3 és 69.2 és 69.3 és 69.7 és 70.4: 6×linker $\mathrm{CH}_{2}, 64.1$ (C-5’), 70.6 (C-2’), 73.0 (C-3’), 82.3 (C-4'), 86.0 (C-1'), 116.7 (C-5), 135.6 (C-8), 151.6 (C-4), 153.8 (C-2), 156.1 (linker-CO), 156.9 (C-6). ESI-MS: 490 [M+Li] ${ }^{+}$.

\section{2. példa:}

\section{5'-O-((3,6-Dioxanon-8-in-1-il)karbamoil)guanozin}

Védetlen guanozin alapú, etinil végü, karbamát kötésü, oligo-etilénoxi linkeres építőelem. 


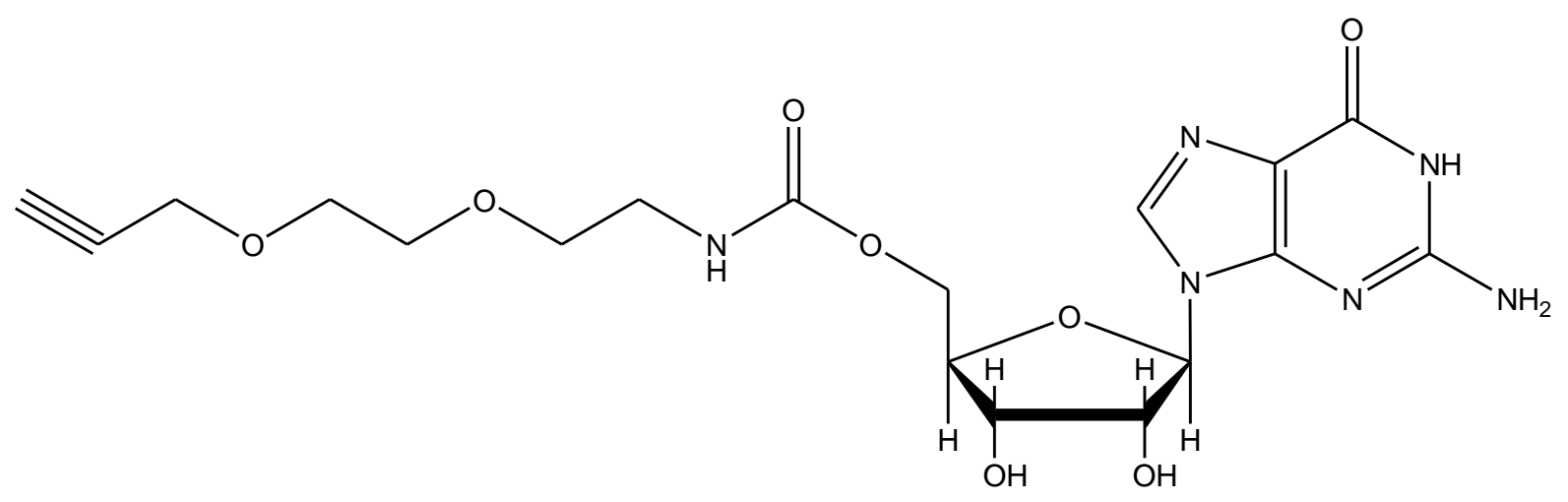

Amorf hab (75 mg, 83\%), $R_{\mathrm{f}}=0,45$ (EtOAc:iPrOH: $\left.\mathrm{H}_{2} \mathrm{O} / 8: 2: 1\right) ;{ }^{1} \mathrm{H}-\mathrm{NMR}\left(\right.$ DMSO-d $\left._{6}\right) ; \delta$ $[\mathrm{ppm}]=3.13(\mathrm{t}, 1 \mathrm{H}, J=2.5 \mathrm{~Hz}, \mathrm{C} \equiv \underline{\mathrm{CH}}), 3.45(\mathrm{~m}, 4 \mathrm{H})$ és $3.53(\mathrm{q}, 4 \mathrm{H}, J=4.0 \mathrm{~Hz})$ és $4.21(\mathrm{~m}$, $6 \mathrm{H})$ : linker $5 \times \mathrm{CH}_{2}, 5^{\prime}-\mathrm{H}_{2}, 4^{\prime}-\mathrm{H}, 3^{\prime}-\mathrm{H}, 4.48\left(\mathrm{dd}, 1 \mathrm{H}, J=2 \times 6.0 \mathrm{~Hz}, 2^{\prime}-\mathrm{H}\right), 5.70$ (d, 1H, J=6.5 $\mathrm{Hz}, 1$ '-H), 7.42 (t, 1H, J=6.0 Hz, linker-NH), 7.93 (s, 1H, 8-H), 10.64 (s, 1H, 1-NH). ${ }^{13} \mathrm{C}-$ NMR (DMSO-d $\left.{ }_{6}\right) ; \delta[\mathrm{ppm}]=40.2$ és 57.6 és 68.5 és 69.4 és 70.6: linker $6 \times \mathrm{CH}_{2}, 64.1(\mathrm{C}-5$ '), $73.0(\mathrm{C} \equiv \underline{\mathrm{CH}}), 77.2\left(\mathrm{C}-2^{\prime}\right), 77.3\left(\mathrm{C}-3^{\prime}\right), 80.4(\underline{\mathrm{C}} \equiv \mathrm{CH}), 82.3\left(\mathrm{C}-4^{\prime}\right), 85.9\left(\mathrm{C}-1^{\prime}\right), 116.6(\mathrm{C}-5)$, 135.6 (C-8), 151.7 (C-4), 153.8 (C-2), 156.1 (linker-CO), 156.9 (C-6). ESI-MS: 459 [M+Li] ${ }^{+}$.

\section{3. példa:}

\section{5'-O-((3-Propiolamidopropil)karbamoil)guanozin}

Védetlen guanozin alapú, etinil végű, karbamát kötésü, alkil-amidoalkil linkeres építőelem.

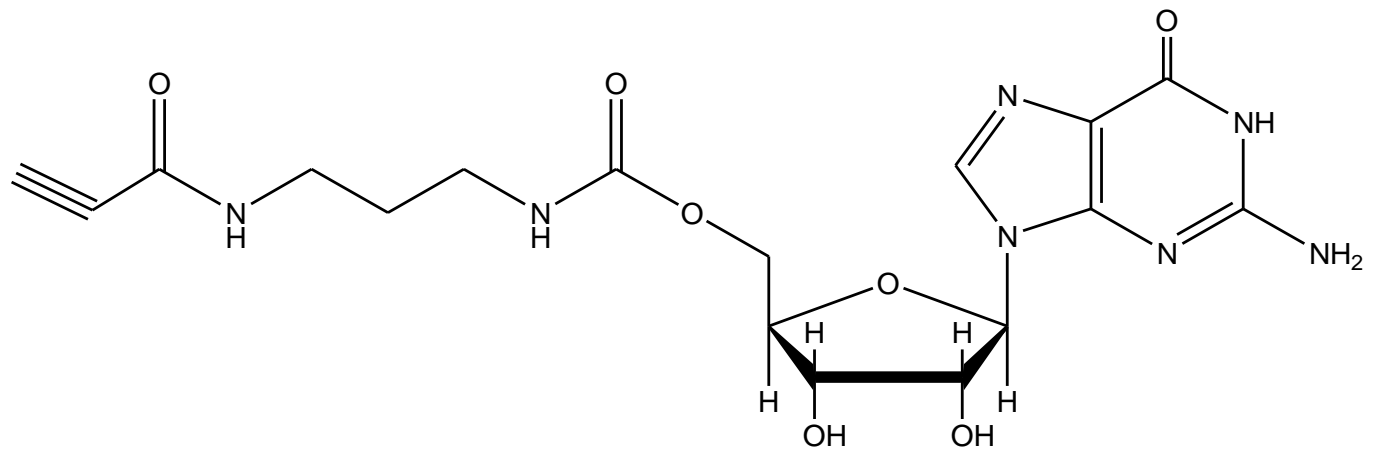

Amorf hab (64 mg, 74\%), $R_{\mathrm{f}}=0,49$ (EtOAc:iPrOH:H $\left.\mathrm{H}_{2} \mathrm{O} / 8: 2: 1\right) ;{ }^{1} \mathrm{H}-\mathrm{NMR}\left(\right.$ DMSO-d $_{6}$ ); $\delta$ $[\mathrm{ppm}]=1.54(\mathrm{p}, 2 \mathrm{H}, J=7.0 \mathrm{~Hz})$ és $2.97(\mathrm{q}, 2 \mathrm{H}, J=6.5 \mathrm{~Hz})$ és $3.07(\mathrm{q}, 2 \mathrm{H}, J=6.5 \mathrm{~Hz}): 3 \times$ linker $\mathrm{CH}_{2}, 4.10(\mathrm{~m}, 1 \mathrm{H})$ és $4.18(\mathrm{dd}, 1 \mathrm{H}, J=12.0 \mathrm{~Hz}, J=3.5 \mathrm{~Hz}): 5^{\prime}-\mathrm{H}_{2}, 4.13(\mathrm{t}, 1 \mathrm{H}, J=2.5 \mathrm{~Hz}$, $\mathrm{C} \equiv \underline{\mathrm{CH}}), 4.47\left(\mathrm{q}, 1 \mathrm{H}, J=6.0 \mathrm{~Hz}, 4^{\prime}-\mathrm{H}\right), 5.34(\mathrm{dd}, 1 \mathrm{H}, J=4.5 \mathrm{~Hz}, J=6.0 \mathrm{~Hz}, 3$ '-H), 5.51 (d, 1H, $\left.J=6.0 \mathrm{~Hz}, 2^{\prime}-\mathrm{H}\right), 5.69\left(\mathrm{~d}, 1 \mathrm{H}, J=6.0 \mathrm{~Hz}, 1^{\prime}-\mathrm{H}\right), 7.34(\mathrm{t}, 1 \mathrm{H}, J=5.5 \mathrm{~Hz})$ és $8.74(\mathrm{t}, 1 \mathrm{H}, J=5.5$ $\mathrm{Hz}$ ): $2 \times$ linker-NH, 7.90 (s, 1H, 8-H), 10.74 (s, 1H, 1-NH). ${ }^{13} \mathrm{C}-\mathrm{NMR}\left(\mathrm{DMSO}_{-} \mathrm{d}_{6}\right) ; \delta[\mathrm{ppm}]=$ 
29.1 és 36.7 és 38.1: $3 \times$ linker $\mathrm{CH}_{2}, 64.1\left(\mathrm{C}-5^{\prime}\right), 70.6\left(\mathrm{C}-2^{\prime}\right), 73.0(\mathrm{C} \equiv \underline{\mathrm{CH}}), 75.6(\mathrm{C}-3$ '), 78.4 $(\underline{\mathrm{C}} \equiv \mathrm{CH}), 82.3$ (C-4'), 86.0 (C-1'), 116.7 (C-5), 135.5 (C-8), 151.6 (C-4), 151.7 és 156.0: 2×linker-CO, 153.8 (C-2), 156.8 (C-6). ESI-MS: 442 [M+Li] ${ }^{+}$.

\section{IPARI ALKALMAZHATÓSÁG}

Ipari szempontból a találmány elsősorban gyógyszerfejlesztési feladatok felgyorsítására alkalmazható azáltal, hogy a találmány szerinti vegyületekből előre, nagy mennyiségben elkészíthetőek a különböző linkert, terminális horgony funkciós csoportot, kapcsolófunkciót és purintartalmú nukleozidtípust tartalmazó, klikkelhető nukleozid koenzimmimikáló molekuláris építőelemek, melyeket alkin-azid klikkreakcióval egy szintén azid, illetve alkin horgony funkciós csoportot tartalmazó inhibitormolekulához kapcsolunk. Az így kapott vegyületek (vegyületkönyvtárak) biológiai rendszerekben párhuzamosan tesztelhetők. Mivel a találmány szerinti szerkezeteket előre el lehet készíteni és a már valamilyen mértékủ biológiai hatást mutató inhibitormolekulákat is el lehet látni a megfelelö komplementer horgony funkciós csoportokkal, majd a klikkreakciók is viszonylag univerzálisan kivitelezhetőek párhuzamos szintézisekkel, ezért az ilyen módon szintetizált biszubsztrát inhibitorok elkészítésének ideje töredékére csökkenthető a hagyományos módon, egyedileg előállítható biszubsztrát inhibitorok előállítási idejéhez képest, azaz az ilyen típusú gyógyszerfejlesztés nagyságrendekkel meggyorsítható.

\section{Szabadalmi igénypontok}

1. Az (I) általános képletü, purinalapú, nukleozid koenzimmimikáló molekuláris építőelemek biokonjugátumok, elsősorban biszubsztrát inhibitorok előállításához,

$$
\mathrm{F}-\mathrm{L}-\mathrm{K}-\mathrm{C}
$$

ahol a képletben

C jelentése az alábbi általános képlettel jellemzett nukleozid molekularész: 


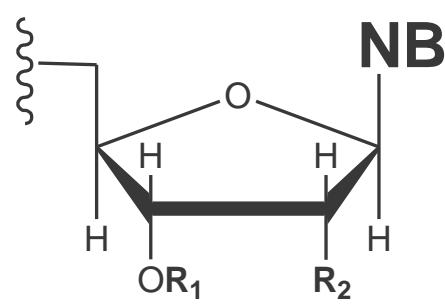

ahol a képletben $\mathrm{R}_{1}$ jelentése $H$ vagy $\mathrm{PG}_{1}$ védőcsoport;

$\mathrm{R}_{2}$ jelentése $\mathrm{H}, \mathrm{OH}$ vagy $\mathrm{O}-\mathrm{PG}_{2}$, ahol $\mathrm{PG}_{2}$ védőcsoport;

NB jelentése az alábbi csoportok közül választott:<smiles>[Y]N(CCCC)c1ncnc2c1ncn2C</smiles><smiles>CN(C(=O)O)c1nc2c(ncn2C)c(=O)[nH]1</smiles>

ahol $\mathrm{PG}_{3}$ jelentése $\mathrm{H}$ vagy védőcsoport;

A jelentése $\mathrm{H}$ vagy a $\mathrm{PG}_{3}$ védőcsoporttal együtt $\mathrm{N}$-dimetilformamidin csoportot jelöl;

$\mathrm{K}$ jelentése a C nukleozid molekularész 5'-szénatomjához kapcsolódó karbamátvagy tiokarbamát-csoport, amely karbamát- vagy tiokarbamát-csoport oxigénatomján keresztül kapcsolódik a C nukleozid molekularészhez;

L jelentése a K karbamát- vagy tiokarbamát-csoport nitrogénatomján keresztül kapcsolódó linkerrész, amely a következők közül választott: - $\left(\mathrm{CH}_{2}\right)_{\mathrm{n}}(\mathrm{CO}) \mathrm{NH}\left(\mathrm{CH}_{2}\right)_{\mathrm{m}^{-}}$képletü alkil-amidoalkil-csoport, - $\left(\mathrm{CH}_{2}\right)_{\mathrm{p}^{-}}$képletü alkiléncsoport vagy - $\left(\mathrm{CH}_{2}\right)_{\mathrm{q}}\left(\mathrm{OCH}_{2} \mathrm{CH}_{2}\right)_{\mathrm{r}^{-}}$képletü oligo-etilénoxi-csoport, ahol a képletekben n jelentése 0-10 értékü egész szám, m jelentése 212 értékü egész szám, p jelentése 1-16 értékü egész szám, q jelentése 1-6 értékü egész szám és r jelentése 1-6 értékü egész szám;

F jelentése az L linkerrész másik végéhez kapcsolódó etinil- vagy azidometilcsoport;

és ezen vegyületek sói, hidrátjai és szeteroizomer formái.

2. Az 1. igénypont szerinti purinalapú, nukleozid koenzimmimikáló molekuláris építőelemek, ahol NB jelentése előnyösen adenin.

3. Az 1-2. igénypontok bármelyike szerinti nukleozid koenzimmimikáló molekuláris építőelemek, ahol L jelentése - $\left(\mathrm{CH}_{2}\right)_{\mathrm{n}}(\mathrm{CO}) \mathrm{NH}\left(\mathrm{CH}_{2}\right)_{\mathrm{m}}$ - képletü alkil-amidoalkil-csoport. 
4. Az 1-2. igénypontok bármelyike szerinti purinalapú, nukleozid koenzimmimikáló molekuláris építőelemek, ahol L jelentése - $\left(\mathrm{CH}_{2}\right)_{\mathrm{q}}\left(\mathrm{OCH}_{2} \mathrm{CH}_{2}\right)_{\mathrm{r}^{-}}$képletü oligoetilénoxicsoport.

5. Az 1-2. igénypontok bármelyike szerinti nukleozid koenzimmimikáló molekuláris építőelemek, ahol L jelentése - $\left(\mathrm{CH}_{2}\right)_{\mathrm{p}}$ - képletü alkiléncsoport.

6. Az 1-5. igénypont bármelyike szerinti nukleozid koenzimmimikáló molekuláris építőelemek, ahol K jelentése karbamátcsoport.

7. Az 1-6. igénypont bármelyike szerinti nukleozid koenzimmimikáló molekuláris építőelemek, ahol F jelentése azidometil-csoport.

8. Az 1-6. igénypont bármelyike szerinti nukleozid koenzimmimikáló molekuláris építőelemek, ahol F jelentése etinilcsoport.

9. Az 1. igénypont szerinti nukleozid koenzimmimikáló molekuláris építőelem a következő vegyületek köréből választva:

3'-O-acetil-5' -O-((3-(2-azidoacetamido)propil)karbamoil)- $N^{6}$-benzoil-2'dezoxiadenozin,

3'-O-acetil-5'-O-((3-(2-azidoacetamido)propil)karbamoil)-2'-dezoxi- $N^{2}$ izobutirilguanozin,

2',3'-di-O-acetil-5'-O-((3-(2-azidoacetamido)propil)karbamoil)- $N^{6}$-benzoiladenozin, 2',3'-di- $O$-acetil-5' - $O$-((3-(2-azidoacetamido)propil)karbamoil)- $N^{2}$-izobutirilguanozin, 3'-O-acetil-5' -O-((3-azidopropil)karbamoil)- $N^{6}$-benzoil-2'-dezoxiadenozin, 3'-O-acetil-5' - $O$-((prop-2-in-1-il)karbamoil)- $N^{6}$-benzoil-2'-dezoxiadenozin, 3'-O-acetil-5'-O-((8-azido-3,6-dioxaoktil)karbamoil)- $N^{6}$-benzoil-2'-dezoxiadenozin, 3'-O-acetil-5' - $O$-((3,6-dioxanon-8-in-1-il)karbamoil)- $N^{6}$-benzoil-2' -dezoxiadenozin, 3'-O-acetil-5' -O-((3-propiolamidopropil)karbamoil)- $N^{6}$-benzoil-2' -dezoxiadenozin, 3'-O-acetil-5'-O-((3-azidopropil)tiokarbamoil)- $N^{6}$-benzoil-2'-dezoxiadenozin, 3'-O-acetil-5' - $O$-(prop-2-in-1-iltiokarbamoil)- $N^{6}$-benzoil-2'-dezoxiadenozin, 3'-O-acetil-5' - $O$-((8-azido-3,6-dioxaoktil)tiokarbamoil)- $N^{6}$-benzoil-2'-dezoxiadenozin, 3'-O-acetil-5' - $O$-((3,6-dioxanon-8-in-1-il)tiokarbamoil)- $N^{6}$-benzoil-2' -dezoxiadenozin, 2',3'-di-O-acetil-5' - $O$-((3-azidopropil)karbamoil)- $N^{2}$-izobutirilguanozin, 2',3'-di-O-acetil-5'-O-(prop-2-in-1-ilkarbamoil)- $N^{2}$-izobutirilguanozin, 2',3'-di-O-acetil-5'-O-((8-azido-3,6-dioxaoktil)karbamoil)- $N^{2}$-izobutirilguanozin, 
2',3'-di-O-acetil-5'-O-((3,6-dioxanon-8-in-1-il)karbamoil)- $N^{2}$-izobutirilguanozin, 2',3'-di-O-acetil-5' - $O$-((3-propiolamidopropil)karbamoil)- $N^{2}$-izobutirilguanozin, 5'-O-((3-(2-azidoacetamido)propil)karbamoil)-2'-dezoxiadenozin, 5'-O-((3-(2-azidoacetamido)propil)karbamoil)-2'-dezoxiguanozin, 5'-O-((3-(2-azidoacetamido)propil)karbamoil)-adenozin, 5'-O-((3-(2-azidoacetamido)propil)karbamoil)-guanozin, 5'-O-((3-azidopropil)karbamoil)-2'-dezoxiadenozin), 5'-O-((Prop-2-in-1-il)karbamoil)-2'-dezoxiadenozin, 5'-O-((8-azido-3,6-dioxaoktil)karbamoil)-2'-dezoxiadenozin, 5'-O-((3,6-dioxanon-8-in-1-il)karbamoil)-2'-dezoxiadenozin, 5'-O-((3-Propiolamidopropil)karbamoil)-2'-dezoxiadenozin, 5'-O-((3-azidopropil)tiokarbamoil)-2'-dezoxiadenozin, 5'-O-((Prop-2-in-1-il)tiokarbamoil)-2'-dezoxiadenozin, 5'-O-((8-azido-3,6-dioxaoktil)tiokarbamoil)-2'-dezoxiadenozin, 5'-O-((3,6-dioxanon-8-in-1-il)tiokarbamoil)-2'-dezoxiadenozin, 5'-O-((3-azidopropil)karbamoil)guanozin, 5'-O-(Prop-2-in-1-ilkarbamoil)guanozin, 5'-O-((8-azido-3,6-dioxaoktil)karbamoil)guanozin, 5'-O-((3,6-dioxanon-8-in-1-il)karbamoil)guanozin, 5'-O-((3-Propiolamidopropil)karbamoil)guanozin és ezen vegyületek sói, hidrátjai és szeteroizomer formái.

10. Az 1-9. igénypontok szerinti vegyületek alkalmazása biokonjugátumok, elönyösen enzimek biszubsztrát inhibitorainak előállítására. 


\section{5'-LINKERREL MÓDOSÍTOTT NUKLEOZIDOK}

\section{Kivonat}

A találmány tárgyát képezik olyan természetes, purinvázas nukleozidokból előállított (adott esetben a cukorrészek 2'- és/vagy 3'-hidroxicsoporjain védett, és adott esetben a nukleobázisok aminocsoportjain védett) nukleozidszármazékok, amelyeknek 5'szénatomjához karbamát/tiokarbamát csoporton keresztül egy nem ionos jellegü (alkilamidoalkil, alkilén- vagy polietilénglikol tartalmú) linker egység kapcsolódik, amelynek másik végén egy terminális (azaz láncvégi) alkin vagy azidometil funkciós csoport található. A találmány tárgya továbbá az említett nukleozidszármazékok alkalmazása biológiailag aktív, nukleozidtartalmú biokonjugátumok, elönyösen enzimek biszubsztrát inhibitorainak gyors, egyszerü és hatékony előállítására. 
IV.

\section{Physical data of all prepared compounds}

\section{2,3,4,5-Tetra-O-acetyl- $\beta$-D-glucopyranosyl azide (47 $\beta)$}

Oil (680 mg, 73\%), $R_{\mathrm{f}}=0.36$ (hexane:EtOAc/7:3), $\mathrm{C}_{14} \mathrm{H}_{19} \mathrm{~N}_{3} \mathrm{O}_{9} ;{ }^{1} \mathrm{H}-\mathrm{NMR} \quad\left(\mathrm{CDCl}_{3}\right) ; \delta$ $[\mathrm{ppm}]=2.02,2.04,2.09$ and 2.11: $(4 \times \mathrm{s}, 4 \times 3 \mathrm{H}, 4 \times \mathrm{OAc}), 3.80(\mathrm{ddd}, 1 \mathrm{H}, J=10.2 \mathrm{~Hz}, J=5.0 \mathrm{~Hz}$, $J=2.4 \mathrm{~Hz}, 5-\mathrm{H}), 4.18(\mathrm{dd}, 1 \mathrm{H}, J=12.8 \mathrm{~Hz}, J=2.4 \mathrm{~Hz}, 6 \mathrm{a}-\mathrm{H}), 4.28$ (dd, 1H, J=12.8 Hz, J=4.9 $\mathrm{Hz}, 6 \mathrm{~b}-\mathrm{H}), 4.66$ (dd, 1H, J=9.1 Hz, J=0.5 Hz, 1-H), 4.96 (dd, 1H, J=9.2 Hz, J=9.2 Hz, 2-H), 5.11 (dd, 1H, J=10.2 Hz, J=9.7 Hz, 4-H), 5.23 (ddd, 1H, J=9.8 Hz, J=9.2 Hz, J=0.5 Hz, 3-H);

${ }^{13} \mathrm{C}-\mathrm{NMR}$ data were consistent with those reported in the literature. ${ }^{168}$ ESI-MS: $374[\mathrm{M}+\mathrm{H}]^{+}$, $391\left[\mathrm{M}+\mathrm{NH}_{4}\right]^{+}$.

\section{2,3,4,5-Tetra-O-acetyl- $\alpha$-D-mannopyranosyl azide $(\mathbf{4 8} \alpha)$}

Oil (736 mg, 79\%), $R_{\mathrm{f}}=0.36$ (hexane:EtOAc/7:3), $\mathrm{C}_{14} \mathrm{H}_{19} \mathrm{~N}_{3} \mathrm{O}_{9} ;{ }^{1} \mathrm{H}-\mathrm{NMR} \quad\left(\mathrm{CDCl}_{3}\right) ; \delta$ $[\mathrm{ppm}]=2.00,2.06,2.12$ and 2.17: $(4 \times \mathrm{s}, 4 \times 3 \mathrm{H}, 4 \times \mathrm{OAc}), 4.16(\mathrm{dd}, 2 \mathrm{H}, J=11.8 \mathrm{~Hz}, J=10.8 \mathrm{~Hz}$, 6- $\left.\mathrm{H}_{2}\right), 4.31(\mathrm{dd}, 1 \mathrm{H}, J=12.5 \mathrm{~Hz}, J=5.8 \mathrm{~Hz}, 5-\mathrm{H}), 5.16(\mathrm{dd}, 1 \mathrm{H}, J=0.5 \mathrm{~Hz}, 1-\mathrm{H}), 5.23-5.32$ (overlapping m, 2H, 2-H and 4-H), $5.39(\mathrm{dd}, 1 \mathrm{H}, J=0.5 \mathrm{~Hz}, 3-\mathrm{H}) ;{ }^{13} \mathrm{C}-\mathrm{NMR}$ data were consistent with those reported in the literature. ${ }^{169}$ ESI-MS: $374[\mathrm{M}+\mathrm{H}]^{+}, 391\left[\mathrm{M}+\mathrm{NH}_{4}\right]^{+}$.

\section{2,3,4,5-Tetra-O-acetyl- $\beta$-D-galactopyranosyl azide (49 $\beta)$}

Oil (671 mg, 72\%), $R_{\mathrm{f}}=0.36$ (hexane:EtOAc/7:3), $\mathrm{C}_{14} \mathrm{H}_{19} \mathrm{~N}_{3} \mathrm{O}_{9} ;{ }^{1} \mathrm{H}-\mathrm{NMR}\left(\mathrm{CDCl}_{3}\right) ; \delta$ [ppm] 2.00, 2.07, 2.10 and 2.18: $(4 \times \mathrm{s}, 4 \times 3 \mathrm{H}, 4 \times \mathrm{OAc}), 4.02(\mathrm{dd}, 1 \mathrm{H} . J=6.5 \mathrm{~Hz}, 5-\mathrm{H}), 4.13-4.22$ (overlapping m, 2H, 6- $\mathrm{H}_{2}$ ), 4.60 (dd, $\left.1 \mathrm{H}, J=9.0 \mathrm{~Hz}, J=0.5 \mathrm{~Hz}, 1-\mathrm{H}\right), 5.04$ (dd, $1 \mathrm{H}, J=10.4 \mathrm{~Hz}$, $J=3.7 \mathrm{~Hz}, 2-\mathrm{H}), 5.17(\mathrm{dd}, 1 \mathrm{H}, J=10.0 \mathrm{~Hz}, J=9.0 \mathrm{~Hz}, 4-\mathrm{H}), 5.43(\mathrm{~d}, 1 \mathrm{H}, J=3.7 \mathrm{~Hz}, 3-\mathrm{H}) ;{ }^{13} \mathrm{C}-$ NMR data were consistent with those reported in the literature. ${ }^{169}$ ESI-MS: $374[\mathrm{M}+\mathrm{H}]^{+}, 391$ $\left[\mathrm{M}+\mathrm{NH}_{4}\right]^{+}, 396[\mathrm{M}+\mathrm{Na}]^{+}$.

Methyl 6-azido-6-deoxy-2,3,4-tri-O-benzoyl- $\alpha$-D-glucopyranoside (59)

Oil (289 mg, 68\%), $R_{\mathrm{f}}=0.67$ (hexane:EtOAc/7:3), $\mathrm{C}_{28} \mathrm{H}_{25} \mathrm{~N}_{3} \mathrm{O}_{8} ;{ }^{1} \mathrm{H}-\mathrm{NMR} \quad\left(\mathrm{CDCl}_{3}\right) ; \delta$ $[\mathrm{ppm}]=3.42(\mathrm{dd}, 1 \mathrm{H}, J=13.5 \mathrm{~Hz}, J=3.0 \mathrm{~Hz}, 6 \mathrm{a}-\mathrm{H}), 3.49-3.55$ (overlapping $\mathrm{m}, 4 \mathrm{H}, 6 \mathrm{~b}-\mathrm{H}$ and $\mathrm{OCH}_{3}$ ), 4.25 (ddd, $1 \mathrm{H}, J=10.1 \mathrm{~Hz}, J=7.0 \mathrm{~Hz}, J=3.1 \mathrm{~Hz}, 5-\mathrm{H}$ ), 5.25-5.32 (overlapping m, 2H, 
1-H and 2-H), 5.51 (dd, 1H, J=9.8 Hz, 3-H), 6.12-6.19 (m, 1H, 4-H), benzoyl protons: 7.30 $(\mathrm{m}, 2 \mathrm{H}), 7.41(\mathrm{~m}, 5 \mathrm{H}), 7.53(\mathrm{~m}, 2 \mathrm{H}), 7.87(\mathrm{~m}, 2 \mathrm{H}), 7.96(\mathrm{~m}, 2 \mathrm{H}), 7.99(\mathrm{~m}, 2 \mathrm{H}) ;{ }^{13} \mathrm{C}-\mathrm{NMR}$ $\left(\mathrm{CDCl}_{3}\right) ; \delta[\mathrm{ppm}]=51.2(\mathrm{C}-6), 55.8\left(\mathrm{OCH}_{3}\right), 69.1(\mathrm{C}-2), 70.1(\mathrm{C}-3), 70.2(\mathrm{C}-4), 71.9(\mathrm{C}-5)$, 97.0 (C-1), 128.3 (2C), 128.4 (2C), 128.5 (2C), 129.6 (2C), 129.8 (2C), 129.9 (2C), 133.1, 133.4, 133.6: benzoyl CHs, 128.6, 128.9, 129.1: benzoyl Cq, 165.8, 166.5 and 167.0: (3×s, $3 \times 1 \mathrm{C}, \mathrm{Bz}-\mathrm{CO})$; ESI-MS: $532[\mathrm{M}+\mathrm{H}]^{+}, 549\left[\mathrm{M}+\mathrm{NH}_{4}\right]^{+}$.

Methyl 6-azido-6-deoxy-2,3,4-tri-O-benzoyl- $\alpha$-D-mannopyranoside (60)

Oil (301 mg, 71\%), $R_{\mathrm{f}}=0.67$ (hexane:EtOAc/7:3), $\mathrm{C}_{28} \mathrm{H}_{25} \mathrm{~N}_{3} \mathrm{O}_{8} ;{ }^{1} \mathrm{H}-\mathrm{NMR} \quad\left(\mathrm{CDCl}_{3}\right) ; \delta$ [ppm]=3.46 (ddd, 1H, $J=13.0 \mathrm{~Hz}, J=3.0 \mathrm{~Hz}, J=1.0 \mathrm{~Hz}, 6 \mathrm{a}-\mathrm{H}), 3.51-3.59$ (overlapping m, 4H, 6b-H and $\left.\mathrm{OCH}_{3}\right), 4.26(\mathrm{ddd}, 1 \mathrm{H}, J=11.0 \mathrm{~Hz}, J=7.0 \mathrm{~Hz}, J=1.0 \mathrm{~Hz}, 5-\mathrm{H}), 5.01$ (dd, 1H, $J=2.5$ $\mathrm{Hz}, 1-\mathrm{H}$ ), 5.69 (dd, $1 \mathrm{H}, J=3.5 \mathrm{~Hz}, J=2.5 \mathrm{~Hz}, 2-\mathrm{H}$ ), 5.83-5.92 (overlapping m, 2H, 3-H and 4H), benzoyl protons: $7.25(\mathrm{~m}, 1 \mathrm{H}), 7.29(\mathrm{~m}, 1 \mathrm{H}), 7.41(\mathrm{~m}, 3 \mathrm{H}), 7.52(\mathrm{~m}, 3 \mathrm{H}), 7.63(\mathrm{~m}, 1 \mathrm{H})$, $7.83(\mathrm{~m}, 2 \mathrm{H}), 7.96(\mathrm{~m}, 2 \mathrm{H}), 8.12(\mathrm{~m}, 2 \mathrm{H}) ;{ }^{13} \mathrm{C}-\mathrm{NMR}\left(\mathrm{CDCl}_{3}\right) ; \delta[\mathrm{ppm}]=51.9(\mathrm{C}-6), 56.3$ $\left(\mathrm{OCH}_{3}\right), 68.4$ (C-2), 70.3 (C-3), 70.9 (C-4), 71.0 (C-5), 99.2 (C-1), 128.2 (2C), 128.4 (2C), 128.5 (2C), 129.6 (2C), 129.7 (2C), 129.8 (2C), 133.1, 133.5 (2C): benzoyl CHs, 128.9, 129.1, 129.2: benzoyl Cq, 166.2, 167.3 and 167.7: (3×s, 3×1C, Bz-CO); ESI-MS: 532 $[\mathrm{M}+\mathrm{H}]^{+}, 549\left[\mathrm{M}+\mathrm{NH}_{4}\right]^{+}$.

Methyl 5-azido-5-deoxy-2,3-di-O-benzoyl- $\beta$-D-ribofuranoside $(\mathbf{6 1})^{167}$

Oil (195 mg, 65\%), $R_{\mathrm{f}}=0.71$ (hexane:EtOAc/7:3), $\mathrm{C}_{20} \mathrm{H}_{19} \mathrm{~N}_{3} \mathrm{O}_{6} ;{ }^{1} \mathrm{H}-\mathrm{NMR}\left(\mathrm{CDCl}_{3}\right) ; \delta$ $[\mathrm{ppm}]=3.52-3.58$ (overlapping $\mathrm{m}, 4 \mathrm{H}, \mathrm{OCH}_{3}$ and $\left.5 \mathrm{a}-\mathrm{H}\right), 3.66(\mathrm{dd}, 1 \mathrm{H}, J=13.0 \mathrm{~Hz}, J=4.0 \mathrm{~Hz}$, $5 \mathrm{~b}-\mathrm{H}), 4.53$ (ddd, 1H, J=6.3 Hz, J=4.0 Hz, 4-H), 5.17 (d, 1H, J=1.0 Hz, 1-H), 5.64 (overlapping $\mathrm{m}, 2 \mathrm{H}, 3-\mathrm{H}$ and 4-H), benzoyl protons: $7.34(\mathrm{~m}, 2 \mathrm{H}), 7.44(\mathrm{~m}, 2 \mathrm{H}), 7.52(\mathrm{~m}$, 1H), $7.59(\mathrm{~m}, 1 \mathrm{H}), 7.88(\mathrm{~m}, 2 \mathrm{H}), 8.03(\mathrm{~m}, 2 \mathrm{H}) ;{ }^{13} \mathrm{C}-\mathrm{NMR}\left(\mathrm{CDCl}_{3}\right) ; \delta[\mathrm{ppm}]=54.1(\mathrm{C}-5), 55.9$ $\left(\mathrm{OCH}_{3}\right), 73.0$ (C-2), 75.6 (C-3), 80.7 (C-4), 106.9 (C-1), 128.2 (2C), 128.3 (2C), 129.5 (2C), 129.6 (2C), 133.2, 133.3: benzoyl CHs, 128.7, 129.0: benzoyl Cq, 165.4 and 165.5: $(2 \times s$, 2×1C, Bz-CO); ESI-MS: $398[\mathrm{M}+\mathrm{H}]^{+}, 415\left[\mathrm{M}+\mathrm{NH}_{4}\right]^{+}$.

3-(1-(2,3,4,6-Tetra-O-acetyl- $\beta$-D-glucopyranosyl)-1H-1,2,3-triazol-4-yl-methyloxy)-13 $\alpha$ hydroxymethyl-14 $\beta$-propyl-des-D-estra-1,3,5(10)-triene (65a)

White solid (76 mg, 81\%), mp 158-160 ${ }^{\circ} \mathrm{C}, R_{\mathrm{f}}=0.33\left(\mathrm{CH}_{2} \mathrm{Cl}_{2}\right.$ :EtOAc/9:1), $\mathrm{C}_{36} \mathrm{H}_{49} \mathrm{~N}_{3} \mathrm{O}_{11} ;{ }^{1} \mathrm{H}-$ $\operatorname{NMR}\left(\mathrm{CDCl}_{3}\right) ; \delta[\mathrm{ppm}]=0.77\left(\mathrm{~s}, 3 \mathrm{H}, 18-\mathrm{H}_{3}\right), 0.91\left(\mathrm{t}, 3 \mathrm{H}, J=6.3 \mathrm{~Hz}, 16 \mathrm{a}-\mathrm{H}_{3}\right), 1.85,2.03,2.07$ 
and $2.08(4 \times \mathrm{s}, 4 \times 3 \mathrm{H}, 4 \times \mathrm{OAc}), 2.85\left(\mathrm{~m}, 2 \mathrm{H}, 6-\mathrm{H}_{2}\right), 3.34$ and $3.51(2 \times \mathrm{d}, 2 \times 1 \mathrm{H}, J=2 \times 10.8 \mathrm{~Hz}$, 17- $\left.\mathrm{H}_{2}\right), 3.99\left(\mathrm{~m}, 1 \mathrm{H}, 5^{\prime}-\mathrm{H}\right), 4.15$ and $4.29\left(2 \times \mathrm{m}, 2 \times 1 \mathrm{H}, 6{ }^{\prime}-\mathrm{H}_{2}\right), 5.17-5.25$ (overlapping $\mathrm{m}, 3 \mathrm{H}$ ), 5.39-5.47 (overlapping m, 2H), 5,88 (d, 1H, J=8.9 Hz): 1'-, 2'-, 3'-, 4'-H, $\mathrm{OCH}_{2} ; 6.70$ (d, 1H, $J=2.2 \mathrm{~Hz}, 4-\mathrm{H}), 6.78$ (dd, 1H, J=8.6 Hz, J=2.2 Hz, 2-H), 7.22 (d, 1H, J=8.6 Hz, 1-H), 7.84 (s, $1 \mathrm{H}, \mathrm{HC}=\mathrm{C}) ;{ }^{13} \mathrm{C}-\mathrm{NMR}\left(\mathrm{CDCl}_{3}\right) ; \delta[\mathrm{ppm}]=14.6(\mathrm{C}-16 \mathrm{a}), 16.0(\mathrm{C}-18), 20.1,20.5(2 \mathrm{C})$ and 20.7 (4×OAc), 25.0, 26.4, 27.4, 30.6, 31.2, 35.6, 41.7, 42.3, 43.5, 45.2, 61.5 and $61.9\left(\mathrm{OCH}_{2}\right.$ and C-6'), 67.7, 70.2, 71.3 (C-17), 72.7, 75.1, 85.7 (C-1'), 112.3 (C-2), 114.4 (C-4), 120.9 $(\mathrm{HC}=\mathrm{C}), 126.6$ (C-1), 133.6 (C-10), 138.2 (C-5), $145.4(\mathrm{HC}=\underline{\mathrm{C}}), 152.0$ (C-3), 168.8, 169.3, 169.9 and $170.8\left(4 \times\right.$ Ac-CO); ESI-MS: $700[\mathrm{M}+\mathrm{H}]^{+}, 1399[2 \mathrm{M}+\mathrm{H}]^{+}$.

3-(1-(2,3,4,6-tetra-O-acetyl- $\beta$-D-glucopyranosyl)-1H-1,2,3-triazol-4-yl-methyloxy)-14 $\beta$ propyl-des-D-estra-1,3,5(10)-triene-13 $\alpha$-carbaldehyde oxyme $\mathbf{( 6 5 \mathbf { b } )}$

White solid (78 mg, 82\%), mp 146-148 ${ }^{\circ} \mathrm{C}, R_{\mathrm{f}}=0.35\left(\mathrm{CH}_{2} \mathrm{Cl}_{2}\right.$ :EtOAc/9:1), $\mathrm{C}_{36} \mathrm{H}_{48} \mathrm{~N}_{4} \mathrm{O}_{11} ;{ }^{1} \mathrm{H}-$ $\operatorname{NMR}\left(\mathrm{CDCl}_{3}\right) ; \delta[\mathrm{ppm}]=0.87\left(\mathrm{t}, 3 \mathrm{H}, J=6.3 \mathrm{~Hz}, 16 \mathrm{a}-\mathrm{H}_{3}\right), 1.08\left(\mathrm{~s}, 3 \mathrm{H}, 18-\mathrm{H}_{3}\right), 1.85,2.02,2.06$ and $2.07(4 \times \mathrm{s}, 4 \times 3 \mathrm{H}, 4 \times \mathrm{OAc}), 2.85\left(\mathrm{~m}, 2 \mathrm{H}, 6-\mathrm{H}_{2}\right), 4.09-4.15$ (overlapping $\left.\mathrm{m}, 2 \mathrm{H}\right), 4.28-4.31$ (m, 1H), 5.23 (m, 1H), 5.39-5.45 (overlapping m, 2H), 5.89 (m, 1H): 1'-, 2'-, 3'-, 4'-, 5'-H, 6'$\mathrm{H}_{2}, 5.17\left(\mathrm{~s}, 2 \mathrm{H}, \mathrm{OCH}_{2}\right), 6.70(\mathrm{~d}, 1 \mathrm{H}, J=2.2 \mathrm{~Hz}, 4-\mathrm{H}), 6.79$ (dd, $\left.1 \mathrm{H}, J=8.6 \mathrm{~Hz}, J=2.2 \mathrm{~Hz}, 2-\mathrm{H}\right)$, $7.19(\mathrm{~d}, 1 \mathrm{H}, J=8.6 \mathrm{~Hz}, 1-\mathrm{H}), 7.32(\mathrm{~s}, 1 \mathrm{H}, 17-\mathrm{H}), 7.85(\mathrm{~s}, 1 \mathrm{H}, \mathrm{HC}=\mathrm{C}) ;{ }^{13} \mathrm{C}-\mathrm{NMR}\left(\mathrm{CDCl}_{3}\right) ; \delta$ [ppm]=14.1 (C-16a), 15.0 (C-18), 19.7, 20.0, 20.1 and 20.3 (4×OAc), 23.9, 25.5, 26.8, 30.0, 31.8, 36.9, 40.4, 41.1, 42.9, 47.5, 61.1 and $61.5\left(\mathrm{OCH}_{2}\right.$ and $\left.\mathrm{C}-6^{\prime}\right), 67.3,69.9,72.3,74.7,85.4$ (C-1'), 112.1 (C-2), 114.1 (C-4), 120.6 (HC=C), 126.2 (C-1), 132.5 (C-10), 137.6 (C-5), 144.9 $(\mathrm{HC}=\underline{\mathrm{C}}), 155.7$ (C-3), 160.6 (C-17), 168.5, 168.9, 169.5 and 170.1 (4×Ac-CO); ESI-MS: 713 $[\mathrm{M}+\mathrm{H}]^{+}, 1425[2 \mathrm{M}+\mathrm{H}]^{+}$.

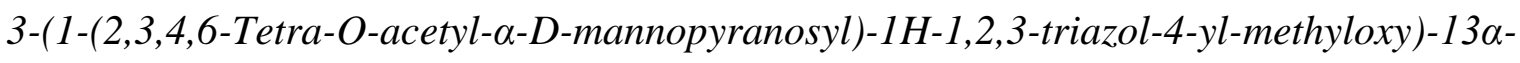
hydroxymethyl-14 $\beta$-propyl-des-D-estra-1,3,5(10)-triene (66a)

White solid (73 mg, 78\%), mp 65-67 ${ }^{\circ} \mathrm{C}, R_{\mathrm{f}}=0.37\left(\mathrm{CH}_{2} \mathrm{Cl}_{2}: \mathrm{EtOAc} / 9: 1\right), \mathrm{C}_{36} \mathrm{H}_{49} \mathrm{~N}_{3} \mathrm{O}_{11} ;{ }^{1} \mathrm{H}-$ $\operatorname{NMR}\left(\mathrm{CDCl}_{3}\right) ; \delta[\mathrm{ppm}]=0.76\left(\mathrm{~s}, 3 \mathrm{H}, 18-\mathrm{H}_{3}\right), 0.85\left(\mathrm{t}, 3 \mathrm{H}, \mathrm{J}=6.3 \mathrm{~Hz}, 16 \mathrm{a}-\mathrm{H}_{3}\right), 2.05,2.06,2.07$ and $2.18(4 \times \mathrm{s}, 4 \times 3 \mathrm{H}, 4 \times \mathrm{OAc}), 2.85\left(\mathrm{~m}, 2 \mathrm{H}, 6-\mathrm{H}_{2}\right), 3.34$ and $3.52(2 \times \mathrm{d}, 2 \times 1 \mathrm{H}, \mathrm{J}=2 \times 10.8 \mathrm{~Hz}$, 17- $\mathrm{H}_{2}$ ), 4.03-4.06 (overlapping m, 2H, 6'- $\mathrm{H}_{2}$ ), 4.36 (dd, 1H, J=12.5 Hz, J=5.4 Hz, 5'-H), 5.22 (s, 2H, $\left.\mathrm{OCH}_{2}\right), 5.37(\mathrm{~m}, 1 \mathrm{H}), 5.91-5.99$ (overlapping m, 3H): 1'-, 2'-, 3'-, 4'-H, $6.71(\mathrm{~d}, 1 \mathrm{H}$, $\mathrm{J}=2.2 \mathrm{~Hz}, 4-\mathrm{H}), 6.78$ (dd, 1H, J=8.6 Hz, J=2.2 Hz, 2-H), 7.22 (d, 1H, J=8.6 Hz, 1-H), 7.79 (s, 
$1 \mathrm{H}, \mathrm{HC}=\mathrm{C}) ;{ }^{13} \mathrm{C}-\mathrm{NMR}\left(\mathrm{CDCl}_{3}\right) ; \delta[\mathrm{ppm}]=14.3(\mathrm{C}-16 \mathrm{a}), 15.6(\mathrm{C}-18), 20.1,20.2(2 \mathrm{C})$ and 20.3 (4×OAc), 24.6, 26.0, 27.0, 30.3, 30.8, 35.2, 38.3, 41.3, 43.1, 44.9, 61.1 and $64.1\left(\mathrm{OCH}_{2}\right.$ and C-6'), 65.7, 67.9, 68.3, 70.9 (C-17), 71.8, 83.2 (C-1'), 111.9 (C-2), 113.9 (C-4), 122.5 $(\mathrm{HC}=\mathrm{C}), 126.3$ (C-1), 133.3 (C-10), 137.8 (C-5), 145.0 (HC= $\underline{\mathrm{C}}), 155.5$ (C-3), 168.8, 169.2, 170.0 and 173.3 (4×Ac-CO); ESI-MS: $700[\mathrm{M}+\mathrm{H}]^{+}, 1399[2 \mathrm{M}+\mathrm{H}]^{+}$.

3-(1-(2,3,4,6-tetra-O-acetyl- $\alpha$-D-mannopyranosyl)-1H-1,2,3-triazol-4-yl-methyloxy)-14 $\beta$ propyl-des-D-estra-1,3,5(10)-triene-13 $\alpha$-carbaldehyde oxyme (66)

White solid (79 mg, 83\%), mp 105-107 ${ }^{\circ} \mathrm{C}, R_{\mathrm{f}}=0.35\left(\mathrm{CH}_{2} \mathrm{Cl}_{2}\right.$ :EtOAc/9:1), $\mathrm{C}_{36} \mathrm{H}_{48} \mathrm{~N}_{4} \mathrm{O}_{11} ;{ }^{1} \mathrm{H}-$ $\operatorname{NMR}\left(\mathrm{CDCl}_{3}\right) ; \delta[\mathrm{ppm}]=0.87\left(\mathrm{t}, 3 \mathrm{H}, J=6.3 \mathrm{~Hz}, 16 \mathrm{a}-\mathrm{H}_{3}\right), 1.07\left(\mathrm{~s}, 3 \mathrm{H}, 18-\mathrm{H}_{3}\right), 2.03,2.04,2.05$ and $2.17(4 \times \mathrm{s}, 4 \times 3 \mathrm{H}, 4 \times \mathrm{OAc}), 2.85\left(\mathrm{~m}, 2 \mathrm{H}, 6-\mathrm{H}_{2}\right), 4.05(\mathrm{~m}, 1 \mathrm{H}), 4.07-4.13$ (overlapping $\mathrm{m}$, $2 \mathrm{H}), 4.35(\mathrm{~m}, 1 \mathrm{H}), 5.36(1 \mathrm{H}): 1^{\prime}-, 2^{\prime}-, 3^{\prime}-, 4^{\prime}-, 5^{\prime}-\mathrm{H}, 5.22\left(\mathrm{~s}, 2 \mathrm{H}, \mathrm{OCH}_{2}\right), 6.70(\mathrm{~d}, 1 \mathrm{H}, J=2.2 \mathrm{~Hz}$, 4-H), 6.79 (dd, 1H, J=8.6 Hz, J=2.2 Hz, 2-H), 7.19 (d, 1H, J=8.6 Hz, 1-H), 7.31 (s, 1H, 17$\mathrm{H}), 7.80(\mathrm{~s}, 1 \mathrm{H}, \mathrm{HC}=\mathrm{C}) ;{ }^{13} \mathrm{C}-\mathrm{NMR}\left(\mathrm{CDCl}_{3}\right) ; \delta[\mathrm{ppm}]=14.5$ (C-16a), 15.3 (C-18), 20.5, 20.6 (2C) and 20.7 (4×OAc), 24.3, 25.9, 27.1, 29.6, 32.1, 37.3, 40.8, 41.4, 43.2, 47.8, 61.5 and $61.8\left(\mathrm{OCH}_{2}\right.$ and C-6'), 66.0, 68.2, 68.7, 72.1, 83.6 (C-1'), 112.4 (C-2), $114.3(\mathrm{C}-4), 122.9$ $(\mathrm{HC}=\mathrm{C}), 126.6$ (C-1 ), 133.0 (C-10), 138.0 (C-5), 145.3 (HC=C $), 156.0$ (C-3), 160.7 (C-17), 169.3, $169.6(2 \mathrm{C})$ and 170.4 (4×Ac-CO); ESI-MS: $713[\mathrm{M}+\mathrm{H}]^{+}, 1425[2 \mathrm{M}+\mathrm{H}]^{+}$.

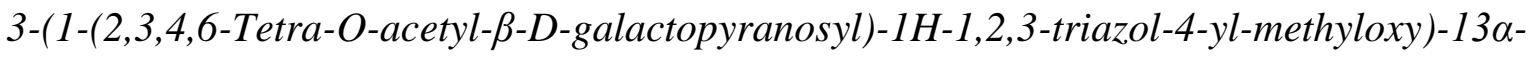
hydroxymethyl-14 $\beta$-propyl-des-D-estra-1,3,5(10)-triene (67a)

Oil (71 mg, 76\%), $R_{\mathrm{f}}=0.30 \quad\left(\mathrm{CH}_{2} \mathrm{Cl}_{2}\right.$ :EtOAc/9:1), $\mathrm{C}_{36} \mathrm{H}_{49} \mathrm{~N}_{3} \mathrm{O}_{11} ;{ }^{1} \mathrm{H}-\mathrm{NMR} \quad\left(\mathrm{CDCl}_{3}\right) ; \delta$ $[\mathrm{ppm}]=0.77\left(\mathrm{~s}, 3 \mathrm{H}, 18-\mathrm{H}_{3}\right), 0.91\left(\mathrm{t}, 3 \mathrm{H}, J=6.3 \mathrm{~Hz}, 16 \mathrm{a}-\mathrm{H}_{3}\right), 1.87,2.00,2.05$ and $2.22(4 \times \mathrm{s}$, $4 \times 3 \mathrm{H}, 4 \times \mathrm{OAc}), 2.85\left(\mathrm{~m}, 2 \mathrm{H}, 6-\mathrm{H}_{2}\right), 3.34$ and $3.52\left(2 \times \mathrm{d}, 2 \times 1 \mathrm{H}, J=2 \times 10.7 \mathrm{~Hz}, 17-\mathrm{H}_{2}\right), 4.13-$ 4.22 (overlapping $\mathrm{m}, 3 \mathrm{H}$ ), 5.18-5.26 (overlapping $\mathrm{m}, 3 \mathrm{H}$ ), 5.54-5.59 (overlapping $\mathrm{m}, 2 \mathrm{H}$ ), 5.84

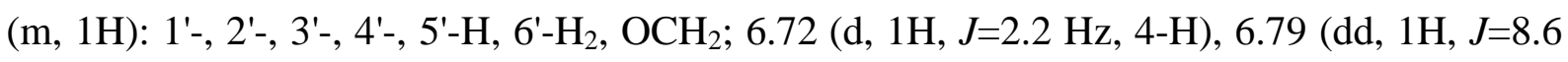
$\mathrm{Hz}, J=2.2 \mathrm{~Hz}, 2-\mathrm{H}), 7.23(\mathrm{~d}, 1 \mathrm{H}, J=8.6 \mathrm{~Hz}, 1-\mathrm{H}), 7.92(\mathrm{~s}, 1 \mathrm{H}, \mathrm{HC}=\mathrm{C}) ;{ }^{13} \mathrm{C}-\mathrm{NMR}\left(\mathrm{CDCl}_{3}\right) ; \delta$ $[\mathrm{ppm}]=14.7$ (C-16a), 16.0 (C-18), 20.2, 20.5 (2C) and 20.6 (4×OAc), 25.0, 26.4, 27.4, 30.7, 31.2, 35.6, 38.7, 41.7, 43.5, 45.2, 61.2 and $62.0\left(\mathrm{OCH}_{2}\right.$ and $\left.\mathrm{C}-6{ }^{\prime}\right), 66.8,67.8,70.8,71.4(\mathrm{C}-$ 17), 74.1, 86.3 (C-1'), 112.3 (C-2), 114.5 (C-4), 120.9 (Hㄷ=), 126.6 (C-1), 133.5 (C-10), $138.2(\mathrm{C}-5), 145.3(\mathrm{HC}=\underline{\mathrm{C}}), 156.2(\mathrm{C}-3), 169.0,169.8,169.9$ and 170.4 (4 × Ac-CO); ESIMS: $700[\mathrm{M}+\mathrm{H}]^{+}, 1399[2 \mathrm{M}+\mathrm{H}]^{+}$. 
3-(1-(2,3,4,6-Tetra-O-acetyl- $\beta$-D-galactopyranosyl)-1H-1,2,3-triazol-4-yl-methyloxy)-14 $\beta$ propyl-des-D-estra-1,3,5(10)-triene-13 $\alpha$-carbaldehyde oxyme (67b)

White solid (76 mg, 80\%), mp 98-101 ${ }^{\circ} \mathrm{C}, R_{\mathrm{f}}=0.28\left(\mathrm{CH}_{2} \mathrm{Cl}_{2}\right.$ :EtOAc/9:1), $\mathrm{C}_{36} \mathrm{H}_{48} \mathrm{~N}_{4} \mathrm{O}_{11} ;{ }^{1} \mathrm{H}-$ $\operatorname{NMR}\left(\mathrm{CDCl}_{3}\right) ; \delta[\mathrm{ppm}]=0.88\left(\mathrm{t}, 3 \mathrm{H}, J=6.3 \mathrm{~Hz}, 16 \mathrm{a}-\mathrm{H}_{3}\right), 1.06\left(\mathrm{~s}, 3 \mathrm{H}, 18-\mathrm{H}_{3}\right), 1.88,2.01,2.05$ and $2.22(4 \times \mathrm{s}, 4 \times 3 \mathrm{H}, 4 \times \mathrm{OAc}), 2.86\left(\mathrm{~m}, 2 \mathrm{H}, 6-\mathrm{H}_{2}\right), 4.15-4.22$ (overlapping $\left.\mathrm{m}, 3 \mathrm{H}\right), 5.16-5.19$ (overlapping m, 2H), $5.24(\mathrm{~m}, 1 \mathrm{H}), 5.55(\mathrm{~m}, 1 \mathrm{H}), 5.58(\mathrm{~m}, 1 \mathrm{H}), 5,84(\mathrm{~m}, 1 \mathrm{H}): 1^{\prime}-, 2^{\prime}-, 3^{\prime}-, 4^{\prime}-$, 5'-H, 6'- $\mathrm{H}_{2}, \mathrm{OCH}_{2}, 6.72$ (d, 1H, J=2.2 Hz, 4-H), 6.79 (dd, 1H, J=8.6 Hz, J=2.2 Hz, 2-H), 7.21 $(\mathrm{d}, 1 \mathrm{H}, J=8.6 \mathrm{~Hz}, 1-\mathrm{H}), 7,30(\mathrm{~s}, 1 \mathrm{H}, 17-\mathrm{H}), 7,91(\mathrm{~s}, 1 \mathrm{H}, \mathrm{HC}=\mathrm{C}) ;{ }^{13} \mathrm{C}-\mathrm{NMR}\left(\mathrm{CDCl}_{3}\right) ; \delta$ [ppm]=14.5 (C-16a), 15.4 (C-18), 20.2, 20.5, 20.6 and 20.7(4×OAc), 24.4, 25.9, 27.2, 29.7, 30.4, 32.2, 37.4, 40.9, 43.3, 47.9, 61.2 and $62.0\left(\mathrm{OCH}_{2}\right.$ and $\left.\mathrm{C}^{\prime}{ }^{\prime}\right), 66.8,67.8,70.8,74.1,86.3$ (C-1'), 112.5 (C-2), 114.5 (C-4), 120.1 (HC=C), 126.6 (C-1 ), 133.0 (C-10), 138.0 (C-5), $144.6(\mathrm{HC}=\underline{\mathrm{C}}), 156.2(\mathrm{C}-3), 160.8(\mathrm{C}-17), 169.0$ and 169.9 (4C, 4×Ac-CO); ESI-MS: 713 $[\mathrm{M}+\mathrm{H}]^{+}, 1425[2 \mathrm{M}+\mathrm{H}]^{+}$.

3-(1-(Methyl-6-deoxy-2,3,4-tri-O-benzoyl- $\alpha$-D-glucopyranosid-6-yl)-1H-1,2,3-triazol-4-yl-

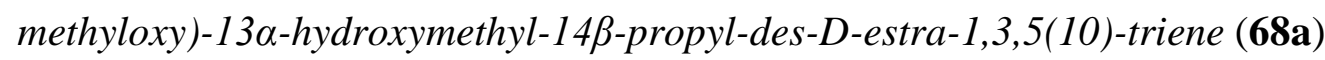

White solid (63 mg, 78\%), mp 109-111 ${ }^{\circ} \mathrm{C}, R_{\mathrm{f}}=0.61\left(\mathrm{CH}_{2} \mathrm{Cl}_{2}\right.$ :EtOAc/9:1), $\mathrm{C}_{50} \mathrm{H}_{55} \mathrm{~N}_{3} \mathrm{O}_{10} ;{ }^{1} \mathrm{H}-$ $\operatorname{NMR}\left(\mathrm{CDCl}_{3}\right) ; \delta[\mathrm{ppm}]=0.73\left(\mathrm{~s}, 3 \mathrm{H}, 18-\mathrm{H}_{3}\right), 0.88$ (t, 3H, J=6.3 Hz, 16a-H $), 2.81(\mathrm{~m}, 2 \mathrm{H}, 6-$ $\left.\mathrm{H}_{2}\right), 3.01\left(\mathrm{~s}, 3 \mathrm{H}, 1^{\prime}-\mathrm{OCH}_{3}\right), 3.31$ and $3.48\left(2 \times \mathrm{d}, 2 \times 1 \mathrm{H}, J=2 \times 10.9 \mathrm{~Hz}, 17-\mathrm{H}_{2}\right), 4.10(\mathrm{~m}, 1 \mathrm{H})$, 4.40-4.48 (overlapping m, 2H), $4.70(\mathrm{~m}, 1 \mathrm{H}), 5.13(\mathrm{~m}, 1 \mathrm{H}), 5.20(\mathrm{~m}, 1 \mathrm{H}), 5.27(\mathrm{~m}, 1 \mathrm{H}), 5.40$ (t, 1H, J=9.4 Hz), 6.13 (t, 1H, J=9.4 Hz): 1'-, 2'-, 3'-, 4'-, 5'-H, 6'- $\mathrm{H}_{2}, \mathrm{OCH}_{2}, 6.67(\mathrm{~d}, 1 \mathrm{H}$, $J=2.2 \mathrm{~Hz}, 4-\mathrm{H}), 6.73(\mathrm{dd}, 1 \mathrm{H}, J=8.6 \mathrm{~Hz}, J=2.2 \mathrm{~Hz}, 2-\mathrm{H}), 7.17$ (d, 1H, J=8.6 Hz, 1-H), 7.28 (t, $2 \mathrm{H}, J=7.7 \mathrm{~Hz}$ ), 7.33-7.4, (overlapping m, 5H), 7.47-7.54 (overlapping m, 2H), 7.84 (d, 2H, $\mathrm{J}=7.7 \mathrm{~Hz}$ ), 7,95-7,99 (overlapping $\mathrm{m}, 4 \mathrm{H})$ : benzoyl protons, $7.77(\mathrm{~s}, 1 \mathrm{H}, \mathrm{HC}=\mathrm{C}) ;{ }^{13} \mathrm{C}-\mathrm{NMR}$ $\left(\mathrm{CDCl}_{3}\right) ; \delta[\mathrm{ppm}]=14.6$ (C-16a), 15.9 (C-18), 25.0, 26.4, 27.4, 30.6, 31.2, 35.6, 38.7, 41.7, 43.5, 45.2, $51.1\left(\mathrm{C}-6\right.$ '), $55.4\left(1^{\prime}-\mathrm{OCH}_{3}\right), 61.9\left(\mathrm{OCH}_{2}\right), 68.4,69.9,70.6,71.3(\mathrm{C}-17), 71.8,96.8$ (C-1'), 112.3 (C-2), $114.4(\mathrm{C}-4), 124.2$ (HC $=\mathrm{C}), 126.5$ (C-1), 128.3 (2C), $128.4(2 \mathrm{C}), 128.5$ (2C), 129.6 (2C), 129.9 (2C), 130.0 (2C), 133.2, 133.4, 133.8: benzoyl CHs, 128.3, 128.8, 129.0: benzoyl Cq, 133.4 (C-10), 138.1 (C-5), $144.7(\mathrm{HC}=\underline{\mathrm{C}}), 155.8$ (C-3), 165.3, 165.4 and $165.9(3 \times \mathrm{Bz}-\mathrm{CO})$; ESI-MS: $858[\mathrm{M}+\mathrm{H}]^{+}, 1715[2 \mathrm{M}+\mathrm{H}]^{+}$. 
3-(1-(Methyl-6-deoxy-2,3,4-tri-O-benzoyl- $\alpha$-D-glucopyranosid-6-yl)-1H-1,2,3-triazol-4-yl-

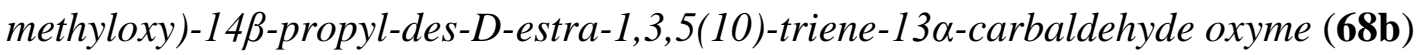

White solid (61 mg, 75\%), mp 119-123 ${ }^{\circ} \mathrm{C}, R_{\mathrm{f}}=0.70\left(\mathrm{CH}_{2} \mathrm{Cl}_{2}\right.$ :EtOAc/9:1), $\mathrm{C}_{50} \mathrm{H}_{54} \mathrm{~N}_{4} \mathrm{O}_{10} ;{ }^{1} \mathrm{H}-$ $\operatorname{NMR}\left(\mathrm{CDCl}_{3}\right) ; \delta[\mathrm{ppm}]=0.87\left(\mathrm{t}, 3 \mathrm{H}, J=6.3 \mathrm{~Hz}, 16 \mathrm{a}-\mathrm{H}_{3}\right), 1.05\left(\mathrm{~s}, 3 \mathrm{H}, 18-\mathrm{H}_{3}\right), 2.84(\mathrm{~m}, 2 \mathrm{H}, 6-$ $\mathrm{H}_{2}$ ), 3.04 (s, 3H, 1'- $\mathrm{OCH}_{3}$ ), 4.43-4.47 (overlapping $\mathrm{m}, 3 \mathrm{H}$ ), 5.14-5.24 (overlapping $\mathrm{m}, 4 \mathrm{H}$ ), 5.41 (t, 1H, J=9.7 Hz), 6.15 (t, 1H, J=9.7 Hz): 1'-, 2'-, 3'-, 4'-, 5'-H, 6'- $\mathrm{H}_{2}, \mathrm{OCH}_{2}, 6.70$ (d, 1H, $J=2.2 \mathrm{~Hz}, 4-\mathrm{H}), 6.77$ (dd, 1H, J=8.6 Hz, J=2.2 Hz, 2-H). 7.17 (d, 1H, J=8.6 Hz, 1-H), 7.29 (t, $2 \mathrm{H}, J=7.5 \mathrm{~Hz}$ ), 7.37-7.44 (overlapping $\mathrm{m}, 5 \mathrm{H}$ ), 7.50-7.57 (overlapping $\mathrm{m}, 2 \mathrm{H}$ ), $7.86(\mathrm{~m}, 2 \mathrm{H}$ ), 7.95-7.99 (overlapping m, 4H): benzoyl protons, $7.36(\mathrm{~s}, 1 \mathrm{H}, 17-\mathrm{H}), 7.84(\mathrm{~s}, 1 \mathrm{H}, \mathrm{HC}=\mathrm{C}) ;{ }^{13} \mathrm{C}-$ $\operatorname{NMR}\left(\mathrm{CDCl}_{3}\right) ; \delta[\mathrm{ppm}]=14.5$ (C-16a), 15.3 (C-18), 24.3, 26.0, 27.2, 30.5, 32.2, 37.4, 40.9, 41.3, 43.3, 47.9, $51.9\left(\mathrm{C}-6\right.$ '), $55.5\left(1^{\prime}-\mathrm{OCH}_{3}\right), 61.8\left(\mathrm{OCH}_{2}\right), 68.4,69.9,70.6,71.8,96.9$ (C-1'), 112.4 (C-2), 114.5 (C-4), 124.9 (HC=C), 126.5 (C-1), 128.3 (2C), 128.4 (2C), 128.6 (2C), 129.6 (2C), 129.9 (2C), 130.0 (2C), 133.2, 133.5, 133.8: benzoyl CHs, 128.3, 128.8, 129.0: benzoyl Cq, 132.9 (C-10), 137.9 (C-5), 145.2 (HC=ㄷ), 156.0 (C-3), 160.7 (C-17), 165.6, 165.7 and $165.8(3 \times \mathrm{Bz}-\mathrm{CO})$; ESI-MS: $871[\mathrm{M}+\mathrm{H}]^{+}, 1741[2 \mathrm{M}+\mathrm{H}]^{+}$.

3-(1-(Methyl-6-deoxy-2,3,4-tri-O-benzoyl- $\alpha$-D-mannopyranosid-6-yl)-1H-1,2,3-triazol-4-yl-

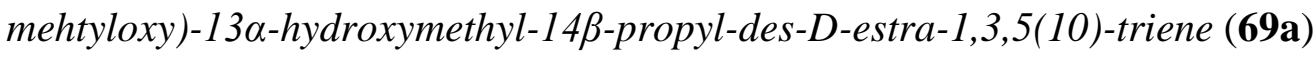

White solid (64 mg, 79\%), mp 101-103 ${ }^{\circ} \mathrm{C}, R_{\mathrm{f}}=0.63\left(\mathrm{CH}_{2} \mathrm{Cl}_{2}\right.$ :EtOAc/9:1), $\mathrm{C}_{50} \mathrm{H}_{55} \mathrm{~N}_{3} \mathrm{O}_{10} ;{ }^{1} \mathrm{H}-$ $\operatorname{NMR}\left(\mathrm{CDCl}_{3}\right) ; \delta[\mathrm{ppm}]=0.77\left(\mathrm{~s}, 3 \mathrm{H}, 18-\mathrm{H}_{3}\right), 0.91\left(\mathrm{t}, 3 \mathrm{H}, J=6.3 \mathrm{~Hz}, 16 \mathrm{a}-\mathrm{H}_{3}\right), 2.82(\mathrm{~m}, 2 \mathrm{H}, 6-$ $\left.\mathrm{H}_{2}\right), 3.11\left(\mathrm{~s}, 3 \mathrm{H}, 1^{\prime}-\mathrm{OCH}_{3}\right), 3.34$ and $3.52\left(2 \times \mathrm{d}, 2 \times 1 \mathrm{H}, J=2 \times 10.9 \mathrm{~Hz}, 17-\mathrm{H}_{2}\right), 4.45(\mathrm{~m}, 1 \mathrm{H})$, $4.55(\mathrm{~m}, 1 \mathrm{H}), 4.76(\mathrm{~m}, 1 \mathrm{H}), 4.91(\mathrm{~s}, 1 \mathrm{H}), 5.17(\mathrm{~m}, 2 \mathrm{H}), 5.63(\mathrm{~m}, 1 \mathrm{H}), 5.74(\mathrm{~m}, 1 \mathrm{H}), 5.87(\mathrm{~m}$, 1H): 1'-, 2'-, 3'-, 4'-, 5'-H, 6'-H $, \mathrm{OCH}_{2}, 6.66$ (d, 1H, J=2.2 Hz, 4-H), 6.73 (dd, 1H, J=8.6 Hz, $J=2.2 \mathrm{~Hz}, 2-\mathrm{H}), 7.18$ (d, 1H, J=8.6 Hz, 1-H), 7.26 (t, 2H, J=7.5 Hz), 7.39-7.42 (overlapping $\mathrm{m}, 3 \mathrm{H}), 7.51(\mathrm{t}, 2 \mathrm{H}, J=7.5 \mathrm{~Hz}), 7,55(\mathrm{t}, 1 \mathrm{H}, J=7.5 \mathrm{~Hz}), 7.63(\mathrm{t}, 1 \mathrm{H}, J=7.5 \mathrm{~Hz}), 7.82(\mathrm{~d}, 2 \mathrm{H}$, $J=7.5 \mathrm{~Hz}), 7.99(\mathrm{~d}, 2 \mathrm{H}, J=7.5 \mathrm{~Hz}), 8.06(\mathrm{~d}, 2 \mathrm{H}, J=7.5 \mathrm{~Hz})$ : benzoyl protons, $7.80(\mathrm{~s}, 1 \mathrm{H}$, $\mathrm{HC}=\mathrm{C}) ;{ }^{13} \mathrm{C}-\mathrm{NMR}\left(\mathrm{CDCl}_{3}\right) ; \delta[\mathrm{ppm}]=14.6$ (C-16a), 16.0 (C-18), 25.0, 26.4, 27.4, 30.7, 31.2, 35.6, 38.7, 41.8, 43.5, 45.3, $51.2\left(\mathrm{C}-6^{\prime}\right), 55.4\left(1^{\prime}-\mathrm{OCH}_{3}\right), 61.9\left(\mathrm{OCH}_{2}\right), 68.2,69.4,69.5,70.4$, 71.3 (C-17), 98.5 (C-1'), 112.3 (C-2), 114.4 (C-4), 124.2 (Hㄷ=), 126.6 (C-1), 128.3 (2C), 128.6 (2C), 128.7 (2C), 129.7 (2C), 129.8 (2C), 129.9 (2C), 133.2, 133.6, 133.8: benzoyl CHs, 128.5, 128.9, 129.2: benzoyl Cq, 133.4 (C-10), 138.1 (C-5), 146.0 (HC=ㄷ), 155.9 (C-3), 165.3, 165.4 and 165.9: (3×Bz-CO); ESI-MS: $858[\mathrm{M}+\mathrm{H}]^{+}$. 
3-(1-(Methyl-6-deoxy-2,3,4-tri-O-benzoyl- $\alpha$-D-mannopyranosid-6-yl)-1H-1,2,3-triazol-4-yl-

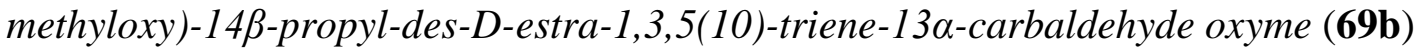

White solid (59 mg, 72\%), mp 112-115 ${ }^{\circ} \mathrm{C}, R_{\mathrm{f}}=0.72\left(\mathrm{CH}_{2} \mathrm{Cl}_{2}\right.$ :EtOAc/9:1), $\mathrm{C}_{50} \mathrm{H}_{55} \mathrm{~N}_{4} \mathrm{O}_{10} ;{ }^{1} \mathrm{H}-$ $\operatorname{NMR}\left(\mathrm{CDCl}_{3}\right) ; \delta[\mathrm{ppm}]=0.88\left(\mathrm{t}, 3 \mathrm{H}, J=6.3 \mathrm{~Hz}, 16 \mathrm{a}-\mathrm{H}_{3}\right), 1.06\left(\mathrm{~s}, 3 \mathrm{H}, 18-\mathrm{H}_{3}\right), 2.82(\mathrm{~m}, 2 \mathrm{H}, 6-$ $\left.\mathrm{H}_{2}\right), 3.11\left(\mathrm{~s}, 3 \mathrm{H}, 1^{\prime}-\mathrm{OCH}_{3}\right), 4.45(\mathrm{~m}, 1 \mathrm{H}), 4.57(\mathrm{~m}, 1 \mathrm{H}), 4.76(\mathrm{~m}, 1 \mathrm{H}), 4.91(\mathrm{~s}, 1 \mathrm{H}), 5.17(\mathrm{~m}$, 2H), $5.63(\mathrm{~m}, 1 \mathrm{H}), 5.74$ (t, 1H, J=9.0 Hz), 5.88 (dd, 1H, J=9.0 Hz, J=3.2 Hz): 1'-, 2'-, 3'-, 4'-, 5'-H, 6'- $\mathrm{H}_{2}, \mathrm{OCH}_{2}, 6.67$ (d, 1H, J=2.2 Hz, 4-H), 6.74 (dd, 1H, J=8.6 Hz, J=2.2 Hz, 2-H), 7.16 (d, 1H, J=8.6 Hz, 1-H), $7.26(\mathrm{~m}, 2 \mathrm{H}), 7.40-7.44$ (overlapping $\mathrm{m}, 3 \mathrm{H}$ ), 7.51 (t, 2H, J=7.5 Hz), 7.55 (t, 1H, J=7.5 Hz), 7.63 (t, 1H, J=7.5 Hz), 7.80 (d, 2H, J=7.5 Hz), 7.99 (d, 2H, J=7.5 Hz), $8.06(\mathrm{~d}, 2 \mathrm{H}, J=7.5 \mathrm{~Hz})$ : benzoyl protons, $7.39(\mathrm{~s}, 1 \mathrm{H}, 17-\mathrm{H}), 7.88(\mathrm{~s}, 1 \mathrm{H}, \mathrm{HC}=\mathrm{C}) ;{ }^{13} \mathrm{C}-\mathrm{NMR}$ $\left(\mathrm{CDCl}_{3}\right) ; \delta[\mathrm{ppm}]=14.5$ (C-16a), 15.4 (C-18), 24.4, 26.0, 27.2, 30.5, 32.2, 37.4, 40.9, 41.3, 43.3, 47.8, $51.2\left(\mathrm{C}^{-6}\right), 55.4\left(1^{\prime}-\mathrm{OCH}_{3}\right), 61.9\left(\mathrm{OCH}_{2}\right), 68.2,69.4,69.5,70.4,98.5\left(\mathrm{C}-1{ }^{\prime}\right), 112.4$ (C-2), 114.4 (C-4), 124.2 (Hㅌ=C), 126.51 (C-1), 128.3 (2C), 128.6 (2C), 128.7 (2C), 129.7 (2C), 129.8 (2C), 129.9 (2C), 133.2, 133.7, 133.8: benzoyl CHs, 128.5, 128.9, 129.1: benzoyl Cq, 132.8 (C-10), 137.9 (C-5), $144.6(\mathrm{HC}=\underline{\mathrm{C}}), 156.0$ (C-3), $160.6(\mathrm{C}-17), 165.3,165.4$ and $165.9\left(3 \times\right.$ Bz-CO); ESI-MS: $871[\mathrm{M}+\mathrm{H}]^{+}, 1741[2 \mathrm{M}+\mathrm{H}]^{+}$.

3-(1-(Methyl-5-deoxy-2,3-di-O-benzoyl- $\beta$-D-ribofuranosid-5-yl)-1H-1,2,3-triazol-4-yl-

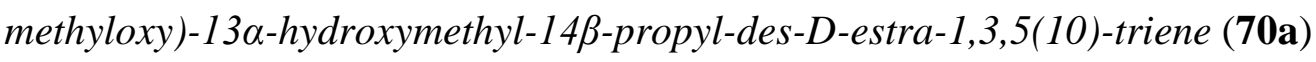

Oil (62 mg, 76\%), $R_{\mathrm{f}}=0.54 \quad\left(\mathrm{CH}_{2} \mathrm{Cl}_{2}\right.$ :EtOAc/9:1); ${ }^{1} \mathrm{H}-\mathrm{NMR} \quad\left(\mathrm{CDCl}_{3}\right), \mathrm{C}_{42} \mathrm{H}_{49} \mathrm{~N}_{3} \mathrm{O}_{8} ; \delta$ $[\mathrm{ppm}]=0.77\left(\mathrm{~s}, 3 \mathrm{H}, 18-\mathrm{H}_{3}\right), 0.91\left(\mathrm{t}, 3 \mathrm{H}, J=6.3 \mathrm{~Hz}, 16 \mathrm{a}-\mathrm{H}_{3}\right), 2.85\left(\mathrm{~m}, 2 \mathrm{H}, 6-\mathrm{H}_{2}\right), 3.33$ and 3.52 $\left(2 \times \mathrm{d}, 2 \times 1 \mathrm{H}, J=2 \times 10.9 \mathrm{~Hz}, 17-\mathrm{H}_{2}\right), 3.48\left(\mathrm{~s}, 3 \mathrm{H}, 1^{\prime}-\mathrm{OCH}_{3}\right), 4.58(\mathrm{~m}, 1 \mathrm{H}), 4.71(\mathrm{~m}, 1 \mathrm{H}), 4.99$ $(\mathrm{m}, 1 \mathrm{H}), 5.18(\mathrm{~m}, 2 \mathrm{H}), 5.12(\mathrm{~s}, 1 \mathrm{H}), 5.63-5.66$ (overlapping $\mathrm{m}, 2 \mathrm{H}): 1^{\prime}-, 2^{\prime}-, 3^{\prime}-, 4^{\prime}-\mathrm{H}, 5^{\prime}-\mathrm{H}_{2}$, $\mathrm{OCH}_{2} ; 6.72$ (d, 1H, J=2.2 Hz, 4-H), 6.79 (dd, 1H, J=8.6 Hz, J=2.2 Hz, 2-H), 7.22 (d, 1H, $J=8.6 \mathrm{~Hz}, 1-\mathrm{H}), 7.33$ (t, 2H, J=7.6 Hz), $7.43(\mathrm{t}, 2 \mathrm{H}, J=7.6 \mathrm{~Hz}), 7.53$ (t, 1H, J=7.6 Hz), 7.59 (t, $1 \mathrm{H}, J=7.6 \mathrm{~Hz}), 7.86(\mathrm{~d}, 2 \mathrm{H}, J=7.6 \mathrm{~Hz}), 8.01(\mathrm{~d}, 2 \mathrm{H}, J=7.6 \mathrm{~Hz})$ : benzoyl protons, $7.86(\mathrm{~s}, 1 \mathrm{H}$, $\mathrm{HC}=\mathrm{C}) ;{ }^{13} \mathrm{C}-\mathrm{NMR}\left(\mathrm{CDCl}_{3}\right) ; \delta[\mathrm{ppm}]=14.7$ (C-16a), 16.0 (C-18), 25.0, 26.4, 27.4, 30.7, 31.2, 35.6, 38.7, 41.7, 43.5, 45.3, $54.0\left(\mathrm{C}^{-5}\right), 55.9\left(1^{\prime}-\mathrm{OCH}_{3}\right), 62.0\left(\mathrm{OCH}_{2}\right), 71.3(\mathrm{C}-17), 73.1$, 75.1, 79.7, 106.8 (C-1'), 112.4 (C-2), 114.4 (C-4), 124.1 (Hㄷ=), 126.6 (C-1), 128.4 (2C), 128.5 (2C), 129.8 (4C), 133.6 (2C): benzoyl CHs, 128.3, 129.0: benzoyl Cq, 133.5 (C-10), $138.1(\mathrm{C}-5), 147.8(\mathrm{HC}=\underline{\mathrm{C}}), 156.1(\mathrm{C}-3), 165.2$ and $165.5(2 \times \mathrm{Bz}-\mathrm{CO})$; ESI-MS: $724[\mathrm{M}+\mathrm{H}]^{+}$, $1447[2 \mathrm{M}+\mathrm{H}]^{+}$. 
3-(1-(Methyl-5-deoxy-2,3-di-O-benzoyl- $\beta$-D-ribofuranosid-5-yl)-1H-1,2,3-triazol-4-yl-

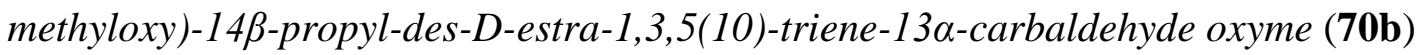
White solid (65 mg, 70\%), mp 95-98 ${ }^{\circ} \mathrm{C}, R_{\mathrm{f}}=0.78\left(\mathrm{CH}_{2} \mathrm{Cl}_{2}\right.$ :EtOAc/9:1), $\mathrm{C}_{42} \mathrm{H}_{48} \mathrm{~N}_{4} \mathrm{O}_{8} ;{ }^{1} \mathrm{H}-\mathrm{NMR}$ $\left(\mathrm{CDCl}_{3}\right) ; \delta[\mathrm{ppm}]=0.88\left(\mathrm{t}, 3 \mathrm{H}, J=6.3 \mathrm{~Hz}, 16 \mathrm{a}-\mathrm{H}_{3}\right), 1.06\left(\mathrm{~s}, 3 \mathrm{H}, 18-\mathrm{H}_{3}\right), 2.85\left(\mathrm{~m}, 2 \mathrm{H}, 6-\mathrm{H}_{2}\right)$, $3.48\left(\mathrm{~s}, 3 \mathrm{H}, 1^{\prime}-\mathrm{OCH}_{3}\right), 4.60(\mathrm{~m}, 1 \mathrm{H}), 4.73(\mathrm{~m}, 1 \mathrm{H}), 4.99(\mathrm{~m}, 1 \mathrm{H}), 5,18(\mathrm{~m}, 2 \mathrm{H}), 5.12(\mathrm{~s}, 1 \mathrm{H})$, 5.63-5.66 (overlapping m, 2H), 1'-,2'-, 3'-,4'-H, 5'- $\mathrm{H}_{2}, \mathrm{OCH}_{2} ; 6.73(\mathrm{~d}, 1 \mathrm{H}, J=2.2 \mathrm{~Hz}, 4-\mathrm{H})$, $6.81(\mathrm{dd}, 1 \mathrm{H}, J=8.6 \mathrm{~Hz}, J=2.2 \mathrm{~Hz}, 2-\mathrm{H}), 7.20$ (d, 1H, $J=8.6 \mathrm{~Hz}, 1-\mathrm{H}), 7.33(\mathrm{t}, 2 \mathrm{H}, J=7.5 \mathrm{~Hz})$, 7.43 (t, 2H, J=7.5 Hz), 7.53 (t, 1H, J=7.5 Hz), 7.59 (t, 1H, J=7.5 Hz), 7.86 (d, 2H, J=7.5 Hz), $8.01(\mathrm{~d}, 2 \mathrm{H}, J=7.5 \mathrm{~Hz})$ : benzoyl protons, 7.35 (s, 1H, 17-H), 7.87 (s, 1H, HC=C); ${ }^{13} \mathrm{C}-\mathrm{NMR}$ $\left(\mathrm{CDCl}_{3}\right) ; \delta[\mathrm{ppm}]=14.5$ (C-16a), 15.4 (C-18), 24.3, 26.0, 27.2, 30.5, 32.1, 37.4, 40.9, 41.3, 43.3, 47.9, $53.8\left(\mathrm{C}-5^{\prime}\right), 55.9\left(1^{\prime}-\mathrm{OCH}_{3}\right), 62.0\left(\mathrm{OCH}_{2}\right), 73.1,75.1,79.6,106.8(\mathrm{C}-1$ ') $112.5(\mathrm{C}-$ 2), 114.5 (C-4), 124.8 (Hㄷ=C), 126.5 (C-1), 128.4 (2C), 128.5 (2C), 129.8 (4C), 133.6 (2C): benzoyl CHs, 129.0 (2C): benzoyl Cq, 132.9 (C-10), 137.9 (C-5), 148.9 (HC=C ), 156.2 (C-3), 161.0 (C-17), 165.2 and 165.5 (2×Bz-CO); ESI-MS: $737[\mathrm{M}+\mathrm{H}]^{+}, 1473[2 \mathrm{M}+\mathrm{H}]^{+}$.

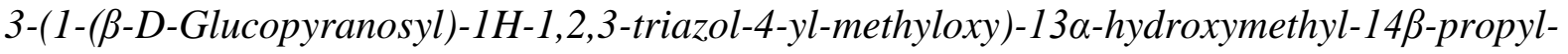
des-D-estra-1,3,5(10)-triene (71a)

White solid (182 mg, 76\%), mp 102-104 ${ }^{\circ} \mathrm{C}, R_{\mathrm{f}}=0.2\left(\mathrm{CH}_{2} \mathrm{Cl}_{2}: \mathrm{MeOH} / 9: 1\right), \mathrm{C}_{28} \mathrm{H}_{41} \mathrm{~N}_{3} \mathrm{O}_{7} ;{ }^{1} \mathrm{H}-$ NMR (DMSO); $\delta[\mathrm{ppm}]=0.68\left(\mathrm{~s}, 3 \mathrm{H}, 18-\mathrm{H}_{3}\right), 0.87$ (t, 3H, J=6.7 Hz, 16a-H $)_{3}, 2.79(\mathrm{~m}, 2 \mathrm{H}, 6-$ $\left.\mathrm{H}_{2}\right), 3.11(\mathrm{~m}, 1 \mathrm{H}), 3.24(\mathrm{~m}, 1 \mathrm{H}), 3.39(\mathrm{~m}, 1 \mathrm{H}), 3.44(\mathrm{~m}, 2 \mathrm{H}), 3.69(\mathrm{~m}, 1 \mathrm{H}), 3.77(\mathrm{~m}, 1 \mathrm{H}), 4.03$ $(\mathrm{m}, 1 \mathrm{H}), 4.39(\mathrm{~m}, 1 \mathrm{H}), 4.63(\mathrm{~m}, 1 \mathrm{H}), 5.14(\mathrm{~m}, 1 \mathrm{H}), 5.27(\mathrm{~m}, 1 \mathrm{H}), 5.38(\mathrm{~m}, 1 \mathrm{H}), 5.54(\mathrm{~m}, 1 \mathrm{H})$ : 1'-, 2'-, 3'-, 4'-, 5'-H, 6'- $\mathrm{H}_{2}, 17-\mathrm{H}_{2}, 5 \times \mathrm{OH} ; 5.08\left(\mathrm{~s}, 2 \mathrm{H}, \mathrm{OCH}_{2}\right), 6.72(\mathrm{~d}, 1 \mathrm{H}, J=8.5 \mathrm{~Hz}, 4-\mathrm{H})$, $6.78(\mathrm{dd}, 1 \mathrm{H}, J=8.5 \mathrm{~Hz}, J=2.4 \mathrm{~Hz}, 2-\mathrm{H}), 7.19(\mathrm{~d}, 1 \mathrm{H}, J=8.5 \mathrm{~Hz}, 1-\mathrm{H}), 8.4(\mathrm{~s}, 1 \mathrm{H}, \mathrm{HC}=\mathrm{C}) ;{ }^{13} \mathrm{C}-$ NMR (DMSO); $\delta$ [ppm]=14.5 (C-16a), 16.0 (C-18), 24.2, 26.1, 27.0, 30.1, 30.8, 35.5, 38.2, 41.4, 43.1, 44.6, 60.6 and $60.7\left(\mathrm{OCH}_{2}\right.$ and C-6'), 69.3 (C-17), 69.5, 71.9, 76.9, 79.7, $87.4(\mathrm{C}-$ 1'), 112.2 (C-2), 113.8 (C-4), 123.6 (HC-C), 126.4 (C-1), 132.7 (C-10), 137.5 (C-5), 141.8 $(\mathrm{HC}=\underline{\mathrm{C}}), 155.7(\mathrm{C}-3)$; ESI-MS: $532[\mathrm{M}+\mathrm{H}]^{+}, 1063[2 \mathrm{M}+\mathrm{H}]^{+}$.

3-(1-( $\beta$-D-Glucopyranosyl)-1H-1,2,3-triazol-4-yl-methyloxy)-14ß-propyl-des-D-estra1,3,5(10)-triene-13 $\alpha$-carbaldehyde oxyme (71b)

White solid (201 mg, 82\%), mp 99-101 ${ }^{\circ} \mathrm{C}, R_{\mathrm{f}}=0.24\left(\mathrm{CH}_{2} \mathrm{Cl}_{2}: \mathrm{MeOH} / 9: 1\right), \mathrm{C}_{28} \mathrm{H}_{40} \mathrm{~N}_{4} \mathrm{O}_{7} ;{ }^{1} \mathrm{H}-$ NMR (DMSO); $\delta[\mathrm{ppm}]=0.83\left(\mathrm{t}, 3 \mathrm{H}, J=6.3 \mathrm{~Hz}, 16 \mathrm{a}-\mathrm{H}_{3}\right), 0.98\left(\mathrm{~s}, 3 \mathrm{H}, 18-\mathrm{H}_{3}\right), 2.80(\mathrm{~m}, 2 \mathrm{H}, 6-$ $\left.\mathrm{H}_{2}\right), 3.25(\mathrm{~d}, 1 \mathrm{H}, J=4.5 \mathrm{~Hz}), 3.40(\mathrm{t}, 1 \mathrm{H}, J=2 \times 9.0 \mathrm{~Hz}), 3.46(\mathrm{~d}, 2 \mathrm{H}, J=8.0 \mathrm{~Hz}), 3.71(\mathrm{dd}, 1 \mathrm{H}$, 
$J=2 \times 5.5 \mathrm{~Hz}), 3.80(\mathrm{dd}, 1 \mathrm{H}, J=8.5 \mathrm{~Hz}, J=6.5 \mathrm{~Hz}), 4.63(\mathrm{~m}, 1 \mathrm{H}), 5.15(\mathrm{~m}, 1 \mathrm{H}), 5.27(\mathrm{~m}, 1 \mathrm{H})$, $5.40(\mathrm{~d}, 1 \mathrm{H}, J=5.5 \mathrm{~Hz}), 5.60$ (d, 1H, J=9.0 Hz): 1'-, 2'-, 3'-, 4'-, 5'-H, 6'- $\mathrm{H}_{2}, 4 \times \mathrm{OH} ; 5.09$ (s, 2H, $\left.\mathrm{OCH}_{2}\right), 6.74(\mathrm{~d}, 1 \mathrm{H}, J=2.2 \mathrm{~Hz}, 4-\mathrm{H}), 6.80$ (dd, 1H, J=8.6 Hz, J=2.2 Hz, 2-H), 7.18 (d, 1H, $J=8.6 \mathrm{~Hz}, 1-\mathrm{H}), 7.20(\mathrm{~s}, 1 \mathrm{H}, 17-\mathrm{H}), 8.40(\mathrm{~s}, 1 \mathrm{H}, \mathrm{HC}=\mathrm{C}) ;{ }^{13} \mathrm{C}-\mathrm{NMR}$ (DMSO); $\delta[\mathrm{ppm}]=14.4$ (C-16a), 15.4 (C-18), 23.8, 25.7, 26.8, 29.9, 31.5, 37.2, 40.5, 40.6, 42.8, 47.0, 60.6 and 60.7 $\left(\mathrm{OCH}_{2}\right.$ and C-6'), 69.5, 71.9, 76.9, 79.9, $87.4\left(\mathrm{C}-1^{\prime}\right), 112.3(\mathrm{C}-2), 113.9(\mathrm{C}-4), 123.7(\mathrm{HC}=\mathrm{C})$, 126.4 (C-1), 132.2 (C-10), 137.4 (C-5), 142.8 (HC=ㅡ), 155.8 (C-3), 157.8 (C-17); ESI-MS: $545[\mathrm{M}+\mathrm{H}]^{+}, 1089[2 \mathrm{M}+\mathrm{H}]^{+}$.

3'-O-Acetyl-5'-azido- $N^{6}$-benzoyl-2',5'-dideoxyadenosine (80a)

White solid (346 mg, 82\%), mp 135-136 ${ }^{\circ} \mathrm{C}, R_{\mathrm{f}}=0.29$ (EtOAc), $\mathrm{C}_{19} \mathrm{H}_{18} \mathrm{~N}_{8} \mathrm{O}_{4} ;{ }^{1} \mathrm{H}-\mathrm{NMR}$ $\left(\mathrm{CDCl}_{3}\right) ; \delta[\mathrm{ppm}]=2.11\left(\mathrm{~s}, 3 \mathrm{H}, 3^{\prime}-\mathrm{OAc}\right), 2.63(\mathrm{~d}, 1 \mathrm{H}, J=8.0 \mathrm{~Hz})$ and $3.27(\mathrm{~m}, 1 \mathrm{H}): 2^{\prime}-\mathrm{H}_{2}, 3.61$ $(\mathrm{d}, 1 \mathrm{H}, J=11.5 \mathrm{~Hz})$ and $3.76(\mathrm{~d}, 1 \mathrm{H}, J=12.0 \mathrm{~Hz}): 5^{\prime}-\mathrm{H}_{2}, 4.27(\mathrm{~s}, 1 \mathrm{H}), 5.39(\mathrm{~s}, 1 \mathrm{H}), 6.54(\mathrm{~m}$, 1H): 1'-, 3'-, 4'-H, 7.55 (t, 2H, J=2×7.0 Hz), 7.64 (d, 1H, J=7.5 Hz), 8.06 (d, 2H, J=7 Hz): benzoyl protons, $8.74(\mathrm{~s}, 1 \mathrm{H})$ and $8.79(\mathrm{~s}, 1 \mathrm{H}): 2-\mathrm{H}$ and $8-\mathrm{H}, 11.23(\mathrm{~s}, 1 \mathrm{H}, 6-\mathrm{NH}) ;{ }^{13} \mathrm{C}-\mathrm{NMR}$ $\left(\mathrm{CDCl}_{3}\right) ; \delta[\mathrm{ppm}]=20.7$ (3'-OAc), $35.0(\mathrm{C}-2$ '), 51.5 (C-5'), 74.6, 82.9, 83.8, 125.9 (C-5), 128.3 (2C), 128.4 (2C), 132.4: benzoyl CHs, 133.2: benzoyl Cq, 143.3 (C-8), 150.4 (C-4), 151.9 (C6), 152.3 (C-2), 165.5 (Bz-CO), 170.0 (Ac-CO); ESI-MS: $423[\mathrm{M}+\mathrm{H}]^{+}$.

3'-O-Acetyl-5'-azido-5'-deoxythymidine $(\mathbf{8 0 b})$

White solid (263 mg, 85\%), mp 115-116 ${ }^{\circ} \mathrm{C}, R_{\mathrm{f}}=0.65$ (EtOAc), $\mathrm{C}_{12} \mathrm{H}_{15} \mathrm{~N}_{5} \mathrm{O}_{5} ;{ }^{1} \mathrm{H}-\mathrm{NMR}$ $\left(\mathrm{CDCl}_{3}\right) ; \delta[\mathrm{ppm}]=1.57\left(\mathrm{~s}, 3 \mathrm{H}, 5-\mathrm{CH}_{3}\right), 1.83\left(\mathrm{~s}, 3 \mathrm{H}, 3{ }^{\prime}-\mathrm{OAc}\right), 2.02$ and $2.27\left(2 \times \mathrm{m}, 2 \times 1 \mathrm{H}, 2^{\prime}-\right.$ $\left.\mathrm{H}_{2}\right), 3.40(\mathrm{~m}, 2 \mathrm{H}), 3.86(\mathrm{~d}, 1 \mathrm{H}, J=2.0 \mathrm{~Hz}), 4.91(\mathrm{~d}, 1 \mathrm{H}, J=3.5 \mathrm{~Hz}), 5.95(\mathrm{t}, 1 \mathrm{H}, J=10.0 \mathrm{~Hz}$, $J=5.0 \mathrm{~Hz}): 1^{\prime}-, 3^{\prime}-, 4^{\prime}-\mathrm{H}, 5 '-\mathrm{H}_{2}, 7.33$ (s, 1H, 6-H), 11.16 (s, 1H, 3-NH); ${ }^{13} \mathrm{C}-\mathrm{NMR}\left(\mathrm{CDCl}_{3}\right) ; \delta$ $[\mathrm{ppm}]=12.0\left(5-\mathrm{CH}_{3}\right), 20.7$ (3'-OAc), $35.0\left(\mathrm{C}-2^{\prime}\right), 51.6\left(\mathrm{C}^{\prime} 5^{\prime}\right), 74.1,81.9,83.9,109.9$ (C-5), 135.9 (C-6), 150.4, 163.6, 170.0 (Ac-CO); ESI-MS: $310[\mathrm{M}+\mathrm{H}]^{+}$.

3'-O-Acetyl-5'-azido- $N^{4}$-benzoyl-2',5'-dideoxycytidine $(\mathbf{8 0 c})$

White solid (302 mg, 76\%), mp 146-147 ${ }^{\circ} \mathrm{C}, R_{\mathrm{f}}=0.32$ (EtOAc), $\mathrm{C}_{18} \mathrm{H}_{18} \mathrm{~N}_{6} \mathrm{O}_{5} ;{ }^{1} \mathrm{H}-\mathrm{NMR}$ $\left(\mathrm{CDCl}_{3}\right) ; \delta[\mathrm{ppm}]=2.11$ (s, 3H, 3'-OAc), $2.53\left(\mathrm{~m}, 2 \mathrm{H}, 2^{\prime}-\mathrm{H}_{2}\right), 3.77$ (dd, 2H, J=9.5 Hz, J=12.0 $\mathrm{Hz}, 5$ '- $\left.\mathrm{H}_{2}\right), 4.25$ (s, 1H), 5.21 (s, 1H), 6.24 (d, 1H, J=4.5 Hz): 1'-, 3'-, 4'-H, 7.42 (s, 1H, 5'-H), $7.54(\mathrm{~d}, 2 \mathrm{H}, J=5,5 \mathrm{~Hz}), 7.65(\mathrm{~d}, 1 \mathrm{H}, J=5,5 \mathrm{~Hz}), 8.04$ (m, 2H): benzoyl protons, 8.24 (s, 1H, 6'$\mathrm{H}), 11.34\left(\mathrm{~s}, 1 \mathrm{H}, 4^{\prime}-\mathrm{NH}\right) ;{ }^{13} \mathrm{C}-\mathrm{NMR}\left(\mathrm{CDCl}_{3}\right) ; \delta[\mathrm{ppm}]=20.7$ (3'-OAc), $36.6\left(\mathrm{C}-2^{\prime}\right), 51.6\left(\mathrm{C}-5^{\prime}\right)$, 
74.3, 82.7, 86.5, 96.6 (C-5), 128.3 (2C), 128.4 (2C), 132.7: benzoyl CH-s, 133.1: benzoyl Cq, 145.2 (C-6), 154.1 (C-2), 163.6 (C-4), 165.1 (Bz-CO), 170.0 (Ac-CO); ESI-MS: 399 [M+H] 3-\{[1-(3'-O-Acetyl-N $N^{6}$-benzoyl-2',5'-dideoxyadenosine-5'-yl)-1H-1,2,3-triazole-4-yl]-

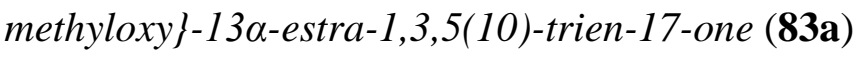

White solid (78 mg, 68\%), mp 141-143 ${ }^{\circ} \mathrm{C}, R_{\mathrm{f}}=0.55$ (EtOAc:MeOH/9:1), $\mathrm{C}_{40} \mathrm{H}_{42} \mathrm{~N}_{8} \mathrm{O}_{6} ;{ }^{1} \mathrm{H}-$ NMR $\left(\mathrm{CDCl}_{3}\right) ; \delta[\mathrm{ppm}]=1.00\left(\mathrm{~s}, 3 \mathrm{H}, 18-\mathrm{CH}_{3}\right), 1.89$ (s, 3H, 3'-OAc), 2.27 (dd, $2 \mathrm{H}, J=10.5 \mathrm{~Hz}$, $\left.J=12.5 \mathrm{~Hz}, 2^{\prime}-\mathrm{H}_{2}\right), 2.54(\mathrm{~d}, 1 \mathrm{H}, J=11.0 \mathrm{~Hz})$ and $2.82(\mathrm{~d}, 1 \mathrm{H}, J=11.5 \mathrm{~Hz}): 6-\mathrm{H}_{2}, 2.55(\mathrm{~m}, 1 \mathrm{H})$, 4.45 (m, 1H), 4.84 (dd, 2H, J=13.5 Hz, J=14.0 Hz), 5.54 (s, 1H): 1'-, 3'-, 4'-H, 5'-- ${ }_{2}, 5.04$ (s, $\left.2 \mathrm{H}, \mathrm{OCH}_{2}\right), 6.42$ (s, 1H, 4-H), 6.61 (d, 1H, J=6.0 Hz, 2-H) 6.69 (d, 1H, J=8.5 Hz, 1-H), 7.06 $(\mathrm{s}, 1 \mathrm{H}), 7.46(\mathrm{~s}, 3 \mathrm{H}), 7.55(\mathrm{~s}, 1 \mathrm{H}), 8.00(\mathrm{~s}, 2 \mathrm{H})$ : benzoyl protons, 2"-, 8"-H, 7.59 (s, 1H, $\mathrm{HC}=\mathrm{C}), 8.72\left(\mathrm{~s}, 1 \mathrm{H}, 6\right.$ "-NH); ${ }^{13} \mathrm{C}-\mathrm{NMR}\left(\mathrm{CDCl}_{3}\right) ; \delta[\mathrm{ppm}]=20.7$ (C-18), 20.8, 20.9 (3'-OAc), 24.9 (2C), 30.2, 31.9, 33.3, 36.1 (C-2'), 41.2 (2C, C-8 and C-9), 49.1 (C-14), 50.0 (C-13), 51.4 (C-5'), $61.6\left(\mathrm{OCH}_{2}\right), 74.4,83.1,85.3,112.3(\mathrm{C}-2), 114.3(\mathrm{C}-4), 125.3(\mathrm{HC}=\mathrm{C}), 123.8\left(\mathrm{C}-5^{\prime \prime}\right)$, 126.7 (C-1), 128.1 (2C). 128.6 (2C), 132.8: benzoyl CH-s, 132.4 (C-10), 135.7: benzoyl Cq, 138.0 (C-5), 139.5 (C-8"), 144.1 (HC=ㄷ), 147.1, 151.4, 155.9 (C-3), 153.4, 165.2 (Bz-CO), 170.3 (Ac-CO), 221.7 (C-17); ESI-MS: $731[\mathrm{M}+\mathrm{H}]^{+}$.

3-\{[1-(3'-O-Acetyl-5'-deoxythymidine-5'-yl)-1H-1,2,3-triazole-4-yl]methyloxy $\}-13 \alpha$-estra1,3,5(10)-trien-17-one $\mathbf{( 8 3 b )}$

White solid (74 mg, 76\%), mp 189-191 ${ }^{\circ} \mathrm{C}, R_{\mathrm{f}}=0.5$ (EtOAc), $\mathrm{C}_{33} \mathrm{H}_{39} \mathrm{~N}_{5} \mathrm{O}_{7} ;{ }^{1} \mathrm{H}-\mathrm{NMR}\left(\mathrm{CDCl}_{3}\right)$; $\delta[\mathrm{ppm}]=1.03\left(\mathrm{~s}, 3 \mathrm{H}, 18-\mathrm{CH}_{3}\right), 1.24(\mathrm{~s}, 2 \mathrm{H}), 1.87$ (s, 3H, 5"- $\left.\mathrm{CH}_{3}\right), 2.09$ (s, 3H, 3'-OAc), 2.20 $\left(\mathrm{d}, 2 \mathrm{H}, J=11.0 \mathrm{~Hz}, 2^{\prime}-\mathrm{H}_{2}\right), 2.78\left(\mathrm{~m}, 2 \mathrm{H}, 6-\mathrm{H}_{2}\right), 4.29$ (m, 1H), 4.84 (dd, 2H, J=9.5 Hz, J=11.5 $\mathrm{Hz}), 5.29$ (s, 1H), 6.16 (m, 1H): 1'-, 3'-, 4'-H, 5'- $\mathrm{H}_{2}, 5.17$ (s, 2H, OCH $), 6.64$ (s, 1H, 4-H), $6.72(\mathrm{~d}, 1 \mathrm{H}, J=6.0 \mathrm{~Hz}, 2-\mathrm{H}), 6.90$ (s, 1H, 6"-H), 7.14 (d, 1H, J=8.5 Hz, 1-H), 7.79 (s, 1H, $\mathrm{HC}=\mathrm{C}), 9.46(\mathrm{~s}, 1 \mathrm{H}, 3 "-\mathrm{NH}) ;{ }^{13} \mathrm{C}-\mathrm{NMR}\left(\mathrm{CDCl}_{3}\right) ; \delta[\mathrm{ppm}]=12.4\left(5^{\prime \prime}-\mathrm{CH}_{3}\right), 20.8\left(3^{\prime}-\mathrm{OAc}\right)$, 21.0, 25.0 (C-18), 28.2 (2C), 30.3, 32.0, 33.4, 36.0 (C-2'), 41.3 (2C, C-8 and C-9), 49.2 (C14), 50.1 (C-13), $51.6(\mathrm{C}-5 '), 61.6\left(\mathrm{OCH}_{2}\right), 74.3,82.0,85.3,111.8$ (C-5"), 112.4 (C-2), 114.4 (C-4), 124.8 (Hㅌ=C), 126.9 (C-1), 132.7 (C-10), 135.6 (C-6"), 138.2 (C-5), 144.2 (HC=ㄷ), 150.3, 163.6, 155.8 (C-3), 170.6 (Ac-CO), 218.8 (C-17); ESI-MS: $618[\mathrm{M}+\mathrm{H}]^{+}$.

3-\{[1-(3'-O-Acetyl-N $N^{4}$-benzoyl-2',5'-dideoxycytidine-5'-yl)-1H-1,2,3-triazole-4-yl]methyloxy\}13a-estra-1,3,5(10)-trien-17-one $(\mathbf{8 3 c})$ 
White solid (67 mg, 61\%), mp $170{ }^{\circ} \mathrm{C}$ (dec.), $R_{\mathrm{f}}=0.47$ (EtOAc: $\left.\mathrm{MeOH} / 9: 1\right), \mathrm{C}_{39} \mathrm{H}_{42} \mathrm{~N}_{6} \mathrm{O}_{7} ;{ }^{1} \mathrm{H}-$ $\operatorname{NMR}\left(\mathrm{CDCl}_{3}\right) ; \delta[\mathrm{ppm}]=1.04\left(\mathrm{~s}, 3 \mathrm{H}, 18-\mathrm{CH}_{3}\right), 2.13$ (s, 3H, 3'-OAc), 2.63 (d, 2H, J=9.0 Hz, 2'- $\left.\mathrm{H}_{2}\right), 2.78\left(\mathrm{~m}, 2 \mathrm{H}, 6-\mathrm{H}_{2}\right), 4.43(\mathrm{~m}, 1 \mathrm{H}), 4.82$ (m, 2H), 5.24-5.26 (overlapping m, 2H): 1'-, 3', 4'-H, 5'- $\mathrm{H}_{2}, 5.17$ (s, 2H, $\left.\mathrm{OCH}_{2}\right), 6.68(\mathrm{~s}, 1 \mathrm{H}, 4-\mathrm{H}), 6.76$ (d, 1H, J=6.0 Hz, 2-H) 7.15 (d, 1H, $J=8.5 \mathrm{~Hz}, 1-\mathrm{H}), 7.53(\mathrm{t}, 3 \mathrm{H}, J=7.0 \mathrm{~Hz}), 7.64(\mathrm{t}, 2 \mathrm{H} J=14.5 \mathrm{~Hz})$ : benzoyl protons, $7.73(\mathrm{~s}, 1 \mathrm{H}$, $\mathrm{HC}=\mathrm{C}), 7.94(\mathrm{~s}, 1 \mathrm{H}, 6 "-\mathrm{H}), 8.04(\mathrm{~s}, 1 \mathrm{H}, 4 "-\mathrm{NH}) ;{ }^{13} \mathrm{C}-\mathrm{NMR}\left(\mathrm{CDCl}_{3}\right) ; \delta[\mathrm{ppm}]=20.8(\mathrm{C}-18)$, 21.0, $25.1\left(3^{\prime}-\mathrm{OCH}_{3}\right), 28.2$ (2C), 29.6, 30.3, 32.0, 33.4, 37.5 (C-2'), 41.4 (2C, C-8 and C-9), 49.2 (C-14), 50.1 (C-13), 51.4 (C-5'),56.3, $62.8\left(\mathrm{OCH}_{2}\right), 74.1,84.0,97.3$ (C-5"), 112.5 (C-2), 114.5 (C-4), 123.9 (C-1), $127.0(\mathrm{HC}=\mathrm{C}), 129.2$ (2C). 129.5 (2C), 132.6: benzoyl CH-s, 132.9 (C-10), 137.6: benzoyl Cq, 138.3 (C-5), 143.5 (HC=ㄷ), 156.0 (C-3), 157.5 (C-2"), 162.7 (C4"), 170.6 (Bz-CO), 171.2 (Ac-CO), 220.5 (C-17); ESI-MS: 707 [M+H]

3-\{[1-(2',5'-Dideoxyadenosine-5'-yl)-1H-1,2,3-triazole-4-yl]methyloxy\}-13 $\alpha$-estra-1,3,5(10)trien-17-one (84a)

White solid (50 mg, 87\%), mp $160{ }^{\circ} \mathrm{C}$ (dec.), $R_{\mathrm{f}}=0.33$ (toluene:iPrOH/1:1), $\mathrm{C}_{31} \mathrm{H}_{36} \mathrm{~N}_{8} \mathrm{O}_{5} ;{ }^{1} \mathrm{H}$ NMR (DMSO); $\delta[\mathrm{ppm}]=0.96\left(\mathrm{~s}, 3 \mathrm{H}, 18-\mathrm{CH}_{3}\right), 2.71\left(\mathrm{~m}, 2 \mathrm{H}, 2^{\prime}-\mathrm{H}_{2}\right), 2.83\left(\mathrm{~m}, 2 \mathrm{H}, 6-\mathrm{H}_{2}\right), 4.21$ (s, 1H), 4.51 (s, 1H), 4.68-4.77 (overlapping m, 2H), 4.99 (dd, 2H J=10.0 Hz, J=12.0 Hz), 5.60 (s, 1H): 1'-, 3'-, 4'-H, 5'-H $, \mathrm{OCH}_{2}, 6.63$ (s, 1H, 4-H), 6.70 (d, 1H, J=8.0 Hz, 2-H) 7.12 (d, 1H, J=8.5 Hz, 1-H), 7.47 (s, 2H, 6"-NH), 7.47 (s, 1H, HC=C), 8.21 (s, 1H), 8.32 (s, 1H): 2"-H and 8"-H; ${ }^{13} \mathrm{C}-\mathrm{NMR}$ (DMSO); $\delta[\mathrm{ppm}]=20.5,24.6$ (C-18), 27.7, 28.0, 29.7, 31.6, 32.9, 38.0 (C-2'), 40.8 (2C, C-8 and C-9), 48.5 (C-14), 49.4 (C-13), $51.5\left(\mathrm{C}-5{ }^{\prime}\right), 60.8\left(\mathrm{OCH}_{2}\right), 71.1$, 83.8, 84.9, 112.4 (C-2), 114.1 (C-4), 119.1, 125.0 (HC=C), 126.7 (C-1), 132.0 (C-10), 137.9 (C-5), 140.1, $142.8(\mathrm{HC}=\underline{\mathrm{C}}), 150.4,151.9,155.6$ (C-6"), 155.8 (C-3), 220.7 (C-17); ESI-MS: $585[\mathrm{M}+\mathrm{H}]^{+}$.

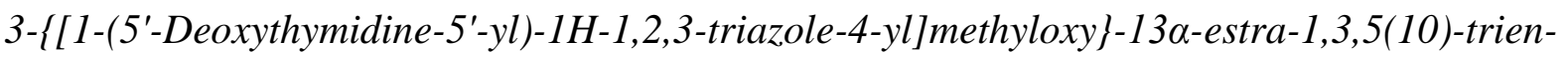
17-one (84b)

White solid (51 mg, 89\%), mp 211-212 ${ }^{\circ} \mathrm{C}, R_{\mathrm{f}}=0.63$ (EtOAc:MeOH/9:1), $\mathrm{C}_{31} \mathrm{H}_{37} \mathrm{~N}_{5} \mathrm{O}_{6} ;{ }^{1} \mathrm{H}-$ NMR (DMSO); $\delta[\mathrm{ppm}]=0.97\left(\mathrm{~s}, 3 \mathrm{H}, 18-\mathrm{CH}_{3}\right), 1.77\left(\mathrm{~s}, 3 \mathrm{H}, 5 "-\mathrm{CH}_{3}\right), 1.88(\mathrm{~m}, 1 \mathrm{H})$ and 2.30 (m, 1H): 2'- $\mathrm{H}_{2}, 2.74\left(\mathrm{~d}, 2 \mathrm{H}, J=3.0 \mathrm{~Hz}, 6-\mathrm{H}_{2}\right), 4.28(\mathrm{~m}, 1 \mathrm{H}), 4.63(\mathrm{~m}, 1 \mathrm{H})$ and $4.71(\mathrm{~m}, 1 \mathrm{H})$ : 5'$\mathrm{H}_{2}, 5.01\left(\mathrm{~s}, 2 \mathrm{H}, \mathrm{OCH}_{2}\right), 4.09(\mathrm{~d}, 1 \mathrm{H}, \mathrm{J}=3.0 \mathrm{~Hz}), 5.50(\mathrm{~s}, 1 \mathrm{H}), 6.16(\mathrm{t}, 1 \mathrm{H}, J=5.0 \mathrm{~Hz}, J=6.0$ Hz): 1'-, 3'-, 4'-H, 6.69 (s, 1H, 4-H), 6.76 (d, 1H, J=8.5 Hz, 2-H), 7.16 (d, 1H, J=7.5 Hz, 1-H), 7.33 (s, 1H, HC=C), 8.16 (s, 1H, 3"-NH); ${ }^{13} \mathrm{C}-\mathrm{NMR}$ (DMSO); $\delta$ [ppm]=12.0 (5"--CH $), 20.4$, 
24.5 (C-18), 27.6, 27.9, 29.7, 31.5, 32.5, 37.8 (C-2'), 40.7 (2C, C-8 and C-9), 48.4 (C-14), 49.4 (C-13), 51.1 (C-5'), $60.8\left(\mathrm{OCH}_{2}\right), 70.7$ (C-3'), 83.8, 83.9, 109.8 (C-5"), 112.3 (C-2), 114.1 (C-4), 125.0 (HC=C), 126.6 (C-1), 131.9 (C-10), 135.9 (C-6"), 137.8 (C-5), 142.9 $(\mathrm{HC}=\underline{\mathrm{C}}), 150.3,155.7$ (C-3), 163.5, 220.5 (C-17); ESI-MS: $576[\mathrm{M}+\mathrm{H}]^{+}$.

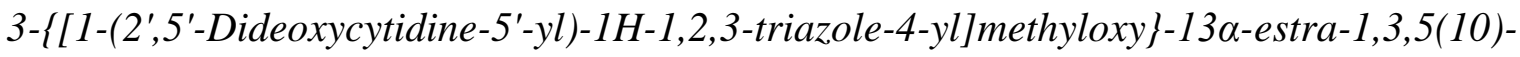
trien-17-one $(\mathbf{8 4 c})$

White solid (45 mg, 81\%), mp $170{ }^{\circ} \mathrm{C}$ (dec.), $R_{\mathrm{f}}=0.41$ (EtOAc:MeOH/95:5), $\mathrm{C}_{30} \mathrm{H}_{36} \mathrm{~N}_{6} \mathrm{O}_{5} ;{ }^{1} \mathrm{H}-$ NMR (DMSO); $\delta[\mathrm{ppm}]=0.96\left(\mathrm{~s}, 3 \mathrm{H}, 18-\mathrm{CH}_{3}\right), 2.29\left(\mathrm{~m}, 2 \mathrm{H}, 2^{\prime}-\mathrm{H}_{2}\right), 2.74$ (m, 2H, 6- $\left.\mathrm{H}_{2}\right), 3.75$ $(\mathrm{m}, 1 \mathrm{H}), 4.21(\mathrm{~m}, 2 \mathrm{H}), 4.62-4.72$ (overlapping $\mathrm{m}, 2 \mathrm{H}): 1^{\prime}-, 3^{\prime}-, 4^{\prime}-\mathrm{H}, 5{ }^{\prime}-\mathrm{H}_{2}, 5.06(\mathrm{~s}, 2 \mathrm{H}$, $\left.\mathrm{OCH}_{2}\right), 6.70$ (s, 1H, 4-H), 6.75 (d, 1H, J=6.5 Hz, 2-H) 7.15 (d, 1H, J=8.0 Hz, 1-H), 7.29 (s, $1 \mathrm{H}, \mathrm{HC}=\mathrm{C}$ ), 8.04 (d, 1H, J=6.5 Hz, 6"-H), 8.19 (s, 1H, 4"-NH2); ${ }^{13} \mathrm{C}-\mathrm{NMR}$ (DMSO); $\delta$ $[\mathrm{ppm}]=24.6$ (C-18), 27.8, 28.1, 29.8, 31.7, 33.0, 36.1 (C-2'), 40.8 (2C, C-8 and C-9), 43.4, 48.6 (C-14), 50.5 (C-13), 51.5 (C-5'), $61.3\left(\mathrm{OCH}_{2}\right), 84.1,84.9,87.3,94.5(\mathrm{C}-5 "), 112.5$ (C-2), 114.2 (C-4), 125.2 (C-1), 126.8 (HC=C), 132.1 (C-10), 137.9 (C-5), 141.1 (C-6"), 142.9 $(\mathrm{HC}=\underline{\mathrm{C}}), 155.0(\mathrm{C}-3), 155.2\left(\mathrm{C}-2^{\prime \prime}\right), 165.6(\mathrm{C}-4 "), 220.7$ (C-17); ESI-MS: $561[\mathrm{M}+\mathrm{H}]^{+}$.

3'-O-Acetyl- $N^{6}$-benzoyl-2'-deoxyadenosine (78a)

Amorphous foam (456 mg, 72\%), $R_{\mathrm{f}}=0.68$ (EtOAc:MeOH/95:5), $\mathrm{C}_{19} \mathrm{H}_{19} \mathrm{~N}_{5} \mathrm{O}_{5} ;{ }^{1} \mathrm{H}-\mathrm{NMR}$ $(\mathrm{DMSO}) ; \delta[\mathrm{ppm}]=2.11(\mathrm{~s}, 3 \mathrm{H}, \mathrm{OAc}), 2.59(\mathrm{dd}, 1 \mathrm{H}, J=2 \times 5.5 \mathrm{~Hz})$ and $3.05(\mathrm{~m}, 1 \mathrm{H}): 2^{\prime}-\mathrm{H}_{2}$, 3.69 (dd, 2H, J=11.5 Hz, J=13.5 Hz, 5'-H $), 4.13$ (s, 1H, 3'-H), 5.41 (d, 1H, J=3.5 Hz, 4'-H), $6.52\left(\mathrm{dd}, 1 \mathrm{H}, J=6.0 \mathrm{~Hz}, J=6.5 \mathrm{~Hz}, 1^{\prime}-\mathrm{H}\right), 7.57(\mathrm{dd}, 2 \mathrm{H}, J=6.5 \mathrm{~Hz}, J=7.0 \mathrm{~Hz})$ and $7.66(\mathrm{dd}, 1 \mathrm{H}$, $J=6.5 \mathrm{~Hz}, J=7.0 \mathrm{~Hz})$ and $8.06(\mathrm{~d}, 2 \mathrm{H}, J=7.0 \mathrm{~Hz})$ : benzoyl protons, $8.72(\mathrm{~d}, 1 \mathrm{H}, J=2.0 \mathrm{~Hz})$ and 8.77 (d, 1H, $J=2.5 \mathrm{~Hz}$ ): 2-H and 8-H, 11.23 (s, 1H, 6-NH); ${ }^{13} \mathrm{C}-\mathrm{NMR}$ (DMSO); $\delta$ [ppm]=21.0 (OAc), 36.5 (C-2'), 61.6 (C-5'), 75.0 (C-3'), 83.8 (C-4'), 85.4 (C-1'), 125.9 (C-5), 128.52 (2C), 128.53 (2C), 132.5, 133.4, 143.0 (C-8), 150.5 (C-6), 151.6 (C-2), 152.0 (C-4), 165.8 (Bz-CO), 170.1 (Ac-CO); ESI-MS: $398[\mathrm{M}+\mathrm{H}]^{+}$.

3'-O-Acetyl-2'-deoxy- $N^{2}$-isobutyrylguanosine (78b)

Amorphous foam (402 mg, 70\%), $R_{\mathrm{f}}=0.55$ (EtOAc:MeOH/95:5), $\mathrm{C}_{16} \mathrm{H}_{21} \mathrm{~N}_{5} \mathrm{O}_{6} ;{ }^{1} \mathrm{H}-\mathrm{NMR}$ $\left(\mathrm{CDCl}_{3}\right) ; \delta[\mathrm{ppm}]=1.21\left(2 \times \mathrm{d}, 6 \mathrm{H}, J=5.5 \mathrm{~Hz}, J=6.0 \mathrm{~Hz}, 2 \times \mathrm{iBu}-\mathrm{CH}_{3}\right), 2.05$ (s, 3H, OAc), 2.46 $\left(\mathrm{dd}, 1 \mathrm{H}, J=5.0 \mathrm{~Hz}, J=5.5 \mathrm{~Hz}, 3^{\prime}-\mathrm{H}\right), 2.83(\mathrm{~m}, 1 \mathrm{H})$ and $2.98(\mathrm{~m}, 1 \mathrm{H}): 2^{\prime}-\mathrm{H}_{2}, 3.81(\mathrm{~d}, 1 \mathrm{H}, J=12.0$ $\mathrm{Hz}$ ) and $3.91(\mathrm{~d}, 1 \mathrm{H}, J=12.0 \mathrm{~Hz}): 5^{\prime}-\mathrm{H}_{2}, 4.13(\mathrm{~m}, 1 \mathrm{H}, \mathrm{iBu}-\mathrm{CH}), 4.56$ (s, 1H, OH in 5'), 5.40 (d, 
$\left.1 \mathrm{H}, J=4.5 \mathrm{~Hz}, 4^{\prime}-\mathrm{H}\right), 6.18$ (dd, 1H, J=6.5 Hz, J=7.0 Hz, 1'-H), 8.01 (s, 1H, 8-H), 10.19 (s, 1H, $\mathrm{iBu}-\mathrm{NH}), 12.26(\mathrm{~s}, 1 \mathrm{H}, 1-\mathrm{NH}) ;{ }^{13} \mathrm{C}-\mathrm{NMR}\left(\mathrm{CDCl}_{3}\right) ; \delta[\mathrm{ppm}]=18.9\left(2 \mathrm{C}, 2 \times \mathrm{iBu}_{-} \mathrm{CH}_{3}\right), 20.9$ (OAc), 36.0 (iBu-CH), 37.3 (C-2'), 62.3 (C-5'), 75.3 (C-3'), 85.6 (C-4'), 86.0 (C-1'), 121.1 (C5), 138.7 (C-8), 147.8 (C-4), 148.1 (C-2), 155.3 (C-6), 170.5 (Ac-CO), 179.9 (iBu-CO). ESIMS: $380[\mathrm{M}+\mathrm{H}]^{+}$.

3'-O-Acetyl- $N^{4}$-benzoyl-2'-deoxycytidine (78c)

Amorphous foam (398 mg, 78\%), $R_{\mathrm{f}}=0.51$ (EtOAc), $\mathrm{C}_{18} \mathrm{H}_{19} \mathrm{~N}_{3} \mathrm{O}_{6} ;{ }^{1} \mathrm{H}-\mathrm{NMR}$ (DMSO); $\delta$ $[\mathrm{ppm}]=2.07(\mathrm{~s}, 3 \mathrm{H}, \mathrm{OAc}), 2.26(\mathrm{~m}, 1 \mathrm{H})$ and $2.47(\mathrm{~m}, 1 \mathrm{H}): 2^{\prime}-\mathrm{H}_{2}, 3.67\left(\mathrm{~m}, 2 \mathrm{H}, 5{ }^{\prime}-\mathrm{H}_{2}\right), 4.13(\mathrm{~m}$, $1 \mathrm{H})$ and $5.21(\mathrm{~m}, 1 \mathrm{H}): 3$ '-H and 4'-H, $5.24(\mathrm{~m}, 1 \mathrm{H}, 5-\mathrm{H}), 6.19\left(\mathrm{dd}, 1 \mathrm{H}, J=5.5 \mathrm{~Hz}, J=6.0 \mathrm{~Hz}, 1^{\prime}-\right.$ H), $7.37(\mathrm{~s}, 1 \mathrm{H}, \mathrm{OH}$ in 5'), $7.53(\mathrm{t}, 2 \mathrm{H}, J=6.5 \mathrm{~Hz}, J=7.5 \mathrm{~Hz})$ and $7.64(\mathrm{t}, 1 \mathrm{H}, J=6.5 \mathrm{~Hz}, J=7.5$ $\mathrm{Hz})$ and 8.01 (d, 2H, J=7.5 Hz): benzoyl protons, $8.38(\mathrm{~d}, 1 \mathrm{H}, J=6.5 \mathrm{~Hz}, 6-\mathrm{H}), 11.25(\mathrm{~s}, 1 \mathrm{H}$, 4-NH); ${ }^{13} \mathrm{C}-\mathrm{NMR}$ (DMSO); $\delta$ [ppm]=20.8 (OAc), 38.1 (C-2'), 61.1 (C-5'), 74.6 (C-3'), 85.5 (C-4'), 86.3 (C-1'), 96.3 (C-5), 128.3 (2C), 128.4 (2C), 132.6, 133.0, 144.7 (C-6), 154.2 (C-2), 163.0 (C-4), 167.2 (Bz-CO), 169.9 (Ac-CO); ESI-MS: $374[\mathrm{M}+\mathrm{H}]^{+}$.

3'-O-Acetylthymidine $(\mathbf{7 8 d})^{170}$

Amorphous foam (511 mg, 83\%), $R_{\mathrm{f}}=0.57$ (EtOAc), $\mathrm{C}_{12} \mathrm{H}_{16} \mathrm{~N}_{2} \mathrm{O}_{6} ;{ }^{1} \mathrm{H}-\mathrm{NMR}$ (DMSO); $\delta$ $[\mathrm{ppm}]=1.78\left(\mathrm{~s}, 3 \mathrm{H}, 5-\mathrm{CH}_{3}\right), 2.06(\mathrm{~s}, 3 \mathrm{H}, \mathrm{OAc}), 2.20\left(\mathrm{~m}, 2 \mathrm{H}, 2^{\prime}-\mathrm{H}_{2}\right), 3.62\left(\mathrm{~m}, 2 \mathrm{H}, 5^{\prime}-\mathrm{H}_{2}\right), 3.97$ (m, 1H, 4'-H), 5.18 (dd, 1H, J=5.0 Hz, J=5.5 Hz, 3'-H), 5.22 (d, 1H, J=5.5 Hz, OH in 5'), 6.19 $\left(\mathrm{dd}, 1 \mathrm{H}, J=2 \times 6.5 \mathrm{~Hz}, 11^{\prime}-\mathrm{H}\right), 7.73$ (s, 1H, 6-H), 11.3 (s, 1H, 3-NH); ${ }^{13} \mathrm{C}-\mathrm{NMR}$ (DMSO); $\delta$ $[\mathrm{ppm}]=12.2\left(5-\mathrm{CH}_{3}\right), 20.8(\mathrm{OAc}), 36.4\left(\mathrm{C}-2^{\prime}\right), 61.3\left(\mathrm{C}^{\prime} 5^{\prime}\right), 74.6\left(\mathrm{C}-3^{\prime}\right), 83.6\left(\mathrm{C}-4{ }^{\prime}\right), 84.5\left(\mathrm{C}-1^{\prime}\right)$, 109.7 (C-5), 135.7 (C-6), 150.4 (C-2), 163.6 (C-4), 169.9 (Ac-CO); ESI-MS: 285 [M+H] ${ }^{+}$.

2',3'-Di-O-acetyl- $N^{6}$-benzoyladenosine $(\mathbf{8 9 a})^{171}$

Amorphous foam (568 mg, 85\%), $R_{\mathrm{f}}=0.49$ (EtOAc), $\mathrm{C}_{21} \mathrm{H}_{21} \mathrm{~N}_{5} \mathrm{O}_{7} ;{ }^{1} \mathrm{H}-\mathrm{NMR}$ (DMSO); $\delta$ $[\mathrm{ppm}]=2.01$ and $2.15(2 \times \mathrm{s}, 2 \times 3 \mathrm{H}, 2 \times \mathrm{OAc}), 3.68(\mathrm{dd}, 1 \mathrm{H}, J=2.5 \mathrm{~Hz}, J=4.0 \mathrm{~Hz})$ and $3.78(\mathrm{dd}$, $1 \mathrm{H}, J=4.0 \mathrm{~Hz}, J=4.5 \mathrm{~Hz}): 5 '-\mathrm{H}_{2}, 4.28\left(\mathrm{~d}, 1 \mathrm{H}, J=2.5 \mathrm{~Hz}, 4{ }^{\prime}-\mathrm{H}\right), 5.43$ (t, 1H, J=5.0 Hz, J=5.5 $\mathrm{Hz})$ and $6.02(\mathrm{t}, 1 \mathrm{H}, J=5.5 \mathrm{~Hz}, J=6.0 \mathrm{~Hz}): 2^{\prime}-\mathrm{H}$ and 3'-H, $6.36\left(\mathrm{~d}, 1 \mathrm{H}, J=6.5 \mathrm{~Hz}, 1^{\prime}-\mathrm{H}\right), 7.57$ $(\mathrm{dd}, 2 \mathrm{H}, J=2 \times 7.5 \mathrm{~Hz})$ and $7.67(\mathrm{dd}, 1 \mathrm{H}, J=7.0 \mathrm{~Hz}, J=7.5 \mathrm{~Hz})$ and $8.06(\mathrm{~d}, 2 \mathrm{H}, J=7.5 \mathrm{~Hz})$ : benzoyl protons, $8.75(\mathrm{~s}, 1 \mathrm{H})$ and $8.79(\mathrm{~s}, 1 \mathrm{H}): 2-\mathrm{H}$ and $8-\mathrm{H}, 11.26(\mathrm{~s}, 1 \mathrm{H}, 6-\mathrm{NH}) ;{ }^{13} \mathrm{C}-\mathrm{NMR}$ $(\mathrm{DMSO}) ; \delta[\mathrm{ppm}]=20.1$ and $20.4(2 \times \mathrm{OAc}), 60.8\left(\mathrm{C}-5^{\prime}\right), 71.0\left(\mathrm{C}-2^{\prime}\right), 72.5\left(\mathrm{C}-3^{\prime}\right), 83.7\left(\mathrm{C}-4^{\prime}\right)$, 
85.0 (C-1'), 125.7 (C-5), 128.39 (2C), 128.43 (2C), 132.4, 133.2, 140.9 (C-8), 150.6 (C-4), 151.8 (C-2), 151.9 (C-6), 165.6 (Bz-CO), 169.2 and 169.5 (2×Ac-CO); ESI-MS: 456 [M+H] 2',3'-Di-O-acetyl-N $N^{2}$-isobutyrylguanosine $(\mathbf{8 9 b})^{172}$

Amorphous foam (455 mg, 73\%), $R_{\mathrm{f}}=0.29$ (EtOAc:MeOH/95:5), $\mathrm{C}_{18} \mathrm{H}_{23} \mathrm{~N}_{5} \mathrm{O}_{8} ;{ }^{1} \mathrm{H}-\mathrm{NMR}$ $(\mathrm{DMSO}) ; \delta[\mathrm{ppm}]=1.13\left(\mathrm{~d}, 6 \mathrm{H}, J=6.5 \mathrm{~Hz}, 2 \times \mathrm{iBu}-\mathrm{CH}_{3}\right), 1.99$ and $2.13(2 \times \mathrm{s}, 2 \times 3 \mathrm{H}, 2 \times \mathrm{OAc})$, $2.80(\mathrm{~m}, 1 \mathrm{H}, \mathrm{iBu}-\mathrm{CH}), 3.72\left(\mathrm{~m}, 2 \mathrm{H}, 5^{\prime}-\mathrm{H}_{2}\right), 4.21$ (d, 1H, J=2.0 Hz, OH in 5'), 5.40 (m, 1H, 2'H), 5.47 (dd, 1H,J=1.5 Hz, J=2.0 Hz, 3'-H), 5.76 (dd, 1H, J=5.5 Hz, J=6.0 Hz, 4'-H), 6.08 (d, $1 \mathrm{H} J=7.5 \mathrm{~Hz}, 1$ '-H), 8.30 (s, 1H, 8-H), 11.69 (s, 1H, iBu-NH), 12.10 (s, 1H, 1-NH); ${ }^{13} \mathrm{C}-\mathrm{NMR}$ $(\mathrm{DMSO}) ; \delta[\mathrm{ppm}]=18.7\left(2 \mathrm{C}, 2 \times \mathrm{iBu}-\mathrm{CH}_{3}\right), 20.1$ and $20.4(2 \times \mathrm{OAc}), 34.7(\mathrm{iBu}-\mathrm{CH}), 60.8(\mathrm{C}-$ 5'), 71.4 (C-2'), 73.0 (C-3'), 83.6 (C-4'), 83.9 (C-1'), 119.9 (C-5), 139.2 (C-8), 148.4 (C-4), 148.8 (C-2), 154.6 (C-6), 169.1 and 169.4 (2×Ac-CO), 180.1 (iBu-CO). ESI-MS: 438 $[\mathrm{M}+\mathrm{H}]^{+}$.

\section{2',3'-Di-O-acetyl- $N^{4}$-benzoylcytidine $(\mathbf{8 9 c})$}

Amorphous foam (431 mg, 79\%), $R_{\mathrm{f}}=0.5$ (EtOAc:MeOH/95:5), $\mathrm{C}_{20} \mathrm{H}_{21} \mathrm{~N}_{3} \mathrm{O}_{8} ;{ }^{1} \mathrm{H}-\mathrm{NMR}$ $(\mathrm{DMSO}) ; \delta[\mathrm{ppm}]=2.05$ and $2.09(2 \times \mathrm{s}, 2 \times 3 \mathrm{H}, 2 \times \mathrm{OAc}), 3.66(\mathrm{~d}, 1 \mathrm{H}, J=12.0 \mathrm{~Hz})$ and $3.77(\mathrm{~d}$, $1 \mathrm{H}, J=12.0 \mathrm{~Hz}$ ): 5'- $\mathrm{H}_{2}, 4.22$ (d, 1H, J=4.0 Hz, 2'-H), 5.36 (t, 1H, J=2×5.0 Hz, 3'-H), 5.40 (m, 1H, 5-H), 5.46 (t, 1H, J=5.0 Hz, J=5.5 Hz, 4'-H), 6.08 (d, 1H, J=5.0 Hz, 1'-H), 7.36 (s, 1H, $\mathrm{OH}$ in $\left.5^{\prime}\right), 7.53(\mathrm{dd}, 2 \mathrm{H}, J=7.5 \mathrm{~Hz}, J=8.0 \mathrm{~Hz})$ and $7.64(\mathrm{dd}, 1 \mathrm{H}, J=7.0 \mathrm{~Hz}, 7.5 \mathrm{~Hz})$ and $8.02(\mathrm{~d}$, $2 \mathrm{H}, J=7.5 \mathrm{~Hz}$ ): benzoyl protons, $8.41(\mathrm{~d}, 1 \mathrm{H}, J=7.5 \mathrm{~Hz}, 6-\mathrm{H}), 11.32(\mathrm{~s}, 1 \mathrm{H}, 4-\mathrm{NH}) ;{ }^{13} \mathrm{C}-\mathrm{NMR}$ $(\mathrm{DMSO}) ; \delta[\mathrm{ppm}]=20.2$ and $20.3(2 \times \mathrm{OAc}), 60.2$ (C-5'), $70.2\left(\mathrm{C}-2^{\prime}\right), 73.3\left(\mathrm{C}-3^{\prime}\right), 82.9\left(\mathrm{C}-4^{\prime}\right)$, 87.8 (C-1'), 96.8 (C-5), 128.3 (2C), 128.4 (2C), 132.7, 133.0, 145.3 (C-6), 154.3 (C-2), 163.4 (C-4), 167.2 (Bz-CO), 169.2 and 169.4 (2×Ac-CO); ESI-MS: $432[\mathrm{M}+\mathrm{H}]^{+}$.

$2^{\prime}, 3^{\prime}$-Di-O-acetyluridine $(\mathbf{8 9 e})^{173}$

Amorphous foam (584 mg, 81\%), $R_{\mathrm{f}}=0.58$ (EtOAc:MeOH/95:5), $\mathrm{C}_{13} \mathrm{H}_{16} \mathrm{~N}_{2} \mathrm{O}_{8} ;{ }^{1} \mathrm{H}-\mathrm{NMR}$ $(\mathrm{DMSO}) ; \delta[\mathrm{ppm}]=2.02$ and $2.10(2 \times \mathrm{s}, 2 \times 3 \mathrm{H}, 2 \times \mathrm{OAc}), 3.64\left(\mathrm{~m}, 2 \mathrm{H}, 5^{\prime}-\mathrm{H}_{2}\right), 4.14(\mathrm{~d}, 1 \mathrm{H}$, $\left.J=2.0 \mathrm{~Hz}, 4^{\prime}-\mathrm{H}\right), 5.37$ (m, 2H, 2'-H and 3'-H), 5.41 (s, 1H, OH in 5'), 5.73 (d, 1H, J=8.0 Hz, 6$\mathrm{H}), 6.02\left(\mathrm{~d}, 1 \mathrm{H}, J=6.0 \mathrm{~Hz}, 11^{\prime}-\mathrm{H}\right), 7.91(\mathrm{~d}, 1 \mathrm{H}, J=8.5 \mathrm{~Hz}, 5-\mathrm{H}), 11.40(\mathrm{~s}, 1 \mathrm{H}, 3-\mathrm{NH}) ;{ }^{13} \mathrm{C}-\mathrm{NMR}$ $(\mathrm{DMSO}) ; \delta[\mathrm{ppm}]=20.1$ and $20.4(2 \times \mathrm{OAc}), 60.7\left(\mathrm{C}^{\prime} 5^{\prime}\right), 71.0\left(\mathrm{C}^{\prime} 2^{\prime}\right), 72.2\left(\mathrm{C}-3^{\prime}\right), 83.1$ (C-4'), 85.3 (C-1'), 102.5 (C-5), 140.2 (C-6), 150.5 (C-2), 162.8 (C-4), 169.3 and 169.5 (2×Ac-CO); ESI-MS: $329[\mathrm{M}+\mathrm{H}]^{+}$. 
$N$-(3-aminopropyl)-2-azidoacetamide (88)

Oil (4.4 g, 90\%), $\mathrm{C}_{5} \mathrm{H}_{11} \mathrm{~N}_{5} \mathrm{O} ;{ }^{1} \mathrm{H}-\mathrm{NMR}$ (DMSO); $\delta[\mathrm{ppm}]=1.51(\mathrm{t}, 2 \mathrm{H}, J=6.0 \mathrm{~Hz}, J=6.5 \mathrm{~Hz})$ and $2.56(\mathrm{~m}, 2 \mathrm{H})$ and $3.13(\mathrm{~m}, 2 \mathrm{H})$ and $3.79(\mathrm{~s}, 2 \mathrm{H}): 4 \times \mathrm{CH}_{2}, 6.30\left(\mathrm{br} \mathrm{s}, 2 \mathrm{H}, \mathrm{NH}_{2}\right), 8.19$ (s, $1 \mathrm{H}, \mathrm{CO}-\underline{\mathrm{NH}}) ;{ }^{13} \mathrm{C}-\mathrm{NMR}(\mathrm{DMSO}) ; \delta[\mathrm{ppm}]=31.9$ and 36.3 and 38.5 and 50.8: $4 \times \mathrm{CH}_{2}, 167.0$ ( $\underline{\mathrm{CO}}-\mathrm{NH})$; ESI-MS: $158[\mathrm{M}+\mathrm{H}]^{+}$.

3'-O-Acetyl-5'-O-((3-(2-azidoacetamido)propyl)carbamoyl)- $N^{6}$-benzoyl-2'-deoxyadenosine (93a)

Amorphous foam (117 mg, 80\%), $R_{\mathrm{f}}=0.43$ (EtOAc:MeOH/95:5), $\mathrm{C}_{25} \mathrm{H}_{28} \mathrm{~N}_{10} \mathrm{O}_{7}$; ${ }^{1} \mathrm{H}-\mathrm{NMR}$ $(\mathrm{DMSO}) ; \delta[\mathrm{ppm}]=2.12(\mathrm{~s}, 3 \mathrm{H}, \mathrm{OAc}), 1.55(\mathrm{~m}, 2 \mathrm{H})$ and $2.99(\mathrm{~m}, 2 \mathrm{H})$ and $3.08(\mathrm{~m}, 2 \mathrm{H})$ and 3.79 (s, 2H): linker $\mathrm{CH}_{2}, 2.62\left(\mathrm{~d}, 2 \mathrm{H}, J=12.0 \mathrm{~Hz}, 2^{\prime}-\mathrm{H}_{2}\right), 4.17(\mathrm{dd}, 1 \mathrm{H}, J=6.5 \mathrm{~Hz}, J=10.0 \mathrm{~Hz}$, 3'-H), 4.28 (m, 2H, 5'- $\left.\mathrm{H}_{2}\right), 5.40$ (s, 1H, 4'-H), $6.52\left(\mathrm{~m}, 1 \mathrm{H}, 1^{\prime}-\mathrm{H}\right), 7.30(\mathrm{~m}, 1 \mathrm{H})$ and $7.57(\mathrm{dd}$, $2 \mathrm{H}, J=2 \times 7.0 \mathrm{~Hz})$ and $7.66(\mathrm{dd}, 1 \mathrm{H}, J=6.0 \mathrm{~Hz}, J=7.0 \mathrm{~Hz})$ and $8.06(\mathrm{~d}, 3 \mathrm{H}, J=6.5 \mathrm{~Hz})$ : benzoyl protons and linker $2 \times \mathrm{NH}, 8.68(\mathrm{~s}, 1 \mathrm{H})$ and $8.78(\mathrm{~s}, 1 \mathrm{H}): 2-\mathrm{H}$ and $8-\mathrm{H}, 11.22(\mathrm{~s}, 1 \mathrm{H}, 6-\mathrm{NH})$; ${ }^{13} \mathrm{C}-\mathrm{NMR}(\mathrm{DMSO}) ; \delta[\mathrm{ppm}]=20.8$ (OAc), 29.2 and 35.6 and 38.0 and 50.7: linker $\mathrm{CH}_{2}, 36.3$ (C-2'), 63.7 (C-5'), 74.5 (C-3'), 82.2 (C-4'), 83.4 (C-1'), 125.7 (C-5), 128.4 (2C), 128.5 (2C), 132.4, 133.2, 142.5 (C-8), 150.4 (C-6), 151.7 (C-2), 152.0 (C-4), 155.7 and 159.3: linker-CO, 167.1 (Bz-CO), 169.9 (Ac-CO); ESI-MS: $581[\mathrm{M}+\mathrm{H}]^{+}$.

3'-O-Acetyl-5'-O-((3-(2-azidoacetamido)propyl)carbamoyl)-2'-deoxy- $N^{2}$-isobutyrylguanosine (93b)

Amorphous foam (123 mg, 83\%), $R_{\mathrm{f}}=0.2$ (EtOAc:MeOH/95:5), $\mathrm{C}_{22} \mathrm{H}_{30} \mathrm{~N}_{10} \mathrm{O}_{8} ;{ }^{1} \mathrm{H}-\mathrm{NMR}$ $(\mathrm{DMSO}) ; \delta[\mathrm{ppm}]=1.13\left(\mathrm{~d}, 6 \mathrm{H}, J=6.5 \mathrm{~Hz}, 2 \times \mathrm{iBu}-\mathrm{CH}_{3}\right), 2.08$ (s, 3H, OAc), 1.57 (dd, 2H, $J=6.5 \mathrm{~Hz}, J=7.0 \mathrm{~Hz})$ and $3.00(\mathrm{~m}, 3 \mathrm{H})$ and $3.10(\mathrm{~m}, 2 \mathrm{H})$ and $3.80(\mathrm{~s}, 2 \mathrm{H})$ : linker $\mathrm{CH}_{2}$ and $3^{\prime}-$ $\mathrm{H}, 2.79(\mathrm{~m}, 1 \mathrm{H})$ and $2.94(\mathrm{~m}, 1 \mathrm{H}): 2^{\prime}-\mathrm{H}_{2}, 4.13(\mathrm{~m}, 1 \mathrm{H})$ and $4.21(\mathrm{~m}, 2 \mathrm{H}): \mathrm{iBu}-\mathrm{CH}$ and $5^{\prime}-\mathrm{H}_{2}$, $5.29\left(\mathrm{~d}, 1 \mathrm{H}, J=4.5 \mathrm{~Hz}, 4^{\prime}-\mathrm{H}\right), 6.23\left(\mathrm{dd}, 1 \mathrm{H}, J=7.0 \mathrm{~Hz}, J=7.5 \mathrm{~Hz}, 1^{\prime}-\mathrm{H}\right), 7.33(\mathrm{~m}, 1 \mathrm{H})$ and 8.08 $(\mathrm{m}, 1 \mathrm{H})$ : linker $2 \times \mathrm{NH}, 8.22(\mathrm{~s}, 1 \mathrm{H}, 8-\mathrm{H}), 11.66(\mathrm{~s}, 1 \mathrm{H}, \mathrm{iBu}-\mathrm{NH}), 12.07(\mathrm{~s}, 1 \mathrm{H}, 1-\mathrm{NH}) ;{ }^{13} \mathrm{C}-$ NMR (DMSO); $\delta[\mathrm{ppm}]=18.9\left(2 \mathrm{C}, 2 \times \mathrm{iBu}-\mathrm{CH}_{3}\right), 20.9(\mathrm{OAc}), 29.4$ and 36.0 and 38.1 and 50.9: linker $\mathrm{CH}_{2}, 34.8$ (iBu-CH), 36.4 (C-2'), 63.7 (C-5'), 74.7 (C-3'), 82.3 (C-4'), 82.8 (C-1'), 120.3 (C-5), 137.2 (C-8), 148.3 (C-4), 148.7 (C-2), 154.8 and 167.2: linker-CO, 155.8 (C-6), 170.0 (Ac-CO), 180.2 (iBu-CO); ESI-MS: $563[\mathrm{M}+\mathrm{H}]^{+}$. 
3'-O-Acetyl-5'-O-((3-(2-azidoacetamido)propyl)carbamoyl)- $N^{4}$-benzoyl-2'-deoxycytidine $(93 \mathrm{c})$

Amorphous foam (128 mg, 86\%), $R_{\mathrm{f}}=0.6$ (EtOAc:MeOH/95:5), $\mathrm{C}_{24} \mathrm{H}_{28} \mathrm{~N}_{8} \mathrm{O}_{8} ;{ }^{1} \mathrm{H}-\mathrm{NMR}$ $(\mathrm{DMSO}) ; \delta[\mathrm{ppm}]=2.08(\mathrm{~s}, 3 \mathrm{H}, \mathrm{OAc}), 1.56(\mathrm{~m}, 2 \mathrm{H})$ and $3.01(\mathrm{~m}, 3 \mathrm{H})$ and $3.10(\mathrm{~m}, 3 \mathrm{H})$ and 3.79 (s, 2H): linker $\mathrm{CH}_{2}$ and 5'- $\mathrm{H}_{2}, 2.40$ (m, 2H, 2'- $\left.\mathrm{H}_{2}\right), 4.29$ (m, 2H, 3'-H and 4'-H), 5.20 (s, $1 \mathrm{H}, 5-\mathrm{H}), 6.18\left(\mathrm{~s}, 1 \mathrm{H}, 1^{\prime}-\mathrm{H}\right), 7.52(\mathrm{~m}, 2 \mathrm{H})$ and $7.63(\mathrm{~m}, 1 \mathrm{H})$ and $8.02(\mathrm{~d}, 2 \mathrm{H} J=6.0 \mathrm{~Hz})$ : benzoyl protons, $7.36(\mathrm{~m}, 2 \mathrm{H})$ and $8.11(\mathrm{~m}, 2 \mathrm{H})$ : linker $2 \times \mathrm{NH}$ and $4-\mathrm{NH}$ and $6-\mathrm{H} ;{ }^{13} \mathrm{C}-\mathrm{NMR}$ $(\mathrm{DMSO}) ; \delta[\mathrm{ppm}]=20.7$ (OAc), 29.2 and 38.0 and 37.4 and 50.7: linker $\mathrm{CH}_{2}, 36.3\left(\mathrm{C}-2^{\prime}\right), 63.5$ (C-5'), 74.3 (C-3'), 82.5 (C-4'), 86.3 (C-1'), 96.5 (C-5), 128.3 (2C), 128.4 (2C), 132.6, 133.1, 144.5 (C-6), 154.2 (C-2), 155.7 and 167.1: linker-CO, 163.1 (C-4), 167.5 (Bz-CO), 169.9 (Ac-CO); ESI-MS: $557[\mathrm{M}+\mathrm{H}]^{+}$.

3'-O-Acetyl-5'-O-((3-(2-azidoacetamido)propyl)carbamoyl)thymidine (93d)

Amorphous foam (135 mg, 82\%), $R_{\mathrm{f}}=0.27$ (EtOAc), $\mathrm{C}_{18} \mathrm{H}_{25} \mathrm{~N}_{7} \mathrm{O}_{8} ;{ }^{1} \mathrm{H}-\mathrm{NMR}$ (DMSO); $\delta$ $[\mathrm{ppm}]=1.78\left(\mathrm{~s}, 3 \mathrm{H}, 5-\mathrm{CH}_{3}\right), 2.07(\mathrm{~s}, 3 \mathrm{H}, \mathrm{OAc}), 1.57(\mathrm{dd}, 2 \mathrm{H}, J=4.0 \mathrm{~Hz}, J=4.5 \mathrm{~Hz})$ and 3.01 $(\mathrm{m}, 2 \mathrm{H})$ and $3.09(\mathrm{~m}, 2 \mathrm{H})$ and $3.80(\mathrm{~s}, 2 \mathrm{H})$ : linker $\mathrm{CH}_{2}, 2.45\left(\mathrm{~d}, 2 \mathrm{H}, J=7.5 \mathrm{~Hz}, 2^{\prime}-\mathrm{H}_{2}\right), 4.10(\mathrm{~d}$, $1 \mathrm{H}, J=11.5 \mathrm{~Hz})$ and $4.25(\mathrm{~d}, 1 \mathrm{H}, J=11.5 \mathrm{~Hz}): 5^{\prime}-\mathrm{H}_{2}, 4.14\left(\mathrm{~m}, 1 \mathrm{H}, 4^{\prime}-\mathrm{H}\right), 5.18(\mathrm{~d}, 1 \mathrm{H}, J=2.5 \mathrm{~Hz}$, 3'-H), $6.18(\mathrm{~m}, 1 \mathrm{H}, 1$ '-H), $7.46(\mathrm{~s}, 1 \mathrm{H}, 6-\mathrm{H}), 7.36(\mathrm{~m}, 1 \mathrm{H})$ and $8.08(\mathrm{~m}, 1 \mathrm{H})$ : linker $2 \times \mathrm{NH}$, 11.36 (s, 1H, 3-NH); ${ }^{13} \mathrm{C}-\mathrm{NMR}$ (DMSO); $\delta[\mathrm{ppm}]=12.1\left(5-\mathrm{CH}_{3}\right), 20.7$ (OAc), 29.2 and 35.6 and 38.0 and 50.7: linker $\mathrm{CH}_{2}, 36.3$ (C-2'), 63.8 (C-5'), 74.2 (C-3'), $81.4\left(\mathrm{C}^{\prime} 4^{\prime}\right), 83.7$ (C-1'), 109.8 (C-5), 135.6 (C-6), 150.4 (C-2), 155.7 and 167.1: linker-CO, 163.5 (C-4), 169.9 (AcCO);. ESI-MS: $468[\mathrm{M}+\mathrm{H}]^{+}$.

2',3'-Di-O-acetyl-5'-O-((3-(2-azidoacetamido)propyl)carbamoyl)- $N^{6}$-benzoyladenosine (94a) Amorphous foam (112 mg, 80\%), $R_{\mathrm{f}}=0.41$ (EtOAc), $\mathrm{C}_{27} \mathrm{H}_{30} \mathrm{~N}_{10} \mathrm{O}_{9} ;{ }^{1} \mathrm{H}-\mathrm{NMR}$ (DMSO); $\delta$ $[\mathrm{ppm}]=2.04$ and $2.15(2 \times \mathrm{s}, 2 \times 3 \mathrm{H}, 2 \times \mathrm{OAc}), 1.57(\mathrm{t}, 2 \mathrm{H}, J=2 \times 6.0 \mathrm{~Hz})$ and $2.73(\mathrm{~s}, 1 \mathrm{H})$ and $2.89(\mathrm{~s}, 1 \mathrm{H})$ and $3.09(\mathrm{~d}, 2 \mathrm{H}, J=5.5 \mathrm{~Hz})$ and $3.79(\mathrm{~s}, 2 \mathrm{H})$ : linker $\mathrm{CH}_{2}, 3.00(\mathrm{~d}, 2 \mathrm{H}, J=5.0 \mathrm{~Hz}$, 5'- $\left.\mathrm{H}_{2}\right), 4.26\left(\mathrm{dd}, 1 \mathrm{H}, J=2.5 \mathrm{~Hz}, J=5.0 \mathrm{~Hz}, 4^{\prime}-\mathrm{H}\right), 5.60(\mathrm{~m}, 1 \mathrm{H})$ and $6.03(\mathrm{~m}, 1 \mathrm{H}): 2^{\prime}-\mathrm{H}$ and 3'$\mathrm{H}, 6.37\left(\mathrm{~d}, 1 \mathrm{H}, J=4.0 \mathrm{~Hz}, 1^{\prime}-\mathrm{H}\right), 7.33(\mathrm{~m}, 1 \mathrm{H})$ and $7.57(\mathrm{dd}, 2 \mathrm{H}, J=7.0 \mathrm{~Hz}, J=7.5 \mathrm{~Hz})$ and 7.67 $(\mathrm{dd}, 1 \mathrm{H}, J=7.0 \mathrm{~Hz}, J=7.5 \mathrm{~Hz}$ ) and $8.06(\mathrm{~d}, 3 \mathrm{H}, J=7.0 \mathrm{~Hz}$ ): benzoyl protons and linker $2 \times \mathrm{NH}$, $8.71(\mathrm{~s}, 1 \mathrm{H})$ and $8.79(\mathrm{~s}, 1 \mathrm{H}): 2-\mathrm{H}$ and $8-\mathrm{H}, 11.26(\mathrm{~s}, 1 \mathrm{H}, 6-\mathrm{NH}) ;{ }^{13} \mathrm{C}-\mathrm{NMR}$ (DMSO); $\delta$ $[\mathrm{ppm}]=20.1$ and $20.3(2 \times \mathrm{OAc}), 29.2$ and 36.3 and 38.0 and 50.7: linker $\mathrm{CH}_{2}, 62.9\left(\mathrm{C}-5^{\prime}\right)$, 70.3 (C-2'), 72.0 (C-3'), 80.2 (C-4'), 85.1 (C-1'), 125.6 (C-5), 128.40 (2C), 128.42 (2C), 132.4, 
133.1, 139.2 (C-8), 150.5 (C-4), 151.9 and 167.1: linker-CO, 154.3 (C-2), 155.6 (C-6), 165.1 (Bz-CO), 169.2 and $169.4\left(2 \times\right.$ Ac-CO); ESI-MS: $639[\mathrm{M}+\mathrm{H}]^{+}$.

2',3'-Di-O-acetyl-5'-O-((3-(2-azidoacetamido)propyl) carbamoyl)- $N^{2}$-isobutyrylguanosine (94b)

Amorphous foam (108 mg, 76\%), $R_{\mathrm{f}}=0.14$ (EtOAc:MeOH/95:5), $\mathrm{C}_{24} \mathrm{H}_{32} \mathrm{~N}_{10} \mathrm{O}_{10} ;{ }^{1} \mathrm{H}-\mathrm{NMR}$ $(\mathrm{DMSO}) ; \delta[\mathrm{ppm}]=1.14\left(\mathrm{~d}, 6 \mathrm{H}, J=6.5 \mathrm{~Hz}, 2 \times \mathrm{iBu}-\mathrm{CH}_{3}\right), 2.02$ and $2.13(2 \times \mathrm{s}, 2 \times 3 \mathrm{H}, 2 \times \mathrm{OAc})$, $1.59(\mathrm{t}, 2 \mathrm{H}, J=6.5 \mathrm{~Hz}, J=7.0 \mathrm{~Hz})$ and $3.03(\mathrm{dd}, 2 \mathrm{H}, J=2 \times 6.5 \mathrm{~Hz})$ and $3.12(\mathrm{~m}, 3 \mathrm{H})$ and 3.81 (m, 2H): linker $\mathrm{CH}_{2}$ and iBu-CH, $4.33\left(\mathrm{~m}, 2 \mathrm{H}, 5^{\prime}-\mathrm{H}_{2}\right), 5.45\left(\mathrm{~m}, 1 \mathrm{H}, 2^{\prime}-\mathrm{H}\right), 5.78(\mathrm{dd}, 1 \mathrm{H}, J=6.0$ $\left.\mathrm{Hz}, J=7.0 \mathrm{~Hz}, 3^{\prime}-\mathrm{H}\right), 6.09$ (d, 1H, J=7.0 Hz, 4'-H), 7.43 (dd, 1H, J=5.0 Hz, J=5.5 Hz, 1'-H), $8.08(\mathrm{~s}, 2 \mathrm{H}$, linker $2 \times \mathrm{NH}), 8.28(\mathrm{~s}, 1 \mathrm{H}, 8-\mathrm{H}), 11.62(\mathrm{~s}, 1 \mathrm{H}, \mathrm{iBu}-\mathrm{NH}), 12.11(\mathrm{~s}, 1 \mathrm{H}, 1-\mathrm{NH})$; ${ }^{13} \mathrm{C}-\mathrm{NMR}(\mathrm{DMSO}) ; \delta[\mathrm{ppm}]=18.7\left(2 \mathrm{C}, 2 \times \mathrm{iBu}-\mathrm{CH}_{3}\right), 20.0$ and $20.3(2 \times \mathrm{OAc}), 28.8$ and 36.4 and 38.0 and 50.7: linker $\mathrm{CH}_{2}, 34.7$ (iBu-CH), 63.0 (C-5'), $70.6\left(\mathrm{C}^{\prime} 2^{\prime}\right), 72.1$ (C-3'), $80.6(\mathrm{C}-$ 4'), 83.7 (C-1'), 120.1 (C-5), 137.0 (C-8), 148.4 (C-4), 148.7 (C-2), 154.6 (C-6), 155.6 and 167.1: linker-CO, 169.1 and 169.3 (2×Ac-CO), 180.0 (iBu-CO); ESI-MS: $621[\mathrm{M}+\mathrm{H}]^{+}$.

2',3'-Di-O-acetyl-5'-O-((3-(2-azidoacetamido)propyl) carbamoyl)- $N^{4}$-benzoylcytidine (94c)

Amorphous foam (118 mg, 83\%), $R_{\mathrm{f}}=0.24$ (EtOAc), $\mathrm{C}_{26} \mathrm{H}_{30} \mathrm{~N}_{8} \mathrm{O}_{10} ;{ }^{1} \mathrm{H}-\mathrm{NMR}$ (DMSO); $\delta$ $[\mathrm{ppm}]=2.08(\mathrm{~s}, 6 \mathrm{H}, 2 \times \mathrm{OAc}), 1.59(\mathrm{t}, 2 \mathrm{H}, J=6.5 \mathrm{~Hz}, J=7.0 \mathrm{~Hz})$ and $3.04(\mathrm{dd}, 2 \mathrm{H}, J=6.0 \mathrm{~Hz}$, $J=6.5 \mathrm{~Hz})$ and $3.12(\mathrm{dd}, 2 \mathrm{H}, J=2 \times 6.0 \mathrm{~Hz})$ and $3.80(\mathrm{~m}, 3 \mathrm{H}):$ linker $\mathrm{CH}_{2}$ and $2^{\prime}-\mathrm{H}, 4.24(\mathrm{~m}, 1 \mathrm{H}$, 5-H), 4.32 (d, 2H, J=9.0 Hz, 5'-H $), 5.35$ (dd, 1H, J=5.5 Hz, J=6.0 Hz, 3'-H), 5.49 (dd, 1H, $\left.J=4.0 \mathrm{~Hz}, J=5.0 \mathrm{~Hz}, 4^{\prime}-\mathrm{H}\right), 6.02\left(\mathrm{~d}, 1 \mathrm{H}, J=3.5 \mathrm{~Hz}, 1^{\prime}-\mathrm{H}\right), 7.38(\mathrm{~m}, 1 \mathrm{H})$ and $8.07(\mathrm{~m}, 1 \mathrm{H})$ : linker $2 \times \mathrm{NH}, 7.53(\mathrm{dd}, 2 \mathrm{H}, J=2 \times 7.5 \mathrm{~Hz})$ and $7.64(\mathrm{dd}, 1 \mathrm{H}, J=2 \times 7.0 \mathrm{~Hz})$ and $8.02(\mathrm{~d}, 2 \mathrm{H}, 7.5$ $\mathrm{Hz}$ ): benzoyl protons, 8.16 (d, 1H, J=6.0 Hz, 6-H), 11.34 (s, 1H, 4-NH); ${ }^{13} \mathrm{C}-\mathrm{NMR}$ (DMSO); $\delta[\mathrm{ppm}]=20.3(2 \mathrm{C}, 2 \times \mathrm{OAc}), 29.4$ and 36.4 and 38.1 and 50.9: linker $\mathrm{CH}_{2}, 63.0\left(\mathrm{C}-5^{\prime}\right), 69.9$ (C-2'), 72.8 (C-3'), 79.8 (C-4'), 89.5 (C-1'), 97.1 (C-5), 128.5 (2C), 128.6 (2C), 132.9, 133.1, 146.2 (C-6), 154.3 (C-2), 155.7 and 167.2: linker-CO, 163.8 (C-4), 166.2 (Bz-CO), 169.3 and 169.4 (2×Ac-CO); ESI-MS: $615[\mathrm{M}+\mathrm{H}]^{+}$.

2',3'-Di-O-acetyl-5'-O-((3-(2-azidoacetamido)propyl)carbamoyl)uridine (94e)

Amorphous foam (134 mg, 86\%), $R_{\mathrm{f}}=0.54$ (EtOAc), $\mathrm{C}_{19} \mathrm{H}_{25} \mathrm{~N}_{7} \mathrm{O}_{10} ;{ }^{1} \mathrm{H}-\mathrm{NMR}$ (DMSO); $\delta$ $[\mathrm{ppm}]=2.05$ and $2.09(2 \times \mathrm{s}, 2 \times 3 \mathrm{H}, 2 \times \mathrm{OAc}), 1.56(\mathrm{~m}, 2 \mathrm{H})$ and $3.00(\mathrm{~m}, 2 \mathrm{H})$ and $3.09(\mathrm{~m}, 2 \mathrm{H})$ and $3.80(\mathrm{~s}, 2 \mathrm{H})$ : linker $\mathrm{CH}_{2}, 4.24\left(\mathrm{~m}, 1 \mathrm{H}, 4^{\prime}-\mathrm{H}\right), 4.16(\mathrm{~m}, 1 \mathrm{H})$ and $4.27(\mathrm{~m}, 1 \mathrm{H}): 5{ }^{\prime}-\mathrm{H}_{2}, 5.29$ 
$(\mathrm{m}, 1 \mathrm{H})$ and $5.40(\mathrm{~m}, 1 \mathrm{H}): 2 \mathrm{\prime}-\mathrm{H}$ and 3'-H, $5.71(\mathrm{~d}, 1 \mathrm{H}, J=7.5 \mathrm{~Hz}, 6-\mathrm{H}), 5.94\left(\mathrm{~m}, 1 \mathrm{H}, 1^{\prime}-\mathrm{H}\right)$, $7.34(\mathrm{~m}, 1 \mathrm{H})$ and $8.07(\mathrm{~m}, 1 \mathrm{H})$ : linker $2 \times \mathrm{NH}, 7.70(\mathrm{~d}, 1 \mathrm{H}, J=7.5 \mathrm{~Hz}, 5-\mathrm{H}), 11.45(\mathrm{~s}, 1 \mathrm{H}, 3-$ $\mathrm{NH}) ;{ }^{13} \mathrm{C}-\mathrm{NMR}(\mathrm{DMSO}) ; \delta[\mathrm{ppm}]=20.1$ and $20.2(2 \times \mathrm{OAc}), 29.2$ and 36.3 and 38.0 and 50.7: linker $\mathrm{CH}_{2}, 63.0\left(\mathrm{C}^{\prime} 5^{\prime}\right), 69.8\left(\mathrm{C}^{2} 2^{\prime}\right), 71.7\left(\mathrm{C}^{\prime} 3^{\prime}\right), 79.5$ (C-4'), $87.0\left(\mathrm{C}-1^{\prime}\right), 102.5(\mathrm{C}-5), 141.0$ (C-6), 150.3 (C-2), 155.6 and 167.1: linker-CO, 162.8 (C-4), 169.2 and 169.3 (2×Ac-CO); ESI-MS: $512[\mathrm{M}+\mathrm{H}]^{+}$.

5'-O-((3-(2-Azidoacetamido)propyl)carbamoyl)-2'-deoxyadenosine (95a)

Amorphous foam (70 mg, 81\%), $R_{\mathrm{f}}=0.26$ (EtOAc:MeOH/8:2), $\mathrm{C}_{15} \mathrm{H}_{20} \mathrm{~N}_{10} \mathrm{O}_{5} ;{ }^{1} \mathrm{H}-\mathrm{NMR}$ $(\mathrm{DMSO}) ; \delta[\mathrm{ppm}]=1.56(\mathrm{~m}, 2 \mathrm{H})$ and $3.00(\mathrm{~m}, 2 \mathrm{H})$ and $3.11(\mathrm{~m}, 2 \mathrm{H})$ and $3.82(\mathrm{~s}, 2 \mathrm{H})$ : linker $4 \times \mathrm{CH}_{2}, 2.58$ (d, 2H, J=11.0 Hz, 2'- $\left.\mathrm{H}_{2}\right), 4.17$ (dd, 1H, J=7.0 Hz, J=10.0 Hz, 3'-H), 4.20 (m, $\left.2 \mathrm{H}, 5{ }^{\prime}-\mathrm{H}_{2}\right), 4.82\left(\mathrm{~s}, 1 \mathrm{H}, 4{ }^{\prime}-\mathrm{H}\right), 5.91\left(\mathrm{~m}, 1 \mathrm{H}, 1^{\prime}-\mathrm{H}\right), 7.25(\mathrm{~m}, 1 \mathrm{H})$ and $8.29(\mathrm{~m}, 1 \mathrm{H})$ : linker $2 \times \mathrm{NH}, 8.64(\mathrm{~s}, 1 \mathrm{H})$ and $8.75(\mathrm{~s}, 1 \mathrm{H}): 2-\mathrm{H}$ and $8-\mathrm{H}, 10.28(\mathrm{~s}, 1 \mathrm{H}, 6-\mathrm{NH}) ;{ }^{13} \mathrm{C}-\mathrm{NMR}$ (DMSO); $\delta[\mathrm{ppm}]=28.7$ and 37.2 and 39.0 and 53.7: linker $4 \times \mathrm{CH}_{2}, 40.0\left(\mathrm{C}-2^{\prime}\right), 59.7$ (C-5'), $71.0\left(\mathrm{C}-3^{\prime}\right)$, 83.4 (C-4'), 86.6 (C-1'), 119.6 (C-5), 143.5 (C-8), 152.6 (C-4), 155.7 (C-2), 156.2 (C-6), 156.0 and 162.4: 2×linker-CO; ESI-MS: $435[\mathrm{M}+\mathrm{H}]^{+}$.

5'-O-((3-(2-Azidoacetamido)propyl)carbamoyl)-2'-deoxyguanosine (95b)

Amorphous foam (74 mg, 82\%), $R_{\mathrm{f}}=0.34$ (EtOAc:MeOH/7:3), $\mathrm{C}_{15} \mathrm{H}_{20} \mathrm{~N}_{10} \mathrm{O}_{6} ;{ }^{1} \mathrm{H}-\mathrm{NMR}$ $(\mathrm{DMSO}) ; \delta[\mathrm{ppm}]=1.57(\mathrm{t}, 2 \mathrm{H}, J=7.0 \mathrm{~Hz})$ and $3.00(\mathrm{~m}, 3 \mathrm{H})$ and $3.11(\mathrm{~m}, 2 \mathrm{H})$ and $3.81(\mathrm{~s}$, $2 \mathrm{H})$ : linker $4 \times \mathrm{CH}_{2}$ and $3^{\prime}-\mathrm{H}, 2.21(\mathrm{~m}, 1 \mathrm{H})$ and $2.60(\mathrm{~m}, 1 \mathrm{H}): 2^{\prime}-\mathrm{H}_{2}, 4.04(\mathrm{dd}, 1 \mathrm{H}, \mathrm{dd}, 1 \mathrm{H}$, $J=4.5 \mathrm{~Hz}, J=11.5 \mathrm{~Hz})$ and $4.20(\mathrm{dd}, 1 \mathrm{H}, \mathrm{dd}, 1 \mathrm{H}, J=3.5 \mathrm{~Hz}, J=11.5 \mathrm{~Hz}): 5 '-\mathrm{H}_{2}, 6.11(\mathrm{t}, 1 \mathrm{H}$, $\left.J=7.5 \mathrm{~Hz}, 4^{\prime}-\mathrm{H}\right), 6.49\left(\mathrm{~s}, 1 \mathrm{H}, 1^{\prime}-\mathrm{H}\right), 7.28(\mathrm{t}, 1 \mathrm{H}, J=5.5 \mathrm{~Hz})$ and $7.87(\mathrm{~m}, 1 \mathrm{H})$ : linker $2 \times \mathrm{NH}$, 8.10 (s, 1H, 8-H), 9.65 (s, 1H, 1-NH); ${ }^{13} \mathrm{C}-\mathrm{NMR}$ (DMSO); $\delta$ [ppm]=29.3 and 36.3 and 37.9 and 50.7: linker $4 \times \mathrm{CH}_{2}, 35.8\left(\mathrm{C}^{2} 2^{\prime}\right), 64.1\left(\mathrm{C}^{\prime} 5^{\prime}\right), 70.8\left(\mathrm{C}-3^{\prime}\right), 82.3\left(\mathrm{C}-4^{\prime}\right), 84.5\left(\mathrm{C}-1^{\prime}\right), 116.6$ (C-5), 135.1 (C-8), 151.0 (C-4), 153.7 (C-2), 155.9 and 167.1: 2×linker-CO, 156.7 (C-6); ESIMS: $451[\mathrm{M}+\mathrm{H}]^{+}$.

5'-O-((3-(2-Azidoacetamido)propyl)carbamoyl)-2'-deoxycytidine (95c)

Amorphous foam (66 mg, 80\%), $R_{\mathrm{f}}=0.25$ (EtOAc:MeOH/7:3), $\mathrm{C}_{14} \mathrm{H}_{20} \mathrm{~N}_{8} \mathrm{O}_{6} ;{ }^{1} \mathrm{H}-\mathrm{NMR}$ $(\mathrm{DMSO}) ; \delta[\mathrm{ppm}]=1.58(\mathrm{~m}, 2 \mathrm{H})$ and $3.01(\mathrm{~m}, 3 \mathrm{H})$ and $3.11(\mathrm{~m}, 3 \mathrm{H})$ and $3.82(\mathrm{~s}, 2 \mathrm{H})$ : linker $4 \times \mathrm{CH}_{2}$ and $5^{\prime}-\mathrm{H}_{2}, 2.40\left(\mathrm{~m}, 2 \mathrm{H}, 2^{\prime}-\mathrm{H}_{2}\right), 4.29(\mathrm{~m}, 2 \mathrm{H})$ and $4.36(\mathrm{~m}, 2 \mathrm{H}): 3^{\prime}-\mathrm{H}$ and 4' $-\mathrm{H}, 4.82(\mathrm{~s}$, $1 \mathrm{H}, 5-\mathrm{H}), 6.32\left(\mathrm{~s}, 1 \mathrm{H}, 1^{\prime}-\mathrm{H}\right), 7.50(\mathrm{~m}, 1 \mathrm{H})$ and $8.35(\mathrm{~m}, 1 \mathrm{H})$ : linker $2 \times \mathrm{NH}, 8.35(\mathrm{~d}, 1 \mathrm{H}, J=6.0$ $\mathrm{Hz}, 6-\mathrm{NH}), 8.43$ (s, 1H, 4-H); ${ }^{13} \mathrm{C}-\mathrm{NMR}$ (DMSO); $\delta[\mathrm{ppm}]=29.4$ and 37.5 and 38.9 and 49.3: 
linker $4 \times \mathrm{CH}_{2}, 35.3\left(\mathrm{C}-2^{\prime}\right), 62.9$ (C-5'), $71.5\left(\mathrm{C}-3^{\prime}\right), 80.4\left(\mathrm{C}-4^{\prime}\right), 87.8$ (C-1'), $94.1(\mathrm{C}-5), 143.7$ (C-6), 150.1 (C-2), 156.7 and 166.8: 2×linker-CO, 162.7 (C-4); ESI-MS: $411[\mathrm{M}+\mathrm{H}]^{+}$.

\section{5'-O-((3-(2-Azidoacetamido)propyl)carbamoyl)-thymidine (95d)}

Amorphous foam (74 mg, 87\%), $R_{\mathrm{f}}=0.32$ (EtOAc:MeOH/9:1), $\mathrm{C}_{15} \mathrm{H}_{21} \mathrm{~N}_{7} \mathrm{O}_{7} ;{ }^{1} \mathrm{H}-\mathrm{NMR}$ (DMSO); $\delta[\mathrm{ppm}]=1.78\left(\mathrm{~s}, 3 \mathrm{H}, 5-\mathrm{CH}_{3}\right), 1.58(\mathrm{dd}, 2 \mathrm{H}, J=7.0 \mathrm{~Hz}, J=14.0 \mathrm{~Hz})$ and $3.00(\mathrm{~m}, 2 \mathrm{H})$ and $3.10(\mathrm{~m}, 2 \mathrm{H})$ and $3.79(\mathrm{~s}, 2 \mathrm{H})$ : linker $4 \times \mathrm{CH}_{2}, 2.08(\mathrm{~m}, 1 \mathrm{H})$ and $2.02(\mathrm{~m}, 1 \mathrm{H}): 2{ }^{\prime}-\mathrm{H}_{2}, 4.01$ $(\mathrm{d}, 1 \mathrm{H}, J=11.0 \mathrm{~Hz})$ and $4.02(\mathrm{~d}, 1 \mathrm{H}, J=11.0 \mathrm{~Hz}): 5^{\prime}-\mathrm{H}_{2}, 4.18\left(\mathrm{~m}, 1 \mathrm{H}, 4^{\prime}-\mathrm{H}\right), 5.22(\mathrm{~d}, 1 \mathrm{H}, J=2.5$ $\left.\mathrm{Hz}, 3^{\prime}-\mathrm{H}\right), 6.18\left(\mathrm{~m}, 1 \mathrm{H}, 1^{\prime}-\mathrm{H}\right), 7.43(\mathrm{~s}, 1 \mathrm{H}, 6-\mathrm{H}), 7.30(\mathrm{t}, 1 \mathrm{H}, J=5.5 \mathrm{~Hz})$ and 8.09 (m, 1H): linker $2 \times \mathrm{NH}, 10.73(\mathrm{~s}, 1 \mathrm{H}, 3-\mathrm{NH}) ;{ }^{13} \mathrm{C}-\mathrm{NMR}$ (DMSO); $\delta[\mathrm{ppm}]=12.1\left(5-\mathrm{CH}_{3}\right), 29.3$ and 38.0 and 38.6 and 50.8: linker $4 \times \mathrm{CH}_{2}, 36.3\left(\mathrm{C}-2^{\prime}\right), 64.1\left(\mathrm{C}-5^{\prime}\right), 70.6\left(\mathrm{C}-3^{\prime}\right), 83.8\left(\mathrm{C}-4^{\prime}\right), 84.2\left(\mathrm{C}-1^{\prime}\right)$, 109.6 (C-5), 135.8 (C-6), 150.4 (C-2), 155.9 and 167.1: 2×linker-CO, 163.4 (C-4); ESI-MS: $426[\mathrm{M}+\mathrm{H}]^{+}$.

5'-O-((3-(2-Azidoacetamido)propyl)carbamoyl)-adenosine (96a)

Amorphous foam (75 mg, 83\%), $R_{\mathrm{f}}=0.26$ (EtOAc:MeOH/8:2), $\mathrm{C}_{15} \mathrm{H}_{20} \mathrm{~N}_{10} \mathrm{O}_{6} ;{ }^{1} \mathrm{H}-\mathrm{NMR}$ $(\mathrm{DMSO}) ; \delta[\mathrm{ppm}]=1.57(\mathrm{t}, 2 \mathrm{H}, J=6.0 \mathrm{~Hz})$ and $3.01(\mathrm{~m}, 2 \mathrm{H})$ and $3.09(\mathrm{~d}, 2 \mathrm{H}, J=5.5 \mathrm{~Hz})$ and 3.79 (s, 2H): linker $4 \times \mathrm{CH}_{2}, 4.32\left(\mathrm{~d}, 2 \mathrm{H}, J=5.0 \mathrm{~Hz}, 5^{\prime}-\mathrm{H}_{2}\right), 4.42(\mathrm{dd}, 1 \mathrm{H}, J=2.5 \mathrm{~Hz}, J=5.0 \mathrm{~Hz}$, 4'-H), $5.60(\mathrm{~m}, 2 \mathrm{H}): 2^{\prime}-\mathrm{H}$ and 3'-H, $6.02\left(\mathrm{~d}, 1 \mathrm{H}, J=4.0 \mathrm{~Hz}, 1^{\prime}-\mathrm{H}\right), 7.55(\mathrm{t}, 1 \mathrm{H}, J=6.0 \mathrm{~Hz})$ and $8.06(\mathrm{~m}, 1 \mathrm{H})$ : linker $2 \times \mathrm{NH}, 8.22(\mathrm{~s}, 1 \mathrm{H})$ and $8.76(\mathrm{~s}, 1 \mathrm{H}): 2-\mathrm{H}$ and $8-\mathrm{H}, 10.21(\mathrm{~s}, 1 \mathrm{H}, 6-\mathrm{NH})$; ${ }^{13} \mathrm{C}-\mathrm{NMR}(\mathrm{DMSO}) ; \delta[\mathrm{ppm}]=28.7$ and 36.0 and 38.0 and 51.2: linker $4 \times \mathrm{CH}_{2}, 61.9\left(\mathrm{C}-5^{\prime}\right)$, 71.5 (C-2'), 72.4 (C-3'), 84.8 (C-4'), 87.3 (C-1'), 125.0 (C-5), 138.4 (C-8), 151.5 (C-4), 153.7 and 166.8: $2 \times$ linker-CO, $155.3(\mathrm{C}-2), 157.6(\mathrm{C}-6)$; ESI-MS: $451[\mathrm{M}+\mathrm{H}]^{+}$.

5'-O-((3-(2-Azidoacetamido)propyl)carbamoyl)-guanosine (96b)

Amorphous foam (80 mg, 86\%), $R_{\mathrm{f}}=0.39$ (EtOAc:MeOH/8:2), $\mathrm{C}_{15} \mathrm{H}_{20} \mathrm{~N}_{10} \mathrm{O}_{7} ;{ }^{1} \mathrm{H}-\mathrm{NMR}$ $(\mathrm{DMSO}) ; \delta[\mathrm{ppm}]=1.59(\mathrm{dd}, 2 \mathrm{H}, J=7.0 \mathrm{~Hz}, J=14.0 \mathrm{~Hz})$ and $3.01(\mathrm{~m}, 2 \mathrm{H})$ and $3.12(\mathrm{~m}, 2 \mathrm{H})$ and $4.00(\mathrm{~s}, 2 \mathrm{H})$ : linker $4 \times \mathrm{CH}_{2}, 4.22(\mathrm{dd}, 1 \mathrm{H}, J=3.0 \mathrm{~Hz}, J=12.0 \mathrm{~Hz}) 4.49(\mathrm{dd}, 1 \mathrm{H}, J=6.0 \mathrm{~Hz}$, $J=11.5 \mathrm{~Hz}) 5^{\prime}-\mathrm{H}_{2}, 5.29$ (d, 1H, J=4.5 Hz, 2'-H), 5.48 (d, 1H, J=6.0 Hz, 3'-H), 5.71 (d, 1H, $\left.J=6.0 \mathrm{~Hz}, 4^{\prime}-\mathrm{H}\right), 6.48\left(\mathrm{~m}, 1 \mathrm{H}, 1^{\prime}-\mathrm{H}\right), 7.32(\mathrm{t}, 1 \mathrm{H}, J=6.0 \mathrm{~Hz})$ and $8.09(\mathrm{~m}, 1 \mathrm{H})$ : linker $2 \times \mathrm{NH}$, 7.89 (s, 1H, 8-H), 10.36 (s, 1H, 1-NH); ${ }^{13} \mathrm{C}-\mathrm{NMR}$ (DMSO); $\delta$ [ppm]=28.8 and 36.4 and 37.9 and 50.7: linker $4 \times \mathrm{CH}_{2}, 63.9\left(\mathrm{C}^{\prime} 5^{\prime}\right), 70.5\left(\mathrm{C}-2^{\prime}\right), 72.8\left(\mathrm{C}-3^{\prime}\right), 82.2\left(\mathrm{C}-4^{\prime}\right), 85.9\left(\mathrm{C}-1^{\prime}\right), 116.5$ 
(C-5), 136.4 (C-8), 150.6 (C-4), 153.6 (C-2), 156.6 (C-6), 155.8 and 167.1: 2×linker-CO; ESIMS: $467[\mathrm{M}+\mathrm{H}]^{+}$.

\section{5'-O-((3-(2-Azidoacetamido)propyl)carbamoyl)-cytidine (96c)}

Amorphous foam (66 mg, 78\%), $R_{\mathrm{f}}=0.19$ (EtOAc:MeOH/7:3), $\mathrm{C}_{14} \mathrm{H}_{20} \mathrm{~N}_{8} \mathrm{O}_{7} ;{ }^{1} \mathrm{H}-\mathrm{NMR}$ (DMSO); $\delta[\mathrm{ppm}]=1.59(\mathrm{dd}, 2 \mathrm{H}, J=6.5 \mathrm{~Hz}, J=13.5 \mathrm{~Hz})$ and $3.04(\mathrm{~m}, 2 \mathrm{H})$ and $3.12(\mathrm{~m}, 2 \mathrm{H})$ and $3.80(\mathrm{~s}, 2 \mathrm{H})$ : linker $4 \times \mathrm{CH}_{2}, 2.36(\mathrm{~m}, 2 \mathrm{H}, 2 \mathrm{\prime}-\mathrm{H}), 4.20(\mathrm{~m}, 1 \mathrm{H}, 5-\mathrm{H}), 4.34\left(\mathrm{~m}, 2 \mathrm{H}, 5^{\prime}-\mathrm{H}_{2}\right)$, $4.42\left(\mathrm{~m}, 1 \mathrm{H}, 3^{\prime}-\mathrm{H}\right), 4.80\left(\mathrm{~m}, 1 \mathrm{H}, 4^{\prime}-\mathrm{H}\right), 6.32$ (d, 1H, J=3.5 Hz, 1'-H), $7.36(\mathrm{~m}, 1 \mathrm{H})$ and 8.05 (m, 1H): linker $2 \times \mathrm{NH}, 8.10(\mathrm{~d}, 1 \mathrm{H}, J=6.0 \mathrm{~Hz}, 6-\mathrm{H}), 9.84(\mathrm{~s}, 1 \mathrm{H}, 4-\mathrm{NH}) ;{ }^{13} \mathrm{C}-\mathrm{NMR}$ (DMSO); $\delta$ $[\mathrm{ppm}]=29.5$ and 36.3 and 38.0 and 51.9: linker $4 \times \mathrm{CH}_{2}, 62.7\left(\mathrm{C}-5^{\prime}\right), 69.8\left(\mathrm{C}-2^{\prime}\right), 71.8$ (C-3'), 78.4 (C-4'), 89.0 (C-1'), 96.3 (C-5), 145.1 (C-6), 155.3 (C-2), 155.7 and 167.1: 2×linker-CO, 162.1 (C-4); ESI-MS: $427[\mathrm{M}+\mathrm{H}]^{+}$.

5'-O-((3-(2-Azidoacetamido)propyl)carbamoyl)-uridine (96e)

Amorphous foam (76 mg, 89\%), $R_{\mathrm{f}}=0.62$ (EtOAc:MeOH/8:2), $\mathrm{C}_{14} \mathrm{H}_{19} \mathrm{~N}_{7} \mathrm{O}_{8} ;{ }^{1} \mathrm{H}-\mathrm{NMR}$ (DMSO); $\delta[\mathrm{ppm}]=1.56(\mathrm{t}, 2 \mathrm{H}, J=7.0 \mathrm{~Hz}$ ) and $3.01(\mathrm{~m}, 2 \mathrm{H})$ and $3.11(\mathrm{~m}, 2 \mathrm{H})$ and $3.80(\mathrm{~s}$, $2 \mathrm{H})$ : linker $4 \times \mathrm{CH}_{2}, 3.91\left(\mathrm{~m}, 1 \mathrm{H}, 4{ }^{\prime}-\mathrm{H}\right), 3.96\left(\mathrm{~m}, 1 \mathrm{H}, 2^{\prime}-\mathrm{H}\right) 4.08(\mathrm{~m}, 2 \mathrm{H}): 5 '-\mathrm{H}_{2}, 4.21$ (m, 1H, 3'-H), 5.65 (d, 1H, J=8.0 Hz, 6-H), 5.79 (d, 1H, J=5.5 Hz, 1'-H), 7.30 (t, 1H, J=4.5 Hz) and $8.09(\mathrm{~m}, 1 \mathrm{H})$ : linker $2 \times \mathrm{NH}, 7.61(\mathrm{~d}, 1 \mathrm{H}, J=8.0 \mathrm{~Hz}, 5-\mathrm{H}), 11.12(\mathrm{~s}, 1 \mathrm{H}, 11.45) ;{ }^{13} \mathrm{C}-\mathrm{NMR}$ $(\mathrm{DMSO}) ; \delta[\mathrm{ppm}]=29.3$ and 36.3 and 38.0 and 50.8: linker $4 \times \mathrm{CH}_{2}, 63.7\left(\mathrm{C}-5^{\prime}\right), 69.9\left(\mathrm{C}-2^{\prime}\right)$, 72.5 (C-3'), 81.8 (C-4'), 87.8 (C-1'), 102.1 (C-5), 140.6 (C-6), 150.7 (C-2), 155.8 and 167.0: 2×linker-CO, $163.0(\mathrm{C}-4)$; ESI-MS: $428[\mathrm{M}+\mathrm{H}]^{+}$.

$N$-(3-aminopropyl)-2-propynamide (100)

Oil (1.5 g, 74\%), $\mathrm{C}_{6} \mathrm{H}_{10} \mathrm{~N}_{2} \mathrm{O} ;{ }^{1} \mathrm{H}$ NMR $\left(\mathrm{CD}_{3} \mathrm{CN}\right) ; \delta[\mathrm{ppm}]=7.44(\mathrm{~s}, 1 \mathrm{H}, \mathrm{CON} \underline{\mathrm{H}}), 3.33(\mathrm{~m}, 3 \mathrm{H}$, $\mathrm{CONHC}_{2} \underline{\mathrm{H}}_{2}$ and $\underline{\mathrm{C}}$ ), 2.95 (ddt, $\left.2 \mathrm{H}, J=13.0 \mathrm{~Hz}, J=7.0 \mathrm{~Hz}, J=6.0 \mathrm{~Hz}, \underline{\mathrm{C}}_{2} \mathrm{NH}_{2}\right), 1.89$ (m, 2H, $\left.\mathrm{CH}_{2} \underline{\mathrm{C}}_{2} \mathrm{CH}_{2}\right) ;{ }^{13} \mathrm{C}-\mathrm{NMR}\left(\mathrm{CD}_{3} \mathrm{CN}\right) ; \delta[\mathrm{ppm}]=27.5,36.6,38.3: 3 \times \mathrm{CH}_{2}, 75.7(\mathrm{C} \equiv \underline{\mathrm{CH}}), 77.5$ $(\underline{\mathrm{C}} \equiv \mathrm{CH}), 115.4\left(\underline{\mathrm{CF}}_{3} \mathrm{COOH}\right), 154.5(\mathrm{CO}), 160.2,160.6$ : $\left(\mathrm{CF}_{3} \underline{\mathrm{COOH}}\right)$; ESI-MS: $127[\mathrm{M}+\mathrm{H}]^{+}$ 3'-O-Acetyl-5'-O-((3-propiolamidopropyl) carbamoyl)- $N^{6}$-benzoyl-2'-deoxyadenosine (105a) Oil (200 mg, 71\%), $R_{\mathrm{f}}=0.35$ (EtOAc:MeOH/9:1), $\mathrm{C}_{26} \mathrm{H}_{27} \mathrm{~N}_{7} \mathrm{O}_{7} ;{ }^{1} \mathrm{H}-\mathrm{NMR} \quad\left(\mathrm{CD}_{3} \mathrm{CN}\right) ; \delta$ $[\mathrm{ppm}]=1.57(\mathrm{p}, 2 \mathrm{H}, J=7.0 \mathrm{~Hz})$ and $3.03(\mathrm{t}, 2 \mathrm{H}, J=7.0 \mathrm{~Hz})$ and $3.14(\mathrm{~m}, 2 \mathrm{H}): 3 \times$ linker $\mathrm{CH}_{2}$, 2.08 (s, 3H, OAc), $2.63(\mathrm{ddd}, 1 \mathrm{H}, J=14.5 \mathrm{~Hz}, J=6.0 \mathrm{~Hz}, J=3.0 \mathrm{~Hz}$ ) and 2.93 (ddd, 1H, $J=14.0$ $\mathrm{Hz}, J=8.0 \mathrm{~Hz}, J=6.5 \mathrm{~Hz}): 2^{\prime}-\mathrm{H}_{2}, 3.23(\mathrm{~s}, 1 \mathrm{H}, \mathrm{C} \equiv \underline{\mathrm{CH}}), 4.21\left(\mathrm{dd}, 1 \mathrm{H}, J=12.5 \mathrm{~Hz}, J=5.0 \mathrm{~Hz}, 3^{\prime}-\right.$ 
H), $4.35\left(\mathrm{~m}, 2 \mathrm{H}, 5 '-\mathrm{H}_{2}\right), 5.40\left(\mathrm{dt}, 1 \mathrm{H}, J=6.0 \mathrm{~Hz}, J=2.5 \mathrm{~Hz}, 4{ }^{\prime}-\mathrm{H}\right), 6.47$ (dd, 1H, J=7.5 Hz, $\left.J=6.0 \mathrm{~Hz}, 1^{\prime}-\mathrm{H}\right), 7.56(\mathrm{~m}, 2 \mathrm{H})$ and $7.66(\mathrm{~m}, 1 \mathrm{H})$ and $8.04(\mathrm{~d}, 2 \mathrm{H}, J=7.5 \mathrm{~Hz})$ : benzoyl protons, $7.30(\mathrm{t}, 1 \mathrm{H}, J=5.5 \mathrm{~Hz})$ and $8.74(\mathrm{t}, 1 \mathrm{H}, J=5.5 \mathrm{~Hz}): 2 \times$ linker-NH, $8.42(\mathrm{~s}, 1 \mathrm{H})$ and $8.68(\mathrm{~s}, 1 \mathrm{H})$ : 2-H and 8-H, 9.63 (s, 1H, 6-NH). ${ }^{13} \mathrm{C}-\mathrm{NMR}\left(\mathrm{CD}_{3} \mathrm{CN}\right) ; \delta[\mathrm{ppm}]=21.2$ (OAc), 29.7 and 37.9 and 38.8: $3 \times$ linker $\mathrm{CH}_{2}, 37.6\left(\mathrm{C}^{\prime} 2^{\prime}\right), 64.9\left(\mathrm{C}^{\prime} 5^{\prime}\right), 75.1(\mathrm{C} \equiv \underline{\mathrm{CH}}), 75.4\left(\mathrm{C}-3{ }^{\prime}\right), 77.9(\underline{\mathrm{C}} \equiv \mathrm{CH}), 84.0$ (C-4'), 85.4 (C-1'), 124.5 (C-5), 129.3 (2C), 129.6 (2C), 133.8, 134.5, 143.3 (C-8), 150.5 (C4), 152.6 (C-2), 152.7 (C-6), 153.5 and 157.5: 2×linker-CO, 167.2 (Bz-CO), 172.0 (Ac-CO). ESI-MS: $556[\mathrm{M}+\mathrm{Li}]^{+}$.

3'-O-Acetyl-5'-O-((3-azidopropyl)carbamoyl)- $N^{6}$-benzoyl-2'-deoxyadenosine (106a)

Oil (212 mg, 81\%), $R_{\mathrm{f}}=0.57$ (EtOAc:MeOH/9:1), $\mathrm{C}_{23} \mathrm{H}_{25} \mathrm{~N}_{9} \mathrm{O}_{6} ;{ }^{1} \mathrm{H}-\mathrm{NMR} \quad\left(\mathrm{CD}_{3} \mathrm{CN}\right) ; \delta$ $[\mathrm{ppm}]=1.65(\mathrm{p}, 2 \mathrm{H}, J=6.5 \mathrm{~Hz})$ and $3.10(\mathrm{q}, 2 \mathrm{H}, J=6.5 \mathrm{~Hz})$ and $3.29(\mathrm{t}, 2 \mathrm{H}, J=6.5 \mathrm{~Hz})$ : linker $3 \times \mathrm{CH}_{2}, 2.07$ (s, 3H, OAc), $2.59(\mathrm{~m}, 1 \mathrm{H})$ and 2.95 (m, 1H): 2'- $\mathrm{H}_{2}, 4.22$ (dd, 1H, J=12.5 Hz, $J=5.5 \mathrm{~Hz})$ and $4.32(\mathrm{~m}, 1 \mathrm{H}): 5{ }^{\prime}-\mathrm{H}_{2}, 5.40\left(\mathrm{dt}, 1 \mathrm{H}, J=6.0 \mathrm{~Hz}, J=2.5 \mathrm{~Hz}, 4^{\prime}-\mathrm{H}\right), 5.86(\mathrm{dd}, 1 \mathrm{H}$, $\left.J=2 \times 6.0 \mathrm{~Hz}, 3^{\prime}-\mathrm{H}\right), 6.46\left(\mathrm{dd}, 1 \mathrm{H}, J=7.5 \mathrm{~Hz}, J=6.0 \mathrm{~Hz}, 1^{\prime}-\mathrm{H}\right), 7.50(\mathrm{t}, J=7.5 \mathrm{~Hz}, 2 \mathrm{H})$ and 7.65 $(\mathrm{m}, 1 \mathrm{H})$ and $7.98(\mathrm{~d}, J=7.5 \mathrm{~Hz}, 2 \mathrm{H})$ : benzoyl protons, $7.33(\mathrm{~s}, 1 \mathrm{H}$, linker-NH), $8.33(\mathrm{~s}, 1 \mathrm{H})$ and $8.64(\mathrm{~s}, 1 \mathrm{H}): 2-\mathrm{H}$ and $8-\mathrm{H}, 9.53(\mathrm{~s}, 1 \mathrm{H}, 6-\mathrm{NH}) .{ }^{13} \mathrm{C}-\mathrm{NMR}\left(\mathrm{CD}_{3} \mathrm{CN}\right) ; \delta[\mathrm{ppm}]=21.2(\mathrm{OAc})$, 29.7 and 38.9 and 49.6: linker $3 \times \mathrm{CH}_{2}, 37.8\left(\mathrm{C}^{\prime} \mathbf{2}^{\prime}\right), 64.8\left(\mathrm{C}-5^{\prime}\right), 75.3\left(\mathrm{C}-3^{\prime}\right), 83.9\left(\mathrm{C}-4^{\prime}\right), 85.1$ (C-1'), 125.6 (C-5), 129.1 (2C), 129.6 (2C), 133.5, 134.7, 143.0 (C-8), 150.8 (C-4), 151.3 (C2), 152.7 (C-6), 157.0 (linker-CO), 166.3 (Bz-CO), 171.3 (Ac-CO). ESI-MS: 530 [M+Li] ${ }^{+}$.

3'-O-Acetyl-5'-O-((prop-2-yn-1-yl) carbamoyl)- $N^{6}$-benzoyl-2'-deoxyadenosine (107a)

Oil (186 mg, 78\%), $R_{\mathrm{f}}=0.54$ (EtOAc:MeOH/9:1), $\mathrm{C}_{23} \mathrm{H}_{22} \mathrm{~N}_{6} \mathrm{O}_{6} ;{ }^{1} \mathrm{H}-\mathrm{NMR}\left(\mathrm{CD}_{3} \mathrm{CN}\right) ; \delta$ $[\mathrm{ppm}]=2.07(\mathrm{~s}, 3 \mathrm{H}, \mathrm{OAc}), 2.43(\mathrm{t}, 1 \mathrm{H}, J=2.5 \mathrm{~Hz}, \mathrm{C} \equiv \underline{\mathrm{CH}}), 2.63(\mathrm{~m}, 1 \mathrm{H})$ and $2.95(\mathrm{dt}, 1 \mathrm{H}$, $J=14.0 \mathrm{~Hz}, J=7.0 \mathrm{~Hz}): 2^{\prime}-\mathrm{H}_{2}, 3.83\left(\mathrm{dd}, 2 \mathrm{H}, J=6.0 \mathrm{~Hz}, J=2.5 \mathrm{~Hz}\right.$, linker $\left.\mathrm{CH}_{2}\right), 4.37$ (m, 2H, 5'$\mathrm{H}_{2}$ ), 5.40 (dt, 1H, J=6.0 Hz, J=2.5 Hz, 4'-H), 6.22 (d, 1H, J=6.5 Hz, 3'-H), 6.44 (t, 1H, J=7.0 $\left.\mathrm{Hz}, 1^{\prime}-\mathrm{H}\right), 7.53(\mathrm{~m}, 2 \mathrm{H})$ and $7.63(\mathrm{~m}, 1 \mathrm{H})$ and $7.97(\mathrm{~d}, 2 \mathrm{H}, J=7.5 \mathrm{~Hz})$ : benzoyl protons, 7.31 $\left(\mathrm{s}, 1 \mathrm{H}\right.$, linker-NH), $8.31(\mathrm{~s}, 1 \mathrm{H})$ and $8.65(\mathrm{~s}, 1 \mathrm{H}): 2-\mathrm{H}$ and $8-\mathrm{H}, 9.62(\mathrm{~s}, 1 \mathrm{H}, 6-\mathrm{NH}) .{ }^{13} \mathrm{C}-\mathrm{NMR}$ $\left(\mathrm{CD}_{3} \mathrm{CN}\right) ; \delta[\mathrm{ppm}]=21.2(\mathrm{OAc}), 31.0\left(\right.$ linker $\left.\mathrm{CH}_{2}\right), 37.7\left(\mathrm{C}-2^{\prime}\right), 65.2\left(\mathrm{C}-5^{\prime}\right), 72.0(\mathrm{C} \equiv \underline{\mathrm{CH}}), 75.3$ (C-3'), $81.4(\underline{\mathrm{C}} \equiv \mathrm{CH}), 83.7$ (C-4'), 85.1 (C-1'), 125.5 (C-5), 129.1 (2C), 129.5 (2C), 133.5, 134.1, 143.1 (C-8), 150.8 (C-4), 151.2 (C-2), 152.3 (C-6), 156.7 (linker-CO), 166.4 (Bz-CO), 171.3 (Ac-CO). ESI-MS: $485[\mathrm{M}+\mathrm{Li}]^{+}$. 
3'-O-Acetyl-5'-O-((8-azido-3,6-dioxaoctyl) carbamoyl)- $N^{6}$-benzoyl-2'-deoxyadenosine (108a) Oil (224 mg, 75\%), $R_{\mathrm{f}}=0.48$ (EtOAc:MeOH/9:1), $\mathrm{C}_{26} \mathrm{H}_{31} \mathrm{~N}_{9} \mathrm{O}_{8} ;{ }^{1} \mathrm{H}-\mathrm{NMR} \quad\left(\mathrm{CD}_{3} \mathrm{CN}\right) ; \delta$ $[\mathrm{ppm}]=2.07(\mathrm{~s}, 3 \mathrm{H}, \mathrm{OAc}), 2.58(\mathrm{~m}, 1 \mathrm{H})$ and $2.96(\mathrm{~m}, 1 \mathrm{H}): 2^{\prime}-\mathrm{H}_{2}, 3.25(\mathrm{~m}, 2 \mathrm{H})$ and $3.30(\mathrm{t}, 2 \mathrm{H}$, $J=5.0 \mathrm{~Hz})$ and $3.44(\mathrm{t}, 2 \mathrm{H}, J=5.5 \mathrm{~Hz}), 3.61(\mathrm{~m}, 6 \mathrm{H})$ : linker $6 \times \mathrm{CH}_{2}, 4.34\left(\mathrm{~m}, 2 \mathrm{H}, 5^{\prime}-\mathrm{H}_{2}\right), 5.40$ (dt, 1H, J=6.0 Hz, J=2.5 Hz, 4'-H), 5.90 (dd, 1H, $\left.J=2 \times 6.0 \mathrm{~Hz}, 3^{\prime}-\mathrm{H}\right), 6.46$ (dd, 1H, $J=7.5 \mathrm{~Hz}$, $\left.J=6.0 \mathrm{~Hz}, 1^{\prime}-\mathrm{H}\right), 7.50(\mathrm{dd}, 2 \mathrm{H}, J=8.5 \mathrm{~Hz}, J=7.0 \mathrm{~Hz})$ and $7.56(\mathrm{~m}, 1 \mathrm{H})$ and $7.98(\mathrm{~d}, J=7.5 \mathrm{~Hz}$, 2H): benzoyl protons, 7.31 (s, 1H, linker-NH), $8.32(\mathrm{~s}, 1 \mathrm{H})$ and $8.64(\mathrm{~s}, 1 \mathrm{H}): 2-\mathrm{H}$ and $8-\mathrm{H}$, $9.56(\mathrm{~s}, 1 \mathrm{H}, 6-\mathrm{NH}) .{ }^{13} \mathrm{C}-\mathrm{NMR}\left(\mathrm{CD}_{3} \mathrm{CN}\right) ; \delta[\mathrm{ppm}]=21.2(\mathrm{OAc}), 37.7\left(\mathrm{C}-2{ }^{\prime}\right), 41.5$ and 51.4 and 70.3 and 70.5 and 70.9 and 71.0: linker $6 \times \mathrm{CH}_{2}, 64.9\left(\mathrm{C}-5^{\prime}\right), 75.4\left(\mathrm{C}-3{ }^{\prime}\right), 83.9\left(\mathrm{C}-4^{\prime}\right), 85.1(\mathrm{C}-$ 1'), 125.6 (C-5), 129.1 (2C), 129.6 (2C), 133.5, 134.7, 143.1 (C-8), 150.8 (C-4), 151.3 (C-2), 153.0 (C-6), 157.0 (linker-CO), 166.3 (Bz-CO), 171.3 (Ac-CO). ESI-MS: 604 [M+Li] ${ }^{+}$.

3'-O-Acetyl-5'-O-((3,6-dioxanone-8-yn-1-yl)carbamoyl)- $N^{6}$-benzoyl-2'-deoxyadenosine (109a) Oil (224 mg, 79\%), $R_{\mathrm{f}}=0.52$ (EtOAc:MeOH/9:1), $\mathrm{C}_{27} \mathrm{H}_{30} \mathrm{~N}_{6} \mathrm{O}_{8} ;{ }^{1} \mathrm{H}-\mathrm{NMR}\left(\mathrm{CD}_{3} \mathrm{CN}\right) ; \delta$ $[\mathrm{ppm}]=2.08(\mathrm{~s}, 3 \mathrm{H}, \mathrm{OAc}), 2.68(\mathrm{t}, 1 \mathrm{H}, J=2.5 \mathrm{~Hz}, \mathrm{C} \equiv \underline{\mathrm{CH}}), 2.58(\mathrm{~m}, 1 \mathrm{H})$ and $3.02(\mathrm{~m}, 1 \mathrm{H}): 2^{\prime}-$ $\mathrm{H}_{2}, 3.30(\mathrm{~m}, 2 \mathrm{H})$ and $3.43(\mathrm{t}, 2 \mathrm{H}, J=5.6 \mathrm{~Hz})$ and $3.63(\mathrm{~m}, 4 \mathrm{H})$ and $4.13(\mathrm{~m}, 2 \mathrm{H})$ : linker $5 \times \mathrm{CH}_{2}, 4.22\left(\mathrm{dd}, 2 \mathrm{H}, J=13.0 \mathrm{~Hz}, J=6.0 \mathrm{~Hz}, 5^{\prime}-\mathrm{H}_{2}\right), 5.41$ (dt, $\left.1 \mathrm{H}, J=6.0 \mathrm{~Hz}, J=2.5 \mathrm{~Hz}, 4{ }^{\prime}-\mathrm{H}\right)$, $5.89(\mathrm{dd}, 1 \mathrm{H}, J=2 \times 6.0 \mathrm{~Hz}, 3 '-\mathrm{H}), 6.46\left(\mathrm{dd}, 1 \mathrm{H}, J=8.0 \mathrm{~Hz}, J=6.0 \mathrm{~Hz}, 1^{\prime}-\mathrm{H}\right), 7.55(\mathrm{~m}, 2 \mathrm{H})$ and $7.66(\mathrm{~m}, 1 \mathrm{H})$ and $7.98(\mathrm{~d}, 2 \mathrm{H}, J=7.5 \mathrm{~Hz})$ : benzoyl protons, $7.30(\mathrm{~s}, 1 \mathrm{H}$, linker-NH), $8.32(\mathrm{~s}$, $1 \mathrm{H})$ and $8.65(\mathrm{~s}, 1 \mathrm{H}): 2-\mathrm{H}$ and $8-\mathrm{H}, 9.53(\mathrm{~s}, 1 \mathrm{H}, 6-\mathrm{NH}) .{ }^{13} \mathrm{C}-\mathrm{NMR}\left(\mathrm{CD}_{3} \mathrm{CN}\right) ; \delta[\mathrm{ppm}]=21.2$ (OAc), 37.7 (C-2'), 41.5 and 58.6 and 69.8 and 70.3 and 70.6: linker $5 \times \mathrm{CH}_{2}, 64.9$ (C-5'), 75.4 $(\mathrm{C} \equiv \underline{\mathrm{CH}}), 75.7\left(\mathrm{C}-3^{\prime}\right), 80.9(\underline{\mathrm{C}} \equiv \mathrm{CH}), 83.9\left(\mathrm{C}-4^{\prime}\right), 85.1\left(\mathrm{C}-1^{\prime}\right), 125.6(\mathrm{C}-5), 129.1(2 \mathrm{C}), 129.6$ (2C), 133.5, 134.7, 143.1 (C-8), 150.8 (C-4), 151.3 (C-2), 152.5 (C-6), 157.0 (linker-CO), 166.3 (Bz-CO), 171.3 (Ac-CO). ESI-MS: $573[\mathrm{M}+\mathrm{Li}]^{+}$.

3'-O-Acetyl-5'-O-((3-azidopropyl)thiocarbamoyl)- $N^{6}$-benzoyl-2'-deoxyadenosine (110a) Oil (218 mg, 80\%), $R_{\mathrm{f}}=0.64$ (EtOAc:MeOH/9:1), $\mathrm{C}_{23} \mathrm{H}_{25} \mathrm{~N}_{9} \mathrm{O}_{5} \mathrm{~S} ;{ }^{1} \mathrm{H}-\mathrm{NMR}\left(\mathrm{CD}_{3} \mathrm{CN}\right) ; \delta$ $[\mathrm{ppm}]=1.79(\mathrm{p}, 2 \mathrm{H}, J=6.5 \mathrm{~Hz})$ and $3.33(\mathrm{~d}, 2 \mathrm{H}, J=6.5 \mathrm{~Hz})$ and $3.50(\mathrm{q}, 2 \mathrm{H}, J=6.5 \mathrm{~Hz})$ : linker $3 \times \mathrm{CH}_{2}, 2.08(\mathrm{~s}, 3 \mathrm{H}, \mathrm{OAc}), 2.68(\mathrm{~m}, 1 \mathrm{H})$ and $3.01(\mathrm{dt}, 1 \mathrm{H}, J=14.0 \mathrm{~Hz}, J=7.0 \mathrm{~Hz}): 2^{\prime}-\mathrm{H}_{2}, 4.45$ (m, 1H, 4'-H), $4.61(\mathrm{dd}, 1 \mathrm{H}, J=11.0 \mathrm{~Hz}, J=4.5 \mathrm{~Hz})$ and $4.79(\mathrm{~m}, 1 \mathrm{H}): 5 '-\mathrm{H}_{2}, 5.44(\mathrm{dd}, 1 \mathrm{H}$, $\left.J=6.0 \mathrm{~Hz}, J=2.5 \mathrm{~Hz}, 3^{\prime}-\mathrm{H}\right), 6.45\left(\mathrm{dd}, 1 \mathrm{H}, J=8.5 \mathrm{~Hz}, J=6.0 \mathrm{~Hz}, 1^{\prime}-\mathrm{H}\right), 7.52$ (t, $\left.J=7.5 \mathrm{~Hz}, 2 \mathrm{H}\right)$ and $7.67(\mathrm{~m}, 1 \mathrm{H})$ and $7.99(\mathrm{~d}, J=7.5 \mathrm{~Hz}, 2 \mathrm{H})$ : benzoyl protons, $7.31(\mathrm{~s}, 1 \mathrm{H}$, linker-NH), 8.30 $(\mathrm{s}, 1 \mathrm{H})$ and $8.65(\mathrm{~s}, 1 \mathrm{H}): 2-\mathrm{H}$ and $8-\mathrm{H}, 9.46(\mathrm{~s}, 1 \mathrm{H}, 6-\mathrm{NH}) .{ }^{13} \mathrm{C}-\mathrm{NMR}\left(\mathrm{CD}_{3} \mathrm{CN}\right) ; \delta[\mathrm{ppm}]=21.2$ 
(OAc), 28.2 and 43.3 and 49.6: $3 \times$ linker $\mathrm{CH}_{2}, 37.8$ (C-2'), 69.9 (C-5'), 75.3 (C-3'), 83.6 (C-4'), 85.3 (C-1'), 125.6 (C-5), 129.1 (2C), 129.6 (2C), 133.5, 133.6, 143.1 (C-8), 150.7 (C-4), 151.2 (C-2), 152.9 (C-6), 166.4 (Bz-CO), 171.3 (Ac-CO), 190.9 (linker-C=S). ESI-MS: 546 $[\mathrm{M}+\mathrm{Li}]^{+}$.

3'-O-Acetyl-5'-O-((prop-2-yn-1-yl)thiocarbamoyl)- $N^{6}$-benzoyl-2'-deoxyadenosine (111a)

Oil (183 mg, 74\%), $R_{\mathrm{f}}=0.66$ (EtOAc:MeOH/9:1), $\mathrm{C}_{23} \mathrm{H}_{22} \mathrm{~N}_{6} \mathrm{O}_{5} \mathrm{~S} ;{ }^{1} \mathrm{H}-\mathrm{NMR}\left(\mathrm{CD}_{3} \mathrm{CN}\right.$ ); $\delta$ $[\mathrm{ppm}]=2.08(\mathrm{~s}, 3 \mathrm{H}, \mathrm{OAc}), 2.48(\mathrm{t}, 1 \mathrm{H}, J=2.5 \mathrm{~Hz}, \mathrm{C} \equiv \underline{\mathrm{CH}}), 2.60(\mathrm{~m}, 1 \mathrm{H})$ and $3.01(\mathrm{dt}, 1 \mathrm{H}$, $J=14.0 \mathrm{~Hz}, J=7.0 \mathrm{~Hz}): 2^{\prime}-\mathrm{H}_{2}, 4.25\left(\mathrm{dd}, 2 \mathrm{H}, J=6.0 \mathrm{~Hz}, J=2.5 \mathrm{~Hz}\right.$, linker $\left.\mathrm{CH}_{2}\right), 4.45$ (m, 1H, 4'H), 4.79 (m, 2H, 5'- $\left.\mathrm{H}_{2}\right), 5.44$ (dd, 1H, J=6.5 Hz, J=3.0 Hz, 3'-H), 6.44 (t, 1H, J=6.5 Hz, 1'-H), $7.52(\mathrm{t}, 2 \mathrm{H}, J=7.5 \mathrm{~Hz})$ and $7.66(\mathrm{~m}, 1 \mathrm{H})$ and $7.99(\mathrm{~d}, 2 \mathrm{H}, J=7.5 \mathrm{~Hz})$ : benzoyl protons, $7.31(\mathrm{~s}$, $1 \mathrm{H}$, linker-NH), $8.30(\mathrm{~s}, 1 \mathrm{H})$ and $8.65(\mathrm{~s}, 1 \mathrm{H}): 2-\mathrm{H}$ and $8-\mathrm{H}, 9.45$ (s, 1H, 6-NH). ${ }^{13} \mathrm{C}-\mathrm{NMR}$ $\left(\mathrm{CD}_{3} \mathrm{CN}\right) ; \delta[\mathrm{ppm}]=21.2(\mathrm{OAc}), 35.3\left(\right.$ linker $\left.\mathrm{CH}_{2}\right), 37.7\left(\mathrm{C}-2^{\prime}\right), 70.5\left(\mathrm{C}-5^{\prime}\right), 72.8(\mathrm{C} \equiv \underline{\mathrm{CH}}), 75.2$ (C-3'), $79.7(\underline{\mathrm{C}} \equiv \mathrm{CH}), 83.4\left(\mathrm{C}-4^{\prime}\right), 85.2$ (C-1'), 125.6 (C-5), 129.1 (2C), 129.6 (2C), 133.6, 134.2, 143.2 (C-8), 150.6 (C-4), 151.2 (C-2), 153.0 (C-6), 165.9 (Bz-CO), 171.3 (Ac-CO), 191.2 (linker $\mathrm{C}=\mathrm{S}$ ). ESI-MS: $501[\mathrm{M}+\mathrm{Li}]^{+}$.

3'-O-Acetyl-5'-O-((8-azido-3,6-dioxaoctyl)thiocarbamoyl)- $N^{6}$-benzoyl-2'-deoxyadenosine (112a)

Oil (224 mg, 73\%), $R_{\mathrm{f}}=0.57$ (EtOAc:MeOH/9:1), $\mathrm{C}_{26} \mathrm{H}_{31} \mathrm{~N}_{9} \mathrm{O}_{7} \mathrm{~S} ;{ }^{1} \mathrm{H}-\mathrm{NMR}\left(\mathrm{CD}_{3} \mathrm{CN}\right) ; \delta$ $[\mathrm{ppm}]=2.08(\mathrm{~s}, 3 \mathrm{H}, \mathrm{OAc}), 2.60(\mathrm{~m}, 1 \mathrm{H})$ and $3.17(\mathrm{~m}, 1 \mathrm{H}): 2^{\prime}-\mathrm{H}_{2}, 3.41(\mathrm{~m}, 2 \mathrm{H})$ and $3.46(\mathrm{t}, 2 \mathrm{H}$, $J=5.5 \mathrm{~Hz})$ and $3.65(\mathrm{~m}, 2 \mathrm{H}), 3.71(\mathrm{~m}, 6 \mathrm{H})$ : linker $6 \times \mathrm{CH}_{2}, 4.44\left(\mathrm{~m}, 1 \mathrm{H}, 4{ }^{\prime}-\mathrm{H}\right), 4.71(\mathrm{dd}, 2 \mathrm{H}$, $\left.J=12.0 \mathrm{~Hz}, J=5.0 \mathrm{~Hz}, 5^{\prime}-\mathrm{H}_{2}\right), 5.47\left(\mathrm{~m}, 1 \mathrm{H}, 3^{\prime}-\mathrm{H}\right), 6.49\left(\mathrm{~m}, 1 \mathrm{H}, 1^{\prime}-\mathrm{H}\right), 7.55(\mathrm{~m}, 2 \mathrm{H})$ and 7.78 $(\mathrm{dd}, J=2 \times 5.0 \mathrm{~Hz}, 1 \mathrm{H})$ and $7.98(\mathrm{dd}, J=2 \times 7.5 \mathrm{~Hz}, 2 \mathrm{H})$ : benzoyl protons, $7.33(\mathrm{~d}, 1 \mathrm{H}, J=1.5 \mathrm{~Hz}$, linker-NH), $8.30(\mathrm{~s}, 1 \mathrm{H})$ and $8.65(\mathrm{~s}, 1 \mathrm{H}): 2-\mathrm{H}$ and $8-\mathrm{H}, 9.46(\mathrm{~s}, 1 \mathrm{H}, 6-\mathrm{NH}) .{ }^{13} \mathrm{C}-\mathrm{NMR}$ $\left(\mathrm{CD}_{3} \mathrm{CN}\right) ; \delta[\mathrm{ppm}]=21.2(\mathrm{OAc}), 37.6\left(\mathrm{C}-2^{\prime}\right), 46.0$ and 51.4 and 70.0 and 70.5 and 70.8 and 70.9: linker 6× $\mathrm{CH}_{2}, 68.9$ (C-5'), 75.3 (C-3'), 83.5 (C-4'), 85.3 (C-1'), 125.7 (C-5), 129.1 (2C), 129.6 (2C), 133.5, 134.7, 143.2 (C-8), 150.8 (C-4), 151.3 (C-2), 152.9 (C-6), 166.3 (Bz-CO), 171.4 (Ac-CO), 190.9 (linker-C=S). ESI-MS: 620 [M+Li] ${ }^{+}$. 
3'-O-Acetyl-5'-O-((3,6-dioxanone-8-yn-1-yl)thiocarbamoyl)- $N^{6}$-benzoyl-2'-deoxyadenosine (113a)

Oil (244 mg, 84\%), $R_{\mathrm{f}}=0.64$ (EtOAc:MeOH/9:1), $\mathrm{C}_{27} \mathrm{H}_{30} \mathrm{~N}_{6} \mathrm{O}_{7} \mathrm{~S} ;{ }^{1} \mathrm{H}-\mathrm{NMR}\left(\mathrm{CD}_{3} \mathrm{CN}\right) ; \delta$ $[\mathrm{ppm}]=2.08$ (s, 3H, OAc), $2.65(\mathrm{t}, 1 \mathrm{H}, J=2.5 \mathrm{~Hz}, \mathrm{C} \equiv \underline{\mathrm{CH}}), 2.53(\mathrm{~m}, 1 \mathrm{H})$ and 3.09 (m, 1H): 2'$\mathrm{H}_{2}, 3.51(\mathrm{~m}, 2 \mathrm{H})$ and $3.65(\mathrm{~m}, 6 \mathrm{H})$ and $4.14(\mathrm{~m}, 2 \mathrm{H})$ : linker $5 \times \mathrm{CH}_{2}, 4.45\left(\mathrm{~m}, 1 \mathrm{H}, 4{ }^{\prime}-\mathrm{H}\right), 4.61$ (dd, $1 \mathrm{H}, J=12.0 \mathrm{~Hz}, J=5.0 \mathrm{~Hz}$ ) and $4.76(\mathrm{~m}, 1 \mathrm{H}): 5^{\prime}-\mathrm{H}_{2}, 5.48$ (dd, $\left.1 \mathrm{H}, J=2 \times 6.0 \mathrm{~Hz}, 3^{\prime}-\mathrm{H}\right), 6.44$ $\left(\mathrm{dt}, 1 \mathrm{H}, J=8.0 \mathrm{~Hz}, J=6.0 \mathrm{~Hz}, 1^{\prime}-\mathrm{H}\right), 7.51(\mathrm{dd}, 2 \mathrm{H}, J=2 \times 8.0 \mathrm{~Hz})$ and $7.62(\mathrm{dd}, 1 \mathrm{H}, J=2 \times 7.5 \mathrm{~Hz})$ and $7.98(\mathrm{~d}, 2 \mathrm{H}, J=7.5 \mathrm{~Hz})$ : benzoyl protons, $7.35(\mathrm{~d}, 1 \mathrm{H}, J=2.5 \mathrm{~Hz}$, linker-NH), $8.30(\mathrm{~s}, 1 \mathrm{H})$ and $8.65(\mathrm{~s}, 1 \mathrm{H}): 2-\mathrm{H}$ and 8-H, $9.49(\mathrm{~s}, 1 \mathrm{H}, 6-\mathrm{NH}) .{ }^{13} \mathrm{C}-\mathrm{NMR}\left(\mathrm{CD}_{3} \mathrm{CN}\right) ; \delta[\mathrm{ppm}]=21.2(\mathrm{OAc})$, $37.6\left(\mathrm{C}-2^{\prime}\right), 46.0$ and 58.7 and 68.8 and 70.0 and 70.7: linker $5 \times \mathrm{CH}_{2}, 69.8$ (C-5'), 75.3 $(\mathrm{C} \equiv \underline{\mathrm{CH}}), 75.7\left(\mathrm{C}-3^{\prime}\right), 80.8(\underline{\mathrm{C}} \equiv \mathrm{CH}), 83.5\left(\mathrm{C}-4^{\prime}\right), 85.3\left(\mathrm{C}-1^{\prime}\right), 125.7(\mathrm{C}-5), 129.1(2 \mathrm{C}), 129.6$ (2C), 133.5, 134.6, 143.2 (C-8), 150.9 (C-4), 151.4 (C-2), 153.0 (C-6), 166.1 (Bz-CO), 171.3 (Ac-CO), 191.0 (linker-C=S). ESI-MS: 589 [M+Li] $]^{+}$.

2',3'-Di-O-acetyl-5'-O-((3-propiolamidopropyl)carbamoyl)- $N^{2}$-isobutyrylguanosine (114b)

Oil (212 mg, 72\%), $R_{\mathrm{f}}=0.25$ (EtOAc:MeOH/9:1), $\mathrm{C}_{25} \mathrm{H}_{31} \mathrm{~N}_{7} \mathrm{O}_{10} ;{ }^{1} \mathrm{H}-\mathrm{NMR}\left(\mathrm{CD}_{3} \mathrm{CN}\right) ; \delta$ $[\mathrm{ppm}]=1.12\left(\mathrm{dd}, 6 \mathrm{H}, J=7.0 \mathrm{~Hz}, J=1.5 \mathrm{~Hz}, 2 \times \mathrm{iBu}-\mathrm{CH}_{3}\right), 1.55(\mathrm{p}, 2 \mathrm{H}, J=7.0 \mathrm{~Hz})$ and $3.03(\mathrm{t}$, $2 \mathrm{H}, J=7.0 \mathrm{~Hz})$ and $3.11(\mathrm{~d}, 2 \mathrm{H}, J=7.0 \mathrm{~Hz}): 3 \times$ linker $\mathrm{CH}_{2}, 2.01(\mathrm{~s}, 3 \mathrm{H}, \mathrm{OAc}), 2.08(\mathrm{~s}, 3 \mathrm{H}$, OAc), $2.68(\mathrm{~m}, 1 \mathrm{H}, \mathrm{iBu}-\mathrm{CH}), 3.21(\mathrm{~s}, 1 \mathrm{H}, \mathrm{C} \equiv \underline{\mathrm{CH}}), 4.23(\mathrm{dd}, 1 \mathrm{H}, J=11.5 \mathrm{~Hz}, J=7.5 \mathrm{~Hz}$,) and 4.45 (dd, 1H, J=11.5 Hz, J=4.0 Hz,): 5'- $\mathrm{H}_{2}, 4.29$ (td, 1H, J=5.0 Hz, J=3.5 Hz, 4'-H), 5.56 (dd, $\left.1 \mathrm{H}, J=6.0 \mathrm{~Hz}, J=5.0 \mathrm{~Hz}, 3^{\prime}-\mathrm{H}\right), 5.68$ (t, 1H, J=5.5 Hz, 2'-H), 5.93 (d, 1H, J=5.0 Hz, 1'-H), 7.16 $(\mathrm{t}, 1 \mathrm{H}, J=5.5 \mathrm{~Hz})$ and $7.77(\mathrm{t}, 1 \mathrm{H}, J=5.5 \mathrm{~Hz}): 2 \times$ linker-NH, $9.75(\mathrm{~s}, 1 \mathrm{H}, 8-\mathrm{H}), 11.98(\mathrm{~s}, 1 \mathrm{H}$, iBu-NH). ${ }^{13} \mathrm{C}-\mathrm{NMR}\left(\mathrm{CD}_{3} \mathrm{CN}\right) ; \delta[\mathrm{ppm}]=19.1$ and 19.2: $2 \times \mathrm{iBu}-\mathrm{CH}_{3}, 20.6$ and 20.8: $2 \times \mathrm{OAc}$, 29.9 and 37.5 and 38.9: $3 \times$ linker $\mathrm{CH}_{2}, 36.7(\mathrm{iBu}-\mathrm{CH}), 64.2\left(\mathrm{C}-5^{\prime}\right), 71.7\left(\mathrm{C}-2^{\prime}\right), 74.0(\mathrm{C} \equiv \underline{\mathrm{CH}})$, $74.3\left(\mathrm{C}-3\right.$ '), $78.3(\underline{\mathrm{C}} \equiv \mathrm{CH}), 81.6\left(\mathrm{C}-4^{\prime}\right), 87.6\left(\mathrm{C}-1^{\prime}\right), 122.3$ (C-5), 139.1 (C-8), 149.3 (C-4), 149.4 (C-2), 153.0 and 156.3: $2 \times$ linker-CO, 157.3 (C-6), 170.5 and 170.7: $2 \times$ Ac-CO, 181.0 (iBu-CO). ESI-MS: $596[\mathrm{M}+\mathrm{Li}]^{+}$.

2',3'-Di-O-acetyl-5'-O-((3-azidopropyl)carbamoyl)- $N^{2}$-isobutyrylguanosine (115b)

Oil (231 mg, 81\%), $R_{\mathrm{f}}=0.55$ (EtOAc:MeOH/9:1), $\mathrm{C}_{22} \mathrm{H}_{29} \mathrm{~N}_{9} \mathrm{O}_{9} ;{ }^{1} \mathrm{H}-\mathrm{NMR} \quad\left(\mathrm{CD}_{3} \mathrm{CN}\right) ; \delta$ $[\mathrm{ppm}]=1.19\left(\mathrm{~d}, 6 \mathrm{H}, J=7.0 \mathrm{~Hz}, 2 \times \mathrm{iBu}-\mathrm{CH}_{3}\right), 1.69(\mathrm{~m}, 2 \mathrm{H})$ and $3.22(\mathrm{~m}, 2 \mathrm{H})$ and $3.33(\mathrm{dd}, 2 \mathrm{H}$, $J=9.5 \mathrm{~Hz}, J=5.0 \mathrm{~Hz})$ : linker $3 \times \mathrm{CH}_{2}, 2.08(2 \times \mathrm{s}, 2 \times 3 \mathrm{H}, 2 \times \mathrm{OAc}), 2.75(\mathrm{~m}, 1 \mathrm{H}, \mathrm{iBu}-\mathrm{CH}), 4.44$ (m, 2H, 5'- $\mathrm{H}_{2}$ ), 4.52 (dd, $\left.1 \mathrm{H}, J=11.5 \mathrm{~Hz}, J=3.5 \mathrm{~Hz}, 4^{\prime}-\mathrm{H}\right), 5.62(\mathrm{dd}, 1 \mathrm{H}, J=5.5 \mathrm{~Hz}, J=3.0 \mathrm{~Hz}$, 
3'-H), 5.74 (dd, 1H, $\left.J=5.5 \mathrm{~Hz}, J=2.0 \mathrm{~Hz}, 2^{\prime}-\mathrm{H}\right), 5.99$ (dd, 1H, $\left.J=5.5 \mathrm{~Hz}, J=2.0 \mathrm{~Hz}, 1^{\prime}-\mathrm{H}\right), 7.83$ (d, $1 \mathrm{H}, J=2.5 \mathrm{~Hz}$, linker-NH), $10.08(\mathrm{~s}, 1 \mathrm{H}, 8-\mathrm{H}), 11.96$ (s, $1 \mathrm{H}, \mathrm{iBu}-\mathrm{NH}) .{ }^{13} \mathrm{C}-\mathrm{NMR}\left(\mathrm{CD}_{3} \mathrm{CN}\right)$;

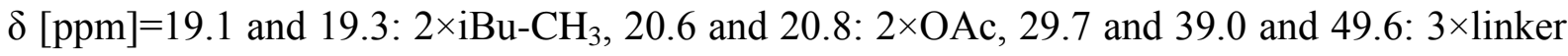
$\mathrm{CH}_{2}, 36.7$ (iBu-CH), 64.2 (C-5'), 72.7 (C-2'), 74.0 (C-3'), 81.6 (C-4'), 87.6 (C-1'), 122.5 (C-5), 139.1 (C-8), 149.3 (C-4), 149.4 (C-2), 156.3 (linker-CO), 157.2 (C-6), 170.5 and 170.7: $2 \times$ Ac-CO, 181.1 (iBu-CO). ESI-MS: $570[\mathrm{M}+\mathrm{Li}]^{+}$.

2',3'-Di-O-acetyl-5'-O-((prop-2-yn-1-yl) carbamoyl)- $N^{2}$-isobutyrylguanosine (116b)

Oil (197 mg, 76\%), $R_{\mathrm{f}}=0.55$ (EtOAc:MeOH/9:1), $\mathrm{C}_{22} \mathrm{H}_{26} \mathrm{~N}_{6} \mathrm{O}_{9} ;{ }^{1} \mathrm{H}-\mathrm{NMR}\left(\mathrm{CD}_{3} \mathrm{CN}\right) ; \delta$ $[\mathrm{ppm}]=1.18\left(\mathrm{~d}, 6 \mathrm{H}, J=7.0 \mathrm{~Hz}, 2 \times \mathrm{BBu}-\mathrm{CH}_{3}\right), 2.00$ (s, 3H, OAc), 2.07 (s, 3H, OAc), 2.49 (t, $1 \mathrm{H}$, $J=2.5 \mathrm{~Hz}, \mathrm{C} \equiv \underline{\mathrm{CH}}), 2.76(\mathrm{~m}, 1 \mathrm{H}, \mathrm{iBu}-\mathrm{CH}), 3.93\left(\mathrm{~m}, 2 \mathrm{H}\right.$, linker $\left.\mathrm{CH}_{2}\right), 4.40\left(\mathrm{~m}, 2 \mathrm{H}, 5^{\prime}-\mathrm{H}_{2}\right), 4.58$ (m, 1H, 4'-H), 5.65 (m, 1H, 3'-H), 5.75 (t, 1H, J=5.5 Hz, 2'-H), 5.99 (d, 1H, J=5.5 Hz, 1'-H), 7.84 (s, $1 \mathrm{H}$, linker-NH), 9.82 (s, $1 \mathrm{H}, 8-\mathrm{H}), 12.07$ (s, $1 \mathrm{H}, \mathrm{iBu}-\mathrm{NH}) .{ }^{13} \mathrm{C}-\mathrm{NMR}\left(\mathrm{CD}_{3} \mathrm{CN}\right) ; \delta$ $[\mathrm{ppm}]=19.2$ and 19.3: $2 \times \mathrm{iBu}-\mathrm{CH}_{3}, 20.6$ and 20.8: $2 \times \mathrm{OAc}, 31.0$ (linker $\left.\mathrm{CH}_{2}\right), 36.7(\mathrm{iBu}-\mathrm{CH})$, $64.6\left(\mathrm{C}^{2} 5^{\prime}\right), 71.6\left(\mathrm{C}-2^{\prime}\right), 72.1(\mathrm{C} \equiv \underline{\mathrm{CH}}), 73.9\left(\mathrm{C}-3^{\prime}\right), 81.2(\underline{\mathrm{C}} \equiv \mathrm{CH}), 81.3\left(\mathrm{C}-4^{\prime}\right), 87.6\left(\mathrm{C}-1^{\prime}\right)$, 122.3 (C-5), 137.2 (C-8), 149.3 (C-4), 149.4 (C-2), 156.3 (linker-CO), 156.9 (C-6), 170.5 and 170.7: 2×Ac-CO, 181.1 (iBu-CO). ESI-MS: 525 [M+Li] ${ }^{+}$.

2',3'-Di-O-acetyl-5'-O-((8-azido-3,6-dioxaoctyl) carbamoyl)- $N^{2}$-isobutyrylguanosine (117b) Oil (252 mg, 79\%), $R_{\mathrm{f}}=0.46$ (EtOAc: $\left.\mathrm{MeOH} / 9: 1\right), \mathrm{C}_{25} \mathrm{H}_{35} \mathrm{~N}_{9} \mathrm{O}_{11} ;{ }^{1} \mathrm{H}-\mathrm{NMR}\left(\mathrm{CD}_{3} \mathrm{CN}\right) ; \delta$ $[\mathrm{ppm}]=1.19\left(\mathrm{~d}, 6 \mathrm{H}, J=7.0 \mathrm{~Hz}, 2 \times \mathrm{iBu}_{-} \mathrm{CH}_{3}\right), 2.01$ (s, 3H, OAc), 2.08 (s, 3H, OAc), $2.75(\mathrm{~m}$, $1 \mathrm{H}, \mathrm{iBu}-\mathrm{CH}), 3.33(\mathrm{~m}, 2 \mathrm{H})$ and $3.34(\mathrm{~d}, 2 \mathrm{H}, J=5.0 \mathrm{~Hz})$ and $3.48(\mathrm{t}, 2 \mathrm{H}, J=5.5 \mathrm{~Hz})$ and 3.65 (m, 6H): linker $6 \times \mathrm{CH}_{2}, 4.41\left(\mathrm{~m}, 2 \mathrm{H}, 5^{\prime}-\mathrm{H}_{2}\right), 4.52\left(\mathrm{dd}, 1 \mathrm{H}, J=11.0 \mathrm{~Hz}, J=3.5 \mathrm{~Hz}, 4^{\prime}-\mathrm{H}\right), 5.62$ (dd, 1H, J=6.0 Hz, J=4.0 Hz, 3'-H), 5.75 (dd, 1H, J=5.5 Hz, 2'-H), 5.99 (t, 1H, $J=5.0 \mathrm{~Hz}, 1^{\prime}-$ H), 7.83 (d, $1 \mathrm{H}, J=2.5 \mathrm{~Hz}$, linker-NH), 9.84 (s, $1 \mathrm{H}, 8-\mathrm{H}), 12.05$ (s, $1 \mathrm{H}, \mathrm{iBu}-\mathrm{NH}) .{ }^{13} \mathrm{C}-\mathrm{NMR}$ $\left(\mathrm{CD}_{3} \mathrm{CN}\right) ; \delta[\mathrm{ppm}]=19.1$ and 19.3: $2 \times \mathrm{BBu}-\mathrm{CH}_{3}, 20.6$ and 20.8: $2 \times \mathrm{OAc}, 36.7(\mathrm{iBu}-\mathrm{CH}), 41.6$ and 51.4 and 70.2 and 70.5 and 70.9 and 71.0: 6×linker $\mathrm{CH}_{2}, 64.4\left(\mathrm{C}-5^{\prime}\right), 71.7(\mathrm{C}-2$ '), 73.9 (C3'), 81.5 (C-4'), 87.6 (C-1'), 122.5 (C-5), 139.1 (C-8), 149.3 (C-4), 149.4 (C-2), 156.3 (linkerCO), 157.2 (C-6), 170.5 and 170.7: 2×Ac-CO, 181.0 (iBu-CO). ESI-MS: 644 [M+Li] ${ }^{+}$. 2',3'-Di-O-acetyl-5'-O-((3,6-dioxanone-8-yn-1-yl) carbamoyl)- $N^{2}$-isobutyrylguanosine (118b) Oil (233 mg, 77\%), $R_{\mathrm{f}}=0.52$ (EtOAc:MeOH/9:1), $\mathrm{C}_{26} \mathrm{H}_{34} \mathrm{~N}_{6} \mathrm{O}_{11} ;{ }^{1} \mathrm{H}-\mathrm{NMR}\left(\mathrm{CD}_{3} \mathrm{CN}\right) ; \delta$ $[\mathrm{ppm}]=1.19\left(\mathrm{~d}, 6 \mathrm{H}, J=7.0 \mathrm{~Hz}, 2 \times \mathrm{BBu}-\mathrm{CH}_{3}\right), 1.97$ (s, 3H, OAc), 2.04 (s, 3H, OAc), $2.67(\mathrm{t}, 1 \mathrm{H}$, 
$J=2.5 \mathrm{~Hz}, \mathrm{C} \equiv \underline{\mathrm{CH}}), 2.83(\mathrm{~m}, 1 \mathrm{H}, \mathrm{iBu}-\mathrm{CH}), 3.46(\mathrm{dd}, 2 \mathrm{H}, J=6.0 \mathrm{~Hz}, J=4.0 \mathrm{~Hz})$ and $3.63(\mathrm{~m}$, $6 \mathrm{H})$ and $4.14(\mathrm{~m}, 2 \mathrm{H})$ : linker $5 \times \mathrm{CH}_{2}, 4.40\left(\mathrm{~m}, 2 \mathrm{H}, 5{ }^{\prime}-\mathrm{H}_{2}\right), 4.51(\mathrm{dd}, 1 \mathrm{H}, J=11.0 \mathrm{~Hz}, J=4.0 \mathrm{~Hz}$, 4'-H), 5.62 (dd, 1H, J=6.0 Hz, J=4.0 Hz, 3'-H), 5.75 (t, 1H, J=5.5 Hz, 2'-H), 5.99 (d, 1H, $J=5.5 \mathrm{~Hz}, 1$ '-H), 7.84 (s, 1H, linker-NH), 9.91 (s, 1H, 8-H), 12.07 (s, 1H, iBu-NH). ${ }^{13} \mathrm{C}-\mathrm{NMR}$ $\left(\mathrm{CD}_{3} \mathrm{CN}\right) ; \delta[\mathrm{ppm}]=19.1$ and 19.3: $2 \times \mathrm{iBu}-\mathrm{CH}_{3}, 20.6$ and 20.8: $2 \times \mathrm{OAc}, 36.7(\mathrm{iBu}-\mathrm{CH}), 41.6$ and 58.7 and 69.8 and 69.9 and 70.1: linker $5 \times \mathrm{CH}_{2}, 64.3\left(\mathrm{C}-5^{\prime}\right), 71.2\left(\mathrm{C}-2^{\prime}\right), 71.7(\mathrm{C} \equiv \underline{\mathrm{CH}})$, $73.9\left(\mathrm{C}-3^{\prime}\right), 80.9(\underline{\mathrm{C}} \equiv \mathrm{CH}), 81.5$ (C-4'), 87.6 (C-1'), 122.5 (C-5), 139.1 (C-8), 149.3 (C-4), 149.4 (C-2), 156.3 (linker-CO), 157.2 (C-6), 170.5 and 170.7: 2×Ac-CO, 181.1 (iBu-CO). ESI-MS: $613[\mathrm{M}+\mathrm{Li}]^{+}$.

5'-O-((3-Propiolamidopropyl)carbamoyl)-2'-deoxyadenosine (119a)

Amorphous foam (58 mg, 72\%), $R_{\mathrm{f}}=0.21$ (EtOAc:MeOH/8:2), $\mathrm{C}_{17} \mathrm{H}_{21} \mathrm{~N}_{7} \mathrm{O}_{6} ;{ }^{1} \mathrm{H}-\mathrm{NMR}$ (DMSO); $\delta[\mathrm{ppm}]=1.56(\mathrm{~m}, 2 \mathrm{H})$ and $2.95(\mathrm{q}, 2 \mathrm{H}, J=6.5 \mathrm{~Hz})$ and $3.10(\mathrm{~m}, 2 \mathrm{H}): 3 \times$ linker $\mathrm{CH}_{2}$, $2.30(\mathrm{ddd}, 1 \mathrm{H}, J=13.5 \mathrm{~Hz}, J=6.5 \mathrm{~Hz}, J=3.5 \mathrm{~Hz}$ ) and $2.78(\mathrm{ddd}, 1 \mathrm{H}, J=13.5 \mathrm{~Hz}, J=7.5 \mathrm{~Hz}$, $J=6.0 \mathrm{~Hz}): 2^{\prime}-\mathrm{H}_{2}, 4.08\left(\mathrm{~m}, 2 \mathrm{H}, 5^{\prime}-\mathrm{H}_{2}\right), 4.14(\mathrm{~s}, 1 \mathrm{H}, \mathrm{C} \equiv \underline{\mathrm{CH}}), 4.20(\mathrm{dd}, 1 \mathrm{H}, J=11.0 \mathrm{~Hz}, J=3.5$ Hz, 3'-H), 4.40 (dt, 1H, J=6.0 Hz, J=3.0 Hz, 4'-H), 6.38 (t, 1H, J=7.0 Hz, 1'-H), 7.26 (t, 1H, $J=5.5 \mathrm{~Hz})$ and $8.76(\mathrm{t}, 1 \mathrm{H}, J=5.5 \mathrm{~Hz}): 2 \times$ linker-NH, $8.14(\mathrm{~s}, 1 \mathrm{H})$ and $8.30(\mathrm{~s}, 1 \mathrm{H}): 2-\mathrm{H}$ and 8 H. ${ }^{13} \mathrm{C}-\mathrm{NMR}$ (DMSO); $\delta$ [ppm] $=29.1$ and 36.7 and 38.1: $3 \times$ linker $\mathrm{CH}_{2}, 38.7(\mathrm{C}-2$ '), $64.3(\mathrm{C}-$

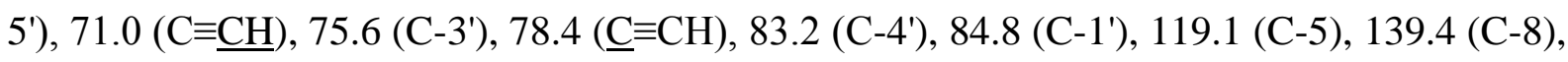
149.3 (C-4), 152.7 (C-2), 156.0 (C-6), 151.6 and 156.1: 2×linker-CO. ESI-MS: 410 [M+Li] ${ }^{+}$.

5'-O-((3-Azidopropyl)carbamoyl)-2'-deoxyadenosine (120a)

Amorphous foam (66 mg, 88\%), $R_{\mathrm{f}}=0.39$ (EtOAc:MeOH/8:2), $\mathrm{C}_{14} \mathrm{H}_{19} \mathrm{~N}_{9} \mathrm{O}_{4} ;{ }^{1} \mathrm{H}-\mathrm{NMR}$ $\left(\mathrm{CD}_{3} \mathrm{OD}\right) ; \delta[\mathrm{ppm}]=1.71(\mathrm{p}, 2 \mathrm{H}, J=7.0 \mathrm{~Hz})$ and $3.15(\mathrm{t}, 2 \mathrm{H}, J=7.0 \mathrm{~Hz})$ and $3.15(\mathrm{t}, 2 \mathrm{H}, J=7.0$ $\mathrm{Hz}$ ): linker $3 \times \mathrm{CH}_{2}, 2.49(\mathrm{ddd}, 1 \mathrm{H}, J=13.5 \mathrm{~Hz}, J=6.5 \mathrm{~Hz}, J=3.5 \mathrm{~Hz})$ and $2.95(\mathrm{ddd}, 1 \mathrm{H}, J=13.5$ $\mathrm{Hz}, J=7.0 \mathrm{~Hz}, J=6.0 \mathrm{~Hz}$ ): $2^{\prime}-\mathrm{H}_{2}, 4.15$ (dd, $\left.1 \mathrm{H}, J=5.0 \mathrm{~Hz}, J=3.5 \mathrm{~Hz}, 4^{\prime}-\mathrm{H}\right), 4.23$ (dd, 1H, $J=12.0$ $\mathrm{Hz}, J=5.0 \mathrm{~Hz})$ and $4.35(\mathrm{dd}, 1 \mathrm{H}, J=12.0 \mathrm{~Hz}, J=4.0 \mathrm{~Hz}): 5^{\prime}-\mathrm{H}_{2}, 4.57(\mathrm{dd}, 1 \mathrm{H}, J=6.5 \mathrm{~Hz}, J=3.5$ $\mathrm{Hz}, 3$ '-H), 6.44 (t, 1H, J=6.5 Hz, 1'-H), 8.13 (s, 1H, linker-NH), 8.20 (s, 1H) and 8.27 (s, 1H): 2-H and $8-\mathrm{H} .{ }^{13} \mathrm{C}-\mathrm{NMR}\left(\mathrm{CD}_{3} \mathrm{OD}\right) ; \delta[\mathrm{ppm}]=30.1$ and 40.9 and 49.9: linker $3 \times \mathrm{CH}_{2}, 39.1(\mathrm{C}-$ 2'), 65.4 (C-5'), 72.7 (C-3'), 85.6 (C-4'), 86.6 (C-1'), 120.4 (C-5), 140.7 (C-8), 150.3 (C-4), 153.8 (C-2), 157.2 (C-6), 158.5 (linker-CO). ESI-MS: 384 [M+Li] $]^{+}$. 
5'-O-((Prop-2-yn-1-yl)carbamoyl)-2'-deoxyadenosine (121a)

Amorphous foam (54 mg, 88\%), $R_{\mathrm{f}}=0.41$ (EtOAc:MeOH/8:2), $\mathrm{C}_{14} \mathrm{H}_{16} \mathrm{~N}_{6} \mathrm{O}_{4} ;{ }^{1} \mathrm{H}-\mathrm{NMR}$ $\left(\mathrm{CD}_{3} \mathrm{OD}\right) ; \delta[\mathrm{ppm}]=2.48(\mathrm{ddd}, 1 \mathrm{H}, J=13.5 \mathrm{~Hz}, J=6.5 \mathrm{~Hz}, J=3.5 \mathrm{~Hz})$ and $2.86(\mathrm{~m}, 1 \mathrm{H}): 2{ }^{\prime}-\mathrm{H}_{2}$, $2.58(\mathrm{t}, 1 \mathrm{H}, J=2.5 \mathrm{~Hz}, \mathrm{C} \equiv \underline{\mathrm{CH}}), 3.87$ (d, 2H, J=2.5 Hz, linker $\left.\mathrm{CH}_{2}\right), 4.16(\mathrm{~m}, 1 \mathrm{H}, 4 \mathrm{\prime}-\mathrm{H}), 4.25$ $(\mathrm{dd}, 1 \mathrm{H}, J=12.0 \mathrm{~Hz}, J=5.0 \mathrm{~Hz})$ and $4.37(\mathrm{dd}, 1 \mathrm{H}, J=12.0 \mathrm{~Hz}, J=4.0 \mathrm{~Hz}): 5 '-\mathrm{H}_{2}, 4.57(\mathrm{dd}, 1 \mathrm{H}$, $\left.J=6.5 \mathrm{~Hz}, J=3.5 \mathrm{~Hz}, 3^{\prime}-\mathrm{H}\right), 6.44$ (t, 1H, J=7.0 Hz, 1'-H), 7.88 (s, 1H, linker-NH), 8.20 (s, 1H) and $8.27(\mathrm{~s}, 1 \mathrm{H}): 2-\mathrm{H}$ and $8-\mathrm{H} .{ }^{13} \mathrm{C}-\mathrm{NMR}\left(\mathrm{CD}_{3} \mathrm{OD}\right) ; \delta[\mathrm{ppm}]=31.1\left(\right.$ linker $\left.\mathrm{CH}_{2}\right), 40.9\left(\mathrm{C}-2{ }^{\prime}\right)$, $65.7\left(\mathrm{C}^{-5}\right), 72.2(\mathrm{C} \equiv \underline{\mathrm{CH}}), 72.7\left(\mathrm{C}-3^{\prime}\right), 81.0(\underline{\mathrm{C}} \equiv \mathrm{CH}), 85.6\left(\mathrm{C}-4^{\prime}\right), 86.6\left(\mathrm{C}-1^{\prime}\right), 120.4(\mathrm{C}-5)$, 140.7 (C-8), 150.3 (C-4), 153.8 (C-2), 157.2 (C-6), 158.1 (linker-CO). ESI-MS: 339 [M+Li] $]^{+}$

5'-O-((8-Azido-3,6-dioxaoctyl)carbamoyl)-2'-deoxyadenosine (122a)

Amorphous foam (71 mg, 79\%), $R_{\mathrm{f}}=0.36$ (EtOAc:MeOH/8:2), $\mathrm{C}_{17} \mathrm{H}_{25} \mathrm{~N}_{9} \mathrm{O}_{6} ;{ }^{1} \mathrm{H}-\mathrm{NMR}$ $\left(\mathrm{CD}_{3} \mathrm{OD}\right) ; \delta[\mathrm{ppm}]=2.50(\mathrm{ddd}, 1 \mathrm{H}, J=13.5 \mathrm{~Hz}, J=6.5 \mathrm{~Hz}, J=3.5 \mathrm{~Hz})$ and $2.82(\mathrm{ddd}, 1 \mathrm{H}, J=13.5$ $\mathrm{Hz}, J=7.0 \mathrm{~Hz}, J=6.5 \mathrm{~Hz}): 2^{\prime}-\mathrm{H}_{2}, 3.39(\mathrm{~m}, 4 \mathrm{H})$ and $3.53(\mathrm{t}, 2 \mathrm{H}, J=5.5 \mathrm{~Hz})$ and $3.67(\mathrm{~m}, 6 \mathrm{H})$ : linker $6 \times \mathrm{CH}_{2}, 4.18\left(\mathrm{dt}, 1 \mathrm{H}, J=5.0 \mathrm{~Hz}, J=3.5 \mathrm{~Hz}, 4^{\prime}-\mathrm{H}\right), 4.26(\mathrm{dd}, 1 \mathrm{H}, J=12.0 \mathrm{~Hz}, J=5.0 \mathrm{~Hz})$ and $4.36(\mathrm{dd}, 1 \mathrm{H}, J=12.0 \mathrm{~Hz}, J=4.0 \mathrm{~Hz}): 5^{\prime}-\mathrm{H}_{2}, 4.59$ (dd, $\left.1 \mathrm{H}, J=6.5 \mathrm{~Hz}, J=3.5 \mathrm{~Hz}, 3^{\prime}-\mathrm{H}\right), 6.46$ (dd, 1H, $\left.J=2 \times 7.0 \mathrm{~Hz}, 1^{\prime}-\mathrm{H}\right), 7.31$ (s, 1H, linker-NH), 8.23 (s, 1H) and 8.27 (s, 1H): 2-H and 8H. ${ }^{13} \mathrm{C}-\mathrm{NMR}\left(\mathrm{CD}_{3} \mathrm{OD}\right) ; \delta[\mathrm{ppm}]=40.9\left(\mathrm{C}-2{ }^{\prime}\right), 41.7$ and 51.7 and 70.9 and 71.1 and 71.3 and 71.4: linker 6× $\mathrm{CH}_{2}, 65.5\left(\mathrm{C}-5^{\prime}\right), 72.7$ (C-3'), 85.6 (C-4'), 86.6 (C-1'), 120.4 (C-5), 140.7 (C-8), 150.3 (C-4), 153.9 (C-2), 157.2 (C-6), 158.5 (linker-CO). ESI-MS: 458 [M+Li] ${ }^{+}$.

5'-O-((3,6-Dioxanone-8-yn-1-yl)carbamoyl)-2'-deoxyadenosine (123a)

Amorphous foam (71 mg, 84\%), $R_{\mathrm{f}}=0.38$ (EtOAc:MeOH/8:2), $\mathrm{C}_{18} \mathrm{H}_{24} \mathrm{~N}_{6} \mathrm{O}_{6} ;{ }^{1} \mathrm{H}-\mathrm{NMR}$ $\left(\mathrm{CD}_{3} \mathrm{OD}\right) ; \delta[\mathrm{ppm}]=2.48(\mathrm{ddd}, 1 \mathrm{H}, J=13.5 \mathrm{~Hz}, J=6.5 \mathrm{~Hz}, J=3.5 \mathrm{~Hz})$ and $2.83(\mathrm{~m}, 1 \mathrm{H}): 2^{\prime}-\mathrm{H}_{2}$, $2.85(\mathrm{t}, 1 \mathrm{H}, J=2.5 \mathrm{~Hz}, \mathrm{C} \equiv \underline{\mathrm{CH}}), 3.27(\mathrm{dt}, 2 \mathrm{H}, J=5.5 \mathrm{~Hz}, J=1.5 \mathrm{~Hz})$ and $3.50(\mathrm{t}, 2 \mathrm{H}, J=5.5 \mathrm{~Hz})$ and $3.61(\mathrm{~m}, 4 \mathrm{H})$ and $4.15(\mathrm{~m}, 3 \mathrm{H}, J=2.0 \mathrm{~Hz})$ : linker $5 \times \mathrm{CH}_{2}$ and $3^{\prime}-\mathrm{H}, 4.23(\mathrm{dd}, 1 \mathrm{H}, J=12.0$ $\mathrm{Hz}, J=5.0 \mathrm{~Hz})$ and $4.35(\mathrm{dd}, 1 \mathrm{H}, J=12.0 \mathrm{~Hz}, J=4.0 \mathrm{~Hz}): 5^{\prime}-\mathrm{H}_{2}, 4.57(\mathrm{dd}, 1 \mathrm{H}, J=6.5 \mathrm{~Hz}, J=3.5$ $\left.\mathrm{Hz}, 4^{\prime}-\mathrm{H}\right), 6.44$ (dd, 1H, $\left.J=2 \times 6.5 \mathrm{~Hz}, 1^{\prime}-\mathrm{H}\right), 8.32$ (s, 1H, linker-NH), $8.21(\mathrm{~s}, 1 \mathrm{H})$ and 8.28 (s, 1H): $2-\mathrm{H}$ and $8-\mathrm{H} .{ }^{13} \mathrm{C}-\mathrm{NMR}\left(\mathrm{CD}_{3} \mathrm{OD}\right) ; \delta[\mathrm{ppm}]=40.9\left(\mathrm{C}-2^{\prime}\right), 41.7$ and 59.0 and 70.1 and 70.9

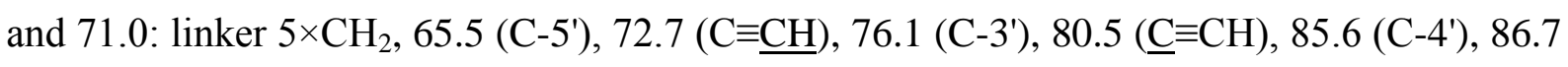
(C-1'), 120.5 (C-5), 140.7 (C-8), 150.3 (C-4), 153.8 (C-2), 157.2 (C-6), 158.5 (linker-CO). ESI-MS: $427[\mathrm{M}+\mathrm{Li}]^{+}$. 


\section{5'-O-((3-Azidopropyl)thiocarbamoyl)-2'-deoxyadenosine (124a)}

Amorphous foam (53 mg, 67\%), $R_{\mathrm{f}}=0.50$ (EtOAc:MeOH/8:2), $\mathrm{C}_{14} \mathrm{H}_{19} \mathrm{~N}_{9} \mathrm{O}_{3} \mathrm{~S} ;{ }^{1} \mathrm{H}-\mathrm{NMR}$ $\left(\mathrm{CD}_{3} \mathrm{OD}\right) ; \delta[\mathrm{ppm}]=1.84(\mathrm{p}, 2 \mathrm{H}, J=6.5 \mathrm{~Hz})$ and $3.38(\mathrm{~m}, 2 \mathrm{H})$ and $3.54(\mathrm{t}, 2 \mathrm{H}, J=7.0 \mathrm{~Hz})$ : linker $3 \times \mathrm{CH}_{2}, 2.50(\mathrm{ddd}, 1 \mathrm{H}, J=13.5 \mathrm{~Hz}, J=6.5 \mathrm{~Hz}, J=3.5 \mathrm{~Hz})$ and $2.84(\mathrm{ddd}, 1 \mathrm{H}, J=13.5 \mathrm{~Hz}$, $J=7.5 \mathrm{~Hz}, J=6.0 \mathrm{~Hz}): 2^{\prime}-\mathrm{H}_{2}, 3.23\left(\mathrm{~m}, 1 \mathrm{H}, 3^{\prime}-\mathrm{H}\right), 4.32\left(\mathrm{~m}, 1 \mathrm{H}, 4^{\prime}-\mathrm{H}\right), 4.60$ (dd, 1H, J=6.0 Hz, $J=3.0 \mathrm{~Hz})$ and $4.81(\mathrm{~m}, 1 \mathrm{H}): 5^{\prime}-\mathrm{H}_{2}, 6.45\left(\mathrm{dd}, 1 \mathrm{H}, J=7.0 \mathrm{~Hz}, J=6.0 \mathrm{~Hz}, 1^{\prime}-\mathrm{H}\right), 7.45(\mathrm{~s}, 1 \mathrm{H}$, linker-NH), $8.21(\mathrm{~s}, 1 \mathrm{H})$ and $8.27(\mathrm{~s}, 1 \mathrm{H}): 2-\mathrm{H}$ and $8-\mathrm{H} .{ }^{13} \mathrm{C}-\mathrm{NMR}\left(\mathrm{CD}_{3} \mathrm{OD}\right) ; \delta[\mathrm{ppm}]=28.7$ and 43.4 and 49.8: linker $3 \times \mathrm{CH}_{2}, 40.1$ (C-2'), 70.4 (C-5'), 72.8 (C-3'), 85.9 (C-4'), 86.5 (C-1'), 120.6 (C-5), 140.7 (C-8), 150.3 (C-4), 153.8 (C-2), 157.2 (C-6), 190.6 (linker-C=S). ESI-MS: $400[\mathrm{M}+\mathrm{Li}]^{+}$.

5'-O-((Prop-2-yn-1-yl)thiocarbamoyl)-2'-deoxyadenosine (125a)

Amorphous foam (31 mg, 45\%), $R_{\mathrm{f}}=0.35$ (EtOAc:MeOH/9:1), $\mathrm{C}_{14} \mathrm{H}_{16} \mathrm{~N}_{6} \mathrm{O}_{3} \mathrm{~S} ;{ }^{1} \mathrm{H}-\mathrm{NMR}$ $(\mathrm{DMSO}) ; \delta[\mathrm{ppm}]=2.32(\mathrm{ddd}, J=13.5 \mathrm{~Hz}, J=6.5 \mathrm{~Hz}, J=3.5 \mathrm{~Hz}, 1 \mathrm{H})$ and $2.78(\mathrm{~m}, 1 \mathrm{H}): 2^{\prime}-\mathrm{H}_{2}$, $3.11(\mathrm{t}, J=2.5 \mathrm{~Hz}, 1 \mathrm{H}, \mathrm{C} \equiv \underline{\mathrm{CH}}), 4.10\left(\mathrm{dq}, J=6.5 \mathrm{~Hz}, J=3.5 \mathrm{~Hz}, 1 \mathrm{H}, 4{ }^{\prime}-\mathrm{H}\right), 4.17$ (d, $J=2.5 \mathrm{~Hz}$, $2 \mathrm{H}$, linker $\left.\mathrm{CH}_{2}\right), 4.45\left(\mathrm{~m}, 2 \mathrm{H}, 5^{\prime}-\mathrm{H}_{2}\right), 4.61\left(\mathrm{~m}, 1 \mathrm{H}, 3^{\prime}-\mathrm{H}\right), 6.31\left(\mathrm{~m}, 1 \mathrm{H}, 1^{\prime}-\mathrm{H}\right), 8.14(\mathrm{~s}, 1 \mathrm{H})$ and 8.31 (s, 1H): 2-H and 8-H. ${ }^{13} \mathrm{C}-\mathrm{NMR}$ (DMSO); $\delta$ [ppm]=34.2 (linker $\mathrm{CH}_{2}$ ), 38.7 (C-2'), 70.2 (C-5'), $70.9(\mathrm{C} \equiv \underline{\mathrm{CH}}), 74.0\left(\mathrm{C}-3^{\prime}\right), 79.6(\underline{\mathrm{C}} \equiv \mathrm{CH}), 83.1$ (C-4'), 84.2 (C-1'), 119.1 (C-5), 139.4 (C-8), 149.2 (C-4), 152.7 (C-2), 156.1 (C-6), 189.8 (linker-C=S). ESI-MS: 355 [M+Li] ${ }^{+}$.

5'-O-((8-Azido-3,6-dioxaoctyl)thiocarbamoyl)-2'-deoxyadenosine (126a)

Amorphous foam (68 mg, 73\%), $R_{\mathrm{f}}=0.45$ (EtOAc:MeOH/8:2), $\mathrm{C}_{17} \mathrm{H}_{25} \mathrm{~N}_{9} \mathrm{O}_{5} \mathrm{~S} ;{ }^{1} \mathrm{H}-\mathrm{NMR}$ $\left(\mathrm{CD}_{3} \mathrm{OD}\right) ; \delta[\mathrm{ppm}]=2.51(\mathrm{ddd}, 1 \mathrm{H}, J=13.5 \mathrm{~Hz}, J=6.5 \mathrm{~Hz}, J=3.5 \mathrm{~Hz})$ and $2.86(\mathrm{ddd}, 1 \mathrm{H}$, $J=13.5 \mathrm{~Hz}, J=7.5 \mathrm{~Hz}, J=6.0 \mathrm{~Hz}): 2^{\prime}-\mathrm{H}_{2}, 3.33(\mathrm{~m}, 4 \mathrm{H})$ and $3.62(\mathrm{~m}, 8 \mathrm{H})$ : linker $6 \times \mathrm{CH}_{2}, 4.25$ (m, 1H, 4'-H), 4.63 (m, 2H, 5'-H $), 4.75$ (dd, 1H, J=12.0 Hz, J=4.0 Hz, 3'-H), 6.49 (m, 1H, 1'$\mathrm{H}), 7.45\left(\mathrm{~d}, 1 \mathrm{H}, J=1.5 \mathrm{~Hz}\right.$, linker-NH), $8.22(\mathrm{~s}, 1 \mathrm{H})$ and $8.29(\mathrm{~s}, 1 \mathrm{H}): 2-\mathrm{H}$ and $8-\mathrm{H} .{ }^{13} \mathrm{C}-\mathrm{NMR}$ $\left(\mathrm{CD}_{3} \mathrm{OD}\right) ; \delta[\mathrm{ppm}]=40.8\left(\mathrm{C}-2^{\prime}\right), 46.2$ and 51.7 and 70.0 and 70.6 and 71.0 and 71.1: linker 6× $\mathrm{CH}_{2}, 69.6\left(\mathrm{C}^{-5}\right), 72.9\left(\mathrm{C}-3^{\prime}\right), 85.8\left(\mathrm{C}-4^{\prime}\right), 86.5\left(\mathrm{C}-1^{\prime}\right), 120.5(\mathrm{C}-5), 140.8$ (C-8), 150.3 (C4), 153.9 (C-2), $157.2(\mathrm{C}-6), 190.6$ (linker-C=S). ESI-MS: 474 [M+Li] ${ }^{+}$.

5'-O-((3,6-Dioxanone-8-yn-1-yl)thiocarbamoyl)-2'-deoxyadenosine (127a)

Amorphous foam (65 mg, 75\%), $R_{\mathrm{f}}=0.46$ (EtOAc:MeOH/8:2), $\mathrm{C}_{18} \mathrm{H}_{24} \mathrm{~N}_{6} \mathrm{O}_{5} \mathrm{~S}$; ${ }^{1} \mathrm{H}-\mathrm{NMR}$ $\left(\mathrm{CD}_{3} \mathrm{OD}\right) ; \delta[\mathrm{ppm}]=2.57(\mathrm{~m}, 1 \mathrm{H})$ and $2.99(\mathrm{~m}, 1 \mathrm{H}): 2^{\prime}-\mathrm{H}_{2}, 2.75(\mathrm{t}, 1 \mathrm{H}, J=2.5 \mathrm{~Hz}, \mathrm{C} \equiv \underline{\mathrm{CH}}), 3.48$ 
$(\mathrm{m}, 2 \mathrm{H})$ and $3.70(\mathrm{~m}, 6 \mathrm{H})$ and $4.15(\mathrm{dd}, 2 \mathrm{H}, J=3.0 \mathrm{~Hz}, J=2.5 \mathrm{~Hz})$ : linker $5 \times \mathrm{CH}_{2}, 4.30(\mathrm{~m}, 1 \mathrm{H}$, 4'-H), 4.64 (m, 2H, 5'-- ${ }_{2}$ ), 4.79 (m, 1H, 3'-H), 6.44 (dd, 1H, J=6.5 Hz, J=6.0 Hz, 1'-H), 7.36 $\left(\mathrm{d}, 1 \mathrm{H}, J=2.5 \mathrm{~Hz}\right.$, linker-NH), $8.21(\mathrm{~s}, 1 \mathrm{H})$ and $8.27(\mathrm{~s}, 1 \mathrm{H}): 2-\mathrm{H}$ and $8-\mathrm{H} .{ }^{13} \mathrm{C}-\mathrm{NMR}$ $\left(\mathrm{CD}_{3} \mathrm{OD}\right) ; \delta[\mathrm{ppm}]=40.8\left(\mathrm{C}-2^{\prime}\right), 46.2$ and 59.1 and 70.0 and 70.1 and 70.5 : linker $5 \times \mathrm{CH}_{2}, 69.6$ (C-5'), $76.1(\mathrm{C} \equiv \underline{\mathrm{CH}}), 76.2\left(\mathrm{C}-3^{\prime}\right), 80.4(\underline{\mathrm{C}} \equiv \mathrm{CH}), 85.8$ (C-4'), $86.5\left(\mathrm{C}-1^{\prime}\right), 120.4(\mathrm{C}-5), 140.8$ (C-8), 150.3 (C-4), 153.8 (C-2), 157.2 (C-6), 191.7 (linker-C=S). ESI-MS: 443 [M+Li] ${ }^{+}$.

5'-O-((3-Propiolamidopropyl)carbamoyl)guanosine (128b)

Amorphous foam (64 mg, 74\%), $R_{\mathrm{f}}=0.49$ (EtOAc:iPrOH: $\left.\mathrm{H}_{2} \mathrm{O} / 8: 2: 1\right), \mathrm{C}_{17} \mathrm{H}_{21} \mathrm{~N}_{7} \mathrm{O}_{7} ;{ }^{1} \mathrm{H}-\mathrm{NMR}$ $(\mathrm{DMSO}) ; \delta[\mathrm{ppm}]=1.54(\mathrm{p}, 2 \mathrm{H}, J=7.0 \mathrm{~Hz})$ and $2.97(\mathrm{q}, 2 \mathrm{H}, J=6.5 \mathrm{~Hz})$ and $3.07(\mathrm{q}, 2 \mathrm{H}, J=6.5$ $\mathrm{Hz}$ ): $3 \times$ linker $\mathrm{CH}_{2}, 4.10(\mathrm{~m}, 1 \mathrm{H})$ and $4.18(\mathrm{dd}, 1 \mathrm{H}, J=12.0 \mathrm{~Hz}, J=3.5 \mathrm{~Hz}): 5^{\prime}-\mathrm{H}_{2}, 4.13$ (t, $1 \mathrm{H}$, $J=2.5 \mathrm{~Hz}, \mathrm{C} \equiv \underline{\mathrm{CH}}$ ), 4.47 (q, 1H, $\left.J=6.0 \mathrm{~Hz}, 4^{\prime}-\mathrm{H}\right), 5.34$ (dd, 1H, J=4.5 Hz, J=6.0 Hz, 3'-H), 5.51 $\left(\mathrm{d}, 1 \mathrm{H}, J=6.0 \mathrm{~Hz}, 2^{\prime}-\mathrm{H}\right), 5.69$ (d, 1H, J=6.0 Hz, 1'-H), 7.34 (t, 1H, J=5.5 Hz) and 8.74 (t, 1H, $J=5.5 \mathrm{~Hz}$ ): $2 \times$ linker-NH, $7.90(\mathrm{~s}, 1 \mathrm{H}, 8-\mathrm{H}), 10.74(\mathrm{~s}, 1 \mathrm{H}, 1-\mathrm{NH}) .{ }^{13} \mathrm{C}-\mathrm{NMR}$ (DMSO); $\delta$ $[\mathrm{ppm}]=29.1$ and 36.7 and 38.1: $3 \times$ linker $\mathrm{CH}_{2}, 64.1\left(\mathrm{C}-5^{\prime}\right), 70.6\left(\mathrm{C}-2^{\prime}\right), 73.0(\mathrm{C} \equiv \underline{\mathrm{CH}}), 75.6(\mathrm{C}-$ 3'), $78.4(\underline{\mathrm{C}} \equiv \mathrm{CH}), 82.3\left(\mathrm{C}-4^{\prime}\right), 86.0\left(\mathrm{C}-1^{\prime}\right), 116.7$ (C-5), $135.5(\mathrm{C}-8), 151.6(\mathrm{C}-4), 151.7$ and 156.0: 2×linker-CO, 153.8 (C-2), 156.8 (C-6). ESI-MS: $442[\mathrm{M}+\mathrm{Li}]^{+}$.

5'-O-((3-Azidopropyl)carbamoyl)guanosine (129b)

Amorphous foam (67 mg, 82\%), $R_{\mathrm{f}}=0.49$ (EtOAc:iPrOH: $\left.\mathrm{H}_{2} \mathrm{O} / 8: 2: 1\right), \mathrm{C}_{14} \mathrm{H}_{19} \mathrm{~N}_{9} \mathrm{O}_{6} ;{ }^{1} \mathrm{H}-\mathrm{NMR}$ $(\mathrm{DMSO}) ; \delta[\mathrm{ppm}]=1.64(\mathrm{p}, 2 \mathrm{H}, J=7.0 \mathrm{~Hz})$ and $3.09(\mathrm{~m}, 2 \mathrm{H})$ and $3.36(\mathrm{~m}, 2 \mathrm{H})$ : linker $3 \times \mathrm{CH}_{2}$, 4.00 (dt, 1H, J=6.0 Hz, J=3.5 Hz, 3'-H), 4.12 (m, 2H, 5'-H $), 4.19$ (dd, 1H, J=12.0 Hz, J=3.5 $\mathrm{Hz}, 4 '-\mathrm{H}), 4.47$ (dd, 1H, J=2×6.0 Hz, 2'-H), 5.53 (dd, 1H, J=5.0 Hz, J=2.0 Hz, 1'-H), 7.42 (t, $1 \mathrm{H}, J=6.0 \mathrm{~Hz}$, linker-NH), $7.90(\mathrm{~s}, 1 \mathrm{H}, 8-\mathrm{H}), 10.72$ (s, 1H, 1-NH). ${ }^{13} \mathrm{C}-\mathrm{NMR}$ (DMSO); $\delta$ $[\mathrm{ppm}]=28.7$ and 37.6 and 48.3: $3 \times$ linker $\mathrm{CH}_{2}, 64.1\left(\mathrm{C}-5^{\prime}\right), 70.6\left(\mathrm{C}-2^{\prime}\right), 73.1\left(\mathrm{C}-3^{\prime}\right), 82.3(\mathrm{C}-$ 4'), 86.0 (C-1'), 116.7 (C-5), 135.5 (C-8), 151.6 (C-4), 153.8 (C-2), 156.1 (linker-CO), 156.8 (C-6). ESI-MS: $416[\mathrm{M}+\mathrm{Li}]^{+}$.

5'-O-((Prop-2-yn-1-yl)carbamoyl)guanosine (130b)

Amorphous foam (58 mg, 80\%), $R_{\mathrm{f}}=0.47$ (EtOAc:iPrOH: $\mathrm{H}_{2} \mathrm{O} / 8: 2: 1$ ), $\mathrm{C}_{14} \mathrm{H}_{16} \mathrm{~N}_{6} \mathrm{O}_{5} ;{ }^{1} \mathrm{H}-\mathrm{NMR}$ (DMSO); $\delta[\mathrm{ppm}]=3.13(\mathrm{t}, 1 \mathrm{H}, J=2.5 \mathrm{~Hz}, \mathrm{C} \equiv \underline{\mathrm{CH}}), 3.79$ (dd, 2H, $J=6.0 \mathrm{~Hz}, J=2.5 \mathrm{~Hz}$, linker $\left.\mathrm{CH}_{2}\right), 4.01$ (dd, 1H, J=5.5 Hz, J=3.5 Hz, 3'-H), 4.14 (m, 2H, 5'- $\left.\mathrm{H}_{2}\right), 4.18$ (dd, 1H, J=12.0 Hz, $\left.J=3.5 \mathrm{~Hz}, 4^{\prime}-\mathrm{H}\right), 4.46$ (dd, 1H, J=6.5 Hz, J=5.0 Hz, 2'-H), 5.69 (d, 1H, J=6.5 Hz, 1'-H), 7.84 
(t, 1H, J=6.0 Hz, linker-NH), $7.92(\mathrm{~s}, 1 \mathrm{H}, 8-\mathrm{H}), 10.28$ (s, 1H, 1-NH). ${ }^{13} \mathrm{C}-\mathrm{NMR}$ (DMSO); $\delta$ $[\mathrm{ppm}]=29.9$ (linker $\left.\mathrm{CH}_{2}\right), 64.5\left(\mathrm{C}-5^{\prime}\right), 70.6\left(\mathrm{C}-2^{\prime}\right), 73.0(\mathrm{C} \equiv \underline{\mathrm{CH}}), 73.3\left(\mathrm{C}-3^{\prime}\right), 81.3(\underline{\mathrm{C}} \equiv \mathrm{CH})$, 82.2 (C-4'), 86.0 (C-1'), 116.7 (C-5), 135.6 (C-8), 151.6 (C-4), 153.8 (C-2), 155.9 (linkerCO), 156.9 (C-6). ESI-MS: $371[\mathrm{M}+\mathrm{Li}]^{+}$.

5'-O-((8-Azido-3,6-dioxaoctyl)carbamoyl)guanosine (131b)

Amorphous foam (82 mg, 85\%), $R_{\mathrm{f}}=0.42$ (EtOAc:iPrOH: $\mathrm{H}_{2} \mathrm{O} / 8: 2: 1$ ), $\mathrm{C}_{17} \mathrm{H}_{25} \mathrm{~N}_{9} \mathrm{O}_{8} ;{ }^{1} \mathrm{H}-\mathrm{NMR}$ (DMSO); $\delta[\mathrm{ppm}]=3.13(\mathrm{q}, 2 \mathrm{H}, J=6.0 \mathrm{~Hz})$ and $3.45(\mathrm{~m}, 4 \mathrm{H})$ and $3.53(\mathrm{~m}, 2 \mathrm{H})$ and 3.55 (ddd, $2 \mathrm{H}, J=5.5 \mathrm{~Hz}, J=3.0 \mathrm{~Hz}, J=1.5 \mathrm{~Hz})$ and $3.63(\mathrm{~m}, 2 \mathrm{H})$ : linker $6 \times \mathrm{CH}_{2}, 3.99(\mathrm{dt}, 1 \mathrm{H}, J=5.5 \mathrm{~Hz}$, $\left.J=3.5 \mathrm{~Hz}, 3^{\prime}-\mathrm{H}\right), 4.12$ (m, 2H, 5'-H $), 4.17$ (dd, 1H, J=12.0 Hz, J=3.5 Hz, 4'-H), 4.47 (dd, 1H, $\left.J=2 \times 6.0 \mathrm{~Hz}, 2^{\prime}-\mathrm{H}\right), 5.70\left(\mathrm{~d}, 1 \mathrm{H}, J=6.5 \mathrm{~Hz}, 1^{\prime}-\mathrm{H}\right), 7.40$ (t, 1H, J=6.0 Hz, linker-NH), 7.92 (s, $1 \mathrm{H}, 8-\mathrm{H}), 10.38(\mathrm{~s}, 1 \mathrm{H}, 1-\mathrm{NH}) .{ }^{13} \mathrm{C}-\mathrm{NMR}$ (DMSO); $\delta[\mathrm{ppm}]=40.2$ and 50.3 and 69.2 and 69.3 and 69.7 and 70.4: 6×linker $\mathrm{CH}_{2}, 64.1$ (C-5'), 70.6 (C-2'), $73.0\left(\mathrm{C}-3^{\prime}\right), 82.3\left(\mathrm{C}-4^{\prime}\right), 86.0$ (C-1'), 116.7 (C-5), 135.6 (C-8), 151.6 (C-4), 153.8 (C-2), 156.1 (linker-CO), 156.9 (C-6). ESI-MS: $490[\mathrm{M}+\mathrm{Li}]^{+}$.

5'-O-((3,6-Dioxanon-8-yn-1-yl)carbamoyl)guanosine (132b)

Amorphous foam (75 mg, 83\%), $R_{\mathrm{f}}=0.45$ (EtOAc:iPrOH: $\left.\mathrm{H}_{2} \mathrm{O} / 8: 2: 1\right), \mathrm{C}_{18} \mathrm{H}_{24} \mathrm{~N}_{6} \mathrm{O}_{8} ;{ }^{1} \mathrm{H}-\mathrm{NMR}$ $(\mathrm{DMSO}) ; \delta[\mathrm{ppm}]=3.13(\mathrm{t}, 1 \mathrm{H}, J=2.5 \mathrm{~Hz}, \mathrm{C} \equiv \underline{\mathrm{CH}}), 3.45(\mathrm{~m}, 4 \mathrm{H})$ and $3.53(\mathrm{q}, 4 \mathrm{H}, J=4.0 \mathrm{~Hz})$ and $4.21(\mathrm{~m}, 6 \mathrm{H})$ : linker $5 \times \mathrm{CH}_{2}, 5^{\prime}-\mathrm{H}_{2}, 4^{\prime}-\mathrm{H}, 3^{\prime}-\mathrm{H}, 4.48\left(\mathrm{dd}, 1 \mathrm{H}, J=2 \times 6.0 \mathrm{~Hz}, 2^{\prime}-\mathrm{H}\right), 5.70(\mathrm{~d}$, $1 \mathrm{H}, J=6.5 \mathrm{~Hz}, 1$ '-H), 7.42 (t, 1H, J=6.0 Hz, linker-NH), 7.93 (s, 1H, 8-H), 10.64 (s, 1H, 1$\mathrm{NH}) .{ }^{13} \mathrm{C}-\mathrm{NMR}(\mathrm{DMSO}) ; \delta[\mathrm{ppm}]=40.2$ and 57.6 and 68.5 and 69.4 and 70.6 : linker $6 \times \mathrm{CH}_{2}$,

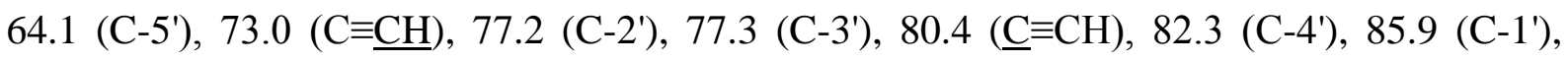
116.6 (C-5), 135.6 (C-8), 151.7 (C-4), 153.8 (C-2), 156.1 (linker-CO), 156.9 (C-6). ESI-MS: $459[\mathrm{M}+\mathrm{Li}]^{+}$.

\section{$N$-(6-aminohexyl)-2-azidoacetamide (134)}

Oil (11.6 g, 84\%), $\mathrm{C}_{8} \mathrm{H}_{17} \mathrm{~N}_{5} \mathrm{O} ;{ }^{1} \mathrm{H}-\mathrm{NMR}$ (DMSO); $\delta[\mathrm{ppm}]=1.24(\mathrm{~m}, 4 \mathrm{H})$ and $1.31(\mathrm{~m}, 4 \mathrm{H})$ and $1.39(\mathrm{~m}, 2 \mathrm{H})$ and $3.07(\mathrm{~d}, 2 \mathrm{H} \mathrm{J}=6.0 \mathrm{~Hz})$ and $3.78(\mathrm{~s}, 2 \mathrm{H}): 7 \times \mathrm{CH}_{2}, 8.10(\mathrm{~s}, 1 \mathrm{H}, \mathrm{CO}-\underline{\mathrm{NH}}) ;{ }^{13} \mathrm{C}-$ NMR (DMSO); $\delta[\mathrm{ppm}]=26.1$ and 26.3 and 29.0 and 33.0 and 38.6 and 41.5 and 50.8: linker $7 \times \mathrm{CH}_{2}, 167.0$ (으-NH); ESI-MS: $200[\mathrm{M}+\mathrm{H}]^{+}$. 
2',3'-Di-O-acetyl-5'-O-((6-(2-azidoacetamido)hexyl)carbamoyl)- $N^{6}$-benzoyladenosine (136) Amorphous foam (276 mg, 81\%), $R_{\mathrm{f}}=0.42$ (EtOAc:MeOH/95:5), $\mathrm{C}_{30} \mathrm{H}_{36} \mathrm{~N}_{10} \mathrm{O}_{9}$; ${ }^{1} \mathrm{H}-\mathrm{NMR}$ $(\mathrm{DMSO}) ; \delta[\mathrm{ppm}]=2.04$ and $2.14(2 \times \mathrm{s}, 2 \times 3 \mathrm{H}, 2 \times \mathrm{OAc}), 1.23(\mathrm{~m}, 4 \mathrm{H})$ and $1.38(\mathrm{~m}, 4 \mathrm{H})$ and 2.97 $(\mathrm{d}, 2 \mathrm{H}, J=5.5 \mathrm{~Hz})$ and $3.06(\mathrm{~d}, 2 \mathrm{H}, J=6.0 \mathrm{~Hz})$ and $3.77(\mathrm{~s}, 2 \mathrm{H})$ : linker $7 \times \mathrm{CH}_{2}, 4.25(\mathrm{dd}, 1 \mathrm{H}$, $\left.J=4.5 \mathrm{~Hz}, J=11.0 \mathrm{~Hz}, 4^{\prime}-\mathrm{H}\right), 4.37\left(\mathrm{~m}, 2 \mathrm{H}, 5^{\prime}-\mathrm{H}_{2}\right), 5.59(\mathrm{~m}, 1 \mathrm{H})$ and $6.03(\mathrm{~m}, 1 \mathrm{H}): 2 '-\mathrm{H}$ and 3'-H, $6.37\left(\mathrm{~d}, 1 \mathrm{H}, J=4.5 \mathrm{~Hz}, 1^{\prime}-\mathrm{H}\right), 7.31(\mathrm{~m}, 1 \mathrm{H})$ and $7.57(\mathrm{dd}, 2 \mathrm{H}, J=7.0 \mathrm{~Hz}, J=7.5 \mathrm{~Hz})$ and $7.66(\mathrm{dd}$, $1 \mathrm{H}, J=7.0 \mathrm{~Hz}, J=7.5 \mathrm{~Hz}$ ) and $8.06(\mathrm{~d}, 3 \mathrm{H}, J=7.0 \mathrm{~Hz})$ : benzoyl protons and linker $2 \times \mathrm{NH}, 8.71$ (s, $1 \mathrm{H})$ and 8.79 (s, 1H): 2-H and 8-H, 11.28 (s, 1H, 6-NH); ${ }^{13} \mathrm{C}-\mathrm{NMR}$ (DMSO); $\delta[\mathrm{ppm}]=20.1$ and $20.3(2 \times \mathrm{OAc}), 25.8$ and 25.9 and 28.8 and 29.2 and 36.5 and 40.2 and 50.7: linker $7 \times \mathrm{CH}_{2}, 62.8$ (C-5'), 70.4 (C-2'), 72.1 (C-3'), 80.3 (C-4'), 85.1 (C-1'), 125.6 (C-5), 128.40 (2C), 128.42 (2C), 132.4, 133.1, 139.6 (C-8), 150.6 (C-4), 151.9 and 166.9: linker-CO, 155.4 (C-2), 155.6 (C-6), 164.8 (Bz-CO), 169.2 and $169.4\left(2 \times\right.$ Ac-CO); ESI-MS: $681[\mathrm{M}+\mathrm{H}]^{+}$.

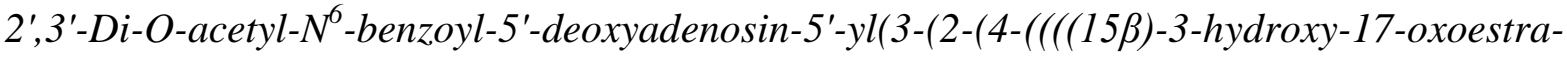
1,3,5(10)-trien-15-yl)oxy)methyl)-1H-1,2,3-triazol-1-yl)acetamido)propyl)carbamate (137) Amorphous foam (112 mg, 78\%), $R_{\mathrm{f}}=0.50$ (EtOAc:MeOH/9:5), $\mathrm{C}_{48} \mathrm{H}_{54} \mathrm{~N}_{10} \mathrm{O}_{12} ;{ }^{1} \mathrm{H}-\mathrm{NMR}$ (DMSO); $\delta[\mathrm{ppm}]=1.03\left(\mathrm{~s}, 3 \mathrm{H}, 18-\mathrm{CH}_{3}\right), 2.04$ and $2.14(2 \times \mathrm{s}, 2 \times 3 \mathrm{H}, 2 \times \mathrm{OAc}), 1.53(\mathrm{t}, 2 \mathrm{H}$, $J=2 \times 6.0 \mathrm{~Hz})$ and $3.02(\mathrm{~m}, 1 \mathrm{H})$ and $3.16(\mathrm{~m}, 1 \mathrm{H})$ and $3.58(\mathrm{~d}, 2 \mathrm{H}, J=5.5 \mathrm{~Hz})$ and $4.50(\mathrm{~s}, 2 \mathrm{H})$ : linker $4 \times \mathrm{CH}_{2}, 2.64\left(\mathrm{~m}, 2 \mathrm{H}, 6-\mathrm{H}_{2}\right), 4.26(\mathrm{dd}, 1 \mathrm{H}, J=5.0 \mathrm{~Hz}, J=5.5 \mathrm{~Hz}, 4 '-\mathrm{H}), 4.46\left(\mathrm{~m}, 2 \mathrm{H}, 5^{\prime}-\right.$ $\left.\mathrm{H}_{2}\right), 5.06\left(\mathrm{~s}, 2 \mathrm{H}, \mathrm{OCH}_{2}\right), 5.60\left(\mathrm{~m}, 1 \mathrm{H}, 3^{\prime}-\mathrm{H}\right), 5.75\left(\mathrm{t}, 1 \mathrm{H}, J=6.0 \mathrm{~Hz}, 2^{\prime}-\mathrm{H}\right), 6.17$ (td, 1H, J=10.0 Hz, J=6 Hz, 1'-H), 6.44 (s, 1H, 4-H), 6.51 (d, 1H, $J=8.5 \mathrm{~Hz}, 2-\mathrm{H}), 7.02$ (d, 1H, J=8.5 Hz, 1$\mathrm{H}), 7.40(\mathrm{~m}, 2 \mathrm{H})$ and $7.56(\mathrm{t}, 1 \mathrm{H}, J=7.5 \mathrm{~Hz})$ and $7.65(\mathrm{~m}, 2 \mathrm{H})$ : benzoyl protons, $7.99(\mathrm{~s}, 1 \mathrm{H}$, $\mathrm{HC}=\mathrm{C}), 8.05(\mathrm{t}, 1 \mathrm{H}, J=6.0 \mathrm{~Hz})$ and $8.29(\mathrm{t}, 2 \mathrm{H}, J=6.0 \mathrm{~Hz})$ : linker $2 \times \mathrm{NH}, 8.71(\mathrm{~s}, 1 \mathrm{H})$ and 8.79 (s, 1H): 2"-H and 8"-H, 11.42 (s, 1H, 6-NH); ESI-MS: $963[\mathrm{M}+\mathrm{H}]^{+}$.

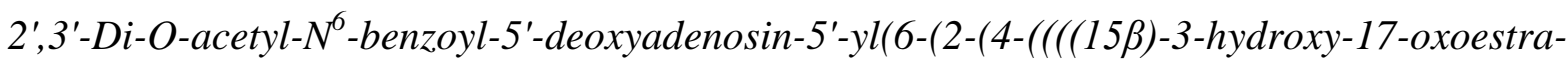
1,3,5(10)-trien-15-yl)oxy)methyl)-1H-1,2,3-triazol-1-yl)acetamido)hexyl)carbamate (138) Amorphous foam (124 mg, 82\%), $R_{\mathrm{f}}=0.56$ (EtOAc:MeOH/9:1), $\mathrm{C}_{51} \mathrm{H}_{60} \mathrm{~N}_{10} \mathrm{O}_{12} ;{ }^{1} \mathrm{H}-\mathrm{NMR}$ $(\mathrm{DMSO}) ; \delta[\mathrm{ppm}]=1.03\left(\mathrm{~s}, 3 \mathrm{H}, 18-\mathrm{CH}_{3}\right), 2.00$ and $2.11(2 \times \mathrm{s}, 2 \times 3 \mathrm{H}, 2 \times \mathrm{OAc}), 1.23(\mathrm{~m}, 4 \mathrm{H})$ and $1.39(\mathrm{~m}, 4 \mathrm{H})$ and $2.95(\mathrm{~d}, 2 \mathrm{H}, J=6.0 \mathrm{~Hz})$ and $3.07(\mathrm{~d}, 2 \mathrm{H}, J=5.5 \mathrm{~Hz})$ and $4.32(\mathrm{~s}, 2 \mathrm{H})$ : linker $7 \times \mathrm{CH}_{2}, 2.72\left(\mathrm{~m}, 2 \mathrm{H}, 6-\mathrm{H}_{2}\right), 4.27\left(\mathrm{dd}, 1 \mathrm{H}, J=5.0 \mathrm{~Hz}, J=5.5 \mathrm{~Hz}, 4{ }^{\prime}-\mathrm{H}\right), 4.45(\mathrm{~d}, 1 \mathrm{H}$, $J=12.0 \mathrm{~Hz})$ and $4.64(\mathrm{~d}, 1 \mathrm{H}, J=12.0 \mathrm{~Hz}): 5^{\prime}-\mathrm{H}_{2}, 5.06\left(\mathrm{~s}, 2 \mathrm{H}, \mathrm{OCH}_{2}\right), 5.54(\mathrm{dd}, 1 \mathrm{H} J=4.0 \mathrm{~Hz}$, $J=4.5 \mathrm{~Hz}, 3$ '-H), 5.94 (t, 1H, J=6.0 Hz, 2'-H), 6.20 (d, 1H, J=5.5 Hz, 1'-H), 6.45 (s, 1H, 4-H), 
$6.51(\mathrm{~d}, 1 \mathrm{H}, J=8.5 \mathrm{~Hz}, 2-\mathrm{H}), 7.02(\mathrm{~d}, 1 \mathrm{H}, J=8.5 \mathrm{~Hz}, 1-\mathrm{H}), 7.34(\mathrm{~m}, 3 \mathrm{H})$ and $7.40(\mathrm{~m}, 2 \mathrm{H}$,$) :$ benzoyl protons, $7.89(\mathrm{~s}, 1 \mathrm{H}, \mathrm{HC}=\mathrm{C}), 8.00(\mathrm{t}, 1 \mathrm{H}, J=6.0 \mathrm{~Hz})$ and $8.18(\mathrm{t}, 2 \mathrm{H}, J=6.0 \mathrm{~Hz})$ : linker $2 \times \mathrm{NH}, 8.38(\mathrm{~s}, 1 \mathrm{H})$ and $8.45(\mathrm{~s}, 1 \mathrm{H}): 2 "-\mathrm{H}$ and $8 "-\mathrm{H} ;{ }^{13} \mathrm{C}-\mathrm{NMR}$ (DMSO); $\delta$ [ppm]=17.4 (18- $\left.\mathrm{CH}_{3}\right), 20.2$ and $20.4(2 \times \mathrm{OAc}), 25.9$ and 26.1 and 30.8 and 32.4 and 38.8 and 40.2 and 59.8: linker $7 \times \mathrm{CH}_{2}, 28.8,29.3,34.7,42.9,43.7$ (2C, C-8 and C-9), 46.7, 48.6 (C-14), 51.6 (C13), 62.1 (C-5'), $63.0\left(\mathrm{OCH}_{2}\right), 70.5$ (C-2'), 72.1 (C-3'), 73.8 (C-15), 80.1 (C-4'), 84.9 (C-1'), 112.8 (C-2), 115.1 (C-4), 125.3 (HC=-C), 125.9 (C-1), 127.1 (C-5"), 129.5 (2C), 129.9 (2C), 131.5, 131.9, 132.4 (C-10), 137.1 (C-5), 141.1 (C-8"), 144.4 (HC=ㄷ), 150.3 (C-4"), 155.3 (C3), 155.7 (C-2"), 156.2 (C-6"), 165.3 (Bz-CO), 169.3 and 169.6 (2×Ac-CO), 151.8 and 170.5: linker-CO, 219.2 (C-17); ESI-MS: $1005[\mathrm{M}+\mathrm{H}]^{+}$.

5'-Deoxyadenosin-5'-yl(3-(2-(4-(()(15ß)-3-hydroxy-17-oxoestra-1,3,5(10)-trien-15-

yl)oxy)methyl)-1H-1,2,3-triazol-1-yl)acetamido)propyl)carbamate (139)

Amorphous foam (64 mg, 83\%), $R_{\mathrm{f}}=0.22$ (EtOAc:MeOH/9:1), $\mathrm{C}_{37} \mathrm{H}_{46} \mathrm{~N}_{10} \mathrm{O}_{9} ;{ }^{1} \mathrm{H}-\mathrm{NMR}$ $(\mathrm{DMSO}) ; \delta[\mathrm{ppm}]=1.02\left(\mathrm{~s}, 3 \mathrm{H}, 18-\mathrm{CH}_{3}\right), 1.56(\mathrm{~m}, 2 \mathrm{H})$ and $3.00(\mathrm{~m}, 1 \mathrm{H})$ and $3.10(\mathrm{~m}, 1 \mathrm{H})$ and $3.57(\mathrm{~d}, 2 \mathrm{H}, J=5.5 \mathrm{~Hz})$ and $4.51(\mathrm{~s}, 2 \mathrm{H})$ : linker $4 \times \mathrm{CH}_{2}, 2.64\left(\mathrm{~m}, 2 \mathrm{H}, 6-\mathrm{H}_{2}\right), 4.26(\mathrm{dd}, 1 \mathrm{H}$, $\left.J=5.0 \mathrm{~Hz}, J=5.5 \mathrm{~Hz}, 4^{\prime}-\mathrm{H}\right), 4.76\left(\mathrm{t}, 2 \mathrm{H}, J=6.0 \mathrm{~Hz}, 5{ }^{\prime}-\mathrm{H}_{2}\right), 5.04\left(\mathrm{~s}, 2 \mathrm{H}, \mathrm{OCH}_{2}\right), 5.54(\mathrm{~d}, 1 \mathrm{H}$, $\left.J=5.5 \mathrm{~Hz}, 3^{\prime}-\mathrm{H}\right), 5.75$ (m, 1H, 2'-H), 6.23 (td, 1H, J=10.0 Hz, J=6.0 Hz, 1'-H), 6.44 (s, 1H, 4H), 6.52 (d, 1H, J=8.5 Hz, 2-H), 7.05 (d, 1H, J=8.5 Hz, 1-H), 7.89 (s, 1H, HC=C), 8.00 (t, 1H, $J=6.0 \mathrm{~Hz})$ and $8.15(\mathrm{t}, 2 \mathrm{H}, J=6.0 \mathrm{~Hz})$ : linker $2 \times \mathrm{NH}, 8.32(\mathrm{~s}, 1 \mathrm{H})$ and $8.41(\mathrm{~s}, 1 \mathrm{H}): 2 "-\mathrm{H}$ and 8"-H; ESI-MS: $775[\mathrm{M}+\mathrm{H}]^{+}$.

5'-Deoxyadenosin-5'-yl(6-(2-(4-(()(15ß)-3-hydroxy-17-oxoestra-1,3,5(10)-trien-15-

yl)oxy)methyl)-1H-1,2,3-triazol-1-yl)acetamido)hexyl)carbamate (140)

Amorphous foam (69 mg, 84\%), $R_{\mathrm{f}}=0.28$ (EtOAc:MeOH/9:1), $\mathrm{C}_{40} \mathrm{H}_{52} \mathrm{~N}_{10} \mathrm{O}_{9} ;{ }^{1} \mathrm{H}-\mathrm{NMR}$ $(\mathrm{DMSO}) ; \delta[\mathrm{ppm}]=1.03\left(\mathrm{~s}, 3 \mathrm{H}, 18-\mathrm{CH}_{3}\right), 1.24(\mathrm{~m}, 4 \mathrm{H})$ and $1.39(\mathrm{~m}, 4 \mathrm{H})$ and $2.95(\mathrm{~d}, 2 \mathrm{H}$, $J=6.0 \mathrm{~Hz})$ and $3.07(\mathrm{~d}, 2 \mathrm{H}, J=5.5 \mathrm{~Hz})$ and $4.51(\mathrm{~s}, 2 \mathrm{H})$ : linker $7 \times \mathrm{CH}_{2}, 2.74\left(\mathrm{~m}, 2 \mathrm{H}, 6-\mathrm{H}_{2}\right)$, $4.05(\mathrm{~d}, 1 \mathrm{H}, J=12.0 \mathrm{~Hz})$ and $4.13(\mathrm{~d}, 1 \mathrm{H}, J=12.0 \mathrm{~Hz}): 5^{\prime}-\mathrm{H}_{2}, 4.21(\mathrm{dd}, 1 \mathrm{H}, J=5.0 \mathrm{~Hz}, J=5.5$ $\left.\mathrm{Hz}, 4^{\prime}-\mathrm{H}\right), 4.27$ (dd, 1H J=4.0 Hz, J=4.5 Hz, 3'-H), 4.43 (t, 1H, J=6.0 Hz, 2'-H), 5.04 (s, 2H, $\left.\mathrm{OCH}_{2}\right), 5.90$ (d, 1H, J=5.5 Hz, 1'-H), 6.47 (s, 1H, 4-H), 6.51 (d, 1H, J=7.5 Hz, 2-H), 7.03 (d, $1 \mathrm{H}, J=7.5 \mathrm{~Hz}, 1-\mathrm{H}), 7.89$ (s, 1H, HC=C), $8.00(\mathrm{t}, 1 \mathrm{H}, J=6.0 \mathrm{~Hz})$ and $8.16(\mathrm{t}, 2 \mathrm{H}, J=6.0 \mathrm{~Hz})$ : linker $2 \times \mathrm{NH}, 8.35(\mathrm{~s}, 1 \mathrm{H})$ and $8.45(\mathrm{~s}, 1 \mathrm{H}): 2 "-\mathrm{H}$ and $8 "-\mathrm{H} ;{ }^{13} \mathrm{C}-\mathrm{NMR}(\mathrm{DMSO}) ; \delta$ [ppm]=17.3 $\left(18-\mathrm{CH}_{3}\right), 26.0$ and 26.5 and 28.9 and 34.7 and 38.7 and 40.2 and 56.5: linker $7 \times \mathrm{CH}_{2}, 28.8$, 
29.3, 32.4, 42.9, 43.7 (2C, C-8 and C-9), 46.7, 48.5 (C-14), 51.6 (C-13), 62.0 (C-5'), 64.1 $\left(\mathrm{OCH}_{2}\right), 70.7$ (C-2'), 73.1 (C-3'), 73.8 (C-15), 82.5 (C-4'), $86.9\left(\mathrm{C}-1^{\prime}\right), 112.9(\mathrm{C}-2), 115.1$ (C4), 124.2 (HC=C), 125.8 (C-1), 129.8 (C-5"), 133.5 (C-10), 137.1 (C-5), 140.5 (C-8"), 143.9 $(\mathrm{HC}=\underline{\mathrm{C}}), 147.7(\mathrm{C}-4 "), 149.6(\mathrm{C}-3), 155.3(\mathrm{C}-2 "), 156.0$ (C-6"), 159.7 and 171.6: linker-CO, 219.3 (C-17); ESI-MS: $817[\mathrm{M}+\mathrm{H}]^{+}$. 